


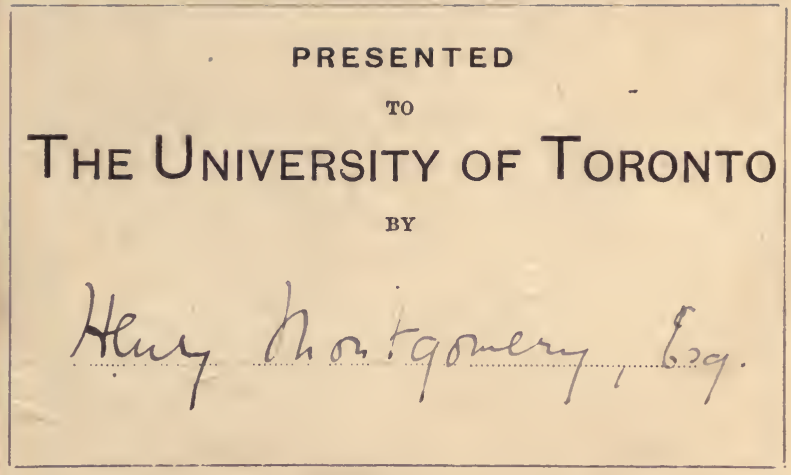




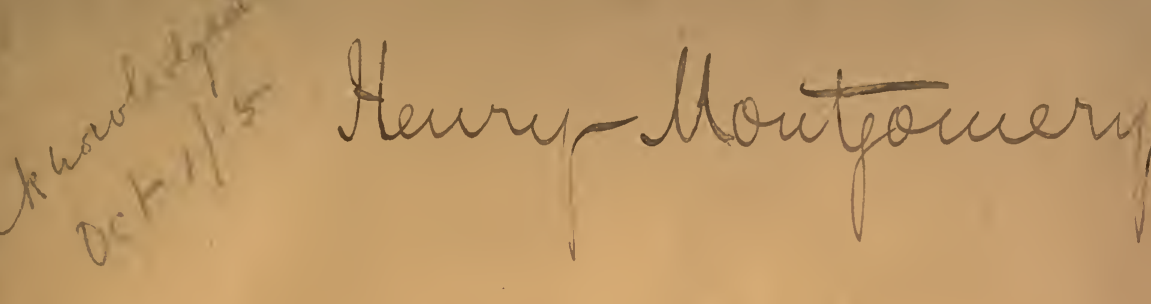




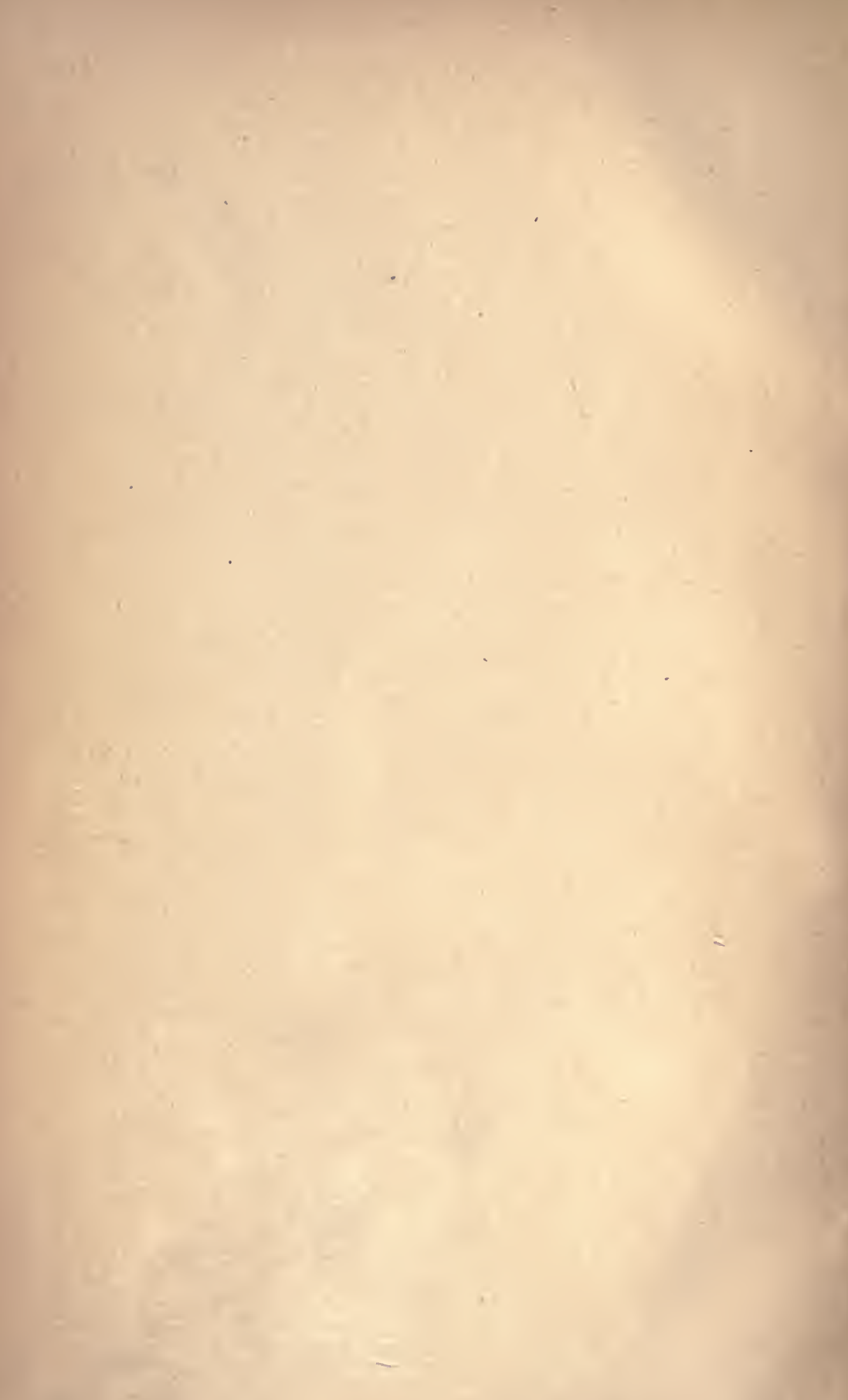


A STUDENTS'

\section{TEXT-BOOK OF BOTANY.}


Digitized by the Internet Archive in 2007 with funding from Microsoft Corporation 


\section{A STUDENTS'}

\section{TEXT-B00K OF BOTANY}

BY

SYDNEY H. VINES M.A., D.Sc., F.R.S.

Fellow of Magdalen College and Sherardian Professor of Botany in the University of Oxford; formerly Fellow of Christ's College and Reader in Botany in the University of Cambridge; Fcllow of the University of London

(FIRST HALF.)

WITH 279 ILLUSTRATIONS
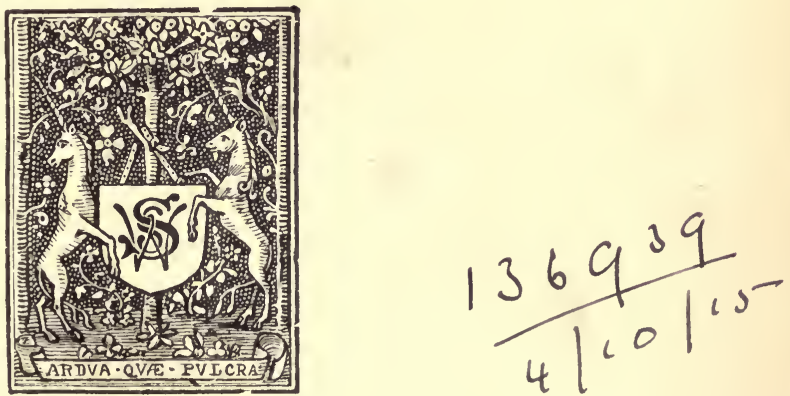

Ilanon

SWA N SONNENSCHEIN \& CO.

NEW YORK: MACMILLAN \& CO. 
1,11212

$\iint_{i} i$

$(4)+1)^{1}=$

Butler \& TAnNer,

The Seliwood Printing Works,

Frome, AND LONDON. 


\section{PREFACE.}

When, some few years ago, it became necessary to revise the English Edition of the late Prof. Prantl's Lehrbuch der Botanik, it appeared to me that the requirements of English students would be more satisfactorily met if the scope of the work were so extended that, whilst retaining all that has made it of value to beginners, it might be more useful to those engaged in the advanced study of the science. With this object in view, the number of pages has been doubled by additions to all four parts of the book, but more especially to Part III. dealing with the Classification of Plants.

Though the form of Prof. Prantl's book is still retained, and here and there paragraphs from the English edition have been inserted, the present is essentially a new and distinct work for which I alone am responsible, and, consequently, on the title-page of which my name alone appears.

I would most gratefully acknowledge the assistance which I have received from my friend Dr. D. H. Scott, Honorary Superintendent of the Jodrell Laboratory, Royal Gardens, Kew, who has kindly read the proofs, and has furnished me with many valuable suggestions and criticisms. The usefulness of the book is enhanced by the incorporation of a number of additional illustrations: most of these are placed at my disposal by the publishers, from their English edition of Prof. Strasburger's Practical Botany; a few are taken from various other sources which are duly acknowledged.

S. H. V.

January, 1894. 


\section{ERRATA.}

Page 29, line 6 from bottom, Marsilia should be spelt Marsilea throughout.

, 61,17 , top, for tranverse read transverse.

" 67,5 " bottom, for Mucorini read Mucorinæ.

" $69,16 \quad$ " the bracket should follow the word intine.

, 117,14 , " for mother-cels read mother-cells.

" " " 4 " , for mother-ces read mother-cells.

" 127 , 3 " top, for Schizeacea read Schizæacex.

" 173 , 14 " top, for other read outer.

" 176,2 " bottom, for protohploem read protophloem.

, 276,9 " top, for asocarp read ascocarp. 


\section{O N TENTS.}

\section{PART I.-MORPHOLOGY.}

PAGR

Introductory

CHAPTER I.-GENERAL MORPHOLOGY.

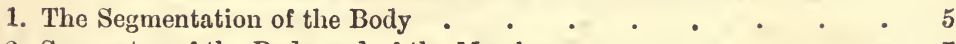

2. Symmetry of the Body and of the Members $\quad$. $\quad$. $\quad$. $\quad$. 7

3. The Development of the Body and of the Members . $\quad$. $\quad$ - 13

4. Arrangement of Lateral Members on a Common Axis . . . $\quad 23$

5. The Mutual Relations of Dissimilar Secondary Members . . $\quad 31$

6. Branch-Systems . • . • • • • . • . 32

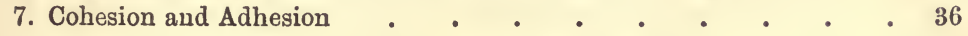

CHAPTER II.-THE SPECIAL MORPHOLOGY OF THE MEMBERS.

A. Vegetative Organs.

8. The Thallus

9. The Thalloid Shoot ${ }^{\circ} \cdot{ }^{-} \cdot{ }^{-} \cdot{ }^{-} \quad 37$

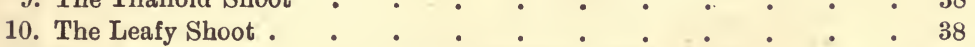

11. The Stem . . . . . . . . . . 44

12. The Leaf . . . . . . . . . . . . 45

13. The Root . . . . . . . . . . . 61

14. Hairs and Emergences . . . . . . . . 64

15. Reproduction . . . • . . . 67

16. General Morphology of the Asexual Reproductive Organs . . $\quad 70$

17. General Morphology of the Sexual Reproductive Orgaus . $\quad$. 80

18. Apospory and Apogamy . . . . . . . . . . $\quad$. 87

19. The Fruit . . . . . . . . . . . . 88

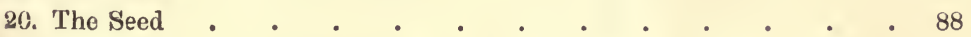

\section{PAR'T II.-THE IN'TLMATE S'TRUC'TURE OF PLANT'S.}

21. Introductory

(Anatomy and Histology).

CHAPTER I.-THE CELL.

22. The Structure and Form of the Cell . . . . . . 93

23. The Protoplasm . . . . . . . . . . 95

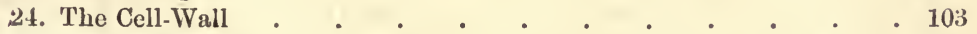

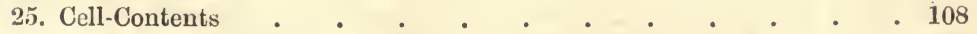

26. Cell-Formation . . . . . . . . . . . 114 
CHAP'TER II.-THE TISSUES.

27. The Connexion of the Cells

28. Intercellular Spaces . . . . . . . . . 130

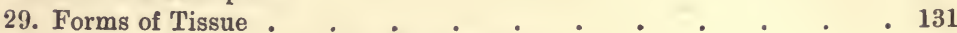

30. General Morphology of the Tissue-Systems . . . . . . 144

31. The Primary Tegumentary Tissue . . . . . . . 153

32. The Fundamental Tissue-System . . . . . . . . 159

33. The Vascular Tissue-System . . . . . . . . 170

34. Histology of the Development of Secondary Members . . . . 181

35. The Formation of Secondary Tissue . . . . . . . 191

36. Formation of Tissue in consequence of Injury _ . . . . 213

\section{PART III.--THE CLASSIFICATION OF PLAN'TS.}

Introductory

GROUP I. THALLOPHYTA . . . . . . . . 220

Class I. Algæ . . . . . . . . . . . 221

Sub-Class I. Cyanophyceæ (Phycochromaceæ) . . . . 231

Order 1. Chroococcaceæ • • • • . • • 233

„ 2. Nostocaceæ . . . . . . . . . 233

"3. Oscillariaceæ . . . . . . . . 233

„ 4. Rivulariaceæ . . . . . . . . 233

"5. Scytonemaceæ • • . • . . . . 233

Sub-Class II. Chlorophyceæ $\quad$. $\quad$. $\quad$. $\quad$. $\quad . \quad 234$

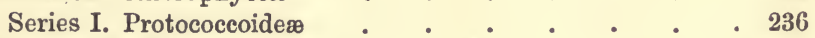

Order 1. Pleurococcaceæ . . . . . . . 236

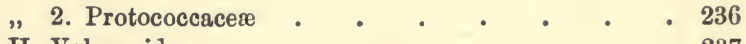

Order 1. Chlamydomonadacer . $\quad . \quad$. $\quad 237$

„2. Volvocaceæ . . . . . . . . . 237

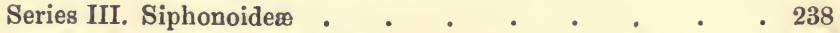

Order 1. Siphonaceæ. . . . . • . . . 238

" 2. Cladophoraceæ . . . . . . . 241

"3. Hydrodictyaceæ . . . . . • . 242

Series IV. Confervoideæ . . . . . . . . 243

Urder 1. Conjugatæ . . . . . . . . . 244

"2. Ulothrichaceæ . . . . . . . 246

" 3. Chætophoraceæ . . . . . . . 247

" 4. Ulvaceæ $. \quad . \quad . \quad . \quad . \quad . \quad . \quad .248$

" 5. Edogoniacer . . . . . . . 248

" 6. Coleochætacer . . . . . . . . 249

Series V. Charoideæ . . . . . . . . 251

Order 1. Characeæ . . . . . . . . 251

Sub-Class III. Phæophyceæ . . . . . . . . 255

Order 1. Syngenetice . . . . . . . 257

2. Diatomaceæ . . . . . 2.58

Series (a). Phæosporeæ . . . . . . . . . 258

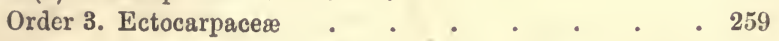


Order 4. Encœliaceæ

„5. Laminariace

"6. Cutleriaceæ .

Series (b). Phæogamæ

Order 7. Tilopteridace

, 8. Dictyotaceæ.

9. Fucaceæ

Sub-Class IV. Rhodophycer

Series I. Nemalioninæ

Order 1. Helminthocladiacex

, 2. Lemaneaceæ

,, 3. Gelidiaceæ .

Series II. Gigartinina

Order 4. Gigartinaceæ . $\quad 272$

" 5. Rhodophyllidaceæ $\quad$ • . . . . . 272

Series III. Rhodymeninæ • . . . . . . . . 272

Order 6. Sphærococсасеæ . . . . . . . $27 \%$

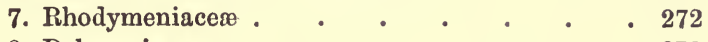

" 8. Delesseriaceæ . . . . . . . 272

, 9. Bonnemaisoniaceæ . . . . . . 272

"10. Rhodomelaceæ . . . . . . . 272

„, 11. Ceramiaceæ. • • • • • • . 272

Series IV. Cryptoneminæ . • • • • • • . 272

Order 12. Glœosiphoniaceæ . . . . . . . 272

"13. Grateloupiaceæ . . . . . . . 272

"14. Dumontiaceæ . . . . . . . 272

" 15. Nemastomaceæ . . . . . . . . 272

" 16. Rhizophyllidaceæ . . . . . . . 272

" 17. Squamariaceæ . . . . . . . . 272

„18. Corallinaceæ $\quad . \quad$. . . . . 272

Scries V. Porphyrinæ . . . . . • . . 272

Order 19. Bangiaceæ . • . . • • . , . 272

Class II. Fungi

Sub-Class I. Schizomycetes . . . . . . . . 280

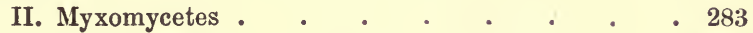

III. Phycomycetes .

Section A. Zygomycetes . . . . . . . . . 285

Order 1. Chytridiaceæ . . . . . . . . 285

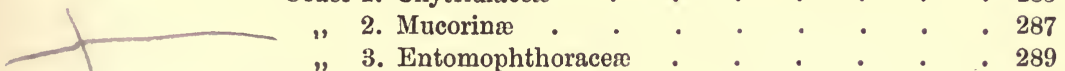

Section B. Oomycetes . . . . . . . . 290

Order 1. Ancylistacer . . . . . . . . 290

2. Peronosporaceæ . . . . . . . . 291

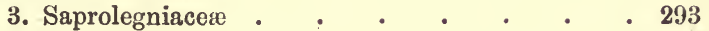

Sub-Class IV. Ascomycetes . . . . . . . . $\quad$. 294

Order 1. Gymnoasceæ . . . . . . 300

„2. Pyrenomycetes . . . . . . . . 301

"3. Discomycetes . . . . . . . . 302

Sub-Class V. Ecidiomycetes . . . . . . . . 303

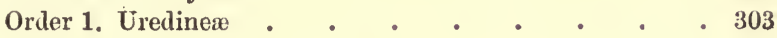


Order 2. Ustilagineæ .

Sub-Class VI. Basidiomycetes

Series I. Protobasidiomycetes .

II. Autobasidiomycetes .

Order 1. Hymenomycetes.

,2. Gasteromycetes

Subsidiary Group. Lichenes .

GROUP II. BRYOPHYTA (MUSCINEE) . • • • • . 324

Class III. Hepaticæ (Liverworts) . . . . . . . 333

Order 1. Marchantiaceæ . . • . . . 336

„2. Jungermanniaceæ • • • . . . 343

3. Anthocerotaceæ • • • • • • . 352

Class IV. Musci (Mosses) . . . . • . • . 354

Order 1. Sphagnaceæ $• . \quad . \quad . \quad . \quad 363$

, 2. Andreæaceæ . . . . . . . . 365

" : 3. Archidiaceæ . . . . . . . 366

, 4. Bryineæ . . . . . . . . 367

GROUP III. PTERIDOPHYTA (VASCULAR CRYPTOGAMS) • . 372

Class V. Filicinæ . • • • • • • . • . 381

Sub-Class. Eusporangiatæ . . . . . . . . 381

Homosporeæ.

Order 1. Ophioglossaceæ . . . . . . . . . 381

, 2. Marattiaceæ $\quad$. $\quad$. $\quad . \quad$. $\quad .383$

Heterosporeæ.

"3. Isoetaceæ . . . . . . . . 384

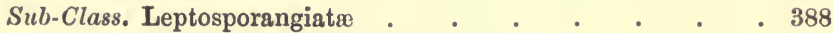

Homosporeæ (Filices) . . . . . . 388

Order 1. Hymenophyllaceæ . . . . . . 404

" 2. Polypodiaceæ . . . . . . . 404

", 3. Cyatheaceæ . . . . . . . . 405

"4. Gleicheniaceæ . . . . . . . 405

" 5. Schizæaceæ. . . . . . . . . . 406

" 6. Osmundaceæ $\quad$. $\quad . \quad$. . . . . . 406

Heterosporeæ (Hydropterideæ) . . . . 406

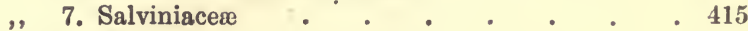

" 8. Marsileaceæ . . . . . . . . . 415

Class VI. Equisetinæ . . . . . • . . . 416

Order 1. Equisetaceæ . . . . . . . . 416

Class VII. Lycopodinæ . . . . • . . . 421

Sub-Class. Homosporeæ . . . . . . . . 421

Order 1. Lycopodiacere . . . . . . . 421

"2. Psilotaceæ . . . . . . . . 425

Sub-Class. Heterosporeæ . . . . . . . . 426

Order 3. Selaginellace $\quad$. $\quad . \quad$. $\quad . \quad$. 426 


\section{PART I.}

\section{MORPHOLOGY.}

Introductory. The province of morphology is the study of the form of the body of plants, including the development of the body, the segmentation of the body into members, and the form and mutual relations of the members, as also the intimate structure (Anatomy and Histology) of the body and its members in so far as structure throws light upon the morphology of any part of the body. It is an essentially comparative study: it classifies into categories the members of a plant, or those of various plants, according to their morphological nature, that is, according to the mode and relations of their development. Each category consists of homologous members; of members, that is, which essentially agree in the mode and relations of their development; or, in other words, which are more or less nearly equivalent morphologically, because they are of common descent.

There are various degrees of Homology, that is, of morphological relationship. - General homnlogy exists between hornologous members when the one is not the precise equivalent of the other; for instance, the sporogonium of a Moss is generally homologous with a Fern-plant; and again, the sporangium of Lycopodium, being borne singly on a sporophyll, is generally homologous with all the sporangia, collectively, borne on a sporophyll of an Osmunda. Special homology exists between two homologous members when the one is the precise equivalent of the other. When this is true in detail, the special homology is said to be complete : for instance, the foliage-leaves, the perianth-leaves, and the sporophylls of a Phanerogam are all specially homologous, they all belong to the one category, leaves; but complete special homology can only exist between the members of each sub-division of the category, between foliage-leaf and foliage-leaf, perianth-leaf and perianth-leaf, and so on. The special homology is incomplete when the members compared present differences in detail; thns between foliage-leaves, perianth-leaves, and sporophylls there exists incomplete special homology; or again, the sporangia of eusporangiate plants are incompletely homologous with those of leptosporangiate plants. Members may have both their general and their special homologies; thus whilst the sporangium of a Lycopodium is generally homologous with all the sporangia on the sporophyll of an Osmunda, it is specially homologous with each individual sporangium. Homologous members are termed the homologues of each other.

Morphology does not, however, include the consideration of the v. S. B. 
functions of the various members of the body, except in so far as the form or other morphological characters of any member may be affected by special adaptation to the performance of some particular function.

For instance, foliage-leaves and sporophylls are specially homologous; but their special homology is incomplete on account of the differences in form, due to special adaptation to their functions, which they respectively present. In this case essentially similar members come to differ widely :-in other cases, essentially dissimilar members come to resemble each other. For instance, tendrils are climbing-organs, and are all much alike; but they may be of very different morphological value; either modified branches, or leaves, or parts of leaves. Tendrils, therefore, are not all homologous; but they are all analogous, that is, whatever their morphological value may be, they are modified in the same direction for the performance of the same function. Similarly the flattened stem-segments of Opuntia, and the phylloclades of Ruscus, are the analogues of foliage-leaves; and again, the subterranean shoots of Psilotum, and the submerged leaves of Salvinia, being absorbent organs, are the analogues of roots and of each other.

From the purely morphological standpoint of development and mutual relation, the various parts of a plant are regarded as members of the body; whilst from the physiological standpoint of function, they are considered as organs of the body, each being specially adapted for the performance of some particular kind of work. The more clearly the members of the body are marked off from each other, and the greater the variety of them, the higher is the degree of morphological differentiation which the body presents; similarly, the more special the adaptation of the organs, and the greater the variety of them, the more complete is the physiological differentiation, or the division of the physiological labour, of the body.

A remarkable fact in the general morphology of plants, is that they are more or less polymorphic: that is to say, a plant assumes, as a rule, at least two different forms in the course of its lifehistory. Most commonly it presents but two forms which, while they may differ more or less widely in form and structure, differ essentially in that the one, termed the sporophyte, bears asexual reproductive organs which produce certain asexual reproductive cells, termed spores, each of which is capable by itself of giving rise to a new organism; whilst the other, the gametophyte, bears sexual reproductive organs, which, as a rule, produce sexual reproductive cells, termed gametes, which, though each is by itself incapable of giving rise to a new organism, yet by their fusion in 
pairs form cells, of the nature of spores, from each of which a new organism can be developed. These two forms alternate more or less regularly in different plants, the asexually-produced spores of the sporophyte giving rise to gametophytes, the sexuallyproduced spores of the gametophyte giving rise to sporophytes. Such a plant is dimorphic, and its life-history presents an alternation of generations, that is, an alternation of a 'sexual with an asexual form.

A typical instance of such alternation of generations is afforded by the lifehistory of a Moss. The sexual generation (gametophyte) is the moss-plant bearing the sexual reproductive organs, male (antheridium), and female (archegonium), of which the former produces $m$ ule reproductive cells (spermatnzoids), the latter a single female cell (oosphere). As the result of the fusion of the male cell with the female cell (sexual process), a cell, the oospore, is produced which is the origin of the asexual generation (sporophyte) known as the mosssporogonium. The sporogonium produces spores asexually, which, on germination, each give rise to a (at least one) moss plant (gametophyte). The gametophyte is thus always developed from a spore produced asexually; the sporophyte, from a spore produced sexually.

This kind of life-history obtains in the majority of plants, but it may be complicated in various ways. Thus, the sexual generation may be represented by two distinct forms, the one male (androphyte), the other female (gynophyte). Again, in some of the lower plants, the gametophyte also gives rise asexually to spore-like reproductive cells (gomidia), which do not, however, enter into the alternation of generations, for they give rise, not to sporophytes, but to repetitions of the gametophyte. The sporopbyte also may similarly repeat itself, though not always in exactly the same form. Further, it occasionally happens that the gametophyte does not actually produce sexual organs or cells at all, though it is essentially capable of doing so ; and successive generations of such gametophytes may be developed by means of gonidia, until at length one arises which is actually sexual. Such non-sexual gametophytes are designated potential gametophytes.

Without entering into detail, the general morphological relations between the two generations may be briefly considered. In the case of the Moss, the morphological differentiation of the sporophyte is, on the whole, not much lower than that of the gametophyte. In the approach to morphological equality between the two generations, the Mosses occupy a central position in the vegetable kingdom. For in all plants higher in the scale than Mosses, the morphological differentiation of the sporophyte is far higher than that of the gametophyte; whilst in plants lower than the Mosses, the gametophyte is, as a rule, more highly differentiated than the sporophyte. In other words, whereas in the higher plants, the sporophyte is the form to which the name 
has been given, and on which classification is based, in the Mosses and the plants below them, it is to the gametophyte that the name has been attached, and it is upon its characters mainly that the classification of these plants depends.

At this point the question naturally arises as to the morphological relation, if any, which may exist between the members of a gametophyte and those of a sporophyte. Since, speaking generally, the morphological differentiation of the one form has proceeded along the same lines as that of the other, a certain correspondence exists between their members. For instance, a foliage-leaf of a Moss (gametophyte) corresponds to that of a Fern (sporophyte); for, in the forms to which these leaves respectively belong, they stand in essentially similar relations, both of development and position, to the other members of the body. But the correspondence does not amount to relationship, and cannot be regarded as constituting homology as defined above (p. 1). It is, however, permissible, to this extent, to institute comparisons between the various members, reproductive organs, etc., of the two generations.

The consideration of the polymorphism of plants is a most important preliminary to the study of their morphology, inasmuch as this knowledge facilitates precision of statement, and prevents that comparison of like with unlike which has been so common in this department of Botany. For instance, since the sporophyte and the gametophyte of one and the same plant are generally very different from each other, it conduces to clearness if, when reference is made to the morphology of any plant, it be definitely stated to which form of it the reference applies. And again, it is impossible to institute sound morphological comparisons between the members of different plants unless it is clearly understood to which form, whether sporophyte or garnetophyte, the members to be compared belong in each case.

The most fundamental preliminary consideration is, however, this - that the body of a plant consists essentially of a mass, larger or smaller, of living substance known as protoplasm. The body may consist simply and only of protoplasm, without any investing membrane to give it a determinate form (e.g. Myxomycetes); or it may consist of protoplasm enclosed by a membrane (e.g. Phycomycetous Fungi and Siphonaceous Algæ); or it may consist, as is generally the case, of a mass of protoplasm segmented by partition-walls into structural units termed cells. In all these possible cases, however, the form and segmentation of the body 
is determined by the protoplasm; for the cell-walls, of which, in many cases, the body largely consists, and which give to it its form, are developed from and by the protoplasm. Hence the study of the morphology of plants is the study of the processes and results of the formative activity of their protoplasm; and these are to be traced both in the variety of form presented by different plants, and in the various stages in the development of any one individual plant.

\section{CHAPTER I.}

\section{GENERAL MORPHOLOGY.}

$\S 1$. The Segmentation of the Body. The body of a plant may be either segmented into members, or unsegmented. The members of a segmented body may either be all similar, or they may be similar and dissimilar. Segmentation into similar members is termed branching.

When the body is unsegmented, or segmented only into similar members (i.e. branched), it is termed a thallus. A plant of this constitution is termed a Thallophyte.

The primary segmentation of the body into dissimilar members consists in the differentiation of shoot and root. A plant of this constitution is termed a Cormophyte.

The Root is usually segmented, but only into similar members : it occasionally gives rise to (adventitious) shoots.

The Shoot may be either unsegmented, or segmented into similar or dissimilar members. A shoot which is either unsegmented, or segmented only into similar members, is termed a thalloid shoot. A shoot which is segmented into dissimilar members presents an axial member, the stem, bearing dissimilar lateral members, the leaves; stem and leaf may be further segmented into similar members, that is, be branched; such a shoot is termed a leafy slioot.

Though the ideas of shoot and root are correlative, the one involving the other, yet there are cases in which the body consists of shoot only, the root being suppressed; as in the gametophyte of Mosses ; in the sporophyte of Salvinia and Psilotum among Vascular Cryptogams; and in Utricularia, Epipogon, and Corallorhiza amoug Phanerogams. In many plants no root is developed until after the stem and leaves have begun to appear. The shoot, in these cases, is recognized as such, and is distinguished from a thallus, by being differentiated into stem and leaves. 
Three main types of morphological constitution may be distinguished:-

1. The body is a thallus.

2. The body consists of root and thalloid shoot (two dissimilar members).

3. The body consists of root and leafy shoot (three dissimilar members).

These members frequently bear others of secondary morphological importance, such as hairs, prickles, and reproductive organs.

In highly organised plants the members can, as a rule, be readily distinguished from each other; but in some cases there is difficulty in distinguishing between leaves and branches of the stem, between leaves and hairs or prickles, between roots and branches of the stem, etc. This difficulty is especially great in the study of less highly organised forms (e.g. gametophytes of Algæ, Muscineæ, and Pteridophyta), in which, whilst there is a certain degree of morphological differentiation, it is insufficient to obviously indicate the morphological nature of the members. In such doubtful cases an investigation of the development, relations, and structure of the member in question is the only method of arriving at a conclusion as to its morphological nature. For the principal members of the plant, stem, leaf, root, occupy certain definite relative positions and present a general co-ordination of structure, and are thus distinguishable from appendages such as hairs, ete. Moreover, their relative positions serve to distinguish them from each other; and thongh co-ordinate in structure, that is, presenting a corresponding degree of complexity of internal structure, yet they generally present distinguishing peculiarities in the details.

The morphological characteristics of the principal members are briefly these :-

The shoot bears the true (spore-producing) reproductive organs. It is frequently differentiated into stem and leaf.

The stem is the axial member of the shoot, and bears the leaves.

The leaf is the lateral member of the shoot; it is borne upon the stem, but usually differs from it in form and details of structure, though stem and leaf are co-ordinate in structure.

The ideas of stem and leaf are correlative, the one involving the other; nevertheless, in some cases (e.g. Ruscus, Cacti, etc.) in which leaves are, apparently, not present, the axis is still termed a stem, because the shoot of such 
plants is differentiated into stem and leaf at some stage of development, though not in the adult stage; in many such plants, members which accord with the preceding definition of the leaf are present, though they do not present the appearance characteristic of foliage-leaves.

The root never bears true (spore-producing) reproductive organs. Like the stem, it is an axis, and it is co-ordinate with the stem in structure, but it does not bear leaves, and its structure presents certain characteristic peculiarities.

It occasionally happens that one member may directly assume the characters of another. Thas, stems sometimes assume the form of foliage-leaves; and roots have been observed to bear leaves, becoming, in fact, leafy shoots, in Anthurium longifolium and Neottia Nidus-Avis.

$\S 2$. Symmetry of the Body and of the Members. Whatever the form of the body or of a member, it has three axes at right angles to each other. When these are all three equal, the body is a sphere (Hæmatococcus, Volvox, etc.) ; when two are equal, and both longer than the third, the body or the member is a flattened circular expansion (e.g., Pediastrum, Coleochoete scutata); when one is longer than either of the others, the body or the member is cylindrical or prismatic when the two shorter axes are equal, and flattened when one of the shorter axes is longer than the other.

In most cases two opposite ends are distinguishable in the body or member, a base and an apex. The base is in all cases the end by which the body is attached to the substratum, and the members to each other, the free end being the apex. The axis joining the base and the apex is distinguished, whether or not it be longer than the other axes, as the organic longitudinal axis. When the body has no distinction of base and apex, there is no organic longitudinal axis; but in cases of this kind (e.g. the filaments of Spirogyra) the longest axis is taken as the longitudinal axis.

Any section, real or imaginary, made parallel to the longitudinal axis, is a longitudinal section; it is a radial longitudinal section if it includes the longitudinal axis; it is a tangential longitudinal section if it does not include it. A section made at right angles to the longitudinal axis is a transverse section; the section of the longitudinal axis is the organic centre of the transverse section, and it commonly is also the geometrical centre of the transverse section, but occasionally the organic and the geometrical centres do not coincide. Thus, in transverse sections of tree-trunks, 
the annual rings are comparatively rarely arranged symmetrically around the geometrical centre. The longitudinal axis, then, is a line passing through the organic centres of the successive transverse sections.

Two kinds of symmetry may be distinguished; the multilateral, including the radial; and the bilateral, including the isobilateral and the zygomorphic. The determination of the nature of the symmetry of a body or member depends upon $(a)$ its external form, (b) the arrangement and form of the members which it may bear, $(c)$ its internal structure.

1. Multilateral and Radial Symmetry.

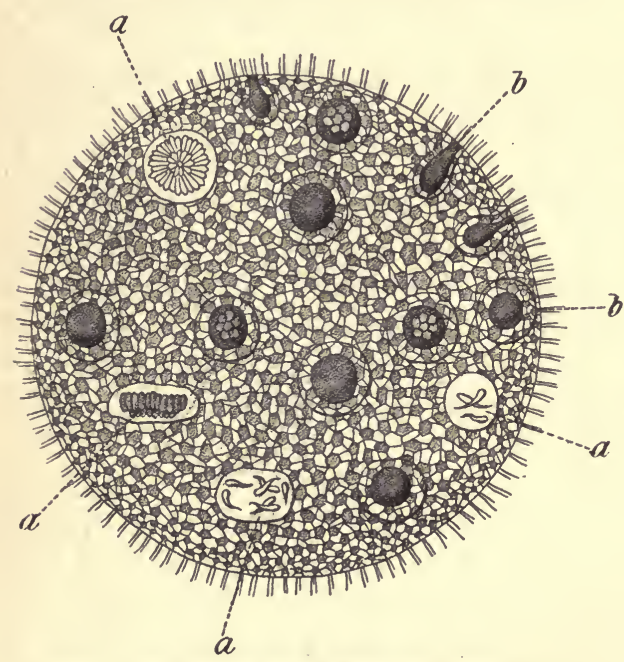

FiG. 1.-Volvox Globator (after Cohn; x about 100), illustrating multilateral symmetry.
Absolute multilateral symmetry is only presented by a body or member which is spherical and has no distinction between base and apex. For example, the body of Volvox can be divided into symmetrical halves in any plane passing through the centre (Fig. 1.).

The more limited form of multilateral symmetry, which may be conveniently distinguished as radial, is that which obtains in cylindrical bodies

or members. It is multilateral symmetry about the longitudinal axis. In this case the body of member can be divided in various planes along the longitudinal axis into a number of similar halves.

A mushroom with a central stalk, an apple, a cylindrical treetrunk, are radially symmetrical as regards their external form.

As regards the position of the lateral members, the trunks of Firs and Spruces, with branches arising on all sides, are radially symmetrical; and, as regards the form of the lateral members, the flowers of the Rose and of the Tulip are radial (see Part III., Symmetry of the Flower). 
The transverse section usually shows complete radial symmetry of structure, at least when the member is young; it may become somewhat asymmetrical when older, as in the case of the treetrunks mentioned above.

A radial body or member can be divided by radial longitudinal sections in two or more planes, into symmetrical halves, which are to each other as an object and its image reflected in a nirror (in Fig. 2, $A$, the halves obtained by the sections $1-1,2-2,3-3$, 4-4,5-5). The possible number of such similar halves is not always the same, but it is in any case at least four. In a mushroom or a fir-stem, there are many possible planes of symmetrical section; but in a Tulip, the sections being taken through the longitudinal axis of the floral leaves, only three are possible; and
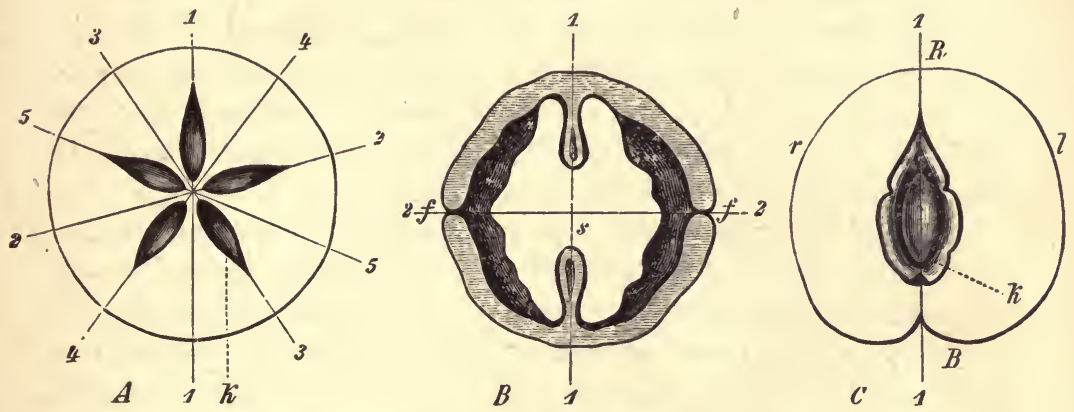

F1G. 2.-Diagrammatic transverse sections of $A$. an apple; $B$, a walnut ; $C$, a peach ; $1-1$, 5-5, are the planes of sy mmetry. A, with five planes of s5mmetry, is radially symmetrical; $k$, carpel. $B$, with two planes of symmetry, is zygomorphic; $f$, the suture; $s$, the seed. $C$, with a single plane of symmetry, is dorsiventral; $R$, dorsal surface; $B$, ventral surface ; $r$, right, and $l$, left flanks; $k$, stone.

in an apple, if they pass through the loculi of the core, only five (Fig. $2 A$ ).

The two halves are not always as exactly alike as an object and its reflected image; this is not the case, for instance, in a fir-trunk, because the lateral branches are not borne at the same level. The two halves are, however, essentially similar. When, however, a body is divisible in at least two p'anes into precisely similar halves, it is said to be polysymmetrical.

2. Bilateral Symmetry. A body or member is said to be bilaterally symmetrical when it presents an anterior, a posterior, and two lateral surfaces; the lateral surfaces, or flanks, being different from the anterior and posterior. Such a body or member is divisible into two symmetrical halves, either in two planes, or in 
one plane only; when it is so divisible in two planes, the halves resulting from the section in one plane, are different from the halves resulting from section in the other.

Bilateral members are distinguished as isobilateral or as zygomorphic (or monosymmetrical), accordingly as they are symmetrically divisible in two planes or in one plane.

a. Isobilateral Symmetry. Isobilateral symmetry is usually manifested in the external form. Thus, a walnut is at once seen to be divisible into two symmetrical halves by section, either through the suture, or at right angles to this plane (Fig. $2, B$ ); so also a flattened erect leaf like that of the Iris.

It may be manifested by the position of the lateral members; for instance, in many shoots (e.g. the Elm) the leaves are borne in two rows, right and left, one row on each flank.

It may be manifested also in the internal structure. Thus, a transverse section of a walnut (Fig. $2 B$ ) shows that internal, as well as external, isobilateral symmetry exists. But this does not obtain in all cases; the internal structure of isobilateral leaves is often not strictly isobilaterally symmetrical.

b. Zygomorphic Symmetry. A zygomorphic or monosymmetrical body or member is divisible into two similar halves in one plane only. Of this there are two principal cases:- first, that in which the anterior and posterior halres are similar, whilst the right and left halves are dissimilar, in other words, when the plane of symmetry is lateral; the body or member is then laterally zygomorphic (e.g. flower of Corydalis): secondly, that in which the anterior and posterior halves are dissimilar whilst the right and left halves are similar, in other words, when the plane of symmetry is antero-posterior; the body or member is then said to be dorsiventrally zygomorphic, or, briefly dorsiventral. Less frequently, as in some flowers (see Part III., Symmetry of the Flower), the plane of symmetry is neither lateral nor antero-posterior, but intermediate between the two, the zygomorphy being oblique.

Of these possible forms of zygomorphic symmetry the dorsiventral is the most common. The term is derived from the use of the terms dorsal and ventral to indicate, respectively, the dissimilar anterior and posterior halves of the body.

The application of the terms dorsal and ventral to the two dissimilar halves of the body or a member requires some explanation. Generally speaking the under surface of a dorsiventral body is the ventral, the upper the dorsal. In the case of leaves, however, the terms dorsal and ventral are used with reference 
to the parent stem: the upper or inner surface is here the ventral, the outer or lower, the dorsal.

The difference between the dorsal and ventral halves may be exhibited in their external form. Thus, the dorsal and ventral halves of many fruits (Peach, Fig. $2 C$; or a pea-pod) may be distinguished at once by their form. Or the difference may be in the nature of the members which they bear (Fig. 3); thus, creeping dorsiventral shoots commonly bear (adventitious) roots or root-hairs on their ventral, and branches or leaves on their dorsal surface; or the one surface may bear lateral members, and the other none. Or, finally, the difference may exist in their internal structure; thus, in dorsiventral foliage-leaves, the internal structure of the dorsal half is different from that of the ventral half.

It must not be overlooked that the terms radial, isobilateral, and dorsiventral, may be all applicable to one and the same body or member, according to the particular feature which is taken into consideration. For example, a branch of the Silver Fir is, in its general appearance, dorsiventral; a dorsal and a ventral half are readily distinguishable. But, since the leaves are arranged symmetrically around it, it is in this respect radial. Again, since the lateral branches arise right and left upon its flanks, it is in this respect isobilateral. Hence it is important to distinguish clearly between the symmetry of any

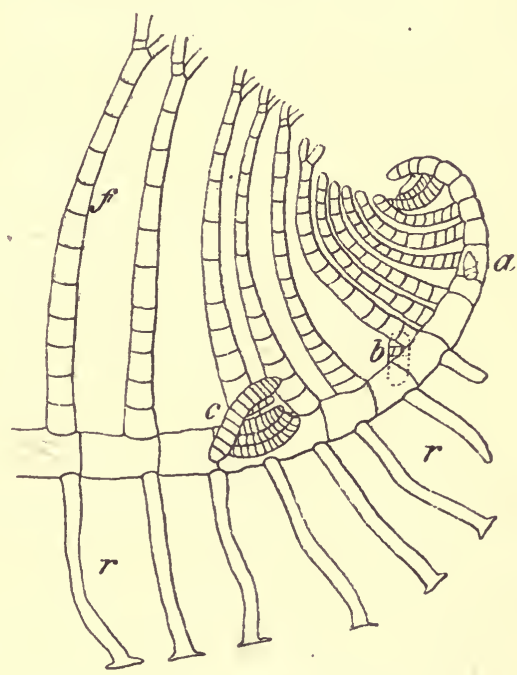

Fig 3.-Polysiphonia (Herposiphonia) (after Naegeli). To illustrate dorsiventrality. The horizontal stem bears the leaves $(f)$ on the dorsal surface; the root-hairs $(r)$ on the ventral surface; and the branches $(a b c)$ on the flanks. part of the body as a whole, and that of its constituent members. Thus in many isobilateral and dorsiventral shoots, the stem, regarded by itself, is radially symmetrical; the isobilaterality or dorsiventrality of the shoot being, in these cases, indicated only by the mode of arrangement of the leaves upon the stem.

The symmetry of a body or of a member may change in the 
course of its development. For instance, the originally radial lateral shoots of many trees and shrubs erentually become isobilateral in consequence of twisting or torsion, by which the leaves come to lie in two rows, one on each flank of the branch (e.g. Elm, Hornbeam). Again, originally radial lateral shoots may become dorsiventral. Thus, in many Coniferæ, the lateral shoots become dorsiventral, as is shown by the position and the size of the leaves. The leaves twist so that their ventral surfaces are directed upwards, and the leaves on the upper are considerably shorter than those borne on the under surface of the branch. The same thing occurs in many flowers (e.g. Epilobium); they are at first radial, but they become dorsiventral. Similarly, an isobilateral member may become dorsiventral. The most familar instance of this is the development of the dorsiventral shoot of Marchantia from the isobilateral gemma; again, many dorsiventral leaves become

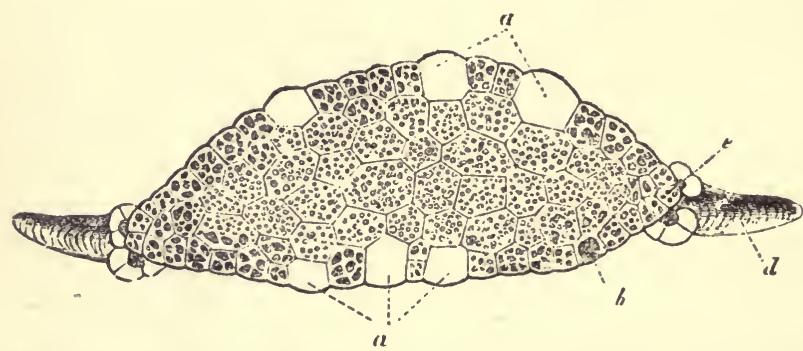

Fic. 4-Isobilateral gemma of Marchantia in tranverse section; a, celis capable of developing into root-hairs; $e$, growing point of one side; $d$, the margin of the gemma projecting on the further side of the depression in which the growing-point is situate $I$ (after Pfeffer).

isobilateral under certain conditions of exposure to light. Further, creeping shoots (e.g. Acorus and Butomus) may, in consequence of torsion, bear all their leaves on the upper (dorsal) surface, whilst the ventral surface bears roots. Again, an isobilateral member may become radial; a stem which bears leaves originally in two rows, and is therefore isobilateral, may subsequently bear leares in many rows, thereby manifesting its radial symmetry. Finally, a dorsiventral member may become radial. For instance, the fertile branches of the dorsiventral Marchantia-thallus are radial; again, the branches of Phyllocladus trichomanoides, are under ordinary circumstances dorsiventral, but if they are especially vigorons they may become radial.

The causes which determine the symmetry of the body or of a 
member are mainly inherent; but it has been ascertained in many cases that external conditions have a preponderating influence, as is well shown in the preceding instances of a change of symmetry due to the intensity and direction of the incident rays of light, or (as in certain dorsiventral flowers) to the action of gravity.

When a body or a member cannot be symmetrically divided into two similar halves in any plane whatever, it is said to be asymmetric. The asymmetry in these cases is frequently associated with dorsiventrality; as in some Mushrooms (e.g. Isenzites abietinn); in some foliage-leaves which are oblique, that is, the right and left halves of which are not symmetrical (e.g. Elm, some Begonias); and in some flowers (e.g. Aconitum, Delphinium).

$\S 3$. The Development of the Body and of the Members. It is explained in a subsequent paragraph dealing with Reproduction, that new organisms are developed either from what are termed vegetative reproductive organs, or from specialized reproductive cells termed spores: the latter case only is now considered.

There are certain important variations in the mode of development of the body from the spore. As a rule, the whole spore takes part in the development of the body; whereas in a few plants (Characeæ, Gymnosperns generally) only a portion of the spore is actively concerned in the process. In the former case the embryogeny is said to be holoblastic; in the latter meroblastic.

Again, the spore gives rise, as a rule, to an embryo which presents a

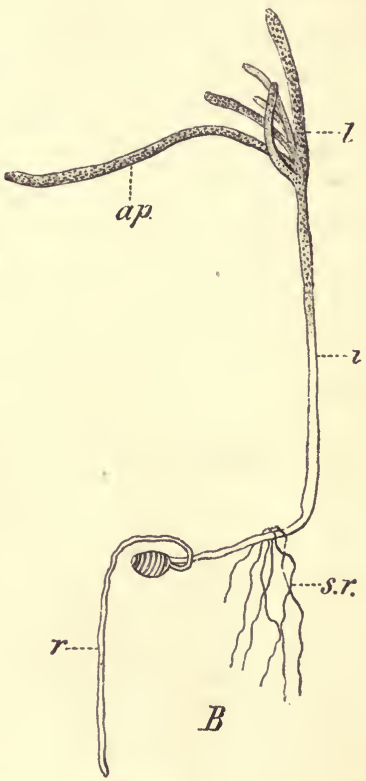

F1G. 5. Chara fragilis (after Pringsheim, $\times 4$ ). Heteroblastic embryogens : ap, apical portion of shoot of the embryo; $r$, primary root of em. bryo, springing from the loospore; $s r$, secondary roots; $l$, leaves amongst which lies the growing-point of the adult shoot.

general similarity to the adult form into which it gradually and directly developes : such an embryogeny is direct or homoblastic. But in certain cases the embryo produced by the spore differs more or less widely from the adult form, and does not directly develope into it, but bears it as a lateral outgrowth; this mode of 
embryogeny is indirect or heteroblastic. In illnstration of heteroblastic embryogeny may be mentioned the Characen, where the oospore gives rise to an embryo (sometimes termed proembryo) of limited development, upon which the adult sexual form arises as a lateral branch (Fig. 5) ; the Mosses, where the spore gives rise to a filamentous embryo (the protonema), upon which the adult Moss-plants arise as lateral branches: similarly, Lemanea and Batrachospermum among the Red Seaweeds, where the spore gives rise to a filamentous embryonic form (Chantransia-form) which bears the adult form as lateral branches. Traces, more or less distinct, of this mode of embryogeny are also to be found in the development of the prothallium of some Ferns, which, in its early stages at least, is filamentous and protonemal (see further under Filicinæ).

Whilst the foregoing striking instances of heteroblastic embryogeny all refer to the gametophyte or sexual generation, indications of a similar embryogeny are not wanting in the case of the sporophyte. Among the lower plants something of the kind is offered by Cutleria (Phæophyceæ) where, from the zygospore, a clubshaped body is developed, from which spring the flat horizontal branches constituting the sporophyte. But a more important instance is that of certain of the nigher Pteridophyta (Selaginella and Lycopodium) and of the Phanerogams generally, where the oospore gives rise, on germination, in the first instance, to a more or less elongated filamentous body termed the suspensor, at the extremity of which the embryo is eventually developed.

From these forms the transition is easy to those in which the embryo, whilst developing directly and continuously into the adult form, possesses organs which are limited in their duration to the embryonic stage: such are the foot of Muscineæ and of most Pteridophyta; the pegs or feeders of the seedlings of Welwitschia, Gnetum, Cucumis, etc.; and the primary leaves (cotyledons), though in some forms they persist for a considerable time.

Without entering at present into the details of embryogeny, it may be pointed out that there are three principal modes in which the development of the embryo from the spore may take place. There is, first, that in which the spore grows out into a filament, septate or unseptate, as generally in the Fungi, the filamentous Algr, the gametophyte of the Mosses and Ferns, the male gametophyte (pollen-tube) of Phanerogams, the sporophyte of most Phaneroga'ns (suspensor); secondly, that in which the spore grows 
at first in all dimensions and undergoes repeated division in two or three perpendicular meridian planes, thus giving rise to a body which is either a flattened expansion (e.g. species of Coleochæte); or a mass of cells (e.g. Volvox, Fucus; sporophyte of Mosses and Vascular Cryptogams); thirdly, that in which free cell-formation takes place within the spore, the cells eventually forming the body of the embryo (e.g. Hydrodictyon; female gametophyte of Phanerogams ; sporophyte of Cycadex and of Gingko).

a. The Development of the Primary Members. With regard to thallophytic plants, it suffices to state that the primary member of the thallus takes origin from the spore in one or other of the preceding modes.

In the case of cormophytic plants, the first step is the differentiation of the body of the embryo into primary shoot and the primary root.

In unseptate plants, such as the Siphoneæ (Algæ), the process of segmentation into primary shoot and root is simple; the spore merely grows out into the shoot at one end, and into the root at the opposite end. In septate plants the segmentation is in many cases clearly indicated (as in Fucus, sporophyte of most Vascular Cryptogams, etc.), by the formation of a wall, termed the basal wall, which divides the spore into two cells. From one of these, termed the epibasal cell, the shoot is developed; from the other, termed the hypobasal cell, the root is developed.

Whatever the mode in which the differentiation of the primary shoot and of the primary root takes place, the relation between them is in all cases such that their longitudinal axes form one straight line, with the growing-point of the shoot at one end, and that of the root at the other.

The segmentation of the body of the embryo into root and shoot is usually permanent, but in many plants which do not grow attached (e.g. Spirogyra, [Fig. 6], and other Zygnemex) it is only to be observed iu the early stages of development.

In some cormophytic plants no primary root is developed, e.g. gametoplyte of Mosses; sporophyte of Salvinia and Psilotum, among Vascular Cryptogams; Wolfia arrhiza, Utricularia, and Orchids, among Phanerogams.

In those cormophytes in which the shoot is differentiated into stem and leaf, the differentiation takes place at an early stage of development. The primary shoot undergoes differentiation into a primary stem, and one, two, or more, primary leaves. A primary. 
leaf which is thus contemporary in origin with the primary stem is termed a cotyledon. The cotyledons, as embryonic members, differ more or less widely in form from the ordinary foliage-leaves of the adult plant.

b. Growth. The development of the embryo into the adult organism is effected by the further growth of the primary members, and by the development of secondary members.

When the adult form is small and lowly organised, the process of growth may consist merely in a slight increase in size of the cell or cells constituting the embryo. But where the adult form is relatively large, the process of growth involves also a considerable increase in the mass of the protoplasm of the embryo. Thus, in the development of a tree such as an Oak, not only is there an

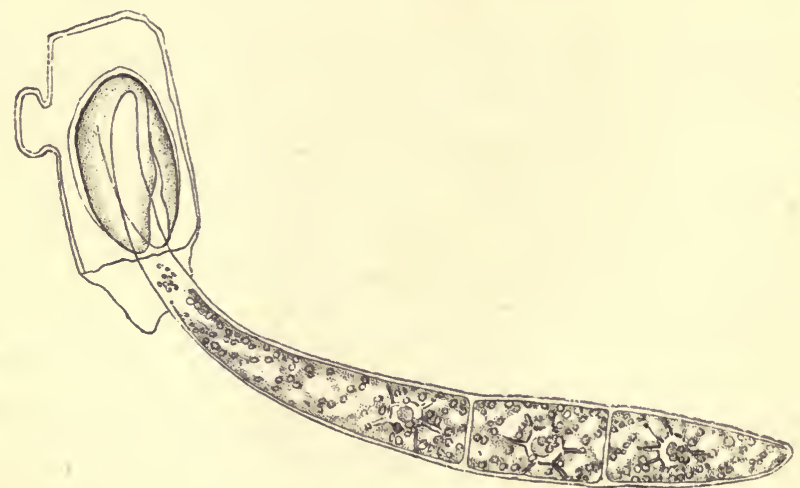

Fra. 6.-Young plant of Spirogyra, showing temporary differentiation into root and shoot; the root-end is still in the zygospore (after Pringsheim, $\times 125$ ).

increase in size of the cells of the embryo, but there is also a formation of additional protoplasm and therefore also a formation of additional cells. The formation of new protoplasm takes place at first throughout the body of the embryo, that is, interstitially, the whole protoplasm being in the embryonic condition; but gradually more or less of the protoplasm passes over into the adult condition, and in those parts no further formation of addi. tional protoplasm or cells takes place. In some cases (e.g. Volvox) the whole protoplasm passes over simultaneously into the adult condition ; but more commonly certain portions of the protoplasm remain embryonic for a longer or shorter time. These persistent embryonic regions are termed growing-points. At first they are 
near together, but as growth proceeds they become more and more widely separated by the increase in the adult portion of the body. In a few cases (e.g. Spirogyra, and some other filamentous Algæ) all the cells remain embryonic, the growth in length of the filament being effected by the transverse division of the cells and the subsequent elongation of the new cells formed.

The primary function of the growing-point is to increase the size, more especially the length, of the member to which it belongs; but where the body is segmented, the growing-points are also the seat of development of the secondary members.

The embryonic regions of the body are termed "growing-points" because they are most commonly situated at the apex of the members. Thus, in a cormophytic embryo, there is a growing-point at the apex of the primary stem, and one at the apex of the primary
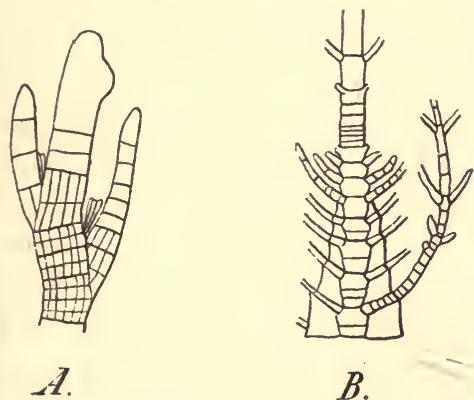

$B$.

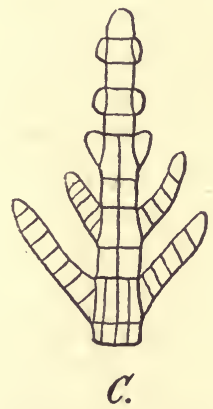

FrG. 7.-Growing-points, showing development of secondary members. $A$, apical growing point, with apical cell, of Stypocaulon scoparium $(\times 30)$. B, intercalary growing-point (where the transverse lines are close together) of Desmarestia ligulata in longitudinal section $(\times 60)$. C, apical growing-point, with apical cell, of Chxtopteris plumosa $(\times 40)$, (after Falkenberg).

root. But this is not necessarily the case. The growing-point may be situated between the base and the apex, as in some Algæ (e.g. Ectocarpus and Laminaria), and in leaves (e.g. Grasses, Onion, Iris, etc.), when it is termed an interculary growing-point. In some cases both an apical and one or more intercalary growing-points co-exist, as in the stem of Hippuris, Myriophyllum, etc.

One of the most remarkable instances of an intercalary growing-point is that occurring in connection with the development of hollow, more or less tubular structures (e.g. inferior ovaries, "calyx-tube" of Rosaceæ, gamopetalous corollas, inflorescence of the Fig. pitchered leaves of Nepenthes, Utricularia, etc.). Taking

V. S. B. 
the case of a hollow floral receptacle (whether inferior ovary or "calyx-tube"), when the apical growth of the axis is arrested, a zone of embryonic tissue lying close behind the apex gives rise to a projecting ring of tissue, which, by continued basal growth, becomes a tube enveloping the apex of the shoot. (For the case of a gamopetalous corolla, see Fig. 21, p. 37).

In the case of a body or a member which assumes a flattened expanded form, the peripheral growth is effected by the marginal cells, which remain embryonic for a longer or a shorter time; when the body or member has no definite axis of growth (e.g. gametophyte of Coleochoete scutata, and that of Anthoceros) the growth is entirely marginal ; but where there are special axes of growth (e.g. foliage-leaves, some fern-prothallia, sexual plant of Marchantiaceæ) growth takes place both marginally and by means of definite growing-points.

The occurrence of apical, intercalary, or marginal growingpoints is general; but it is only in a few cases that there is in a member a growing-point which effects growth in thickness. It is, in fact, the general rule that, when a member has attained its definitive size, it does not increase in thickness. But to this rule there are certain constant exceptions. Thus, the stems and roots of perennial Dicotyledons and Gymnosperms, as well as those of a few Monocotyledons and Pteridophyta, grow thicker year by year by means of a layer of embryonic cells, forming a hollow cylinder, and lying at some little distance within the external surface (see Part II.). This layer, unlike other growing-points, does not, however, give rise to secondary members.

In the apical growing-point of many multicellular plants, as in those of some Algæ (e.q. Sphacelaria, Chara) of the Muscineæ, and of most Pteridophyta, there is one cell, situated in the organic centre of the growing-point, and distinguished from the other embryonic cells by its size (Fig. $3 A, C$ ). This is the apical cell. In some cases there is a group of such apical cells (e.g. species of Selaginella). In these cases, all the new cells formed in the growing-point are derived from the apical cell or cells, from which, as they grow, segments are continually being cut off by cell-division.

The length of time during which a growing-point remains embryonic is not the same in all cases. It may either persist throughout the life of the plant, as is often the case in primary shoots and roots, when the growth of the member is said to be unlimited; 
or it may sooner or later pass over into the adult condition, when the growth of the member is said to be limited. Leaves usually have limited growth; occasionally roots (e.g. the primary roots of Monocotyledons), and also shoots (e.g. dwarf-shoots).

c. The Development of the Secondary Members. After the differentiation of the primary members of the embryo, all other members are developed from them and are generally termed secondary.

When the segmentation of the body is complex, various orders of members may be distinguished. Members borne directly on the primary members are said to be secondary members of the first order; those borne on secondary members of the first order are said to be of the second order, and so on.

Two kinds of secondary members may be distinguished: the normal and the adventitious. The distinction depends upon $(a)$ the place of origin, and (b) the order of development of the members. For instance, when a stem or a leaf bears a root, that root is adventitious, because secondary. roots are typically only pro-
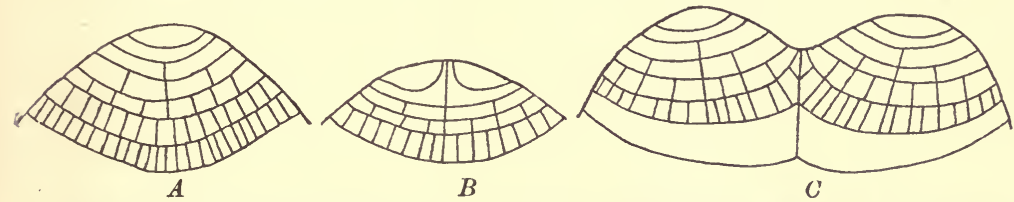

Fig. 8. -Dichotomous branching of Dictyota dichotoma (after Naegeli). A, growingpoint with apical cell before division; $B$, growing-point with divided apical cell; $C$, development of the dichotomous branches.

duced by primary roots; again, when a member is developed out of its proper order, that member is adventitious.

Secondary members may or may not be developed from the growing-point of the parent member.

The normal secondary members are developed from the growingpoint of the parent member.

The growing-point may produce secondary members either by dividing into two (dichotomy) or by lateral outgrowth.

The result of dichotomy is, in all cases, to give rise to new members, which are similar to the parent member and to each other. In no case are morphologically dissimilar members produced by dichotomy. Dichotomy is therefore a form of branching (see p. 5).

The product of lateral development may be either a similar or a dissimilar member; if the former, it is a case of lateral branching.

The normul secondary lateral members of the shoot (i.e., leaves and branches) make their appearance, in most cases, as outgrowths 
from the growing-point of the parent member, whether the growing-point be apical or intercalary (as in Ectocarpus and other Phæosporeæ (Fig. 7); in other words, they are developed exogenously. This is always true of leaves, but there are cases in which normal branches are developed from internal cells of the growing-point, and have therefore to penetrate the external layers of tissue before reaching the surface (e.g. Polyzonia, Amansia, Vidalia, Rhytiphlœa among the Red Seaweeds).

When, as is commonly the case, the leaves are formed in rapid

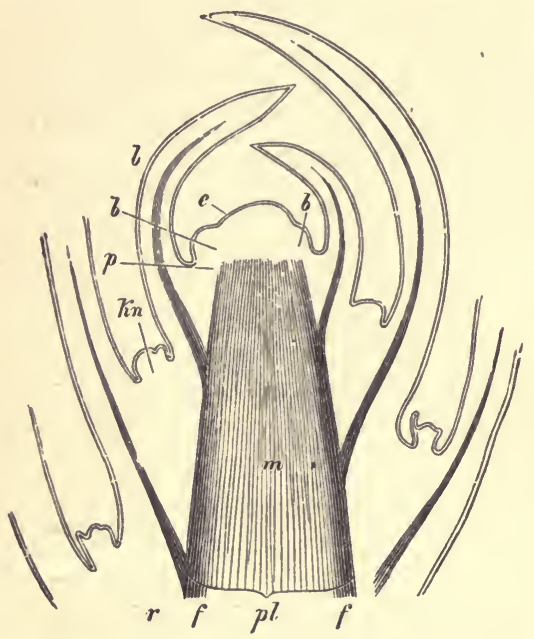

FIG. 9.-Diagrammatic longitudinal section through the growing-point of a stem; $b$, the leaves; $k n$, their axillary buds; $e$, epidermis; $f$, fibrovascular bundles ; $r$, the cortex; $p l$, plerome; $m$, pith.

first year beyond the bud-stage.

Buds may be distinguished, according to their position, as terminal or lateral; but it must be borne in mind that a bud which is lateral on the parent shoot is the terminal bud of a lateral shoot. Sometimes the primary shoot of the embryo has a terminal bud, which is designated the plumule. The terminal bud may either pass gradually over into the fully grown portion of the shoot behind it, as in the herbaceous shoots of annual plants; or it may be sharply marked off from the older part of the shoot, as may be clearly seen in the winter-buds of shrubs and trees, in consequence of the periodical arrest of the growth of the shoot. 
The point at which a leaf is developed on the stem and remains attached is termed the insertion of the leaf; and the insertion of a leaf, or those of two or more if at the same level, marks a node of the stem, and the portion of the stem, whether long or short, between two consecutive nodes is the internode. When two or more leaves are inserted at each node, or when the single leaf has a broad sheathing insertion (e.g. Grasses), the nodes of the stern are strongly marked, giving it a jointed appearance.

The normal secondary lateral members of the root are not developed directly from the growing-point of the parent root, but at some distance behind it where the tissues are already differentiated. They are developed endogenously; that is to say, the growing-point is formed by the division of one or more cells belonging to an internal layer of tissue of the parent root, so that the young root has to penetrate the cortical tissue before reaching the surface.

. Adventitious members are of frequent occurrence, and are generally not developed from the growing-point of the parent member, but their growing-points are new formations.

Adventitious branches may be developed on the margin or surface of a thallus (e.g. Metzgeria, Pellia, etc.).

Adventitious shots are commonly developed from the callus (see Part II.) which covers the cut surfaces of wounded parts (e.g. development of shoots from pieces of leaves of Begonia, Achimenes, etc.); or they may be developed, independently of any injury, on a leaf (eg. Aspidium Filix Mas, Bryrphyllum calycinum, Cardamine prutensis, etc.) ; or on a root, as in a large number of trees and other plants: the development of adventitious branches on a stem is comparatively rare (e.g. Psilotum, Begonia; some Liverworts, such as Jungermannia bicuspidata, etc.).

Adventitious shoots are, in most cases, developed exogenously; but endogenous development has been observed (e.g. in some Liverworts, in roots of Anemone sylvestris, Ailanthus glandulosa, Sium latifulium). In some cases they are formed by the direct conversion of the growing-point of a root (e.g. Neottia Nidus-Avis, Cataselum tridentatum, see p. 7).

The true adventitious shoots should be clearly distinguished from those apparently adventitious shoots which are due to the overgrowth of a normal but dormant bud (see p. 32) by the surrounding tissues (e.g. Equisetum, Gleditschia sinensis and triacanthus, Symphoricarpus vulgaris, etc.).

Adventitious roots may be developed from a callus, or from leaves 
(e.g. Cardamine pratensis), or, more commonly, from stems, sometimes from the growing-point of the stem (e.g. Isoetes, Angiopteris, etc.); they are usually of endogenous origin, but sometimes of exogenous (e.g. Nasturtium officinale, Cardamine pratensis, Neottia Nidus-Avis, Phylloglossum, Lycopodium cernuum).

In some few cases, the segmentation of a member into similar members, takes place neither by lateral nor by dichotomous development, but by an alto-

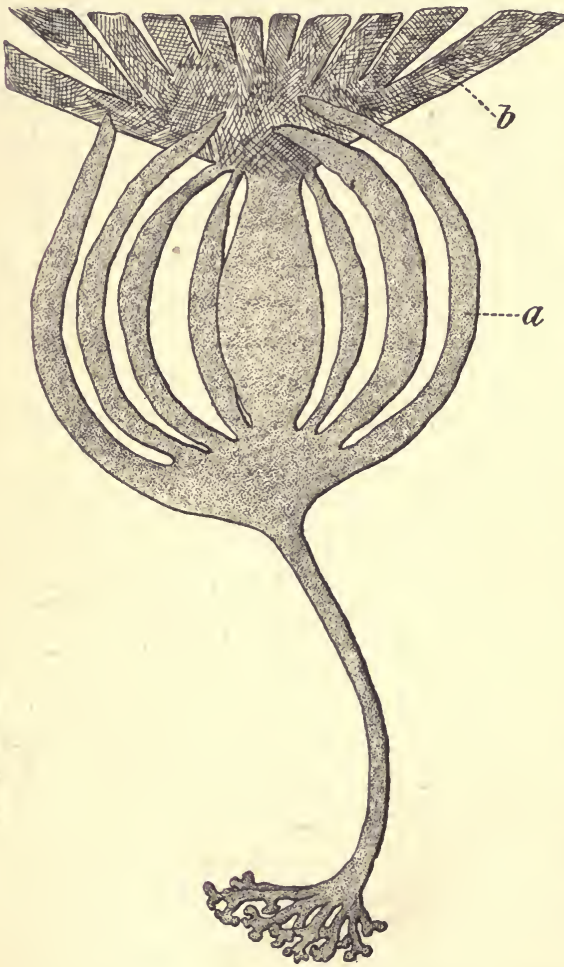

FıG. 10.-Laminaria digitata (after Harvey; much reduced). The intercalary growing-point is situated at the junction of the old frond $(b)$ with the new frond (a); $a$ is gradually splitting into segments. gether peculiar process. For instance, a portion of the fullgrown thalloid shoot of some Laminarieæ is segmented into similar members. To begin with it is unsegmented; but it gradually splits, by degeneration of rows of cells, into segments which remain united only at the base. The same thing occurs in the leaves of some Palms and Aroids (e.y. Philodendron).

The members when once formed commonly persist; but frequently they become separated and fall off after a time, when they are said to be deciduous. The most common instance is that of foliage-leares. In most perennial plants the foliage-leaves all fall off in the autumn; but in some-the evergreen trees and shrubs - the leaves, which may last for more than one year, do not all fall off at the same time. Those parts of the plant which are connected with reproduction are especially deciduous; for instance, shoots which subserve vegetative reproduction, the leaves constituting the perianth of flowers, sometimes the whole inflorescence (e.g. catkin), sometimes the fruit (e.g. cherry), seeds, etc. When a member 
thus falls off it leaves a more or less permanent scar; the scar on a node which marks the position of a fallen leaf is termed a leafscar.

Hairs and reproductive organs are generally developed as lateral outgrowths upon the members, but occasionally they are developed terminally from the apical growing-point, in some cases directly from the apical cell. They are commonly developed from one or more superficial cells, but in some cases the deeper layers of cells take part in their formation.

d. The Order of Development of the Lateral Nembers. Lateral members, with the exception of those which are developed adventitiously, are developed in a definite order. The rule is that they are developed in such an order that the youngest are nearest to the growing-point, whether the growing-point be apical or intercalary. This order is termed progressive succession.

When the growing-point is apical, the youngest lateral members are nearest the apex; this form of progressive succession is termed acropetal (see Fig. $7 \mathrm{C}$ ).

When the growing-point is intercalary (Fig. $7 \mathrm{~B}$ ), the lateral members may be developed on one side, or on both sides, of the growing-point. When the growing-point is near to the base of the parent member, the lateral members are developed above it; that is, in basipetal succession. When the growing-point is in the middle of the parent member, the lateral members are developed both above and below it.

Occasionally, particularly in the lower plants and in connexion with the production of the reproductive organs, the law of progressive succession is deviated from by the intercalary development of members between those already formed.

\section{$\S 4$. Arrangement of Lateral Members on a Common}

Axis. The relative position of members borne on a parent member, which may be conveniently designated the common axis, may be regarded from two points of view: in relation either to the long axis, or to the surface of the parent member.

In the former case, similar lateral members may arise singly, at any given level, or several together; the former is termed the scattered arrangement, the latter the whorled, the group of lateral members at the same level constituting a whorl (Fig. 11). In accordance with the law of progressive development, it may be inferred that the members of a whorl, inasmuch as they are all at the same distance from the growing-point, are all of the same age. 
This is actually true in many cases, and such whorls are said to be simultaneous. There are, however, what are termed successive whorls; whorls, that is, the constituent members of which are not developed simultaneously, but in a definite sequence (e.g. leafwhorls of Characeæ). These must not be confounded with spurious whorls, which arise in this way, that members which were originally developed at different levels, come, by subsequent displacement, so to approach each other that they appear to stand at the same level (e.g. the nppermost leaves on the stem of Lilium bulbiferum, and the so-called whorls of branches of the Coniferæ).

The arrangement of the lateral members upon the surface of the parent member is intimately connected with the symmetry

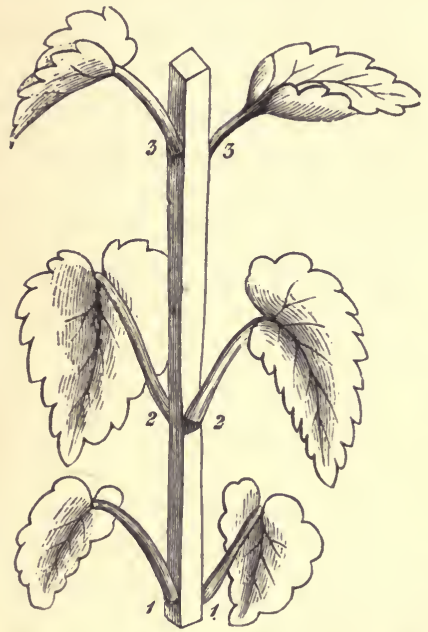

Fra. 11.-Stem of Lamium with whorld of two leaves ; 1-1, 2-2, 3-3, the succes. sive whorls. of the parent member, as already indicated in $\S 2$. The three forms of symmetry will be considered separately, regard being had exclusively to lateral members developed in progressive succession.

1. Radial Arrangement. Beginning with the whorled arrangement, it must be noticed, in the first place, that the members of a whorl are all similar, and are arranged symmetrically on the circumference of the parent member. If a whorl consists, for instance, of two members, they are placed ex. actly opposite to each other on the surface of the stem, and the distance between them, measured from the points of insertion, will amount to just half the circumference of the stem. Similarly, if the whorl consist of three or four members, the distance between any two adjacent members will be one-third or one-fourth of the circumference, and so forth. The lateral distance between the points of insertion of two adjacent members, measured on the circumference of the stem, is called their divergence, and it is expressed in fractions of the circumference.

Moreover, it is a rule, though not without exceptions, that the successive whorls alternate, so that the members of any whorl lie opposite to the intervals between the members of the whorls above 
and below it. Thus the members of alternate whorls are exactly above each other (Fig. 11).

This arrangement, as in fact all relations of position, may be very plainly exhibited by means of diagrams (e.g. Figs. 12-14). Such a diagram consists of a ground-plan of the stem, regarded as being a cone, and looked at from above : the insertion of each member will lie upon one of a series of concentric circles, and the higher the insertion of the member upon the stem, the nearer to the centre will be the circle of the diagram upon which its insertion is indicated.

It may be perceived in the diagram Fig. 12, that when the members are arranged in alternate whorls they form twice as many longitudinal series on the stem as there are members in each whorl, provided, of course, that the number of members in each whorl is the same. The longitudinal series, which are indicated in the diagram by radii, are called orthostichies.

This particular arrangement of alternate whorls of two members occurs rery frequently, and is termed the decussate arrangement. The two members of each whorl are said to be opposite.

Examples of alternating whorls are afforded by the leaves of the Characer, of Equisetum, and of Hippuris. Instances of whorls of three members are found in the leaves of the common Juniper. Decussate leaves occur in most Caryophyllaceæ, Syringa (Lilac), Lonicera (Honey-

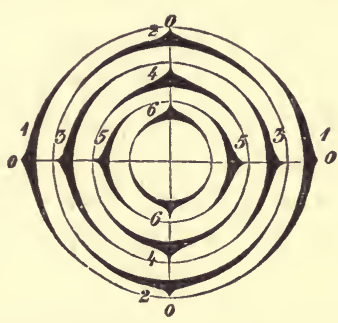

Fra. 12.-Dingram of a shoot with alternate two-leaved whorls. $0,0,0,0$, the four orthostichies. 1, 1, 2, 2, 3, 3, etc., the successive whorls. suckle), Ash, Maple; in the last named the lateral branches are also decussate.

It is comparatively rare for equal successive whorls to be superposed; that is, that the members of each whorl lie exactly above or below those of the others, so that there are only as many orthostichies as there are members in each whorl. This is the case, however, in some flowers (see Part III., Phyllotaxy of the Flower).

When the successive whorls consist of different numbers of members, as on the stem of Polygonatum verticillatum, in the flowers of Pomaceæ, etc., complicated relations of alternation are induced which need not be further considered here.

When the similar lateral members are arranged in a scattered manner it is easy to detect that, within a certain region of the 
common axis, their divergence is constant; that is, that the distance between any member and its immediate predecessor and successor is a certain fraction of the circumference. In a simple case, when the

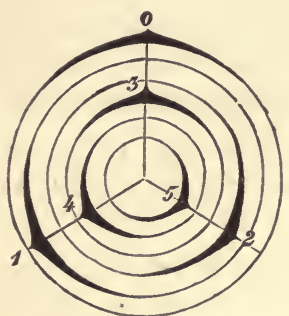

Fig. 13.-Diagram of multilaterul scattered arrangement, with divergence of $\frac{1}{3}$.

divergence is $\frac{1}{3}$ (Fig. 13), starting with any member 0 , the insertion of the next member developed in acropetal succession on the common axis, which may be numbered 1 , will be separated from that of 0 by just $\frac{1}{3}$ of the circumference, and the next member, numbered 2, will be separated from 1 by $\frac{1}{3}$ of the circumference, and 3 from 2 , and so on. Hence 3 lies directly over 0 , 4 over 1,5 over 2 , and so on; so that there are three orthostichies. In proceeding from 0 to $1,2,3$, and so on, always in the same direction, the circumference of the common axis is traversed in a spiral which, in the course of each whole turn, touches the bases of three lateral members and intersects the same orthostichy. This spiral will pass through the insertion of every lateral member, and as it does so in the order of their development, it is known as the genetic spiral. The number of lateral members throngh which the genetic spiral passes in its course between any

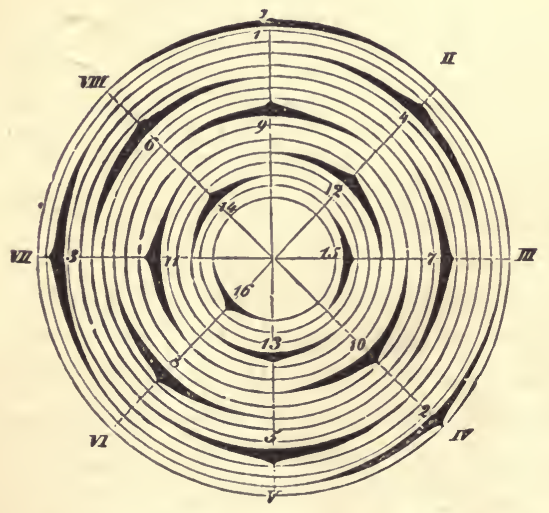

FIG. 14.-Diagram of a shoot with a constant divergence of $\frac{s}{8}$. I, II, IJI, ete., the orthostichous lines. (Alter Sachs.) two on the same orthostichy, is termed a cycle.

It might, however, be said with equal accuracy, that the divergence is ${ }_{3}^{2}$, and that by passing from member to member by $\frac{2}{3}$ of the circumference, a spiral "would be traced which connects the members in genetic sequence. But in this case two turns of the spiral would have to be traversed before returning to the orthostichy started from; i.e. the cycle will consist of two turns of the spiral instead of one. For the sake of simplicity, the spiral is not traced in this longer way, but in the shorter way. 
However, this example will serve to indicate the relation between the construction of the spiral and the fraction which is used to express the divergence. The denominator of this fraction gives the number of the orthostichies, the numerator the number of turns of the spiral in the cycle.

Another very common divergence is $\frac{2}{5}$, the geometrical conditions of which are readily intelligible. From the Figures 14 and 15 , which represent a divergence of $\frac{3}{8}$, it is easy to see that in this case there are eight orthostichies, that number 9 stands over 1,10 over 2 , and so on, and further, that the spiral passes through the insertion of a member at every third orthostichy, and turns three times round the axis in the course of one cycle.

If, for instance, it is required to determine the arrangement of the leaves (phyllotaxis) on a stem, it is necessary to find the leaf which is exactly above the one, numbered 0 , selected as a starting-point, and then to count the number of leaves which are met with in following the shorter spiral round the stem between these two leaves. The number of the leaf which lies in the same orthostichy is the denominator of the fraction of divergence, and the numerator is the number of turns made by the spiral between the two leaves.

When the number of orthostichies is greater than eight, it becomes very diffcult to detect them, particularly when the lateral members are closely arranged, as the leaves in the rosettes of the House-leek, as the flowers in the capitulum of the Sunflower, or as the scales in a fir-cone. Another set of lines, lying obliquely, then strike the eye, called parastichies, which also run round the stem in a spiral, but touch only some of the lateral members; for instance, in Fig. 15, a line which con-

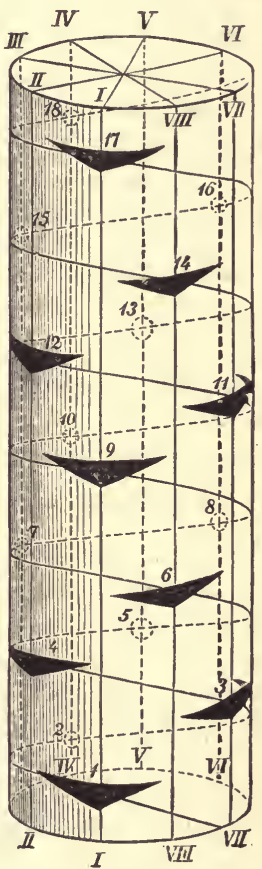

Fig. 15.-Diagram of an axis, the lateral members of which have the constant divergence of $\frac{3}{8}$; those of the anterior surface are indicated by their insertions, those of the posterior by circles; they are connected by the genetic spiral. I, I, II, III, etc., are the eight orthostichies. nects the nembers $3,6,9$, and 12 . It is evident that the number of parallel parastichies must be as great as the difference between 
the numbers of the members in any one such line. Thus in Fig. 15, again, another parastichy connects the members $2,5,8,11$, and so on; and a third, the members 1, 4, 7, 10, etc. From this it is possible to deduce a simple method for ascertaining the arrangement in complicated cases; the parastichies which run parallel in one direction are counted, and the members in one of them are numbered according to the above-mentioned rule; by repeating the process in another system of parastichies which intersects the first, the number of each member will be found.

As an illustration:-In Fig. 15 there are three left-hand parastichies; taking the members of any one of them, we mark the first 1 , the second 4 , and so on:' there are two right-hand parastichies; so beginuing with the member already marked 1 , we mark the next 3 , the next 5 , and thus complete the nunbering of the members. Having numbered them, it is at once apparent that 9 is ou the same orthostichy as 1 , and that the divergence is $\frac{3}{8}$.

The commonest divergences are the following :

$$
\frac{1}{2}, \frac{1}{3}, \frac{2}{5}, \frac{3}{8}, \frac{5}{13}, \frac{8}{21}, \frac{13}{3} \text {. }
$$

This series is easy to remember, for the numerator of each fraction is the sum of those of the two preceding, and it is the same with the denominators. There are, however, divergences which do not enter into this series, namely $\frac{1}{4}, \frac{2}{7}, \frac{2}{9}$, etc.

As examples of the divergence $\frac{1}{3}$, the leaves of many Mosses, of the Sedges, and the leaves and branches of the Alder, may be mentioned : 2 is a very common divergence for leaves on herbaceous stems, and those of Willows, Oaks, etc. $;$ the needle-like leaves of Firs and Spruces have commonly the divergences $\frac{3}{8}$ and $\frac{5}{13} ; \frac{8}{21}, \frac{13}{3}$, occur in pine-cones, in the capitula of mauy Compositæ, etc.; the leaves of some Algæ, such as Polysiphonia, have the divergence 1 .

It has been already pointed out that these laws of position stand in the closest relation to the progressive development of the lateral members. It can be demonstrated that the relation of position, when once established, is maintained, for each new lateral member arises just at the spot on the growing-point where there is the greatest amount of space between the members already formed, and that it thus falls into the order which its predecessors have established. So long as the relation of size between the rudiments of the lateral members and the surface of the common axis remains constant, the divergence likewise remains constant; but if the former condition be altered, if, for example, the newly developed members are smaller than their predecessors, it will be readily understood that the number of orthostichies and parastichies must 
be increased. Hence we find changes in the divergence taking place just in those regions in which the size of the lateral members alters, for instance, at the base and at the apex of pine-cones, and at the base of the inflorescences of Compositæ. Furthermore, subsequent alterations may be induced by growth, either of the axis or of the developing lateral members.

2. Isobilateral Arrangement. Isobilaterally arranged similar lateral members arise on two diametrically opposite sides of the common axis, and thus form two rows or orthostichies. Usually the members of the two rows arise at different levels, so that they alternate (Fig. 16). In this case, also, it is possible to construct a genetic spiral; and it will be such, that at every half-turn it passes through the insertion of a lateral member, and connects all the existing members in the order of their age. It is obviously quite immaterial in which direction this spiral may be traced. Examples of alternate arrangement are afforded by the leaves of many Mosses (Fissidens) and Ferns, the leaves and branches of many trees such as Elm, Hornbeam, Lime, and the leares of

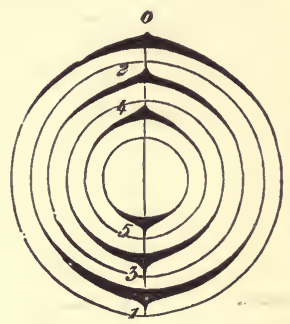

Fig. 16. - Diagram of alternating distichous $\left(\frac{1}{2}\right)$ arrangement. the Grasses. It is only rarely that the members of the two rows stand in pairs at the same level, thus forming superposed whorls of two members each; this is the case with the leaves of some Algæ (Pterothamnion), and of many Naiadeæ, in the latter, probably in consequence of subsequent displacement.

3. Dorsiventral Arrangement. This arrangement of lateral members may be manifested in very different ways. In some cases the common axis bears lateral members on one side only; in others, the common axis bears dissimilar lateral members on its different sides. As examples of the former, the flowering shoots of Vetches and their allies, which bear flowers on one side only, may be mentioned, as also the thallus of Marchantia and similar Liverworts which bear scales and root-hairs on the rentral surface only. The stem of Marsilia is an example of the latter; it bears leaves on the dorsal surface, lateral branches on the flanks, right and left, and roots on the ventral surface: this relation holds good also in the case of Azolla and Pilularia, and in Caulerpa among Algæ. In Salvinia the dorsal surface of the stem bears the foliage-leaves, the flanks the branches, and the ventral surface the aquatic leaves; 
in Selaginella, likewise, the leaves are borne on the dorsal and ventral surfaces, and the branches on the flanks. In Utricularia, and in the inflorescences of the Boragineæ, the branches are borne on the dorsal surface, the leaves (when present) on the flanks. In the Lemnaceæ, the branches are produced on the dorsal, the roots on the ventral, side of the shoot.

The members borne on the flanks, in these cases, are in rows, one on each flank; and a similar serial arrangement can usually be traced in the members borne on the dorsal and ventral surfaces. Thus, in the inflorescences of the Boragineæ, the flowers are arranged in two longitudinal rows; in those of the Vetches there may be two rows (Vicia Faba, commonly), or many rows (Vicia Cracca). The leaves of some Algæ such as Caulerpa (Fig. 17) and

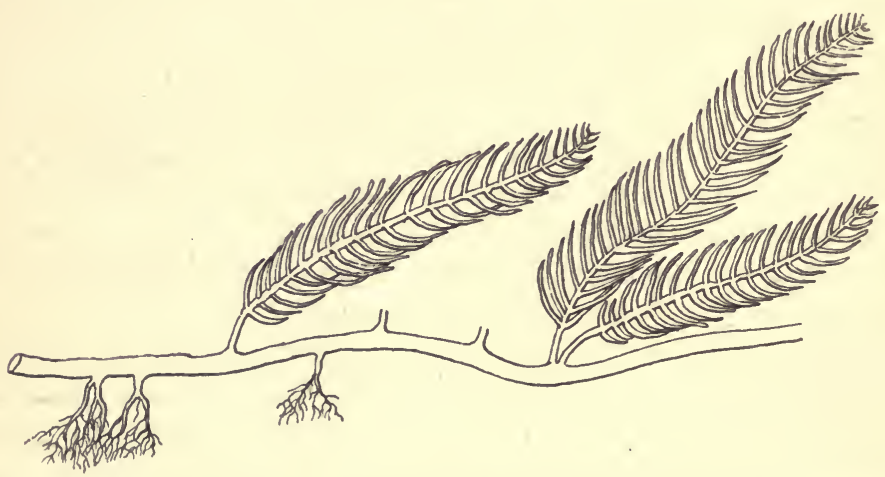

Fig. 17. A portion of the body of Caulerpa plumaris showing dorsiventral arrangement of members. The horizontal stem bears leaves on its upper (dorsal) surface, and roots on its lower (ventral) surface.

Herposiphonia (Fig. 3) are borne in one row on the dorsal, and the roots in one row on the ventral surface of the stem; similarly in some Ferns (Lygodium palmatum, Polypodium Heracleum) there is a single dorsal row of leaves. In Azolla, Pilularia, and Marsilia, there are two dorsal row of leaves, in Selaginella there are two ventral and two dorsal rows of leaves, and in Salvinia two ventral and four dorsal rows.

The whorled arrangement is not excluded by dorsiventrality : for instance, in Salvinia, the leaves are arranged in alternating whorls of three, two of the leaves being borne dorsally, and the third ventrally, and thus the four dorsal and the two ventral rows of leaves are produced. 
The affinity between the dorsiventral arrangement and the isobilateral is indicated by the fact that many axes develope their lateral appendages on their flanks, though they eventually come to be dorsal. For instance, the creeping shoots of Butomus and other plants produce their leaves in two lateral rows, which, however, eventually undergo displacement on to the dorsal surface: again, in the twigs of the Beech, the two rows of leaves approach each other on the ventral surface, and the lateral branches approach each other on the dorsal.

Dorsiventral or bilateral arrangement may not uncommonly be found in the same plant with radial arrangement, but in different parts : thus in the Hornbeam and the Elm the leaves of the primary shoot of the seedling are arranged radially, whilst on the twigs of the adult plant the leaves are arranged bilaterally (see p.12).

\section{$\S 5$. The Mutual Relations of Dissimilar Secondary} Members. In most plants the position of the lateral branches of the shoot is closely related to the arrangement of the leaves. In radial and isobilateral shoots it is the general rule that the lateral buds are developed in the angle, termed the axil, made by a leaf, the subtending leaf, with the portion of the stem above its insertion (see Fig. $9 \mathrm{kn}$ ). This kind of branching is termed axillary.

Other relations, leading to what is termed extra-axillary branching, may however obtain in these shoots. This may be due to displacement, so that the branch springs either from the parent shoot above the axil, or from the surface of the subtending leaf. It may also be due to the suppression of the subtending leaf, as is frequently the case in inflorescences. In some cases (e.g. Polysiphonia elongata) a branch may be developed in the place of a leaf, occupying its position in the genetic spiral. In other cases, as in many Mosses and Ferns, the bud is developed below the in-; sertion of the corresponding leaf; and in some Mosses, by the side of it.

Axillary branching sometimes occurs in dorsiventral shoots (e.g. Naiadew), but the lateral branches are more frequently developed by the side of the leaves. Thus, in Pilularia, Marsilia, Azolla, etc., where the leaves are borne dorsally and the branches on the flanks of the stem, each branch is in relation with the lower edge of the corresponding leaf; and in Utricularia and the inflorescences of the Boragineæ, where the branches are borne dorsally and the leaves laterally, each branch is in relation with the upper edge of the corresponding leaf. 
There may, however be no definite relation between the branches and the leaves. For instance, the lateral branches of Lycopodium are developed without any relation to the position of the leaves, and in dichotomous branching no such relation can exist.

When the shoot grows by means of a single apical cell, a direct genetic relation can be traced between a branch and its corresponding leaf. Thus, in Mosses, Equisetum, etc., the branch and the leaf are both derived from the same segment of the apical cell.

It does not necessarily follow, in those cases in which there is a definite relation between leaf and branch, that every leaf has a branch developed in relation with it, though this is frequently the case. Floral and scaly leaves, for instance, have, as a rule, no buds in their axils.

It occasionally happens, in axillary branching, that more than one bud is developed in the axil of a leaf. These buds may be arranged either one above the other (e.g. Aristolochia Sipho, Menispermum canadense, Juglans regia in the axils of the cotyledons, Honeysuckle, Gleditschia sinensis) in progressive succession, so that the youngest is lowest in the axil ; or side by side (as in Allium nigrum, bulbs of Muscari botryoides, inflorescences of species of Musa, among Monocotyledons; and in some Willows, Poplars, and Maples, among. Dicotyledons). In some cases, however (e.g. Cuscula), the presence of several buds in one axil is not due to independent development, but to the branching of a single original bud.

All the shoots that originate as lateral buds are not necessarily developed into branches; thus, in most trees, the buds which are formed in the axils of the lowest leaves of the shoots of each year usually remain undeveloped, and are only incited to growth wher the other buds are destroyed. Buds which thus remain undeveloped for a long period, often for years, are called dormant, and the shoots which are ultimately produced from them are said to be deferred.

$\S 6$. Branch-Systems. The development from a parent member of members similar to itself is termed branching, and it frequently takes place in such a way as to lead to an aggregate of similar members, constituting a branch-system. The morphological nature of the member does not determine the form of branch-system to which it gives rise; the leaf, the stem, the root, the thallus, all present essentially the same types of branchsystems. 
Two principal types of branching may be distinguished (see p. 19), the dichotomous and the lateral; but it must be borne in mind that this distinction is somewhat arbitrary, and that these types are connected by intermediate forms.

1. In dichotomous branching, the apical growing-point divides into two new growing-points (Fig. 8) which are at first equally vigorous; and they may (a) either remain so, or (b) the one may develope more vigorously than the other.

(a) When the former is the case, the dichotomy developes in a bifurcate manner (Fig. $18 \mathrm{~A}$ ). The subsequent dichotomies may all take place in the same plane, as in the thallus of many Liverworts, and in the leaves of Schizrea dichotoma (Fern), so that the whole branch-system lies in one plane, and is bilateral. Or the subsequent dichotomies may take place in rarious planes, which commonly intersect at right an. gles, as in the roots of Isoetes, where the branch-system is radial.

(b) When the latter is the case, the branch-system bccomes sympodial. The basal portions, or podia, of the successive bifurcations constitute an axis, termed a pseud-axis, or sympodium, on which the wcaker branches appear as lateral out-growths (Fig. 18 $B, C)$. The more vigorous branches may be always those

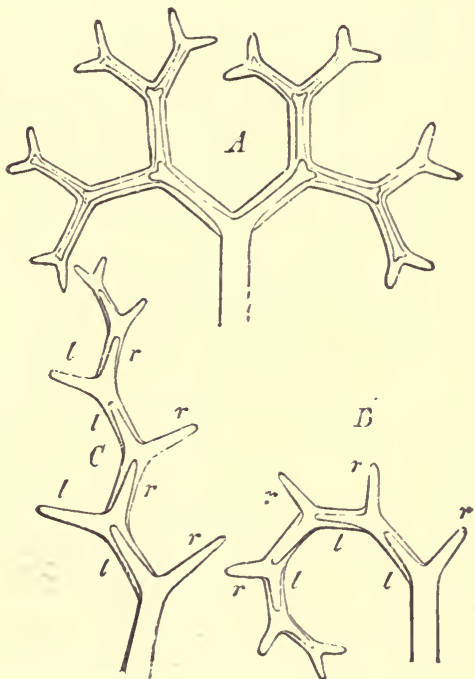

FIG 18.-Diagram of the various modes of development of a Dichotomy. A Bifurcate dichotomy. $B$ Helicoid dichotomy; here the left-hand $(l)$ branch is always more vigorous than the right $(r) \cdot C$ Scorpioid dichotomy; the right and left branches are alternately more vigorous in their growth. of one side, producing what is termed a helicoid or hostrychoid dichotomous branch-system (Fig. 18, B), as in the thalloid shoot of Fucus ; or they may be developed alternately on opposite sides, when a scorpioid or cincinnal dichotomous branch-system is produced (Fig. 18, C).

Dichotomous branching is the less common type. It occurs in some Algx, (e.g. Cladostephus, Dictyota dichotoma, Fucus, some Florideæ); in some Liverv. S. B. 
worts (e.g. Marchantiacex); in the leares of some Ferns; in the roots of Lycopodium and Isoetes; in the stem of some Lycopodiums (L. alpinum, dichotoma). In the Phanerogams it only occtirs in inflorescences and flowers.

It will be obserred that dichotomous branching necessarily involves the limitation of growth of the branching member.

2. In lateral branching, the new members are developed laterally from the parent member. Two forms may be distinguished, the monopodial and the cymose.

a. Monopodial branching. The characteristic feature of a monopodial branch-system is the presence of a main axis (monopodium), formed by the continued elongation of the branching
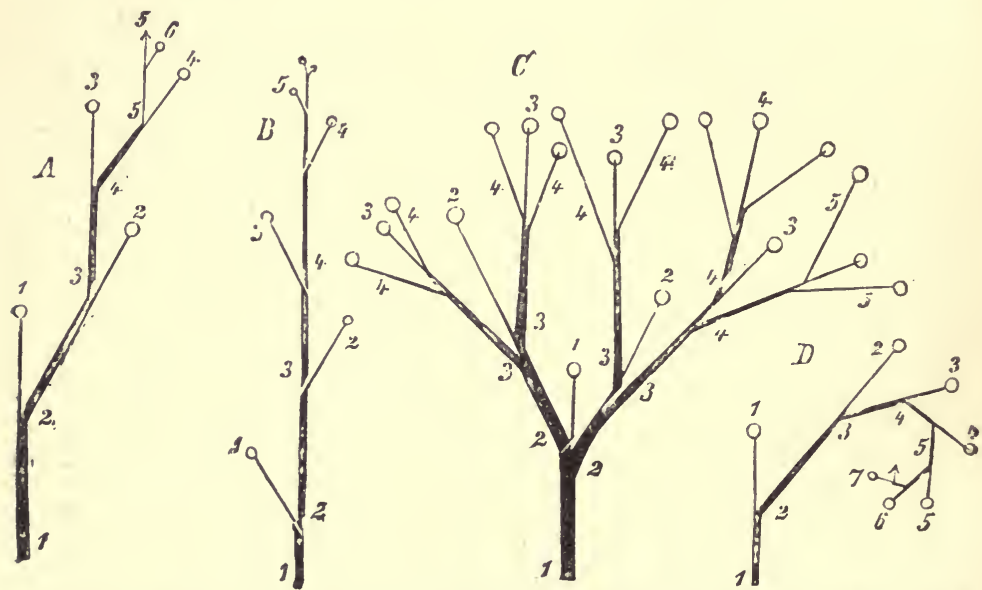

Fig. 19.-Cymose branch-systems represented diagrammatically. When the branches are regarded as all lying in one plane (that of the paper), $A$ and $B$ represent the Rhipidium, and $D$ the Drepanium. When the branches are regarded as lying in various planes, $A$ and $B$ represent the scorpioid (cincinnal) cyme, and $D$ the helicoid (bostrychoid) cyme; $C$, the dichasial cyme, the branches being regarded as lying in various planes.

member, bearing a number of less highly developed lateral axes. This is due either to the greater rapidity, or longer duration, of the growth of the branching member as compared with that of the lateral members.

A good example of the former case is afforded by Firs. Here both the primary shoot and the main lateral shoots have unlimited growth; but the former grows more rapidly than the latter, and so constitutes a main axis.

A good example of the latter is afforded by racemose inflorescences. Here the growth of each of the members of the branch- 
systems is limited by the formation of a terminal flower; but the terminal flower is developed last at the apex of the main axis; hence it grows for a longer period than the lateral axes, although, as is commonly the case, the rapidity of the growth of the lateral axes may have been greater than that of the main axis.

3. Cymose branching. The characteristic feature of a cymose branch-system is the absence of a main axis. This is due to the diminished rapidity, or shorter duration, of the growth of the branching member as compared with that of the lateral members. When a main axis is formed, it is a pseud-axis, that is, it is not produced by the continuous elongation of one and the same member, but is built up from segments of axes of different orders. Such a pseud-axis is termed a sympodium.

a. No pseudaxis is formed when two or more lateral axes elongate with equal vigour, and more vigorously than the primary axis. When the number of vigorous lateral axes happens to be two, the branch - system bears a

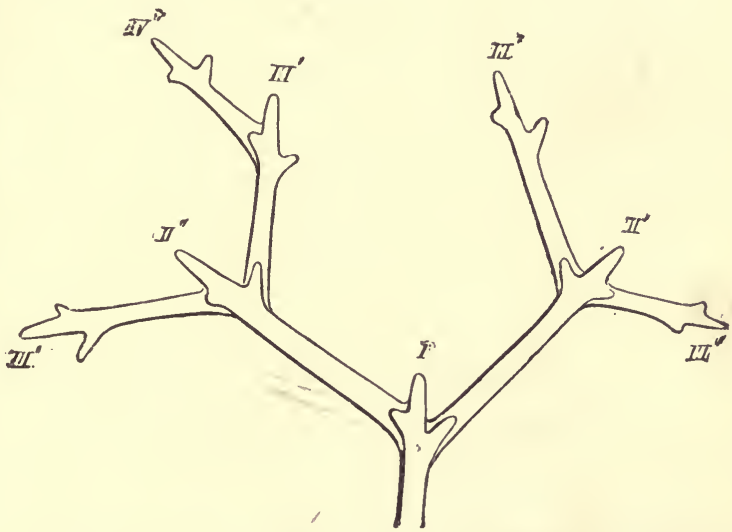

FrG. 20.-Diagram of a False Dichotomy or Dichasium; the Roman numerals indicate the order of development of the shoots of the system. Those numbered $I I^{\prime}$ and $I I^{\prime \prime}$ are equally vigorous, and much more so than the primary axis $I$. (From Sachs.)

superficial resemblance to a true dichotomy, and is hence termed a false dichotomy, or dichasium (Fig. $19 C$; Fig. 20). When many lateral axes are developed close together, the branch-system is termed a pleiochasium.

If the dichasial branching be repeated, the various dichasia may lie in one plane (as in the Mistletoe); or, as is more frequently the case, in different planes. Examples are afforded by the inflorescences of the Spurges (Euphorbia); the branches of the Lilac (Syringa), in which usually the terminal bud dies, and the 
two highest lateral buds carry on the development of the branch; and in those of Rhamnus cathartica, the terminal bud of which becomes a thorn.

( $\beta$ ) A pseud-axis, or sympodium, is formed when only one lateral axis developes vigorously in each case. 'Thus, in Fig. $19 A$, in which the darker lines indicate the more vigorous growth, the lateral axis has grown more vigorously than the parent axis, and so on. The pseud-axis, which is thus formed, is at first crooked; but in most cases it subsequently becomes straight (Fig. $19 A$ becomes $B$ ). Examples of the formation of sympodia are afforded by many subterranean stems, such as that of Polygo. natum (see p. 42, Fig. $23 \mathrm{~B}$ ), which annually come above ground, whilst a lateral branch maintains the direction of growth underground. Much the same thing may be observed, though not so clearly, in the branches of many shrubs and trees. Amongst inflorescences, also many examples of the formation of sympodia. are to be found (see Part IIr.). The vigorous lateral brancly which carries on the further growth of the plant is termed an innovation-shoot.

The various forms of sympodial branch-systems may be classified as follows:-

1. Sympodia in which all the branches lie in one plane, forming a bilateral branch-system :

a. The Rhipidium (fan); the lateral branches are developed alternately in two opposite directions (Fig. $19 A, D$ ).

b. The Drepanium (sickle); the more vigorous branches are all developed on one side (Fig. $19 \mathrm{D}$ ).

2. Sympodia in which the branches lie in different planes, forming a radial branch-system :

a. The Scorpioil Cyme (Cincinnus); the lateral branches. are developed alternately on opposite sides.

b. The Helicoid Cyme (Bostryx); the lateral branches are all developed on one side.

$\S 7$. Cohesion and Adhesion. It sometimes happens that the originally free edges of parts subsequently grow together; for instance, the margins of the carpellary leaves to form ovaries. In some Florideæ, originally separate branches of the shoot have. been observed to grow together. But a more common case is that the rudiments of distinct members become united into one whole by the growth of their common base (see p. 17). For example, a gamopetalous corolla (see infra, Part III.) arises in this way, that 
the whorled leaf-rudiments are raised up by the intercalary growth of their common base (Fig. 21 $A, r)$, and come to be merely lappets on the rim of a tube (Fig. $21 \mathrm{~B}$ ). This explanation applies also to perfoliate anc? connate leaves (see Fig. 29).

The union brought about in either of these ways may affect members developed at the same level, or members dereloped at different levels; in the former case the term cohesion is used; in the latter, the term adhesion. Examples of the former are afforded by gamopetalons corollas, syncarpous ovaries, etc.; and of the latter by epipetalous stamens, by leaves adhering to the shoots borne in their axils as in the Lime, etc.

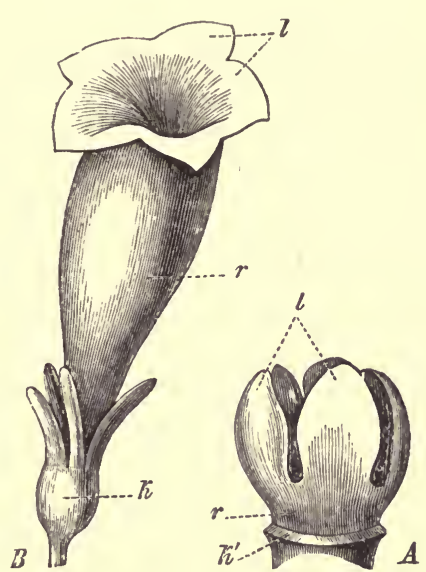

FIG. 21. - Flower of Petunia. A very young $(\times 50) ; B$ mature (nat. size); $k$ the calyx; $k^{\prime}$ the line along which the calyx has been removed; $r$ the tube; $l$ the lobes or teeth of the corolla.

\section{CHAPTER II.}

THE SPECIAL MORFHOLOGY OF THE MEMBERS.

A. Vegetative Organs.

$\S 8$. The Thallus. Among those plants in which an alternation of generations is not known to occur, the body is a thallus in the lower Fungi (e.g. Schizomycetes, Saccharomycetes, etc.), and in many Algæ (e.g. Cyanophyceæ, some Chlorophyceæ, such as Volvox, Desmids, Confervoideæ; some Phæophyceæ, such as Ectocarpus, Sphacelaria, etc.).

Among those plants in which alternation of generations is known to occur, the body may be a thallus in one or both generations; it is, for instance, a thallus in both generations in some Algæ (e.g. Coleochæte, some Rhodophyceæ), and in Riccia among the Hepaticæ: the gametophyte is a thallus in some Algæ, in all the Hepaticæ except the foliose Jungermanniaceæ, in most Vascular Cryptogams, and in all Phanerogams: the sporophyte is a thallus in all Rhodophycex; and in some Phanerogame, as 
an exception, the vegetative body, apart from the reproductire organs of the sporophyte, is a thallus (e.g. Wolffia arrhiza).

The thallus offers considerable variety of form. It may be spherical; or filamentous, branched or unbranched; or a flattened expansion, branched or unbranched; or a massive tuberous body. It commonly bears hairs. The symmetry of the thallus is multilateral, isobilateral, or dorsiventral. Complete multilateral symmetry is exhibited when the thallus is spherical (e.g. Volvox, Fig. 1); isobilateral symmetry when the thallus is flattened (e.g. Desmids, Coleochæte) with similar surfaces; dorsiventral symmetry, when the thallus is flattened, with dissimilar dorsal and ventral surfaces (e.g. most Hepaticæ, and fern-prothallia).

The branching of the thallus takes place in accordance with the general laws laid down on p. 32 ; the flattened thallus frequently branches dichotomously (c.g. some thalloid Hepaticæ). The main axis and the branches may be either limited or unlimited in growth.

The branches of the thallus may be modified in form in connexion with some special function. 'Thus, the development of reproductive organs is in some cases confined to certain branches, and these then differ in form from the ordinary regetative branches (e.g. some Hepaticæ).

§9. The Thalloid Shoot. The body is differentiated into a root and a thalloid shoot; in the gametophyte of some Algre (some Siphonoideæ, Confervoideæ, Phæophyceæ, and Florideæ), and of some Vascular Cryptogams (Equisetum, Osmunda, Lycopodinm); in the sporophyte of some Algre (e.g. Dictyotaceæ) and of the Bryophyta (except Riccia).

The vegetative body of the sporophyte has a thalloid shoot in some Phanerogams (e.g. Lemna).

The morphology of the thalloid shoot is very much the same as that of the thallus. In some cases, however (e.g. Laminaria, see Fig. 10, p. 22), it is differentiated into a basal cylindrical stalklike portion, and a terminal flattened thalloid expansion. The branching is, not uncommonly, dichotomous (e.g. Lictyota dichotoma, Fig. 8, p. 19).

$\S 10$. The Leafy Shoot. The shoot is differentiated into stem and leaf in some Algæ (e.g. Caulerpa, Bryopsis, Cladostephus, Sargassum, the Characeæ, and the gametophyte of somo Florideæ); the adult gametophytic shoots of some Hepatica 
(foliose Jungermanniaceæ), and of all Mosses; the sporophyte of Vascular Cryptogams and Phanerogams.

The distinction between stem and leaf is not, however, obvious in all these plants. In the lower forms, this is due to the low degree which the morphological differentiation has attained; whilst in the higher forms it is due to the degenerate developmentamounting in some cases to complete suppression - of the leaves; and also, in some cases, to the assumption of a more or less leaflike form by the stem or its branches. The true morphological nature of the members can only be ascertained, in these cases, by a study of their development and of their relation to each other.

In plants which live for more than one year, the shoot may either persist from year to year, or it may die down to the surface of the soil in each year, the subterranean parts being alone persistent. Shoots which last only one year are termed annual.

The general fcrm of the leafy shoot varies widely. Even on one and the same plant there may be different forms of leafy shoots, the differences being due either to peculiarities in the conditions of development, or of function. Marked differences exist, for instance, between submerged or subterranean and aerial shoots; also between vegetative shoots and those bearing the reproductive organs.

The form of the shoot depends largely upon the amount of elongation which the internodes of the stem undergo. Thus, there is in some plants (e.g. some Florideæ; Sphagnum, and other Mosses; the Larch, Pine, and Taxodium, among the Coniferæ; and many Angiosperms) a well-marked distinction of two forms of vegetative shoots. These are the ordinary elongated branched shoots; and short shoots, termed dwarf-shoots, which elongate but little, branch scarcely at all, and are frequently of but short, duration (see p. 19). Thus, in some plants (e.g. many pleurocarpous Mosses; most Ferns, Conifers, and many other plants) the primary shoot continues to grow throughout the life of the plant; whilst in others, the growth of the primary shoot is limited, the further development of the shoot being effected by a lateral branch, itself of limited growth; so that, by the repetition of this process a cymose branch-system is produced (see p. 35). This mode of development by innovation occurs in many so-called uniaxial plants whose primary shoot terminates in a flower; also in the acrocarpous Mosses where the elongation of the shoot is arrested by the development of the sexual reproductive organs, 
and, in other cases; independently of the derelopment of reproductive organs, as in Hylocomium splendens, a pleurocarpous Moss, the shoots of which grow for but one year; and in the seedlings of the Lime, and of the Elm, which form no terminal bud at the close of the first year, the further development of the shoot being effected by the highest lateral bud.

In those shoots of trees which are produced in one season's growth, the lowest internodes, especially those lying between the bud-scales, are rery short; so that it is easy, by noticing the closely-arranged scars of the bud-scales, to determine, in a shoot several years old, the amount of growth during each year. The terminal and the lateral buds of such an annual shoot usually remain in the bud-condition during the first year until the beginning of the next period of growth, so that the age of such a branch-system can be determined by the extent of the branching, the number of years corresponding to the number of times that branching has taken place. In some trees, however, ( $\bullet . g$. the Oak) a second shoot, which had hitherto existed in the bud-condition, is regularly developed in the middle of summer. As a general rule, it is only the more anterior (near the apex) of the lateral buds on the shoot which develope in the subsequent year into branches, as is very clearly seen in the whorled branches of the Coniferæ; when, however, the more posterior lateral buds do develope, the branches produced are successively the shorter the further they are from the apex (e.g. Elm). Whilst in many trees (Coniferæ, Oak) the terminal bud of a shoot always grows into a new shoot in the next year, in others (Lime, Elm, sometimes Beech) this is not the cass, but the elongation of the shoot is effected in a sympodial manner by means of the highest lateral bud (see p. 35).

In the Larch, the dwarf-shoots bear the fascicled leaves, and spring from the axils of the leaves of an ordinary shoot of the same year ; they usually elongate but slightly each year, but they may, under certain circumstances, develope into ordinary shoots. In the Scots Pine, the dwarf-shoots bear only two green leaves, in addition to scaly leaves; they arise in the axils of the leaves of the ordinary shoots of the same year, and they fall off when the leaves die. In dicotyledonous trees, these dwarf-shoots occur especially in advanced age, or when the growth of the tree is stunted. They are very conspicuous in the Apple, Pear, and other similar trees, and are the only parts of the tree which produce flowers and fruit.

The Bulb and the Corm are examples of shoots with short stems; they are, in fact, forms of the bud, produced underground.

The Bulb consist of a flattened discoid stem (Fig. 22 B), bearing a number of scaly leaves closely arranged on its upper surface, and roots on its lower surface. The leaves may either invest each other, as in the Onion, when the bulb is said to be tunicate; or they may overlap at their edges, as in the Lily, when the bulb is said to be imbricate.

Aerial buds develope in some plants into small bulbs, termed lulbils, as in Lilium bulbiferum, Dentaria bulbifera, and in some species of Onion.

The Corm consists of a rounded or flattened stem which occupies a relatively 
larger proportion of space than that of the bulb, and is invested by only a few scaly leaves. It occur's in Crocus and other Iridaceæ.

The Tuber is likewise a shortened shoot, with a swollen stcm aril small scaly leaves; it is usually developed underground, as in the Potato and the Jerusalem Artichoke (Helianthus tuberosus, Fig. $22 \mathrm{~A}$ ).

The mcrphological nature of the tuber is readily demonstrated by uncorering the underground shoots of a Potato-plant, when they develope into ordinary

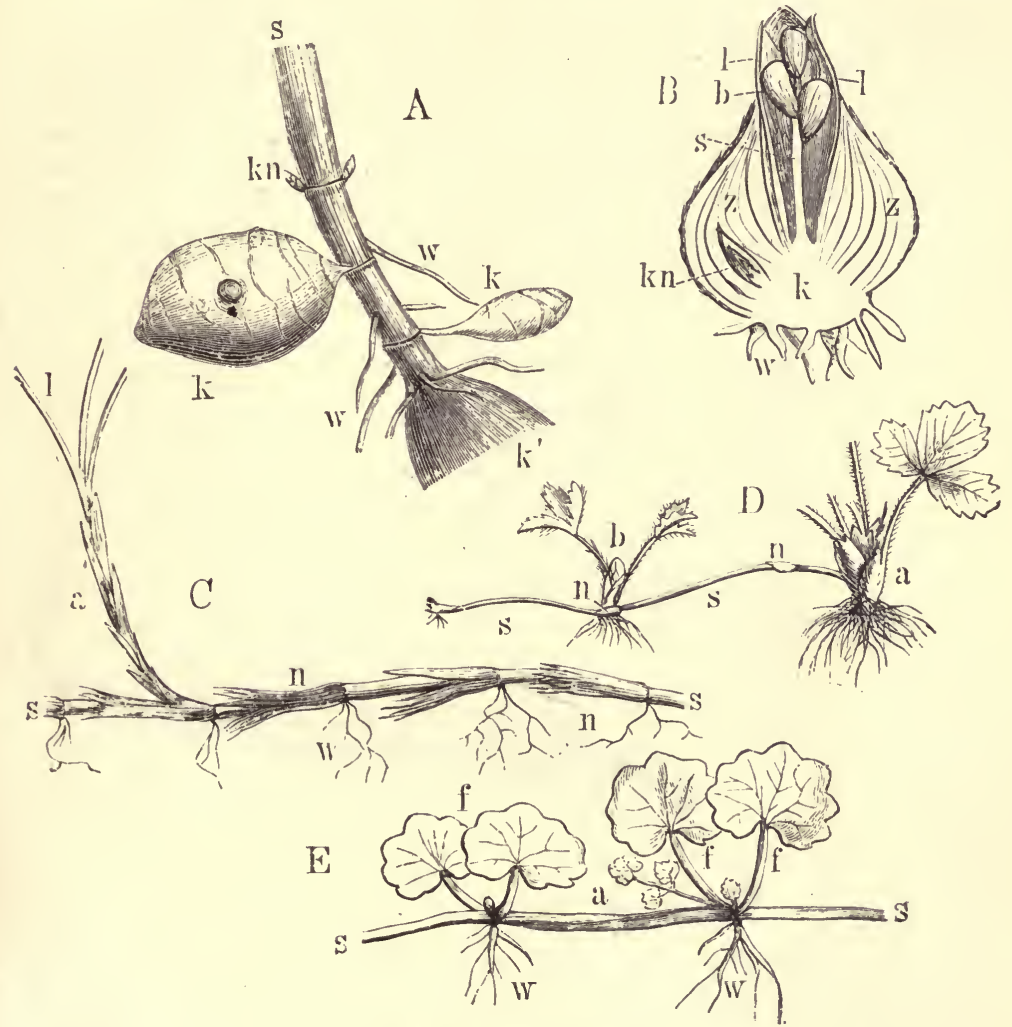

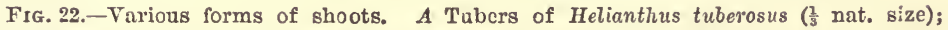
$s$ lower part of the stem springing from last year's tuber $k^{\prime}$; in the axils of the upper leaves arise the buds $k n$, and in those of the lower leaves the tubers $k$ with very small scaly leaves and buds. B Bulb of Hyacinthus orientalis (reduced); $k$ the discoid stem, $z$ the scaly leaves, $s$ the stalk which subsequently elongates and bears the flowers above ground, with the buds $b$; $l$ foliage-leaves, $w$ roots; $l n$ an axillary bur which becomes next jear's bulb. $C$ Elongated rbizome of Carex arenaria $\left(\frac{2}{3}\right)$; scaly leaves $n$; $a$ erect shoot with scaly and foliage-leaves $l$. D Runner $s$ of the Strawberry, Fragaria (reduced). springing from the plant $a$, with scaly leaves $n$, from the axil of which a new plant $b$ arises. $E$ Creeping stem of the Ground IrJ, Glechoma hederacea (reduced) ; $f f$ decussate leares; the internodes are twisted; $a$ axillary shoot; $w$ root. 
foliage-shoots. Again, if the derelopment of tubers be prevented by cutting off the underground shoots, the buds in the axils of the leaves above the ground derelope into tubers.

'The Flower is another form of shortened shoot, the leaves of which, when present, are arranged closely together. The morphology of the flower is discussed in subsequent paragraphs.

Shoots may grow erect into the air; or they may grow horizontally either above or below the surface of the soil.

A shoot which grows horizontally on the surface of the soil is tcrmed a creeping shoot (Fig. $22 \mathrm{Ki}$ ).

The Runner or Stolon is allied to the creeping shoot. It is an elongated lateral shoot which takes root at some distance from the parent plant, and which by the dying away of the intermediate portion, becomes a new individual. The runner may grow either just above (Fig. $22 \mathrm{D}$ ), or just below the surface of the soil ; it bears sometimes scaly leaves, sometimes foliage-leaves (Hieracium Pilosella). Runners usually spring from shoots with limited growth, but sometimes from those with unlimited growth, e.g. Onoclea Struthiopteris.

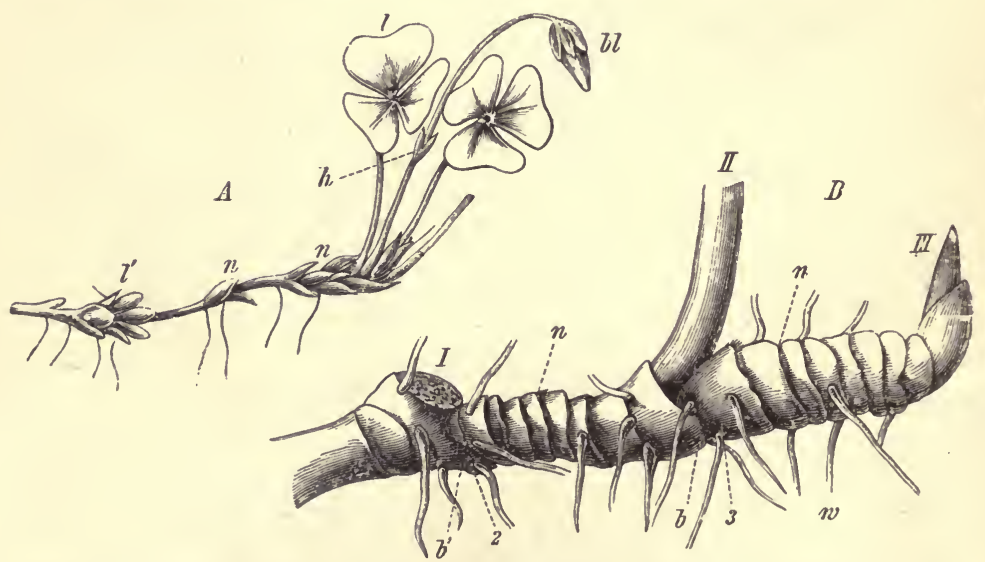

Frg. 23.-A Rhizome, with unlimited growth, of Oxalis Acetosella (Wood-Soriel); $n$ scaly leaves; $l$ foliage-leaves; $l$ remains of older foliage-leaves; $b l$ flower; $h$ bracts. $B$ Rhizome, with limited growth, of Polygonatum officinale (Solomon's Seal); I scar of last jear's herbaceous aerial shoot; II aerial shoot of this year, which is the anterior portion of the shoot 2; III bud of next year's herbaceous aerial shoot, which is the continuation of the shoot $3 ; n$ scaly leaves; $b$ and $b^{\prime}$ leaves from the axils of which the shoots 2 and 3 have ariṣen; w roots.

When a shoot grows horizontally beneath the soil, it is termed a Rhizome. It is characteristic of those plants the subterranean parts of which alone are persistent. The growth in length of the rhizome is sometimes unlimited, sometimes limited. When the former is the case, it continues to elongate at its apex and bears either only foliage-leaves (e.g. Pteris aquilina); or foliage-leaves and scales in regular alternation (Fig. $23 A, l, n$ ), in the axils of which annual shoots arise; or only scales in the axils of which annual shoots 
bearing foliage-leaves and flowers arise, as in Herb Paris. Nore commonly the growth in length is limited, in which case the apex grows out into an aerial annual shoot, whilst from the axil of a leaf at its base one or more subterranean shoots are produced which carry on by innovation the elongation of the rhizome. If the older portions of the rhizome persist for a long time, the basal portions of the annual shoots together form a sympodium (Fig. $23 \mathrm{~B}$ ); if, however, they soon perish, then each annual shoot appears to constitute a distinct individual (e.g. Ranunculus acris, Neottia). It is by the simultaneous formation of a number of short innovation-shoots that the tufts of Grasses and Sedges are produced. The innoration-shoots commonly develope roots of their own, but they may remain connected with the main root of the plant as in Anemone Pulsa. tilla.

In rare cases (Haplomitrium Hookeri and some other foliose Hepaticæ; Psilotum among Vascular Cryptogams), the functions of roots are performed by subt e r r a n e a u shoots; these shoots are more slender than the subaerial shoots, and bear the merest rudiments of leaves.

Shoots which are unable to grow erect by themselves ob: tain, in some cases, the ad-

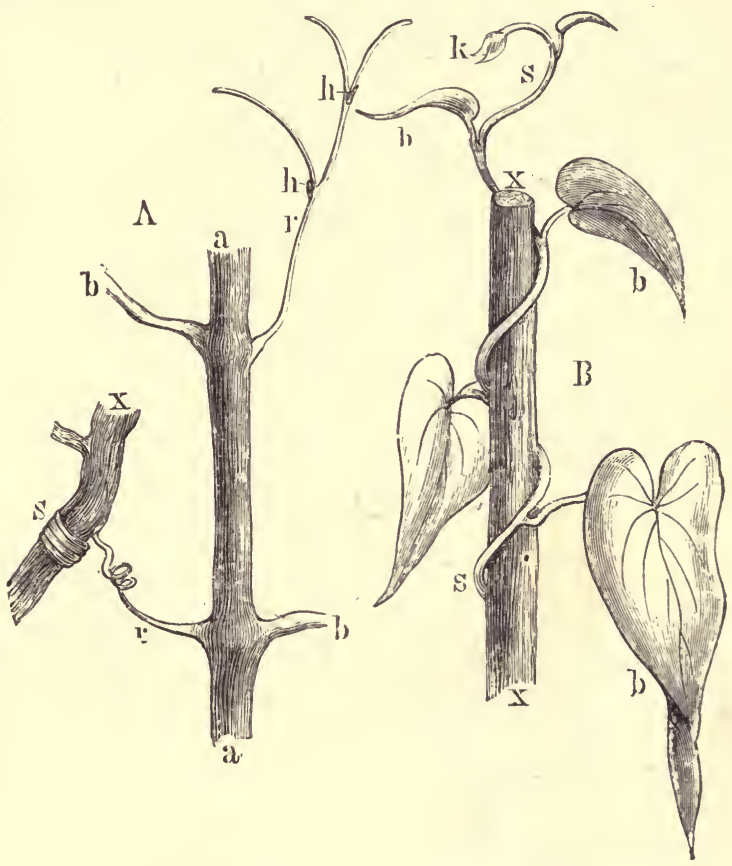

Fig 24. $-A$ Part of the shoot of the Vine ( $\frac{2}{3}$ nat. size) with two tendrils $r r$; the upper one bears small leaves $h$ and branches; the lower one has become attached to a support $x$ and has rolled up spirally; $b b$ petioles; in this case the tendrils are branches which are peculiar in that they are opposite to the leaves. B Twining shoot of Ipomoa $s$, with leaves $b$ and $a$ bud $k ; x x$ is the support.

vantages of that position by climbing. The structure of the shoot may be modified so as to subserve climbing. Branches are in some cases (Uncaria) developed in the form of hooks, and may or may not bear leares; these hooks serve to attach the plant to others. In other cases, branches bearing small scaly leaves are developed into tendrils, which twine round supports. In other cases the whole shoot twines round a support (Fig $24 A B$ ). 
Brauches are sometimes developed as thorns (Fig 25). Thorns are hard, pointed structures; they sometimes form the extremity of an ordinary shoot, as in Rhamnus cathartica; or they are dwarf-shoots, as in Cratagus coccinea; they may bear branches which spring from the axils of scaly leaves, as in Gleditschia and the Sloe (Fig. 25).

The morphology of the constituent members of the leafy shoot, namely the stem and the leaf, will now be considered.

$\S 11$. The Stem. The stem of an annual plant or of an annual shoot is succulent in texture, and is said to be herbaceous.

A primary stem which persists for several years, though it is herbaceous at first, becomes hard and woody in texture, and is termed a trunti.

The stem is commonly branched; but it may be unbranched, as in Tree-Ferns, Cycads, many Palms and Grasses.

The form of the stem varies very widely. It may be short and much thickened, as in the bulb, corm and tuber, mentioned above (p. 40) and in some Cacti; or a

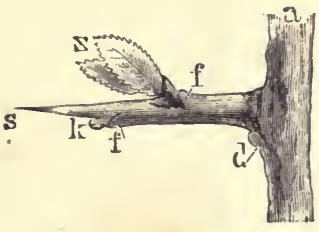

Fig 25.-Thorn of the Sloe, Prunus spinosa, a branch, $d$ leaf-scar, from the axil of which the thorny branch 8 springs; on the thorn are $f f$ leaf-scars; in the axil of the upper one is the branch $z$, in tuat of the lower, the bud $k$. portion of it may be much thickened into a tuber, as in certain epiphytic Orchids, where one or more of the basal internodes form a pseudo-bulb; and in Vitis gongylodes, where any internode may become tuberous.

The form of the elongated stem is commonly cylindrical or prismatic. The prismatic form is, in some cases, determined by the arrangement of the leaves; thus, stems bearing decussate leaves (see Fig. 11, p. 24), that is, leaves arranged in four othostichies, the stern is quadrangular. When the stem has an angular form, the edges frequently grow out into a leafy expansion: such a stem is said to be winged. In some cases, as in Grasses, Bamboos, Pinks, etc., the stem presents a jointed appearance at the nodes; a stem with this pecnliarity is termed a culm or haulm.

When the development of the foliage-leaves of a shoot is degenerate, the stem performs the functions of the leaves : it is then of a green colour, and generally assumes such a form as to have a relatively large surface. Thus, the whole stem and its branches may become flattened, as in Opuntia (Cactaceæ) and in Genista sagiltalis (Papilionaceæ) : or certain branches only, termed phyllo- 
clades, aro flattened and leaf-like as in Ruscus (Liliaceæ), Phyllanthus (Euphorbiaceæ), Mühlenbeckia (Polygonaceæ), Carmichaelia (Papilionacer), Phyllocladus (Coniferæ), and are either isobilaterally or dorsiventrally symmetrical. The phylloclades frequently bear flowers but not always in the same position. Thus, in Ruscus audroy!ynus the flowers are borne on the margin of the phylloclade; in liuscus aculeatus and $R$. Hypoglossum, they are borne on the upper surface of the phylloclade; and in $R$. Hypophyllum, on the under surface.

Leaf-like branches are also formed in Asparagus; they are not flattened, but are small and acicular; something of the same kind also occurs in Equisetum.

$\S$ 12. The Leaf. All leaves, except the seed-leares or cotyledons, are developed exogenously as lateral outgrowths upon the growing-point of a stem: they are developed, as a rule, in progressive (acropetal or basipetal) succession, though irregularity in this respect sometimes occurs in the case of floral leares.

The leaf is developed either from the superficial layer of cells only, or from this and other deeper layers, and soon appears as a lateral protuberance on the growing-point. At this stage it is undifferentiated, and may be termed priinordial. In some plants with very simple leaves (e.g. Chara) the developing leaf undergoes no further change beyond increase in

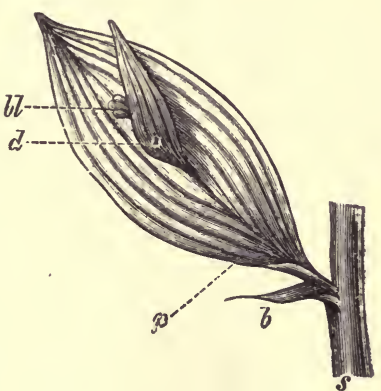

Frg. 26. - Phylloclade of Ruscus Hypoglossum (nearly nat. size): $s$ stem; $b$ leaf, in the axil of which the phylloclade $p$ is developed; $d$ leaf of the phylloclade bearing flowers $b l$ in its axil. size; but in most plants the leaf undergoes differentiation or segmentation along its longitudinal axis or phyllopodium. In the most complete case, the phyllopodium is differentiated into three regions: a basal portion, the leaf-base or hypopodium; an apical portion, the epipodium; and an intermediate portion, the mesopodium, leaf-stall, or petiole; but the last-named portion is frequently absent. Most commonly the leaf assumes a flattened form in consequence of the development of a relatively thin membranous wing along one or other of these regions in the lateral plane: the epipodium is typically winged, and then constitutes what is known as the blade or lamina of the leaf; the mesopodium is rarely winged, the hypopodium more frequently so. 
The growth in length of the primordial leaf is at first apical in all cases; it may be persistently apical (e.g. Ferns, generally); or apical growth may be early arrested, further elongation being effected by basal growth (e.g. Iris, Onion, Myriophyllum, Potentilla anserina); or, more rarely, basal and apical (e.g. Achillea Millefolium, and other Compositæ) growth may occur simultaneously.

A characteristic feature of leaves is that their growth in length is limited; but this is not without exception; in fact, there are all intermediate forms between those which have limited and those which have unlimited growth. Thus, in most Phanerogams the leaves have limited growth; the cells of the leaf are all actually formed at the time of its unfolding, and all that takes place subsequently is that the cells grow to their definitive size. In a few

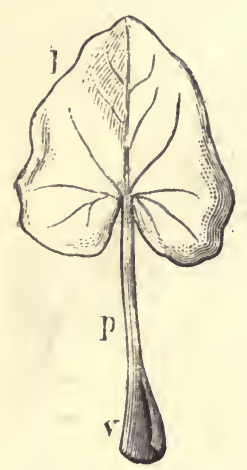

F'IG. 27.-Leaf of $R a-$ unculus Ficaria : vleafbase (hypopodium) ; $p$ petiole (mesopodium) $\imath$ Jamina (epipodium). of these plants, however, (e.g. Guarea and other Meliaceæ) the pinnate leaves have an apical growing-point by which new cells are formed, and the growth in length of the leaf and the development of lateral branches is carried on after the leaf has unfolded. Longcontinued apical growth appears to be the general rule in Ferns : in Pteris aquilina and in Aspidium Filix Mas the leaf grows for thrce years; and in Gleichenia, Lygodium, many Hymenophyllaceæ, and Nephrolepis, the leaf grows for many years after its appearance above the soil. The most striking example of long-continued basal growth is that of the two leaves of Welwitschia which persise and grow basally as long as the plant lives, and consequently attain a great length.

The leaves are inserted upon the nodes (p. 21) of the stem, the plane of insertion being usually transverse to the longitudinal axis of the parent stem; but in some Bryophyta (Blasia, Schistostega) the plane of insertion is parallel to the longitudinal axis of the stem.

The IIypopodium or Leaf-Base. The leaf-base commonly developes into a cushion of tissue, termed the pulvinus, which forms the articulation by which the leaf is attached to the stem; in the Gooseberry the pulvinus developes into a spine. In many cases the leaf-base is sheathing, and embraces a part or the whole of the circumference of the node $\cdot$ in the former case the leaf is said to 
be semi-amplexicaul; in the latter, amplexicaul (e.g. Grasses, Onion, Fool's Parsley).

The leaf-base sometimes produces a pair of opposite lateral branches which are termed stipules; when they are present the leaf is said to be stipulate, and when they are absent, as is more commonly the case, the leaf is said to be exstipulate. The stipules are commonly winged appendages, similar in colour and texture to the lamina, and they are then said to be leafy (Fig. $28 \mathrm{~B}, \mathrm{C}$ ), as in the Willow, the Violet, and the Rubiaceæ where they are branched, and they are especially large in plants, like the Pea, where the lamina is relatively small; in other plants, on the contrary, they

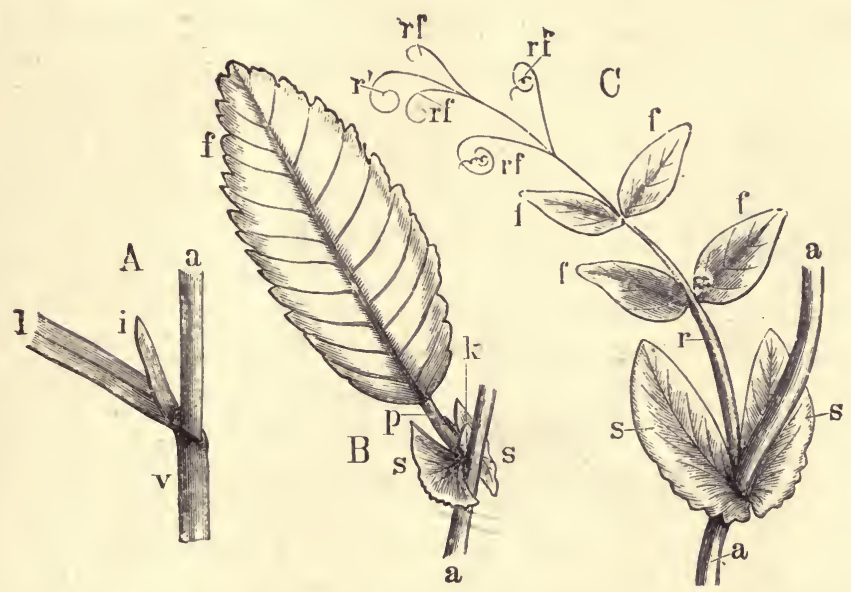

Fig. 28.-A Part of a sessile leaf of Grass (Poa trivialis) with the ligule $i$; $a$ the haulm; v the sheathing leaf-base; $l$ lamina of the leaf. $B$ Leaf of a Willow (Salix Caprea); $a$ stem; $s$ stipules; $p$ petiole; $f$ lamina ; 7 axillary bud (nat. size). C Leaf of a Pea (Pisum arvense); $a$ stem; $s$ stipules; $r$ mesopodium o: petiole; $f f$ leafets; $r f r f$ the upper leaflets metamorphosed into tendrils; $r^{\prime}$ end of the epipodium likewise transformed into a tendril.

are small brownish scales, which fall off soon after the leaf is unfolded, as in the Beech, the Elm, and the Lime. Sometimes the stipules appear as teeth on the upper margin of the sheathing leafbase, as in the Rose. Occasionally the two stipules are connate, that is, they are more or less united; when they cohere by their outer margins they form a single opposite stipule, opposite, that is, to the leaf to which they belong, as in Astragalus; when they cohere by their inner margins they form an axillary stipule, that is, a stipule in the axil of the leaf to which they belong, as in Meli- 
snthus and Houttynia cordata; in the Polygonaceæ they cohere by both their inner and outer margins, thus forming a tube, termed an ocrea, which surrounds the internode above the insertion of the leaf ; when the stipules of opposite leaves cohere they form on each side an interpetiolar stipule, as frequently in the Rubiaceæ and in the Hop; this may also take place when there are several leaves in a whorl, as in the epicalyx of certain Rosaceæ.

In some cases (e.g. Smilax) the stipules are developed in the form of tendrils, and in other cases (e.g. Robinia) as spines.

Stipules are comparatively common in Dicotyledons; they are absent in the Coniferæ; absent in Monocotyledons, excepting the Naiadaceæ and Smilax; absent in most Pteridophyta, except the Marattiacere among Ferns. In Tropceolum majus only the two

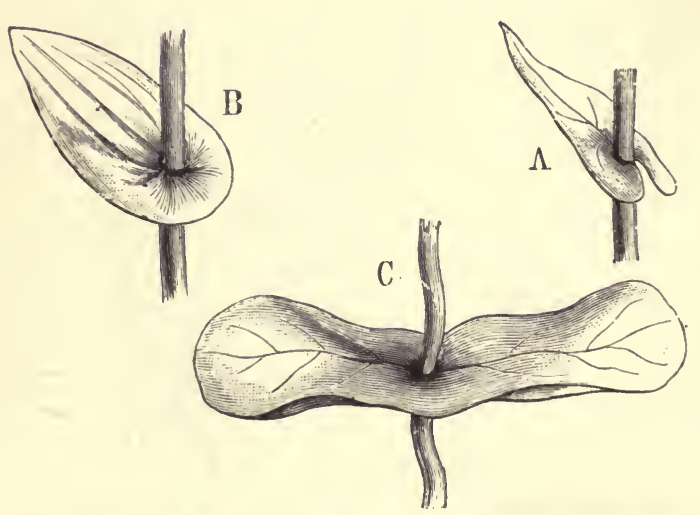

Frg. 29.-The insertion of sessile leares. $A$ Auriculate leaf of Thlaspi perfoliatum. B perfoliate leaf of Bupleurum rotundifolium. C connate leaves of Lonicera Caprifolium.

leaves which succeed the cotyledons have stipules.

The leaflets of a compound leaf sometimes have stipules at their bases, as in Phaseolus, which are dis tinguished as stipeis.

In a leaf without a pe. tiole it sometimes happens that the leaf-base is winged in continaity with the lamina; the result is that the wings extend round the stem, either incompletely (Fig. $29 A$ ) when the leaf is said to be auriculate; or completely $(B)$ when it is said to be perfoliate; when this occurs in two opposite leaves, the leaves become connate $(C$; see p. 37$)$.

There is, in some cases, a delicate membranous ventral outgrowth on the leaf at the junction of epipodium and hypopodium, termed the ligule; it occurs in Grasses (Fig. $28 \mathrm{~A}$ ), in Selaginella and Isoetes, and in the perianth-leaves of some flowers (Narcissus, Lychnis).

The Mesopodium or Petiole is commonly, but not always, present. 
When it is present the leaf is said to petiolate; when it is absent, sessile. It is developed by intercalary growth in a portion of the primordial leaf lying between the hypopodium on the one side and the epipodium on the other. The most common form of the petiole is somewhat cylindrical; though, where the dorsiventrality of the leaf is well-marked, it is convex on the lower (dorsal) surface, and flattened or grooved on the upper (ventral) surface. In the Aspen (Populus tremula) it is flattened laterally.

Occasionally (e.g. Orange, Fig. $32 G$; Nepenthes, Fig. 37; Dionæa) the petiole is winged.

In some cases (e.g. Australian Acacias) the petiole has somewhat the form of a lamina. Its flattened surfaces are directed laterally, the edges upwards and downwards, so that the symmetry is isobilateral. A petiole of this form is termed a phyllode. In such cases, the lamina, originally present, soon falls off.

The Epipodium may be either winged or unwinged. The winged epipodium constitutes the lamina or blade of the leaf, and is typically flattened and expanded in form and dorsiventral in symmetry: but this is not always the case, for in some plants it assumes the form of a sac or pitcher (e.g. Utricularia, Nepenthes, etc.), and in others the symmetry is isobilateral (e.g. adult leaves of Eucal!/ptus Globulus).

The form of the unwinged epipodium presents great variety; thus, in Lathyrus Aphaca the epipodium branches into leaf.tendrils, and this is partially the case also in the Sweet Pea (Fig. $28 \mathrm{C}$ ); it is filamentous in Chara and some other Algæ; cylindrical or prismatic, as in Onion, Sedum, Mesembryanthemum, Aloe; acicular as in Pinus; narrow, and flattened antero-posteriorly (eusiform) so that the margins correspond to the dorsal and ventral surfaces: of a dorsiventral leaf, with isobilateral symmetry, as in Iris and Gladiolus.

The flattened dorsiventral lamina is normally so placed with regard to the parent stem that a plane, which includes the longitudinal axes of both the stem and the leaf, cuts the lamina into two lateral halves; in other words, it is so placed that its upper (ventral) surface faces the apex of the stem, and its lower (dorsal) surface is directed away from it. As a rule, the two lateral halves of the lamina are symmetrical; but in some cases (e.g. Elm, Begonia) they are unsymmetrical, when the lamina is said to be oblique.

The ultimate form of the lamina mainly depends upon the v. S. B. 
degree of elongation of the epipodium. When the epipodium elongates considerably, the lamina has a well-marked primary axis from which more or less numerous secondary axes of growth successively spring, and these in turn bear lateral axes of a higher order: the resulting lamina is then of the pinnate type (Fig. 30 $A$ ). When, however, the epipodium remains short, it constitutes merely an intercalary growing-point from which a number of equal secondary axes spring, and the resulting lamina is of the palmiate type (Fig. $30 \mathrm{~B}$ ).

The development of the peltate lamina, closely connected with that of the palmate type, is effected by a peculiar form of basi-petal
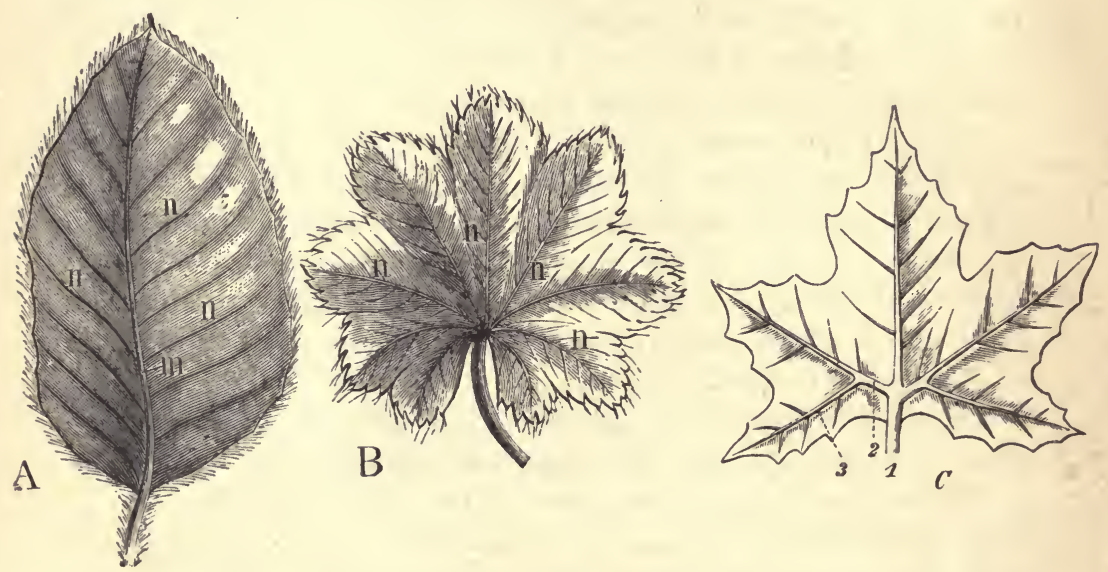

FrG. 30.-A Pinnate leaf of the Beech, Fagus sylvaticı; $m$ mid-rib, $n$ lateral ribs. $B$ Pal-

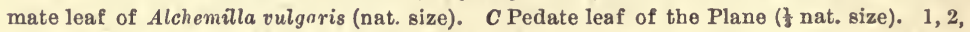
3 , are the ribs or axes of the 1 st, 2 nd, and 3 rd order.

growth. In peltate foliage-leaves (e.g., Tropæolum, Nelumbium, Hydrocotyle, Cotyledon, Lupinus, etc.) the petiole is inserted in the middle of the under surface of the lamina, so that the long axis of the former is perpendicular to the plane of expansion of the latter. At first the derelopment is that of a palmate leaf, the petiole being inserted at the base of the lamina, and at the point of insertion there is an intercalary growing-point from which spring several axes (Fig. $31 \mathrm{~B}, 1,2,3$ ) in basipetal succession. But in this case the last-formed axes (4-4,5-5, in the figure) grow out in front of the petiole, with the result that the whole lamina gradually comes to lie perpendicularly to the petiole. 
The main axes of growth frequently grow thicker than the rest of the lamina, so that they project as ribs on the under surface. The thickened primary axis (epipodium) of a pinnate lamina is termed a mid-rib.

The Branching of the Leaf is commonly confined to the epipodium, and then it takes place in the lateral plane; less commonly it occurs in the mesopodium (e.g. species of Ophioglossum, Botrychium, Marsilia), and then (as in these plants) the branching frequently takes place in the antero-posterior (or dorsiventral) plane. As a rule the primordial leaf is unsegmented, though in the foliose Jungermannieæ it consists of two segments from the first.

The branching of the epipodium is, like that of a stem or a root, either dichotomous or lateral, and essentially the same forms of branchsystems are produced. Dichotomous branching is comparatively rare: it has been observed in the Hymenophyllaceæ, the branches either remaining distinct or forming sympodia. The two first leaflets of Marsilia are said to be formed by dichotomy. Lateral branching is the more common form, and the resulting branch-systems are typically monopodial. But in some cases (e.g. leaf of Plane, Fig. $30 \mathrm{C}$; of Helleborus, and of some Aroids) there is apparently cymose branching with formation of a sympodium.

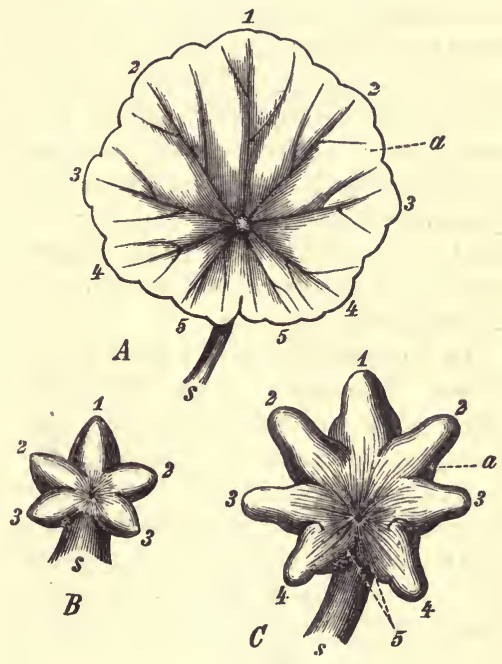

Fig. 31. - Development of peltate leaf of Hydrocotyle: $A$ full-grown (nat. size); $B$ vers young; $C$ somewhat older ( $B$ and $C \times 50)$; $S$ petiole; 1-5 primary axes of growth in young leaves, ribs in adult leaf; $a$ secondary axes of growth.

The ribs of the lamina represent distinct axes of growth; they are, in fact, branches of the epipodium. The degree of segmentation of the lamina depends upon the relation between the growth of the various main axes and the marginal growth of their respective wings (see Figs. 30 and 31). When these keep pace with each other the lamina is altogether unsegmented, that is, its margin is entire; when the growth of the axes is 
rather more vigorous than that of the corresponding wings, the margin becomes somewhat uneven (dentate, serrate); when the difference between them is considerable, the lamina is lobed; and when still greater, it consists of a number of distinct segments, leaflets, connected only by their common attachment to the midrib, in the case of pinnate leaves, or to the petiole in the case of palmate or peltate leaves. Whilst inequalties of the margin are indications of branching, the lamina is regarded as simple so long as the segmentation is incomplete; it is only when the segmentation is complete, as in the last-mentioned case, that the leaf is said to be compound.

The following examples will serve to illustrate the foregoing principles. The simple leaf of the Beech (Fig. 30) has an entire pinnate lamina; the leaf of the Shepherd's Purse (Capsella Bursa-Pasturis, Fig. $32 \mathrm{C}$ ) is simple, but the lamina is deeply pinnately lobed. Various forms of compound pinnate leaves are represented by Fig. $28 C$, and by Fig. $32 B, D, E, F, H$, where the distinct segments or leaflets, termed pinna, are inserted on the common primary axis (phyllopodium). In $H$ each pinna is itself compound, being segmented into pinnules which bear the same relation to the secondary axis of each pinna as that secondary axis does to the primary axis of the whole leaf; such a leaf is said to be bipinnate, and when the segmentation is carried further the leaf becomes tripinnate, etc.

In compound pinnate leaves, the leaflets are commonly opposite to each other. When only one pair of leaflets is present, the leaf is said to be unijugate; when two pairs, bijugate; when many pairs, multijugate. When the axis (whether primary or secondary) is terminated by a leaflet, the leaf is said to be imparipinnate (Fig. $32 \mathrm{D}$ ) ; when there is no terminal leaflet, the leaf is paripinnate (Fig. 32 E). When, as in the Potato and Potentilla anserina, pairs of small leaflets alternate with pairs of larger ones, the compound leaf is said to be interruptedly pinnate. The difference in size of the leaflets is simply due to the more active growth of the larger ones.

The order of development of the leaflets of compound pinnate leaves depends upon the position of the growing-point in the longitudinal axis (see p. 17). When it is apical, the leaflets are developed in acropetal succession (e.g. Pea, Ailanthus, etc.); when it is basal, in basipetal succession (e.g. Myriophyllum, Potentilla anserina); when there is both an apical and a basal growingpoint, in divergent succession, that is, both acropetally and basipetally (e.g. Achillea Millefolium, etc.).

With regard to palmate leaves, Fig. $32 A$, is an example of a deeply lobed lamina; and $B$, of a compound palmate leaf. It will be observed that in the compound palmate lamina of the Clover (Fig. 32, B) there are three leaflets; 
such a leaf is said to be ternate. This segmentation may be repeated in the leaflets, when the leaf is said to be biternate, triternate, etc. On comparing Fig. $32 B$ and $F$, the close relation between pinnate and palmate leaves becomes apparent. A ternate leaf is usually considered to belong to the palmate type, but it might almost equally well be regarded as an imparipinnate unijugate leaf.
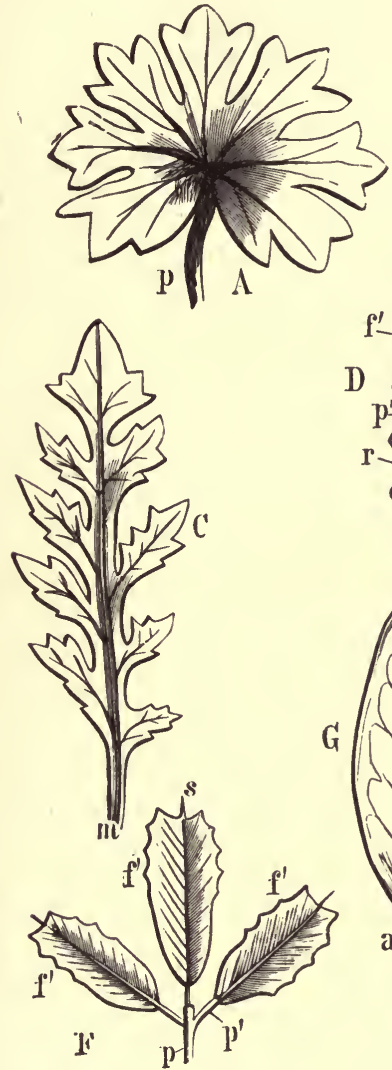

$r$

G

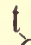

D<smiles>C1=C[AlH][Al]1</smiles>

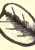

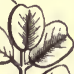
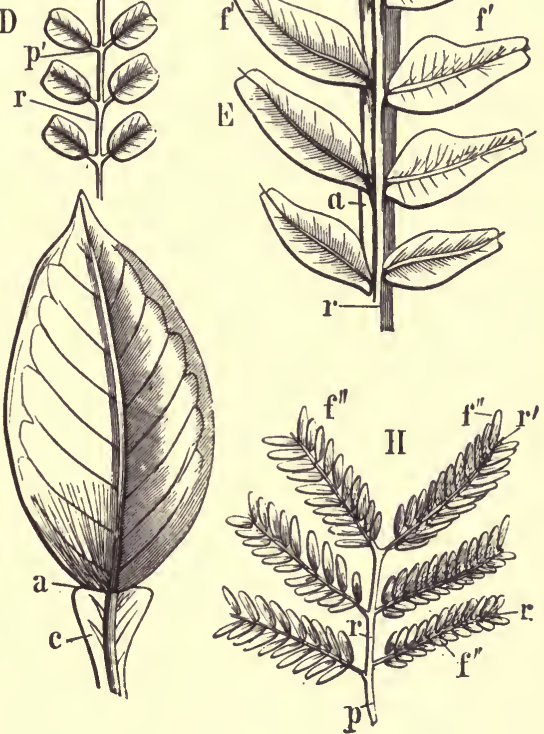

Fr.. 32.-Segmentation of leavee. $p$ Petiole; $p^{\prime}$ petiolnle; $f^{\prime}$ leaflet; $r$ pbyllopodium. $A$ Palmatifid or palmately lobed leaf of Geraninm. $B$ Ternate (compound palmate) leaf of Clover. C Pinnatisected leaf of Shepherd's Purse (Capsella). Compound pinnate leaves: $D$ Imparipinnate leaf of Hippocrepis comosa; $t$ terminal leaflet. $E$ Paripinnate leaf of Pistacia Lentiscus; $a$ wing of the phyllopodium. F Imparipinnate nnijugate leaf of Medicago. This differs from $B$, which is ternate, inasmuch as the secondary leaf-stalks $p^{\prime}$ do not all spring from one point, but the common leaf-stalk $p$ extends beyond the insertion of the single pair of pinnæ; s projecting rib, or mucro. G Leaf of the Orange; the articulation $a$ between the blade and the winged petiole shows tbat it is really a compound leaf with a single terminal leaflet. $H$ Bipinnate leaf of Acacia : $r$ 'secondary axis ; $f^{\prime \prime}$ secondary pinnæ or pinnules. 
Occasionally the margin of the lamina bears outgrowths which are not connected with branching, but are of the nature of emergences, as in Mnium serratum, the Cherry Laurel, Naias, various Conifers, etc.

A number of terms are used in Descriptive Botany for the purpose of precisely describing the various parts of plants. The more important of these terms, and those the meaning of which is not obvious, will now be defined.

(1) The Outline of bilateral bodies, such as the lamina of the leaf, but of multilateral bodies, such as fruits, as well, is said to be linear when the two margins run nearly parallel to each other; e.g. the leaves of most Grasses. If the margins are curved and intersect at each end at an angle, the outline is said to be lanceolate or elliptical, accordingly as the long axis is many times longer than, or only twice as long as, the transverse axis. If the two curved margins round off at each end, then the terms oblong and oval are to be sub. stituted for the two preceding.

If the longest transverse diameter lies relatively near to the base, then the outline is said to be ovate; if relatively near to the apex, obovate.

(2) The Apex may be either acute or obtuse; when it is long drawn out it is said to be acuminate; when there is a sharp projecting point, it is said to be mucronate (Fig. $32 \mathrm{~F}$ ); truncate, when it is, as it were, cut short across (Fig. $32 D)$; emarginate, when there is a depression in the obtuse apex; obcordate, when the apical depression is deep.

(3) The Base may be described by many of the preceding terms, but the following are especially applied to it: it is cordate when it is deeply indented in the median line; sagittate, when the lobes on each side of the indentation are angular and diverge backwards; hastate, when the lobes diverge outwards.

(4) The Margin is said to be entire when it does not present any depressions or prominences; when the prominences are slight and rounded, the margin is said to be crenate; dentate or toothed, when the prominences are pointed and stand straight outwards; serrate, when the pointed prominences slant forward.

If the incisions in the margin are deep, the part, a leaf-blade for instance, or a gamosepalous calyx, is said to be lobed when the incisions do not extend to the middle; if they extend to the middle, it is said to be partite; and dissected when they extend nearly to the base (Fig. $32 \mathrm{C}$ ).

The segmentation of the lamina takes place in some Monocotyledons (Palms) in an altogether different manner from that described above. The lamina is at first entire, but it becomes divided by the dying away of strips of tissue (see also p. 22).

The Venation of the Lamina. The mid-rib and other ribs of the lamina indicate the course of the larger vascular bundles; and from these, numerous branches are given off which permeate the tissue of the lamina, constituting its Venation. When the leaf decays, the ribs and the vascular tissue persist longer than the soft parts as a skeleton which retains the general form of the lamina. 
In Ouvirandra fenestralis most of the softer tissue decays whilst the leaf is still living, so that the lamina consists of little more than the vascular skeleton.

The main features of the venation are determined by the type of development of the lamina. In a pinnate lamina, the venation is pinnate; in a palmate lamina, palmate; in a pedate leaf, pedate; in a dichotomously branching lamina, the venation is also dichotomous, or as it is 'specially termed, furcate. But there is considerable variety in the distribution of the smaller vascular bundles: thus the venation of the individual segments of a palmate or a pedate leaf is frequently pinnate.

According to the distribution of the veins and their branches, the following varieties of

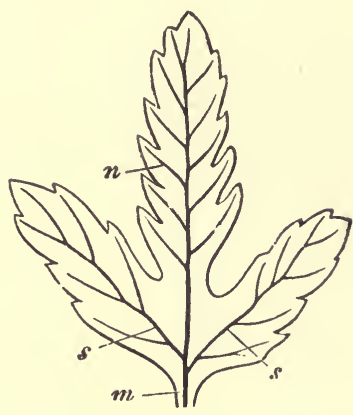

Fig. 33.-Leaf of a young Fern, with free pinnate venation; $m$ the midrib; $s$ s the large lower lateral veins; $n$ the weak upper lateral veins $(\times 3)$.

venation may be distinguished; they are, however, connected by intermediate forms.

$a$. The venation is said to be free when the veins end free, without forming anastomoses, at the margin of the leaf; this is the case in the leaves of many Ferns (Fig. 33) ; of Gingko (Salisburia), Araucaria imbricata and others, among Coniferæ; of most Cycads; of Water-Crowfoots, etc.

$b$. The venation is said to be parullel, when numerous adjacent veins run parallel to each other towards either the apex (Fig. 34) or the margin of the blade, and then unite by curving inwards (Fig. $34 a$ ). They are connected in their course by short veinlets (Fig. $34 v$.) which run usually at right angles to them. This form of venation is to be found in the leaves of most Monocotyledons, such as Grasses, Lilies, and Palms, with various modifications. For example in some cases (e.g. Orchis Morio) many veins enter the blade, but they branch scarcely at all; in other cases lateral veins spring at an acute angle from a midrib which is prominent at the base at least, and then run towards the apex (e.g. Maize and other Grasses, Dracænas, etc.) ; in others, again, the lateral veins spring almost perpendicularly from the well-developed mid-rib, and run out to the margin parallel to each other, and then turn towards the apex of the leaf (e.g. Canna, Musa, etc.).

c. The venation is said to be reticulate, when the

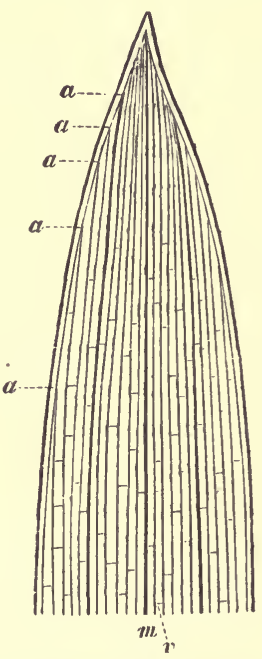

Fis. 31. - Apex of a Grass-leaf showing parallel venation; $m$ middle vein; $\boldsymbol{a}$ anastomoses; $v$ veinlets $(\times 4)$. 
reins branch repeatedly at various angles, and the branches for the most part anastomose (Fig. 35). Some of them, however, end blindly in the meshes of

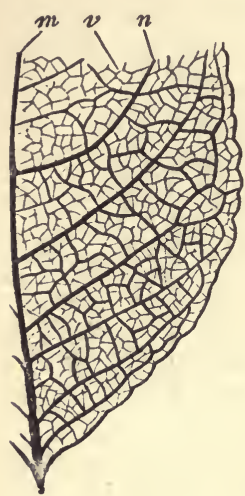

FiG. 35.-Portion of a leaf of Salix caprea with reticulate venation: $m$ mid-rib; $n$ the larger lateral ribs; $v$ the anastomising veins (nat. size). the network. This kind of venation is characteristic of Dicotyledons; but it also occurs in some Monocotyledons (e.g., Paris, Dioscorea, Smilax, many Araceæ) and many Ferns.

The Different Forms of Leaves.-The leaves of different plants, as nnight be expected, are not alike, but differ more or less widely in size, shape, colour, and texture. But even the leaves borne on one and the same plant are not all alike, the reason of their dissimilarity being that, as there are different functions to be performed, the leaves are variously adapted in form and structure to the performance of special functions. Further than this, the same leaf may present different successive forms, or a difference of form in its various parts, because it may perform different functions, either at different times, or simultaneously by its different parts.

1. Foliage-leares are usually known simply as leaves (Fig. $36 \mathrm{~L}$ ). They are conspicuous on account of their green colour, and in accordance with their nutritive function (see Part IV.), they are expanded as much as possible to the sun-light. If they are small they are very numerous (Conifers), and the larger they are the fewer they are (Sun-flower, Paulownia). They nearly always possess a well-developed lamina, which presents the varions peculiarities of conformation previously described.

The texture of the leaf is dependent upon the mode and duration of its existence. The texture of most leaves may be described as herbaceous. Leaves of this kind last usually for only a single season, and die or fall off in the autumn. Leaves of firmer texture, which are said to be coriaceous, survive the winter, and either fall off when the new leaves are developed (the Privet), or continue to live for several years (Holly, Box, and most Conifers); the acicular leares of the latter may persist for as many as twelve years (Silver Fir). Fleshy or succulent leaves occur in plants inhabiting $d^{n} y$ regions or positions, such as Aloe, Sedum, etc.

It is worthy of note that foliage-leares of different form sometimes occur on the same shoot. For instance, it is commonly the 
case that the first leaves of young plants are of a form different from, and usually simpler than, that of those which are subsequently produced, and exhibit a greater resemblance to those of allied plants. Thus, Eucalyptus glubulus has at first oval dorsiventral leaves, and subsequently elongated isobilateral leaves. Again, the primary leaves or cotyledons, when they develope into foliage leaves, are always different in form from the subsequently developed foliage-leaves, being much simpler. In many waterplants, the submerged leaves are different from those which float at the surface; thus, in many species of Potamogeton, the submerged leaves are narrow and ribbon-like, whereas the floating leaves are broadly elliptical; in many aquatic species of Ranunculus, the former are finely divided, whereas the latter have a circular lamina. Again, the submerged leaves of Salvinia are filamentous, whereas the floating leaves are flattened and oval.

The simultaneous occurrence of two forms of foliage-leaf on a plant is termed heterophylly.

In certain plants the foliage-leaves assume re-

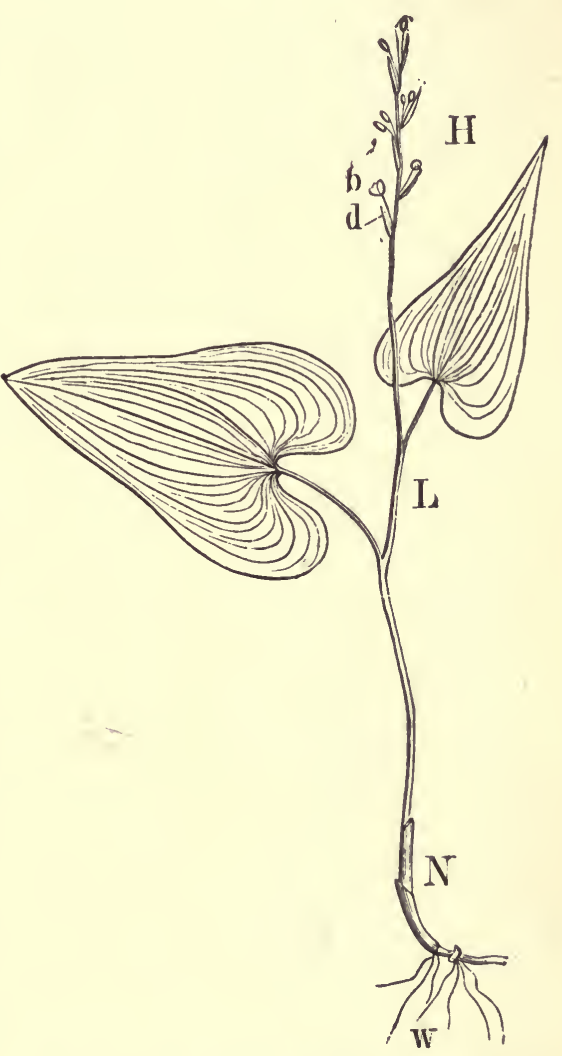

Fre. 36.-Three forms of leaves on the stem of Maianthemum bifolium (nat. size): $N$ cataphyllary region; $L$ region of the foliage-leaves; $H$ hypsophyllary region; $d$ the bracts; $b$ the flowers in their axils. $w$ Roots. markable forms in connection with their adaptation for eatching small animals or for collecting water (e.g. Nepenthes, Cephalotus, Sarracenia, Utricularia, Dischidia, etc.). In these the lamina is metamorphosed into a pitcher or ascidium. The development of 
the pitcher begins in very much the same way as that of the lamina of a peltate leaf; but instead of remaining flat, it becomes tubular by continued basal intercalary growth (see p. 17). The leaf may, as in Sarracenia and Darlingtonia, be sessile; or it may be petiolate, as in Cephalotus and Nepenthes: in Nepenthes (Fig. $37)$ the petiole is winged for some distance in its lower portion. The lid, when present, is a development of the apical, or sub-apical (Nepenthes), portion of the lamina; at its first development it adheres firmly to the rim of the ascidium, from which it erentually separates, except at the point of attachment; the lid is bilobed.

2. Leaf-Tendrils (see p. 49) are leaves or parts of leaves which

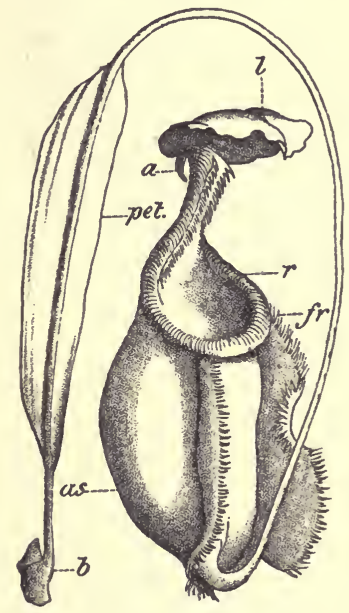

Frg. 37.-Pitchered leaf of Nepenthes. $a$ Organic apex of leaf ; $b$ leaf-base; pet petiole, winged in its basal portion; as ascidium; $l$ its lid; $f r$ fringe of ascidium (reduced). have a somewhat filamentous form, and which possess the property of twisting spirally round foreign bodies, thus fixing the plant (see Part IV.). In species of Clematis, Tropæolum, etc., this function is performed by the petiole of the foliage-leaf; but in the Vetches and Peas there is a division of labour of this kind, that the anterior leaflets of the pinnate leaf are modified into tendrils (Fig. 28, $O, r f$ ); in $L a$ thyrus Apliaca all the leaflets undergo this metamorphosis, and the special functions of the foliage-leaves are discharged by the stipules. The tendrils of the Cucurbitaceæ are also metamorphosed leaves.

3. Leaf-Spines are leaves or parts of leaves which are moditied into pointed, hard, woody structures. Spiny teeth are often present on foliage leaves (e.g. Holly, Thistles); in species of Caragana and Astragalus the phyllopodium of the pinnate leaf becomes a spine after the falling-off of the green leaflets; finally, the entire leaf becomes spiny in Berberis (Fig. 38).

4. Scales or cutaphyllary leaves (Fig. $36 \mathrm{~N}$ ). These are usually of a yellow or brown colour, of simple structure, without projecting veins, and are attached to the stem by a broad base. They may be regarded in some cases as leaf-bases, the laminæ of which have not dereloped; and in other cases, as entire leaves which 
have remained in a rudimentary condition. They always occur on subterranean stems (e.g. the scales of the Onion, see also Figs. 22 and $23 n$ ), and sometimes on aërial stems. Many plants which are not green (Orobanche, Neottia) produce only cataphyllary leaves in addition to the floral leaves. The most common form in which they occur upon aerial stems is that of scales investing the buds of trees. In this case they are the lowest leaf-structures borne by the annual shoot, and usually fall off as the bud developes.

Some few indigenous trees have naked buds without scales, as Viburnum Lantana, Cornus sanguinea, Rhamnus Frangula; their buds are protected by a dense growth of hairs.

The following varieties of bud-scales may be distinguished :-

a. The bud-scales are the stipules of leaves which develope a lamina; as in Alnus, Liriodendron, Marattiaceæ.

$b$. The bud-scales are the stipules of leaves which develope no lamina: Oak, Beech.

c. The bud-scales are leaf-bases, the lamina not being developed : Maple, Ash, Horse-Chestnut, Prunus Padus.

$d$. The bud-scales are laminæ or epipodia: Lilac, Privet, Abietineæ.

In the last case the bud-scales may be caused to develope into foliage-leaves by cutting off the top of the branch, or removing its leaves, at the time when the bud-scales are developing.

Cataphyllary leaves are sometimes thickened so as to serve as depositories for nutritive substances, as in the bulbs of the Onion, Lily, etc.

5. Bracts and Floral Leaves (Hypsophylls and Sporophylls; Fig. 36 H). These leaves are generally peculiar in form, texture, and colour; their morphology is discussed in connexion with that of the reproductive organs in $\S 16$, p. 76 , as also in Part III.

Vernation and Prefoliation. The forms of young leaves and their relative position in the bud, that is their vernation and prefoliation (astivation and prefloration of floral leaves), require special consideration.

The vernation (or astivation) is said to be plane when the leaf is not folded at all; it is conduplicate when the two halves of the leaf are folded inwards 
face to face on the midrib as on a hinge (e.g. the Bean); it is plicate when the leat is folded in numerous longitudinal or oblique pleats (e.g. the Beech) ; it is crumpled, when the foldings are in all directions (e.g. the petals of the Poppy); it is incolute, when the lateral halves are rolled inwards towards the mid-rib on the ventral surface (e.g. the Violet); it is revolute, when they are rolled inwards towards the mid-rib on the dorsal surface (e.g. the Dock); it is convolute when the whole leaf is rolled up from one lateral margin to the other, so as to form a single roll (e.g. Canna); or, finally, it is circinate, when the leaf is rolled longitudinally on itself from the apex dowuwards (e.g. Ferns).

The form of vernation of the individual leaf is determined by the relative activity of growth in its different parts. For instance, the conduplicate, involute, convolute, and circinate forms are all due to the fact that the leaves which present them are hyponastic, that is, that the dorsal surface grows more rapidly at first than the ventral ; and this may be either in the transverse plane, when the infolding is lateral or transverse (conduplicate, involute, convolute); or in the longitudinal plane, when the infolding is longitudinal (circinate). Revolute vernation is, on the contrary, due to the fact that the leaf is transrersely epinastic, that is, that the ventral surface grows more rapidly at first in the transverse plane than does the dorsal. The expansion of the leaf, in either case, is due to a reversal of the activity of growth; that is, the surface which grew the less actively in the early stage of development, grows the more actively in the later stage (see also Part IV., Epinasty and H!|ponast!!).

The prefoliation (or preforation) is said to be valvate when adjacent leaves in the bud merely touch by their margius; when some are overlapped by others it is imbricate; an intermediate form is that in which one margin of each leaf is directed obliquely inwards, and the other obliquely outward overlapping the inner margin of the next leaf, and is termed contorted or twisted (e.g. petals of the Periwinkle).

Valvate prefoliation is only possible in the case of whorled leaves, whereas inbricate prefoliation is characteristic of spirally arranged leaves. A common form of imbricate prefoliation or prefloration is the quincuncial, which occurs in the many dicotyledonous flowers which have a ${ }_{5}^{2}$ calyx; the five imbricate sepals are so arranged that two are wholly internal, two wholly external, and one partly internal and partly external, connecting the outer two with the inner two (see Part III., Phyllotaxy of the Flower). Where the phyllotaxy is distichous $\left(\frac{1}{2}\right)$, the vernation of the leaves is generally conduplicate, and the margins of each older leaf overlap those of the next younger leaf, giving rise to a form of imbricate prefoliation distinguished as equitant (e.g. Iris); in some cases the overlapping is by one margin only, in which case the prefoliation is said to be semi-rquitant. 


\section{$\S 13$. The Root. It must be clearly apprehended that a} subterranean member is not necessarily a root; nor can a member be termed a root because it is found to absorb water and salts in solution, for in rootless plants this function may be discharged by shoots, or leaves, or hairs; nor can a member be termed a root because it serves as an organ of attachment to the substratum, for such organs may be emergences (see p. 66); only such members can be regarded as roots which bear neither leaves nor true reproductive organs.

It is not always easy to distinguish at once between root and other members. Thus, in some of the lower simpler forms of plants (e.). Algæ, gametophytes of some Vascular Cryptogams) it is difficult to distinguish between roots and root-hairs, for they are identical in structure, and in neither case do they bear leaves or reproductive organs, But a study of their development affords the distinction. For example, the first stage in the development of the gametophyte of Equisetum, and some other Vascular Cryptrgams, consists in the division of the spore by a trauverse wall into two halves, the epibasal and the hypobasal. The furmer grows out into a multicellular filament which developes into the thalloid shoot; the latter grows out, in a diametrically opposite direction, into a delicate unicellular filament, the primary root. It will be observed that, at the time of their first development, root and shoot are here co-ordinate in structure (p. 6). In the course of its growth, the thalloid shoot produces ontgrowths from its cells on the ventral surface, which are identical in structure with the primary root. These are not, however, roots, but root-hairs; for they are not co-ordinate in structure with the shoot at the time of their development. Again, the simple tubular outgrowt ths on the under surface of the creeping stem of Caulerpa (Fig. 17), are not root-hairs, but roots, for they are co-ordinate in structure with the stem. Similarly, the distinction between roots and emergences of the nature of haptera and haustoria (see p. 66) is not always immediately obvious. Thus, in its endogenous development, the haustorium of Cuscuta resembles a root, but it differs from a root in that it is developed from the cortex. Finally, subterranean shoots often closely resemble roots, but may be distinguished by the small scaly leaves which they bear.

The root is sometimes wanting in plants where it might be expected to be present, in plants, that is, of which the body is not a thallus (e.g. gametophyte of Mosses : sporophyte of Salvinia, Psilotum, Utricularia, Epipogon, Corallorhiza).

In the sporophyte of the Vascular Cryptogams and Phanerogams, there are certain peculiarities connected with the structure and development of the root which contribute to its morphological distinction. As a rule, the growing-point of the root is not exposed, like that of stems or leaves, but is covered by a structure termed the root-cap. As a rule also, the growing-point of the root, 
whether normal or adventitions, is developed, not at the surface, but in the interior of the tissue, that is, endogenously.

There are exceptions to both these rules. The primary root of some parasitic plants, such as Orobanche and Cuscuta, has no root-cap, as also the small lateral roots which spring from the larger roots of the Horse-Chestnut. In some cases (e.g. old roots of Azolla caroliniana, Hydrocharis, Pistia Stratiotes) a root-cap is present at first, but eventually disappears, the growth in length of the root being arresteâ.

Exogenous development has been observed in the adventitious roots of Cardamine pratensis (roots of adventitious buds developed on leaves); of Neottia Nidus Avis; of Nasturtiım officinale and silvestre; of Ruppia rostellata (embryo); Lycopodium, Phylloglossum.

The root which is developed at the opposite pole of the embryo to the shoot, is termed the primary root (see p. 15). When the primary root persists and continues its growth (as in Oak, Radish, Bean, etc.), it is termed a tap-root. In many cases (generally in Monocotyledons) the growth of the primary root is limited, so that it attains but feeble development. In other cases (e.g. Orchids, Phylloglossum, Selaginella) no primary root is developed, all the roots being adrentitious. The symmetry of the root is most commonly radial. In some cases, however, the root is isobilateral, as is shown as well by its internal structure as by the development of two opposite longitudinal rows of lateral roots. In other cases (e.g. attached aerial roots of epiphytic Orchids; roots of Podostemaceœ) its symmetry is more or less distinctly dorsiventral.

Roots branch either dichotomously (e.g. Isoetes), or laterally (see p. 33). In lateral branching the secondary roots are developed in acropetal succession on the primary root, and so on. The growing-points of the lateral roots are derived from that of the parent root (see p. 21); but, since the endogenous lateral roots take some time in reaching the surface, they are only perceptible externally at some distance from the apex of the parent root. The terminal apical portion of the parent root consequently bears no lateral roots. On anatomical grounds (see Part II.) the secondary roots are arranged in longitudinal rows on the primary roots; an arrangement which also obtains in the branches of the secondary roots, and of higher orders.

All roots which are not developed as branches of the primary root, that is, which are developed from other members, as well as all branches which are not developed in acropetal succession on the primary, secondary, or higher order of branches, are said to be adventitious (see p. 21). 
Adventitious roots are most abundantly produced when the normal rootsystem is feeble. They are usually developed by the formation of growingpoints in members which are adult; but in some cases they spring from the growing-point of the shoot. The roots of Marattiaceæ, of Lycopodium Phlegmaria and other species, of Gunvera, of Nuphar, all take origin from the growing-point of the shoot; they may either at once grow out to the surface, or they may grow down through the tissue of the stem, emerging at its base (Lycopodium), or between some of the lower leaf-scars (Marattia). In Neottia Nidus Avis the adventitious roots are largely developed from the intercalary growing-point of the rhizome.

The form of the root is usually cylindrical; when it is very delicate, as in Grasses, it said to be fibrous; in some plants, as mentioned above, it is hair-like. The primary or the secondary roots may become much swollen, serving as depositories for nutritive substances; the Turnip, the Carrot, the Beet, the Radish, have swollen primary roots; the Dahlia has swollen secondary roots.

Various terms are employed to designate the different forms of swollen roots; that of the Turnip is termed napiform; that of the Carrot, conical; that of the Radish, fusiform or spindle shaped; those of the Dahlia and of some terrestrial Orchids, tuberous.

Many plants have aerial roots which are peculiar both morphologically and physiologically. The roots of epiphytes, that is, plants (mostly Orchids, and Bromeliaceæ) which grow on trees without, however, being parasitic, never reach the ground, but serve as a means of

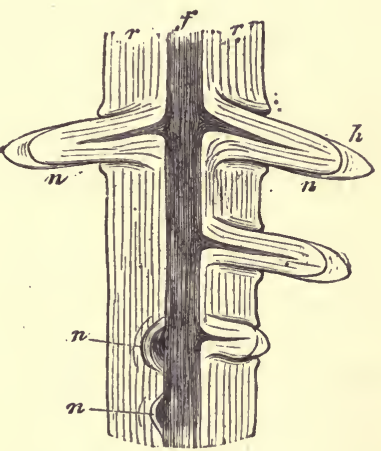

FIG. 39.-The lateral roots $n$ arising endogenously from the pericycle of the tap-root of Vicia Faba (Longitudinal sec. mag. 5 times). $f$ Axial cylinder (stele); $r$ cortex of the main root; $h$ root-cap of the lateral root.

attachment: they frequently contain chlorophyll and serve as organs of assimilation, especially in Podostemaceæ. Some plants climb by means of aerial roots (e.g. Ivy, Tecoma radicans), which are developed on the ventral surface of the dorsiventral stem, and adhere closely to the tree-trunk or wall on which the plant is climbing.

In some rare cases the aerial root is a tendril, as in Vanilla aromatica, Lycopodium rupestre and other species, and in some Melastomaceæ (Medinilla radicans, Dissochæta). 
Roots are occasionally developed as thorns, as in the Palms Acanthoriza and Iriartea, and in Myrmecodia (Rubiaceæ).

In some species of Jussiæa (e.g. J. repens) which live in swamps, some of the adventitious roots develope into floats, containing large intercellular spaces.

$\S 14$. Hairs and Emergences. Under these terms are included various appendages of a lower morphological value than the stem, the leaf, or the root, npon all of which they may be borne.

They are frequently of adventitious origin, and are commonly not developed in any definite order of succession. But when they are developed in progressive succession, as in the gametophyte of some of the lower plants, it is by no means easy to certainly distinguish them from other members of the body. For instance, in certain Liverworts (e.g. Riccia, Marchantia) the lower (ventral) surface of the thalloid gametophyte bears one or two rows of scales : from their regular arrangement these ventral scales might be regarded as leaves, were it not that in other forms (e.g. Corsinia, Clevea) they are arranged quite irregularly. The close relation between hairs and leaves in the gametophyte is further indicated by the fact that in some foliose Liverworts (e.g. Jungermannia bicuspidata) the ventral leaves (amphigastria) of other forms are each represented by a hair.

(a) Hairs. Hairs are always developed from superficial cells; a hair usually takes origin from a single superficial cell, but sometimes from more than one. Their growth is generally apical, but sometimes basal.

Hairs vary in form and structure; they may be unicellular, when they are termed simple; or multicellular, when they are termed compound or articulate: they may be branched or unbranched; they may be filamentous or scaly. They subserve various functions, being protective, secretory, or absorbent.

Various terms are used to describe hairs: filamentous hairs which are secretory have frequently a dilated apex, and are termed capitate; flattened hairs which are star-shaped, are termed stellate; discoid flattened hairs are termed radiate or peltate; the erect flattened hairs of Ferns are termed palece or ramenta. When hairs are stiff they are termed bristles or seta.

Special terms are used to indicate the nature and the distribution of the hairs on a member. A surface which bears no hairs is said to be glabrous; when the hairs are scattered the surface is pilose; when the hairs are close and short, villous; when they are longer, tomentose. When the hairs are rather stiff, the surface is hirsute; when bristly, hispid. When the hairs are borne on the 
margin only, the member is said to be ciliate. A surface with closely appressed hairs is lepidote; a member bearing ramenta is ramentaceous.

The root-hairs demand special notice. Root-hairs are hairs which perform the functions of absorption and attachment; they are commonly developed on roots,
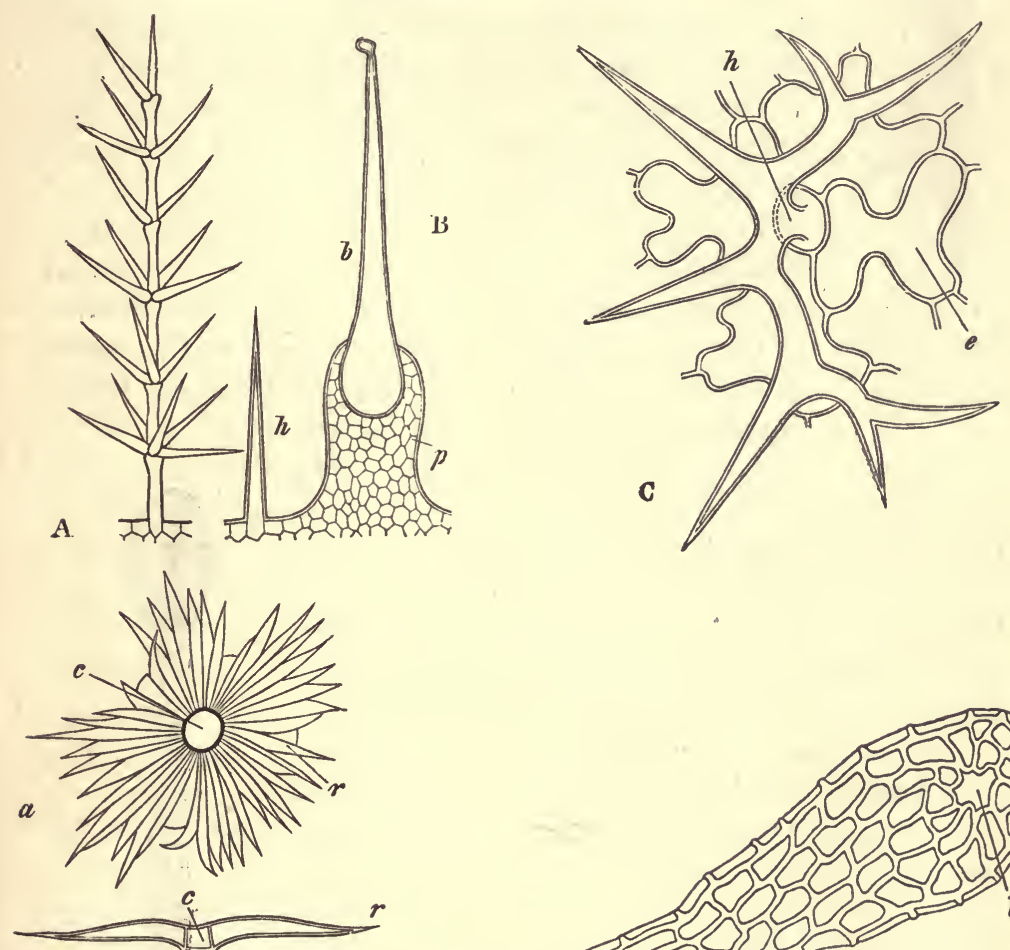

b

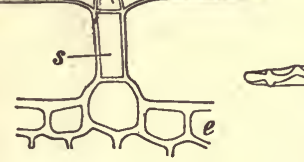

D

FIG. 40.-Different forms of hairs. $A$ Branched compound hair (Verbascum). $B b$ Stinging-hair with basal cnshion $p ; h$ simple hair (Urtica). $C$ Branched simple hair, seen from the surface; $e$ epidermis (Matthiola). D Scaly compound hair (Hippophae); $a$ seen from the surface; $b$ seen in section; $c$ central cell; $r$ radiating cells; 8 stalk-cell; $b$ epidermis. $E$ Ramentum (Asplenium); $b$ the point of attachment.

though not always, for they are absent from the roots of a number of aquatic plants (e.g. Butomus umbellatus, Caltha palustris, Hippuris, Myriophyllum, Menyanthes, Nymphæa, Lemna); they may be developed on the thallus, or the thalloid shoot, in the gametophyte of Liverworts and homosporous Vascular Cryptogams; on the stem, though rarely (e.g. Corallorhiza, Epipogon, Psilotum), 
or even on leaves (e.g. Salvinia). They are always unicellular, and it is only rarely that they are found to branch. On roots, at any rate, they are

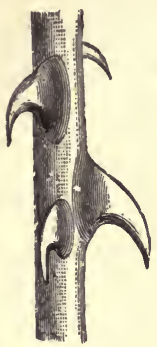

FIG. 41. Prickles on the stem of the Rose(nat.size). developed in acropetal succession.

(b) Emergences. These appendages differ from hairs in that they are developed not only from superficial cells, but from others lying beneath them.

The commoner forms of emergences are prickles (Fig. 41) and warts; more specialised forms are the tentacles of the leaf of Drosera (Figs. 42 and 43); the ligule of the leaf of Grasses (Fig. 28), Selaginella, and Isoetes (see p. 48); the corona of Narcissus; the cupule of Lunularia and Marchantia.

The more highly developed emergences (e.g. many prickles, tentacles of Drosera) of Vascular Plants frequently contain vascular tissue.

A remarkable kind of emergence is the organ of attachment, termed a hapteron, developed on the stalks of some Algæ (e.g. Laminaria), on the stems and branches of Podostemaceæ and on the tendrils of some Ampelideæ and Bignoniaceæ among Phanerogams: it contains no vascular tissue even in Vascular Plants.

The suckers, or haustoria, of parasitic plants, (e.g. Cuscuta, Orobanche, Thesium, Rhinanthus, etc.) are also emergences, being developed from the cortical tissue of the root or stem bearing
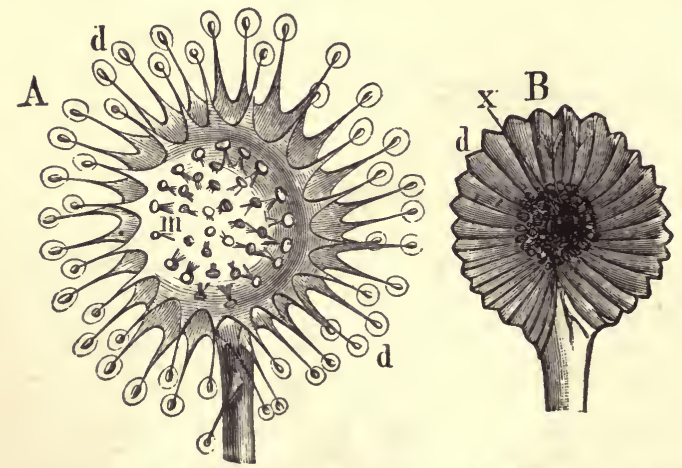

Fig. 42.-Leaf of Drosera rotundifolia. A Expanded; $d$ the glandular tentacles of the edge of the leaf; $m$ the short tentacles in the middle. $B$ The marginal tentacles have bent towards the middle at the touch of an insect, $x$.

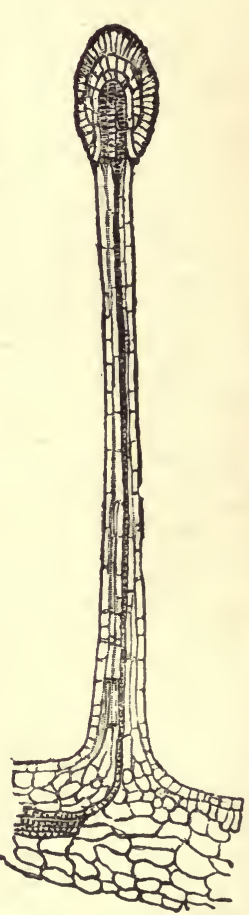

Fig. 43. - Tentacle of Drosera rotundifolia. (After Strasburger: $x$ 60.) 
them. Those of Rhinanthus, Thesium and Orobanche, are developed exogenously; those of Cuscuta, endogenously. They contain vascular tissue.

\section{B. REPRODUCTIVE ORGANS.}

$\S 15$. Reproduction. Reproduction consists essentially in the development of one or more new organisms from the whole or from a part of the protoplasm of a parent organism.

This may be effected either by the separation of a member or a portion of the body, which, by developing the missing members, constitutes a new individual; or by the production of special reproductive cells termed spores. Two modes of reproduction are therefore distinguishable: vegetative multiplication, and sporereproduction.

1. Vegetative Multipliation is essentially connected with the process of growth.

The simplest modes of this occur in unicellular plants. In Pleurococcus, for instance, the cell divides into two, each of which constitutes a new organism. In this case the parent ceases to exist as an individual. In Yeast, the cell produces out-growths each of which becomes an independent unicellular organism. In this case the number of the progeny is not limited, and the parent organism persists. This is termed multiplication by gemmation.

In more complex plants vegetative reproduction is commonly effected in this way, that the main axis of the shoot or of the thallus, dies away: the branches thus become isolated and constitute independent organisms. This occurs very commonly in the protonema of Mosses, in the rhizomes of many Phanerogams, etc. In those cases in which the leaves produce adventitious buds (e.g. Bryophyllum calycinum, many Ferns), the adventitious buds develope into independent plants after the leaf has fallen from the plant bearing it.

In many plants special organs for vegetative multiplication are produced, which may be generally termed gemmre. In a few cases the gemmæ are unicellular; as those of Vaucheria tuberos" (cœnocyte), and of Monospora among the Algæ, whic'l are the terminal cells of branches; those of some Fungi (Mucorini, Tremellineæ, some Ascomycetes) where they are segments of mycelial branches; and those which are produced on the margins of the leaves of Jungermannia ventricosa, Scapania nemorosa, and other Hepaticæ. 
It is not possible to discriminate absolutely between a unicellular gemma and a spore. There is, in fact, a gradual transition between this form of vegetative multiplication and the simpler forms of spore-reproduction.

In other plants, multicellular gemmæ are produced. They are two-celled in Aneura multifida and some other Hepaticæ; whilst in yet others the gemmæ are multicellular flattened isobilateral plates (Fig. 4); they may be developed in special receptacles (cupules) on the upper surface of the thallus (Lunularia, Marchantia), or on the margin of the leaves. In some Mosses flattened gemmæ are produced in receptacles formed of leaves at the apex of the shoot, as in Tetraphis pellucida, and Aulacomnion androgynum : and rounded tuberous gemmæ are frequently formed on the protonema. The prothallia of some Ferns (Trichomanes) are reproduced by few-celled filamentous gemmæ; and that of Lycopodium Plilegmaria by ovoid tuberous gemmæ.

Among the Algæ, Sphacelaria tribuloides, Meloliesia callithannioides (Florideæ), and Chara, produce multicellular gemmæ. In Sphacelaria and Melobesia, they are branches of the thallus: in Chara they may be peculiar branches of the shoot (proembryonic branches) or isolated subterranean nodes (starch-stars).

In some Fungi (Ascomycetes and Basidiomycetes) compact masses of tissue, which may be regarded as organs for vegetative reproduction and are termed sclerotia, are formed on the mycelium. In the Lichens, rudimentary branches of the thallus, termed soredia, are produced and set free.

In the Vascular Cryptogams and Phanerogams, vegetative reproduction of the sporophyte is generally effected by buds, the leaves or stem of which have become swollen, serving as depositories for nutrient substances. These buds may be subterranean, and then they are of considerable size, when they are termed bulls or corms according to their structure (see p. 40): or the buds may be borne on a swollen subterranean stem (e.g. potato-tuber); or be associated with tuberous roots (e.g. many terrestrial Orchids). Sometimes they are aerial, being borne on the stem; on account of their small size they are termed bulbils (e.l. Lilium bulbiferum, Dentaria, Nephrolepis tuberosa, etc.). In Psilotum, however, vegetative propagation is effected by small flattened gemmæ, oval in shape, and consisting of a few large cells forming a single layer.

2. Spore-Reproduction. The term spore is applied to a specialised asexual reproductive cell which is capable, by itself, of giving rise to a new organism. 
There are two principal modes of origin of spores, and all plants produce spores in one or other of these modes. In the one, the spores are formed from the protoplasm of any part, or of some special part, of an organism; in the other, they are formed by the fusion of two masses of protoplasm derived either from two distinct organisms, or from distinct parts of the same organism. In the former case they are said to be formed issexually; in the latter, they are formed sexually, the fusion of the two masses of protoplasm being a sexual process (p. 3 ); the organs concerned are distinguished respectively as asexual and sexual, and are in all cases confined to the shoot.

In the Muscineæ and all the higher plants, the asexual formation of spores is absolutely restricted to the sporophyte; and the sexual formation of spores is absolutely restricted to the gametophyte. But in lower plants (Alyæ, Fungi), the sexuality of the gametophyte is frequently so far incomplete that it still retains the power of producing spores (distinguished as gonidia) in a purely asexual manner (see p. 3).

The spore (or gonidium) is generally a single cell, consisting of a nucleated mass of protoplasm containing various nutritive substances (oil, starch, etc.) : but in some cases (e.g. zongonidium of Vaucheria) where it is multinucleate, it is a cœnocyte (see Part II., Introduction).

The spore frequently has a cell-wall, which is commonly thick, and in some cases consists of two layers, an outer, the exine (or exospore), which is cuticularised, and an inner, the (intine or endospore), which is delicate and consists of cellnlose.

In some cases the spore has no cell-wall. It may then be capable or incapable of spontaneous movement. When motile, it either swims by means of one, two, four, or many cilia, or it creeps in an amoboid manner by means of psendopodia. Motile spores are termed zoospores (or zoogonidia). Ciliated zoospores are common among the Algæ (e.g. Hæmatococeus, Vaucheria, Ulothrix, Botrydinm, Ectocarpus), and they occur in some Fungi (Saprolegnieæ, Peronosporeæ). Amœboid zoospores occur in the Myxomycetes among the Fungi; in Chromophyton, and in the Floridean genera Helminthora, Bangia, and Porphyra (carpospores), among the Algæ. Non-motile naked spores occur only in the Florideæ; both the asexually-produced (tetragonidia) and the sexually-produced (carpospores) spores belong to this category, with the exceptions mentioned above. 
It may be remarked that in some Fungi and Lichens the spores are apparently multicellular. This is, however, not actually the case. The appareutly multicellular spores are really aggregates of unicellular spores.

The spores produced asexually by the sporophyte of any one plant are commonly of one kind only; when this is the case the plant is said to be homosprrous. But in some of the Pteridophyta, and in all Phanerogams, which are therefore said to be helerosporous, there are two kinds of asexually produced spores, which differ in size and in the nature of the organisms to which they respectively give rise, and are distinguished as microspores and macrospores. In the Phanerogams, the microspores are commonly termed pollen-grains; and the macrospores, embryo-sacs.

$\S 16$. General Morphology of the Asexual Reproductive Organs. In the great majority of plants the asexual production of spores takes place in the interior of an organ termed a sporangium (gonidangium in the gametophyte): but in some cases (e.g. most Fungi) they are formed by abstriction (see Cell-formation in Part IJ.) from branches of the shoot.

Whilst in some plants the asexual production of spores is not limited to any particular portion of the body, in others it is so limited. When this is the case, the portion of the body which performs this function differs more or less widely in form from the vegetative portions, and it is distinguished as the sporophore. When the body is differentiated into root and shoot, the sporophore is always part of the shoot.

In those plants in which the shoot is differentiated into stem and leaf, the development of spores is commonly confined to the leaves. A leaf bearing one or more sporangia is termed a sporophyll.

(a) The Sporangium (incl. Gonidangium). In unicellular plants (e.g. Yeast, Hæmatococcus) the cell, that is the whole body of the organism, becomes one sporangium. In this case the development of spores closes the life of the organism, for the protoplasm is used in the formation of the spores, and the cell-wall is ruptured to allow of their escape.

In simple multicellular plants (e.g. Ulva, Ulothrix) each cell eventually acts as a sporangium, giving rise to spores. With the formation of spores the life of each cell is closed; so that when all the cells have formed spores the life of the organism is ended.

In plants of higher organization the formation of spores is limited to certain cells, so that the formation of spores no longer 
necessarily puts a term to the life of the organism. It is in these plants that distinct sporangia are to be found.

In the Algæ and Fungi, the sporangium, when present, consists of a single cell (or a coenocyte). It may be comparatively undifferentiated, as in Bangiaceæ and other Florideæ, where it is simply a cell of the thallus the contents of which form one or more spores; or it may be a distinctly differentiated organ as in the Cutleriaceæ, Sphacelarieæ, Ectocarpeæ, Laminarieæ, and some Florideæ, among the Algæ; and in the Phycomycetes and Ascomycetes among the Fungi.

In all plants higher than the Algæ and the Fungi, the sporangium is multicellular. It is, however, unilocular, that is, it contains but one cavity in which spores are developed, though this is sometimes chambered by incomplete walls (trabeculce) as in Isoetes.

In the Muscineæ, where the sporophyte apparently produces only a single sporangium, termed the capsule or theca, this organ constitutes the whole (Riccia) or a considerable portion of the sporophyte. Its structure is simple in Riccia and other Hepaticæ but it becomes highly elaborate in the true Mosses (e.g. Polytrichum). It must, however, be borne in mind that the theca of the Muscineæ is not completely homologous with a single sporangium of a Fern or a Phanerogam, but with at least a cluster (sorus) of such sporangia : hence the exceptional complexity of its structure.

In the Pteridophyta and the Phanerogams the sporophyte produces a number of sporangia. In the heterosporous forms there are two kinds of sporangia which respectively produce the two kinds of spores: those which produce macrospores are termed macrosporangia; those which produce microspores, microsporangia. In the Phanerogams the macrosporangium is commonly termed ovule, and the microsporangium pollen-sac.

When the shoot of the sporophyte is differentiated into stem and leaf, the sporangia are generally borne on the leaves (sporophylls): but in some plants they are borne on the stem. This is the case in most Selaginellas, among the Pteridophyta: the macrosporangia (ovules) are borne on the stem in various Phanerogams ; among Gymosperms, in the Taxeæ, and Gnetaceæ; among Angiosperms, in the Polygonaceæ, Chenopodiaceæ, Amaranthaceæ, Primulaceæ, Compositæ, Gramineæ, Naiadaceæ, Piperaceæ, and others, the macrosporangia being either terminal or lateral: the microsporangia are less commonly borne on the stem, but this is the case in some Angiosperms, such as Naias and Casuarina. 
The sporangia may be borne singly, or, as is more commonly the case, in groups, each such group being termed a sorus. The sporangia of a sorus are generally quite distinct from each other; but in some cases (e.g. most Marattiaceæ, Psilotum, Tmesipteris) the sporangia are coherent, forming what appears to be a multilocular sporangium but is really a synangium.

In those heterosporous plants in which the sporangia are in sori, the two kinds of sporangia are borne in distinct sori; the only exception to this rule is afforded by the Marsiliacex, where each sorus includes both microsporangia and macrosporangia.

The sporangium is sometimes more or less completely covered by a membranous investment to which the general term indusium may be applied. In most Ferns (e.g. Hymenophyllaceæ, Aspidieæ, Asplenieæ, etc.) and in Salvinia, the indusium covers a whole sorus; this is true also of the sori of microsporangia of Azolla, and in some Cupressineæ (Cupressus, Thuja, species of Juniperus) the sorus of microsporangia is covered by an outgrowth which is doubtless an indusium. On the other hand, when the sporangia are borne singly, each individual sporangium may have its indusium : this is the case with the macrosporanginm of Azolla; the sporangia (of both kinds) of Isoetes, where the indusium is specially termed a velum; the macrosporangia (ovules) of Phanerogams, each of which is invested by one or two integuments, which are, however, merely indusia.

The mature sporangium of these higher plants is either borne upon a stalk (sometimes termed funicle); or it is sessile, and then it is commonly more or less imbedded in the tissue of the parent member, as in the case of the sporangia of the Ophioglosseæ, and of the pollen-sacs of most Phanerogams. This latter arrangement is due to the fact that the growth of the adjacent vegetative tissue keeps pace with that of the developing sporangium, so that the sporangium does not stand out on the surface.

The development of the sporanginm begins, in all cases, at the surface of the parent member. The area which bears the sporangium, especially when a number of sporangia are developed close together, generally projects more or less as a cushion of tissue to which the term placenta is applied. In the Ferns (except Marattiaceæ, Ophioglosseæ, and Isoeteæ) and in the Hydropterideæ (Rhizocarps), the sporangium is developed from a single superficial cell : in the rest of the Pteridophyta and in the Phanerogams it is developed from a group of superficial cells, and in some cases 
from cells of deeper layers as well. These Ferns and the Hydropterideæ are hence distinguished as leptosporangiate from the rest of the Vascular Plants which are said to be eusporangiate.

The most important morphological feature in the development of the multicellular sporangium is the differentiation of the sporogenous tissue, that is, of the mother-cells of the spores. These are derived from a hypodermal cell or group of cells, termed the archesporium, which may be distinguished at an early stage in the development of the sporangium, by the highly granular protoplasm and the large nucleus. The mother-cells of the spores are usially formed by the division of the archesporial cell or cells, but occasionally the archesporial cells themselves become sporemother-cells. The sporogenous cells, as they develope, become more or less completely invested by a layer of highly granular cells, forming a membrane termed the tapetum, which temporarily separates them from the wall of the sporangium; the tapetum may be derived wholly or in part from the archesporium or from the wall of the sporangium.

The structure and form of the archesporium varies widely in the different groups of plants. It may be a solid mass of cells, as in all Hepaticæ except Anthoceros; or a layer of cells, as in Anthoceros, Mosses (except Archidium), Isoetes, pollen-sacs of some Phanerogams; or a row of cells, as in Lycopodinæ, pollen-sacs of some Phanerogams; or a single cell, as in the Leptosporangiate Filicinæ, in Equisetum, and in the macrosporangia (ovules) of most Phanerogams.

The constitution of the archesporium in the Eusporangiate Pteridophyta and in the Phanerogams, depends upon the form of the sporanginm. The young sporangium in all these plants consists of one or more longitudinal rows of cells, covered by an epidermis; when there are several rows of cells, the lateral rows radiate outwards in the apical portion of the sporangium. When the sporangium is circular in transverse section, and is narrow, it is only the terminal cell of the central axial row which constitutes the archesporium; when the sporangium is elongated transversely, the terminal cells of several of the rows lying in the plane of elongation, become archesporial cells, so that the archesporium consists of a row of cells; when the sporangium is broad, the terminal cells of several of the adjacent central rows become archesporial cells, so that the archesporium consists of a layer of cells. 
The archesporinm gives rise in some cases simply and only to the mother-cells of the spores, as in Riccia among the Liverworts, and in the Mosses; but more commonly it gives rise also to cells which are not sporogenous. Thus, in all Hepaticæ, except Riccia, the archesporium gives rise to sterile cells, which, in most, Hepaticæ, become the elaters; and generally in the Pteridophyta and Phanerogams, some at least of the tapetal cells are derived from the archesporium; in Isoetes, the tissue of the trabeculæ is derived from the archesporium.

The sporogenous cells usually divide so as to give rise each to four spore-rudiments, though there are exceptions to this rule. Thus, only one of the mother-cells in the macrosporangium of Selaginella divides into four, the others being abortive; and in that of Phanerogams the mother-cell, or cells where there is more than one, does not divide, but developes directly into a single macrospore (embryo-sac). In all homosporous plants, the four spore-rudiments formed by each mother-cell all come to maturity; and this is the case also as regards the microsporangia of heterosporous plants. In the macrosporangia of the heterosporous Pteridophyta, the spore-rudiments all reach maturity in Selaginella and Isoetes, so that the mature macrosporangium of Selaginella contains four, and that of Isoetes many, macrospores: but in the Hydropterideæ (Salvinia, Pilularia, etc.), where each macrosporangium contains sixteen mother-cells, so that sixty-four spore-rudiments are formed, only one of these sixty-four comes to maturity, so that each macrosporangium produces only a single macrospore.

In most cases the asexually-produced spores are set free from the organism producing them. An exception to this is offered by the macrospore (embryo-sac) of Phanerogams, in which plants the macrospore remains permanently enclosed in the macrosporangium (ovule), and the macrosporangium remains attached for a considerable time to the plant bearing it. It is on account of this peculiarity that seeds are produced in Phanerogams. The production of seeds is the characteristic difference between Phanerogams and Cryptogams.

When spores are formed by abstriction, they are set free almost as soon as they are formed. When they are produced in sporangia they are usually set free by the rupture or dehiscence of the sporangium. In some cases the wall of the sporangium simply degenerates; in other cases there is a special mechanism, some- 
times very elaborate, for its dehiscence. In a few cases the whole sporangium falls off from the parent plant, e.g. the microsporangia and macrosporangia of Salviniaceæ; here the spores never become free from the wall of the sporangium, but germinate inside it.

(b) The Sporophore. Beginning with the lower plants, a wellmarked asexual spore-producing organ is, in many cases, a striking feature of the incompletely sexual gametophyte; this organ, on account of its being borne by the gametophyte, is distinguished as a gonidiophore, and its spores as gonidia (see p. 3). It is to be found in many Fungi, where it represents, in fact, the shoot of the body, and is a specialised, erect-growing branch of the mycelium. It may be simple (e.g. Mucor, Peronospora, Eurotium) or compound (Agaricus) ; in some cases it bears sporangia, or rather gonidangia, in which gonidia are formed (Mucor, Peronospora); whilst in others (Eurotium, Agaricus) it bears short filaments, termed sterigmata, from which the gonidia are formed by abstriction. In some Ascomycetous Fungi the simple gonidiophores which form gonidia by abstriction, are collected into groups (sori), each of which is enclosed in a receptacle, the whole constituting a pycnidium. Among the Algæ, the gonidiophore is represented in certain Rhodophyceæ (e.g. Dasya, species of Polysiphonia) by specialised branches of the shoot, termed stichidia, which bear gonidangia (tetragonidangia).

Turning to the sporophyte, the sporophore in these lower plants is not highly developed. In some few Fungi (e.g. Mucor) it is essentially similar to the gonidiophore; in other Fungi (e.g. Ascomycetes) and in certain Algæ (Rhodophyceæ) the whole sporophyte is simply a sporophore in the form of a receptacle containing sporangia; it is termed in the one case an ascocarp, and in the other a cystocarp.

The sporophyte of the Muscineæ affords a good example of a highly specialised sporophore in an organism the shoot of which is not differentiated into stem and leaf. The entire shont of the sporophyte constitutes the sporophore, which consists (except in Riccia) of a longer or shorter stalk (seta), bearing a terminal capsule (theca) of more or less complex structure (see p. 71).

In the majority of the higher plants, in which the shoot of the sporophyte is differentiated into stem and leaf, there are wellmarked sporophores (see Fig. 36). The sporophore may be the terminal portion of the primary shoot or of a branch; or it may be an entire branch. It is commonly known, among Phanerogams, 
as the inflorescence, but there is no reason for confining the use of this term to this group of plants. The sporophore or inflorescence is characterised by its limited growth in length, and can usually be distinguished from a regetative shoot by peculiarities of form, and, when they are present, by the nature of its leaves.

The distinction of an inflorescence from a vegetative shoot is easy when the former is an entire branch borne laterally on the latter; but when a monopodial vegetative shoot terminates in an inflorescence, the transition from the one region to the other is so gradual, that it is difficult to determine where the one begins and the other ends.

The sporophore may be simple, or it may be branched, and it then affords some of the most striking examples of the various branchsystems (see p. 32). When the branch-system is such that there is a well-defined main axis, this is termed the rhachis of the inflorescence. The rhachis and the branches of the inflorescence are commonly elongated and cylindrical, or flattened, or prismatic in form; but they are in many cases dilated at the apex into a flattened, depressed or conical receptacle, as in the Compositæ, etc.

The sporophore may be destitute of leaves (e.g. Salisburia adiantifolia). When it bears leaves they usually differ more or less widely in form, colour, and structure from the foliage-leares of the plant. Of these leaves there are two kinds: those which bear sporangia, hence termed sporophylls; those which do not bear sporangia, termed hypsopliylls (see p. 59).

When no spornphylls are present, the sporangia are borne directly by the rhachis or the branches of the sporophore, at or near the apex, in a cluster if there are several. When sporophylls are present, they are also usually collected together at the apex of the rhachis or of a branch, in consequence of the shortness of the terminal internodes. Any axis of the sporophore, bearing one or more sporangia or sporophylls, is termed a flourer.

When hypsophylls are present, some of them are commonly aggregated round the sporangia or the sporophylls, as in most Angiosperms, constituting what is termed the perianth of the flower.

When the rhachis is unbranched, it bears a single terminal flower (e.g. Equisetum, Violet); when it branches, each axis, of whatever order, terminates in a flower. It is on this account that the growth of the axes of inflorescences is limited. It occasionally happens, as a monstrosity, that the axis grows through the flower and produces foliage-leaves; this is termed proliferation. 
When the rhachis bears a single terminal flower, it is commonly termed the peduncle of the flower; when the rhachis is branched, the branches may be so short that their flowers appear to spring directly from the rhachis, and the flowers are said to be sessile; when the branches are longer and bear terminal flowers, they are termed pedicels, and the flowers are said to be pedivillate. For further details as to inflorescences, see Part III.

When no sporophylls are present, the form of the flower is extremely simple. When sporophylls are present, the form of the flower varies with the degree of elongation attained by the terminal internodes of the axis. When they elongate to some extent, the flower forms a cone, as in Equisetum, Lycopodium, Selaginella, Pinus. When they remain short, as generally in Angiosperms, the apex is more or less broadened, forming a flattened, depressed, or shortly conical torus on which the sporophylls and the perianthleaves are borne. The various forms of flowers are desclibed in detail in Part III.

In heterosporous plants it is commonly the case that the two kinds of sporangia are borne together on the same axis of the sporophore; that is, they are included in the same flower (e.g. Selaginella, most Angiosperms), which is then said to be ambisporangiate; but they are frequently confined to distinct axes, as in the Gymnosperms, and in some Angiosperms (e.g. Beech, Birch, Oak, Walnut, etc.) ; these distinct flowers are said to be monosporangiate, and are distinguished, according to the kind of sporangia which they respectively bear, as microsporangiate or macrosporangiate; in some cases one individual bears exclusively microsporangiate, and another exclusively macrosporangiate flowers, as in the Hemp, the Yew, etc.

(c) The Sporophylls. In many cases, most Ferns and Lycopodinæ, for example, the sporophylls are similar to the foliageleaves, differing only in that they bear sporangia; but more commonly the sporophylls are distinguished by some peculiarity in form or structure. Thus in the Flowering Fern (Osmunda regalis) the sporophylls differ from the foliage-leaves in that no green leaf-tissuie is developed in them. In Botrychium, Ophioglossum, and the Hydropterideæ (Rhizocarpæ), the sporophyll is a branch or segment of a foliage-leaf, characterised by a peculiar form and by the absence of green leaf-tissue. In Marsilia and Pilularia the sporophyll forms a hollow capsule, enclosing the sporangia. In Equisetum, the sporophyll is a peltate scale bearing the sporangia on its inner or under surface. In the Gymnosperms the sporo- 
phylls are generally small scaly leaves; and in the Angiosperms they differ widely in form from the foliage-leaves. In some of the Algæ too, as in Cladostephus (Sphacelarieæ), there are definite sporophylls.

The distribution of the sporangia among the sporophylls in heterosporous plants is an important point. In the Hydropterideæ (Rhizocarpæ), both the microsporangia and the macrosporangia are borne by the same sporophyll; but in all other heterosporous plants they are borne by distinct sporophylls, which may be distinguished respectively as microsporophylls and macrosporophylls. In the Phanerogams the microsporophyll is termed a stamen; the macrospor'phyll, a carpel; but there is no reason for confining these terms to this group of plants.

The term stamen is not, however, always strictly confined to microspornphylls, but it is also applied to portions of the axis bearing microsporangia. For instance, in Callitriche, Casuarina, Naias, etc. (see p. 71), the microsporangia (pollen-sacs) are borne on a segment of the sporophore, which is termed a stamen.

In heterosporous plants, both kinds of sporophylls are generally present in one and the same flower: when, however, the flower includes only microsporophylls, it is termed microsporophyllary or staminate; and when it includes only macrosporophylls, it is termed macrosporophyllary or carpellary.

In some cases the sporangia are borne, not upon, but in close relation with, a leaf, which is nevertheless regarded as a sporophyll. Thus, in Selaginella, the sporangium is in the axil of the sporophyll. Again, the leaves which invest the macrosporangia (ovules) of Polygonaceæ, Primulaceæ, etc., are termed carpels, though they do not acturlly bear the sporangia.

The distribution of the sporangia on the sporophyll is various. They maiy be borne exclusively on the under (dorsal) surface, as in most Ferns, Equisetum and Gymnosperms (pollen-sacs); or exclusively on the upper (ventral) surface, as in the Lycopodinæ, Marsiliaceæ, macrosporangia of Coniferæ and of some Angiosperms (e.g. Butomus); or on both surfaces, as in Osmunda; or on the lateral margins, as in Ophioglossum and the $\mathrm{H}_{y}$ menophyllaceæ, and in many Angiosperms (e.g. Leguminosæ, Violaceæ, Liliaceæ) ; or on the apices of segments of the sporophyll, as in the Salviniacer.

The number of the sporangia borne by a sporophyll also varies widely. In some cases there is only one, as in Selaginella, Lycopodium, Isoetes; or two, as in most Coniferæ; or four, as in most Angiosperms (microsporangia) ; or many, as in the Filicinæ. 
In most cases the sporangia are free on the surface of the sporophyll; but in some cases they are enclosed in a cavity formed either by the infolding and junction of the margins of the sporophyll, or by the junction of the margins of adjacent sporophylls. The sporangia of the Marsiliacer are thus enclosed by the sporophyll, as are also the macrosporangia of all Angiosperms. In the latter group the resulting structure is termed the ovary.

(d) The Hypsophylls (Fig. 36, p. 57). Under this common term are included bracts and perianth-leaves.

Bract. This term is generally applicable to the leaves, other than the sporophylls and perianth-leaves, which are borne by the rhachis or branches of the inflorescence: those which are borne on the pedicels of individual flowers are, however, distinguished as bracteoles or prophylla.

The bract is frequently not distinguishable from a foliage-leaf, but it may be rednced to a scaly leaf, or it may be very large and even highly coloured, when it is said to be petaloid. An example of the occurrence of bracts in the Pteridophyta is afforded by Equisetum, where there is a whorl of small bracts, forming what is known as the ring, just below the cone or flower. In some Monocotyledons (e.g. Palms, Arums, etc.) there is a large bract, termed a spathe, which invests the whole inflorescence: it is usually not green in colour, as in the Trumpet Lily (Zantedeschia athiopica) where it is white. In some cases the bracts are arranged in whorls round the inflorescence (e.g. Compositæ) forming an involucre.

The bracteoles sometimes form an investment, termed an epicalyx, to the flower (e.g. Malva, Camellia, etc.).

The Perianth-leaves are leaves developed in immediate relation with the sporophylls, or with the sporangiferous axis, of a flower, to which they form a protective or attractive investment termed the perianth. A perianth is present only in Phanerogams, and is confined almost exclusively to the Angiosperms: the Gnetaceæ are the only Gymnosperms in which it is represented. The leaves may be arranged in a single whorl, or in two or more; or they may be all alike, either green and inconspicuous, or of other bright colours and conspicuous; most frequently the leaves of the outer whorl (sepals constituting the calyx) are small and green in colour, being especially protective in function, whilst those of the inner whorl (petals constituting the corolla) are large and brightly coloured, being especially attractive in function. (For further details, see The Flower, Part II1). 


\section{$\S 17$. General Morphology of the Sexual Reproductive}

Organs. The general morphology of the sexual reproductive organs agrees in many respects with that of the asexual reproductive organs.

In the great majority of plants the sexual reproductive organs give rise to sexual reproductive cells, termed gametes; hence the organs may be generally termed gametangia. In some cases the formation of gametangia is limited to a certain portion of the body of the gametophyte, which differs more or less from the vegetative portions of the shoot and may be distinguisled as a gametophore. When a part of the body is differentiated as a shoot, the gametophore is part (or the whole) of the shoot. Since, in most plants, the morphological differentiation of the gametophyte is not so complete as that of the sporophyte, it follows that the gametangia are less frequently developed on leaves than are the sporangia. In those cases in which the gametangia are borne by leaves, the leaves may be termed gametophylls.

(a) The Gametes. A gamete is a sexual reproductive cell-a reproductive cell, that is, which is incapable by itself of giving rise to a new organism; in this respect it differs from a spore. A spore is, however, formed from the fusion of two gametes of different sexes; that is, by a sexual process (see p: 69).

In those of the lower Algæ and Fungi in which sexual sporeformation takes place, the gametes produced by the organism are all externally similar; hence these plants are termed isogamous; the sexual process, which consists here in the fusion of two similar gametes, is termed conjugation; and the spore formed by conjugation is termed a zygospore.

In all the higher plants, hence termed heterogamous, the gametes are not all alike; but there are two kinds, the male and the female. The male and female gametes may be generally distinguished by their difference in size, the male being the smaller, and by the greater activity of the male gamete in connection with the sexual process which is here termed fertilisation, the male gamete being considered to fertilise the female.

The gradual transition from isogamy to heterogamy can be most clearly traced in the Algæ: special attention is directed to this in the account of the Algæ in Part III.

The gametes of isogamous plants, in those cases in which they are set free from the gametangium and are free-swimming, are well 
defined, ciliated, somewhat pear-shaped masses of protoplasm destitute of a cell-wall (e.g. Botrydium, Ulothrix, Ectocarpus, etc.), and are distinguished as planogametes. When, however, they are nat free-swimming (as in the Conjugate Algæ) they have no defined form nor are they ciliated.

The gametes of heterogamous plants. The male gamete, when the conditions are such that it must of necessity be free-swimming, is generally a well-defined ciliated mass of protoplasm, termed a spermatozoid; spermatozoids occur in the heterogamous Green and Brown Algæ (e.g. Vaucheria, Volvox, Sphæroplea, Edogonium, Chara, Fucus), in the Bryophyta, and in the Pteridophyta. In the lower forms the spermatozoid is more or less rounded or pearshaped, somewhat resembling a planogamete of the isogamous forms: but in the higher it is club-shaped or filamentous, thicker at the posterior end, pointed at the anterior end where the two or more cilia are borne, and more or less spirally coiled.

An exception to this form of free male gamete is afforded by the Red Algæ, where the gametes are small rounded or oval bodies destitute of cilia, and are distinguished as spermatia; when first set free they have no cell-wall, but they develope one before they come into contact with the female organ. Very similar to these are the spermatia of certain Ascomycetous Fungi, which have, however, a cell-wall from the very first; but there is some doubt as to the sexual nature of these cells.

When, owing to the proximity of the male and female organs at the time of fertilisation, the male gamete has no considerable distance to traverse (e.g. Peronosporeæ, Phanerogams), it is not differentiated as a spermatozoid, but it is simply an amorphons cell without a cell-wall.

The ferrale gamete, or oosphere, is not ciliated, nor is it, as a rule, set free, but remains in the female organ until after fertilisation: but in Fucus and its allies, the oosphere is extruded from the female organ before fertilisation. It is, generally speaking, spherical in form, as its name denotes.

The gametes are developed from one or nore mother-cells in the gametangium. In isogamous plants, as a rule, each mothercell gives rise to more than one gamete, and commonly to a considerable number (e.g. Botrydium, Ulothrix); but in Ectocarpus and some other Phæosporeæ, each mother-cell produces but a single gamete. Whilst in the higher heterogamons plants the male gametes are each developed singly from a mother-cell, in the

V.s. B. 
lower it is the rule that the male gametes are produced several together from one mother-cell. The female gametes are developed singly in the mother-cell, except in the Saprolegnieæ among Fungi, and in some genera of Fucaceæ (Pelvetia, Ozothallia or Ascophyllum, Fucus), in which from two to eight (Fucaceæ) or up to twenty (Saprolegnieæ) oospheres are produced from one mother-cell.

With regard to the development of the gametes, it is sometimes the case that the whole of the protoplasm of the mother-cell is used in their formation. Thus, the gamete of Spirogyra is formed by the rejurenescence of the whole protoplasm of a cell of the filament; and the oospheres of Fucus are formed by the division of the whole of the protoplasm of the mother-cell. But in most cases a portion of the protoplasm, and more particularly of the nuclear substance, is excluded from taking part in the formation of the gametes: a portion of it is either directly cut off by division, or is simply not used in the development of the gamete. Thus, in the Muscineæ, Pteridophyta, and Gymnosperms, the development of the oosphere begins with the division of the nucleus of the mother-cell (central cell) into two; this is followed by the division of the mother-cell into two unequal parts, no cell-wall being however formed; the larger portion is the oosphere; the smaller, which eventually decomposes, is termed the ventral canal-cell, on account of its position in the female organ. In certain Algæ the development of the oosphere is attended by. (e.g. Vaucheria, (Edogonium, Coleochæte) the discharge of a mass of protoplasm from the female organ prior to fertilisation, which probably corresponds to the ventral canal-cell of the higher plants.

With regard to the development of the spermatozoid, it appears, in those cases in which it has been most fully investigated (Bryophyta, Pteridophyta), that only a portion of the cytoplasm and nuclear substance of the mother-cell is used in its formation; the residue is usually discharged with the spermatozoid, as a vesicle which adheres to it, until thrown off by its active movements. (For details, see Part II., Cell-Formation, p. 116.)

The masses of protoplasm which are derived from the mothercells, but are excluded in any of the above ways from entering into the formation of the gametes, are termed, generally, polar bodies. Their physiological significance is considered in Part IV. 
(b) The Gametangia. The general morphology of the gametangia is very much the same as that of the sporangia.

With regard to the terminology employed in designating these organs, they are said to be male when they contain protoplasm which is capable of effecting fertilisation; and female, when they contain protoplasm capable of being fertilised. When there is no external indication of the physiological nature of the organ, it is simply termed a gametangium. But when the male and female organs respectively are clearly differentiated, special names are given to them in order to indicate peculiarities in their structure or function, or the group of plants to which they belong. In the first place a distinction must be drawn, in the case of these differentiated gametangia, between those which give rise to clearly differentiated gametes, and those the protoplasm of which does not undergo such differentiation. To the former category belongs the male organ, termed antheridium, in which spermatozoids are developed, and the female organs, termed oogonium or archegonium, in which one or more oospheres are differentiated. To the latter category belong the male organ termed pollinodium (e.g. in Peronosporew and some Ascomycetes), and the female organs termed procarp (Florideæ) or archicarp (Ascomycetous Fungi).

In the lowest plants in which the sexual formation of spores takes place, the whole cell, when the organism is unicellular, or any cell, when the organism is multicellular, becomes a gametangium, without being specially modified for the purpose. This is the case, not only in isogamous plants (e.g. Pandorina, Ulothrix, Conjugatæ), but in some heterogamous plants (e.g. Sphæroplea) in which the gametes are perfectly differentiated into spermatozoids and oospheres.

In plants of higher organisation there are specialised gametangia, In the simpler forms of these the male and female gametangia are externally similar, as in the Volvocineæ, Ectocarpus, and Cutleria, among the Algæ, and in the Zygomycetes and some Ascomycetes (e.g. Eremascus) among the Fungi. In the more complex forms, the male and female gametangia are dissimilar.

The undifferentiated gametangia are generally unicellular and unilocular; but they are multicellular and multilocular, in some Phæosporeæ (e.g. Ectocarpus, Giraudia, Scytosiphon, Cutleria).

The differentiated gametangia are of various structure. The antheridium is unicellular in most of the lower plants (Green 
Algæ, except Characeæ; Fucaceæ), as also generally in Phanerogams. In all the other cases it is multicellular, and of simple structure, except in the Characeæ, where the structure is extremely complex. In some cases (Rhizocarps) the antheridium consists almost entirely of the mother-cells of the spermatozoids ; in most cases the mother-cells are surrounded by a parietal layer of cells. The pollinodium is generally unicellular.

The oogonium is either unicellular, as is generally the case, or it is a cœnocyte (e.g. Peronosporeæ, Vaucheria). The archegoninm is generally multicellular, consisting of a cellular wall investing the oosphere, usually prolonged into a tubular neck; but in some of the higher plants, Welwitschia among the Gymnosperms, and all Angiosperms, the archegonium is reduced to a single cell, the oosphere. The archicarps and procarps are unicellular in some cases, multicellular in others; in most cases the organ is prolonged into a filament, the trichogyne, by means of which fertilisation is effected. The oogonia (except those of Peronosporeæ, Saprolegniæ, and Characeæ) and the archegonia, open, so that their contents are in direct relation with the surrounding medium; in the procarps and archicarps this is not the case.

Further details are given in Part III. in connexion with the plants to which the various organs belong.

(c) The Gametophore. In some plants in which the gametophyte is well-developed, the sexual organs are not borne indifferently on any part of the body, but are confined to particular regions or branches of the thallus or of the shoot, which may be distinguished as gametophores; as in some Algæ (e.g. Himanthulia lorea), Liverworts (e.g. Marchantia), Mosses (e.g. Sphagnum), and some Ferns. In Himanthalia lorea (Fig. 44) the vegetative portion of the body is conical in form and is attached at its pointed end, and from the middle of the cup-like upper surface there grows a long branched gametophore. In Marchantia, and some other Liverworts, some of the flattened prostrate branches of the thallus develope terminally into an erect cylindrical gametophore, bearing male or female organs (antheridia or archegonia) on a receptacle at its summit. In Sphagnum, also, the antheridia and archegonia are borne respectively on distinct and specialised branches. Such nnisexual gametophores may be specially designated antheridiophores or archegoniophores. In some Ferns which have an altogether filamentous gametophyte (e.g. Trichomanes), the female organs (archegonia) are borne on short multicellular lateral branches form- 
ing cushion-like gametophores, or, more precisely, archegoniophores. When, as in most Ferns, the adult gametophyte is a flattened dorsiventral cellular expansion, the archegonia are borne on a cellular cushion projecting on the ventral surface, which constitutes the archegoniophore. This kind of archegoniophore reaches its highest development in the Fern Gymnogramme leptophylla, where the cushion grows out into a tuberous subterranean archegoniophore.

When the shoot is differentiated into stem and leaf, the sexual organs are in some cases borne on more or less specialised leaves which may be termed gametophylls, as in some Algæ, such as the Characeæ (both antheridia and oogonia), the higher Sphacelarieæ (gametangia of Cladostephus) and the Rhodomeleæ (e.g. antheridia of Polysiphonia).

The sexual organs may either be scattered over the surface of the member bearing them, or they may be developed in groups (sori). Occasionally a sorus is enclosed in a receptacle; such receptacles are the conceptacle of the Fucacer and of the Corallinex (Flori-

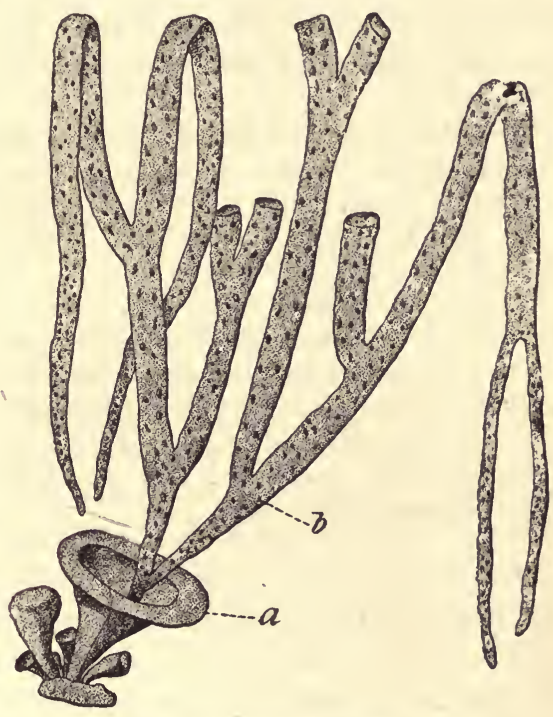

Fig. 44.-Himanthalia lorea (munb reduced), a vegetative part of body; $b$ branched gametophore. deæ); the spermogonium of the Ascomycetous and Acidiomycetous Fungi; the receptacle of many Hepaticæ.

In some Hepaticæ (e.g. foliose Jungermannieæ), and in all Mosses, the sorus of sexual organs is surrounded by leaves, which may differ more or less from the ordinary foliage leaves. The investment thus formed is termed a perichatium, and the leaves are termed perichaetial leaves.

Since, as has been pointed out, the gametangia correspond to the sporangia, the gametophore corresponds also to the sporophore; they are both portions of the shoot, or of the thallus, which are 
specially adapted to bear the reproductive organs, in the one case sexual, in the other, asexual. And just as an axis of the sporophore bearing one or more sporangia (whether directly or on sponphylls) is termed a flower, and the sporophore itself an inflorescence; so these terms may be applied to the gametophore, though the physiological differences between the sporangia and gametangia must be borne in mind. It has, in fact, long been customary with reference to Mosses, to speak of the sori of sexual organs, with their perichrtia, as "flowers."

(d.) The distribution of the Sexual Organs. The male and female organs are either borne by the same gametophyte, or they are borne by distinct male or female gametophytes; in the former case the organism is said to be monocious, in the latter dinecious.

The following are instances of monocious gametophytes:-

Alga; Volvax Globator, Rhynconema (Zygnemeæ), Vaucheria, Sphæroplea, Coleochæte, some species of Chara and Nitella, Fucus platycarpus, Halidrys, Cystoseira, Pycnophycus.

Fungi; monœeism is the rule.

Muscinea ; essentially monœcious.

Pteridophyta; homosporous forms generally monœecious, except Equisetum.

The following are instances of dioecious gametophytes:

Alga; Volvox minor, Eudorina, Conjugatæ generally, Cutleria, most species of Fucus, Ozothallia (Ascophyllum), most Red Algæ.

Pteridophyta; Equisetum, and all heterosporous forms (Hydropterideæ Isoeteæ, Selaginelleæ).

The Phanerogams have not been included in the preceding list, for the conditions which obtain among them in this respect are peculiar, and demand separate consideration. Inasmuch as the Phanerogams are heterosporous, they are essentially diœcious, since each kind of spore produces its corresponding male or female gametophyte. But in consequence of the fact (see p. 74) that the macrospore is not set free, but remains attached to the sporophyte, and germinates in that position, the female gametophyte is attached to the sporophyte. On this account, and on account of the rudimentary development of the male gametophyte (pollentube), the spores, that is the pollen-grain and the embryo-sac, have come to be inaccurately regarded as sexual reproductive cells, and the stamens and carpels, which are really sporophylls, as sexual reproductive organs. Hence a Phanerogam is said to be monocious when the same individual bears both stamens and carpels, diøecious when they are borne by distinct individuals. 
Monœcism, in this sense, is the general rule in Phanerogams; but diøcism obtains in the Cycadaceæ, the Taxeæ, the Araucarieæ, some Juniperinæ, and Ephedra, among Gymnosperms; and in various Angiosperms, such as Naias, the Pandaneæ, some Palms, Cannabineæ, Salicineæ, Ancuba, etc.

When in monœeious plants the male and female organs are both present in the same sorus, as in some Algæ (e.g. Fucus platycarpus, Halidrys, and other monœcious Fucaceæ) and in some Mosses, the sorus is said to be bisexual or hermaphrodite, and the plant is said to be monoclinous; when they are borne in different sori on the same plant (e.g. in Hepaticæ generally, some Mosses), the sorus is said to be unisexual, male or female as the case may be, and the plant diclinous. These terms are also applied to the flowers of Phanerogams in accordance with the foregoing explanation; diclinism is the rule in the Gymnosperms, and it occurs also in various Angiosperms.

$\S 18$. Apospory and Apogamy. Although it is the rule that the gametophyte springs from the spore produced asexually by the sporophyte, and that the sporophyte springs from the spore produced sexually by the gametophyte, yet the transition from the one generation to the other may be effected otherwise.

In some cases vegetative reproduction is substituted for reproduction by an asexually-produced spore : this process is termed Apospory. Thus in some Ferns (e.g. Athyrium Filix foemina) the gametophyte (prothallium) is produced directly by budding from the leaves of the sporophyte.

In other cases, either vegetative reproduction, or reproduction by asexually-produced spores, is substituted for reproduction by sexually-produced spores: this process is termed Apogamy, distinguished in the one case as vegetative apogamy, and in the other as parthenogenetic apogamy or parthenogenesis. Examples of vegetative apogamy are afforded by some Ferns (e.g. Pteris cretica) where the sporophyte is developed as a bud upon the gametophyte; and also in certain Ascomycetous Fungi where the sporophyte (ascocarp) is directly developed upon the mycelium; in neither case is there any development of sexual organs. Examples of parthenogenetic apogamy are afforded by the Saprolegnieæ, where, although oogonia are developed, there is no fertilisation, but the cells (corresponding to oospheres) contained in the oogonia germinate as though they were oospores; and also by certain Ascomycetes where the archicarp derelopes without fertilisation into an 
ascocarp. In either case the result is that a sporophyte is developed from that which either is, or represents, a gametophyte, without the intervention of a sexual process.

$\S$ 19. The Fruit. Although the forms of fruit occurring among plants are so various in their form and in their structure, it is possible to include them all in a single definition. A fruit is the product of a process of growth initiated as a consequence of a sexual act in structures which are not themselves immediately conoerned in the sexual act.

To begin with instances among the lower plants, the cystocarp of the Red Algre and the ascocarp of the Ascomycetous Fungi are fruits. In these cases the effect of the fertilisation of the female organ is not merely that the female organ gives rise to sporangia (carposporangia in the one case, asci in the other); but the adjacent vegetative tissues are stimulated to growth, forming an investment to the structures developed directly from the fertilised female organ, the whole constituting a fruit.

Similarly, in the Bryophyta, and to a less extent in the Pteridophyta, the effect of the fertilisation of the oosphere is not merely to cause the formation of an oospore and the development of an embryo, but the wall of the archegonium is stimulated to fresh growth and forms an investment, the calyptra, which encloses the embryo-sporophyte for a longer or shorter period, the whole constituting at this stage a fruit.

The most remarkable instances of fruit-formation are, however, to be found in the Phanerogams. Here, as a result of the fertilisation of the oosphere, various parts of the flower are stimulated to growth; most commonly it is only the macrosporophylls (carpels) which are so affected, but the stimulating influence may extend to the perianth-leaves or to the axis of the flower, the resulting tissues being either hard and woody, or soft and succulent (see Part III., under Phanerogams). The peculiar feature of the fruit of these plants, as contrasted with those of the lower plants, is that here the tissues affected all belong to the sporophyte, whereas in the lower plants they belong to the gametophyte: this is the necessary result of the peculiar relation of the female gametophyte to the sporophyte which obtains in the Phanerogams (see p. 86).

$\S 20$. The Seed. As this is a structure which is peculiar to Phanerogams, its morphology is discussed in connection with that group (see Part III). 
PART II.

\section{THE INTIMATE STRUCTURE OF PLANTS.}

\section{(Anatomy and Histology).}

§21. Introductory. The body of a plant, like that of an animal, consists essentially of living matter termed protopla:m. The body may consist simply of a mass of protoplasm, as the plasmodium of the Myxomycetes ; or it may consist of a mass of protoplasm invested at the surface by a definite membrane which is not protoplasmic (e.g Phycomycetous Fungi and Siphonaceous Algæ); or it may consist of a mass of protoplasm segmented into portions by non-protoplasmic partition-walls. A body of this last type of structure may be conveniently distinguished as septate, from those of the two former types which are unseptate.

On examining the protoplasm of any plant, it will be found to contain certain well-defined protoplasmic bodies termed nuclei; it is, in fact, the case that all protoplasm is nucleated. In.an unseptate body, such as those mentioned above, the nuclei, which are very numerous, are scattered irregularly throughout the protoplasm. In the septate body of certain plants (e.g. higher Fungi; some Algæ, such as Cladophora and Hydrodictyon) the septation of the body and the distribution of the nuclei stand in no direct rela. tion to each other, the protoplasm being segmented into portions each of which includes a number of nuclei; such a plant-body may be designated as incompletely septate. In the rest of the septate plants, the septation of the protoplasm and the distribution of the nnclei stand in a direct relation to each other, such that each of the portions into which the protoplasm is segmented contains but a single nucleus; a plant-body of this structure may be described as completely septate.

The portions of protoplasm which are delimitated by the septa in the body of a completely septate plant, are, both morphologically and physiologically, units of protoplasm. "They are frequently spoken of as cells, but it is more accurate to reserve this term to 
the protoplasmic unit together with the wall (cell-wall) by which it is invested, and to term the protoplasmic unit an energid. The structure of the body or any part of it can only be accurately described as cellular when it consists of one or more such cells, that is, when it is either unicellular (e.g. Yeast, Hæmatococcus, etc.) or multicellular. The body of an unseptate plant (such as the Phycomycetous Fungi and the Siphonaceous Algæ), as also a segment of the body of an incompletely septate plant (such as Cladophora, Hydrodictyon, etc.), is not a single cell, but is an aggregate of protoplasmic units (energids) enclosed within a common wall. Such a body, or part of a body, may be conveniently distinguished as a coenocyte, and the plants in which it occurs may be said to have coenocytic structure.

Even in typically cellular plants structures occur which are cœnocytic. Thus, in the early stages of its development in the embryo-sac of a Phanerogam, the endosperm is generally unseptate, consisting of a layer of protoplasm with many nuclei scattered through it; it eventually becomes a cellular tissue by the delimitation of the constituent energids by means of cell-walls. But even when the cell-walls are formed, they do not always enclose single energids ; in Corydalis cava, for instance, the net-work of cell-walls encloses several energids in each mesh, so that the structure of the endosperm is at first cœnocytic; eventually, however, the nuclei in each cœnocyte fuse together until only one remains, and in this way the transition from cœnocytic to cellular structure is effected. Again, a "laticiferous cell" of a Euphorbia (and other Phanerogams) is essentially a cœnocyte like the body of a Vaucheria or a Botrydium.

On the other hand, there is such a thing as a multinucleate cell. It has been observed, for instance, that in old internodal cells of Chara, and in old parenchymatous cells of Lycopodium and of various Phanerogams (e.g. Tradescantia, Taraxacum, Cereus, Solanum, etc.) that, from being uninucleate, they become multinucleate by the direct division or fragmentation of the nucleus (see p. 96).

The distinction between a cœnocyte and a multinucleate cell would appear to be this: that the former is either multinucleate from the first or becomes so at a very early stage in its development, whilst the latter becomes multinucleate at a quite late period; and further, that in the cœenocyte the nuclei multiply by indirect division (see p. 97), whereas in the multinucleate cell they multiply by direct division or fragmentation. 
There is another kind of structure occurring in cellular plants which has to be distinguished from both the cell and the cœnocyte: that is the syncyte. This structure is developed from alreadyformed cells by an absorption, more or less complete, of the cellwalls, which places the cavities of the adjacent cells in direct continuity. The commonest case of this occurs in the development of vessels, where the transverse septa of a longitudinal row of cells are absorbed so that a continuous tube is formed.

But even in the fully-developed cellular plant-body it appears to be very frequently the case that the energid in one cell is not absolutely cut off from those of the adjacent cells, but that there is continuity of the protoplasm; that is, that the protoplasm of one cell is connected with that of the contiguous cells by means of very delicate protoplasmic fibrils which traverse the pits or pores of the intervening cell-walls (Fig. 45). This connection appears, however, to exist from the first development of the cells, and thus differs from the case of the syncyte where the absorption of the intervening cell-walls is a secondary process.

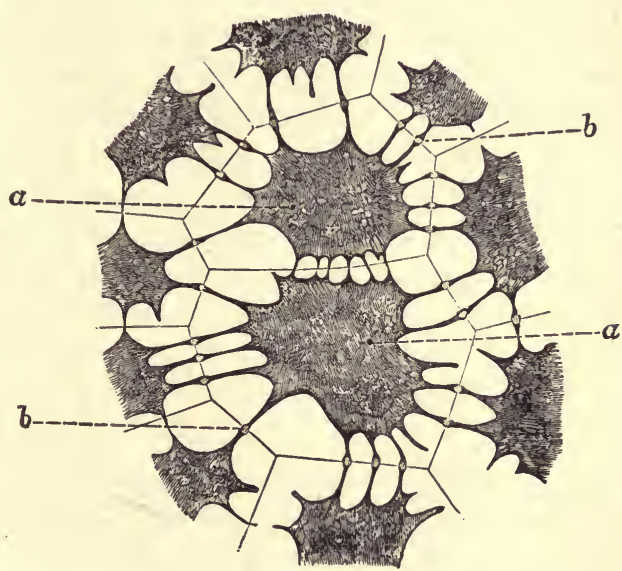

FIG. 45 (highly magnified, after Gardiner).-Continuity of the protoplasm of contiguous cells of the endosperm of a Palm-seed (Bentinckia) : a contracted protoplasm of a cell; $b$ a group of delicate protoplasmic fibrils passing through a pit in the cell-wall.

The term tissue is generally applied to any continuous aggregate of cells (or of coenocytes); but it is essential to define the term more accurately. A true tissue is an aggregate of cells (or of cœnocytes) which (1) have a common origin, whether formed simultaneously (e.g. development of endosperm of Phanerogams), or successively, as in the case of a tissue developed from a growing-point; which (2) are coherent from the first and are governed by a common law of growth; and which (3) are physiologically interdependent and cannot, in fact, exist otherwise than as part of the tissue. 
This definition may be further illustrated by the consideration of aggregates of cells (or of cuenocytes) which do not constitute true tissue. For instance, the body of Hydrodictyon consists of a number of coherent cœnocytes which were originally free cells, and which are physiologically independent; similarly the cells forming the body of a Spirogyra do not constitute a true tissue, on account of their physiological inrependence. In the higher Fungi (e.g. Agaricus) a nearer approach to a true tissue is made by the aggregation of filaments (hyphe) of the mycelial body into masses such that the growing-points of the aggregated hyphæ fo:m a collective apicul growing-point. These various forms of cell-aggregation may be distinguished as spurious tissues.

The tissue, true or spurious, of which the body of a plant consists may be either homogeneous or heterngeneous; that is, the cells (or the cœnocytes) may be all alike, constituting therefore but one kind of tissue; or they may not be all alike, the different kinds of cells being more or less grouped together so as to form different kinds of tissue. A body which consists of different kinds of tissues is said to be histologically differentiated.

The structural differences between the various forms of tissue in a histologically differentiated body are essentially connected with the special adaptation of each form of tissue to the performance of some particular function in the economy; their differences are, in fact, evidence of their physiological interdependence. In a histologically undifferentiated body (e.g., Hydrodictyon, Spirogyra, etc.), the cells (or cœnocytes) are all similar because they all have to discharge similar functions; in fact, each cell (or cœnocyte) discharges all the functions of a living body; at first nutritive in function, it closes its existence as a reproductive organ. A body such as this, consisting of physiologically independent structural units, is distinguished as a coenobium.

It is a remarkable fact that, whilst the cells of the various tissues of a histologically differentiated body present characteristic peculiarities of form, size, and relative arrangement, the most striking distinctive peculiarities are exhibited, not, as in animals, by the protoplasm of the cells, but by the cell-walls in respect of their thickness, their chemical composition and physical properties, and their markings (p. 103).

Inasmuch as the cellular plants are the more numerous, and present greater variety of structure, the following account deals almost exclusively with them. And since the cell is the structural unit of these plants, it will be advantageous to study the cell as such first, and then to proceed to the study of the tissues. 


\section{CHAPTER I.}

THE CELL.

\section{$\S 22$. The Structure and Form of the Cell. In a fully} developed living cell the following three principal constituents may be distinguished (Fig. $46 B C$ and $D$ ) :-

(1) A closed membrane, the cell-wall $(h)$, consisting generally of a substance termed cellulose.

(2) A layer of gelatinous substance, the protoplasm $(p)$, lying in close contact at all points with the internal surface of the cell-wall; the protoplasm gives the chemical reactions of proteid. In it lies a nucleus (h:), in which one or more smaller bodies, nucleoli (ki) maygenerally be distinguished.

(3) Cavities, one or more, in the protoplasm, termed vacuoles $(s)$, which are filled with a watery liquid, the cell-sap.

The structure of a conocyte is essentially the
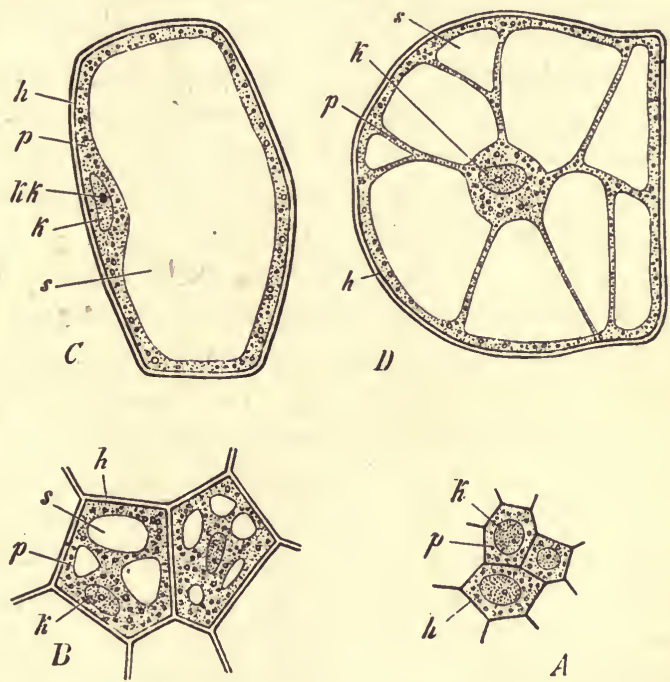

Fig. 46.-Cells and their structure. A Young cells from the ovary of Symploricarpus racemosa $(\times 300) ; B$ cells from an older ovary of the same plant $(\times 300) ; C$ and $D$ from the fruit of the same plant $(\times 100) ; h$ cell-wall ; $p$ protoplasm: $k$ nucleus; $k k$ nucleolus; $s$ vacuole. In $C$ there is a single large vacuole, the whole of the protoplasm forming the parietal layer. In $D$ there are several vacuoles, and the nucleus lies in a central mass of protoplasm connected with the parietal layer by numerous straads.

same as that just described, except that several (sometimes very many) nuclei are present.

The young cell presents a somewhat different appearance (Fig. $46 \mathrm{~A}$ ). At this stage the protoplasm occupies the whole cellcavity. But, in the subsequent development of the cell, the increase in bulk of the protoplasm does not keep pace with the 
superficial growth of the cell-wall. Hence, since the protoplasm must remain in contact with the cell-wall at all points, the result is that cavities, the vacuoles, are formed which become filled with cell-sap (Fig. $46 \mathrm{~B}$ ). The vacuoles, small at first, increase with the growth of the cell, and may fuse together to a greater or less extent owing to the gradual withdrawal of more and more of the protoplasm into the now extensive parietal layer.

Cells such as these are examples of the kind of cells which compose the succulent parts of plants, such as the cortex of stems and roots, the tissue of leaves, succulent fruits, etc., in fact the bulk of the actually living tissues of the plant. In the higher plants it is generally the case that a considerable number of the cells of the body eventually lose the whole of their proper contents, containing, in fact, nothing but air or water; such are cork-cells and vascular wood-cells. Such structures are no longer living cells, but are merely their skeletons, and are of use only in virtue of the mechanical properties of their cell-walls.

On the other hand, there are frequently found in connection with the processes of reproduction, what have been termed primordial cells, such as zoospores, zoogonidia, gametes, spermatozoids, and oospheres (see p. 69 and p. 80), each of which is simply an energid, or rarely a complex of several energids (e.g., zoogonidium of Vaucheria), without any cell-wall, though the zoospores and zongonidia eventually secrete a cell-wall when they come to rest, as do also the oospheres after fertilisation.

The size and form of the cell vary widely. While some cells are so small that little more than their outline can be discerned with the help of the strongest magnifying power (about 0.001 of a millimetre in diameter), others obtain a considerable size (from 0.1 to 0.5 millim.), so as to be distinguishable even by the naked eye (e.g., in pith of Dahlia, Impatiens, Sambucus). Many grow to a length of several centimetres, as the hairs upon the seed of Gossypium (cotton); and if cœnocytes be included, such as the laticiferous tubes of the Euphorbiaceæ, the Siphonaceous Algæ, and the Phycomycetous Fungi, very much larger dimensions in length are attained.

The Form of such cells as constitute an entire individual, or exist independently, not forming part of a tissue (e.g. spores), is generally spherical, or ovoid, or cylindrical. The various organs of highly organised plants consist of many varieties of cells, and even in the same organ cells lie side by side which are of very 
different form. The two main types of cells are, first, such as are spheroidal or polyhedral, with nearly equal or slightly differing diameters (Fig. 46), as in pith, juicy fruits, fleshy tubers; and secondly, such as are narrow and greatly elongated (Fig. 94), as in the case of fibres.

$\S 23$. The Protoplasm. The protoplasmic contents of a cell present certain clearly differentiated portions. In the first place there is a nucleus; closely associated with the nucleus is a body termed the centrosphere; and finally, there are more or less numerous plastids. These all lie in the general protoplasm of the cell which may be distinguished as the cytoplasm.

a. The Cytoplasm is of viscid tenacious consistence, but it is not a fluid. Chemical examination shows that it consists (at least, when dead) of proteid substance, and apparently of a single such substance termed cytoplastin; intimately associated with this are varying quantities of other organic substances, such as other proteids, fats, and carbohydrates, together with water, and a small proportion of inorganic ash-constituents. As it is the seat of all the nutritive processes of the cell, it must obviously contain at different times all the varions chemical substances which enter into, or are formed within the cell.

The cytoplasm, apart from the granules of foreign matter generally present in it, may be distinguished as cyto-hyaloplasm, of which the delicate firmer superficial layer of the cytoplasm, known as the ectoplasm, solely consists. As a rule, the cytohyaloplasm is distinguishable into the formative cyto-hyaloplasm or kinoplasm, and the nutritive cyto-hyaloplasm; the former is always intimately associated with the nucleus, and is active in the processes of cell-formation; the latter constitutes generally the main bulk of the cyto-hyaloplasm. It would appear that the capacity of a cell for growth and multiplication, that is, the embryonic condition of the cytoplasm, must depend upon the presence of a certain proportion of kinoplasm.

b. The Nucleus is always situated in the cytoplasm, and, in actively growing cells at least, in the kinoplasm. It consists of various proteid substances. Its structure, when at rest, may be generally described as follows. It is bounded at the surface by a membrane which belongs, however, to the cytoplasm, or, more accurately, to the kinoplasm. It consists mainly of a semi-fluid clear ground-substance, the nucleo-hyaloplasm, which, from the chemical point of riew, is a substance termed paralinin. In the nucleo- 
hyaloplasm lies a fibrillar network consisting of a substance termed linin, in which are distributed a number of granules of a substance

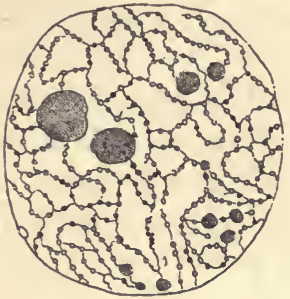

Fra. 47.-Resting nucleus from the young endoeperm of Fritillaria imperialis (after Strasburger : $\times 1000$ ); showing the fibrillar network with its chromatingranules, and several nucleoli. termed chromatin. One or more small granules, termed nucleoli, are to be seen lying in the ground-substance, and consist of a substance termed pyrenin. On treating the nucleus with staining reagents, the fibrillar network becomes stained on account of the absorption of the colouringmatter by the chromatin-granules, as also do the nucleoli. Its form is most commonly spherical, but it may be lenticular, or elongated, and straight or curved.

A formation of a nucleus de novo does not take place under any circumstances; hence all the nuclei in a plant have been derived by repeated division from the nuclens of the spore from which the plant has developed. The division of the nucleus may be either direct or indirect (mitotic); in all cases it
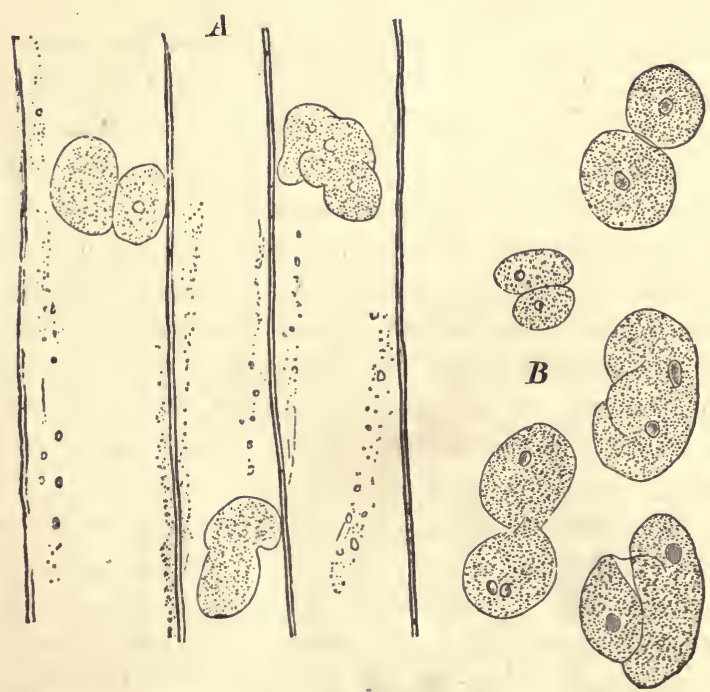

Frg. 48.-Direct nuclear division, for cells of old internodes of Tradescantia virginica: $A$ drawn from fresh material; $B$ isolated nuclei, after treatment with acetic methyl-green. (After Strasburger: $\times 510$.) divides into not more than two parts.

Direct division or fragmentation of the nucleus commonly occurs in old cells (see p. 90), which then become multinucleate; it is not associated with cell-division. So far as the process has been investigated, it consists 
simply in the constriction of the nucleus into two halves (Fig. 48).

Indirect or mitotic division of the nucleus is generally associated with cell-division; in cœnocytes, however, the indirect nuclear division is not followed by cell-division, but each division results simply in a corresponding increase in the number of protoplasmic units present (energids, see p. 90). The description of this mode of nuclear division is included in the account of celldivision (p. 118).

c. The Centrosphere, though a perfectly independent body, is always closely associated with the nucleus. It is spherical in form, and consists of a central particle (the centrosome), surrounded by a considerable hyaline area, limited by a granular outline. It undergoes division in connection with the division of the nucleus, as described in the section dealing with that subject. It appears that there are normally two of these bodies associated with the nucleus, lying close together (Fig. 49) in the kinoplasm.

d. The Plastids are differentiated portions of the protoplasm which, like the nucleus, are not formed de novo, but multiply by division. Their form varies widely. Structurally, they seem to consist of a groundsubstance with imbedded fibrils,

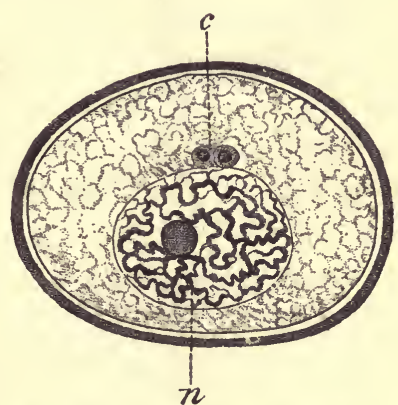

Fre. 49. - Young pollen-grain of Lilium Martagon, showing, $c$ two centrospheres, and $n$ the resting nucleus. (After Guignard : $\times 750$.) denser at the surface. Chemically, they have been described as consisting of two proteid substances; the one, termed chloroplastin, constitutes the ground-substance, and seems to be similar to the eytoplastin of the cytoplasm; the other, termed metaxin, is the material of the fibrils, and appears to be altogether peculiar to the plastids.

The plastids may either be colourless, when they are termed leucoplastids; or coloured, when they are termed cliromatophores. The chromatophores are distinguishable as chloroplastids, when they contain the green colouring-matter chloraphyll; or as chromoplastids when they contain no, chlorophyll, but some other colouringmatter. Plastids are not found in the Fungi, nor, apparently, in the Cyanophyceæ among the Algæ.

V.S. B. 
The Leucoplastids may be spheroidal, fusiform, or cylindrical in shape; they are especially numerous in the neighbourhood of the

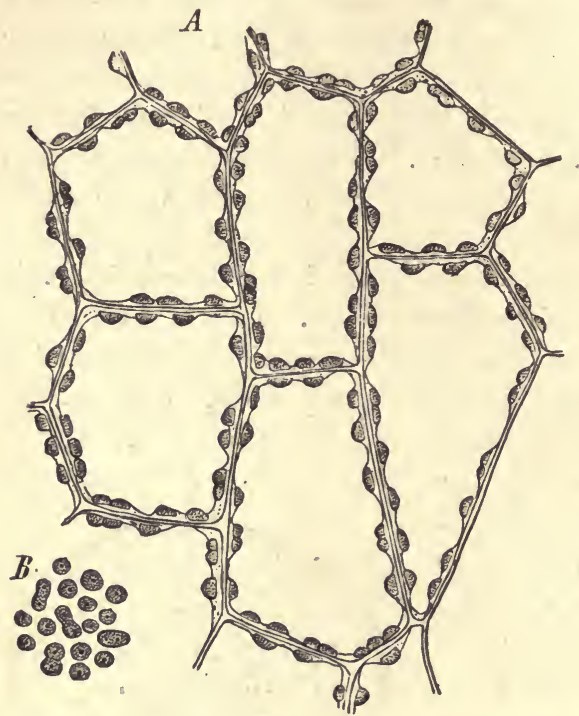

Fig. 50.-Chloroplastids in the cytoplasm of the cells of the prothallium of a Fern. A Optical section of the cells; $B$ part of a cell seen from the surface. Some of the plastids have begun to divide $(\times 400)$. nucleus. In parts of plants which, in the ordinary course, eventually become exposed to light, the leucoplastids develope into chloroplastids. Conversely, when a part which is normally exposed to light is kept in darkness, the chloroplistids become replaced by leucoplastids. The essential function of the leucoplastids is to form starch-grains.

The Chloroplastids or Clilorophyll-bodies, are of various form. The characteristic feature of them is their function, which is twofold. In the first place, they can, like the leucoplastids, generally produce starch-grains; in the second place, they are capable, in virtue of the colouring-matter present in them, of constructing organic substance from carbon

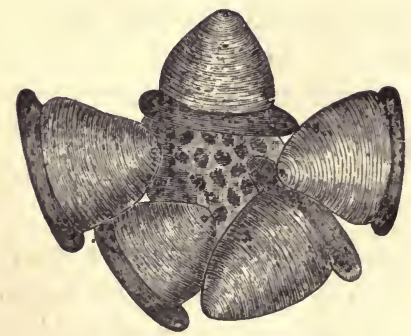

FiG. 51.-Group of rod-like leucoplastids, each bearing a pyramidal starch-grain, collected round the nucleus in a cell of the pseudo-bulb of an Orchid (Phajus grandifolius). ( $\times 850$ : after Schimper.) dioxide and water under the influence of light (see Part IV.). Their function is thus not only starch-forming or amyloplastic, but also assimilatory. These two functions may be, and usually are, carried on simultaneously; hence when, under the influence of light, organic substance is being produced in the chloroplastid, it usually becomes filled with starchgrains, and sometimes to such an extent that the substance of the chloroplastid constitutes but the 
wall of a vesicle (Fig. 52). But starch-grains may be formed in a chloroplastid, as in a leucoplastid, in the absence of light; the organic substance required for the building-up of the starch-grain being not produced in the chloroplastid itself, but supplied from other parts of the plant.

These plastids are termed chloroplastids, because the colouring-matter upon which their assimilatory function depends is most commonly the familiar green colouring-matter, chlorophyll. But they are not always green. In some of the Algæ they are red or brown, because in addition to chlorophyll there is present in the one case (Rhodophyceæ), a red colouring-matter, phycoerythrin, and in the other (Phæophyceæ) a brown colouring-matter, plycoxanthin. Both these substances are, however, related to chlorophyll.

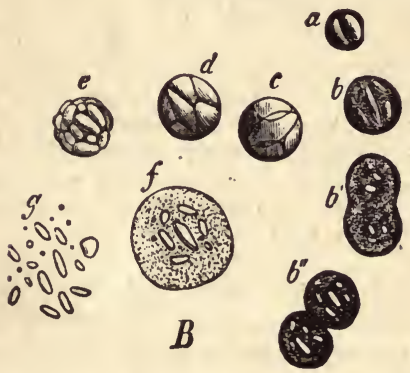

FiG. 52.-Isolated chloroplastils with starchy contents from the leaf of Funaria hygrometrica (550). a A young corpuscle; $b$ an older one, $b^{\prime}$ and $b^{\prime \prime}$ have begun to divide; $c d e$ old curpuscles in which the starchy contents fill almost the whole space; $f$ and $g$ after maceration in water by which the substance of the corpuscle has been destroyed and only the starchy contents remain. (After Sachs.)

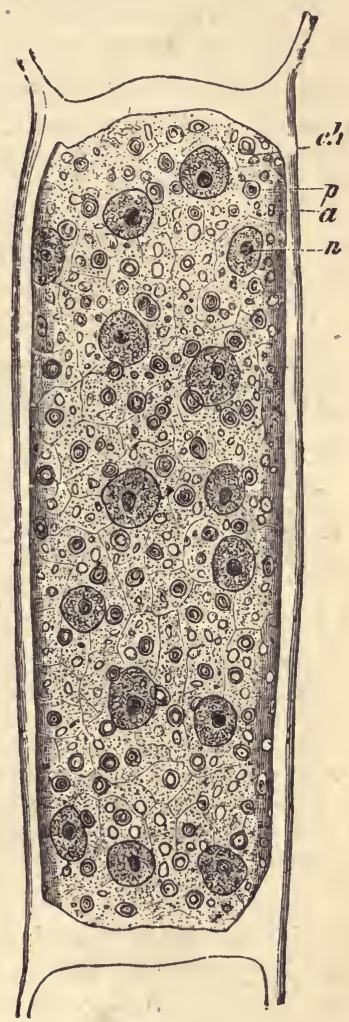

Fig. 53.-Cladophora glonerata (after Strashurger : $\times$ 540). A cœnocyte of the filament (chromic acid and carmine preparation): $n$ nucleus; $c h$ chloroplastid; the polygonal chloroplastids form a continuous layer, the outlines of the individual plastids remaining visible; $p$ pyrenoids; $v$ starchgrains.

When the colouring-matter is dissolved out by alcohol or some other solvent, the protoplasmic plastid is left colourless, but unchanged in form or size. The chlorophyll appears to exist in an 
oily solution, and to be confined to the fibrillar portions of the plastid, in the form of droplets (grana).

The most common form of chloroplastid-the only one occurring in the bigher plants-is the chlorophyll-corpuscle (Fig. 52), which is flattened and discoid. Usually, many corpuscles are present in a cell, but occasionally (e.g. Anthoceros) there is only one. In the Algæ the chromatophores, though sometimes small and discoid (e.g. Vaucheria, Fucus, etc.), are more commonly large, occurring singly, and of very various form.

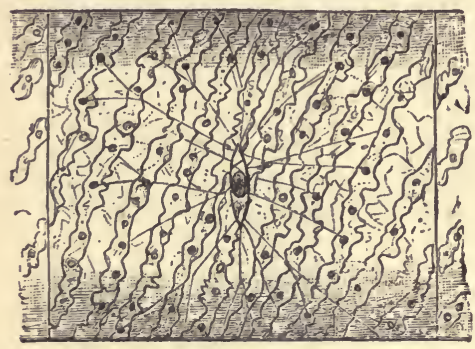

F16. 51.-Spirogyra majuscula (after Strasburger: $\times 240$ ). A cell of a flament, showing the nuclens suspended in the centre; also the spirally-wound chromatophore with pyrenoids.

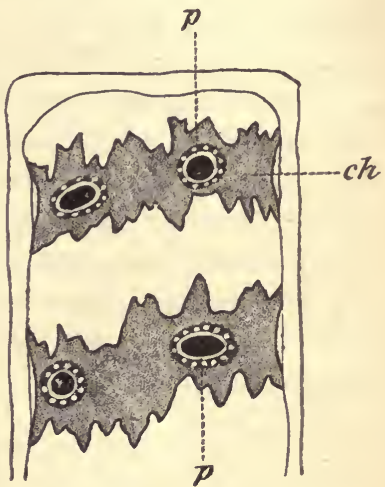

Fig. 55.-Part of a cell of Spirogyra showing the chromatophore $\mathrm{ch}$, with the pyrenoids $p$, surrounded by a dense layer of protoplasm in which are nu. merous starch-grains. (After Schmitz: $\times$ 800.)

The chromatophores of the Algæ present a great variety of form. Generally speaking, those of the higher forms are small corpuscles of a more or less discoid form; while in the lower forms the chromatophores are few in number, often single, in each cell, and are relatively large, assuming commonly the shape of a flattened plate, sometimes elongated and straight or spirally coiled (Figs. 53, 54). In the latter case the large flattened chromatophores present one or more spherical thickenings, each of which is termed a pyrenoid (Figs. $53,55)$, and consists of a homogenous colourless mass of proteid substance. From their limitation to the lowest forms of Algæ (some Diatoms, among Phæophyceæ ; Bangiaceæ, Nemalieæ, among Rhodophyceæ ; Conjugatæ, Confervoideæ, among Chlorophycer), it would appear that there is some connexion between the presence of pyrenoids and an incomplete differentiation of reproductive and vegetative cells in the plant in which the prrenoids occur (see Alga, Part III.). They may, in fact, be regarded as masses of reserve proteid. The ouly plant, outside the Alga, in which a pyrenoid has been found in the chrcmatophore, is Anthoceros. 
This view of the significance of the pyrenoids is supported by the fact that starch-grains, i.e. reserves of carbohydrate, are very generally deposited in the cliromatophore immediately round the pyrenoid. In most of the Chlorophycer which have pyrenoids, the pyrenoid is (under appropriate conditions) completely enclosed by a sort of shell of starch-grains lying in the adjacent portion of the chromatophore (see Fig. 55). In these large chromatophores, the assimilatory and amyloplastic functions are not uniformly distributed: whilst the general mass of the chromatophore carries on the former, the latter is coufined to the portion of it which closely invests the pyrenoids.

Another fact, bearing on the significance of the pyrenoids, is that they vary in bulk from time to time, in relation, apparently, to the condition of nutrition of the cell : hence it is probable that they may yet be found in plants which, at present, seem not to possess them. For instance, the singular fact that they have been discovered in some Diatoms and not in others, may perhaps be explicable on this ground.

Chromatophores multiply by division into two, effected by median constriction (Figs. $50 \mathrm{~B} ; 52$ ): pyrenoids, when present, are multiplied in the same way.

The chloroplastids ultimately undergo degeneration, when, as in the case of falling leaves, for instance, all that remains of them is a few yellow granules.

In many cases the green colour of parts of plants containing chloroplastids, is masked by the presence of other colouring-matters held in solution in the cell-sap (e.g. the leaves of Amararthus, Coleus, Ccpper Beech, Copper Hazel, etc.).

The Chromoplastids are generally derivatives of chloroplastids which have undergone a change both in form and colour. They occur most commonly in the cells of yellow floral leaves, such as those of Tropæolum (Fig. 56) : in the superficial cells of many fruits of a red or orange colour (e.g. berries of Solanum, fruit of Tomato). The yellow colour of the root of the Carrot is due to the presence of lencoplastids, in each of which there is a large orangecoloured crystal of carotin. The chloroplastids of many Coniferæ (e.g. Biota orien-

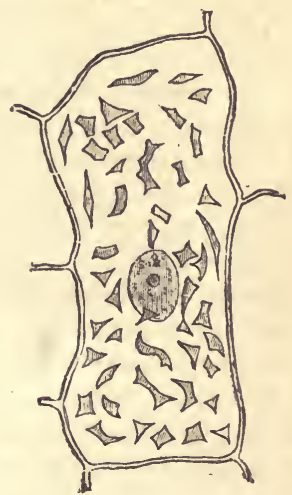

Fra. 56.-From the upper side of the calyx of Tropeolum majus. The inner wall of an epidermal cell with the cbromoplastids. (After Strasburger : $\times 540$.) talis) assume a reddish colour at the beginning of winter.

A brief account may be appended of the structures peculiar to primordial 
cells or cœnocytes (p. 94). The primordial reproductive cells of the $A^{\prime}$ gæ contain chloroplastids (except spermatozoids of Characex): in the higher plants these cells do not contain chloroplastids, but the oospheres contain leucoplastids which become the plastids of the embryo and from which all the plastids of the future plant are eventually developed. In the Algæ, likewise, whatever be the form of the reproductive cell, a portion of it consists of liyaline kinoplasm (p. 95); in tlie case of motile cells (zoospores, zoogonidia, planngametes, spermatozoids), the anterior portion consists of hyaline colourless kinoplasm, whilst the thicker posterior portion consists of granular cytoplasm containing the chloroplastids when present; similarly the oospheres of some heterogamous green Algæ (e.g. (Edogonium, Vaucheria, Cbaraceæ), have an anterior region of byaline kinoplasm (commonly known as the receptive spot). In the higher plants the spermatozoids consist exclusively of kinoplasm. The cœnocytic zoogonidium of Vaucheria is peculiar in that it has no limited kinoplasmic area, but is entirely corered by a layer of kinoplasm (see Fig. 75).

Many of the primordial reproductive cells are motile (zoospores, zoogonidia, planogametes, spermatozoids), and move by means of cilia. A cilium is a delicate filament of kinoplasm which is contractile, and by its oscillations serves to propel through the water the body to which it belongs. The number of cilia borne by these cells varies considerably: there may be a single cilium (e.g. zoospores of Botrydium, and occasionally those of Hydrodictyon); or a pair (generally in planogametes; frequently in zoospores and zoogonidia; less commonly in spermatozoids, as those of most heterogamous Algæ, of the Bryophyta, and of Lycopodium and Selaginella); or four (e.g. zoogonidia of certain green Algæ, Ulothrix, Cladophora, Chætophora, Ulva); or many (e.g. all motile cells of Edogonium; zoogonidia of Vaucheria; spermatozoids of Filicinæ and Equisetinæ).

The position of the cilia is determined mainly by the distribution of the kinoplasm: where, as in the cœuocytic zoogonidium of Vaucheria, there is a continuous superficial layer of kinoplasm, the cilia are developed over the whole surface; where the kinoplasm forms the anterior end, the cilia are restricted to this region; when there are many cilia (e.g. (Edogonium), they form a circlet round the base of the kinoplasmic area, and in the spermatozoids of the Filicinæ and Equisetinæ, which consist entirely of kinoplasm, the numerous cilia are borne laterally, generally near the apex, but sometimes (e.g. Marsilia) at some distance behind it ; when there are one, two, or four cilia, they are either apical (motile cells of most Green Algæ, spermatozoids of Bryophyta, and of Lycopodium and Selagine'la), or they are borne laterally (e.g. spermatozoids of Volvox and Vaucheria, among Green Algæ; all motile reproductive cells of the Brown Algæ) at the base of the kinoplasmic area.

Another peculiar feature of some of these motile primordial cells, is the presence of an eye-spot. This is a small corpuscle of a red colour, consisting apparently of a specialised mass of oxtoplasm permeated by colouring-matter; it turns dark-blue on treatment with iodine. An eye-spot is present in the motile cells of the isogamous Green Algæ, in the zoogonidia of Edogonium, in the spermatozoids of Volvox and Eudorina, and in all motile cells of the Brown Algæ.

Yet another remarkable feature is the presence of a contractile vacuole, that is, a vacuole in the cytoplasm which expands and contracts rhythmically. These 
are to be found generally in the zoospores, zoogonidia, and planogametes of the Algæ, as also in those of the oogamous Phycomycetes and of the Myxomycetes among Fungi.

These peculiar structures, the hyaline area, the cilia, and the contractile vacuole, are not confined to isolated free-swimming cells, but are also characteristic of cells forming part of a multicellular motile body (e.g. Volvocineæ).

$\S 24$. The Cell-Wall is a non-protoplasmic membrane consisting, at least at its first formation, of an organic substance termed cellulose, of water, and of a small proportion of inorganie mineral constituents. Its growth, as well as its first formation, is the result of the vital activity of the protoplasm; it is, in fact, formed from and by the protoplasm.

1. The Growth of the Cell.Wall. The cell-wall grows in surface and in thickness.

a. The growth in surface of the cell-wall may take place in either of two ways, both of which are, however, dependent upon pressure exerted from within upon the wall. In the one case the stretched wall grows continuously by means of material supplied to it by the cytoplasm, the wall remaining unbroken. In the other, the stretched wall is ruptured at certain parts, new portions of cell-wall being at once intercalated to close the gap. The former is of more common occurrence : the latter has been observed in some Algæ, for instance, in the growth of the cells of CEdogonium, and in connexion with the apical growth and with the development of lateral members in Caulerpa, Cladophora, Bryopsis, Derbesia, and Polysiphonia.

Growth in surface takes place to such an extent that the volume of the cell not infrequently becomes a hundred-fold greater than it was originally. Thus, for instance, in a leaf still enclosed in a leaf-bud, the cells of which it will consist when fully developed are all actually present, and it is simply by their increase in volume that the leaf attains its full size.

In the comparatively rare cases in which the superficial growth of the cell-wall is equal at all points, the cell preserves its original form: but more coinmonly the cell-wall grows more vigorously at certain points than at others; thus, for instance, a primarily spheroidal or cuboidal cell may become iabular, cylindrical, fusiform, stellate, etc.

b. The grouth in thickness of the cell-wall is effected by the deposition of successive layers on the internal surface of the firstformed layer. The cell-wall does not usually begin to thicken 
until after its growth in surface has ceased, the cell having then attained its definite size; but cases of simultaneous growth in

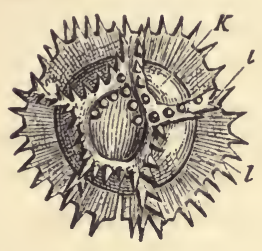

Fig. 57.-Ripe pollen-grain of Cichorium Intybus; the almost spherical surface of the cell-wall is furnished with ridge-like projections prolonged into spines, and forming a network. (After Sachs.) surface and in thickness have been observed.

The growth in thickness of the cellwall is also rarely uniform; the cell-wall commonly becomes more thickened at some points than at others, and thus acquires inequalities of surface. In the case of isolated cells or of free cell-walls, the prominences existing in this way on the external surface appear as warts, tubercles, spines, etc. (Fig. 57). Cells that are united to form tissues have their inequalities on the internal surface of the cell-wall, the prominences sometimes having definite form, and projecting into the interior of the cell; such are the annular (Fig. $58 r$ ) and spiral thickening (Fig. 58s) of the walls of certain vessels; in the so-called reticulated cell-walls, the thickening is in bands which are united into a network, so that circular or
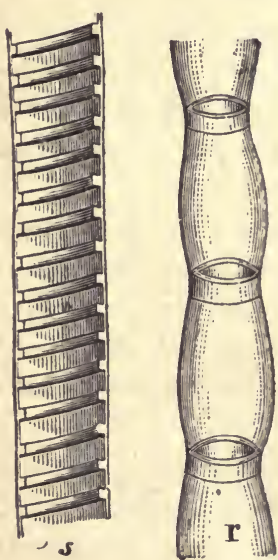

Fig. 58. $-r$ Annular, 8 spiral thickening of the walls of vessels; $r$ seen from outside, 8 in longitudinal section highly magnified (diagrammatic). oval thin spaces are left. In other cases, solitary and relatively small thin spaces are left in the wall in the course of the growth in thickness, which appear, when seen on the external surface, as bright spots, commonly called pits, and are seen in section to be canals of greater or less length, according to the relative thickness of the walls (Figs. 59, 60). Very frequently the pit, when seen from the surface, presents the appearance of two concentric circles, or ellipses; for this reason, that the opening of the canal into the interior of the cell is narrow, whereas the external opening is broad (Fig. $62 \mathrm{~A}$ ). Such bordered pits occur in the wood-cells of Conifers (Fig. 63), in the walls of many vessels (Fig. 62), and elsewhere. The scalariform thickening of the walls of many vessels arises from the regular and close arrangement of bordered pits which are much elongated transversely. 
The Structure of the Cell-avall. When the cell-wall is at all thickened it presents indications of structure.

It presents, in the first place, a layered appearance when examined in longitudinal or transverse action (Fig. 60). This layering or stratification of the cell-wall is readily intelligible when

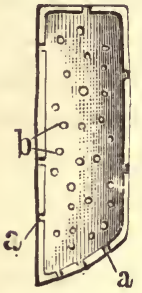

Frg. 59.-A cell with pitted walls, from the wood of the Elder (Sambucus). A longitudinal section showing the pits in the lateral walls as channels, $a$; and in the farther wall as roundish spots, $b .(\times 210$. $)$

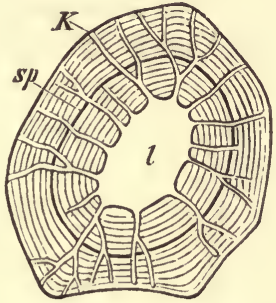

Fig. 60.-Transverse section of a bast-cell from the root of Dahlia variabilis ( $x$ $800)$; $l$ the cell-cavity. $K$ Pitcanals which penetrate the stratification; $s p$ a crack by which an inner system of layers has become separated. (After Sachs.)

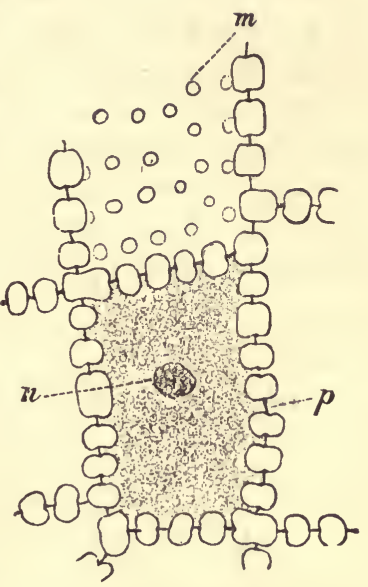

Frg. 61.-Cells from the endo. sperm of Ornithogalum umbella. tum showing simple pits : $m$ pits seen in surface view; $p$ closing membrane seen in longitudinal section; $n$ nucleus. ( $\times 210$ : after Strasburger.)

it is remembered that the thickening of the wall is due to the deposition of successive layers from within.

It presents, secondly, a delicate striation, when examined in surface-view, the lines running at a

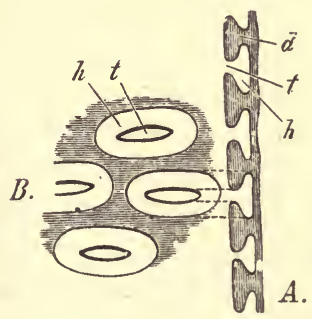

FIG. 62.-Oval bordered pits in the wall of a vessel of Helianthus. A In longitudinal section, $B$ As seen from the surface; $t$ the pit; $h$ the pit-chamber $(\times 600)$.

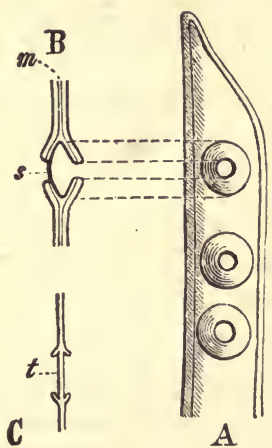

Fig. 63.-Circular bordered pits on the wood-cells of the Pine. $A$ Seen from the surface. $B$ In section; $s$ the closing membrane; $m$ the middle lamella. $C$ An earlier stage, in section. $(\times 500$, diagram.) 
larger or smaller angle to the long axis of the cell, sometimes even transversely. The planes of striation are commonly different in the different layers constituting the thickness of the wall, and these seem in the surface-riew to cross each other (Fig. 64). The cause of striation appears to be this, that when a considerable area of cell-wall has to be formed, it is deposited by the protoplasm not as one continuous sheet, but in the form of delicate spirally-wound bands with their edges in contact. The lines of the striation are the planes of contact of the edges of these spiral bands. A wellmarked illustration of the spiral mode of deposition of cell-wall

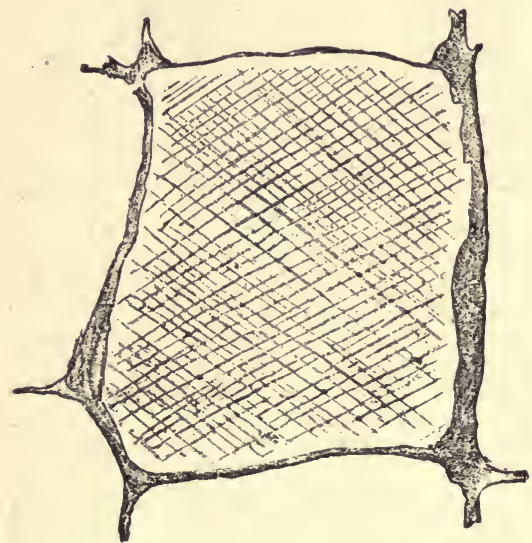

Fig. 61.-Surface view of the wall of a cell, showing striation, from the pith of Dahlia variabilis. ( $\times 210$ : after Strasburger.)

by protoplasm is afforded by the spiral vessels already mentioned (Fig. $58 s$ ).

3. The Chemical Composition of the Cell-wall. As a rule, the organic constituent of the newly formed cellwall is cellulose $\left(\mathrm{C}_{6} \mathrm{H}_{10} \mathrm{O}_{5}\right)$, a carbohydrate, the characteristic reaction of which, is that it turns blue when treated with sulphuric acid and iodine, or with a mixture of iodine, iodide of potassium, and chloride of zinc (chor-zinc-iod).

It is, however, commonly the case that when a cell. wall has undergone thickening, some at least of its constituent layers do not consist of cellulose. The chemical changes which are presented by cell-walls may be distinguished as follows:-

$a$. The cell-wall may undergo cuticularisation: e.g. walls of epidermal cells, of cork-cells, of spores. The cuticularised or corky cell-wall, contains a substance termed cutin. It is but slightly permeable to water; it is extensible and highly elastic; it turns yellow when treated with snlphuric acid and iodine, or with iodised chloride of zinc. The cuticularisation of the cell-wall is most marked in the external layers; in fact the external layer consists entirely of cutin, whilst the internal layers (of which they may be several, as the cuticularised wall is often much thickened) consist more and more largely of cellulose, the 
innermost layer consisting frequently of pure cellulose, though it is sometimes more or less lignified (cork). 'This can be shown by treating the cuticularised tissue with strong chromic acid for some time, or by warming it in a mixture of nitric acid and chlorate of potash, when the cutin is removed, and the remaining tissue gives the characteristic cellulose-reactions.

$\beta$. The cell-wall may undergo lignification; that is, the cell-wall becomes impregnated with a substance termed lignin,.. which makes it hard and elastic, and though readily permeable to water it cannot absorb or retain much in its substance. The characteristic tests for lignin are, that a cell-wall containing it (a) turns yellow when treated with aniline chloride and hydrochloric acid, and $(b)$ turns pink when treated with phloroglucin and hydrochloric acid. When a lignified cell-wall is macerated in a mixture of nitric acid and chlorate of potash, or in a strong solution of chromic acid, the lignin is dissolved out and the wall ceases to to give the lignin-reactions, and now gives the cellulose-reactions. Lignification takes place in the sclerenchymatous and tracheal tissues, less commonly in the parenchymatous tissue, of the sporophyte of the Pteridophyta (Vascular Cryptogams) and Phanerogams; it does not occur in any of the lower plants, nor in any gametophyte.

$\gamma$. The cell-wall may become more or less mucilaginous; in its dry state it is then hard and horny; when moistened, it absorbs a large quantity of water, becoming greatly increased in bulk and gelatinous in consistence; it usually turns blue when treated with sulphuric acid and iodine, or with iodised chloride of zinc, but in some cases it does not give this reaction, and in yet others (e.g. asci of Lichens, bast of Lycopodium, endosperm of Peony, and cotyledons of rarious leguminous seeds) it turns blue with iodine alone. Mucilaginous cell-walls are common in the coats of seeds (e.g. Flax or Linseed, Quince); they are very remarkable in the case of the macrospores of Pilularia and Marsilia ; in tissues, they are well seen in the Malvacer : they occur in all sub-divisions of the vegetable kingdom.

In some cases the change goes so far as to result in the conversion of the cell-wall into gum, soluble in water, as in some species of Astragalus and in certain Rosaceous trees (Cherry, Plum, Almond, Peach, etc.)

These modifications may occur either singly or together in the different layers of one cell-wall, as in corky, or suberised 
cell-walls, where cuticularisation and lignification occur simultaneously,

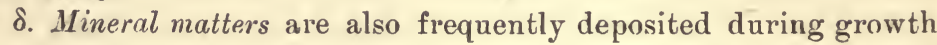
in considerable quantity in the cell-wall, particularly salts of lime and silica; they are usually intercalated between the solid organic particles of the cell-wall, so that they cannot be directly detected, but remain, after burning, as a skeleton which retains the form of the cell. Silica is present in the stems of Grasses and of Equisetacex. Calcium oxalate sometimes occurs in a crystalline form (Fig. 65.) Calcium carbonate is also frequently deposited in cellwalls, as in certain Algæ, (e.g. Acetabularia, Corallina, Jania, etc.); also in hairs of some of the higher plants (e.g. many Boraginaceæ) ;

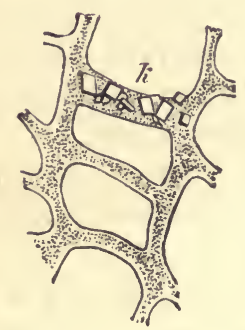

FIG. 65:-Crystals of calcium oxalate in the wall of the bast-cells of Cephalotaxus Fortunei. ( $\times 600$ : after Solus.)
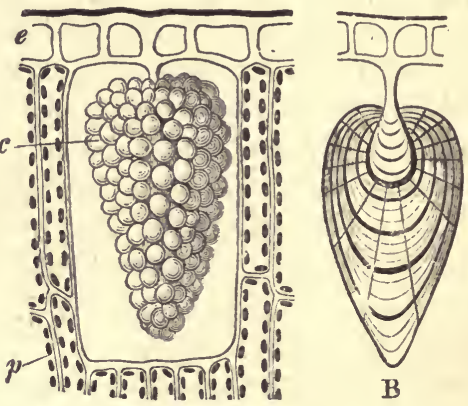

A.

FIG. 66. - A eystolith from the leaf of Celtis Tala $(\times 200)$. A Normal condition; c cystolith; 6 epidermal layer; $p$ palisade-tissue. $B$ The csstolith after treatment with hydrochloric acid which has dissolved the calcium carbonate, leaving the stratified cellulose basis.

but most peculiarly in the cystoliths present in the epidermal cells of the leaves of the Urticaceæ and Acanthaceæ: it may occur either as granules or as crystals.

A cystolith (Fig. $66 \mathrm{~A}$ ) consists of a basis of cellulose incrusted with calcium carbonate. On treating a section, containing a cystolith, with acid, the calcium earbonate is dissolved with evolution of bubbles of $\mathrm{CO}_{z}$, leaving the cellulose basis (B) which presents both striation and stratification. The cellulose basis is, in fact, a local thickening of the cell-wall.

$\S 25$. Cell-Contents. The following are the principle cellcontents which are not protoplasmic and are, in fact, not living: they are moreover not universally present in cells, but are con- 
fined to special cells, and frequently to special plants: starchgrains; fats; proteid grains and crystalloids; mineral crystals; the cell-sap, and the substances dissolved in it.

a. Starch-grains are small solid granules of various shaperounded, oval, lenticular, etc.- consisting of starch with a certain amount of water and a small proportion of incombustible ash. They are specially abundant in those parts of plants which serve as depositories of reserve-materials, e.g. rhizomes and roots of perennial plants during the winter, tubers of the potato, seeds such as those of the cereal and leguminous plants. They can be extracted by maceration from the organs in which they occur, and then appear as a white powder which is known as starch. Starch is a carbohydrate; its percentage composition is the same as that of cellulose, and may be represented as $\mathrm{C}_{6} \mathrm{H}_{10} \mathrm{O}_{5}$, but its molecule is smaller and less complex. It is readily detected by the characteristic blue colour which it assumes on treatment with an aqueous solution of iodine. When boiled with water, or when treated with potash, the grains swell enormously and form a paste.

The substance of the starch-grain is always stratified, being disposed in layers round an organic centre, the hilum; this stratification, as also in the case of cell-walls, is the result of the deposition of successive layers one on the other. The hilum is the most watery portion of the grain, whilst the external layer is the most dense.

It is, as already mentioned ( $p$ 98), the general rule that starchgrains are produced by means of plastids; in parts of plants exposed to light, by chloroplastids; in parts of plants not exposed to light, by leucoplastids. In the former case the grains are usually formed in the interior of the plastid (see Fig. 52); in the latter case, on its surface. In both cases the mode of develop. ment is the same; a small rounded mass, the hilum, which is the organic centre of the grain, is first formed, and then the starchy matter is deposited upon this in successive layers by the activity of the plastid. If all parts of the primitive starch-grain are equally within reach of the plastid, and if then the deposition of new layers is equally active all over the circumference, the grain maintains its rounded for'm, the hilum is its geometric as well as its organic centre, and the layers are concentric. This, from the nature of the case, most commonly occurs when the grains are formed in the interior of the plastids. "Very commonly, 
however, the plastid remains in contact with but one end of the developing grain; hence the deposited layers are thicker and more numerous on the end of the grain next the plastid, and the layers become excentric (Fig. $67 \mathrm{~A}$ ) ; the hilum thus necessarily becomes removed further and farther away from the plastid.

It not uncommonly happens that compound starch-grains are to be found. Spuriously compound grains are simply grains which

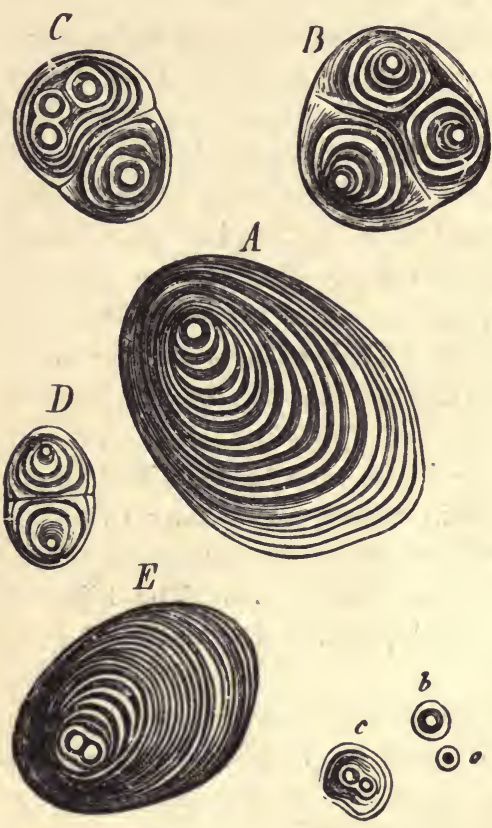

FIG. 67. - Excentric starch-grains from the tuber of a Potato $(\times 800)$. A A fully developed simple grain. $B-E$ Compound grains; $a b$ young simple grains; c joung compound grain. (After Sachs.)

they occur; thus those of the Potato (Fig. 67) are excentrically oval; those of leguminous plants (Fig. 69), concentrically oval; those of Rye, Wheat, and Barley, lenticular (Fig. 70).

The distribution of starch throughout the different classes of plants is a matter of considerable interest. Generally speaking, it is confined to plants which possess chloroplastids, though a substance turning blue with iodine has been found to occur, diffused throughout the protoplasm, in certain Schizomycetes (Clostridium 
butyricum, Sarcina ventriculi, Bacterium pastorianum). But, on the other hand, it is not always present in plants which possess typical chloroplastids; thus, it is absent, for instance, from the Onion, species of Vaucheria, etc. In the case of plants which have other colouring-matters besides chlorophyll, starch may be altogether absent (Cyanophyceæ, Diatomaceæ); or it may be replaced by some other substance (most Phæophyceæ and Rhodophyceæ). In these Phæophyceæ and Rhodophyceæ there occur small colourless granules distributed in the cytoplasm, consisting of a somewhat mucilaginous substance termed paramylon, which,

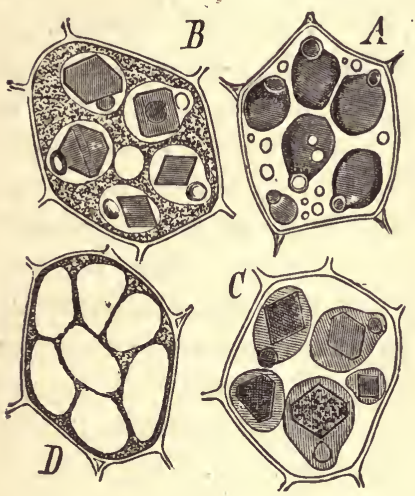

Fig. 68.-Cells from the endosperm of Ricinus communis $(\times 800)$. A Fresh, in thick glycerine; $B$ in dilute glycerine ; $C$ warmed in glycerine; $\boldsymbol{l}$ ) after treatment with alcohol and iodine; the grains have been destroyed by sulphuıic acid, the cytoplasm remaining behind as a net.work. In the grains the globoid may be recognised, and in $B C$ the crystalloid. (After Sachs.)

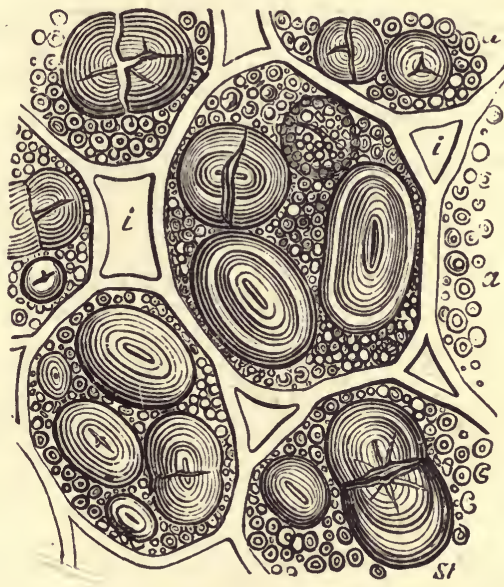

Fra. 69.-Cells of a very thin section throngh a cotyledon of the embryo in a ripe seed of Pisum sativum; the large concentrically stratified grains St are staich-grains (cut through); the small granules $a$ are aleuron, consisting of proteids; $i$ the intercellular spaces. (After Sachs.)

whilst it does not usually give the characteristic reaction of starch, is probably allied to it chemically. A further peculiarity of these plants is that these granules seem not to be formed inside the chromatophores, but in the contiguous cytoplasm.

$\beta$. Fats occur very commonly in the cells of plants as oily drops scattered throughout the cytoplasm. They are more particularly abundant in seeds, in many of which oil is the form in which the non-nitrogenous reserve material is deposited (e.g. Palm, CastorOil plant, Rape, Flax, etc.) ; it is also present in some fruits (e.g. Olive). 
$\gamma$. Proteid Grains, or Alewron, are granules of various sizes, oval or spherical in form, which occur in seeds, and are of physiological importance in that they are the sonrce from which the embryo is supplied with nitrogenous food when the seed germinates. They consist of a mixture of proteid substances belonging to the globulins and the albumoses. They present no indications of structure, and are much larger in oily than in starchy seeds.

The proteid grain always contains a mass of mineral matter. Most commonly this is a rounded body, the globoid (Fig. 68), consisting of double phosphate of lime and magnesia; less frequently

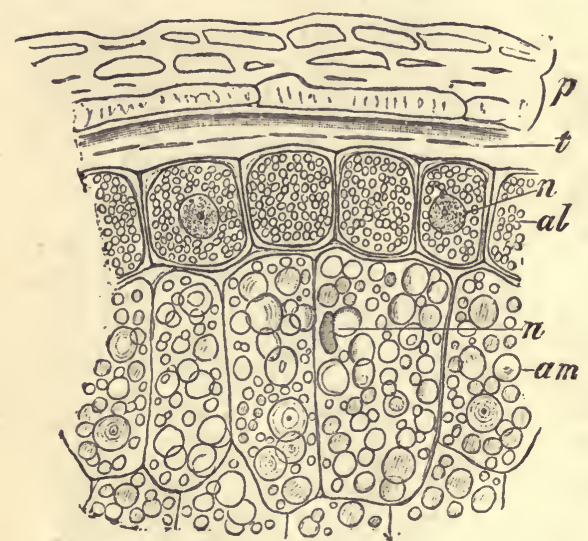

Frg. 70.-Part of a section of a grain of wheat Triticum vulgare : $p$ pericarp; $t$ seed-coat or testa; internal to which are cells belonging to the endosperm; the external layer contains small proteidgrains (al) but no starch, the more internal cells contain starch-grains am; $n$ the nucleus. (After Stras. burger : $\times 240$.) there is a crystal, or a cluster of crystals, of calcium oxalate.

In the large grains of oily seeds it is frequently the case that a portion of the proteid (globulin) of the grain crystallises out, constituting the crystalloid; there are occasionally two or more crystalloids in the grain (Fig. 68).

The grains are secreted in vacuoles of the cytoplasm which, when the grains have been dissolved out, remains as a network (Fig. $68 \mathrm{D}$ ).

Proteid crystalloids are also occasionally found, independently of aleuron, in the cells of plants, (e.g. tuber of the Potato; epidermal cells of leaf of Poly. podium irroides; some Rihodophyceæ).

The crystalloids (whether free or in proteid grains) differ from ordinary mineral crystals in that, when treated with various reagents, they absorb liquid and swell up. They are for the most part cubical, tetrahedral, or rhomboidal in form.

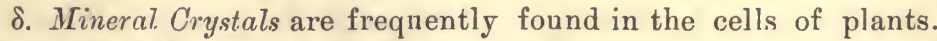
They sometimes consist, but in comparatively few cases, of calcium carbonate; for example, the crystals in the protoplasm of Myxomycetes, and the crystalline masses occurring in the cells of the 
pericarp and testa of some plants (e.g. Celtis australis, Lithospermum officinale, Cerinthe glabra).

In all other cases the crystals consist of calcium oxalate, which crystallises in two systems according to the proportion of water which it contains; to the one system, the quadratic, belong the octahedra (Fig. $71 k$ ); to the other, the clinorhombic, belong the acicular crystals, distinguished as raphides, which occur in bundles in the cells of Monocotyledons more especially (Fig. 72), and are generally associated with mucilage in the cell.

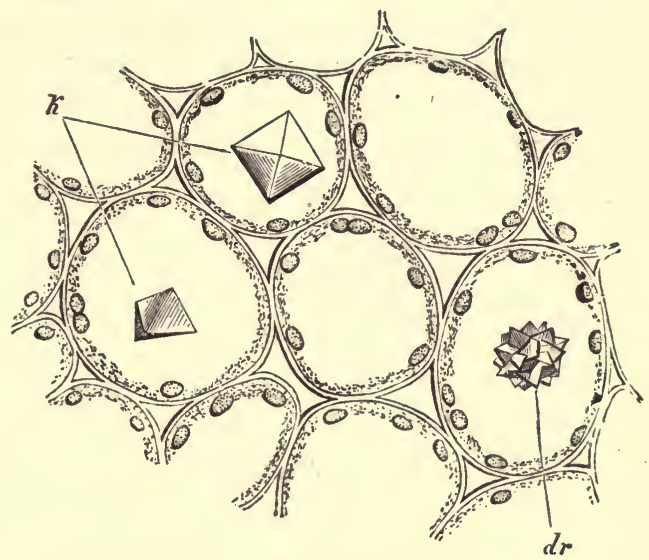

Frg. 71.-Crystals of calcium oxalate in the cells of the petiole of a Begonia $(\times 200)$. $k$ Solitary crystals ; $d r$ cluster.

It sometimes happens that the crystal, or group of crystals, becomes surrounded by a layer of cellulose attached to the wall at one or more points (e g. leaf of Citrus vulyaris, pith of Keria japonica).

$\epsilon$. The Cell-Sap saturates the cell-wall, the protoplasm, in fact the whole organised structure of the cell; it also fills the vacuole, when present, in the cytoplasm. It is a watery solution of the most various substances. In all cases is holds salts in solution, con-

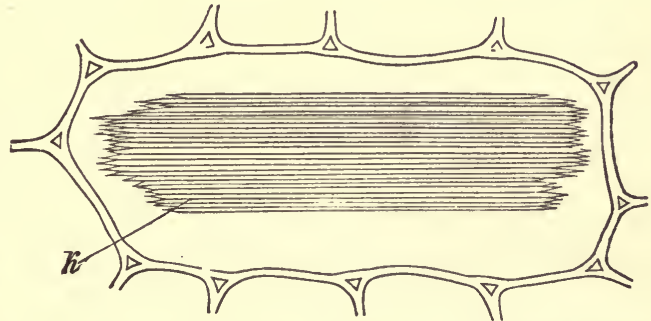

Fre. 72.-Raphides $(k)$ in a cell of a bulb-scale of Urginea maritima $(\times 200)$.

sisting mainly of alkaline bases in combination either with inorganic acids, such as nitric, phosphoric, and sulphuric acid, or with organic acids, such as malic (e.g. apple and other fruits), citric (lemon, etc.), and others. It frequently contains tannin, and

V. S. B. 
nitrogenous substances such as asparagin. It very commonly is rich in sugar ; either grape-sugar $\left(\mathrm{C}_{6} \mathrm{H}_{12} \mathrm{O}_{6}\right)$, as in the grape and other fruits, and in fact most parts of plants at particular times ; or cane-sugar $\left(\mathrm{C}_{12} \mathrm{H}_{22} \mathrm{O}_{11}\right)$ as in the Sugar-cane, the Maple, and the Beetroot. In some plants (e.g. Jerusalem Artichoke, Dahlia, Globe Artichoke) the cell-sap is rich in inulin, a substance having the same percentage composition as starch (represented by formula $\mathrm{C}_{6} \mathrm{H}_{10} \mathrm{O}_{b}$ ): when a portion of tissue, of one of these plants, such as a piece of the tuberous root of the Dahlia, is kept in spirit, the

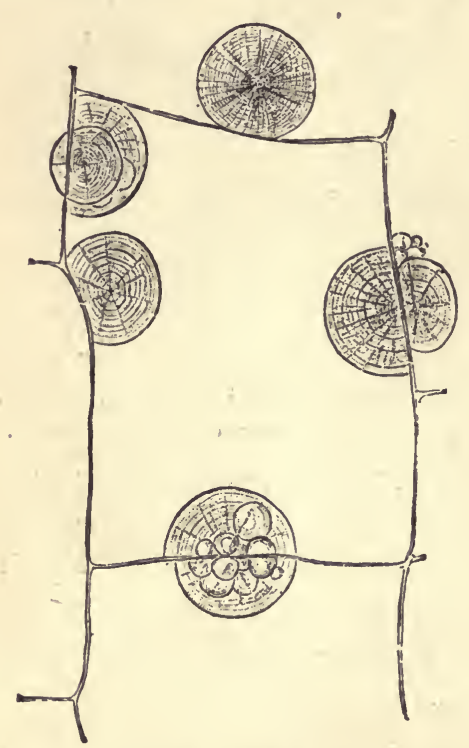

FrG. 73.-Sphærocrystals of inulin in the tissue of the tuberous root of Dahlia variabilis after prolonged action of alcohol. (After Strasburger : $\times 240$.) inulin slowly precipitates in the form of sphærocrystals (Fig. 73) adhering to the walls.

The cell-sap also very frequently holds colouring-matters in solution; for instance, the colouring-matters of most red and blue flowers (erythrophyll and anthocyanin); of many fruits, such as the Cherry and Elderberry; of "copper leaves," such as those of Copper Beech and Hazel, and of the Beet-root.

$\S 26$. Cell-Formation. The formation of a cell is necessarily dependent upon a pre-existing cell; the direct development of a cell from the necessary chemical substances - that is, spontaneous generation-has not yet been observed. Moreover, it can only take place when the protoplasm concerned is in the embryonic condition; as, for instance, in growing-points, germinating spores, etc.

Cell-formation consists essentially in the reorganisation of the protoplasmic unit (energid, p. 90) or units in which it occurs; it may take place about one centre, or, more frequently, about two or more centres, with consequent multiplication of cells. Hence, cellformation does not necessarily involve a multiplication of cells, still less a formation of cell-walls; it necessarily involves the formation of a new cell. 
The following two modes of cell-formation may be distinguished :-

1. Cell-formation without division of the cytoplasm.

2. Cell-formation with division of the cytoplasm.

1. Cell-formation without division. This process does not lead to the multiplication of cells, but merely to the development of a new cell. Two cases are distinguishable: $(a)$ that in which the new cell is formed from a single cell, that is, direct cell-formation; (b) that in which the new cell is formed by the fusion of the cytoplasm of two cells, that is, cell-formation by conjugation.

(a) In direct cell-formation without division, the cytoplasm simply undergoes reorganisation and enters npon a new individuality. It is confined to the development of reproductive cells; such as zoogonidia and spores, the spermatozoids of the higher Cryptogams, and oospheres in many cases. This particular case of cellformation is sometimes termed rejuvenescence.

A good illustration of this is afforded by the development of the zoogonidium of Edogonium. The cytoplasmic contents of an ordinary cell of the filament become more abundant ; the kinoplasm (see p. 95), with the nucleus and centrosphere, travels to one side of the cytoplasm, appearing at the surface as a hyaline, colourless area; the cytoplasm begins to contract away from the wall (Fig. 74 $\mathrm{A}$, lower cell), and secretes a delicate cell-wall of its own; the cilia are developed in a circlet from the margin of the kinoplasmic area. The cell-wall is ruptured (as at $Z$ ), and the zoogonidium, lying loosely in its own proper cell-wall, as in a vessicle, is extruded into the water. It now begins to move inside the

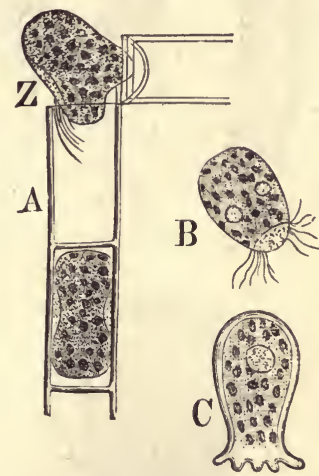

Fig. 74.-Rejuvenescence as exhibited in the formation of the zoogotidium of EEdogonium. $A$ portion of a filament; in the lower cell the protoplasm is beginning to contract, in the upper the young zoogonidium is escaping $(Z) . \quad B$ a zoogonidium. $C$ the beginning of germination. $(\times 350)$. vesicle by the action of its cilia; the vesicle becomes disorganised, and the zoogonidium is set free. It swims by means of its cilia (Fig. $74 \mathrm{~B}$ ) with the colourless end in front; so that what was the transverse axis of the mother-cell bas now become the longitudinal axis of the zoogonidium, an indication of the complete reorganisation which has taken place. After a short period of movement, the zoogonidium comes to rest, attaches itself to some solid body by its byaline end, withdraws its cilia, and secretes a cell-wall (Fig. $74 \mathrm{C}$ ).

The plants in which there are highly differentiated spermatozoids, each developed singly in a mother-cell, are the Characeæ (Algæ), the Bryophyta, and the Pteridophyta. In all these plants the development of the spermatozoid pro- 
ceeds in essentially the same manner as that of the zoogonidium described above. In the Characeæ, where the spermatozoid still retains some zoogonidial characters, the hyaline pointed anterior portion, bearing a pair of cilia, is developed from the kinoplasm; the thick posterior portion, which is lighly granular, is developed from the nutritive hyaloplasm of the cell; the nucleus lies centrally at the junction of the two portions. In the Bryophyta and in the Pteridophyta the spermatozoid consists simply of kinoplasm with a nucleus; it contains no nutritive cyto-hyalop lasm, and so differs essentially from a zoogonidium. In these two groups of plants the mature spermatozoid consists of an anterior kinoplasmic portion bearing the cilia, and a posterior portion consisting

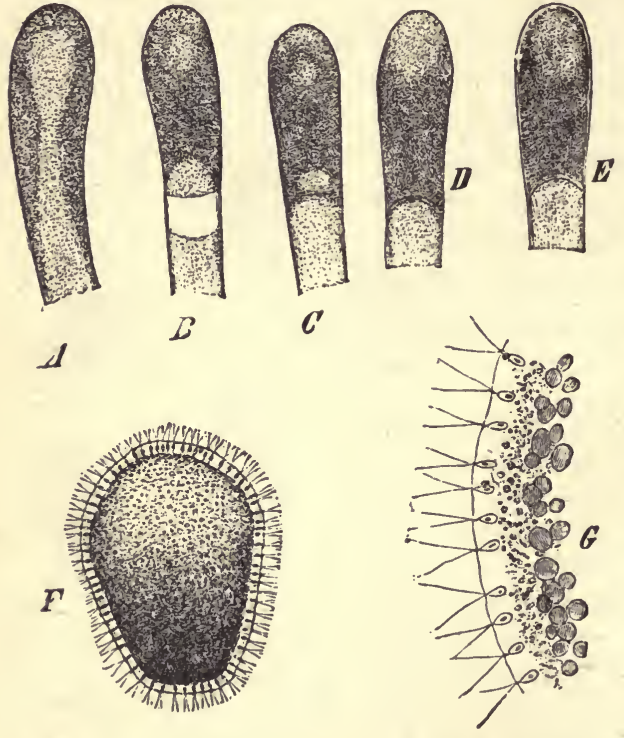

FıG. 75.-Development of the cœnocytic zongnnidium of Vaucheria sessilis. $A-E$ Stages in the development of the zoogonidium within the gonidangium $(x 95) ; F$ : free zoogonidium ( $\times 20$ ) ; $G$ a portion of $F$ more highly magnified ( $x 450)$ showing the hyaline superficial layer bearing the pairs of cilia, with a nucleus opposite the foint of origin of each pair. (After Strasburger.) of the elongated and curved nucleus invested by a thin layer of kinoplasm. In the Pteridophyta the posterior nuclear portion of the spermatozoid more or less completely surrounds a mass of nutritive cyto-hya'oplasm which remains attached to the spermatozoid in the form of a vesicle for a short time after extrusion from the antheridium, becoming eventually disorganised.

The non-motile male cell (spermatium) of the Red Algæ is developed singly in a mother-cell, and appears to consist merely of a small mass of kinoplasm with a nucleus.

Oospheres are, as a rule, dereloped singly in the female organ, though there are some exceptions (see p. 82) : their development has not yet been so minutely studied as has that of zoogonidia and spermatczoids. In the simplest case, as in the oogonium of Edogonium, the cytoplasmic contents of the oogonium contract away from the cell-wall and round themselres into a spherical form; at one.side a colourless hyaline area is differentiated, the receptive spot, the rest of the oosphere containing chloroplastids, etc. This hyaline receptive spot corresponds to that in the zoogonidium of the same plant, as also to the hyaline anterior portion of the spermatoz iids already described; it is doubtless developed in the same way, and consists of kinoplasm. At this stage the oogonium opens by the rupture of the cell-wall, and a portion of the hyaline 
substance (presumably kinoplasm) of the receptive spot is ejected into the water; the oosphere is now ready for fertilisation. In the archegonium of Bryophyta, Pteridophyta, and most Gymnosperms, the " central cell" undergoes division into two; a smaller cell, the ventral canal-cell, next the neck of the archegonium; and a larger lower cell which rounds itself off and constitutes the oosphere.

This process of cell-formation is closely followed in some cœnocytic plants. Thus the zoogonidia of Vaucheria are developed in essentially the same manner as those of Edogonium, the differences being those which are necessarily involved by the fact that the one is developed from a cell, and the other from a conocyte. In Vaucheria, the many nuclei travel, with the kinoplasm, to the periphery of the developing zoogonidium; the kinoplasm, instead of a limited area as in Edogonium, forms a layer over the whole surface in which lie the numerous nuclei, and from which many pairs of cilia are developed, a pair opposite each nucleus (Fig. 75).

The development of the oosphere in Vaucheria resembles in its main features that described for Edogoniurn; but here the mass of protoplasm encloses many nuclei at first, though it appears that there is but one nucleus in the mature oosphere, which has awell-defined receptive spot. In Peronospora likewise, where it is formed from a part only of the protoplasm, the single oosphere contains, at first, many nuclei, but only one when mature. The reduction in the number of the nuclei in these cases appears to be brought about by fusion.

In the foregoing cases of cell-formation with the development of a single new cell, the cell formed is a primordial cell destitute of a cell-wall, at least, for a time. In other cases the cells surround themselves at an early stage with a proper wall of their own: this takes place in connection with the development of the spores in the Bryophyta, Pteridophyta, and Phanerogams.

In illustration of this mode of cell-formation, a brief general account of the development of spores in the ligher plants may be given. The motber-cells of the spores undergo division in a manner described under the head of cell-division (p.125), so as to give rise to four special mother-cel s, lying either all in one plane (e.g., some Pteridophyta, Monocotyledons), or arranged tetrahedrally in a pyramid (some Bryophyta and Pteridophyta, most Gymnosperms, Dicotyledons). In each of these special mother-cells a single spore (resp. pollen-grain) is developed. The ectoplasmic layer of the cytoplasm becomes converted into a membrane, the exiue (or exospore), which, though at first consisting of cellulose, becomes eventually cuticularised, nnd acquires a more or less elaborate structure. In a few cases this is the only coat of the spore; but, as a ru'e, a second membrane, the intine (or endospore), is eventually formed internally to the exine, frow the ectoplasmic layer of the cytoplasm : it consists a ways of cellulose. The walls of the special mother-ces become disorganised, and the suores are set free.

The development of the proper coats of the spores, as also their subsequent growth iu surface and in thickness, is effected solely by means of the cytoplasm 
of the spore. In some cases, however (e.g. Hydropterideæ), a coat, termed perinium, is formed round the spore, externally to its proper coats, not from its own cytoplasm, but from cytoplasm in the sporangium derived from the cells of the disintegrated tapetal layer.

(b) Cell-formation by Conjugation takes place solely in connection with the sexual process. The fusion of vegetative cells is not uncommon, but it does not lead to the formation of a single cell, but of a syncyte (p. 91). In the sexual process, however, two gametes, whether externally alike, as in isogamous plants, or externally dissimilar, as in heterogamous plants, fuse together, cytoplasm with cytoplasm, centrosphere with centrosphere, nucleus with nucleus, completely losing their individuality, and constitute a single new cell, a zygospore or an oospore, which is the starting point for the development of a new organism.

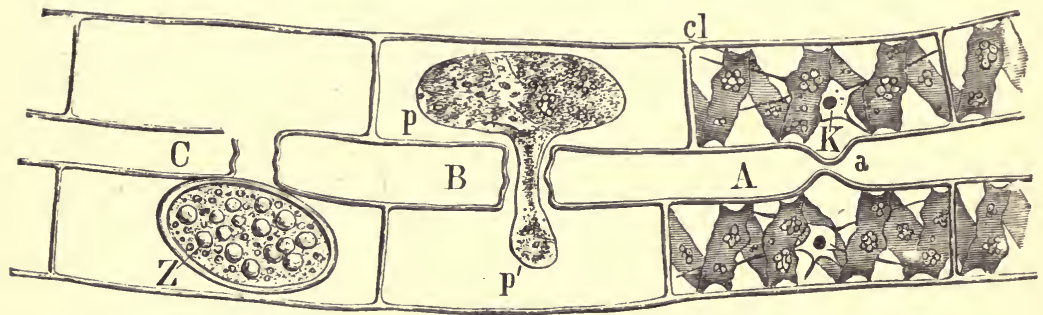

Fra. 76.-Conjugation in Spirogyra $(\times 400)$. At $A$ two cells of adjacent flaments are about to conjugate, and are putting out protuberances (a) towards each other : $c l$ chromatophore; $k$ nucleus. At $B$ the gamete $p$ of the one cell is passing over and fusing with that of the other $(p)$. At $C$ the process of conjugation is completed, the zygospore $Z$ being the product.

It will have been observed, from the preceding instances, that cell-formation is frequently preceded by nuclear fusion. This is so in cell-formation by conjugation; and in many cases of cell-formation from a cœnocyte (e.g. development of endosperm in the embryo-sac of some Angiosperms; development of the oosphere in incompletely septate plants, such as Vaucheria, Peronospora, Pythium).

2. Cell-Formation with Cell-Division. Since in all cases, with possible occasional exceptions in coenocytes, this mode of cellformation is preceded by indirect or mitotic nuclear division, the consideration of it may be preceded by an account of this form of nuclear division.

Indirect or Mitotic Division of the Nucleus. The indirect division of the nucleus presents a series of remarkable phenomena which are collectively designated by the term karyokinesis. Beginning with the nucleus in the resting- 
state (see p. 95), the first fact indicating the imminence of nuclear division is that the two centrospheres separate and take up positions on opposite sides of the nucleus, thus indicating the plane in which the nuclear division is to take place, viz., at right angles to a straight line joining the centrospheres: the change of position of the centrospheres is doubtless effected by the kinoplasm in which they lie. Changes are now perceptible in the nucleus itself. The fibrillar network contracts and becomes more deuse, and breaks up into distinct fibrils (chromosomes) consisting now of broad discs of chromatin with narrower intervening discs of linin: the tangle of the somewhat V-shaped fibrils becomes looser as they separate and move towards the surface of the nucleus. At this stage the so-called nuclear membrane loses its definiteness, the kinoplasm entering the nucleus without, however, displacing the proper ground-substance of the nucleus. The kinoplasm forms a number of threads, extending from one centrosphere to the other, constituting the kinoplasmic spindle, of which the centrospheres are the two poles (Fig. 77). Along these threads the fibrils move till they reach the equatorial plane of the spindle, where they constitute the nuclear disc, and are so placed that their free ends point to either one pole or the other. Whilst these changes have been going on, the nucleoli have disappeared, being diffused in the nuclear ground-substance, which can, in consequence, be stained at this stage. The fibrils now undergo longitudinal splitting into two, and then the nuclear disc separates intu two halves, in such a way that one of each pair of fibrils produced by the splitting of each primary fibril goes to each half. The fibrils constituting each half of the nuclear disc now move towards the

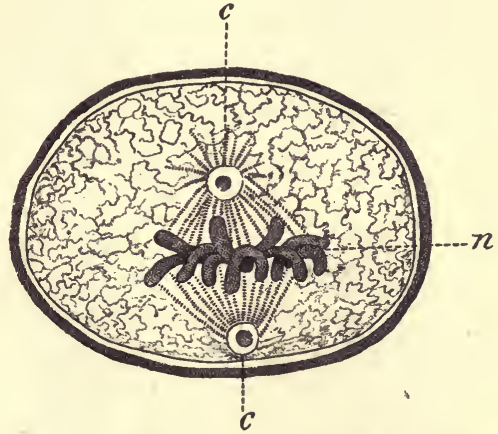

Fra. 77.-Germinating pollen-grain of Lilium Martagon with a dividing nucleus: the kinoplasmic spindle is formed with a centrosphere (c) at each pole; $n$ is the nuclear disc formed by the chromosomes. (After Guignard: $\times$ 750.) corresponding pole along the spindle-threads, changing their postion as they go, so that when they reach the pole their free ends point towards the equatorial plane (Fig. $78 f$ ). On reaching the pole, each group of fibrils constitutes a new nucleus; it becomes invested by a membrane, nucleoli reappear, and the fibrils resume the form and structure of the resting nucleus. The two nuclei are now completely formed, and are still connected by kinoplasmic spindle-threads. If no cell-division is immediately to take place, no further change occurs beyond the disappearance of the threads.

Two modes of cell-formation with division may be conveniently distinguished. In the one, often distinguished as free cell-for: mation, several cells are formed simultaneously in the cavity of a parent cell (or coenocyte); in the other, designated simply celldivision, only two cells are, as a rule, formed as the result of the 


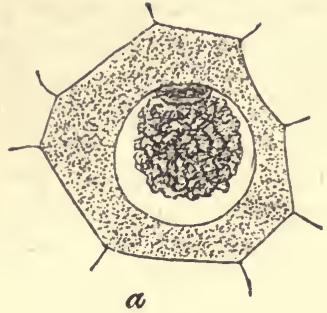

$a$
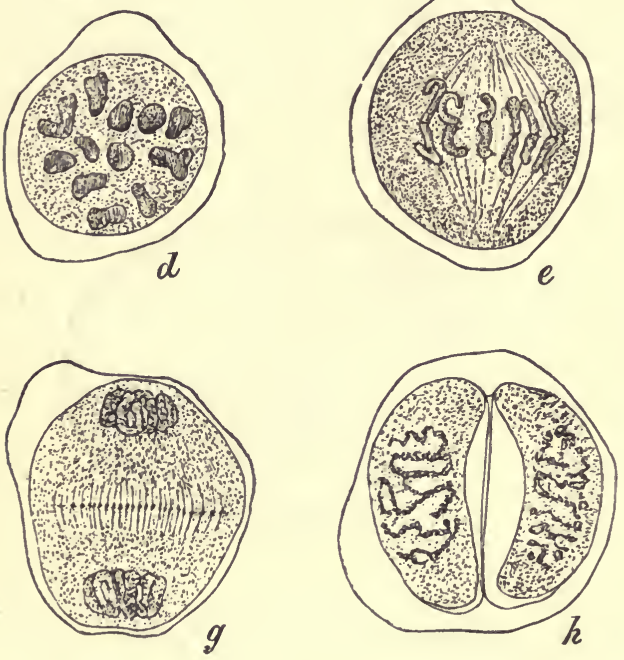
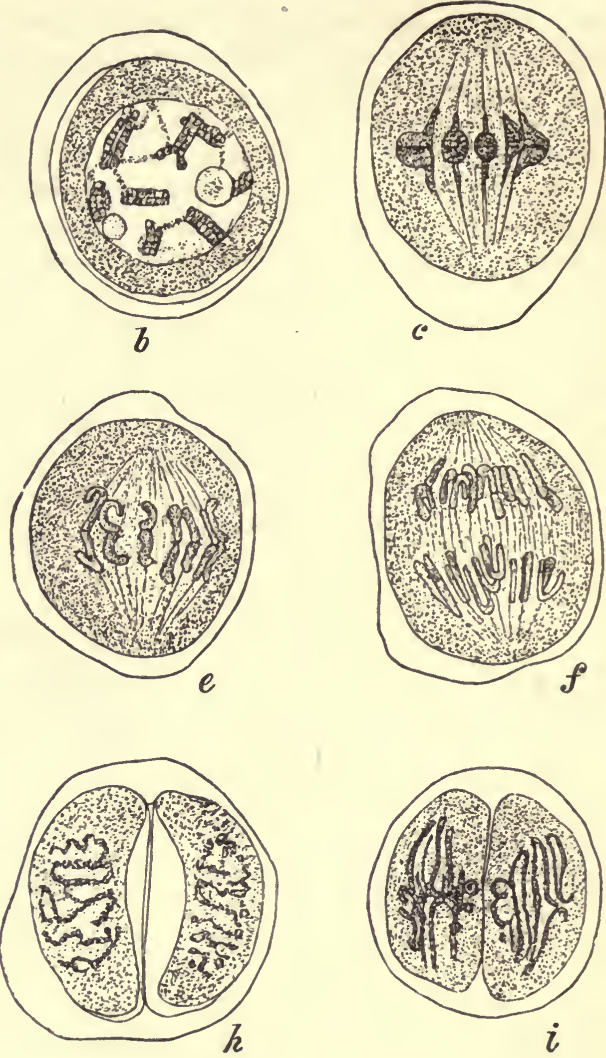
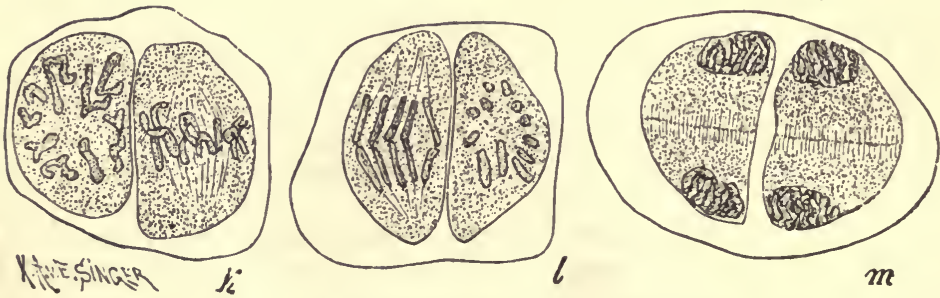

Frg. 78.-Fritillaria persica ( $\times 800$ : after Strasburger). Division of a mother-cell of the pollen: $a$ contraction of the fibrillar network; $c$ kinoplasmic spindle with equatorial nuclear disc seen in profile; $b$ and $d$ nuclear disc seen from the pole, in $b$ the fibrils are splitting longitudinally; $e$ division of the nuclear disc into two; $f$ separation of the two halves of the nuclear disc; $g$ two nuclei still connected by spindle-threads, in which the cell-plate is forming; $h-m$ division of the daughter-cells; $h$ and $i$, breaking up of the network and formation of kinoplasmic spindle; $k$ spindle, in profile in the right, from the pole in the left; $l$ separation of the segments, in profile in the right, from pole in the left; $m$ nuclei with connecting threads and cell-plates. 
partition of the parent cell. A further, though not absolute, distinction is, that in the latter mode each nuclear division is immediately followed by a corresponding cell-division, whereas in the former, no cell-division takes place until all the (or very many) nuclear divisions have been completed. Finally, when the cell-formation is accompanied, as it frequently is, by the derelopment of a cell-wall, the cell-wall formed in connexion with simple cell-division is merely a septum in the plane of division, that is, a wall which abuts upon the side-walls of the parent cell, whereas in free cell-formation walls are formed all round the new cells.

(a) Free cell-formation may take place either in a cell or in a cœnocyte. In the former case it is preceded by successive indirect nuclear divisions-the cell becoming, in fact, a cœnocyte for the time being-until the requisite number of nuclei are formed; in the latter case nuclear division may or may not be necessary.

The product of this process of cell-formation is either, as commonly happens, a number of free cells, with or without proper cell-walls; or, a cellular tissue.

The formation of isolated cells occurs only in connexion with the development of reproductive cells and only in certain plants : e.g. the zoogonidia and gametes of cœenocytic isogamons Algæ, such as some Conferroideæ and Siphoneæ, and the Hydrodictyeæ ; the spermatozoids and oospheres of the cœnocytic but heterogamous Sphæroplea; the zoogonidia of the Phæosporeæ, and the spermatozoids of the Fucaceæ, among cellular Algæ; among Fungi, the spores and gonidia of the Mucorinæ, the zoogonidia and oospheres of the Saprolegnieæ (Fig. 79), the ascospores of the Ascomycetes (Fig. 80); in the Phanerogams, the egg-apparatus of Angiosperms, and the embryo-sporophyte of Eiphedra.

In this case the process of cell-formation is simple; the protoplasm, under the intluence of the kinoplasm, segregates round the individual nuclei, constituting distinct cells which may or may not develope proper walls ; the development of the walls (if present) takes place in the manner already described (p. 117).

The development of a tissue by free cell-formation is not common; it occurs in the development of the endosperm of the Phanerogams, in that of the female prothallium of Isoetes, and in that of the embryo-sporophyte of Gingko and of the Cycads (p. 15). Here, after the formation by division of the requisite number of nuclei, the cytoplasm becomes marked out into units 
(energids), one to each nucleus, and then cell-walls are formed along the lines of demarcation, constituting the units into cells; when, as is frequently the case, the cytoplasm of the mother.cell is simply a parietal layer, the developing cells secrete a cell-wall over their free surface, as well as the intermediate septa. In

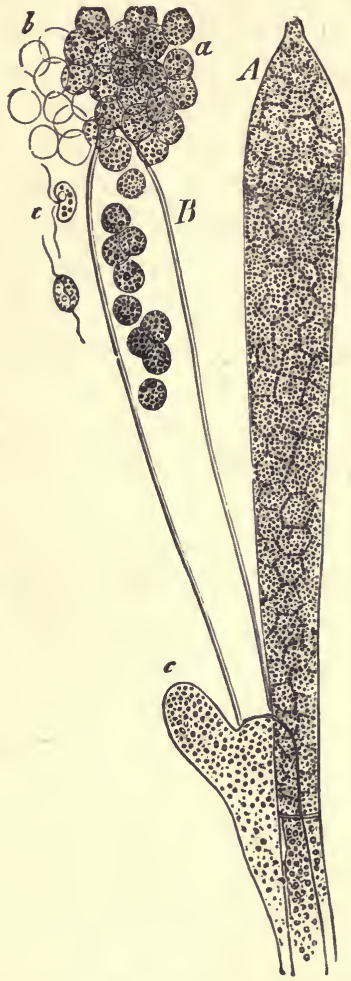

Fig. 79.-Gonidanginm of an Achlya $(\times$ 550). A Still closed. B Allowing the zoogonidia to escape, beneath it a lateral branch $c ; a$ the zoogonidia just escaped; $b$ the abandoned membranes of the zoogonidia which have already swarmed; e swarming zoogonidia. (After Sachs: $\times 550$.)

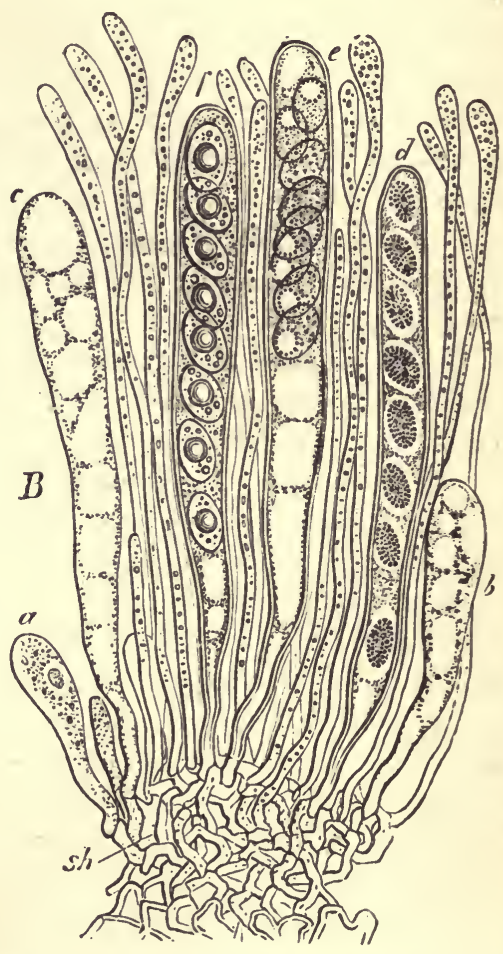

FIg. 80.-Cell-formation in the asci of Peziza convexula. af Successive steps in the development of the asci and spores. (After Sachs: $\times 550$.)

rare cases (e.g. endosperm of Corydalis cava), the cell-walls enclose several energids constituting cœnocytes, but eventually each cœnocyte becomes a cell by the fusion of the nuclei (see pp. 90,118).

A somewhat similar process of tissue-formation occurs in the Hydrodictyeæ; 
but here the cells are at:first free zoogonidia without any cell-wall, which subsequently aggregate together so as to form the body. of the plant, and secrete cell-walls (see pp. 15, 92).

A case which closely connects the foregoing with the typical form of cell-division is that offered by the development of the pollen-grains of Dicotyledons and Conifers, and of the spores of Pteridophyta and Bryophyta in general. Here (Fig, 78) the nuclear divisions are limited to the first generation; the nucleus of the mother-cell divides into two, and each of those again into two, so that four nuclei are produced. The protoplasm around these is marked out into corresponding areas by lines, along which cell-walls are formed, which meet in the middle, and abut externally on the wall of the mother-cell; in this way four special mother-cells are formed, in each of which a spore is developed (see p. 125).

The marking:out of the protoplasm into units in the process of free cellformation is effected by the kinoplasm. As the nuclei lie free in the protoplasm, connecting threads of kinoplasm are formed between them-or rather between the centrospheres adjacent to the nuclei - each of which becomes somewhat thickened in the middle
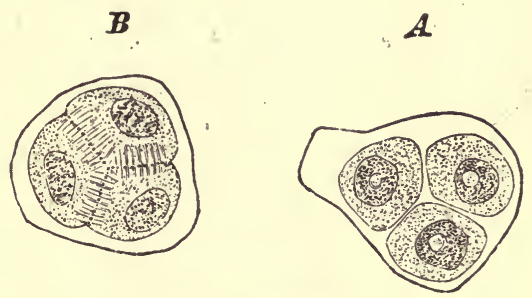

Fig. 81.-Helleborus foetidus (after Strasburger : $\times$ 540). Quadripartition of mother-cell of pollen; in $B$ the connecting threads and cell-plates are shown; in $\boldsymbol{A}$ the walls have been formed. Only three are visible, the fourth not being in focus; the mode of development is tetrahedral.

line, the thickenings coming into lateral contact thus forming a cell-plate (Fig. $81 \mathrm{~B}$ ), which marks the limits of the future cells. When free cells are to be produced, the cell-plates mark the planes of separation; when a tissue is to be produced, the cellplates both mark the position in which, and supply the material out of which, the septa are formed.

(b) Cell-division may give rise to free cells, though more commonly it gires rise to a tissue; in either case, it consists essentially in the bipartition of the cytoplasm, once or repeatedly; septa may or may not be formed; and their formation follows on the division of the eytoplasm.

The development of free primordial cells by cell-division is confined to the reproductive cells of certain of the lower plants; 
for instance, the zongonidia and gametes of some isogamous Volvocineæ (e.g. Pandorina), and Confervoideæ (e.g. Ulothrix), the spermatozoids of Volvox, the oospheres of Fucus. The process is a simple one, consisting in the indirect dirision of the nucleus, followed by a corresponding division of the cytoplasm, no septum being formed. Commonly this process occurs but once, two cells being formed in the mother-cell; or it may be
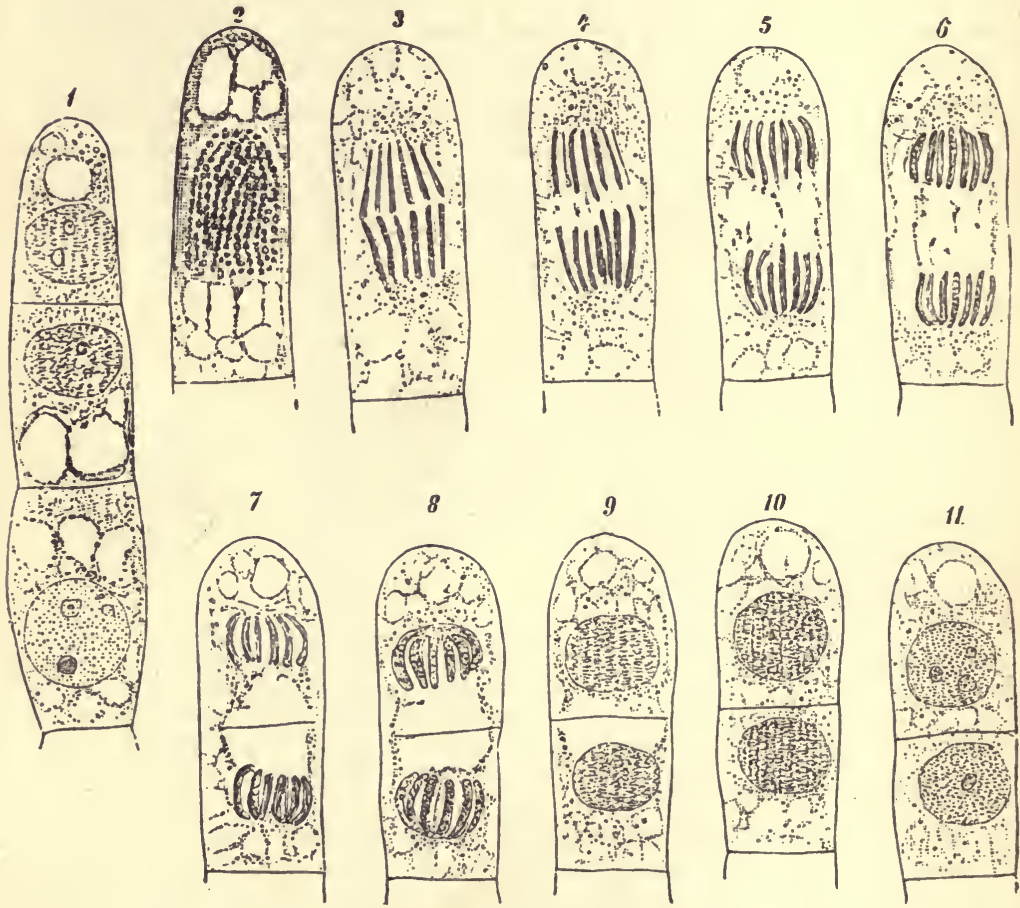

Frg. 82.-Cell-division in staminal hair of Tradescantia virginica ( $\times$ 540: aftor Strasburger). 1-6 Mitotic division of nucleus; 7-11 development of the septum in the kinoplasmic spindle.

repeated twice, giving rise to four cells; or thrice, giving rise to eight cells (e.g. oospheres of Fucus); or many times, giving rise to a large number of cells (e.g. spermatozoids of Volvox).

The typical case of cell-division is that which is attended by the formation of septa, resulting in the development of cells which remain coherent to form a tissue. The process begins with indirect division of the nucleus (Fig. 82, 1-6); when this is com- 
pleted, a cell-plate is formed in the kinoplasmic spindle, and in and from this a septum of cellulose is formed (Fig. 82, 7-11). If the spindle is not wide enough to reach quite across the cell, it is extended laterally by the formation of new connecting-threads, until the septum is attached to both lateral walls. Thus the walls of the new cells are, for the most part, those of the parent cell, the septrum being the only new formation. It is a universal law that the plane in which the septum is formed is perpendicular to that of the wall at any point of contact.

Variations of this mode of cell-formation occur in isolated cells, and in cells forming part of a free surface. In some cases (e.g. branching of Moss-protonema) the mother-cell throws out a lateral protuberance, and a wall is formed at the junction of the two. In other cases, as in the development of the spores of many Fungi, and in the multiplication of Yeast-cells, the lateral protuberance expauds into a rounded body, the neck of communication with the mother-cell remaining narrow. Eventually a cell-wull is formed across the narrow neck, and the cells separute from each other. This mode of cell-formation is known as gemmation or abstriction.

Closely connected with the division into two, which is characteristic of cellformation in the regetative parts of plants, is the division of the mother-cell into four, which is characteristic of the development of the spores in the higher plants

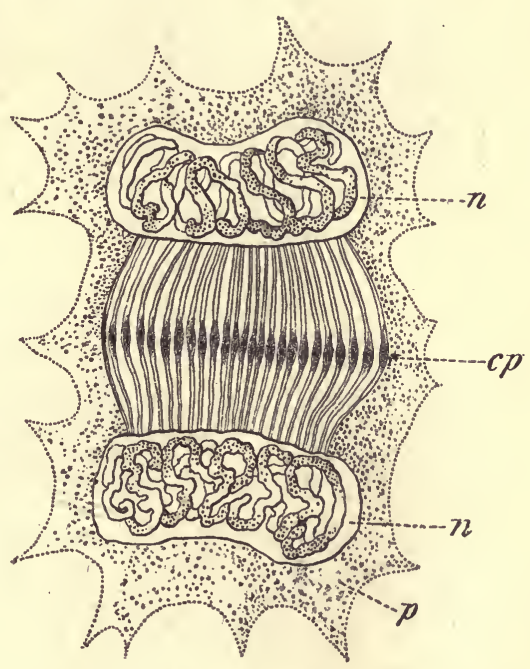

Fig. 83.- Earls stage of cell-division in a young endosperm-cell of Fritillaria imperialis (diagram. matic; after Strasburger : $\times 1000) . n n$ Two recently formed nuciei with connecting threads between them; the threads show median thickenings which will constitute the cell-plate $c p ; p$ cytoplasm.

(spores of Bryophyta, Pteridophyta, and pollen-grains of Phanerogams; see pp. 117, 123); in these cases the division of the mothercell may take place in either of the two following ways:-

1. Each nuclear division is followed by cell-division with the formation of a septum (Fig. 84 $A$; also Fig. 78); hence the process of the development of the four special mother-cells is one of successive cell-division, the mother-cell being first of all divided 
into two, and then each of the two daughter-cells is similarly divided into two ; this is characteristic of the development of the microspores of Isoetes; and of the pollen-grains of most Monocoty. ledons.

2. The nucleus of the mother-cell divides into two, and both these again divide into two before any cell-division occurs; kinoplasmic spindles are formed between the four nuclei (see Fig. 81) in which cell-plates and erentually septa are formed simultaneously in the cell-plates, and thus the four special mothercells are formed, in each of which a spore is developed (p. 117).
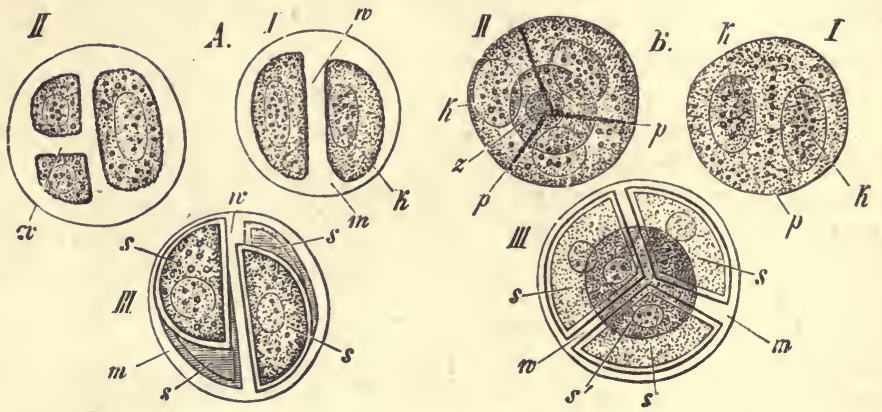

Fig. 81.-Division into four of spore-mother-cells of Ferns. $A$ Schizæa; $B$ Pelloa rotundifolia. I. II. III. successive stages; $k$ nuclens; $r$ cell-plate; $s$ spore; $s s^{\prime}$ spore lying behind the others; $m$ wall of mother-cell; $w$ septa formed in connexion with the divisions (x 300). A Show s successive division; $B$ sim ultaneous division.

The relative directions of the planes of division necessarily affect the arrangement and form of the spores. Thus, when in (1) the divisions of the two daughter-cells, or when in (2) the divisions of the two secondary nuclei, take place in one plane, the four resulting spores lie in one plane, and have a rounded form. Such spores are said to be bilateral; they occur in the Cycads and most Monocotyledons (pollen-grains), in Schizæa (Fig. 81 A III.), and some other Ferns. On the other hand, when in (1) the divisions of the two daughter. cells, or when in (2) the divisions of the two secondary nuclei take place in two planes at right angles to each other, the four resulting spores do not lie in one plane, but are arranged in a pyramid, each spore having the form of a trilateral pyramid with a spherical base. Such spores are said to be tetrahedral, or radial; they occur generally in Dicotyledons (pollen-grains, Fig. 81), in some Ferns (Fig. $84 \mathrm{~B}$ ) and in Equisetum. In (2) when the fuur secondary nuclei all lie in one plane four spindles are formed, each nucleus being thus connected with the two adjacent nuclei; but when the nuclei are arranged pyramidally, six spindles are formed, each nucleus being thus connected with the three others.

In some plants the spores are developed sometimes in the one way and sometimes in the other; this is the case in the Liverworts and the Mosses; 
amongst Ferns; whereas in the Hymenophyllaceæ and Cyatheaceæ only tetrahedral spores have been observed, the occurrence of tetrahedral or of bilateral spores varies from genus to genus in the Polypodiaceæ, Schizeaceæ, and Gleicheniaceæ; in the Marattiacęæ and in Ophioglossum both tetrahedral and bilateral spores may be developed in the fame sporangium; this last condition also obtains in Psilotum and in species of Lycopodium; both modes of development have been observed in the pollen-grains of Allium Moly among Monocotyledons and also in some Dicotyledons (Fig. 85).

The division of the cytoplasm of the spore mother-cells is frequently accompanied by a considerable ingrowth of the wall of the cell, so that the cytoplasm becomes lobed (Fig. 85); the septa subsequently formed in the cell-plates become attached to these ingrowths. In some cases of cell-division the whole septum is formed as an annular ingrowth (e.g. Spirogyra). This is also the case in incompletely septate plants (e.g. Cladophora, etc.), where the derelopment of the septa has no relation whatever to nuclear division.

In incompletely septate plants the process of protoplasmic division and the development of septa goes on quite independently of the nucleus. This is so to some extent in certain cases of spore-formation, viz. in the development of the spores of Anthoceros
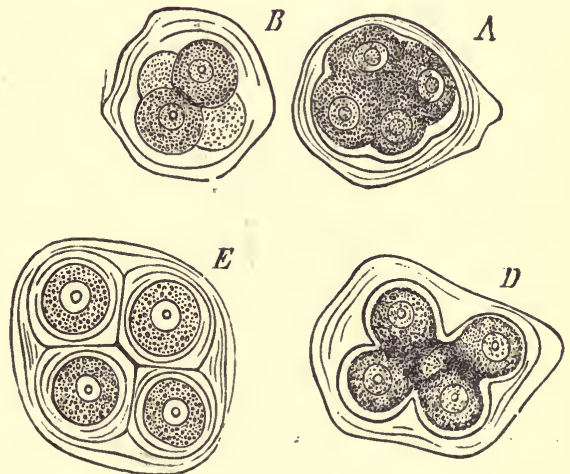

Fig. 85.-(After Sachs). Development of pollengrains of Althoa rosea. A the four nuclei have been formed; $D$ the cytoplasm is becoming lobed by the ingrowths formed on the wall of the mothercell; $E$ four special mother.cells formed by the development of septa connected with the lateral ingrowths. In $A D E$ the grains are developed in one plane; $B$ is a case of pyramidal arrangement.

and of the macrospores of Isoetes, where the division begins in the cytoplasm, the division of the nucleus taking place last of all; whereas, as has been already shown, the rule in completely septate plants is that the division of the nucleus precedes the division of the cytoplasm. 


\section{CHAPTER II.}

THE TISSUES.

$\S 27$. The Connexion of the Cells. As already explained (p. 121), in the development of a tissue, whether by free cell-formation or by cell-division, septa are formed, that is, walls which are common to contiguous cells; these are very thin at first, and appear under the highest magnifying power as a simple plate. As the walls increase in thickness (see p. 103) and acquire a more or less distinctly stratified structure, as seen in transverse

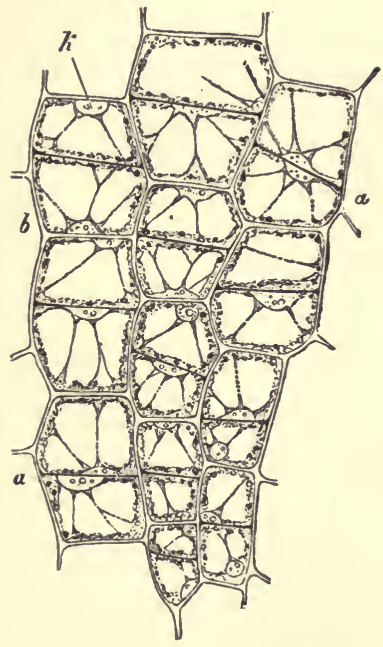

FIG. 86.-Formation of tissue by cell-division in the cortex of the growing stem of Vicia Faba $(\times 300)$. a a The delicate septa have just been formed; $k$ nucleus. section, the net-work of primary septa stands out from the thickening layers proper to each cell (Fig. 87). The primary septum between any two cells is now distinguished as the middle lnmella (sometimes also termed intercellular substance); it attains a considerable bulk at points. where several septa meet at an angle (Fig. 88). Its chemical composition essentially resembles that of the tissue in which it is examined. In a tissue where the thickened cell-walls consist of cellulose, the middle lamella simply consists of a denser, more resistent form of cellulose; in lignified, cuticularised, or mucilaginous tissue, the middle lamella presents the chemical characteristics of the tissue in the highest degree, since it is more completely modified chemically than the rest of the cell-wall; or, in other words, since it contains less residual cellulose than the other layers of the wall, whether they be lignified, cuticularised, or mucilaginous, as the case may be.

When, as is generally the case, the cells of the tissue have pitted walls, the pits of any one cell are exactly opposite those of the cells contiguous to it (Fig. 87), and are closed by the middle lamella which is, however, penetrated by the protoplasmic fibrils connecting the energids of the respective cells (see Fig. 45, p. 91). 
In most cases the closing-membrane between two opposite pits persists (Fig. 87) ; always whilst the contiguous cells contain protoplasm, less frequently when these cells eventually lose their protoplasm. A good example of the latter case is afforded by the vascular cells of the wood (tracheids) of Conifers. Here the pits are bordered (see p. 104), and are closed by a membrane (Fig. $88 \mathrm{C}$ ) which is somewhat thickened in the middle, the thickened area being called the torus, and is either situate in the middle line between the two pits (Fig. $88 \mathrm{C}$ ) or is forced to one side $(B)$.

On the other hand it is commonly the case that the thin pitmembrane undergoes absorption,

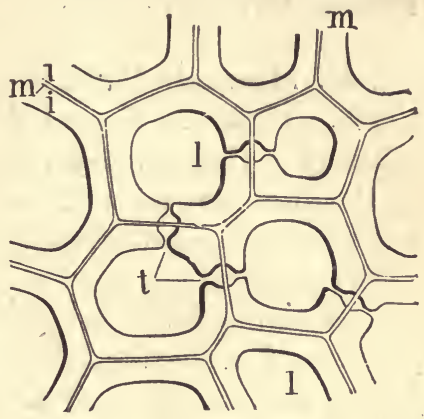

Fig. 87.-Transverse section of the cortical cells of Trichomanes speciosum ( $\times 500$ ). Middle lamella $(m) ; i i$ the secondary layers of the cell-wall adjoining the middle lauella; $l$ cell cavity; $t$ bordered pits which are opposite in adjoining cells, but are closed by the middle lamella.

so that the cavities of the adjacent cells become continuous, and in some cases the entire septum may be absorbed; in either case

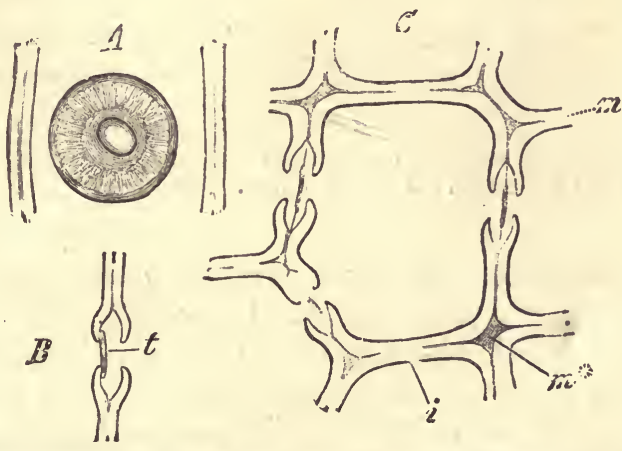

Fig. 88. - Pinus sylvestris ( $\times 540$ : after Strasburger). A surface-view of a bordered pit; $B$ bordered pit as seen in a longitudinal tangential section of the wood; $t$ the torus of the closing-membrane which is thrust to one side of the pit-cavity; $C$ transverse section of a trache:d showing bordered pits with closing-membranes; $m$ middle lamella ; $i$ secondary layers of cell-wall ; $m^{*}$ thickened middle lamella at the junction of several septa.

the result is a syncyte (p. 91), of which the most familiar examples are the wood-vessels of many plants, where the transverse septa of a longitudinal series of cells are more or less completed absorbed, giving rise to a tube; but the absorption of the wall may

v. S. B. 
take place in any plane, as in the development of the anastomosing net-work of laticiferous vessels in many plants (e.g. Compositæ, etc.; see p. 141).

$\S 28$. Intercellular Spaces are lacunæ between the cells of a tissue. They are formed in two ways: either schizogenously, by splitting of the common wall of contiguous cells ; or 7ysigenously, by the disorganisation of certain cells. They contain either air or certain peculiar substances.

The intercellular spaces formed schizogenously and containing air, commonly occur in parenchymatous tissue at the angles of junction of a number of cells. The cells of such a tissue, when young, are angular and are in complete mutual contact at all

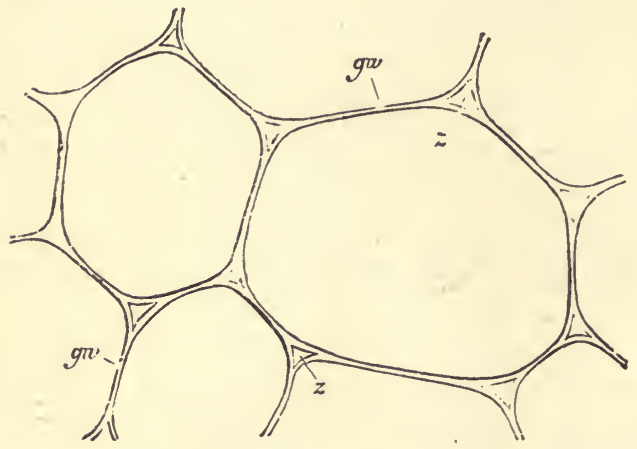

Fig. 89.-Intercellular spaces $(z)$ between cells from the stem of Zea Mais ( 550$)$; $g w$, the common wall. (After Sachs.) points of their surface (see Fig. 86): but towards the close of their growth they tend to assume a more rounded form, with the result that the common cell-walls split at the angles, and thus a system of intercellular spaces is formed (Fig. 89). It is a remarkable fact that such intercellular spaces as these are exclusively confined to the sporophyte of the higher plants (Bryophyta and upwards). Sometimes these spaces-then called air-chambers-attain a considerable size, so that portions of tissue are widely separated from each other, as in the petioles of the Water-lily and in other aquatic plants.

The large air-cavities in the stems and leaves of Juncus and other allied plants are produced lysigenously by the drying-up and rupture of considerable masses of cells; this is true also of the cavities extending through whole internodes of many herbaceous stems (e.g. Grasses, Umbelliferæ, Equisetum), as also of those occurring in leaves (e.g. Leek).

The intercellular spaces which contain certain peculiar sub-. stances are treated of under the head of Glandular Tissue (p. 137). 
$\S 29$. Forms of Tissue. According to the form and arrangement of the constituent cells, the thickness and chemical composition of their walls, the nature of their contents, etc., it is possible to classify the forms of tissue in various ways.

Taking, first, the capacity for growth and cell-formation, embryonic tissue or meristem is distinguishable from adult or permanent tissue. The former consists of cells (e.g. in the growingpoint of a cellular plant) which grow and divide; whereas the latter consists of cells which have ceased to grow and divide, having attained their definitive form and size; and whilst meristem consists entirely of true cells, permanent tissue may consist wholly or in part of cells which have lost their cytoplasm.

Taking, next, the form of the individual cells and the mode of combination into a tissue which their form determines, two forms of tissue termed parenchyma and prosenchyma are distinguished. In parenchymatous tissue there is no great difference in the three axes of the somewhat cubical cell, and the cells are in contact by broad flat surfaces (Figs. 86, 89). In prosenchymatous tissue, on the other hand, (Figs. 90, 92), the cells are mach longer than they are broad, having pointed ends which overlap and dovetail in between those of other cells of the tissue.

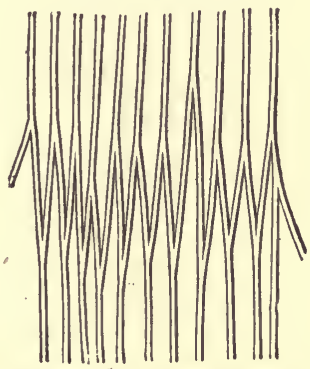

FIG. 90. - Prosenchymatous tissue, longitudinal section (diagram, magnified), the pointed ends of the elongated cells fit in between each other.

By combining the distinctive characters which have just been mentioned, with others which relate to the nature of the cellcontents and to the constitution of the cell-wall and are intimately connected with the functions of the cells, the following forms of permanent tissue may be distinguished :-

1. Thin-walled parenchymatous tissue consists of cells having cell-walls of cellulose. So long as the cells are functionally active they contain cytoplasm ; they may eventually lose their cell-contents and become dry and filled with air (e.g. pith of Elder). This form of tissue is the main seat of the protoplasm in the plant, and it is in the cells of this tissue that the chemical processes connected with nutrition are more particularly carried on. It is especially well-developed in fleshy and succulent parts (e.g. leaves, fruits, tubers, tuberous roots, etc.). 
2. Thick-walled parenchymatous tissue. Of this there are two principal forms: (1) that in which the cell-walls are lignified; (2) that in which they are not lignified but consist of cellulose. The former occurs as wood-parenchyma in the secondary wood, and in the secondary medullary rays, of Dicotyledons. The latter commonly occurs as collenchyma just below the surface of herbaceous parts such as mid-ribs of leaves, petioles, young shoots, etc., and serves to give them firmness (Fig. 91). Both forms of this tissue retain their cytoplasm for a long time after complete differen.

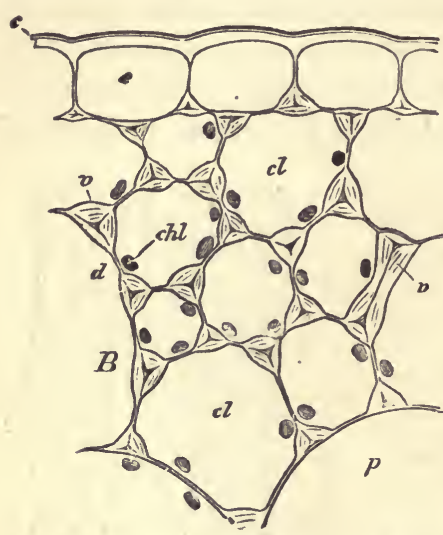

Fig. 91.-Transverse section of part of leaf-stalk of a Begonia ( $\times 550$ : after Sachs). $E$ Epidermis, the cells of which have thickened and cuticularised ex. ternal walls; $c$, cnticle. $B$ Collenchymatons tissue, with walls thickened at the angles $v$; the walls of the epidermal cells are similarly thickened where they abut on the collenchyma; $c l$ individual collenchymatous cells; chl chloroplastids; $p$ large thin-walled parenchy. matous cell. tiation. The middle lamella ( $p$. 128) of thick-walled parenchyma with cellulose walls, consists of a peculiarly dense form of cellulose.

3. Cuticularised tissue consists of cells of various form, generally parenchymatous, the walls of which have undergone more or less complete cuticularisation (see p. 106). The most conspicuous examples of this tissue are the epidermis, and the periderm; in the former, the cuticularisation is confined almost exclusively to the external wall of the cell (Fig. 91), and the cells retain their cytoplasm; in the latter, the cuticularisation extends over the whole cell-wall, and the cytoplasm is soon lost. In both cases the cuticularisation is most marked in the external layers of the cell-wall. In cork-cells there is a certain amount of lignification of the walls as well. The middle lamella (p. 128) of cuticularised tissue consists entirely of cutin (or suberin). Whilst cuticularisation generally occurs in the walls of free cells (e.g. spores), or of the superficial cells (epidermis, periderm) of a multicellular body, it occurs sometimes in internal tissues (e.g. endodermis).

4. Sclerenchymatous tissue, or sclerenchyma, consists typically of prosenchymatous cells which lose their cytoplasm relatively early, and then contain only water or air, and are distinguished as fibres; but in some cases they retain their cytoplasm, and are then dis- 
tinguished as fibrous cells. The cell-walls are thickened, sometimes so much so as almost to obliterate the cavity or lumen (Fig. $92)$; they are frequently lignified throughout, or only partially, or not at all (e.g. bast-fibres of Flax and Hemp); they coinmonly have simple round pits, or oblique and narrow bordered pits (Fig. 94).

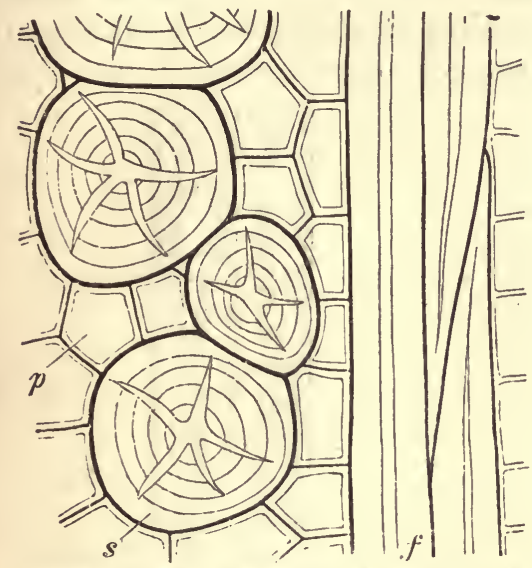

Fıg. 92.-Longitudinal section of the cortex of the Oak, showing 8 short sclerotic cells; $f$ fibrous sclerenchyma; $p$ parenchymatous cells. $(x 300$.)

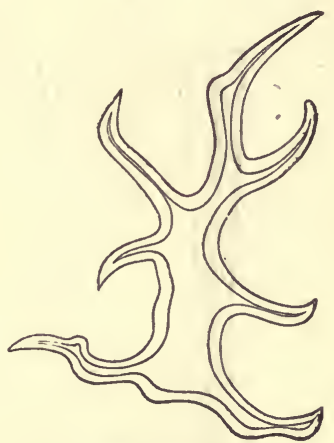

Frg. 93.-Isolated sclerotic cell from the leaf of Exostemma (Rubiaceæ). ( $\times$ 300.)

Sclerenchymatous tissue usually occurs in masses so as to give firmness and rigidity to the various parts in which it is present; it constitutes, together with the collenchyma, the mechanically supporting-tissue or stereom of the plant.

Isolated sclerotic cells (without cytoplasm) of irregular form (Fig. 93) are of frequent occurrence (e.g., in the flesh of Pears, in coriaceous leaves as those of Camellia, Hakea, Olea, etc.): when these cells project freely into air-cavities (e.g. Nymphæaceæ, Aroids, Limnanthemum, Rhizophora) they are sometimes called internal hairs; short, straight cells occur in the secondary bast and cortex of many trees (Fig. 92).

In some cases (e.g. Vinca, Nerium, Urtica, Humulus, etc.), the young bastfibres have been found to become cœnocytic in consequence of the multiplication of their nuclei by indirect division. In other cases the sclerenchymatous fibres become septate in consequence of the nuclear divisions being followed by the formation of septa; such apparently multicellular fibres (not uncommon in the secondary wood of Dicotyledons) are termed chambered fibres.

5. Tracheal tissue consists of cells which early lose their cytoplasm; their cell-walls are generally, but not always, lignified, and 
are either pitted with simple or bordered pits, or have annular, spiral, or reticulate, etc., thickenings (see p. 104); when fully developed the tissue contains only either air or water.

The following varieties of this tissue may be distinguished :-

a. The tracheids, which are closed, generally prosenchymatous, cells (Fig. $95 A B$ ), occur characteristically in the wood of certain sporophytes (e.g. most Pteridophyta, Coniferæ) and are then completely lignified; but they also occur elsewhere, as in the tegu-
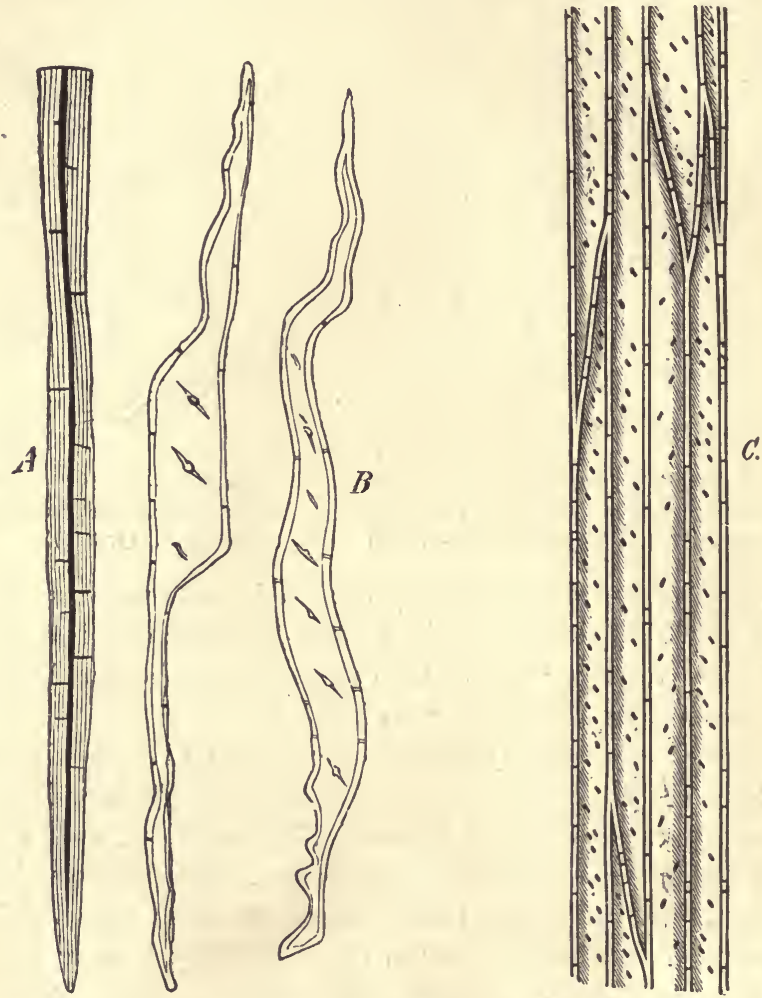

FıG. 91.-Sclerenchymatous tissue. A The end of a bast-fibre, with strongly thickened pitted walls (longitudinal section $\times 300$ ). $B$ Wood-fibres from the root of the Cucumber ( $\times 300)$, surface view and section. C Fibres from the stem of Helianthus tuberosus ( $\times 300)$.

mentary tissue (velamen) of the aerial roots of certain Orchids, where they are partially lignified; in certain cells of the anther; and in the leaves and cortical tissue of the stem of Sphagnum (gametophyte) where they are not lignified at all (Fig. 95).

$b$. The trachece are true vessels, that is, articulated tubes, the contiguous cell-cavities having been rendered continuous by the 
complete or partial absorption of the intervening walls (Fig. 95 $\mathrm{Ca}$ ) ; the former is more frequently the case when the intervening walls are horizontal, the latter when they are oblique; they occur in the wood of many Phanerogams.

Tracheal tissue is the characteristic constituent of the vascular tissue-system to be described sủbsequently; it is especially adapted for the conduction of water. It should be noted that in all forms of lignified tissues, whether tracheal, sclerenchymatous, or parenchymatous, the middle lamella is the most highly lignified part ( $p$. 128); it dissolves readily in a mixture of nitric acid and chlorate of potash, thus leading to the isolation of the constituent cells.

When a tracheal cell with a pitted wall abuts upon cells contdining living protoplasm, it not unfrequently happens that the thin
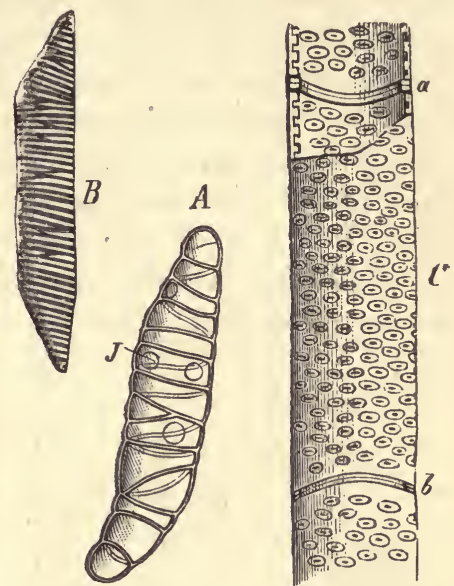

Fra. 95.-Tracheal tissue. A Tracheid from the leaf of Sphagnum. JThe holes in the external wall. $B$ Tracheid from the leaf of Polypodium vulgare. C Part of a trachea with bordered pits from the stem of Helianthus; it has been cut into at the upper end; $a$ and $b$ the articulations, where the absorbed transverse walls existed. pit-membranes begin to bulge, in consequence of the pressure upon them of the contents of the living cells, into the cavity of the tracheal cell, and actually grow (Fig. 96). Cell-division may take place in these ingrowths, so that a mass of cellular tissue is formed in the cavity of the tracheal cell. These ingrowths are termed tyloses; they are constantly to be found in some kinds of wood, (e.g. Robinia) and occasionally in many others.

4. Sieve-Tissue.

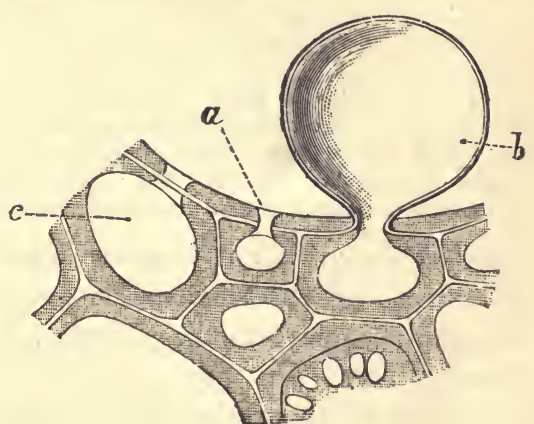

Fig. 96 (after Weiss).-Portion of wood-vessel of Vitis vinifera, in transverse section, with adjacent cells $a b c$, one of which has grown into the lumon of the vessel forming a tylose $b$. tissue consists mainly of long articulated tubes, the contents of 
the contiguous segments communicating by means of the sieveplates, which usually lie on the transverse walls, either singly, when the transverse wall is horizontal, as generally in herbaceous plants (Figs. 97), or several together, when the transverse wall is oblique, as generally in woody plants (Fig. 98). Each sieve-plate is a thin area of the wall which is perforated by a number of closely placed open pits. The sieve-plate is covered on both surfaces, and the pits are lined, by a peculiar substance termed callus (Figs. $97 C c ; 98 B C c ; 99$ ), which at least in many plants periodically closes the pits in autumn. Sieve-plates may also occur on the lateral walls (Fig. 99). The rest of the wall of the sieve-

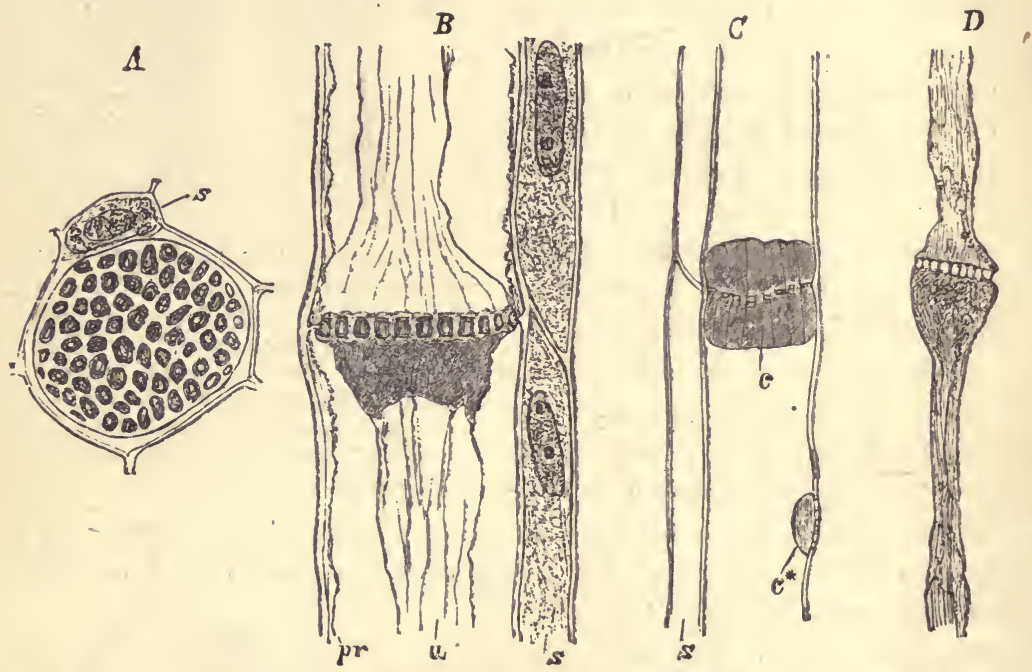

FIG. 97.-Sieve-tissne of an herbacoons Angiosperm (Cueurbita Pepo). A Transverse sieve-plate in surface-view; $B$ in longitudinal section; $C$ sieve-plate elosed by a plate of callus $c ; c^{*}$ sieve-plate on lateral wall, closed by callus; $D$ contents of tube left after solution of the wall by sulphurie acid; $s$ companion-cells; $p r$ lining layer of protoplasm; w gelatinous contents. ( $\times 510$ : after Strasburger.)

tube is rather thin : it is never lignified, but consists of cellulose. 'The long straight sieve-tubes are connected in their course by short transverse branches, so that they form one continuous system of tubes.

- In their normal active condition each segment of the sieve-tube is lined by a layer of protoplasm (Fig. $97 \mathrm{~B} \mathrm{pr}$ ), in which starchgranules are sometimes to be found, enclosing some gelatinous substance; there is, however, no nucleus present; the reaction of the contents is alkaline. 
With the sieve-tubes of Angiosperms are closely associated cells, termed companion-cells (Fig. $97 \mathrm{~s}$ ), which are filled with granular proteid contents and have well-marked nuclei; each companioncell is of common origin with the corresponding segment of a sieve-tube, both being derived from one mother-cell. Companioncells are not developed in Gymnosperms and Pteridophyta.

The sieve-tissue, like the tracheal tissue, is a characteristic constituent of the vascular tissue-system : it is very frequently associated with tracheal tissue so as to form one vascular bundle, but it may occur in independent bundles (e.g. in the pith of the stem of some Solanaceæ, Campanulaceæ, and Compositæ, and in the cortex of the stem of Cucurbitacem, and some other plants), and generally in roots. It serves for the conduction of organic substance, more especially of proteid substance. Tissue of this kind has been found to be present in plants so low in the scale as some of the larger Algæ (Laminarieæ).

5. Glandular Tissue. Under this general

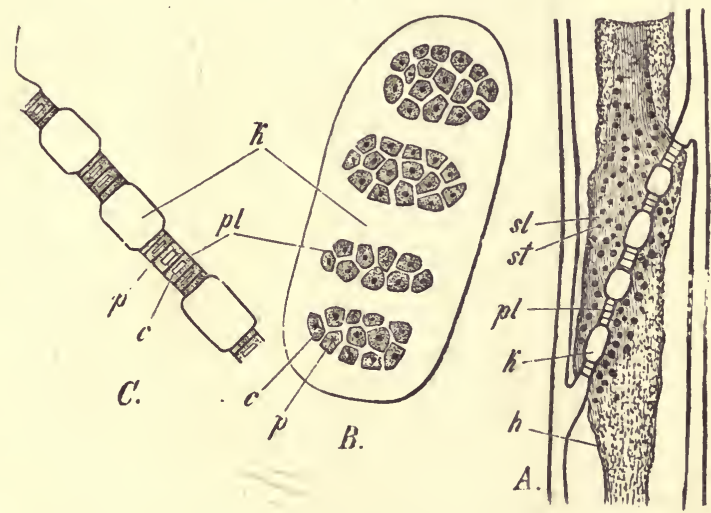

Frg. 98. - Sieve-tissue of woody plants. Portions of sieve-tubes from the secondary bast of the Vine. $A$ Entire transverse wall and adjacent parts in longitudinal section $(\times 300)$; $p l$ the sieve-plates; $k$ the thicker portions of the cell-wall; $h$ the protoplasmic lining; $s l$ gelatinous substance; st starch-granules. $B$ Part of a transverse wall seen from the surface. C The same in section $(\times 700) ; p$ pits; $c$ callus; $p l$ the four sicve-plates.

term are included cells which produce more or less peculiar substances termed secreta, by a process known as secretion. The cells may be isolated, or they may be collected into groups; the secretum may be accumulated in the cavity of the secreting cell, or it may be thrown out at the surface (excreted); the process of secretion may or may not involve the destruction of the secreting cell.

The following are the chief varieties of glandular tissue :-

(a) Solid multicellularglands. Good examples of these are the chalk-glands of the leaves of many Saxifragaceæ and Crassulaceæ, 
and the nectaries present in flowers (floral nectaries) or in other parts (extra-floral nectaries) of various plants. In both these forms of gland the secretum, chalk in the one case and sugar in ,the other, is in solution, and is excreted at the surface. In the chalk-gland the secretum escapes through a special channel, a water-stoma (Fig. $100 w$; see also Fig. 121, $\S 31$ ). In the nectary the secretum is simply poured out on the surface of the gland.

Chalk-glands are remarkable in that they are developed from the same primary tissue as the vascular bundles, in connexion with which they always occur. These glands belong in fact to the vascular tissue-system (see $\S 33$ ).
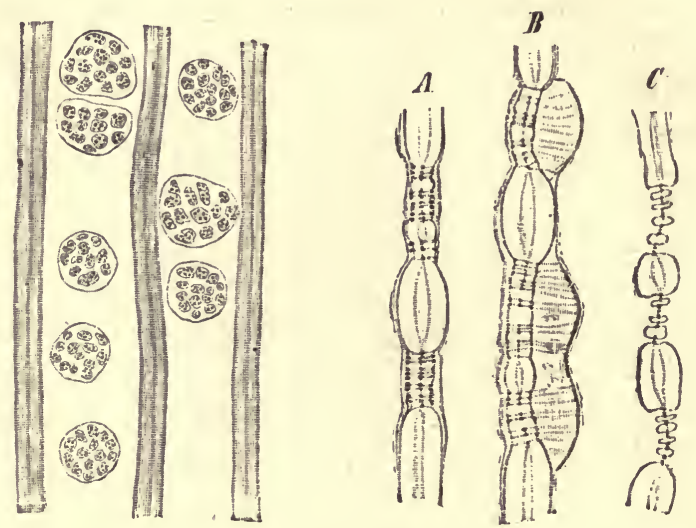

FIG. 99.-Sieve-tissue of woody plants. Surface-view of parts of two sieve-tubes of Pinus sylvestris, with sieve-plates on the lateral longitudinal walls. Parts of walls of these sieve-tubes treated with iodised chloride of zinc: $\boldsymbol{A}$ before the formation of a callus-plate; $B$ after the closure of the sieves by callus; $C$ an old sieve-tube which is no longer active, and from which all trace of callus has disappeared. ( $\times 540$ : after Strasburger.)

(b) Hollow multicellular glands are intercellular spaces surrounded by secreting cells, and are, in some cases, of schizogenous, in other's of lysigenous, origin (see p. 130.) The secretum may be mucilage, or gum, or a mixture of gum and resin (gum-resin), or ethereal oil, or a mixture of ethereal oil and resin (balsam). The cavities are either rounded closed spaces, or are elongated canals, extending for some distance through the tissue; the former are nsually of lysigenous, the latter of schizogenous, origin.

As examples of lysigenous hollow glands, may be mentioned the cavities filled with gum, which occur in the tissue of Cherry-trees; the oil-glands of the Orange and Lemon, and in the leaves of the Rutaceæ, Myrtaceæ, and Hypericum, where they can be discerned 
with the naked eye as transparent dots. The development of these oil-glands begins with the division of one or two cells of the young leaf, a group of cells being formed in the cytoplasm of which oil-drops make their appearance. The walls between the cells (Fig. 101 $B C$ ) undergo absorption, so that a cavity is formed which is bounded by the closely-packed adjacent cells, and contains a large oil-drop formed by the fusion of the oil-drops of the original cells.

The most striking examples of schizogenous hollow glands are the various kinds of ducts, such as the resin-ducts which permeate the tissues of most Coniferæ and Anacardiaceæ; the gum- or mucilage-

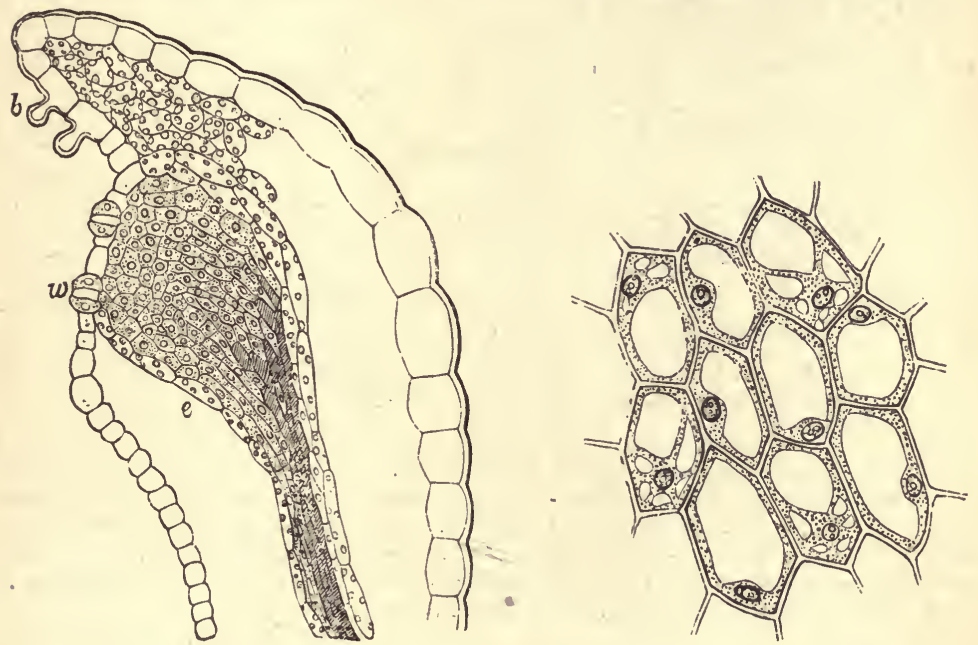

FIG. 100 (highly magnified; after Gardiner).--Left-hand figure : transverse section of the margin of a leaf of Saxifraga crustata, showing the chalk-gland $e$, which is continuous at its base with a vascular bundle; $w$ water-stoma; $b$ hairs to which the deposit of calcium carbonate adheres on the evaporation of the exuded drops of water. Right-hand fignre: some of the cells of the gland.

ducts of the Marattiaceæ, some species of Lycopodium, Cycads, Canna, Opuntia, etc.; the gum-resin-ducts of the Umbelliferæ, and of some Araliaceæ and Compositæ (Tubulifloræ). Here the cells of the group formed by a series of divisions (Fig. $102 \mathrm{~A} \mathrm{E}$ ), separate from each other so as to leave a passage, of which they form the wall, and into which they pour their secreta.

(c) Sacs, each consisting of a single cell. To this category belong the cells which contain crystals, as those in the tissues of many Monocotyledons (Fig. 72), in the bast of many dicotyledonous trees, in leaves (Fig. 103), and petioles (Fig. 71): the cells which 
contain mucilage, as in the parenchyma of Tiliaceæ and Malvaceæ, in the bark of Elms and Firs, in the pseudo-bulbs of Orchids, etc.:

A
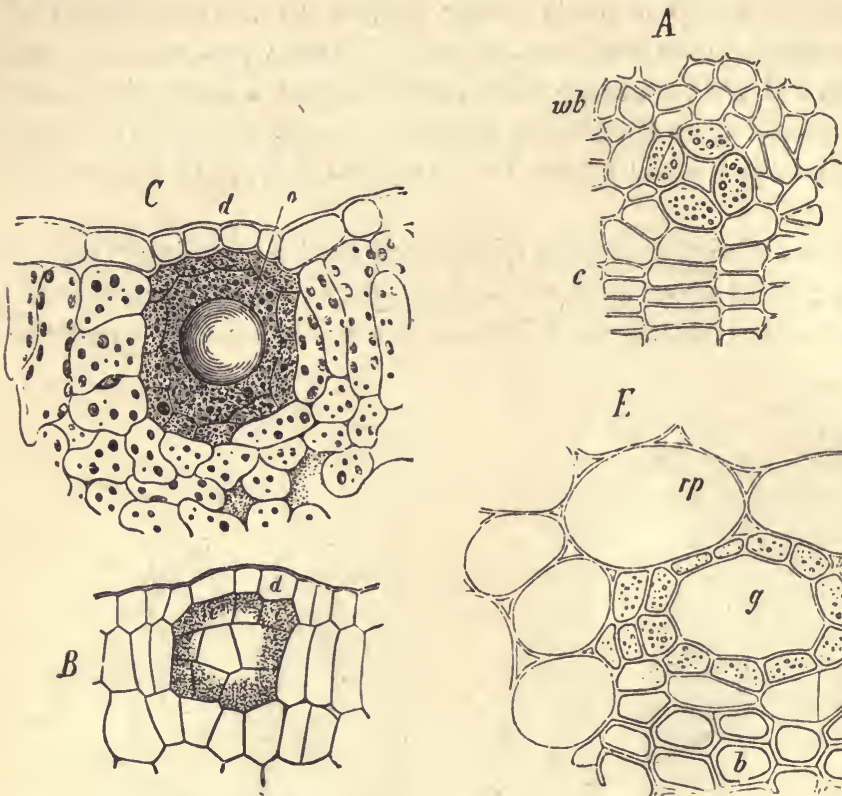

Frg. 101.-Iysigenous oil-gland below the upper surface of the leaf of Dictam. nus Fraxinella ( $\times 320)$. B At an early stage; $C$ mature; $c$ mother-cells of the gland before their absorption ; 0 a large drop of ethereal oil. (After Sachs.)

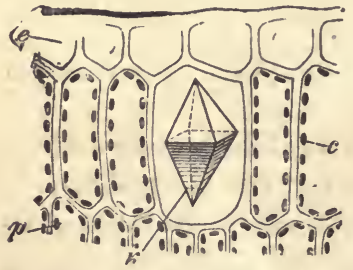

Frg. 103.-Sac containing a crystal, from the leaf of Rhamnus Frangula: $e$ upper epidermis; $p$ palisade-tissue : $c$ chloroplastids; $k$ the crystal. ( $\times 200$.)

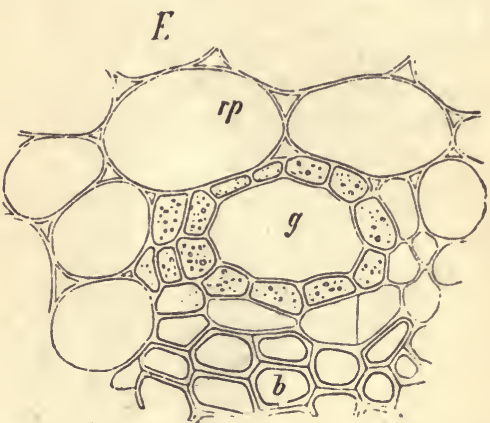

Fr6. 102.-Schizogenous resin-duct in the young stem of the Ivy (Hedera Helix), transverse section (×800). A An early, $E$ a later, stage; $g$ the resin-ducts; $c$ the cambium: $w b$ the sof $t$ bast; $b$ bast-fibres; $r p$ cortical parenchyma. (After Sachs.)

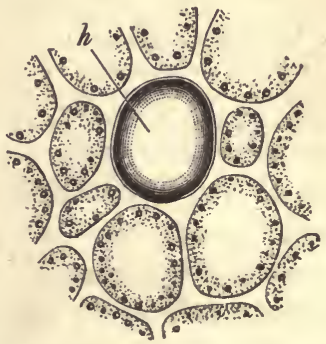

FIG. 104.-Part of section of the petiole of the Camphor-tree (Cinnamonum Camphora), showing a resin-sac $h$.

the cells which contain tannin, as in many Ferns and other plants : the cells which contain oil-resin as in the Laurineæ (Camphor, Fig. 104), the Zingiberaceæ, many Conifers (wood of Silver Fir), etc. 
These cells are frequently arranged in longitudinal rows: for instance, the tannin-sacs of the Hop; the sacs containing raphides and mucilage in Tradescantia and many other Monocotyledons; the gum-resin sacs ("vesicular vessels") of the bulb-scales of the Onion; the sacs containing crystals of calcium oxalate in the cortex of many woody Dicotyledons; the sacs containing milky juice or latex (commonly gum-resin) in the Sycamore, the Convolvulaceæ, and the Sapotaceæ (especially in Isonandra Gutta, the latex of which constitutes gutta-percha).

d. Luticiferous vessels. These structures resemble the sacs containing milky juice (latex) in the nature of their contents, and differ from them structurally only in that the walls between adjacent cells have become absorbed, thus forming syncytes (p. 91).

In the simplest case, the laticiferous vessel merely consists of a longitudinal row of cells whose transverse septa have become absorbed, thus forming a syncyte of the nature of a vessel. When two such vessels are in con-

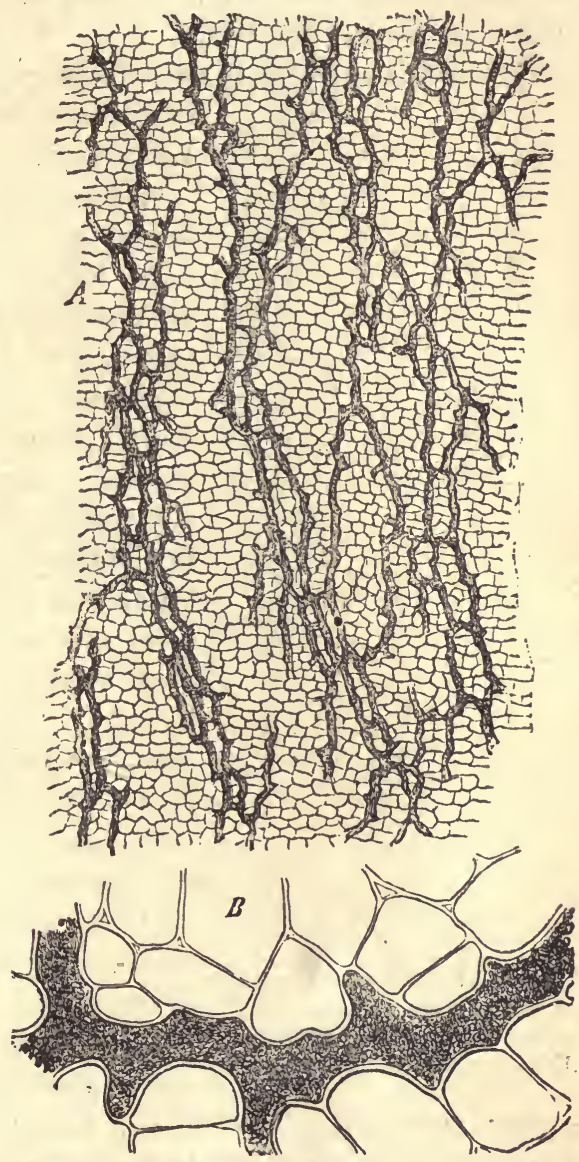

F16. 105.-Laticiferous vessels from the cortex of the root of Scorzoutera hispanica, tangential section. A Slightly magnified; $B$ a small portion highly magnifled. (After Sachs.)

tact laterally, the cell-walls are absorbed at the point of junction, and in this way a continuous system of laticiferous vessels is formed. This occurs in the greater Celandine.(Chelidonium 
majus), and in the Bananas (Musa) where, however, the latex is not milky.

More commonly, as in the Cichoriaceæ (e.g. Dandelion, Scorzonera), the Campanulaceæ, and in most Papaveraceæ (but not in Sanguinaria, Glaucium, and Bocconia, where the latex is contained in sacs), the cell-fusions take place in all directions, producing a dense network (Fig. 105).

Structures apparently of the nature of laticiferous vessels occur

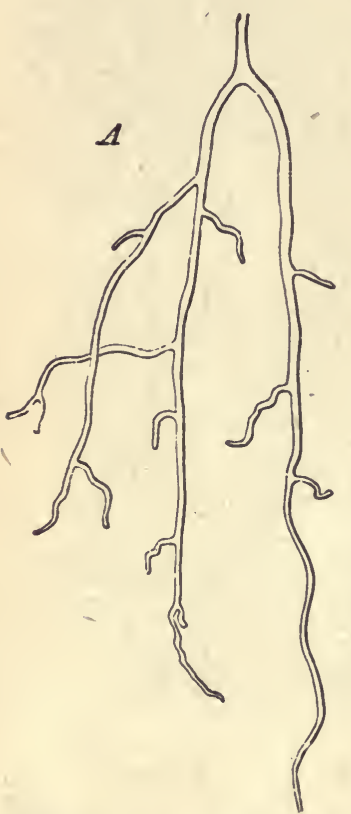

Frg. 106.-A portion of a laticiferous cœnocyte dissected out of the leaf of a Euphorbia. ( $x$ 120 : after Haberlandt.) in certain Basidiomycetous Fungi (e.g. Lactarius).

e. Laticiferous conocytes, commonly known as "laticiferous cells," occur in some Euphorbiaceæ (Euphorbieæ, Hippomaneæ), in the Urticaceæ, Аpocynaceæ, and Asclepiadaceæ. As already explained (p. 90), these "cells" are really cœnocytes; they are visible in the early stages of the development of the embryo, and they grow and branch in the tissue as if they were independent organisms (Fig. 106). As they extend from one end of the plant to the other, they attain a very considerable length in many cases. Their walls are frequently thickened (e.g. Euphorbia), but, like those of the laticiferous vessels, they are not lignified. They contain protoplasm with many nuclei, which multiply by mitotic division, and in the older parts latex is abundantly present. The latex of the Euphorbiaceæ contains curious rod-like or dumb-bell-shaped starch-grains (Fig. 107).

Very much elongated structures, somewhat resembling the laticiferous cœnocytes just described, have been observed in certain plants, but it is a question whether they are cells or cœnocytes. They may contain tannin (e.g. Elder, Polygonaceæ), or latex (Cnicus, Carduus, Arctium).

f. Epidermal Glands. Whilst all the preceding forms of glandular tissue are developed in the internal tissues of plants, somewhat similar glandular structures are developed from the superficial layer (epidermis); most commonly in the form of hairs ( $p$ 64), 
either unicellular or multicellular. When the multicellular hair consists of a single row of cells, the secretion is generally confined

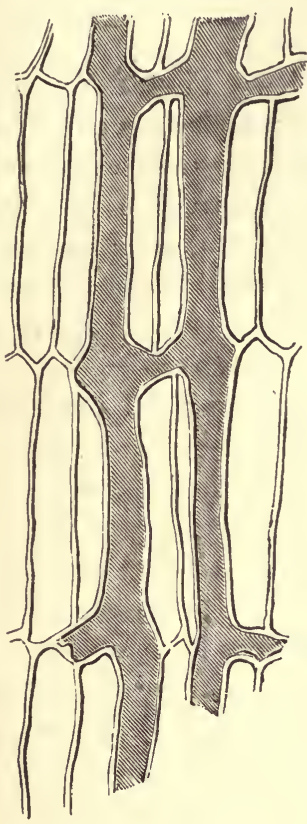

$B$

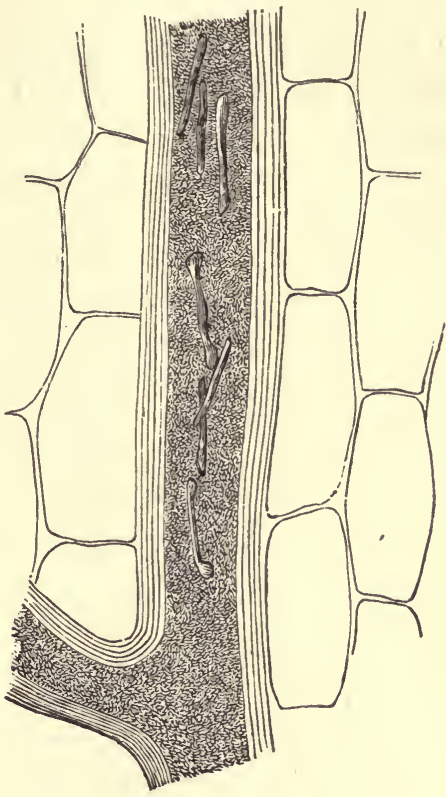

$A$

Frg. 107.-(Highly magnified, after Dippel). A Part of a laticiferous cœnocyte of Euphorbia splendens. In the latex are peculiar rod-shaped starch-grains. $B$ Network of laticiferous vessels from the root of Cichorium Intybus.

either to a large terminal cell, or to several of the distal cells; in any case the secretion begins with the terminal cell, and extends backwards to other cells towards the base. The gland, though epidermal in origin, does not, however, always project from the surface, but may be more or less sunk in the internal tissue (e.g. glands in the leaf of the Psoralea hirta).

The secretum (which may consist of mucilage, or gum-resin, or ethereal oil, balsam, etc.) is accumulated either in the cavity of the secreting cells (e.g. mucilaginous hairs at the growingpoint of Liverwort-gametophytes and of Fernsporophytes), or between the external cuticle and

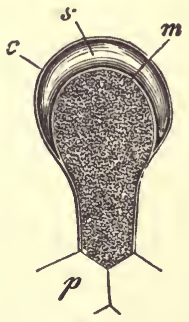

Fig. 108. - Glandular hair from the base of a ramentum of Aspidium Filix mas $(\times 200): s$, the secretum, lying between the outer and inner layers of the cell-wall, $c$ and $m$. 
the deeper layers of the cuticularised cell-wall (e.g. mucilaginous hairs [colleters] on the buds of many Phanerogams, resinous hairs generally; Fig. 108).

\section{$\S 30$. General Morphology of the Tissue-Systems.} When a form of tissue constitutes a complex which extends continuously throughout the body of a plant, or over considerable areas, it is spoken of as a tissue-system, for instance, a laticiferous system, a resin-duct system, a sieve-tube system, etc.; or a more elaborate system may be produced by the combination of two or more systems : for instance, the sieve-tube system and the tracheal system taken together constitute the vascular tissue-systrm. Further, by the study of the anatomy of fully-developed parts some idea can be obtained of the relative morphological importance and arrangement of the tissue-systems. Thus, confining attention for the present to the sporophyte of the Vascular Plants (i.e. Pteridophyta and Phanerogams), it is found that some of these tissuesystems, such as the laticiferous system and the resin-duct system, are present in certain plants only. Since they are absent in the majority of the plants under consideration, it is clear that these two tissue-systems can only be of secondary importance. On the other hand it is clear that the tissue-systems which are present in all these plants and in all parts of them, must be of primary importance. Observation shows that this applies to three tissue-systems. It is found, first of all, that all these plants and their parts (at any rate when young) are corered at the surface by a definite membrane consisting of (usually) a single layer of cells constituting the Tegumentary Tissue-System (Fig. 109 e). It is found secondly that tracheal tissue and sieve-tissue, either separate or closely associated, are distributed in strands, termed vascular bundles (Fig. $109 \mathrm{f}$ ), throughout the internal structure, constituting the Vascular Tissue-System; and it is found, finally, that the rest of the structure of the plant is made up of tissue, largely parenchymatous, but usually to a certain extent prosenchymatous, which constitutes the Fundamental or Ground TissueSystem (Fig. $109 \mathrm{~g} g$ ).

The other tissue-systems are subordinate to these three principal tissue-systems, and are distributed throughout them; for instance, the mechanical tissue-system (stereom), including collenchyma and sclerenchyma, is developed as well in relation with the vascular as with the fundamental tissue-system; and, similarly, 
the glandular tissue-system is developed in relation with either the vascular, the fundamental, or the tegumentary tissue-system.

It is, however, impossible to arrive at the essentially morphological relations of the tissne-systems without a study of their development, a study which will now be entered upon with the consideration of the apical growing-points of the stems and roots of the sporophyte of the Vascular Plants.

As already pointed out (p. 18), the growing-point consists, in these plants, of embryonic tissue, the cells of which may be of approximately uniform size, constituting a small-celled primary meristem; or there may be at the organic apex a cell conspicuously larger than the rest, the apical cell; or a group of several larger initial cells.

\section{a. Growing-points consisting} of small-celled meristem are, with rare exceptions, to be found in the roots and stems of Phanerogams, as also in the root of Lycopodium and Isoetes among the Pteridophyta. Although the cells are all embryonic, they nevertheless present such a degree of differentiation as to make it possible to distinguish three well-defined rudimentary tissue-systems.

In the stem, a growing-point of this kind usually presents the appearance shown in Fig. 110. It consists, in the first place, of a well-defined super-

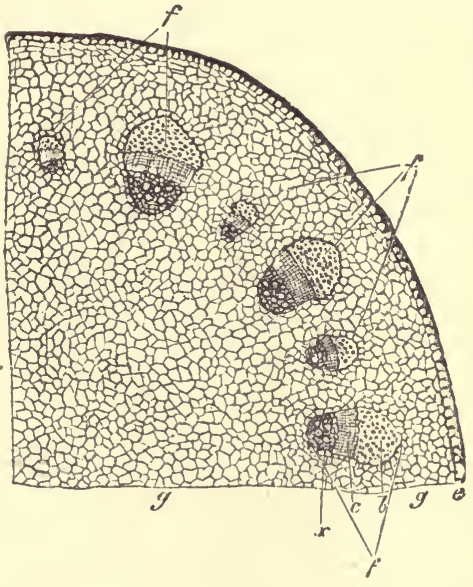

Fra. 109.-The tissue-systems in a crosssection of the petiole of Helleborus $(\times 20)$. 6 Epidermis; $g$ fundamental tissue; $f$ vascular system; $x$ xylem ; $c$ bast ; $b$ sclerenchymatous tissue.

ficial layer which, on being traced backwards, is seen to be continuous with the primary tegumentary tissue (epidermis) of the older parts; this layer is, in fact, the embryonic epidermis or dermatogen $(d)$; it is quite distinct, morphologically, from the subjacent cells, and is characterized by the fact that its cells only undergo division in planes perpendicular to the surface (anticlinal), and not in any plane parallel to the surface (periclinal). Consequently, whilst the dermatogen increases in area, so as to keep pace with the growing tissues within, it does not become many-layered, but remains a single layer of cells. 
In the middle of the growing-point is a solid mass of somewhat elongated cells $(p p)$ constituting the plerome, and terminating in one or more initial cells; on tracing this backwards into the older part of the stem it is found to give rise to a single axial cylinder of tissue, the stele, in which the vascular tissue is developed; such a stem is said to be monostelic. In some cases, however, more than one plerome-strand is present at the growingpoint, and the stem consequently contains more than one stele (e.g. Gunnera), and is said to be polystelic.

Between the dermatogen externally and the plerome internally is a layer-less frequently several layers-of cells constituting the periblem; the cells of these layers undergo divisions both anticlinally and periclinally, so that both the area of each layer

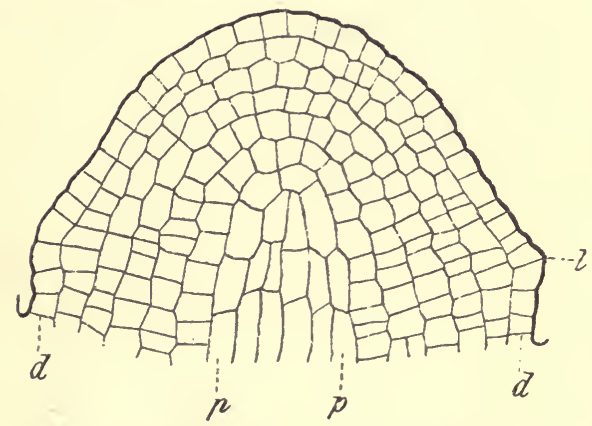

Frg. 110.-Median longitudinal section of the growing-point of the stem of Hippuris vulgaris. Tbe growing-point consists of a small-celled meristem, differentiated into dermatogen $d$, plerome $p p$, and periblem consisting of the five layers of cells between the plerome and the dermatogen; $l$ rudiment of $a$ leaf. (After de Bary; $\times 225$. ) and the number of the layers are increased. On tracing the periblem backwards into the older parts, it is found to be continuous with the extra-stelar fundamental tissue.

The growing-point of the root (Fig. 111) of one of these plants essentially resembles that of the stem in its structure; the small-celled meristem is differentiated, at least primarily, into dermatogen, plerome, and periblem. But there is this distinctive peculiarity about the dermatogen of the root, that its cells undergo division, not anticlinally only, as in the stem, but periclinally also, so that the epidermis of the root is many-layered (except in Hydrocharis and Lemna, where it remains a single layer). This many-layered epidermis, however, is gradually exfoliated as the parts grow older, and persists only at the apex constituting the root-cap (see p. 6). The only other important fact to be noticed at present is that the root has only a single stele, that is, it is always mono. stelic.

The foregoing description is applicable to all growing-points with a small- 
celled meristem. It is, however, frequently the case, especially when the stem or root is rather bulky, that the distinction of the initial layers is not clear, and that they seem, in fact, to have to a greater or less extent a common origin, and various such "types" of structure of the growing-point have been described; these "types" are, however, only variations of the relations as described above, due to irregularities of growth.

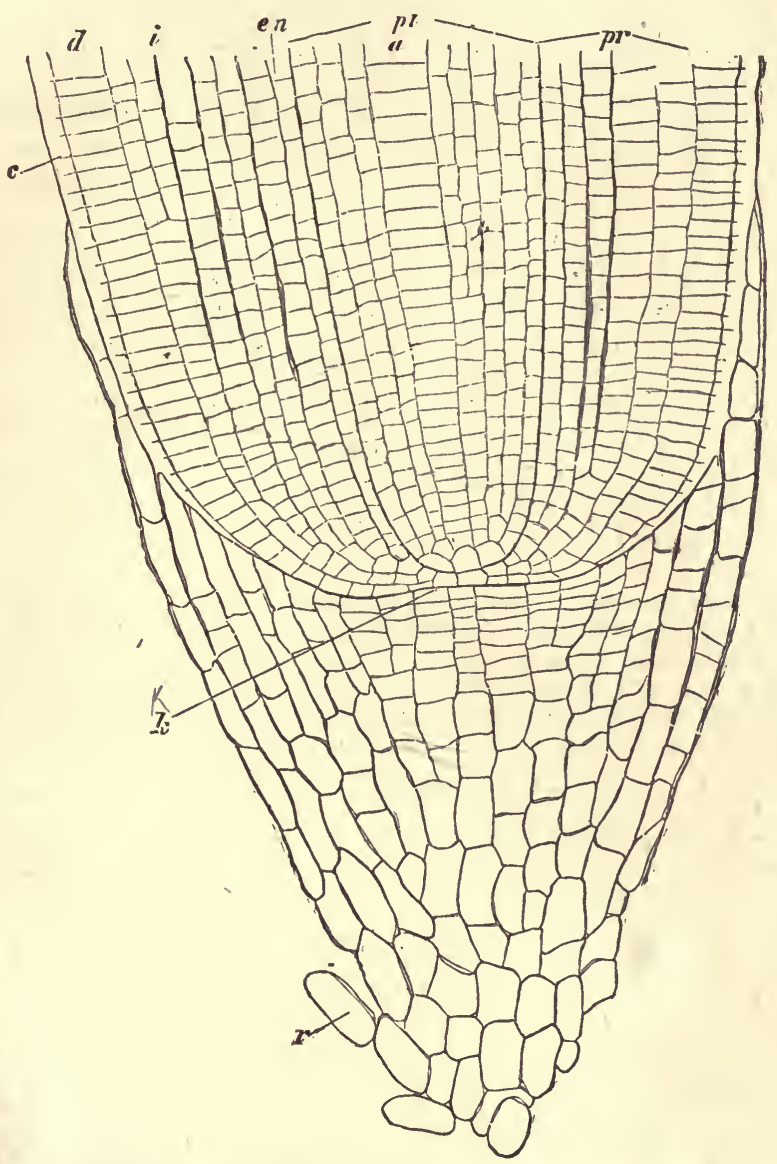

FrG. 111.-Median longitudinal section through the growing-point of the root of Hordeum vulgare (Barley) : $r$ root-cap; $k$ initial cells of the dermatogen of the many-layered epidermis; $d$-en cortex ; $d$ epiblema with mucilaginous external layer of cell-wall $c$; $i$ cortical tissue with intercellular spaces; en endodermis; the whole periblem $\left(p v^{*}\right)$ is derived from the single layer of two initial cells at the apex; $p l$ plerome; $a$ row of cells which give rise to a large central wood-vessel. (After Strasburger : $\times 180$.)

b. Growing-points with a single apical cell are to be found in 
stems and roots of most Pteridophyta: for instance, in the stems

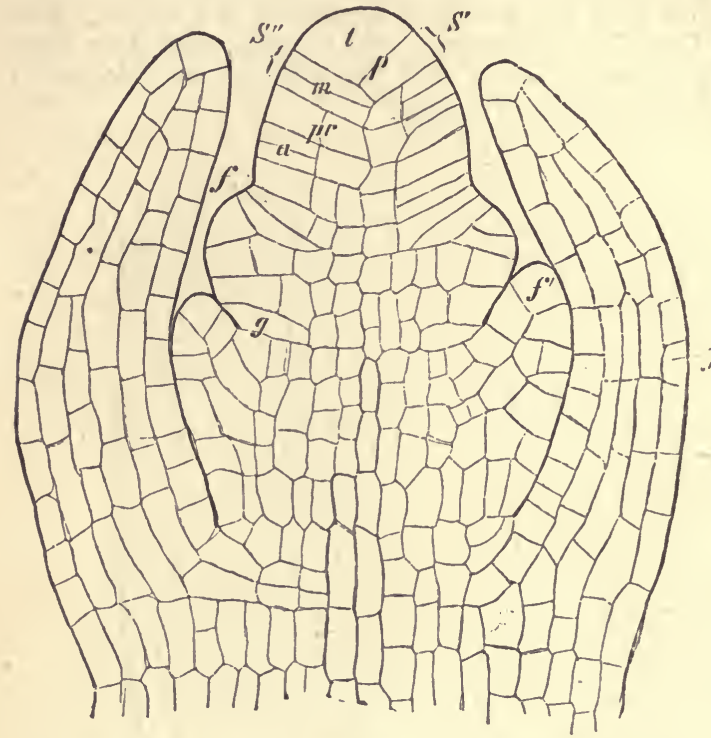

Frg. 112.-Growing-point of the stem of Equisetum arvense, in longitudinal section; $t$ apical cell; $s^{\prime} s^{\prime \prime}$ successive segments; $p$ anticlinal segment-wall; $m$ wall dividing the segment into an upper and a lower cell; $p r$ periclinal wall dividing the segment into an inner and an outer cell; $f f^{\prime} f^{\prime \prime}$ successive whorls of leaves; $g$ initial cell of a lateral bud. (After Strasburger : $\times$ 240.)

and roots of all Leptosporangiate Filicinæ, and in those of the Ophioglosseæ (but not in those of the Marattiaceæ) ; in those of the Equisetinæ; and in those of some species of Selaginella ( $S$. Martensii and Kraussiana). The shape of the apical cell is generally a three-sided pyramid with a spherical base, the base being at the surface of the member and the apex being directed inwards; less commonly the apical cell has only two sides or flanks and is then somewhat lenticular in shape
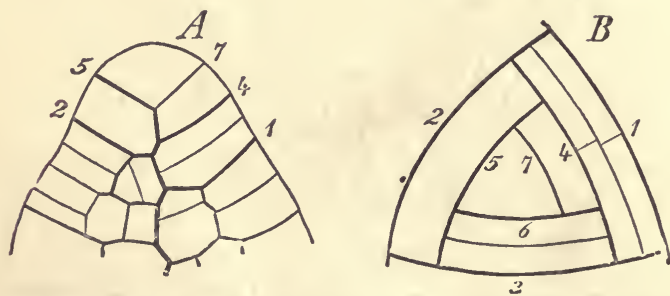

FIG. 113.-Diagrams illustrating the division of the apical cell of the stem of Equisetum: $A$ longitudinal section ; $B$ surface view. The numbers 1-7 indicate the successive segmental walls; the fainter lines indicate the walls of subsequent divisions of the segments. onic tissue-systems are not continuous as in the Phanerogams,

(e.g. that of the rhizome of Pteris aquilina, stem of Salviniaceæ, and frequently in the above species of Selaginella).

In growingpoints of this structure it is seen (Fig. 112) that the embry- 
but are interrupted at the apex by the large apical cell. The apical cell is, in fact, the initial cell for all the tissue-systems. The apical cell undergoes division by walls formed parallel to each of its (two or three) flanks successively, the segments thus formed growing and dividing to form the tissues of the stem or root. In the root the apical cell also undergoes divisions parallel to its curved base. After the cutting off of a segment the apical cell grows to its previous size, so that the repeated segmentation does not diminish the bulk of the apical cell.

The most important morphological fact in connection with the subsequent division of the segments cut off from the flanks of the apical cell is that each such segment is divided by a periclinal wall into an external and an internal half; from the external half are developed cells belonging to the cortical ground-tissue, the outermost layer of which eventually acquires the characters of an epidermis, though it is not the morphological equivalent of the epidermis of the stem of Phanerogams, but is only the external layer of the cortex, being of common origin with the other cortical layers; from the internal half of the

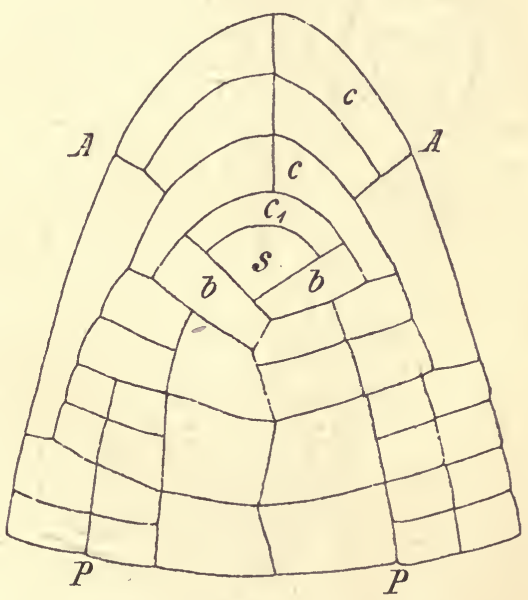

Frg. 114.-Diagram of growing-point of a Fernroot. A $A$ Anticlinal walls; $P P$ periclinal walls; $s$ apical cell $; b b$ segments cut off from the flanks of the apical cell; $c^{\prime}$ segment cut off the base of the apical cell; $c$ c cells derived from previous segments cut off from the base of the apical cell, now forming the root-cap. (After Bower.) segment is developed a portion of one or more plerome-strands, and a certain amount of internal ground-tissue as well.

The segments cut off parallel to the base of the apical cell of the root (Fig. 114 $c^{\prime}$; Fig. $115 k$ ) represent a true dermatogen, a structure, which, as mentioned above, is wanting in the stem. These dermatogen-segments grow and divide both anticlinally and periclinally to form the root-cap (Fig. 114c c; Fig. $115 k^{n}$ ); but this many-layered epidermis only persists at the growing-point, since it becomes entirely exfoliated as the parts grow older. 
c. Growing-points with a group of common initial cells occur in certain Pteridophyta (e.g. in the stems and roots of Marattiaceæ, of Osmunda sometimes; stems of Lycopodium, Isoetes, some Selaginellas). In these cases, there is a group of frequently four cells which are the common initials of the tissue-systems. The general relations of the tissue-systems are here essentially the

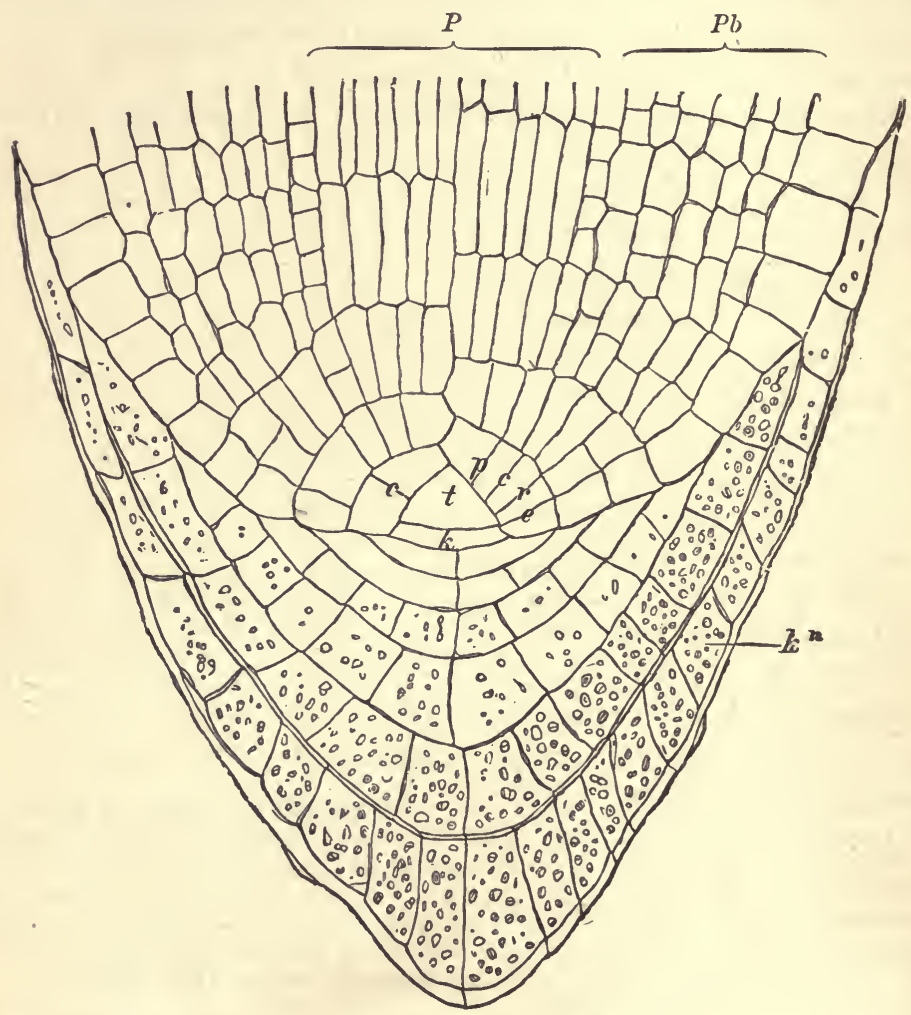

Fra.115.-Median longitudinal section through the apex of the root of Pteris cretica; $t$ apical cell; $k$ initial segment of dermatogen; $k^{n}$, outermost layer of root-cap; $p$ wall marking limit between the plerome $P$ and the periblem $P b$; $c$ cell marking the inner limit of the outer cortex. (After Strasburger : $\times 240$.)

same as in those forms in which the growing-point has a single apical cell : in these cases, as in those, there is no properly differentiated dermatogen in the stem, and consequently there is no layer which is morphologically equivalent to the epidermis of the stem in the Phanerogams. 
The Growing-point in the lower plants. In the gametophyte of the Muscineæ, the growing-point of the stem or of the thallus has either a single apical cell (all Mosses; Jungermanniaceæ) or a group of apical cells (Marchantiaceæ, Anthoceroteæ) : the growing-point of the sporophyte of the Liverworts bas a group of four initial cells, whilst that of the Mosses has a single two-sided, apical cell. In none of these plants is there a true dermatogen ; consequently, like the stem of the Pteridophyta, they are destitute of a true epidermis. In both the stem of the gametophyte and the thalloid shoot of the sporophyte of certain Mosses, what may be regarded as a single central stele is differentiated.

In the higher Algæ, the shoot (or thallus) also grows by means of a single apical cell: in the more filamentous forms (e.g. some Florileæ, Characeæ) the apical cell is hemispherical in form, and segments are cut off by transverse walls in one plane only; in other more bulky forms of Florideæ there is a group of initial cells; in nearly all these forms a more or less distinct differentiation of a central medullary tissue and of a cortical tissue takes place : in the Fucacer there is a single apical cell in the growing-point, with either three or four flanks along which segments are cut off; when the apical cell is four-sided, segments are also cut off internally along the truncate base of the cell; the tissues soon show differentiation into a cortical and a medullary region.

In unseptate or imperfectly septate plants, having apical growth (e.g. Siphonaceous Algæ, Cladophora, etc.), the growing-point (like the rest of the body) is not cellular, but consists merely of embryonic protoplasm.

d. The Morpholngy of the Stele. The plerome, constituting the young stele, always gives rise to vascular tissue and usually to a certain amount of fundamental tissue which is distinguished as intra-stelar fundamental tissue, or more briefly as conjunctive tissue.

The first indication of the development of vascular tissue in the stele is afforded by the differentiation of a varying amount of procambium or primary desmogen, consisting of somewhat elongated narrow cells formed by repeated longitudinal division, which is the embryonic tissue from which the vascular tissue is eventually formed. The procambium frequently constitutes one solid central strand, surrounded by more or less conjunctive tissue constituting the pericycle; this is sometimes the case in slender roots (see Fig. 131), in slender monostelic stems (e.g. many aquatic Phanerogams, such as Callitriche, Myriophyllum, Elodea, Naias; rhizomes of Adoxa, Corallorhiza, Epipogum; among Pteridophyta, Isoetes, Salvinia, Azolla, Psilotum, Lycopodium, Hymenophyllum, Lygodium, Gleichenia, Schizæa), and generally in the steles of polystelic stems. More commonly, however, the procambium of stout roots and monostelic stems is developed as a number of strands variously arranged in the stele, generally in a circle or in several circles; the strands thus forming an incomplete hollow cylinder enclosing a central mass of conjunctive tissue, the medulla or pith, 
whilst the conjunctive tissue between the strands constitutes the medullary rays.

In all cases the stele (whether one or more) is at an early stage marked off from the extra-stelar ground-tissue, the layer of the ground-tissue which abuts on the stele being specially differentiated as a sheath, the endodermis (see Fig. 116 End.), which forms a continuous covering to the stele or any isolated portion of it.

All primary stems are typically monostelic to begin with, but as they increase in bulk this type of structure is departed from in various ways; typical monostely is, however, the rule in the stem of Phanerogams, and is frequent in that of Pteridophyta (in Hymenophyllum, Trichomanes, Lygodium, Gleichenia, Osmunda, Todea, lower part of the stem of the Ophioglosseæ, Salvinia, Azolla, Lycopodium, Isoetes, some species of Selaginella).

'The variations from the primitive monostelic structure are polystely (p. 146) and sclizostely. In polystely, the whole of the single stele passes over, as the stem grows and enlarges, into a varying number of steles which can be traced to the growingpoint as distinet plerome-strands. Polystely is rare in stems which have a growing-point without an apical cell, whilst it is common in stems where the growing-point has an apical cell: hence it is rare in Phanerogams (occurs in Auricula and Gunnera), and is common in Pteridophyta (especially Leptosporangiate Ferns, and some Selaginellas).

An important modification of the polystelic structure is that which is termed gamostelic; in this case the several steles are not distinct for any considerable distance in their longitudinal course; but some or all of them fuse with each other at more or less frequent intervals for longer or shorter distances; this is common in Ferns, Marsilia, etc.

In schizostely, the single primitive stele breaks up into as many distinct strands as it possesses vascular bundles; and since each snch strand may consist of but little more than the vascular bundle with a pericycle, the chief part of the conjunctive tissue of the primitive monostele is excluded from the schizosteles, and becomes, in fact, extra-stelar ground-tissue (see Fig. $116 \mathrm{~B}$ ), each schizostele being invested by its own segment of the endodermis. This obtains, among Phanerogams, in the Nymphæaceæ, Hydrocleis, Limnocharis, some species of Ranunculns ( $R$. aquatilis and Lingua); among Pteridophyta, in the upper part of the stem of the Ophioglosser, and in Equisetum. The schizo- 
steles may remain distinct in the internodes, or they may fuse more or less (Fig. $116 \mathrm{C}$ ).

The general morphology of the tissues of the leaf is essentially the same as that of the stem which bears it. When the stem is polystelic, one or more complete steles enter the petiole of the leaf which is, consequently, either monostelic or polystelic. When the stem is monostelic, each leaf receives a portion, termed a meristele, of the stele of the stem; this meristele may be either entire, or be split up into a number of schizosteles, each of which may consist of but little nore than a vascular bundle.
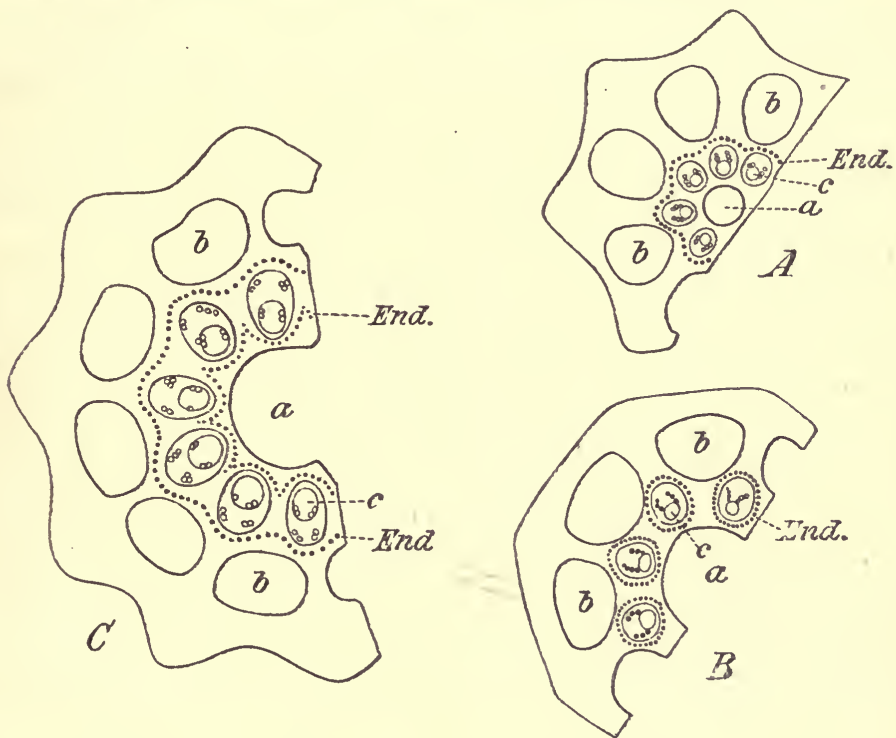

F1G. 116.-Portions of transrerse sections of stems of species of Equisetum, illustrating sclizostely (after Pfitzer: $\times 36$ ). $B$ Typical schizostelic rhizome of $E$. litorale; $C$ schizostelic gamodesmic rhizome of $E$. silvaticum; $A$ aerial stem of $E$. palustre, in which the structure is the same as in $C$, but the markings of the internal endodermal lajer are not developed, so that the stem appears to be monostelic; $a$ central cavity; $b$ rallecular cavities in the cortex; $c$ carinal cavities in the schizosteles; End. endodermis.

The primary tissues-that is, the tissues which are developed from the primary meristem of a growing-point or of an embryowill now be considered in detail. The following account, unless it is expressly stated otherwise, refers exclusively to the sporophyte of the Vascular Plants.

$\S 31$. The Primary Tegumentary Tissue. The primary tegumentary tissue may be generally described as the external 
layer of cells covering the body of the plant, and is commonly termed the epidermis; but neither the morphological nature of this tissue, nor its structure, is uniform throughout the Vegetable Kingdom.

Morphology. A true epidermis only exists in those plants, and in those parts of them, where there is a definite dermatogen; a true epidermis can, therefore, only be present in the Phanerogams and in the roots of the Pteridophyta, in view of the structure of the growing-points as described in the previous paragraph, and the word epidermis is, strictly speaking, only applicable to such a tegumentary tissue. It is, however, convenient to apply this term generally to the primary tegumentary tissue of the shoot, and to apply the term epiblema to the primary tegumentary tissue of the root, apart from the root-cap.

As regards the shoot, whilst there is a true epidermis in Phanerogams, that of the Pteridophyta (as also of the lower plants) is merely the external layer of the cortex.

In the root there is considerable variety in the morphological nature of the epiblema. Thns, in Hydrocharis and Lemna, the dermatogen is and remains a single layer of cells which persists in the adult portion of the root as the epiblema which is, therefore, a true epidermis morphologically equivalent to that of the stem. In most cases, however, the dermatogen becomes many-layered; this persists at the apex as a root-cap, but gradually exfoliates on the older parts behind the apex, either partially, so that a single layer of it, the innermost, persists as the epiblema of the root (as in most Dicotyledons, Gymnosperms, Lycopodium, Isoetes); or entirely (as in Monocotyledons, and in Nymphæaceæ among Dicotyledons), so that the epiblema is merely the external layer of the cortex. The root of Pistia and Pontederia has no dermatogen, and consequently no epidermis at all, the epiblema being the external layer of the cortex : the root of these plants is, in this respect, quite similar to the shoot of the Pteridophyta, etc., mentioned above.

Structure. In the great majority of cases the primary tegumentary tissue consists of a single layer of cells; but to this rule there are several important exceptions. Thus, the epidermis of the foliage-leaves of certain plants (e.g. Ficus, Peperomia, Begonia) consists of two or more layers of cells. Similarly, the root-cap to be found in nearly all roots is a many-layered epidermis. Again, the aerial root of certain epiphytic plants (Orchids, Aroids) has 
a many-layered epiblema, known as the velamen, consisting of empty tracheidal cells with reticulated and perforated walls (see p. 134).

The cells of the epidermis of the shoot of land-plants, are characterised by the thickening and cuticularisation of their cell-walls (see p. 132). The external wall is usually much more thickened than the other walls; its outermost layer, termed the cuticle, is always cuticularised, and is clearly defined from the inner layers, which may be also more or less cuticularised. The cuticle may be stripped off as a membrane, over a considerable area; it frequently forms surfaceprojections. Particles of wax are included in the cuticle of many plants, and serve to prevent the surface from being wetted by water. This wax often appears on the surface in the form of small granules, rods, or flakes, and this

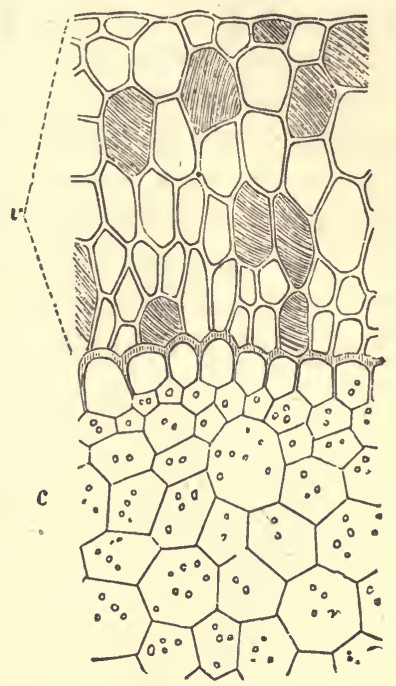

Frg. 117.-Part of a transverse section of the air-root of an Orchid : $v$ manylayered epiblema, or velamen; $c$ cortex. (Magnified; after Unger.) forms the bloom which is easily wiped off : it sometimes attains a considerable bulk, as in the fruits of Myrica cerifera and the trunks of some Palms (Ceratoxylon andicola, and Klopstockia cerifera). The epidermal cells are sometimes sclerotic, as in prickles, thorns, and leafspines. Chloroplastids are not usually present in the epidermal cells of land-plants; they are to be found, however, in the cells of most Ferns, of Selaginella, and of some Phanerogams, more especially aquatics.

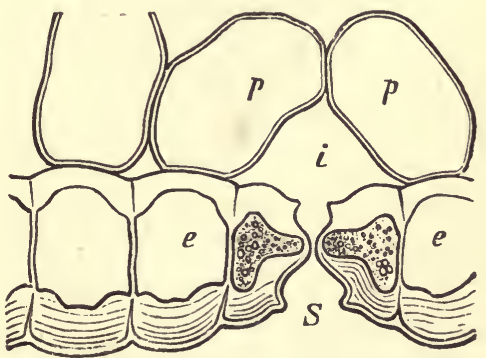

FiG. 118.-Epidermis (e) with a stoma (S) from a cross-section of a leaf of Hyacinthus orientalis $(\times 800): p$ parenchyma of the fundamental tissue; $i$ an air-cavity.

The form of the epidermal cells, as seen in surface view, presents considerable variety. Generally speaking, the cells of an elon- 
gated member are themselves elongated in the same direction as the member; whereas, in broad, flattened members, there is less difference between the diameters of the cells; in either case the side-walls of the cells very frequently have an undulating outline, so that adjoining cells fit closely together forming a continuous membrane, the continuity of which is, however, interrupted in certain cases by well-defined apertures, termed stomata, which permit communication between the intercellular spaces of the internal tissues and the external air.

The Stomata are confined exclusirely to the sporophyte-generation, and make their first appearance in the Moss-sporogoninm. Each stoma is an aperture bounded by two (sometimes only one, as

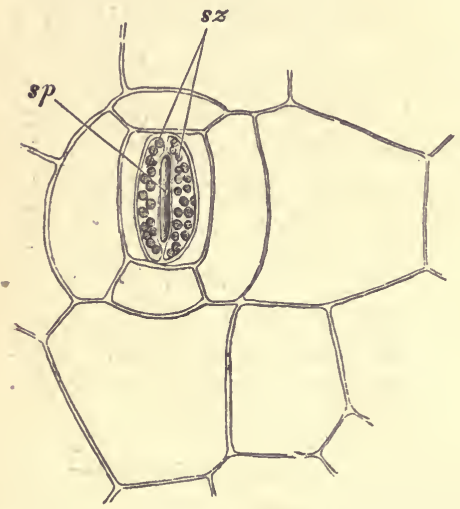

Fig. 119.-Stoma of a leaf of Commelina calestis, surface view ( $\times 300)$ : sp opening; $s z$ the two guard-cells surrounded by several subsidiary epidermal cells. in the Mosses) specialised epidermal cells, termed guard-cells, which always contain chloroplastids (Fig. 119). The aperture of the stoma leads into the aircavity (Figs. 118, 120), a large intercellular space between the epidermis and the subjacent tissue, which communicates with other more internal intercellular spaces. The stoma originates thus: a young epidermal cell is divided by a septum into two halves, each of which becomes a guard-cell; the septum then gradually splits into two and thus the aperture between the gaard-cells is formed; when the septum does not quite reach across the mother-cell, the aperture is surrounded by a single annular guard-cell, as in the Mosses. The size of the aperture may be increased or diminished by changes in the bulk of the guard-cells; the mechanism and conditions of this process are considered in Part IV.

Stomata are found on almost all sub-aerial parts of the sporophyte of land-plants from the Mosses upward; they are especially abundant on leaves (as many as 600 to the square millimetre), and, in dorsiventral leaves, more particularly on the lower (dorsal) surface, but in floating dorsiventral leaves (e.g. Nymphæa) they are confined to the upper surface; in radial and isobilateral leaves 
the distribution of the stomata is uniform on all sides; they are wanting in submerged leaves, and are always absent from roots.

A peculiar form of stoma is found in some plants, known as a water-stoma (Fig.121). It consists of two large, almost spherical, guard-cells which cannot alter their form so as to close the aperture. Water-stomata occur on the leaves of some of those plants (e.q. Alchemilla, Crassula, Ficus, Saxifraga, Colocasia, Papaver, Tropæolum) which excrete water in the form of drops; they are situated over the termination of the vascular bundles on the margins or at the apex of the leaf; when chalk-glands are present (p. 137), water-stomata are developed in connexion with them (see Fig. 100).

In some plants (e.g. Grasses) which excrete drops of water, the water escapes through fissures in the epidermis of the leaf.

The epidermis of the submerged shoots of water-plants differs from that of land-plants in that it is not cuticularised, in the absence of stomata, and in that its cells frequently contain chloroplastids.

The epiblema of the subterranean root is commonly known as the pili-

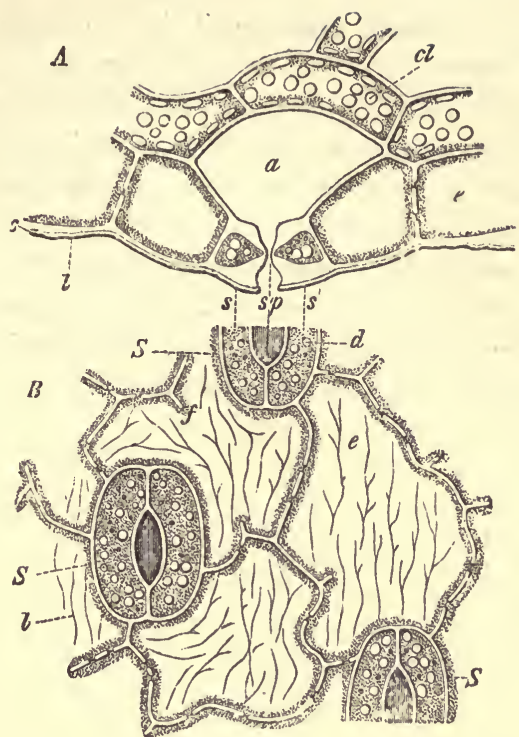

FrG. 120.-Epidermis with stomata, from the lower surface of the leaf of Helleborus fotidus: $A$ in section; $B$ surface view $(\times 300)$; e epidermal cells; $c$ cuticle; $l$ thichenings of the external wall; $f$ folls of the lateral walls; $s$ stoma; $s$ guard-cells; $s p$ aperture; $a$ air-cavity; $c l$ mes phyll.

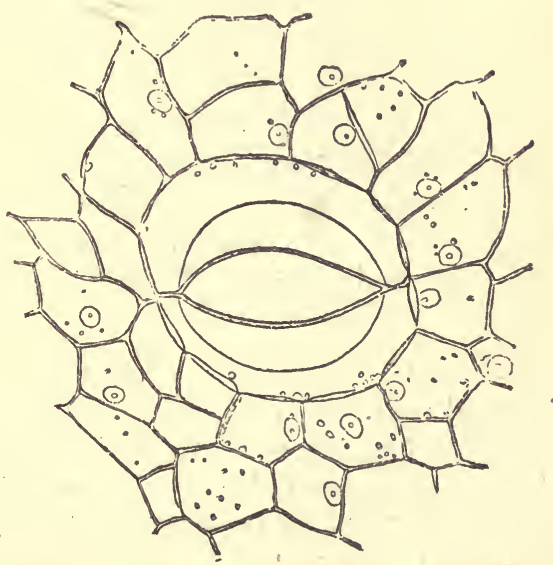

Fra. 121.-Water-stoma from the margin of the leaf of Tropeolum majus, with surrounding epidermal cells. (After Strasburger : $\times 240$.) 
ferous layer because it is the layer from which the root-hairs (see p. 65), when present, are developed. Its cell-walls are not cuticularised, but are frequently (especially in the root-hairs) more or less mucilaginous. It is generally of but short duration, and to be found only on the younger parts of roots which are the regions of active absorption.

In aerial roots (Orchids, etc.) where the epiblema persists as a velamen (see Fig. 117, p. 155) of one or several layers of cells, the walls are thickened, cuticularised (especially the superficial layer), and somewhat lignified.

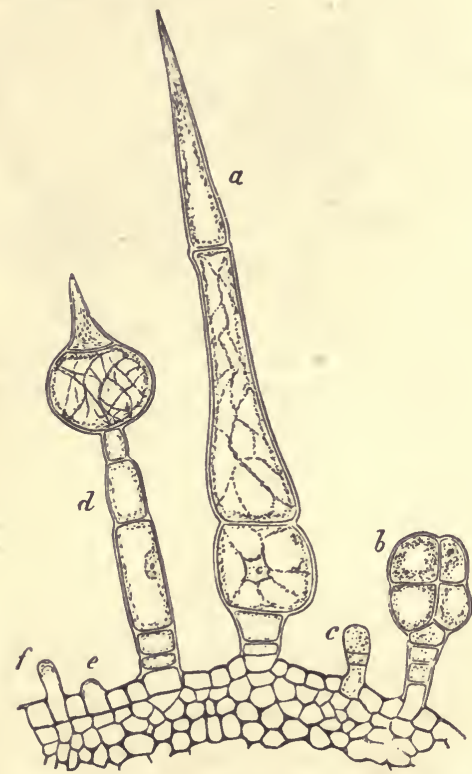

Fig. 122.-Hairs on a soung ovary of Cucurbita ( $\times 100)$ : b glandular hair; $c$ ef early stages of development.

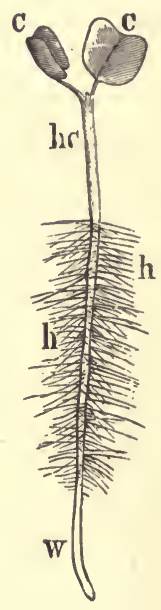

Frg. 123,-Root hairs $(h)$ on the primary root $(w)$ of a seedling of the Buckwheat: he hypocotyl; cc cotyledons.

The many-layered root-cap (see p. 146), in its younger, more internal part, consists of parenchymatous cells, with cell-walls of cellulose, forming a compact tissue without intercellular spaces. As the cells grow older, and come to be situated more externally, they lose their protoplasmic contents. The disintegration of the root-cap is due, in some cases, to the mucilaginous degeneration of the middle lamella of the cell-walls; whilst in other cases, where the cell-walls become cuticularised, the superficial layers of the 
cap are successively split off and exfoliated by the pressure of the internal growing tissues.

Hairs (see p. 64), are frequently developed on the primary tegumentary tissue, and are generally formed each as an outgrowth of a single superficial cell (Fig. 122; see also Fig. 40, p. 65; and Fig. 108, p. 143).

The hairs of the subaerial parts of plants are, like the epidermal cells, cuticularised. In many cases the protoplasmic contents disappear at an early stage (as in Cotton, the hairs on the outer coat, or testa, of the seed of Gossypium) and are replaced by air. Sometimes the cell-wall contains deposits of lime or of silica. The hairs are frequently glandular (see p. 142).

The root-hairs (Fig. 123; also see p. 65) are developed each from a single cell of the epiblema or piliferous layer; they are not developed in the immediate neighbourbood of the growing-point but at some little distance behind it. Moreover, as they grow older, the root-hairs die off; hence they are only to be found on a very limited region of a primary or a secondary root.

\section{$\S 32$. The Fundamental Tissue-system, or Ground-tissue,} is constituted by the tissue which belongs neither to the epidermis, on the one hand, nor to the vascular tissue on the other. Two regions of this tissue-system are distinguishable, according to their relation to the stele, as extra-stelar and intra-stelar; the former being developed from the periblem, the latter from the plerome, of the growing-point.

The Extra-stelar Fundamental Tissue.-Morphology. The limits of this tissue vary with the structure of the part concerned. When the part, whether it be stem, leaf, or root, has a true epidermis (see p. 154), the external limit of the extra-stelar tissue is the layer of cells lying immediately beneath the epidermis; when, however, there is no true epidermis, the extra-stelar tissue extends to the surface, and the superficial tegumentary layer is merely its external layer. Again, when the member is monostelic, the internal limit of the extra-stelar tissue is the layer termed the endodermis, which abuts upon the central stele; in this case the extra-stelar tissue consists of several layers of cells bounded externally by the true epidermis (if present), or reaching to the surface, and bounded internally by the stele, when it is spoken of as the cortex of the member of which it forms part. In a polystelic member, the internal limit of the extra-stelar tissue is 
still the endodermis, but each individual stele is invested by a distinct endodermis; here the fundamental tissue includes not merely the cortex, but also the tissue between and among the steles. The relations of the parts are very much the same in a schizostelic as in a polystelic member (see Fig. $116 \mathrm{~B}$ ).

The following are the regions or layers of the primary extrastelar tissue which can be distinguished morphologically.

1. The tegumentary tissue, in those parts in which there is no true epidermis.

2. The hypoderma is the external layer (or layers) of the fundamental tissue where a true epidermis is present; when the integumentary tissue is not a true epidermis but is derived from the external layer of the cortex, the hypoderma is derived fiom the outermost layer but one of the primitive cortex (periblem); in the root, the hypoderma is distinguished as the exodermis.

3. The general ground-tissue.

4. The endodermis, the layer of the ground-tissue which abuts on a stele; in the root the endodermis is the innermost layer of the internal cortical tissue.

Structure. Speaking generally, the extra-stelar fundamental tissue consists mainly of parenchymatous cells which have cellulose walls and retain their protoplasmic cell-contents; however, supporting-tissue (stereom) is largely differentiated in the fundamental tissue, whether as a collenchyma or as sclerenchyma. In cylindrical members (stems, roots, etc.) the cells are generally somewhat elongated in the direction of the long axis of the member.

1. The tegumentary tissue derived from the periblem has already been described (p. 154).

2. The hypoderma of stems and leaves commonly consists of stereom, either collenchymatous or sclerenchymatous :

collenchymatous hypoderma is especially characteristic of the stems and leaf-stalks of herbaceous Dicotyledons (see Fig. 91, p. 132), but it occurs also among Pteridophyta in the petioles of the Marattiaceæ :

sclerenchymatous hypoderma may form a continuous layer of more or less prosenchymatous cells (e.g. stem of some Ferns, Equisetum hiemale, most Selaginellas, Casuarina, leaf of many Cycads, Conifers, some Orchids, etc.) ; or it may form numerons isolated strands (e.g. stems of Cyperaceæ, species of Juncus [Fig. 124 C], some Umbelliferæ and Papilionaceæ, many Equisetums; 
leaf-blade of terrestrial forms of Isoetes, and of Cyperaceæ, Typha', Sparganium, Dasylirion, Phormium, many Palms, Welwitschia). The spines of leaves (e.g. Holly), also entire spiny leaves or stipules, various emergences, such as the warts of Aloe verrucosa and the prickles of the Rose, and the thorny branches of many plants (e.g. Hawthorn, etc.) owe their hardness mainly to the development of sclerenchymatous hypoderma, the cells of which are generally elongated and fibrous, though they may be short as in Aloe verrucosa and the Rose.

A peculiar form of hypoderma, termed aqueous tissue, is present in the leaves of certain plants (॰.g. some Ferns, Polypodium Lingua, Aspidium coriaceum; species of Tradescantia ; also in the Soitamineæ, various Palms, Orchids, Bromeliaceæ, etc.) ; it consists of one or more layers of thinwalled parenchymatous cells, destitute of chloroplastids, containing much watery sap, and arranged closely together without interspaces; the tissue serves as a reservoir for water.

The hypoderma of the root, the exodermis, commonly consists of
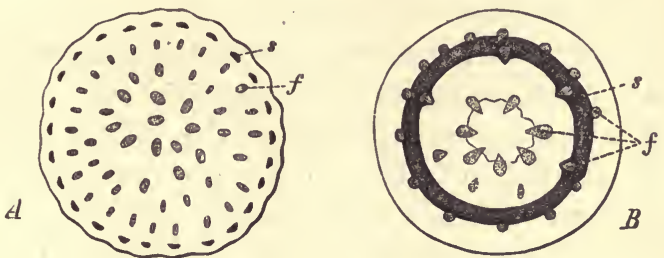

c

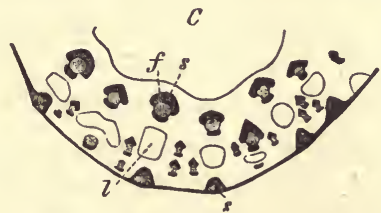

Fig. 121.-Diagram (after Schwendener) illustrating the distribution of the supporting-tissue or stereom, as seen in transverse section of stems: A of Arum maculatum having isolated cortical stereom-strands; $B$ of Allium vineale, with continuous pericyclic stereom-ring; $C$ of Juncus glaucus (hollow), with bypodermal stereom-strands and conjunctive stereom-strands : $f$ vascular bundles; s stereom-strands ; $l$ air-cavities.

a single layer of cells, but in some plants the primitive layer undergoes periclinal divisions, so that the exodermis comes to consist of several layers (e.g. the Date, Pandanus, Asparagus, etc.).

The walls of the exodermal cells generally undergo cuticularisation and frequently become very much thickened, especially on the lateral and external walls, in view of the position which it eventually occupies as the external layer of the root (see p. 158). In some cases it presents a peculiar localised thickening in the form of a band extending round the upper, lower, and lateral walls of the cells, a thickening which is therefore confined just to the surfaces which are in contact with other cells belonging to

v. S. B. 
the same layer, and which appears in a transverse section as a dark dot on the radial walls of the cells.

In some cases the cells of the exodermis are prosenchymatous and sclerenchymatous (e.g. species of Carex, aerial roots of a species of Philodendron).

When the exodermis is invested by tegumentary tissue (as in aerial roots of Orchids, for instance) some of its cells retain their thin unaltered walls, and are the passage-cells, by means of which water can penetrate into the interior of the root.

3. The general ground-tissue of stems, leaves, and roots, lying within the hypoderma, consists mainly of parenchymatous tissue, with, frequently, a considerable differentiation of masses of fibrous sclerenchymatous stereom.

In the root, where the extra-stelar ground-tissue is entirely cortex, it can generally be distinguished into two regions, an external, in which the arrangement of the cells is somewhat irregular, and an internal, in which the cells are arranged in radiating rows.

In aerial stems and foliage-leaves, the more external, at least, of these cells frequently take part in the assimilatory processes of the plant; the cells contain chloroplastids and constitute assimilatory tissue. Towards the most highly illuminated surface of the member, the cells are frequently so arranged that their longer axes are perpendicular to the surface, that is, are perpendicular to the incident rays of light; assimilatory tissue of this structure is termed palisade-tissue; the whole of the internal ground-tissue of a leaf-blade is termed generally mesophyll.

In view of its great physiological importance a somewhat detailed account of the structure of the mesophyll of the leaf-blade seems necessary.

The mesophyll consists of parenchymatous thin-walled cells of various form. When the blade is thin, the whole mesophyll consists of assimilatory tissue; but when it is more or less fleshy and succulent, the more central part consists of cells without chloroplastids, the assimilatory tissue being confined to the surface.

When the mesophyll is altogether assimilatory, the arrangement of the cells is correlated with the symmetry of the leaf-blade. In a dorsiventral lamina (Fig. 125) the structure of the mesophyll is different in relation with the upper (ventral) and the lower (dorsal) surfaces. Towards the upper surface, which is more directly exposed to light, the somewhat elongated cylindrical cells form a compact palisade-tissue one or more rows in thickness; whereas, towards the lower shaded surface, the cells are less regular, frequently somewhat stellate in form, leaving large intercellular spaces between them, constituting what is known as the spongy parenchyma. The loose structure of the mesophyll towards the lower surface of the blade is correlated with the presence of numerous stomata in the epidermis of that surface (see p. 156). 


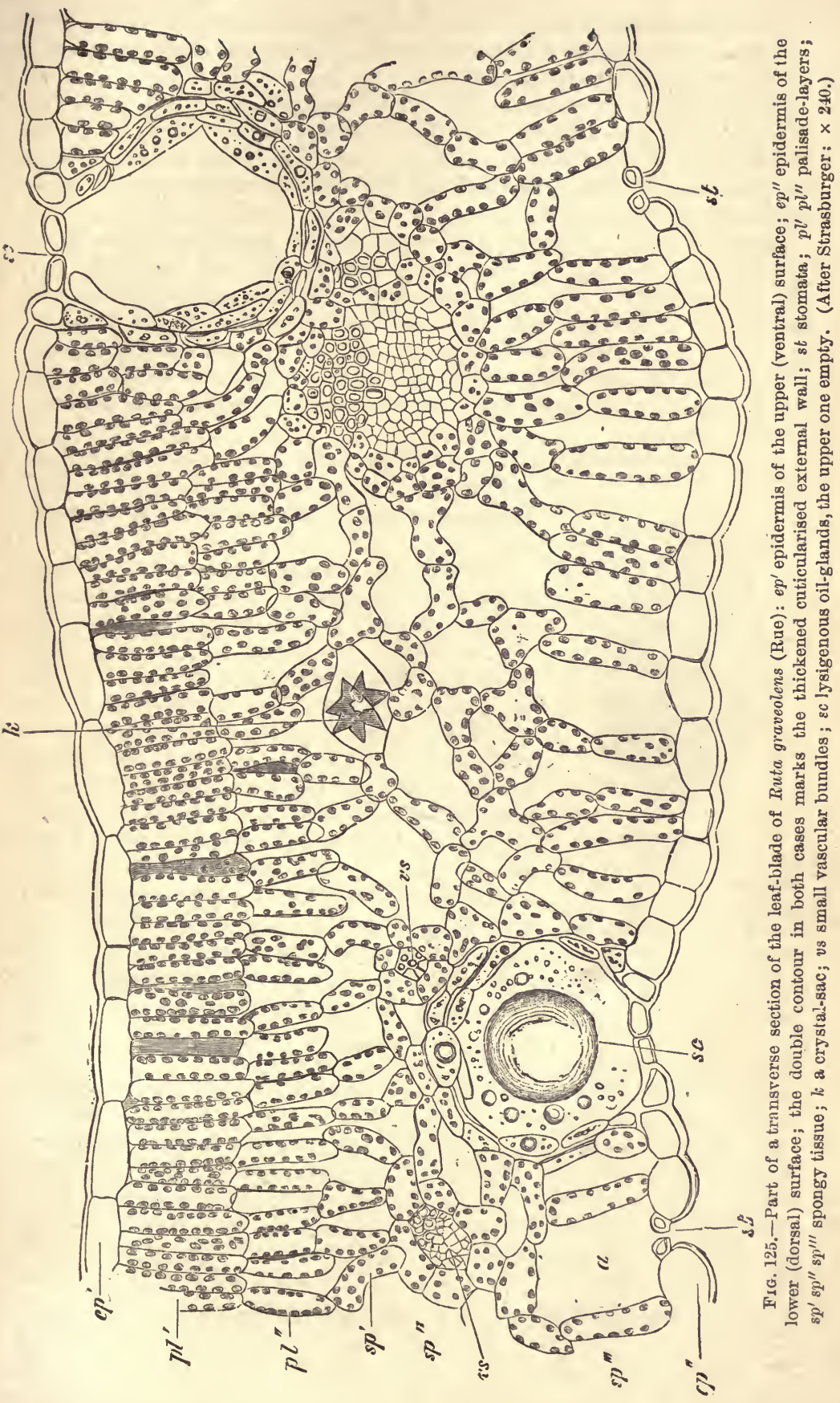


When the palisade-parenchyma consists of several layers, the transition from the one form of tissue to the other is gradual. The vascular bundles run along the junction of the two forms of tissue.

In a few cases (e.g. Allium ursinum, Alstrœmeria, etc.) the leaf is twisted, so that it is the morphologically lower (dorsal) surface which is directly exposed to the light; in these cases the palisade-tissue is developed in relation with that surface, the spongy tissue in relation with the morphologically upper (ventral), but shaded, surface.

When it so happens that all sides of the leaf are equally exposed to light, the palisade-parenchyma is developed in relation with both the dorsal and the ventral surfaces; this is true, not only of isobilateral and of radial leaves, but also of dorsiventral leaves (e.g. leaf-blade of Anchusa italica, Linosyris vulgaris, Silene inflata, Dianthus Caryophyllus, etc.); in which case the spongy parenchyma is either absent, or consists of a few layers in the middle of the blade, but the intercellular spaces between the palisade-cells are, however, relatively large.

In some cases, the mesophyll is not differentiated into palisade and spongy

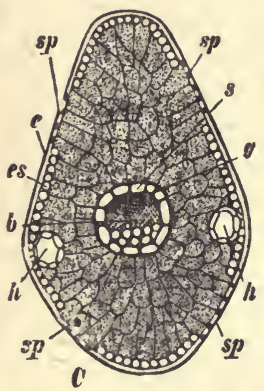

Frg. 126. - Diagrammatic transverse section of the acicular leaf of a Fir: e epidermis; es sclerenchymatous hypoderma; $s p$ stomata; $h$ resin-ducts; $s \in n$. dodermis enclosing the single meristele; $g$ rood; $b$ bast.

Erythronium Dens-Canis, species of Gladiolus and Tritonia).

The colourless mesophyll of succulent and coriaceous leaves consists of large cells, containing much watery sap, con-tituting in fact (see p. 161) un aqueous ti×sue (e.g. leaves of Aloë, Mesembryanthemum, some Myrtaceæ and Proteaceæ, Welwitschia, etc.). In some Orchids (e.g. Oncidium maximum), the cells of the aqueous tissue are scattered among the assimilatory cells; in many Orchids the cells of the aqueous tissue are tracheidal, having spirally-thickened walls, as they are also in the stem and leaf of Nepentues.

In many cases, especially in aquatic plants, the ground-tissue has 
large air-cavities, either lysigenous or schizogenous (see p. 130); generally speaking, they are of schizogenous origin in aquatic plants, of lysigenous origin in land-plants (see Fig. $116 \mathrm{~b}$ ). These cavities frequently extend throughout the whole length of the root or the leaf, and through an entire internode of the stem; but they may be interrupted at intervals by diaphragms (e.g. leaf of some Monocotyledons; root of Hydrocharis; stem of Alisma, Pontederia, Marsilia). When these cavities are lárgely developed the member becomes a float (e.g. root of Jussiæa, see p. 64).

Assimilatory tissue is present in some aerial and some aquatic roots (e.f. some Orchids, Podostemaceae, etc.).

4. The Endodermis is, in the great majority of cases, a single layer of cells; it is but rarely altogether wanting (e.g. roots of Podostemaceæ); it sometimes consists of two layers, formed by the tangential division of the cells of the primitively single layer (e.g. root of Equisetum; stem of some Pterido-

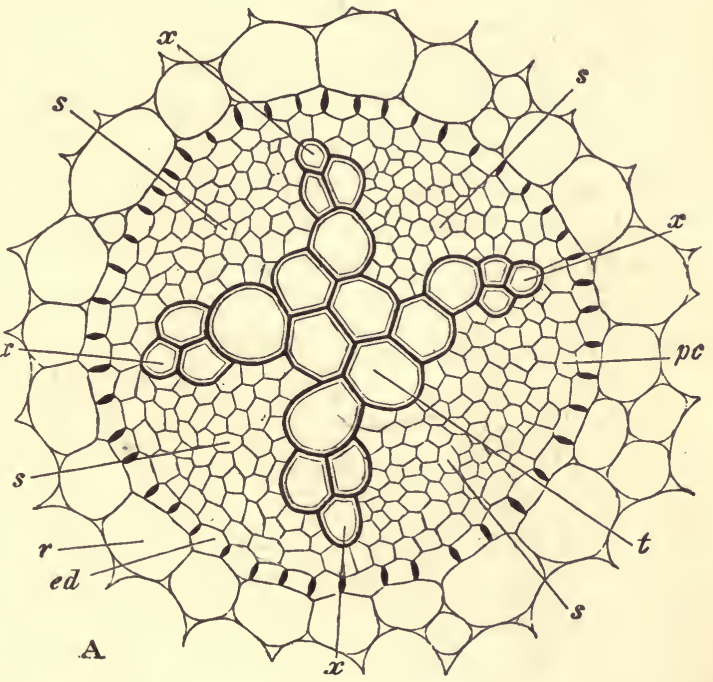

Fig. 127.-Transverse section of central portion of the root of Ranunculus vepens ( $\times 300)$ : ed the endodermis, enclosing the single central stele; its radial walls show the sections of the cuticularised thickening-bands; $x$ the four protoxslem-bundles; $t$ the solid xylem; $s$ the four phloem-bundles; $p c$ the pericycle; $r$ the cortical ground-tissue.

phyta, such as the rhizome of Nephrolepis, and the stem of Salvinia and Azolla).

Most cornmonly the cells of the endodermis are thin-walled, with a suberised thickening-zone extending round the lateral and upper and lower surfaces of the wall (see exodermis, p. 161), and showing in transverse section (Fig. 127) as a black dot on the radial wall. This peculiar marking is by no means always present: it is frequently wanting in the endodermis of the stem in 
which case the endodermis can, in many cases, be distinguished by the presence of starch-grains in its cells. When the endodermis is double, this marking is confined to the outer of the two layers.

This marking is not confined to the endodermis; it sometimes occurs also in the exodermis of roots (see p. 161), and in one or more layers of the internal cortex in some roots (one layer, next the endodermis, in Cupressus, Taxus, Prunus, Rosa, Lonicera, etc.; several layers, Juniperus, Sequoia, many Cruciferæ such as Mustard and Wallflower).

The walls of the endodermal cells frequently become sclerotic either over their whole surface, or more frequently on the internal and lateral surfaces (Fig. 129). When this is the case, some of the cells remain thin-walled, as passage-cells, opposite to the wood-bundles within.

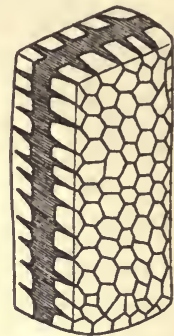

Frg. 128.-A cell from the sub-endo. dermal layer of the root of the Mustard, seen obliqueiy from the internal surface, showing the suberised thickening zone. (After van Tieghem: $\times 350$ ).

The Intra-stelar Fundamental Tissue, or Conjunctive Tissue of the Stele.-Morploology. The morphology of the conjunctive tissue,

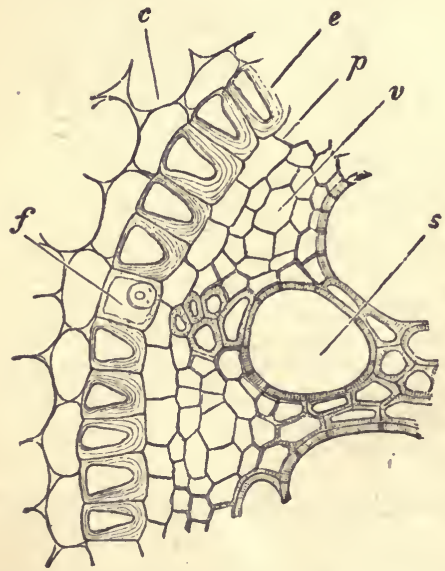

Frg. 129.-Part of a transverse section of a root of Iris florentına; e sclerotic endolermis, with $f$ a thin-walled passage-cell; $v$ bast; 8 wood-vessel; $c$ cortical groundtissue; $p$ pericycle. (After Strasburger: $\times 210$. of the stele varies somewhat in accordance with the development of the vascular tissue. When a solid vascular cylinder is produced, there may be no conjunctive tissue at all, the whole of the plerome having developed into vascular tissue; or the conjunctive tissue may be limited to one or more peripheral layers, the pericycle, investing the vascular cylinder; or, again, in addition to the pericycle, the conjunctire tissue may extend inwards to some extent between the bundles (interfascicular) of the stele; on the other hand, when the rascular cylinder is hollow (see Fig. 130), the central space is occupied by medullary conjunctive tissue, constituting the pith, and 
connected with the pericycle by interfascicular conjunctive tissue constituting the medullary rays. Pith and medullary rays are generally absent from the steles of a polystelic member.

Structure. The Pericycle (at one time generally termed the pericambium) is altogether wanting in a few cases only; it is absent when the endodermis consists of two layers (see p. 165); it is also absent in the roots of Podostemaceæ, rootlets of Pontederia crassipes, in the stem of Ceratophyllum and probably of other water-plants.

It is usually a continuous membrane; but in some cases it is interrupted by projections of the vascular tissue (e.g. by the xylem-bundles in the root of some Gramineæ and $\mathrm{Cy}$ peraceæ; by the phloembundles in the roots of Potamogeton, Naias, Zostera). "It may consist throughout of a single layer of cells (e.g. roots of most Angiosperms and of some Vascular Cryptogams; stems of Dipsacaceæ, Valerianaceæ, Rubiaceæ, Lobeliaceæ, Campanulaceæ, Plantagineæ, Polemoniaceæ, etc., and generally of aquatic Angiosperms); or of more than one layer throughout (roots of some Dicotyledons, e.g. Vine, Dipterocarpus, Ficus rubiginosa, etc., and of Gymnosperms generally; commonly in the stem and leaf-stalk); or in part of one layer and part of more than one (e.g.

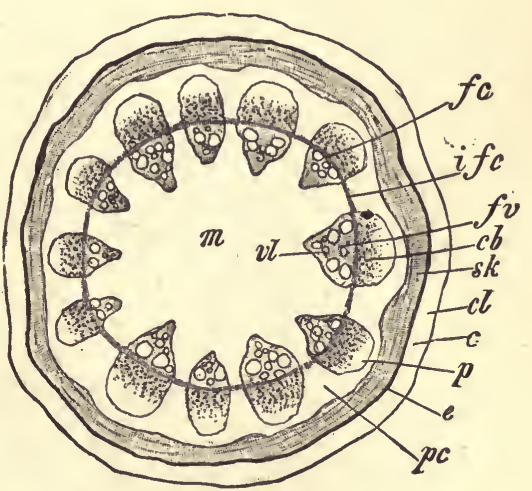

FIG. 130.-A transverse section of a young stem of Aristolochia Sipho, illustrating the arrangement of the primary tissues in a monostelic stem, in which the vascular cylinder is hollow, enclosing a pith. (After Strasburger: $\times 9$ ). $c$ Cortical groundtissue, with collenchyma $c l$; $e$ endodermis ; $p c$ pericycle, continuous by means of interfascicular conjunctive tissue (medullary rays) with the medullary conjunctive tissue $m$ (pith); sk ring of sclerenchyma belonging to the pericycle; $f v$ vascular bundles in an interrupted circle; they are open and collateral; $c b$ bast; $p$ protophloem; $f c$ fascicular cambium; ifc interfascicular cambium; $v l$ wood; the central pointed end of each wood-bundle consists of protoxylem, and the central ends of the whole ring of wood-bundiles coustitute the medullary sheath. root of some Ferns and Leguminosæ).

The pericycle may be homogeneous or heterogeneous; that is, it may consist of the same kind of tissue throughout, or of several kinds of tissue. The typical homogeneous pericycle consists of 
thin-walled parenchymatous cells, with protoplasmic contents, which are capable of becoming merismatic. In some cases the primarily thin-walled cells eventually become sclerotic, either throughout the whole pericycle, or in certain parts only; this commonly occurs in the roots of Monocotyledons.

Generally speaking, the pericycle of the root is homogeneous; when it is heterogeneous, it is so in consequence of the presence of glandular tissue (secretory ducts) (e.g. Umbelliferæ, Araliaceæ, Pittosporeæ, Hypericaceæ) ; it never contains fibres.

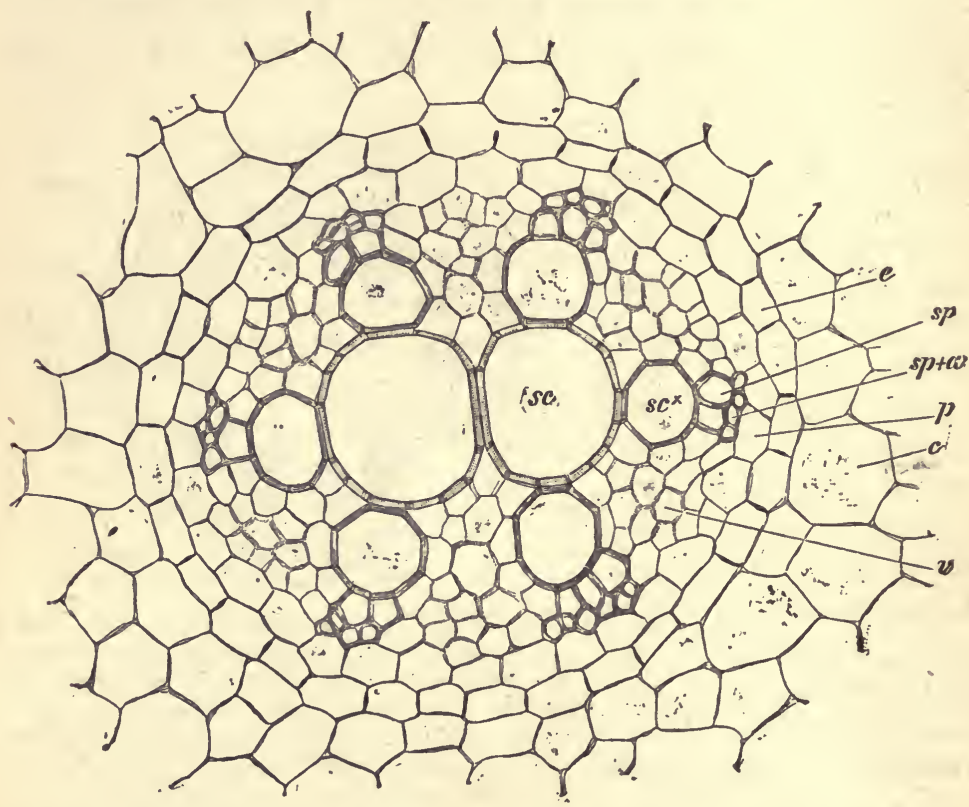

Fig. 131.-Tranverse section of a root of Allium Cepa, showing the central stele without pith : $c$ cortex; $\theta$ endodermis; $p$ pericycle; $s p$ and $a$, spiral and annular vessels (protoxylem); sc pitted wood-vessels of the primary wood; $v$ bast-bundle; the six wood. bundles alternate with the six bast-bundles; the wood-bundles develope centripetally and meet, so that no pith is formed. (After Strashurger : $\times 210$.)

The pericycle of the stem and of the leaf-stalk, on the contrary, is generally heterogeneous, owing principally to the differentiation of a portion of it into collenchyma (e.g. some Compositæ, Barkhausia foetida, Sonchus oleraceus), or into fibres which are generally sclerotic, but not in all cases (e.g. Apocynaceæ, Asclepiadaceæ, Convolvulaceæ, Flax); or it may be heterogeneous in consequence of the presence of secretory ducts (e.g. Hypericum, Pittosporum, 
Hydrocotyle vulgaris, Bupleurum fruticosum and other Umbelliferæ) ; or, in consequence of the presence of both secretory ducts and of fibres (e.g. Ligulifloral and Tubulifloral Composites.)

A remarkable form of conjunctive tissue is that which invests the two vascular bundles in the acicular leaves of Pinus, and, to a less degree, of other Conifers. The tissue consists of parenchyma with some fibrous sclerenchyma; in the parenchyma two special kinds of cells can be distinguished, which constitute what is sometimes termed the transfusim-tissue; namely, cells with unlignified and unpitted walls, distinguished by their abundant protoplasmic and proteid contents ; tracheidal cells with slightly lignified walls and bordered pits, without protoplasmic contents; the former may be regarded as an extension of the siere-tissue of the bundle, the latter as an extension of the tracheal tissue.

The fibres (stereom) of the pericycle are distributed in various ways. They may either form a continuous ring, separated from the phloem of the vascular bundles by several layers of parenchymatous pericycle-cells (e.g. Berberis, Cucurbitaceæ, Caryophyllaceæ, Lonicereæ, Aristolochiaceæ (Fig. 130), and many Monocotyledons, especially in Gramineæ, Cyperaceæ, and Juncaceæ; or the ring may be in direct contact with the vascular bundles (many Dicotyledons, e.g. Hypocharis radicata, Podophyllum, Plantago, etc. ; many Monocotyledons, e.g. Restiaceæ, Liliaceæ, Smilaceæ, Iridaceæ, Orchidaceæ, Typhaceæ, Tamus, etc. [see Fig. 124B]); or the fibres may form strands opposite to the phloem of each bundle, either abutting directly on the phloern, or separated from it by one or more layers of parenchymatous pericycle-cells (e.g. among Dicotyledons, various Compositæ, Labiatæ, Leguminosæ, Ranunculaceæ, etc.; exactly this arrangement does not occur in Monocotyledons); or the fibres may be scattered either singly or in groups, without any relation to the vascular bundles (e.g. many Solanaceæ, Iberis sempervirens, species of Viburnum, Fraxinus dimorpha, Ligustrum vulgare, Apocynaceæ, Asclepiadaceæ, Malvaceæ, etc).

The Pith (or medulla) consists, typically, of parenchymatous cells with thin walls and protoplasmic contents; but in many cases sclerenchyma is differentiated in it.

The most important fact with regard to the parenchyma of the pith is that, in many cases, the cells forming the central portion of the pith soon die, or even the whole of them (e.g. Elder). When this is the case, the dead cell-walls frequently undergo disorganisation, so that the stem becomes hollow.

The sclerenchyma of the pith may consist of scattered strands (e.g. stems of some Palms, such as Cocos, Astrocaryum, Leopoldinia); or it may form a ring connecting the inner ends of the bundles of the hollow vascular cylinder (e.g. Bougainvillea spectabilis, woody Piperaceæ such as Artanthe and Chavica).

The bulk of the pith varies very much. It is relatively very large in tuberous shoots, such as the Potato, Apios, etc. 
The Interfascicular Conjunctive Tissue consists typically of parenchymatous cells with thin walls and protoplasmic contents; but it is frequently sclerenchymatous where it abuts on the vascular bundles, thus contributing to the formation of a more or less complete sheath of sclerenchyma round them (e.y. many Monocotyledons).

The various systems of sclerenchymatous supporting-tissue (stereom) described above, the hypodermal, the cortical, the pericyclic, the interfascicular, and the medullary, may be connected with each other in various combinations. Thus, the hspodermal and the cortical systems may be continuous; or the hypodermal, cortical, and pericyclic; the pericyclic and the interfascicular, etc.; as the mechanical couditious of the member may render necessary (see Fig. 124).

§ 33. The Vascular Tissue-System. The primary vascular tissue is differentiated from the procambium or primary desmogen (see p. 151) of the stele in the form of strands or bundles, vascular bundles. The vascular tissues of the bundles are either tracheal tissue (p. 133), which is always lignified, and is termed uood or xylem; or sieve-tissue (p. 135), which is termed bast or phliem. A vascular bundle may consist, either exclusively of wood or of bast; or of both wood and bast, when it is said to be a conjoint bundle. It is generally the case that a varying proportion of sclerenchyma (stereom) is associated with the vascular tissue; hence the bundles are frequently spoken of as fibro-vasuular bundles.

As a rule, an equal number of wood-bundles and of bast-bundles are differentiated in a stele, whether they be isolated or conjoined; there may be only one of each (e.g. finer branches of the dichotomous roots of most Lycopodiums) or there may be a very considerable number (e.g. stems of Monocotyledons). There are, however, some exceptions to this rule: thus, the stele of the root of some Lycopodiums (L. inundatum and Selago) and Ophioglossums (O.vulgatum and lusitanicum) contains one bast-bundle and two wood-bundles; again, in the roots of Selaginella and Isoetes, the stele encloses one wood-bundle and two bast-bundles.

The primary vascular bundles differentiated in a stele (whether a monostele or a polystele) are frequently distinct from each other for a considerable distance, for instance, throughout an internode of a stem; but very commonly they are found to fuse at shorter intervals (e.g. stem of Lycopodium), or they may be altogether fused into one or more vascular masses; a stele presenting this intimate connexion of the bundles is said to be gamodesmic. An 
analogous condition is sometimes presented by schizostelic members, where the schizosteles are developed in partial continuity (e.g. stem of Equisetum, see Fig. 116). The resulting vascular mass is generally a solid cylinder, but it is occasionally a hollow cylinder.

With regard to the occurrence of vascular tissue in the gametophyte generation, and in the sporophyte of the lower plants, it may be stated that liguified vascular tissue (i.e. wood) does not occur in any gametophyte, nor in the sporophyte of any plant below the Pteridophyta. However, in the stem of the gametophytic shoots of some Mosses there is a solid central stele conristing of tissue which is functionally vascular tissue; the same is true of the stem (seta) of the Moss-sporophyte in certain cases. Sieve-tissue has been found in some of the larger Brown Seaweeds.

The primary vascular tissue-system extends continuously throughout the body of the sporophyte of the higher plants; the vascular bundles of root, stem, and leaf are all in direct communication.

The arrangement and course of the vascular bundles are intimately connected with the morphology of the plant and with the differentiation of its members. In elongated members (stems, petioles, roots) the bundles run longitudinally, so that a transverse section of such a member shows transverse sections of its vascular bundles.

In the primary root the longitudinal course of the bundles is simple; there is an axial vascular cylinder, either solid or hollow, consisting of straight more or less distinct bundles of wood and bast, and extending from the growing-point backwards to where the root merges into the stem; from this cylinder there arise lateral offsets, which constitute the steles of the lateral branches of the root.

In the stem the course of the bundles is more complicated, on account of the fact that the stem bears lateral members, leaves, which differ from itself or from its branches. In some cases, the bundles of the stem, when traced upward toward the growingpoint, are found to terminate in the young leaves; whilst in other cases the bundles end (like those of the root) in the plerome of the growing-point; bundles of the former kind are distinguished as common (i.e. common to stem and leaf), and, in their course in the stem, are termed leaf-traces; bundles of the latter kind are distinguished as cauline (i.e. confined to the stem).

Stems with common bundles are generally monostelic; the leaf 
traces do not, however, follow a uniform course in all cases. Thus, they may proceed to the centre of the stem and form a solid vascular cylinder (e.g. Isoetes among Pteridophyta; and certain aquatic Monocotyledons; species of Potamogeton, Zanichellia, Althenia, Ruppia). Or they may form a hollow cylinder.

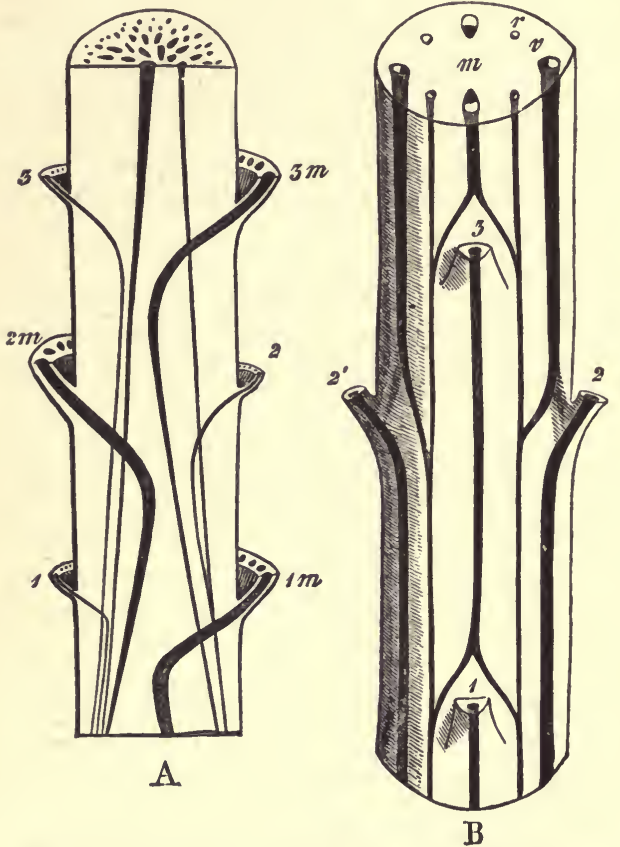

Fra. 132.-Diagram of the course of the vascular bundles in stems. A Longitudinal section through the axis of a Palm-stem, showing a transverse section of half of it. 'The leaves (cut off above theinsertion) are hypothe. tically conceived of as distichous and amplexicaul, and so are seen on both sides of the stem, $1 \mathrm{~m} 2 \mathrm{~m} 3 \mathrm{~m}$ being the median line of each. $B$ Ontside view and transverse section of Cerastium (hypothetically transparent, to show the internal bundles). The decussate leaves $(1,2,3)$ are cut off. 'The bundle proceeding from each leaf divides into two above the leaf immediately below it, and the branches of all the bundles unite to form the four thin bundles which alternate in the section with the thicker ones. In the section, $m$ is the pith, $v$ the cortex, $v$ the medullary ray. The xylem in the fibro-vascular bundles is indicated by shading.
In the simplest case of this (as in Osmundaceæ, most Gymnosperms and Dicotyledons) the bundles (leaf-traces) entering the stem from a leaf are few in number, or even only one; they penetrate to an equal depth in the stem (also in the schizostelic Equisetum, Fig. 116), and run vertically downwards through one or two internodes, joining at a node with the bundles entering the stem from a lower leaf; sometimes their lower ends are bifur: cate so that they join with the bundles of the lower leaves (Fig. $132 B)$. When the leaf-traces entering the stem from a leaf are more numerous, they penetrate to various depths in the stele, and their course is usually not vertical, but more or less curved: they may then form two circles (e.g. Cucurbitaceæ, Phytolacca, Piperaceæ) ; or many circles, more or less irregular, 
trenching on the pith (e.g. many Ranunculaceæ, such as Actæa, Cimicifuga, Thalictrum, Podophyllum, Diphylleia; Nymphæaceæ ; Monocotyledons generálly). A good example of this is afforded by a Palm stem (Fig. 132 A). The median leaf-traces first tend toward the centre of the stem; they then bend outward, thinning out gradually as they descend, and coalesce with the lateral bundles, which do not penetrate so deeply, in the pericycle at a point much lower down. Furthermore, each bundle is somewhat twisted in its course, so that the lower end lies toward a different side of the stem from that on which it entered it. In these cases, when there is a well-defined external ring, the more internal bundles are termed medullary bundles.

In some plants a number of independent phloem-bundles are developed in the other part of the pith of the stem, just within the ring of normal vascular bundles (e.g. Solanaceæ, Convolvulaceæ, Gentianaceæ, Apocynaceæ, Asclepiadaceæ, some Tubulifloral Compositæ, Campanulaceæ, etc.), which are termed medullary phloem-bundles.

Stems with cauline bundles may be monostelic or polystelic; monostelic stems with cauline bundles are generally gamodesmic having a solid vascular cylinder (e.g. Lycopodium among Pteridophyta; some aquatic Dicotyledons, Utricularia, Aldrovanda, Callitriche, Myriophyllum, Ceratophyllum; some aquatic Monocotyledons, Elodea canadensis, Hydrilla verticillata, Naias; and the saprophytic Orchidaceous plants Epipogon Gmelini and Corallorhiza innata); polystelic stems with cauline bundles (e.g. most Ferns, Hydropterideæ, Selaginella, among Pteridophyta) are generally gamostelic, the steles forming a network, which can be isolated as a skeleton of vascular tissue, each mesh of which corresponds to the insertion of a leaf.

The leaf-traces of stems with common bundles, as also the leafbundles in stems with a cauline vascular tissue-system, do not always at once join the stele, but may remain isolated for a longer or shorter distance, constituting in fact meristeles (see p. 15:3) in the cortical region of the stem, or, as they are more commonly called, cortical bundles (e.g. Casuarina; species of Begonia; some Ferns, such as Pteris, Aspidium, etc.)

The relative position of the phloem and of the xylem in a ronjoint bundle is subject to some variation; they may either be side by side, when the bundle is said to be collateral; or the one may more or less completely invest and surround the other, when the bundle is said to be concentric. 
In the collateral bundle, the wood and the bast are so situated that they both lie on a straight radial line drawn through the bundle from the centre of the member to the surface, the wood being nearer the centre, and the bast nearer the surface (see Fig. 130). This type of bundle is common in the monostelic or

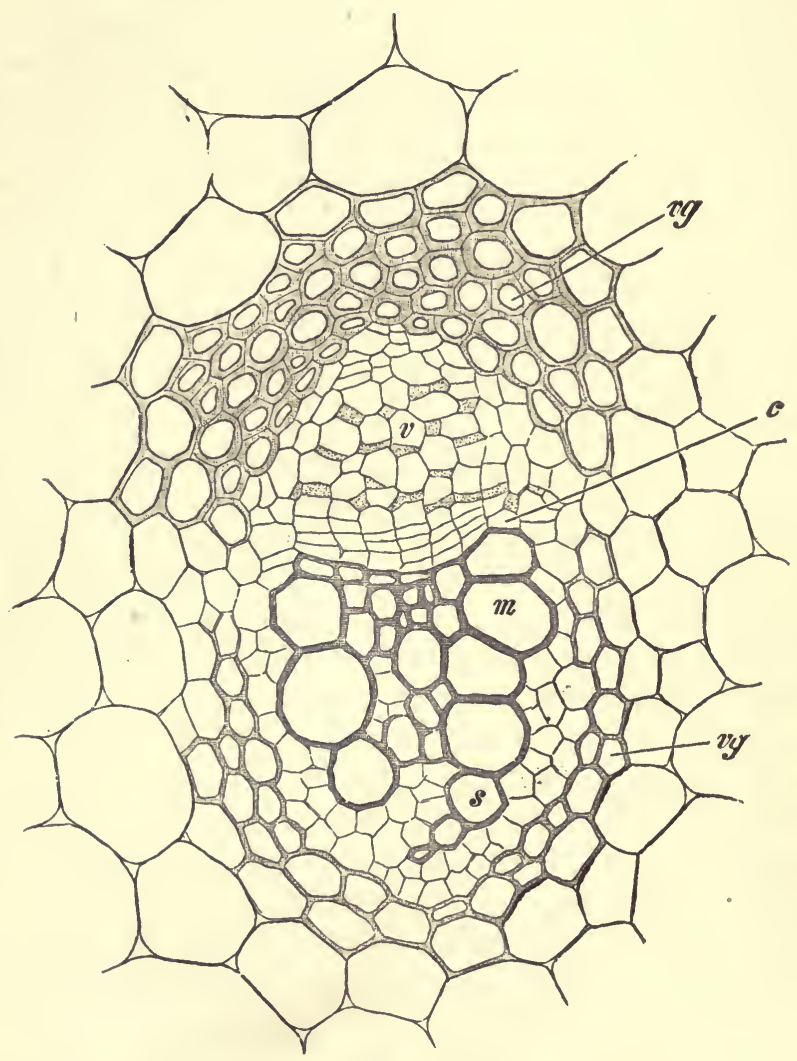

FIG. 133.-Transverse section of an open, collateral, conjoint, vascular bundle of the stem of Ranunculus repens: s spiral vessel of the protoxylem at the inner (central) end of the wood; $m$ pitted vessel of the wood; $c$ cambium; $v$ a sieve-tube of the bast with adjacent granular companion-cells; $v g$ sheath of sclerenchymatous conjunctive tissue. (After Strasburger : $\times$ 180.)

schizostelic stems and leaf-stalks of Phanerogams and of some Pteridophyta (Osmundaceæ, Ophioglosseæ, Equisetum).

In some stems (e.g. Myrtaceæ, Onagraceæ, Apocynaceæ, Solanaceæ, most Convolvulaceæ, Cucurbitaceæ, etc.) there' is a second 
bast-bundle on the inner (medullary) side of the wood of the conjoint bundle; such a bundle is distinguished as bicollateral.

In a concentric, bundle, either the bast is surrounded by the wood, or the wood by the bast, more or less completely: the bicollateral bundle is, in fact, a structure intermediate between the collateral and the concentric bundle. The former type of concentric bundle occurs in the rhizomes of various Monocotyledons (Acorus, Iris, Cyperus, Carex, etc.), and in the medullary bundles of the stem of some Dicotyledons (Rheum, Statice, Ricinus, Piper, etc.). The latter type is rare in Phanerogams (e.g. the cortical and medullary bundles of the Melastomaceæ) ; but it prevails in the Filicinæ and in Selaginella, when the gamodesmic bundles (two or more) of each stele of the polystelic stem, form a central mass of wood completely, or nearly completely, surrounded by a ring of bast.

The relative position of the phloembundles and xylembundles when they are distinct from each other is such that they alternate with each other so that a radius drawn

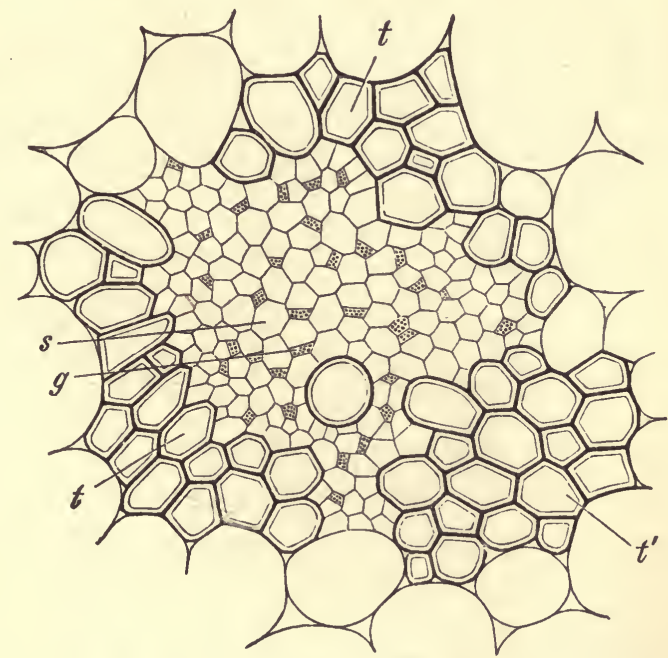

Fre. 131.-Transverse section of a concentric bundle, with external wood, from the rhizome of Iris $(x 350): t$ tracheæ; $t^{\prime}$ protoxylem; $s$ sieve-tubes; $g$ companion-cells, of the internal bast.

from the centre to the surface of the member cuts through either a phloem or a xylem-bundle, but not through both (Fig. 136). This arrangement occurs only in monostelic members; it is common to all roots, and occurs in the stem of Lycopodium and Psilotum though in a less regular manner than in roots. It is commonly termed the radial arrangement.

The Differentiation of the Primary Vascular Bundle. The first indication of the development of vascular tissue in the plerome is the differentiation of one or more strands of narrow elongated 
merismatic cells, the procambium or primary desmogen (see p. $151)$; each procambium-strand of the plerome becomes a vascular bundle of the stele.

The development of the vascular tissue does not take place simultaneously throughout the whole transverse section of the procambium-strand, but begins at one definite point, and extends in one or more directions from that point.

The development of the xylem-bundle (or part of a conjoint bundle) begins with the differentiation of one or a few tracheids or tracheæ, constituting the protoxylem; the walls of the corre-

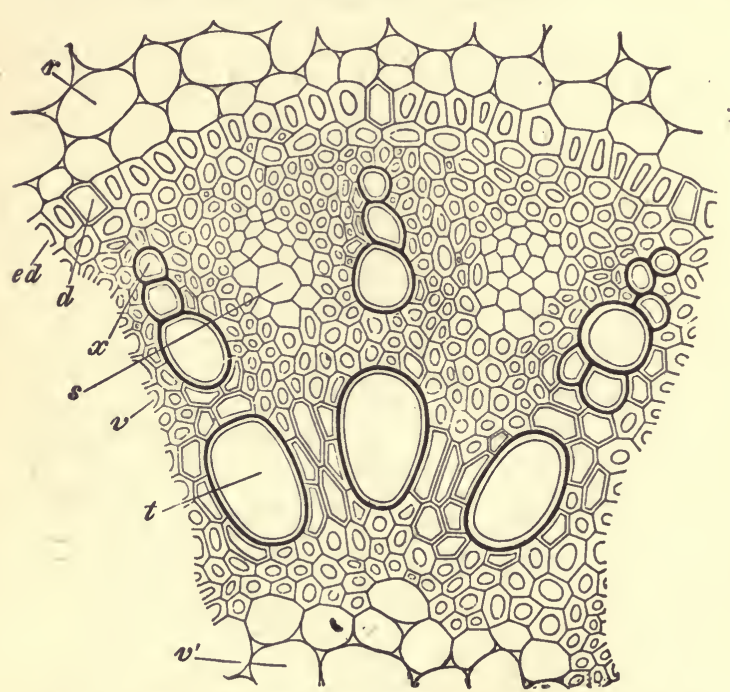

Fig. 135. - Part of a transverse section of the stele of the Sar. saparilla-root (Smilax): $r$ cortex; ed endodermis with passagecells $d$; the pericycle and the interfascicular conjunctive tissue $v$ are sclerenchymatous; $v^{\prime}$ the pith; $x$ the protoxylem, and $t$ a pitted vessel of a wood-bundle: 8 a bast-bundle. The alternation, or radiul arrangement, of the wood and bast-bundles is shown. ( $x$ 300.) sponding procambium cells become spirally thickened and lignified, and the protoplasmic contents of the cells disappear. It is an important generalisation that spiral or annular vessels (or tracheides) are characteristic of, and absolutely confined to, the protoxylem of the bundle. The remainder of

the primary wood (i.e. the wood which is developed from the procambium) is then gradually differentiated, the walls of the tracheides or tracheæ presenting one or other of the rarious kinds of pitted marking (p. 104).

Similarly, the development of the phloem-bundle (or part of a conjoint bundle) begins with the differentiation of a small group of sieve-tubes and companion-cells, constituting the protohploem, which do not, howerer, differ in any marked manner from the 
rest of the primary phloem, but their cavities soon become obliterated, so that they then look like strands of swollen cellwall (Fig. 137).

The details of the differentiation of the primary vascular tissue are essentially the same as in the case of the secondary vascular tissue described on p. 202.

The longitudinal differentiation of the primary vascular tissue does not take place in the same order in all cases. In roots, and in stems with cauline vascular tissue, the longitudinal differentiation proceeds acropetally. In stems with common bundles the differentiation usually begins in the procambium-strand at a node, proceeding both downwards in the internode of the stem, and outward into the young leaf.

In the majority of instances, the whole of the procambium - strand becomes differentiated into permanent tissue, either wood or bast; this is true for all roots, and for the stems of nearly all Pteridophyta and Monocotyledons (Fig. 137). Bundles of this kind are said to be closed. In the stems of most Gymnosperms and Dicotyledons, on the other hand, the whole of the procambium is not con-

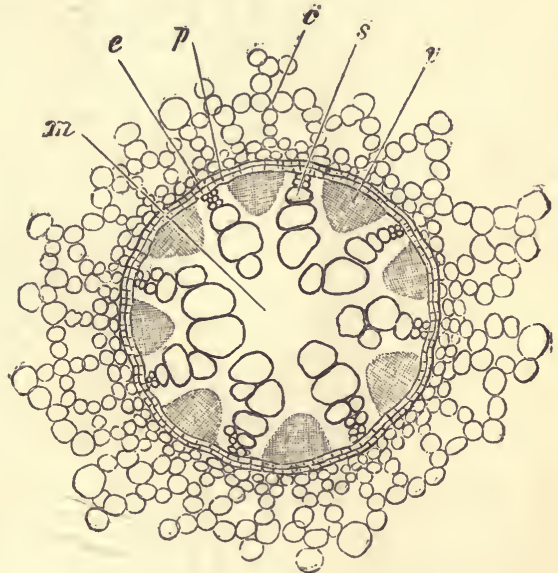

FIG. 136.-Transverse section of the central part of the root of Acorus Calamus (after Strasburger: $\times$ 90); c lacunar cortex; $e$ enclodermis ; $p$ pericycle; $s$ primary wood-bundles; with the small spiral vessels (protoxylem) externally; $v$ bast-bundles; $m$ pith; the arrangement of the bundles is radial.

verted into the primary wood and bast of the collateral conjoint bundle, but a portion of it persists as an embryonic merismatic tissue, the cambium, forming a transverse zone between the wood on the inner (central) side and the bast on the outer side (see Figs. 130, 139). Such a bundle is said to be open.

Some few Dicotyledons have closed bundles (i.e. no cambium) in the stem, e.g. Adoxa, Ranunculus Ficaria, Nymphæaceæ, Myriophyllum, Utricularia, etc.

The position of the protoxylem and of the protophloem in the transverse section of the bundle is not the same in the different members

V. S. B. 
The protophloem is in all cases external: and though the protoxylem is also generally external, it is sometimes internal (as in the bundles in the petiole of Cycads, in the stem of Isoetes, and in the concentric bundles of stems and petioles of many Ferns), being more or less surrounded by the rest of the primary xylem.

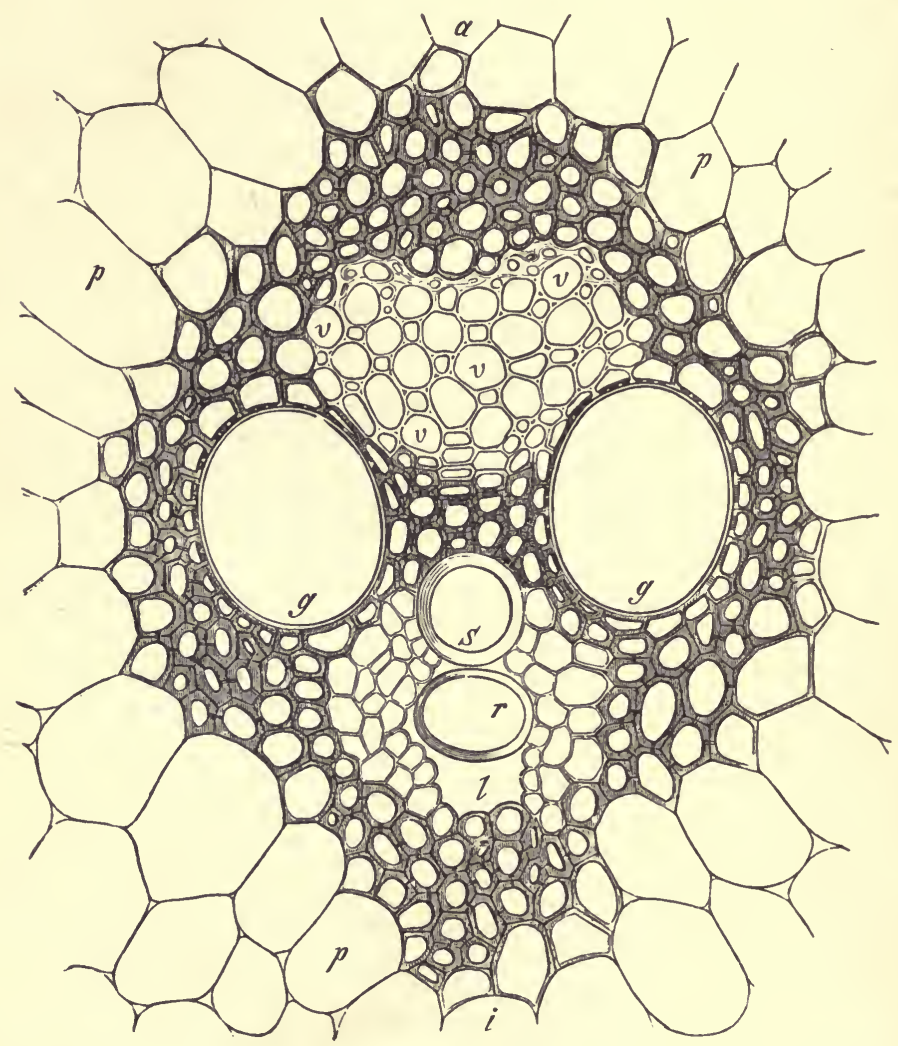

FIG. 137.-Transverse section of a conjoint, collateral, closed, vascular bundle of the stem of a Monocotyledon (Zea Mais): $a$ outer or peripheral end of the bundle; $i$ inner or centra l end; $p$ conjunctive tissue, the portion immediately investing the bundle being sclerenchymatous; $l$ lysigenous intercellular space; $s \tau$ spiral and annular vessels constituting the protoxylem; $g g$ large pitted vessels, between which lie the smaller pitted vessels of the wood; $v v v$ sieve-tubes of the bast with intervening companion-cells; just outside the bast, and within the sclerenchymatous sheath, the remains of the protophloem are visible. (After Sachs : $\times 553$. )

In members, whether monostelic or polystelic, in which the primary bundles or the steles are arranged in one or more circles (or, 
other figure corresponding to the sectional outline of the member), the orientation of the bundles in the stele, as indicated by the position of the protoxylem, bears a definite relation to the symmetry of the transverse section of the member. For instance, in medullate monostelic stems (Fig. 130) the protoxylem forms the innermost or central portion of the bundle; the broken circle of protoxylemgroups is sometimes specially designated the medullary sheath. This condition also obtains in schizostelic members, as in the rhizomes and aerial stems of Equisetum (see Fig. 116). In the root, whether the vascular cylinder be medullate or not, the protoxylem is always outermost or peripheral, abutting on the pericycle (Figs. 135-6). This is also the case in monostelic stems which are not medullate (e.g. stem of Lycopodium). The protophloem is always external, abutting on the pericycle.

The protoxylem is a structure of considerable morphological importance, serving as it does to mark the individuality of the xylem-bundle of which it forms part. This means of distinction is often of great use in determining the constitution of large masses of primary vascular tissue, indicating whether they consist of one bundle, or are gamodesmic, consisting of several fused bundles (e.g. solid vascular cylinders of roots, stem of Lycopodium, vascular strands of polystelic stems, etc.), and if the latter, of how many bundles they consist.

It has been customary to speak of such a gamodesmic vascular mass as a single bundle describing it as diarch, triarch, tetrarch, etc., according to the number of protoxylem-groups detected; but this use of the terms is inaccurate. Every xylem-bundle has but one protoxylem-group; that is, it is monarch; wherever two or more protoxylem-groups are to be found, they indicate the fusion of a corresponding number of bundles; in this sense the terms may be convenient to describe the composition of masses of vascular tissue.

The transition from the root to the stem. Inasmuch as, generally speaking, the type of primary structure of the root differs so considerably from that of the corresponding stem, the transition from the one to the other is a matter of some importance. Taking as an illustration the case of a plant with a monostelic stem, the passage from the radially arranged separate bundles of the primary root to the collateral conjoint bundles of the stem is effected on this wise: -generally speaking, on tracing the wood-and bast-bundles of the root upwards into the stem, the wood-bundles are found to twist on themselves so that the protoxylem of each bundle, from being peripheral in the root, comes to be central in the stem; at the same 
time they change their position somewhat, so that they come to lie on the same radii as the bast-bundles, or the bast-bundles may also deviate somewhat from their straight course, and thus the conjoint collateral bundles come to be constituted. As a rule, these changes of position are accompanied by an increase in number of the bundles, each of the bundles of the root bifurcating above, so that there are commonly twice as many bundles in the stem as in the corresponding root.

The structure of the primary bundle. The primary wood (whether
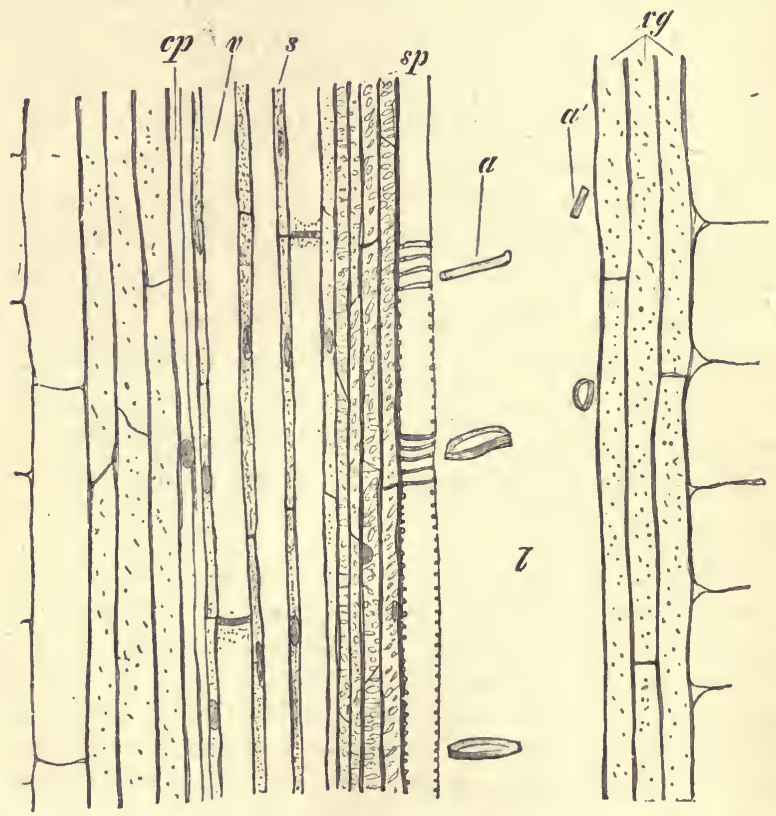

FrG. 138.-Radial longitudinal section of a conjoint, closed, collateral bundle from tho stem of a Monocotyledon (Zea Mais; after Strasburger, $\times 180$ ); to the right is the central (medullary) limit of the bundle; to the left the peripheral (cortical) limit; $c p$ protophloem; $v$ sieve-tubes of the bast, with companion-cells $s ; s p a a^{\prime}$, the protoxylem; $a a^{\prime}$ remains of ruptured annular vessel lying in the lysigenous lacuna $l$; $v g$ sheaths of sclerenchymatous conjunctive tissue. (Compare this with Fig. 137.)

in an isolated or a conjoint bundle) consists essentially of lignified tracheal tissue (tracheæ, or tracheids, p. 134), together with a varying proportion of wood-parenchyma, more or less lignified, the cells being occasionally somewhat fibrous. The protoxylem (see $\mathrm{p}$. 176 ) is usually a conspicuous feature; in transverse section, on account of the relative smallness of its tracheæ (or tracheids); in 
longitudinal section, on account of the loose spiral or annular thickenings of their walls. The looseness of the spiral or annular markings is due to the fact that these vascular cells are the first formed constituents of the bundles, and that consequently they are considerably stretched by the continuance, for a time, of the growth in length of the adjacent undifferentiated tissues; hence the successive thickenings become more or less widely separated, and the wall of the vessels may be torn and destroyed (Fig. 138).

The primary bast or phloem consists essentially of sieve-tissue (p. 135) and of parenchyma. The sieve-tissue consists in all cases mainly of sieve-tubes of simple structure (Fig. 97, p. 136), constituting the vascular tissue of the bast, with which companioncells are associated in Angiosperms but not in Gymnosperms and Pteridophyta. In some Angiosperms, particularly in the closed bundles of Monocotyledons (Fig. 137), there is no bastparenchyma, the whole bast consisting of sieve-tubes and companion-cells : but this tissue is generally present, and is readily distinguishable from the companion-cells by the larger size of its cells. In some cases (e.g. some Palms) the bast-parenchyma is to some extent replaced by sclerenchymatous fibres; otherwise the occurrence of fibres in the primary bast is rare.

The cambium is present in the collateral primary bundles of the stem of most Gymnosperms and Dicotyledons; it is never present in primary bundles of any other type of structure; nor, on the other hand, is it always present in a collateral bundle (absent in Equisetum, Monocotyledons, some herbaceous Dicotyledons, sec p. 177).

It lies between the bast externally and the wood internally, and consists essentially of a single layer of merismatic embryonic cells rich in protoplasmic contents, and with walls of cellulose. In transverse section (see Fig. 133) the cells are oblong, with their longer axes placed tangentially; in longitudinal section (Fig. 153) the cells are seen to be elongated and somewhat prosenchymatous, like the procambium-cells, where they abut on the wood or on the bast; but where they abut on primary medullary rays they are short and parenchymatous.

Variations in the structure of a bundle. It is mentioned on p. 173 that the leaf-trace bundles of Palms thin out as they curve outwards towards the pericycle in the lower part of their course; the bundle is, in fact, thickest where it is most deeply placed in the stem; the difference in size of the bundle, as seen in trans- 
verse section, is due a variation in the number, and to some extent also, in the size of its constituent elemeuts, more especially in the wood.

The variation in structure of a vascular bundle can be well observed in connexion with the foliage-leaf. The number of bundles entering the leaf (petiole, when present) from the stem
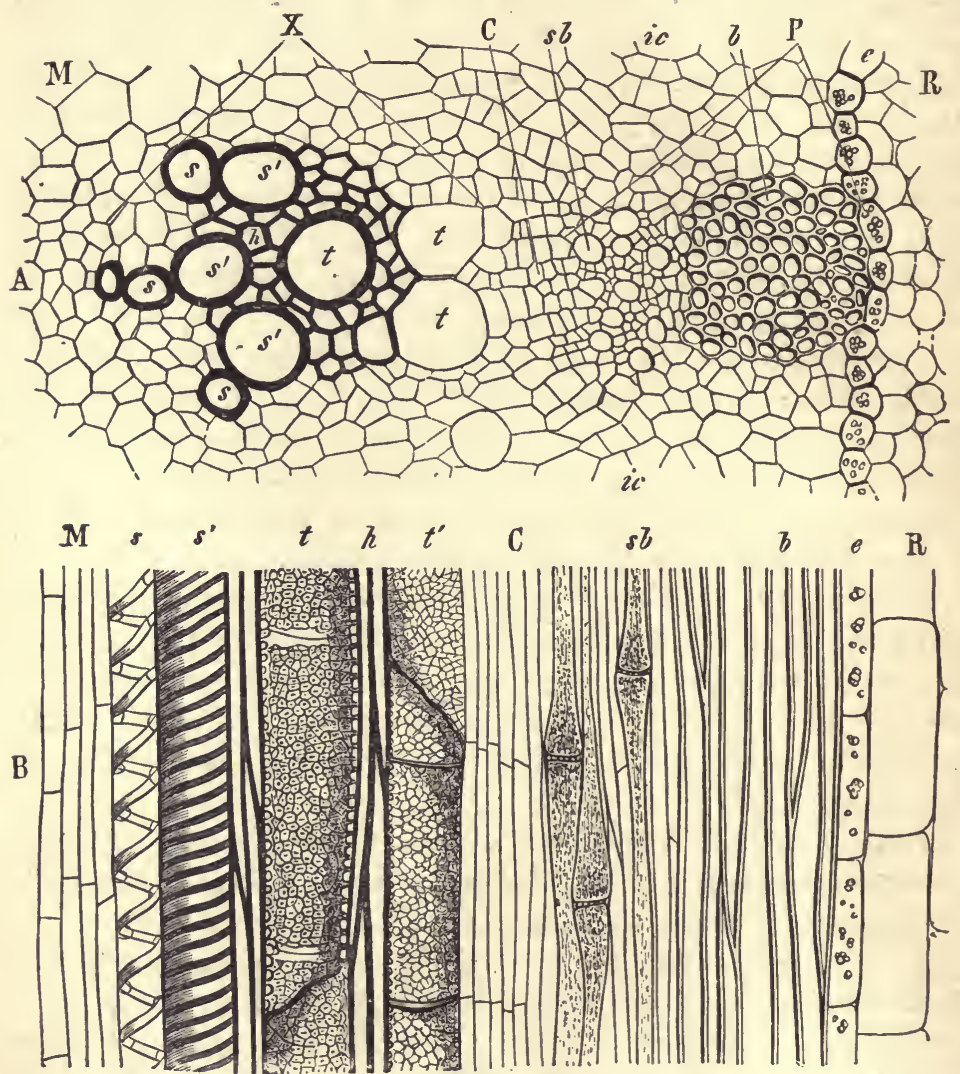

s?

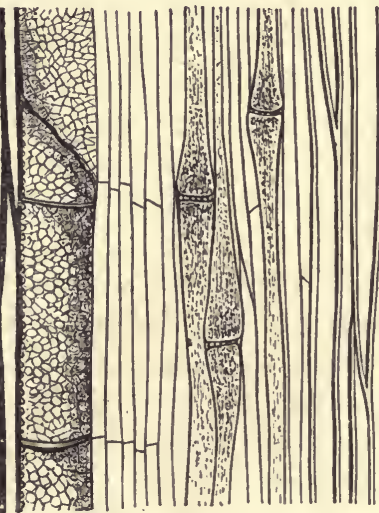

b e R

F'IG. 139. - A Transverse section of an open conjoint, collateral, vascular bundle in the stem of the Sunflower. $M$ Pith. $X$ Xylem. $C$ Cambium. $P$ Phloem. $R$ Kortex; $s$ Swall, and $s^{\prime}$ large spiral vessels (protoxylem); $t$ pitted vessels; $t$ ' pitted vessels in course of formation from the cambium; $h$ wood-fibres; $s b$ siere tubes; $b$ fibres of the heterogeneous pericycle; $e$ endodermis or bundle-sheath; $i c$ inter-fascicular conjunctive tissue. $B$ Radial vertical section through a similar bundle (somewhat simplified) lettered like the former. $(\times 150)$.

varies from one to many; these bundles, when derived from a monostelic stem, are segments or branches of the stele (meristeles), 
when derived from a polystelic stem, they are entire steles. The structure of the leaf-bundles corresponds essentially with that of the stem-bundles; if the latter are concentric or collateral, etc., so are the former, as a general rule; but in the Cycads the bundles in the petiole have the protoxylem central next to the bast (see p.178) instead of in the normal position which it occupies in the stembundles; and again, whilst the bundles in the petiole of most Ferns are, like those of the stem, concentric, in the ribs of the lamina they become collateral. At the same time it should be pointed out that whilst the general relations of the bundle are usually the same in both stem and leaf, the changed conditions usually involve a somewhat different description. For instance, the common conjoint bundles of the stem of a Dicotyledon are collateral, the protoxylem being the most internal or central part of the bundle, the protophloem the most external or periptrerat part; on tracing a bundle into a leaf which is dorsiventral, and lies in a nearly horizontal plane of expansion, the xylem of the conjoint bundle will be found to lie towards the upper (ventral) surface of the leaf, with the protoxylem uppermost, whilst the phloem is directed towards the lower (dorsal) surface, with the protophloem lowermost; the description of the position and relations of the bundle must be in accordance with the symmetry of the member of which it forms part.

The Termination of the Vascular Bundle. The gradual thinning out and termination of the vascular bundle can nowhere be more satisfactorily studied than in leaves. The bundles, when traced towards their ultimate ramifications, are seen to diminish in bulk in consequence, partly, of a reduction in number of the constituent elements, and partly also to the smaller size of the elements which still remain. The mode of termination of the vascular bundles in foliage-leaves is briefly as follows. In many cases the bundles have only free ends, as in most Pteridophyta (e.g. Adiantum, Selaginella), and generally in small reduced leaves. In others, there are no free ends, but the finer branches anastomose with each other to form a closed system; this is characteristically the case where the venation is parallel (e.g. Monocotyledons, see p. 55). In others, again, the finer branches anastomose, forming a network from the meshes of which the ultimate branches project among the mesophyll-cells as free ends : this obtains generally among Dicotyledons. The free ends of the bundles consist of one or two rows of short tracheids with close spiral markings; no sieve-tubes can 
be traced quite to the extremity; they disappear further back, and their place is taken by parenchymatous cells.

Bundles often terminate in connection with glandular tissue; for instance, in chalk-glands (see Fig. 100, p. 139), or nectaries.

$\$ 34$. Histology of the Development of Secondary Members. It has been already pointed out (p. 17) that the growing-point is the seat of development, not only of new tissue, but also of new members; and further (p. 19), that secondary members are developed either by dichotomy or by lateral outgrowth.

A. Development of normal branches of the shoot or of the thatlus. only takes place at the growing-point, whether apical or intercalary.

a. By dichotonzy. This only occurs in apical growing-points; two modes may be distinguished accordingly as the growing-point has or has not an apical cell:

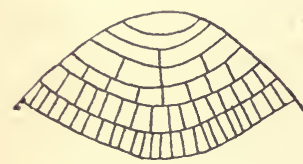

A

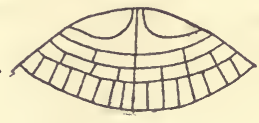

$B$

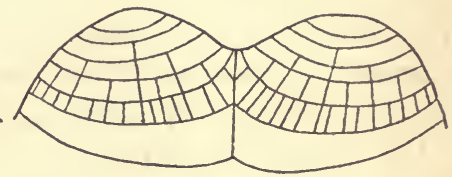

C

Frg, 140.- $A$ B C successive stages in true dichotomous branching by longitudinal division of an apical cell; from the shoot of Dictyota dichotoma (highly magnified; after Naegeli).

-when there is an apical cell, true dichotomous branching is effected by the longitudinal division of the apical cell into two, each of which becomes the apical cell of a branch:

A spurious form of dichotomy occurs in some plants (e.g. thalloid Jungermanniex); here, though the apical cell of the branch is developed from a segment of the apical cell of the main shoot, yet since the really lateral branch grows quite as vigorously as the main shoot, the result is an apparently dichotomous branching.

-when there is no apical cell, the growing-point becomes broadened, and the central portion of it passes over into condition of permanent tissue, leaving two distinct masses of embryonic tissue, which constitute the growing-points of the two branches (e.g. Marchantiacex).

b. By lateral outgrowth; this may occur in either an apical or intercalary growing-point : 
-when there is a single initial cell in the growing-point, the growing-point of the branch is developed either directly from the initial cell itself, as in some Algæ (Fig. $141 \mathrm{~A}$ ), or more commonly from a segment of the initial cell, as in many Algæ (Fig. 141 C), Mosses, Liverworts, etç. :

- when there is not a single initial cell (e.g. Phanerogams), the growing-point of the branch is formed by division of cells of the periblem, including several layers, which grow and divide, forming a lateral protuberance with the growth of which the dermatogen keeps pace; the primary meristem of the branch undergoes differentiation into tissue-systems corresponding to those of the parent members, and continuous with them.
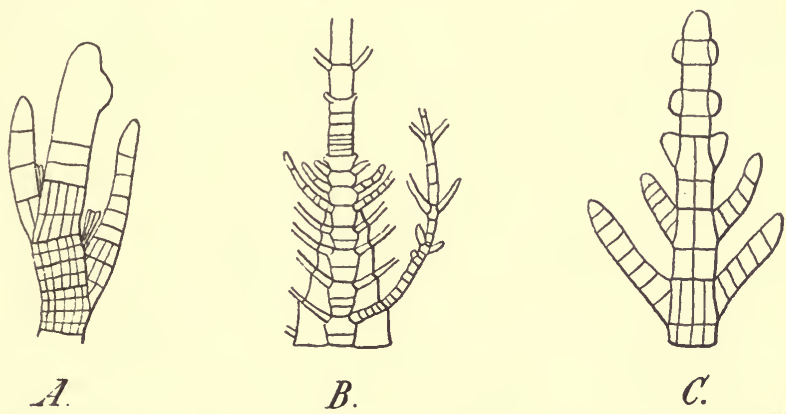

FIG. 141.-Illustrating development of lateral members; $A$ (Stypocaulon scoparium, $\times 30$ ): from the apical cell itself : $B$ (Desmarestia ligulata, $\times 60)$ from the segments of an inter. calary growing-point; $C$ (Chatopteris plumosu, $\times 40)$ from the segments of the apical cell. (After Falkenberg).

Normal branches, however the details of their development may vary, agree in this, that they are, with rare exceptions (see p. 20 ), of exogenous origin.

B. Development of Leaves only takes place at the growing-point of a stem, and always by lateral outgrowth (see p. 45).

When the growing-point of the stem has a single initial cell, the growing-point of the leaf is developed either from the apical cell itself, or, more commonly, from the whole or a part of a segment of the apical cell.

When the growing-point of the stem has not a single initial cell, as in Phanerogams, the growing-point of the leaf is formed by the division of cells belonging to one or more of the superficial layers of the periblem, accompanied by growth and division of the corresponding cells of the dermatogen. 
The primary meristem of the leaf becomes differentiated into tissue-systems corresponding to, and continuous with, those of the stem which bears it. In the developing leaves of those vascular plants which have common bundles (see p. 177), the differentiation of the protoxylem begins at the point of junction of leaf and stem, extending outwards in the procambium-strands of the leaf, and inwards in those of the stem.

The development of secondary branches of the leaf takes place in essentially the same manner as that of the leaf from the stem. Dichotomous branching of the leaf (see p. 51) takes place in the same way as dichotomous branching of the stem.

It will be seen that the derelopment of a leaf on any stem takes place in essentially the same way as the development of a lateral branch on that stem; it is only later that leaves and branches assume their distinctive characters.

C. Development of Branches of the Ront. It has been pointed out that the only normal secondary members produced by the root are root-branches, or secondary roots; these may be developed either by dichotomy or by lateral outgrowth.

a. By dichotomy. This has only been observed in certain sporphytes among the Pteridophyta (Lycopodium, Isoetes). Here the growing-point broadens, under the root-cap, the central portion passing over into permanent tissue, whilst the two sides remain merismatic and form the growing-points of the two secondary roots; the old root-cap is exfoliated, and each growing-point forms a new one for itself. The successive dichotomies take place in planes at right angles to each other.

b. By lateral outgrowth. It has been already stated (p. 62) that the lateral development of secondary members does not take place at the growing-point of the root, but at a considerable distance behind it, where the tissues have already assumed their permanent differentiation. The lateral roots are developed endogenously from a layer of this tissue which remains embryonic longer than the adjacent tissues. This layer may be either the pericycle, as in Phanerogams, or the endodermis, as in most Vascular Cryptogams.

In the Phanerogams (Fig. 142), the growing-point of a lateral root is formed by the growth and division of a group of pericyclecells, lying usually just externally to the outer end of a xylembundle; hence there are as many longitudinal rows of lateral roots produced as there are xylem-bundles in the parent root, and cor- 
responding with them in position. But to this rule there are some exceptions; for instance, when, as in the Grasses and Cyperaceæ, the pericycle is wanting opposite the xylem-bundles, the lateral roots are developed, not opposite to the xylem-bundles, but opposite to the phloem-bundles; again, when there are only two xylembundles in the parent root, four rows of lateral roots are produced each root being developed on one side of a xylem-bundle of the parent root. A similar displacement occurs in Umbelliferæ, Araliaceæ and Pittosporeæ, where the pericycle is interrupted opposite to each xylem-bundle by an oil-duct (see p. 168).
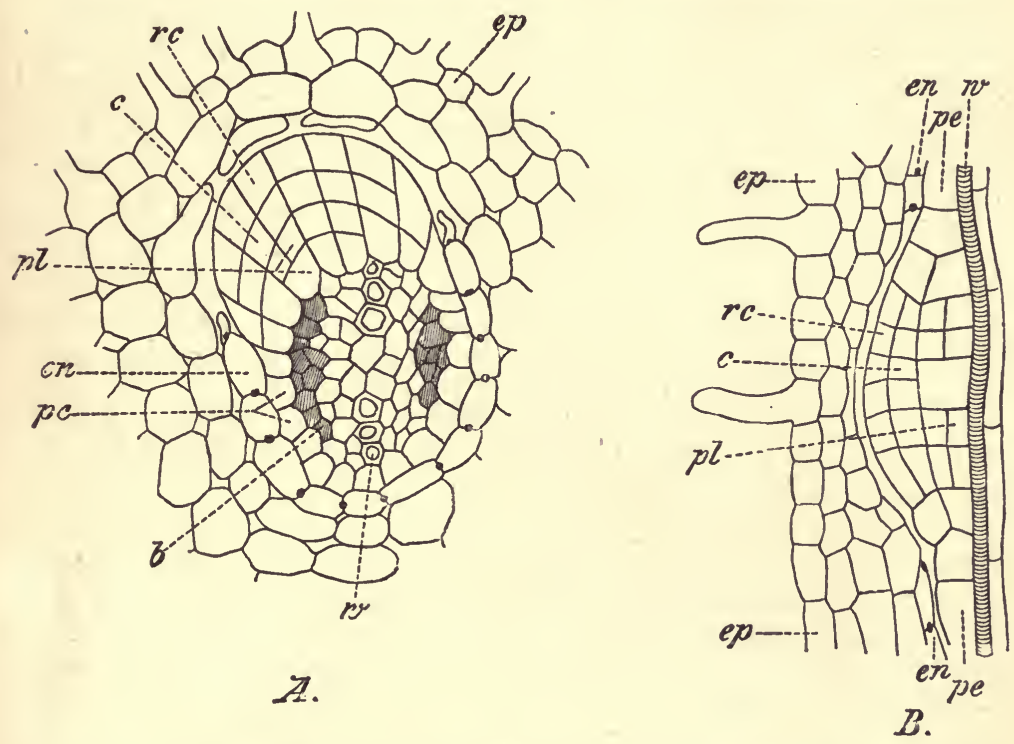

FIG. 142.-Illustrating the development of a secondary root in a Phanerogam. $A$ transverse, $B$ longitudinal, section; ep epiblema; en endodermis; pe pericycle; $w$ protoxylem and $b$ phloem of the parent-root; $r c$ root cap; $c$ periblem, and $p l$ plerome, of the developing lateral secondary root. (Teesdalia nudicaulis; $\times$ about 300 ; after van Tieghetn).

In most Vascular Cryptogams (except Lycopodium and Isoetes, where secondary roots are produced only by dichotomy), the apical cell of a secondary root is formed from one of a row of large endodermic cells, the rlizogenic cells, lying just externally to each xylem-bundle of the parent root. In Equisetum, where the endodermis consists of two layers (see p. 165), the secondary roots are developed from cells belonging exclusively to the inner laver, which are adjacent to the xylem-bundles. 
It will be understood that, in order to reach the surface, the lateral secondary roots must penetrate the external tissues of the parent root. This is not effected by purely mechanical means, but by chemical action, leading to solution and absorption, exerted on the tissues, either by the rootlet itself, or, more commonly, by a digestive sac which invests the rootlet, and is formed in Phanerogams by the growth and division of the cells of the endodermis (and sometimes one or two layers of cortical cells), in Vascular Cryptogams, by the growth and division of one or more of inner layers of cortical cells just external to the endodermis, of the parent root.

D. Development of Hairs. These structures are in all cases developed from the superficial cells of the parent member, that is, from dermatogen-cells in those parts in which this layer is differentiated; in the great majority of cases each hair arises from a single superficial cell. Hairs are generally developed in acropetal succession, but considerable irregularity is not uncommon, and they are frequently developed on members in which the tissues have already acquired their permanent characters (see p. 64).

E. Development of Emergences. When exogenous they are developed from the superficial and from one or more of the subjacent layers of tissue of the parent member, that is, from the dermatogen and periblem of those members in which this differentiation of the primary meristem obtains. When they are endogenous (e.g. haustoria of Cuscuta, see p. 67), they are developed exclusively from the periblem.

The haustoria of these parasitic plants are frequently regarded as roots, either normal or adventitious, especially in the exceptional case of endogenous origin; but this view is inadmissible, in the first place, because they are developed, not from the pericycle, but from the cortex of the parent-member; and in the second, because, with the mode of origin, they are developed relatively late, whereas, in accordance with the general rule (see p. 190), they ought, were they roots, to take origin from more deeply seated tissues of the parent member.

E. Develnpment of Reproductive Organs. The question as to the relation of these members to the primary meristem, only arises with reference to those plants, the bodies of which consist of many layers of tissue; their origin in plants, the bodies of which consist either of filaments, or of flattened expansions of a single layer of cells, need not be considered here.

In the cases under consideration, the reproductive organs may be developed either from the superficial layer alone, or from that and one or more of the subjacent layers. 
Organs developed from the superficial layer alone (dermatogen when differentiated): these may be developed each from a single cell; as all sexual organs; sporangia of all Ferns (except Ophioglosseæ and Marattiaceæ) i.e. all leptosporangiate Ferns and Rhizocarps (Hydropterideæ) ; or they may be developed from a group of superticial cells, as the sporangia of the Ophioglosser and Marattiaceæ (eusporangiate Ferns), of Equisetum, the Lycopodiaceæ, Selaginella.

The antheridia of Fucus are peculiar in that they are single terminal cells of branched hairs. It is a question whether or not the antheridia of Anthoceros (Liverworts) are of endogenous origin. Iu Mosses the apical cell of the adult shoot generally give rise to a sexual organ.

Organs developed from the superficial and deeper layers. In most cases the organ is developed from the superficial and the subjacent (hypodermal) layer, e.g. microsporangia (pollen-sacs) and macrosporangia (ovules) of most Phanerogams; in some cases cells of one or more decper layers take part in the formation of the organ (e.g. sporangia of Isoetes, ovules of Geum, Symphytum, Verbascum, etc.) ; rarely only. a single cell of the hypodermal layer is concerned (e.g. ovule of Orchids); in Balanophora the ovule appears to be developed from a single superficial cell.

The primitive sporogenous tissue (archesporium, see p. 73) is, in the sporangia of all Vascular Plants, derived from the hypodermal layer of the young sporangium; it may consist of a single cell, or of a row of cells, or of a layer of cells. In the Mosses the archesporium is more deeply seated, arising from the external layer of the endothecium (rudimentary plerome) as in most Mosses, or from the innermost layer of the amphithecium (rudimentary periblem) as in Sphagnum and in the Liverwort Anthoceros.

F. The Development of Adventitious Secondary Members (see p. 21).

1. On the stem. The most common case is that of the development of roots, but occasionally shoots (buds) are developed adventitiously.

The adventitious developinent of roots on the stem takes place most commonly by the formation of a growing-point, by the division of a group of pericycle-cells in the way described above (p. 186) with reference to the development of normal lateral roots on the parent root. In any one plant the two processes are similar in every detail. When they are developed on old stems, they arise from more deeply placed tissues, such as those of the primary 
or even the secondary bast. In both these cases the adventitious root is developed endogenously.

In other cases, adventitious roots are developed from more superficial layers of tissue (e.g. Equisetum, Selaginella; roots developed in connection with buids, as in Ranunculus Ficaria, Nasturtium, Cardamine, Anemone, etc.) that is, exogenously.

The adventitious development of buds on the stem may take place either exogenously or endogenously. In the former case the buds may be developed each from a single epidermal cell (e.g. Begonia prolifera, underground shoots of Psilotum), or from the epidermis and subjacent layers (e.g. Linaria vulgaris). In the latter case the adventitious bud arises from the pericycle (e.g. Cuscuta, epicotyl of Convolvulus arvensis).

Adventitious buds are commonly developed in the Algæ and Liverworts, either exogenously, from single superficial cells at the margin or on the surface of the thallus of Delesseria and other Alge, or of that of Metzgeria furcata among Liverworts, or endogenously, as in Fucus and apparently also in Metzgeria.

2. On the root. Adventitious buds may be formed either exogenously or endogenously on the root; in the former case they arise from the superficial layers (e.g. Aristolochia clematiti.s); in the latter, from the pericycle (e.g. Alliaria officinalis, Anemone sylvestris, etc.)

3. On the leaf. Adventitious buds developed on leaves are of exogenous origin, the epidermis being more especially concerned in their production. Adventitious roots are usually of endogenous origin, being derived from cells of the pericycle; but in some cases (e.g. Cardamine pratensis, Nasturtium officinale and silvestris), where they arise in direct connexion with adventitious buds, they are exogenous, being derived from the epidermis and the superticial cortical layers of the axis of the bud.

Adventitious buds and roots are also developed from the callus (see p. 21) formed on the injured surfaces of stems, roots, and leaf-stalks: the former may be endogenous or exogenous, the latter are endogenous.

From the foregoing account of the development of adventitious buds and roots, it is clear that no definite rule as to their mode of origin can be laid down, based on their morphological character. However, the following rule appears to hold good, that the mode of origin of an adventitious member depends upon the age of the part from which it is developed when the part is very young, the 
adventitious member is developed exogenously; when the part is older with its tissues more or less differentiated, the adventitious member is developed endogeneously, usually from the pericycle, but sometimes from still deeper tissues, according to the relative age of the part.

$\S 35$. The Formation of Secondary Tissue. In addition to the formation of primary tissue from the primary meristem of the growing-point, as above described, a formation of secondary tissue takes place in many plants, which is in most cases associated with a growth in thickness and may give rise to secondary stelar tissue, or to secondary extra-stelar tissue.

A. The Normal Formation of Secondary Stelar Tissue in the stem takes place in most Gymnosperms and Dicotyledons (as also in some Ophioglosser), and is effected by the continuous merismatic activity of the cambium of their open collateral bundles. These are arranged in a circle in a transverse section (Fig. $143 A$ ) : the commencement of growth in thickness is preceded by tangential divisions in the conjunctive tissue (Fig. 139) which lies between the bundles; this gives rise to cambium which becomes
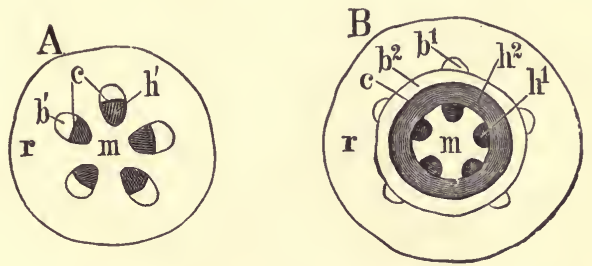

FIG. 143.-Diagrammatic transverse sections of a normal dicotyledonous stem which grows in thickness. $A$ Very yonng: there are five isolated bundles; $m$ pith; $r$ cortex; $b^{\prime}$ primary bast; $h^{\prime}$ primary wood; $c$ cambium. $B$ After growth in thickness has commenced: $h^{2}$ secondary wood; $b^{2}$ secondary bast.

continuous with that of the vascular bundles. A closed hollow cylinder is thus formed, which appears, in a transverse section, as a ring, the cambium-ring (Fig. $143 \mathrm{~B} \mathrm{C}$ ) completely separating the pith from the cortex : it consists of two portions corresponding to its mode of origin; fascicular cambium, i.e. the cambium belonging to the vascular bundles, and the inter-fascicular cambium, i.e. that which is formed between the bundles in the primary medullary rays (see Fig. 130).

A cambium-ring is likewise formed in the root of these plants (Fig. 144). The first indication of the formation of a cambiumlayer is the division of the cells of the conjunctive parenchyma on the inner surface of each bast-bundle; then those on the flanks of the bast-bundles begin to divide; and thus a number of arcs 
of cambium are formed, extending from the inner surface of each bast-bundle to the pericycle. The pericycle-cells lying externally to the outer ends (protoxylem) of the wood-bundles now divide, and connect the arcs of cambium. Thus a continuous cambiumlayer is formed, which has at first a wavy outline, as seen in transverse section, but which becomes circular as the development of the secondary tissue proceeds.

The cambium-layer of the primary root is continuous with that of the primary stem; hence, in a plant in which stem and root grow in thickness, there is a continuous layer of merismatic tissue extending from one end of it to the other ; for the cambium of the branches of both stem and root is continuous with that of the

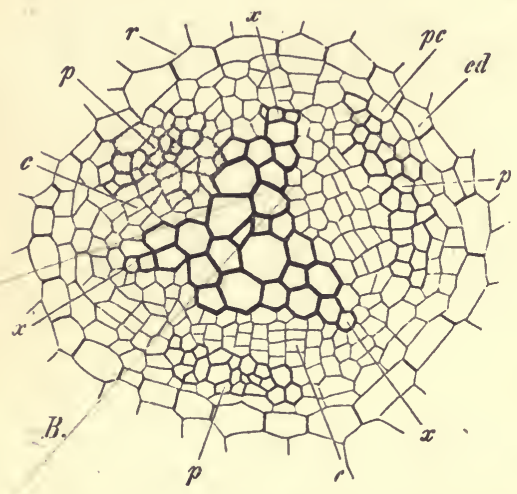

Fig. 144.-Transverse section of the stele of the root of Sambucus nigra, where secondary growth in thickness is commencing. $r$ Cortex; $e d$ endodermis; $p c$ pericycle: $x x x$ the three groups of protoxylem; $p p p$ the three groups of phloem; $c$ dividing cells of the conjunctive tissue forming part of the developing cambium-ring. primary members; and further, the cambium is continuous with the merismatic tissue of the growing-points of the primary stem and root and of their branches.

The cells of the cambiumring, in the stem and root alike, constantly undergo both tangential and radial division, so that the number of the cells increases in the radial direction as well as in the circumferential; the growth of these cells produces an extension of the organ in both these directions. Of the cells formed by tangential division, those lying on the inner side of the cambium, are transformed into the elements of the wood (Fig. $143 B h^{2}$ ), those on the outer side, into the elements of the bast, while the cells of the intermediate zone continue to be capable of dividing. The activity of the cambium thus gives rise to secondary wood and secondary bast, as distinguished from the primary constituents of the bundle, which existed previously to, and independently of, the activity of the cambium. The primary wood of the bundle is thus the innermost part of it, and the primary bast the most external. 
The tangential division of the cambium-cells takes place in a regular order, termed, in honour of the discoverer, Sanio's law of cambial division. Each cambium-cell divides into two by a tangential (parallel to surface of member) wall; one of these two eells remains merismatic,-the other undergoes further division, by a tangential wall, into two which may be either directly converted into permanent tissue (either wood or bast) or after having undergone yet another tangential division. When an addition is to be made to the wood, the outer of the two first-formed cells remains merismatis, the inner forming permanent tissue; when to the bast, it is the inner of the two frst-formed cells which remains merismatic, and the outer which is converted into permanent tissue.

Not only does the fascicular cambium add secondary wood and bast to the primary bundles of the stem, but the interfascicular cambium generally forms (except Menispermaceæ, Cucurbitaceæ, woody Piperaceæ, Aristolochia, Casuarina, and some otber plants, where it only forms conjunctive tissue) new secondary bundles between

Fig. 14.̆. - Part of a transverse section of a branch of Pinus sylvestris, jllustrating the development of tissue from the cambium : the lower part of the section is the central (rood), the upper the peripheral (bast) : $i$ initial lajer (cambium proper), on each side of which are still

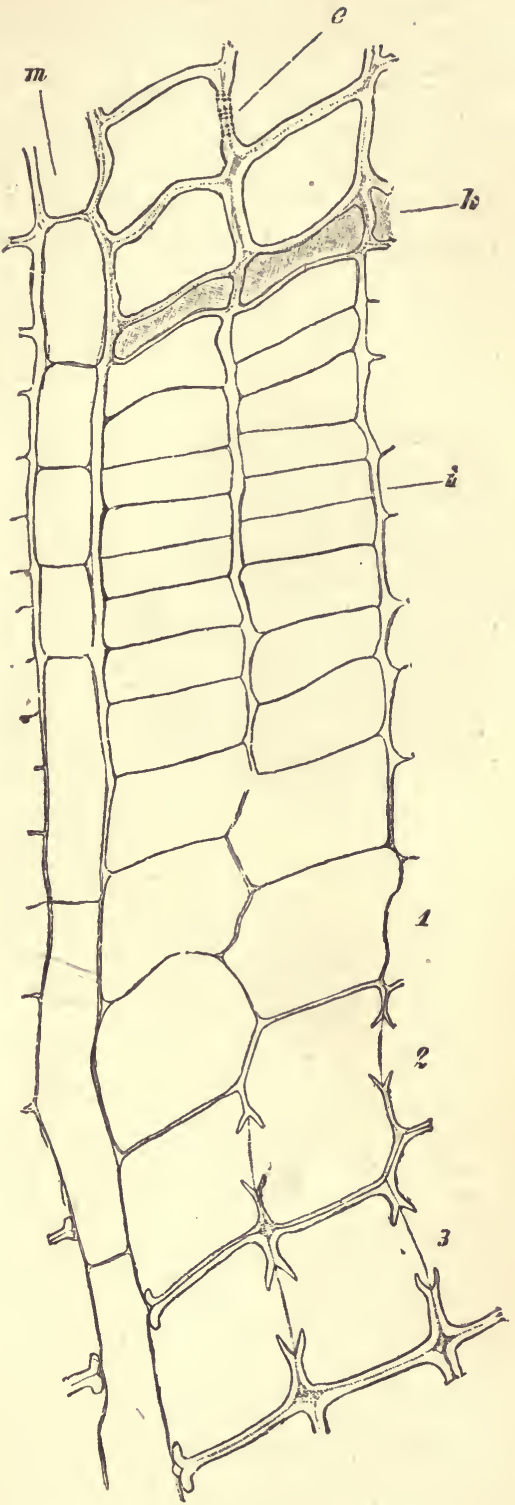
young desmogen-cells in process of differentiation into either wood or bast; 1, 2, 3 joung xylem-tracheids, with developing bordered pits; $k$ cells of the hast-parenchyma with brown contents; $e$ sieve-tube with lateral sieve-plate; $m$ a medullary ray, to which additions are also made in the cambial region. (After Strasburger : $\times 510$.)

V. S. B. 
the primary, and in this way a compact ring of wood and of bast is formed. These secondary bundles are of course destitute of protoxylem and protophloem.

In roots the secondary vascular tissue is developed in essentially the same manner as in the stem; the wood inwards, the bast outwards, from the cambium-layer; and the same forms of tissue are produced. It is, however, only in certain cases (e.g. Taraxacum, Scorzonera hispanica, Rubia, Taxus, Cupressus, etc.) that the cambium of the root produces wood internally, and bast externally, over its whole surface, so that a complete ring of secondary vascular tissue is formed : in most cases (e.g. Centranthus, Tropæolum, Urtica, Cucur-
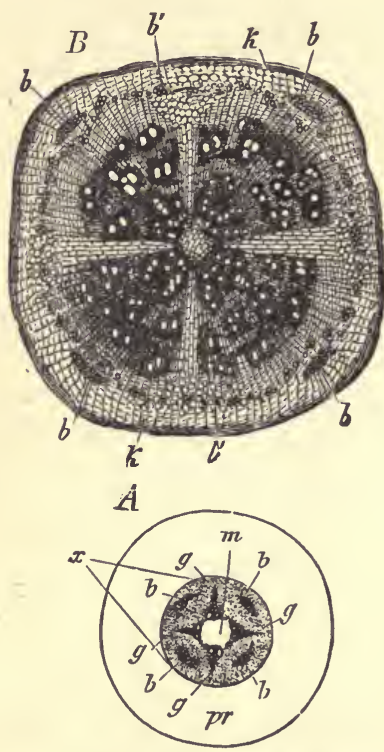

Fig. 146. - A Transverse section of a young root of Phaseolus multiflorus : $p r$ cortex; $m$ pith; $x$ stele; $g$ primary xylem-bundles; $b$ primary phloembundles. $B$ Transverse section of an older root of the same plant, which is growing in thickness: $b^{\prime}$ secondary bast; $k$ periderm : the four rays extending to near the centre consist of secondary ground-tissue, and correspond in position to the primary wood-bundles. (Sliglitly magnified; after Sachs.) bita, Phaseolus, Convolvulus, Clusia, etc.) secondary vascular tissue is formed ouly opposite to the primary bast-bundles, whereas, opposite to the primary woodbundles, the cambium produces only ground-tissue, thus giving rise to broad medullary rays opposite to these bundles (Fig. 146).

The Tissues developed from the Cambium. - In stems and roots in which the growth in thickness is normal, the cambium gives rise to secondary wood, secondary bast, and secondary conjunctive tissue (medullary rays).

The structure of the secondary wood differs essentially from that of the primary wood only in that it includes no spiral or annular vessels resembling those of the protoxylem (see p. 176). It always includes tracheal tissue ; nearly always woodparenchyma (see p.132); frequently sclerenchyma: the cell-walls of all these forms of tissue are usually more or less completely lignified.

The secondary tracheal tissue may consist either solely of tracheæ (e.g. Platanus, Fraxinus excelsior and Ornus, Citrus, Viscum, Hydrangea); or solely of tracheids (e.g. Coniferæ, Drimys Winteri); or, as is generally the case, of both tracheæ and tracheids. The cell-walls of the tracheal tissue are, as a rule, marked with bordered pits; 
but occasionally, especially in soft wood, the walls are reticulately thickened.

The secondary wood-parenchyma consists of oblong cells, which are generally so arranged that their long axes are parallel to that of the member of which they form part: they occur in short longitudinal strands, consisting commonly of a single row of cells (Fig. $148 C^{\text {) }}$, but sometimes, in the middle only, of more than one

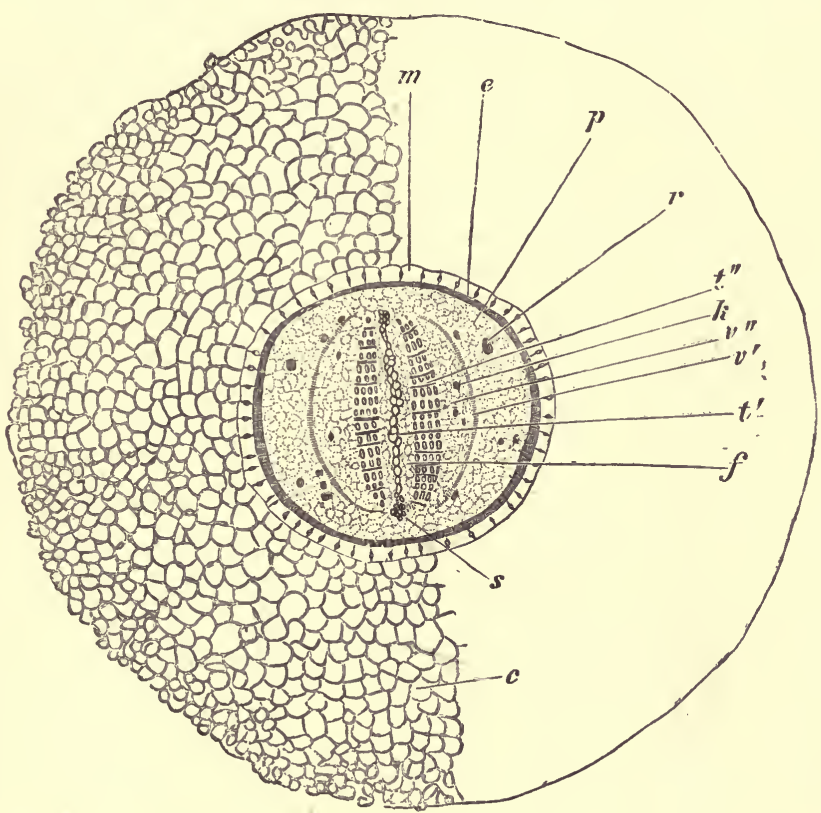

FIg. 147.-Transverse section of a root of the Yew (Taxus baccata) which has begun to grow in thickness: $c$ cortex; $m$ sub-endodermal layer (see p. 166); $e$ endodermis; $p$ pericycle; $s$ protoxylem-group of one of the two confluent primary xylem-bundles; $t^{\prime}$ tracheids of primary wood; $f$ interfascicular conjunctive tissue; $t^{n}$ secondary wood formed from a cambium-layer situated just externally to it ; $v^{\prime \prime}$ secondary bast; $v^{\prime}$ primary bast which is becoming crushed and disorganised by the cambial development of new tissues; $k$ cells of secondary bast, containing crystals; $r$ cells of pericycle containing resin. (After Strasburger ; $\times$ 42).

row. They are true cells, containing protoplasm and a nucleus, and other substances, such as starch (especially in perennial stems and roots in winter), tannin, etc. Their walls are generally lignified, but usually not very much thickened, and have circular or elliptical simple pits. In many soft fleshy stems and roots (e.g. Potato, Radish, Turnip, Beetroot), where this tissue is the 
principal product of the activity of the cambium, the cell-walls are not lignified.

The secondary sclerenchyma consists of elongated prosenchymatous cells, with more or less thickened lignified walls marked with narrow oblique bordered pits
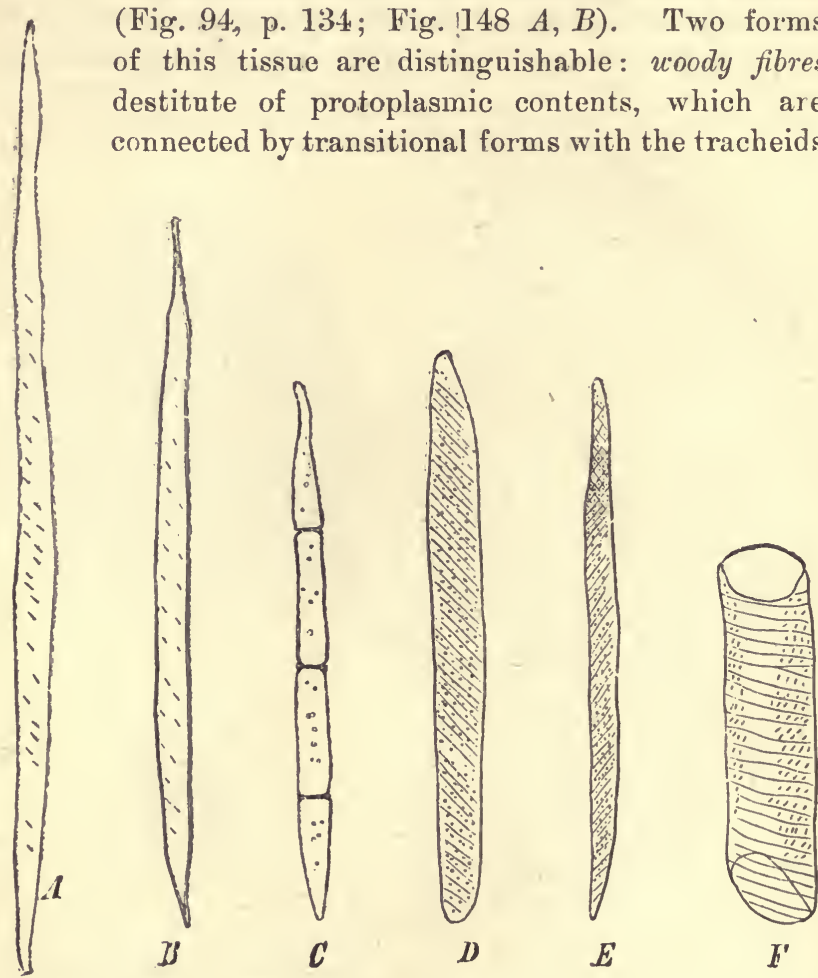

Fig. 148.-Isolated constituents of the seconilary wood of the lime (Tiiiv pavvifolia). $A$ and $B$ wood-fibres; $C$ wood parenchyma; $D$ and $E$ tracheids; $F$ segment of a wood-vessel (trachea). $G$ is a bast-fibre. ( $\times 180$; after Strasburger.)

(see p. 134) : fibrous cells, with protoplasmic cell-contents, which are allied to the wood-parenchyma; in fact, one fibrous cell corresponds. to a row of wood-parenchyma cells; the walls of the fibrous cells sometimes remain thin, as in Viscum and some other plants, where they replace the wood-parenchyma both structurally and functionally. Both the woody fibres and the thick-walled fibrous cells 
may eventually become chambered by the formation of delicate transverse septa (see p. 133).

The structure of the secondary wood of the root is in some cases (e.g. Conifers) almost identical with that of the corresponding stem; this is the case, to a somewhat less degree, in woody Dicotyledons; whilst in herbaceons Dicotyledons the structure may be very different in the two members, owing, chiefly, to the development of more wood-parenchyma, but less fibrous tissue, in the root (see above p. 194).

The following is a brief enumeration, with examples, of the chief varieties of structure presented by the secondary wood of the stem.

The secondary wood may consist-

1. Solely of tracheids : Taxus laccata (Yew), Drimys Winteri.

2. Of tracheids and wood-parenchyma : Conifers (except Taxus).

3. Of vessels, tracheids, and wood-parenchyma: Ilex, Staphylea, Rosa, Pyrus, Cratægus.

4. Of vessels, tracheids, wood-parenchyma, and thin-walled fibrous cells: Jasminum, Kerria, Potentilla, Casuarina, Aristolochia.

5. Of vessels, tracheids, thick-walled fibrous cells, and wood-parenchyma: Acer, Sambucus, Euonymus, Vitis, Fuchsia, Hedera.

6. Of vessels, tracheids, and thin- and thick-walled fibrous cells: Ephedra, Mahonia, Berberis.

7. Of vessels, tracheids, woody fibre, and wood-parenchyma: Calycanthus, Rhamnus, Ribes, Quercus, Carpinus, Prunus.

8. Of vessels, tracheids, woody fibre, wood-parenchyma, and thin-walled fibrous cells; this is the most common type of structure, and is to be found in most dicotyledonous trees and shrubs, e.g. Salix, Populus; Allnus, Betula, Juglans, Tilia, Ailanthus, Magnolia, Robinia, Gleditschia, Ulex.

9. Of vessels, woody fibre, and wood-parenchyma : Avicennia.

10. Of vessels, woody fibre; and thin-walled fibrous cells: Viscum.

11. Of vessels, woody fibre, wood-parenchyma, thin-walled fibrous cells: Platanus, Fraxinus, Citrus.

12. Of vessels, thick-walled fibrous cells, and wood-pareneliyma : Cheiranthus, Begonia.

A transverse section of a stem or a root of most coniferous or dicotyledonous trees or shrubs exhibits, even to the naked eye, a series of concentric layers in the secondary wood known as the annual rings. These layers result from the fact that the wood formed in the spring is differently constituted from that which is formed later in the year. The anatomical cause of the distinctness of the annual rings is the same in all cases, namely, that the last-formed xylem-elements of an annual ring have a very small radial diameter. In Conifers this distinction is emphasized by the 
fact that the spring-wood is formed of thin-walled tracheids (Fig. $150 \mathrm{f}$ ) and the autumn-wood of thick-walled tracheids (Fig. $150 \mathrm{~h}$ ). In dicotyledonous trees the number and size of the vessels diminishes in each annual ring from its inner to its outer limit. When this takes place very gradually, the eye cannot detect any conspicuous difference between the spring- and autumn-wood (as in the wood of the Beech, Lime, Maple, and Walnut); but some kinds of wood show a ring of conspicuously large vessels in the spring-wood, while in the autumn-wood there are numerous much smaller vessels (as in the wood of the Oak, Elm, and Ash).

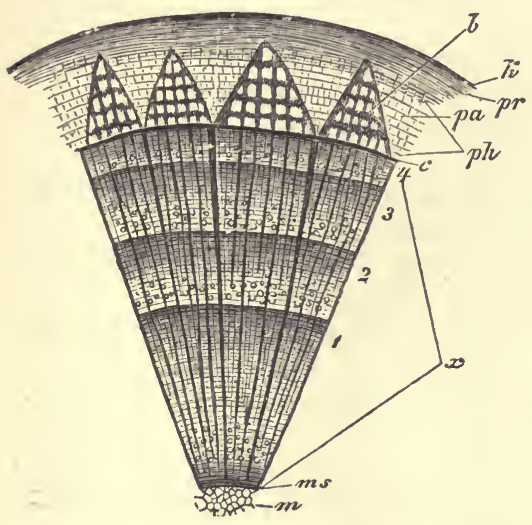

Fit. 149.-Part of a transverse section of a twig of the Lime, four years old (slightly magnified): $m$ pith; $m s$ medullary sheath; $x$ eecondary wood; 1234 annual rings; $c$ cam. bium ; $p a$ dilated outer ends of primary medul. lary rays; $b$ bast ; $p r$ primary cortex; $k$ cork.

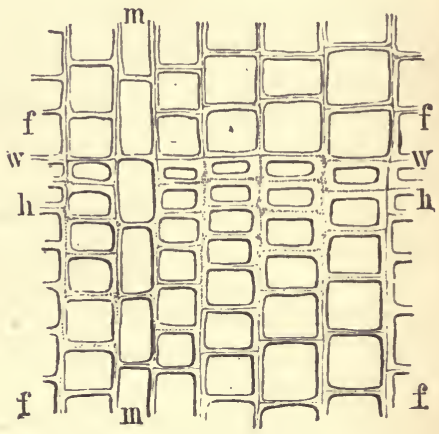

Fra. 150.-Transverse section of portion of the secondary wood of a branch of the Fir at the junction of two annual rings : $m$ a medullary ray-all the other cells belong to the wood; $f$ large-celled spring-wood; $h$ small-celled autumnwood; $w$ the limit between the autumn. wood of one year and the spring-wood of the following year; between $h$ and $w$ is the flattened limiting layer $(\times 250)$.

The thickness of the annual ring varies in different plants, and even in any one plant, under different conditions of growth; and not only the thickness, bnt also the number and relative distribution of the constituents of the wood.

The following case will serve to illustrate the variation in thickness and structure of the annual ring. In a well-grown Ash-tree (Fraxinus excelsior) the annual ring was found to be $2-3 \mathrm{~mm}$. in thickness, and to consist of an internal (spring) zone of wide vessels with wood-parenchyma and rather thinwalled woody fibres, followed by a layer of thick-walled woody fibres with scattered smaller vessels surrounded by wood-parenchyma, and then by an external (autumn) zone consisting of wood-parenchyma with small very thickwalled vessels. In vigorous young Ash-trees growing in a damp soil, the annual 
ring was found to be $15 \mathrm{~mm}$. in thickness : here the fibres had thinner walls, and the vessels, though more uniform in size, were not quite so wide as in the narrower ring previously described.

The annual ring is by no means always of equal thickness all round : it is frequently thicker on one side of a stem or of a root than the other, so that the general structure is strongly excentric.

The secondary wood gradually becomes distinguishable into an older internal portion, the heart-wood (duramen), and a younger outer portion, the sap-wood (alburnum). This arises from the fact that, as the wood becomes older, the cells of the wood-parenchyma and the fibrous cells die and lose their protoplasmic cell-contents; as a consequence, the heart-wood has less water in its composition than the sap-wood. In some cases this change is accompanied by a colouration of the cell-walls of the heart-wood, with the result that the distinction of duramen and alburnum is most marked (e.g. Pine, Larch, Oak); it is but rarely that this distinction is not observable (e.g. Buxus, Acer pseudoplatanus and platanoides).

The structure of the secondary bast essentially resembles that of the primary bast. It always consists of sieve-tubes and of parenchyma, and very frequently of thick-walled fibres as well.

The sieve-tubes of the secondary bast have the compound sieveplates shown in Fig. 98, p. 137 ; in Dicotyledons they have companion-cells developed in relation with them. The parenchyma very much resembles that of the secondary wood, except that its cell-walls are not lignified; it is abundantly developed in certain fleshy roots (e.g. Taraxacum, Rubia, and the Carrot and Parsnip), where it constitutes the chief part of the secondary bast. Prosenchymatous cells with unlignified walls, corresponding to the thinwalled fibrous cells of the secondary wood (p. 196), are sometimes present. The bast-fibres closely resemble the woody fibres, but their walls are not lignified (Fig. $148 \mathrm{G}$ ).

In many cases the secondary bast contains no bast-fibres (e.g. Abietineæ, Fagus, Betula, Alnus, Platanus, Cornus, Ephedra, etc.). When, as is usually the case, bast-fibres are present, their arrangement presents considerable variety : there may be alternating tangential layers of fibres (hard bast) and of sieve-tubes and parenchyma (soft bast), as in the case of the Cupressineæ and some Taxoideæ, and, though with less regularity, in many Dicotyledons (e.g. Vitis, Spiræa, species of Acer, Tilia, species of Salix, etc.); more commonly the tangential layers of fibres are interrupted here and there by soft bast (e.g. Quercus, Corylus, Carpinus, Pyrús, 
Juglans, Sambucus, Rhamnus, Ulmus, Populus); or there may be scattered groups of fibres (e.g. Cinchona, Morus, Larix, Celtis, Ficus elastica).

The secondary bast does not, as a rule, attain so considerable a size as the secondary wood, nor does it exhibit annual rings: this is due to the fact that, except in some fleshy roots, it is formed in smaller quantity, and further, to the fact that the older bast becomes crushed and flattened by the development of the more internal layers subsequently formed.

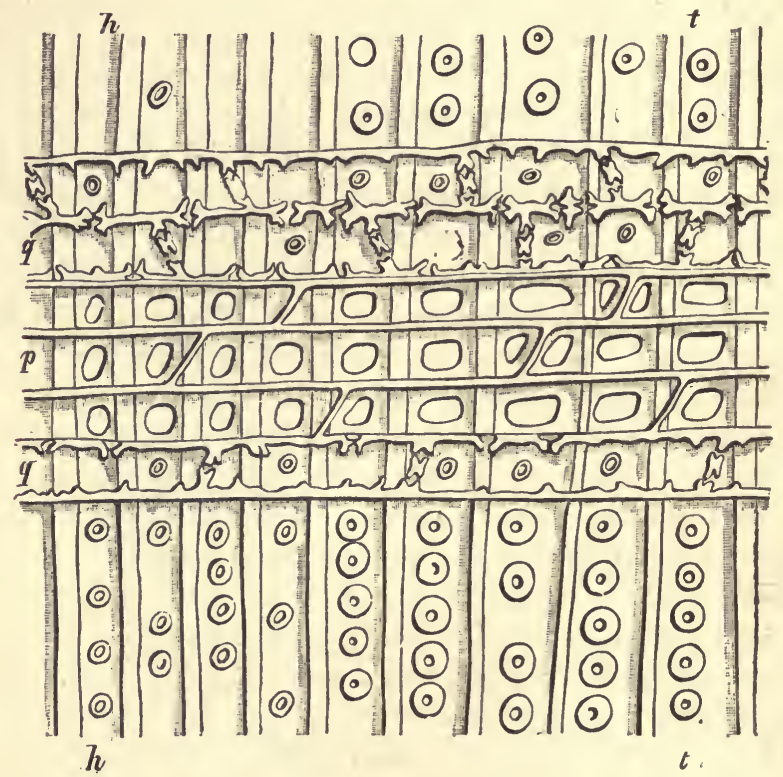

Fig. 151.-Radial longitudinal section of the wood of the stem of a Pine, along the length of a medullary ray $q p q$, consisting of six horizontal rows of cells, one above the other :$t$ tracheids with bordered pits; the tracheids $h$ with smaller bordered pits are the autumnwood of one year, those to the right with larger pits constitute the spring-wood of the next year; $q$ tracheidal elements of the medullary ray ; $p$ true cells of the ray : where the cells of the medullary rays abut on the tracheids the pits are simple and large $(x 300)$.

The structure of the secondary conjunctive tissue (medullary rays). The cambium-ring not only adds to the existing primary medullary rays, but gives rise to new (secondary, tertiary) rays in the successive years of growth (see Fig. 149), amongst the vascular tissue.

The cells of the medullary rays are typically parenchymatous, somewhat brick-shaped, with their long axes along radii from the 
centre to the periphery of the member (Fig. 149); their more or less thickened walls are lignified (p. 132), and they have protoplasmic contents. Occasionally, however, some of the cells of a ray lose their protoplasmic contents and constitute tracheids (e.g. Abietineæ, Fig. $149 q q$ ); in some few cases the ray consists of long fibrous cells, in place of parenchyma (e.g. shrubby Begonias).

The medullary ray is, then, a strand of cells passing radially. among the longitudinally arranged tissues of the wood and of the bast (Fig. 149). Its size varies, even in the same member, both as regards its vertical (height) and its lateral (breadth) dimensions. With regard to the former, the ray may consist of only a single row of cells (as in Abietineæ', Quercus, Fagus); the limits may be generally stated at 1-12 rows of cells, though in some cases they are considerably larger than this when they include resin-ducts (e.g. Abietineæ) or other forms of secretory tissue. In any case, the secondary medullary rays, unlike the primary, do not extend throughout the whole length of an internode. The breadth of the secondary medullary rays is never nearly so great as their height: as seen in tangential longitudinal section, they are narrow above and below and broader in the middle; it is only in the middle that they ever consist of more than one row of cells in breadth, the upper and lower margins consisting of a single row only. With

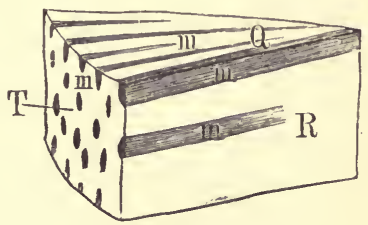

FIG. 152.-Diagrammatic representation of the course of the medullary rays in' a segment cut out of the wood of a tree-trunk. $Q$ ' Horizontal surface; $\boldsymbol{R}$ Radial surface; $T$ Tangential (external) surface of the wood; the shaded portions $m$ are the medullary rays. regard to their radial extent, it is only the primary medullary rays which extend from pith to pericycle; the subsequently formed rays (secondary; tertiary, etc.) extend between the wood and the bast of the year in which they were formed.

As instances of especially large secondary medullary rays should be mentioned those formed in roots (see Fig. 146, p. 194) where the cambium forms only conjunctive tissue opposite the primary xylem-bundles.

In some few stems the formation of secondary conjunctive tissue is especially connected with the primary medullary rays (e.g. Cucurbitaceæ, Menispermaceæ; woody Piperaceæ; Aristolochia, Casuarina, Atragene, Begonia, Berberis, etc., see p.193). In these plants the formation of secondary vascular tissue is confined to the 
fascicular cambium, the interfascicular cambium in the primary medullary rays giving rise only to conjunctive tissue; thus the primary medullary rays persist as broad bands of conjunctive tissue between the bundles, and are not broken up, as is usually the case, by the formation of secondary bundles by the interfascicular cambium.

A certain amount of secondary growth, independently of the cambium, takes place in some cases in the outer portion, external to the cambium, of the primary medullary rays of stems growing in circumference. In all cases the effect of growth in circumference is to tend to stretch the cells in a tangential direction. In the cases under consideration (e.g. Tilia, Fig. 149, p. 198) the cells of the outer portion of the primary medullary rays yield to this tension more than the rest of the tissue, and also undergo radial division, thus the bast-portions of the bundles come to be separated by considerable areas of conjunctive tissue.

The Differentiation of the Secondary Tissues.-The cells, formed as the result of division in the cambium, which are to become transformed into secondary permanent tissue are (apart from the primary medullary rays) collectively termed secondary desmogen (see Fig. 145). They have, to begin with, the same form and structure as the corresponding cambium-cells (see p. 181), but they gradually undergo changes in both respects, as they become transformed into permanent tissue.

The development of the desmogen-cell into one or other of the various forms of permanent tissue, already described, may be either accompanied or unaccompanied by cell-division. In the former case, the divisions may be transverse or longitudinal; the desmogen-cell undergoes transverse division when the product is a row of short cells (e.g. wood-parenchyma, Fig. $153 \mathrm{D}$, and Fig. $148 \mathrm{C}$; bast-parenchyma; secondary medullary rays; woodvessels with short segments) : the desmogen-cell generally undergoes longitudinal division once or twice, by tangential walls, soon after it has been cut off from the cambium (Fig. 145); but this does not take place in the line of the medullary rays, where the radial diameter of the young cells is greater than it is near the bast or the wood; again, the desmogen-cells may undergo longitudinal division in a plane other than the tangential, as for instance the longitudinal division of the mother-cell, which separates the sieve-tube-segment from the companion-cell in the bast of Angiosperms.

The product of a desmogen-cell may have much the same form and size as the desmogen-cell (e.g. small medullary rays; rows of 
parenchyma-cells, bast or wood; thin-walled fibrous cells): but more commonly the product differs very materially from the desmogen-cell, being very much wider (e.g.tracheæ), or very much longer longitudinally (wood-and bast-fibres), or very much longer radially (e.g. cells of medullary ray); that is to say, the derelopment of the desmogen-cell into permanent tissue is generally accompanied by very considerable growth.

The radial and tangential divisions of the cambium-cells and of the desmogencells take place in such a manner that the products are, at first, arranged in very definite radial rows (Fig. 145). When the resulting tissue consists of elements which are for the most part essentially alike, this regular radial arrangement persists in the permanent tissue ; for instance, in the wood of Conifers (Fig. 150), which consists almost exclusively of tracheids; but where some of the elements (as generally in the wood of Dicotyledons) attain a much greater size (as seen in transverse section, Fig. 139), the original radial arrangement is lost.

In those cases in which the permanent tissues consist of very long or very wide fibres or vessels, it is evident that the relative position of the original desmogencells must have undergone considerable change in the course of development; the long fibre is in contact, longitudinally, with a greater number of cells than was the original desmogen-cell; and similarly, the wide trachea touches, at its circumference, a larger number of cells than did the desmogen-cell, originally, from which the segment of the vessel was dereloped. This gradual change of relative position

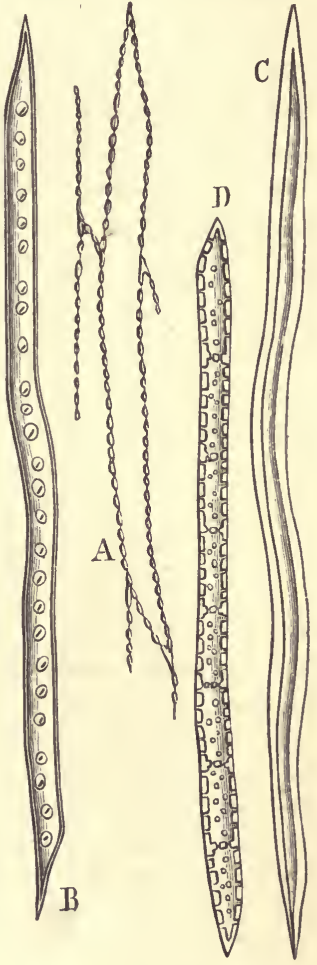

Fig.153.- $A$ Desmogen-cells seen in tangential section. $B$ 'I'racheid seen from outside. $C$ woody-fibre ; and $D$ vertical row of wood-parenchyma. cells seen in section, from the Oak; isolated by maceration. constitutes what is termed sliding-growth; it is the expression of the independent growth of each desmogen-cell, in the course of its development into the particular element of the permanent tissue which it is destined to form. This process is by no means confined 
to the vascular tissues, but takes place wherever a young developing cell grows more actively, in any dimension, than the cells with which it is at first in contact; a notable example is the growth of the laticiferous cœenocytes of Euphorbia (see p. 141).

Whilst undergoing these changes of form, the desmogen-cells undergo, as already indicated, changes in the structure and chemical composition of their cell-walls in accordance with the particular kind of tissue to which they are to give rise; and, in some cases (tracheæ, tracheids, fibres) they lose their protoplasmic cell-contents; the walls become more or less thickened (spiral, annular, reticulate, in primary wood) and pitted (with simple pits ; or circular bordered pits ; or oval bordered pits, either small and numerous, or large extendirg across a whole face of the wall, giving it a scalariform appearance, see p. 104); and then the absorption, more or less complete, of the septa takes place, which leads to the formation of the vessels.

Glandular tissue is frequently developed in the secondary wood and bast, in the form, sometimes, of saes containing erystals, in the parenchyma (including medullary rays) of the wood (e.g. Vitis, and some leguminous trees) or more commonly in that of the bast : of resin-ducts which oceur in the secondary wood of certain Abietineæ, runuing horizontally in the medullary rays and rertically in the wood, but rarely found in the secondary bast, whereas in other plants which possess these structures, they are rare in the wood but abuudant in the bast (e.g. Terebinthaceæ, etc.): of laticiferous vessels, rare in the wood (except the Papayaceæ, where the wood consists largely of parenchyma), abundant in the bast.

The foregoing is an account of the development of secondary vascular and conjunctive tissue, as it takes place in the great majority of Gymnosperms and Dicotyledons : but this is bo no means the only mode in which this development takes place. The following are the more remarkable deviations from the mode already described :-

1. There is a normal cambium-ring, but an additional layer of meristem is formed from pith-cells on the inner side of the ring of vascular bundles, producing secondary wood peripherally, and secondary bast centrally ; stem of Tecoma (Bignonia) radicans, and of species of Acanthus and Campanula, some Apocynaceæ (Apocynum cannabinum), Periploca graca, Acantholimon glumaceum.

2. There are several distinct eambium-rings, each producing a solid cylinder of wood and bast : stems of climbing Sapindaceæ (e.g. Serjania, Paullinia). The cause of this peculiar structnre is that the primary bundles are arranged, not in a simple ring, but irregularly, at very different distances from the surface; hence, when the interfascicular cambium is developed, it does not connect all the bundles together; but separate groups of them, generally a larger central group and several smaller peripheral groups, each with its own distinct cambium. ring.

3. The normal cambium-layer has only a limited period of activity; the 
subsequent growth in thickness is effected by successive secondary cambiumrings developing rings of secondary vascular bundles; these secondary cambium-rings may be developed:- $(a)$ in the pericycle; stem of Chenopodiaceæ, Amarantaceæ, Phytolacca, Nyctagineæ, and of some Gnetums, Cycas, and Encephalartos among Gymnosperms: (b) in the primary cortex; stems of some Menispermaceæ (e.g. Cocculus laurifolius, Cissampelos Pareira): (c) in the secondary bast; stem of Glycine (Wistaria): $(d)$ in the secondary wood; twining stems of Baubinia, and some Bignoniaceæ and Malpighiaceæ: $(e)$ in the secondary cortex (phelloderm), derivel from the pericycle; root of Chenopodiaceæ, Amarantaceæ, Nyctagineæ. In some cases, however (e.g. roots of many Convolvulaceæ), secondary cambium-layers are formed in the secondary cortex (pbelloderm), whilst the primary cambium-layer still remains active.

4. The cambium-layer is normal, but it does not produce equal amounts of wood, or of bast, or of both wood and bast, at all points of its circumference, as is normally the case, with the result that the cambium-layer is not a circle in transverse section, but is very irregnlar and undulated in form, the wood and the bast dovetailing into one another, as it were, by their respective projecting thicker portions. (a) The development of bast is uniform, that of the wood uneven; stems of various species of Cissus, Piper, Bauhinia (Caulotretus heterophyllus); root of Ononis spinosa; (b) the development of neither wood nor bast is uniform, but at the points at which the development of the bast is less active, that of the wood is more active; twining stems of many Bignoniaceæ (Bignouia, Callichlamys), of Phytocrene (Olacineæ), and of some Malpigbiaceæ (Banisteria, Tetrapterys), A pocynaceæ (Condylocarpon, Echites).

An interesting modification of this peculiar mode of development occurs in the stem of species of Strychnos; at certain regions the cambium-layer produces thick masses of secondary bast which project into the wood; after a time the cambium of these regions ceases to act, whilst a new segment of secondary cambium is formed in the pericycle across the projecting masses of bast at the level of the rest of the cambium-layer; thus the cambium-ring is reconstructed, forming wood centrally and bast peripherally, with the result that the masses of bast mentioned above becnme covered peripherally by a layer of wood, constituting in fact isolated groups of bast, termed Phloemislands, surrounded by wood.

5. There is no primary cambium-layer, the bundles being all closed; secondary growth in thickness is effected by a ring of meristem quite external to the primary bundles; this occurs in the stems and roots of Monocotyledons (arborescent Liliaceæ, such as Yucca and Dracæna ; and some sbrubby Iridaceæ, such as Aristea); the ring of meıistem is usually developed in the pericyc'e, but in the roots of Dracæua it is formed partly from the pericycle and partly from the cortex. This meristem-ring is not termed a cambium-ring, because it does not form wood on one side, and bast on the other, but it forms, centrifugally, entire closed concentric (with external wood) bundles, together with intervening fundamental tissue.

6. There is no proper cambium-layer, but the primary bundles are invested by a pericyclic meristem-ring, which gives rise externally to a considerable amount of parenchymatous secondary cortex, and internally to a small amount of vascular tissue : stem of Isoetes. 
The development of secondary vascular tissue takes place almost exclusively in such stems as are monostelic and in which the primary bundles are common. It is clear that the additions to the primary bundles in the older internodes of the stem, as well as any secondary bundles which may have been formed from the cambium, are not common, but cauline ; they are, however, in communication with the primary common bundles of the young unthickened internodes which are bearing leaves; in fact, the newly-formed secondary

vascular tissue of the lower

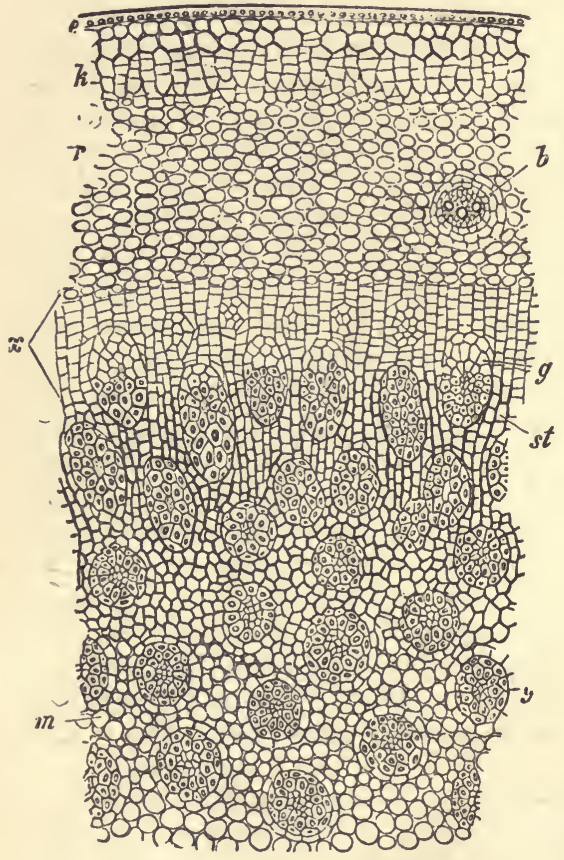

Fig. 154.-Portion of a transverse section of the stem of a Dracana : $e$ epidermis; $k$ periderm; $r$ primary cortex, with a leaf-trace-bundle $b ; x$ meris natic zone in which new bundles $g-g$ are in course of development; $m$ primary, and st second. ars, fundamental tissue. (Magnified: after Sachs.) internodes of the stem is in communication, on the one hand with the root, and, on the other with the leaves; and the channels of communication between root and leaf are main. tained year by year by the annual formation of young conducting-tissue, both wood and bast, in the older parts of the stem and of the root.

It will be remarked that the development of secondary vascular tissue takes place in those plants the stems of which branch more or less (e.g. an Oak), while it usually does not take place in those plants the stems of which do not branch (e.g. the Palm), or do so only slightly. It is obvious that, when the stem is of branching habit, the number of leares must increase year by year, whereas when the stem does not branch the number of leaves does not vary materially. Hence the whole matter may be summed up thus, that the development of secondary vascular tissue in a stem is directly correlated. with an increase in the area of leaf-surface: as in each year the leaf- 
surface of a tree increases in consequence of repeated branching, so does the annual ring of secondary vascular tissue become larger in circumference and possibly also of greater thickness; when, however, the tree begins to grow old, and its branches, instead of increasing in number, begin to die off, then the annual growth in thickness becomes arrested. Some further explanation of this is given in Part IV.

B. The formation of Secondary Extra-stelar Tissue. It is clear that the more or less considerable development of secondary stelar tissue in the interior of a young stem or root, must have a very considerable effect on the primary extra-stelar ground-tissue (cortex), and on the primary tegumentary tissue. This effect will be one of pressure and tension; the radial growth of the stelar tissue will exert a radial pressure upon the external tissues, while the tangential growth of the stelar tissue will exert a tangential tension on the external tissues (see p. 202). The radial pressure of so firm a structure as is usually that of the secondary vascular tissue tends to cause more or less rapid obliteration of the softer cortical tissue ; whilst the tangential tension stretches the cortical cells and tends to cause them to grow tangentially, and to multiply by radial division. According to the predominance of the radial pressure or of the tangential tension, the primary cortex is either rapidly destroyed, or it persists for a very considerable period.

It should, however, be pointed out that the development of secondary extra-stelar tissue does sometimes occur in members in which no development of secondary stelar tissue takes place, as in the roots of some Pteridophyta (Marattiaceæ, some Ophioglosseæ), and of some Monocotyledons (aerial roots of Philodendron, etc.; terrestrial roots of Iris, etc.).

It may be stated generally that the epidermis and the primary cortical tissue of herbaceous dicotyledonous stems keep pace by growth with the formation of new stelar tissue in the interior. This is true also of most woody shoots during the first year of their growth and in certain cases (e.g. Mistletoe, Holly, Acer striatum, etc.), of woody shoots during their entire existence; in some cases (e.g. Euonymus) the epidermis persists and grows for several years, but is at length disorganised., These primary tissues persist also in some roots (e.g. Faba vulyaris, Alclemilla vulgaris, Gaillardir aristata) in which the development of secondary vascular tissue is not very active. The extension of the tissues is effected by tangential growth and radial division of the cells. 
The secondary extra-stelar tissue, is formed by a layer of merismatic cells, which is known as the Phellogen.

In the stem the place of origin of the phellogen is by no means uniform. It may be stelar or extra-stelar : it is sometimes formed by the epidermis becoming merismatic (e.g. Pomeæ, Salix, Viburnum Lantana, Jasminum, Nerium Oleander, Aucuba, Euonymus, Solanum, etc.); most commonly it is the hypodermal layer of cells, the outermost layer of the cortex, which becomes merismatic and constitutes the phellogen (e.g. Platanus, Acer, Fagus, Quereus, Castanea, Betula, Alnus, Ulmus, Populus, Ailanthus, Abies pectinata, etc.); in some cases (e.g. Robinia Pseudacacia, Gleditschia triacanthos, Cytisus Laburnum), it is the second or third layer of the cortical parenchyma, reckoned inwards from the epidermis, which becomes the phellogen: in other cases the phellogen is formed at a greater depth from the surface, being developed from a more internal layer of cells of the cortex, sometimes even from the endodermis (e.g. Coffea arabica; subterranean shoots of some Leguminosæ such as Lotus corniculatus, Trifolium alpestre); or, finally, it is stelar, being formed from a layer of cells belonging to the pericycle (e.g. Myrtaceæ, Onagraceæ, Hypericaceæ, Ericaceæ, most Caryophyllaceæ, Lonicereæ, Vitis, Clematis, Berberis, Rosa, Spiræa, Ribes, etc.)

The development of tissue from the phellogen follows the same law as in the case of the cambium (see p. 193). Generally speaking, a tissue, the periderm, is formed on the outer side of the phellogen by repeated centripetal division; whilst on the inside of the phellogen a tissue, the phelloderm, is formed by repeated centrifugal division. The periderm constitutes the secondary tegumentary tissue of the stem or root; the phelloderm constitutes the secondary cortex. The developmental relations between the two tissues are not constant. In some cases the formation of phelloderm only begins after a considerable mass of periderm has already been produced; but in others, the formation of the two tissues goes on almost simultaneously. The relation between the amount of periderm and the amount of phelloderm formed by one and the same phellogen is by no means constant, and may be generally stated thus:-the more superficial the phellogen, the greater the relative amount of periderm; and further, a larger proportion of phelloderm is formed in subterranean than in subaerial stems. Hence whilst the development of periderm is most marked in subaerial stems with superficial phellogen, there is little or no 
phelloderm in these stems; again, in subaerial stems with a deeplyplaced (e.g. pericyclic) phellogen, periderm and phelloderm are developed about equally; finally, in subterranean stems with a pericyclic phellogen, the well-developed phelloderm may exceed the periderm.

In the root, as in the stem, the position of the phellogen, and the products of its activity, are varions.

The phellogen is developed but rarely (e.g. Solidago) from the epiblema; more commonly from the exodermis, or from the next internal layer of the primary cortex, as in those Pteridophyta (Marattiaceæ, Ophioglosseæ) and Monocotyledons (aerial roots of Philodendron, Monstera, Imantophyllum, etc.; terrestrial roots of Iris, Agave, Asphodelus) in which any formation of periderm takes place; as also in a few woody Dicotyledons (e.g. Artanthe, Clusia, Ruyschia, Jasminum) in which the formation of secondary vascular tissue takes place relatively late; and in the Cycads among Gymnosperms. In the great majority of Dicotyledons and Gymnosperms the phellogen of the root is stelar in origin, being derived from the pericycle.

As in the stem, so in the root, the phelloderm is more highly developed when the phellogen is deeply placed than when it is superficial; but even with a uniform position of the phellogen, the relation between the periderm and the phelloderm developed, varies considerably; thus, among plants with a pericyclic phellogen, whilst the development of periderm and phelloderm is sometimes about equal (e.g. Willow), no phelloderm, but only periderm is developed in Nerium, whilst in some others (e.g. Faba vulgaris, Alchemilla vulgaris, Gaillardia aristata), where the primary cortex persists (see p. 207), only phelloderm is developed.

It frequently happens in both stems and roots that the firstformed primary phellogen has but a limited period of merismatic activity; this is always the case when the primary phellogen is of deep origin (pericyclic in roots), whereas when it is of superficial origin (e.g. epidermal or hypodermal phellogen in stem of Beech, Hornbeam, Silver Fir, Cork-Oak, Cork-Elm), the primary phellogen is frequently persistent. In the former case, however, when the primary phellogen has passed over into some form of permanent tissue, a new secondary phellogen, also of limited duration, is developed internally to the first, and this process is repeated at intervals; hence the phellogen-layers become successively more v. S. B. 
and more deeply seated, penetrating at length into the bast-tissue of the stele.

The periderm, or secondary tegumentary tissue, the tissue formed externally from the phellogen, consists of parenchymatous cells more or less cubical in form, though sometimes somewhat elongated tangentially (Fig. 155); the cell-walls may be thin or considerably thickened; generally speaking, the walls are completely suberised (see p. 106), whence the tissue is often termed Cork; the cells gradually lose their protoplasmic contents, and become filled with air ; moreover, no intercellular spaces are formcd in the tissue.

In view of its structure, it is clear that the periderm is a tissue

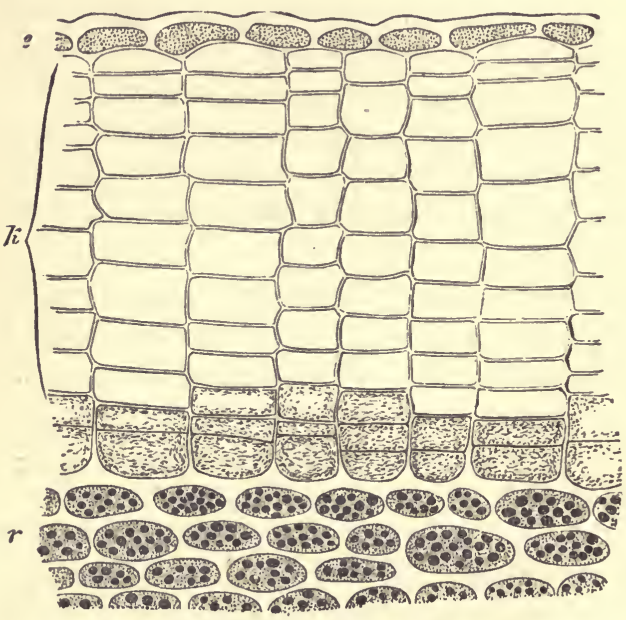

Fig. 155.-Periderm of one-year's shoot of Ailanthus glandulosa (trans. sect. ; $\times 350$ ) : e the dead epidermis ; $k$ cork ; the inner shaded layers are merismatic, the innermost being the phellogen, those external to it being young periderm cells; $r$ primary cortex.

which. offers an obstacle to the passage of water; hence all the tissues, in a stem or root, lying externally to the periderm can receive no supplies of water, and must dry up, and are eventually exfoliated. The more deeply seated the phellogen, the greater is the amount of primary tissue thrown off; thus, when the phellogen arises in the inner layers of a heterogenous pericycle (see p. 167), as in Berberis, Lonicera, etc., where the outer portion of the pericycle is fibrous, the epidermis, the primary cortex, and the outer portion of the pericycle are exfoliated.

The cells of the periderm are not always completely suberised. In some cases (roots and stems of Onagraceæ, Hypericaceæ, some Rosaceæ, etc.) some of layers of the periderm consist of cells with a suberised zone like that of the cells of the endodermis (see p. 166), though these cells usually become completely suberised eventually. 
In other cases (e.g. stem of Poterium, Alchemilla, Agrimonia, Epilobium) the periderm consists mainly of cells with cellulosewalls, between which intercellular spaces are formed, together with occasional compact layers of cells with a suberised zone.

It should not be overlooked that the regeneration of the root-cap is a case of development of secondary tegumentary tissue, though of a different type, inasmnch as it is effected by the primary meristem of the growing-point of the root instead of from a layer of secondary meristem as is the case with the periderm. As the root elongates and makes its way through the soil, the primary root-cap becomes worn away at the surface, but this is compensated by the development of new tissue interually (see p. 158): In some aquatic plants (e.g. Lemna, Hydrocharis, Pistia, etc.), in which the root does not penetrate the soil, the primary root-cap persists. In the case of roots having limited growth in length (e.g. Azolla, Hydrocharis, tuberous roots of Orchis and of Ranunculus Ficaria), the root-cap is altogether thrown off when the growth in length of the root comes to an end.

When the primary periderm is of superficial origin, it forms for many successive years the external investment of the branch; it may attain considerable thickness, as in the Cork-Oak, and at the same time exhibit an alternation of dense and loose layers (e.g. the Birch, in which the layers may be peeled off in thin white sheets); sometimes (as in Acer campestre and the Cork-Elm) it forms winglike projections from the angles of the branches. In a few trees, as the Silver Fir, the primary periderm persists for some years, or, as in the Beech, during the whole life of the tree; the outer cork-cells split off as the trunk of the tree increases in thickness, while the phellogen, growing and extending in a tangential direction, gives rise to new layers of cork. When, as in most cases, new layers of phellogen arise after a few years in the deeper tissues, leading to the development of corresponding layers of periderm, an external investment of a more or less complicated structure comes to be formed. In consequence of the impermeability to water of these secondary layers of periderm, all the tissues lying externally to them become dried up. These driedup tissues, which may belong to different tissue-systems and include the most various forms of cells, constitute what is known as Bark. When the primary periderm is superficial, the new secondary layers of periderm are only ares of the circumference, and as their margins are in contact with the periderm which has been previously formed (Fig. 156), a scaly bark is formed, that is, isolated patches of tissue are transformed into bark. 
This bark is stretched and torn by the increasing size of the trunk, and the scales of it may be shed, as is the case in the

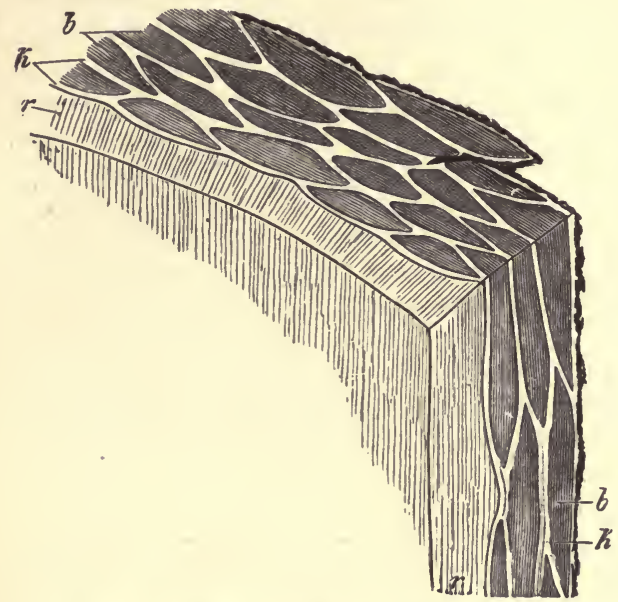

Fig: 156.-Formation of Bark in a Larch, as seen in a piece of the outer portion of the stem cut both transversely and longitudinally (nat. size): $r$ the secondary cortex ; $k$ plates of cork ; $b$ the scales of bark cut off by the cork.

Plane, or they may adhere one upon the other, as in the Pines and Larches, or remain connected by the bastfibres in long strips, as in Robinia. When, on the other hand, the primary periderm has been formed in the deeper layers of the cortex, the secondary periderm often forms complete concentric rings; thus hollow cylinders of the cortex are transformed into bark (ringed bark). The longitudinal rupture of this kind of bark is effected by the bast-fibres enclosed in it (e.g. Vine, Clematis, and Thuja).

There are frequently in the periderm of both stems and roots, organs corresponding to the stomata of the epidermis, serving, like them, to admit air to the living internal tissues; these are the Lenticels. They are usually circumscribed circular areas of the periderm where the cork-cells formed in the course of the summer are not arranged closely together, but are separated by intercellular spaces. In winter the lenticels are closed by ordinary peri-

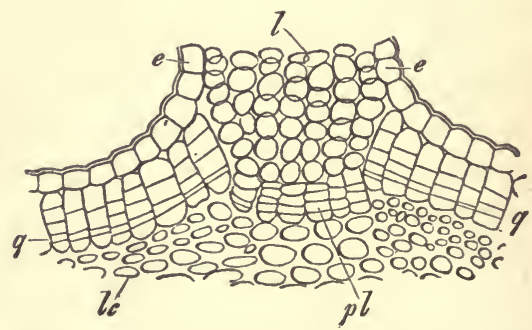

Frg. 157.-Lenticel in the transverse section of a twig of Elder ( $\times 300): e$ epidermis; $q$ phellogen; $l$ cells, and $p l$ the phellogen of the lenticel; $l c$ cortical parenchyma containing chlorophyll.

derm. They are most easily detected in branches of one year's growth, where they are to be seen in the summer in the form of 
brownish or whitish specks. When the periderm of the stem is superficial, the lenticels are developed under the places where the stomata occur in the epidermis, and these spots are commonly the starting-points of the formation of the periderm; but this is not the case in stems with a deep periderm, nor is it ever the case in roots. In many trees, as the Birch, the lenticels become much extended in width by the growth of the branch in circumference. When the periderm is very thick, as in the Cork-Oak, the lenticels form deep canals filled with a pulverulent mass of cells. Sometimes lenticels are not formed; they are not present in the stems of some plants which have a pericyclic phellogen (e.g. Vitis, Clematis, Rubus, Lonicera).

The phelloderm or secondary cortical tissne, the tissue formed internally from the phellogen, consists of cells which have essentially the same structure as those of the primary cortex : the secondary cortex can, however, be distinguished from the primary by the regular radial rows in which, like those of the periderm, its cells are arranged. The cells have protoplasmic cell-contents, and, when developed near the surface of aerial stems, they contain chloroplastids : their walls are usually thin and consist of cellulose, but, like those of the cells of the primary cortex, they may become more or less thickened and eventually lignified.

Just as the periderm replaces the disorganised epidermis as a tegumentary tissue, so the phelloderm replaces the primary cortex as a nutritive (metabolic) tissue when the primary cortex becomes obliterated under the conditions explained on p: 207.

It may be noted that, in the stem of Isoetes, the secondary cortex is developed on the outside of a layer of meristem which, at the same time, forms vascular tissue internally (p. 205): the amount of the former very greatly exceeds that of the latter.

\section{$\S 36$. Formation of Tissue in consequence of Injury.} When the internal tissues of most parts of plants are laid bare by injury, they are gradually covered by a formation of cork taking place in the outermost layer of cells which remain uninjured and capable of growth. This is easily seen in injured fruits, leaves, and herbaceous stems, in which the wounds that have been covered by a layer of cork are distinguished by a grey-brown colour. The process is very easy to observe in potato-tubers, for each portion of living tissue taken from one, if only prevented from drying too quickly, will soon be covered over the whole surface by a layer of 
cork precisely similar in structure to the ordinary rind. In plants in which the wood is well developed, cork is not immediately formed-particularly when the cambium is wounded or laid barebut all the living cells which border on the wound become merismatic and give rise to a homogeneous parenchymatous tissue known as the Callus. If the wound is small, the callus-cells proceeding from the different sides soon come into contact and close up into a single mass of tissue, which then gives rise to cork on its onter surface, and, joining the old cambium at the margins,

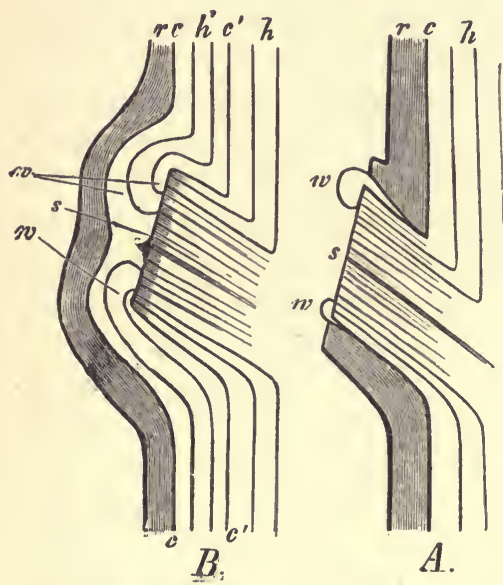

F1G. 158.-Diagrammatic longitudinal section of a woody stem: $A$ a short time after the amputation of a lateral branch $8 ; B$ when the wound is completely closed; $r$ cortex ; $c$ cambium; $h$ wood; $c^{\prime}$ position of the cambiumlayer at the time of amputation; $h^{\prime}$ wood formed since the amputation; $w$ the cushion of callus formed over.the surface of the wound.

forms a new layer of cambium which fills up the cavity. If the wound is a large one, cork and new cambium are formed in the callus at the margins of the wound, and it is not wholly closed till after repeated rupture of the approaching cushions of callus. The wood exposed by the wound, which usually assumes a dark colour under the influence of the air, does not grow with that formed from the new cambium of the callns; bence inscriptions, for instance, which are cut in the cortex so as to reach the wood, though subsequently covered by a number of annual layers of wood corresponding to the number of years, may easily be found. A similar explanation accounts for the fact that the surfaces of the stumps of cut-off branches become orergrown; the callus first appears as a ring from the cambium exposed in the tranverse section, and afterwards closes like a cap over the old wood. Foreign bodies-nails, stones, and stems of other plants-may thus become enclosed in the wood of a tree and be overgrown by it; the cortex, being forced against the foreign object by the pressure of the growing wood, splits, and the callus formed in the rent grows round the object, enclosing it and producing new cambium. 
Stems of plants of the same species will grow together if they are in close contact; the callus formed by the cortex of both, coalesces and gives rise to a common cambium. On this depend the various modes of artificial grafting, in which branches or buds with a portion of the cortex are taken from a variety or an allied species and placed so that their cambium is in contact with that of a stem which serves as the stock, and subsequently they grow together. 


\section{PART III.}

\section{THE CLASSIFICATION OF PLANTS.}

Introductory. A systematic classification of plants may be arrived at by either of two methods. In the first, the different forms of plants are arranged according to some one given principle; by this means order is established, and a definite position in the system is assigned to each plant. Many such systems have been devised, and are known as artificial systems. The principle of classification in such a case must be determined more or less arbitrarily and without considering whether or not, in the resulting arrangement, the plants which are nearly allied are always brought together, and those which are less nearly allied are kept apart. The best known of these artificial systems is that of Linnæus, called the sexual system, which classifies plants by the number and mode of arrangement of the floral organs. This system is, however, only applicable to Phanerogams.

The natural system, to the gradual derelopment of which a more exact knowledge of the reproduction of Cryptogams has largely contributed, has for its object the classification of plants according to their fundamental relationships; and as these are established once for all by Nature itself, the natural system is not based upon any arbitrary principle of classification, but depends upon the state of our knowledge of these fundamental relationships. These find their chief expression in the structure and other characteristics of the reproductive organs, as well as in the peculiarities of polymorphism presented by the life-history (see p. 2). This is more particularly true with regard to the definition of the larger groups of the Vegetable Kingdom; within these groups relationships may be exhibited sometimes in one way and sometimes in another, so that it is not possible to lay down any universal rules for determining close affinities.

As the investigation of this subject is still far from complete, 
the natural system cannot be regarded as being perfectly evolved; the various general sketches which have hitherto been given are therefore no more than approximations to the truth. The system followed in the following pages has no pretension to be regarded as absolutely correct; it is simply the arrangement which appears to answer most nearly to the present state of knowledge of morphology and affinity.

The following are the main divisions of the Vegetable Kingdom :-

1st Group. Thallophyta.

Class 1. Algæ.

Class 2. Fungi.

2Nd Group. Bryophyta.

Class 3. Hepaticæ.

Class 4. Musci.

3Rd Group. Pteridophyta.

Class 5. Filicinæ.

Class 6. Equisetinæ.

Class 7. Lycopodinæ.

4Th Group. Phanerogamia.

Division A. Gymnospermse.

Class 8. Gymnospermæ.

Division B. Angiosperma.

Class 9. Monocotyledones.

Class 10. Dicotyledones.

In considering the distinguishing characteristics of these four great groups, it may be pointed out, in the first place, that whereas in the Bryophyta, Pteridophyta, and Phanerogamia, without exception, the life-history presents a regular alternation of generations, in the Thallophyta the alternation is generally irregular and is, in many cases, altogether wanting. The Thallophyta and the Bryophyta agree with each other, and differ from the Pteridophyta and the Phanerogamia, in that $(a)$ in their life-history, "the plant"-that is, the form to which the name is attached (see p. 3) -is, generally speaking, the gametophyte, whereas in the two latter groups it is the sporophyte; and in $(b)$ the relatively rudimentary differentiation, both morphological and histological, of their sporophyte, whereas their gametophyte is commonly more highly differentiated than that of the two latter groups. Finally, though resembling them in many respects, the Phanerogamia differ from the Pteridophyta in that they produce seeds: in fact, the 
Phanerogamia may be contrasted, as seed-bearing plants, with the three groups ('Thallophyta, Bryophyta, Pteridophyta) of plants which do not bear seeds, and which are collectively termed Cryptogamia.

F'urthermore, the Thallophyta are characterised by the fact that the female organ is never an archegonium, whereas in the other three groups it is never anything else than an archegonium, though it may present variations of form and structure (see p. 84): the Bryophyta, Pteridophyta, and Phanerogamia may, on this account, be collectively designated Archegoniata.

The above-mentioned Classes are of very unequal extent; for while certain of them, as the Equisetinæ, include few forms and those for the most part very closely allied, others, as the Dicotyledones and the Fungi, include an enormous number of very different forms. These discrepancies arise from the very nature of the natural system, for a great diversity does not necessarily display itself within the limits of a single Class; and it must not be forgotten that when the living representatives of a Class, for instance the Equisetinæ or the Lycopodinæ, are few, they are but the surviving remnant of once various and numerous forms which have become in great measure extinct.

Those Classes which include a sufficiently large number of forms are subdivided into subordinate divisions, as (1) Sub-classes, (2) Series, (3) Cohorts, (4) Orders, and these again, if necessary, into Sub-orders, etc. ; but these names are applied in the most arbitrary manner to the different sub-divisions. The two narrowest systematic conceptions, viz., Genus and Species, are used to indicate an individual plant. Uuder the term Species are included all.individuals which possess in common such a number of constant characters that they may be considered to be descended from a common ancestral form. New peculiarities may arise in the course of multiplication: the individuals characterised by these new peculiarities are regarded in classification as varieties of the species. When sereral species resemble each other so distinctly that their general characters indicate a relationship, they are grouped together in a Genus. The limits of genera are consequently by no means fixed, but vars according to the views of individual botanists. In the larger genera the species are grouped into Sub-genera.

The scientific name of every plant consists-on the plan introduced by Linnæus-of two words, the first indicating the name of 
the genus, and the second that of the species. Thus, for instance, the greater Plantain, Plantago major, and the Ribwort, Plantago lanceolata, are two species of the genus Plantago. Since in early times the same plants were often described under different names, and as different plants were often designated by the same name, it is necessary in systematic works, in order to avoid confusion, to append to the name of the plant the name of the botanist who is the authority for it. Thus Plantago lanceolutu L., indicates that Linnæus gave the plant this name, and at the same time that the plant meant is the one which Linnæus described and to which he gave the name. Again, the Spruce Fir is called Picea excelsa Link, while the same plant was placed by Linnæus in the genus Pinus under the name Pinus Abies L., and by De Candolle in the genus Abies (Don) as Abies excelsa DC.; hence these names are synonymous: but Pinus Abies Duroi, or Abies excelsa Link, is another plant altogether, the Silver Fir (Abies pectinata D C).

The method by which each plant has its place assigned to it in the natural system is exhibited in the two following examplesI. Plantago major; II. Agaricus muscırius :

I. Group: Phanerogamia.

Division : Angiospermæ.

Class: Dicotyledones.

Sub-class: Gamopetalæ.

Series: Hypogynæ.

Cohort: Lamiales.

Order: Plantaginaceæ.

Genus: Plantago.

Species : major.

II. Group : Thallophyta.

Class : Fungi.

Sub-class : Basidiomycetes.

Series: Autobasidiomycetes.

Order: Hymenomycetes.

Family: Agaricinæ.

Genus: Agaricus.

Sub-genus: Amanita.

Species : muscarius. 


\section{GROUP I.}

\section{THALLOPHYTA.}

THIS group includes the more lowly-organised plants. As already mentioned, the alternation of generations is here either irregular or wanting. When the alternation of generations is irregular, the irregularity is mainly due to the fact that the gametophyte is capable of reproducing itself, it may be through several successive generations, by means of asexually-produced reproductive cells (gonidia; see p. 3) : this production of gonidia by the gametophyte does not occur in any other group of plants, and in this group it frequently happens that a gametophyte which produces gonidia bears no sexual reproductive organs, and is, therefore, not an actual, but a potential gametophyte. When an alternation of generations is wanting, its absence may either be due to the fact that, as in the lowest Algæ and Fungi, sexual reproduction has not yet made its appearance; or it may be due to the fact that, as in certain Algæ (e.g. Spirogyra, Fucus, Chara), the product of the sexual process is a cell (zygospore or oospore; see p. 80), which gives rise directly to a gametophyte, so that no sporophyte is developed.

The morphology of these plants is such that the body, whether of the sexual or the asexual form, is generally a thallus, though in certain cases there are more or less distinct indications, especially in the gametophyte, of that differentiation of the body into root, stem, and leaf, which is so familiar in the sporophyte of the Pteridophyta and Phanerogamia. In those forms in which the sexual organs are differentiated, the female organ may be an oogonium, or a procarp, or an archicarp, but it is never an archegonium.

These plants are further characterised by the simplicity of their structure: the body may be unicellular, or cœnocytic and unseptate or incompletely septate (see p. 89), or it may be multicellular. One conspicuous structural feature (shared, however, with the Bryophyta), is the absence of lignified cell-walls, the cell-walls consisting generally of some form of cellulose, and being frequently mucilaginous. In the lower forms, vegetative reproduction by some mode of cell-division is not uncommon.

The division of the group into the two classes Algæ and Fungi appears to be artificial, inasmuch as it is based upon a single 
character, the presence (Algæ) or absence (Fungi) of chlorophyll. But the division is really natural, since this one character is correlated with various others. It is, indeed, becoming usual to regard the Algæ and the Fungi as altogether distinct groups : but it appears to be preferable to continue to regard them as classes of the group Thallophyta, inasmuch as the Fungi have doubtless arisen from the Algæ, and since they possess many features in common.

\section{Class I.-ALGA.}

These are plants of the simplest structure, which either live in water in the form of green, blue-green, red, or brownish filaments or masses of cells, or clothe damp surfaces such as rocks, walls, or the bark of trees, with a covering of one or other of these colours. In the sea they attain often a very considerable bulk; some of them are of a beautiful red or brown colour, and attract the attention of the observer, partly by their considerable size, and partly by the elegance of their form.

The most important feature in which the plants of this Class differ from the Fungi is the presence of chlorophyll and the consequent mode of life. The Algæ are able to form the organic substances necessary for their nutrition, whereas the Fungi are obliged to obtain them from other organisms. The presence of chlorophyll is obvious enough in the green Algæe, but it exists also, though less evidently, in Algæ which have a bluish-green, olivegreen, brown, or red colouring-matter in addition in their chromatophores. The nature of this additional colouring-matter is usually the same throughout whole families which also resemble each other in their modes of reproduction. Hence this characteristic affords a trustworthy basis for classification, on which the Algæ are divided into the following sub-classes :-

Sub-class 1: Cyanophyce (or Phycochromaceæ), blue-green Algæ, containing a blue colouring-matter phycocyanin;

2: Chlorophyces, green Algæ, containing only chlorophyll and its derivatives ;

3: Рндорнусеж, brown Algæ, containing a yellow or brown colouring-matter phycophoein;

" 4: RHODOPнyces, red Algæ, containing a red or purple colouring-matter phycoerythrin. 
The colouring-matters phycocyanin, phycophæin, and phycoerythrin, can be extracted by means of water; they thus differ from chlorophyll, which is insoluble in water. The presence of chlorophyll in the Cranophyceæ, Phæophyceæ, and Rhodophycex, can be proved by extracting the other colouring-matters with water; the plants then assume a green colour.

Structure. The body may be unicellular; or conocytic and unseptate (as in the Siphonaceæ), or incompletely septate (Cladophoraceæ); or multicellular. The unicellular forms either exist singly, or a number may be held together in a colony by a mucilaginous common cell-wall, either as a filament (e.g. some Desmidieæ) or a mass (palmelloid Protococcaceæ, Syngeneticæ, Chroococcaceæ). In some of the multicellular forms (e.g. Spirogyra, Pandorina, Ulva) all the cells of the body are quite similar; at first regetative, they eventually become reproductive, so that there is no ristinction between nutritive and reproductive cells: in these histologically undifferentiated forms the body is a conobium (see p. 92). Even the most highly organised forms attain but a low legree of histological differentiation, amounting (as e.g. in the Fucaceæ) only to a distinction between peripheral assimilatory tissue and central conducting tissue : in some of the Laminariaceæ the conducting-tissue has the form of sieve-tubes.

Morpholog!y. The body may be entirely undifferentiated; this condition is most common in the unicellular forms, but it also occurs among the multicellular (e.g. Volvox); or it may present. a distinction of base and apex (e.g. Rivularia); or it may be differentiated into root and thalloid shoot (e.g. Botrydium, Fucus); or into root, stem, and leaf (e.g. Caulerpa, Cladostephus, Sargassum, Chara, Polysiphonia).

The undifferentiated body (thallus), as also the thalloid shoot, presents great variety of form : it may be spherical, or filamentous, or a flattened expansion, and its symmetry may be multilateral, isobilateral, or dorsiventral.

The growth in length of the thallns or of the shoot is effected in a variety of ways. It may be either apical or intercalary. In cellular plants the apical growth is effected either by a single apical cell (e.g. Characeæ, Sphacelarieæ, Fucaceæ, Dictyota, Fig. 140 , most Rhodophyceæ); or by a marginal series of apical cells (e.g. Coleochæteæ, some flattened Rhodophyceæ); whereas in those coenocytic plants (Siphonoideæ) which grow apically, there is no apical cell, but an apical mass of embryonic protoplasm. In some cases of intercalary growth there is no growing-point, all the cells 
of the body being merismatic (e.g. Spirogyra, Ulothrix, Ulva); in other cases there is a definite intercalary growing.point, as in Laminaria (Fig. 159) and other Phæophyceæ, in some of which growth is tricliothallic, that is the shoot terminates in a single multicellular hair (e.g. Desmarestia, Fig. 160), or in several hairs (e.g. Cutleria), or in a tuft of hairs (e.g. Carpomitra Cabrerce), and towards the base of each such hair lie the merismatic cells which constitute the intercalary growing - point. In some few cases (e.g. Volvocoideæ, Botry. dium) there is no growth after the embryo-stage, as the whole protoplasm of the body passes over into the adult condition.

The primary root is never developed in dne proportion to the shoot; consequently, in order to ensure the attachment of the plant, adventitious roots are very commonly formed on the shoot, and when the shoot is dorsiventral unicellular root-hairs are commonly developed on the surface in contact with the substratum. In some cases special organs of attachment (haptera,

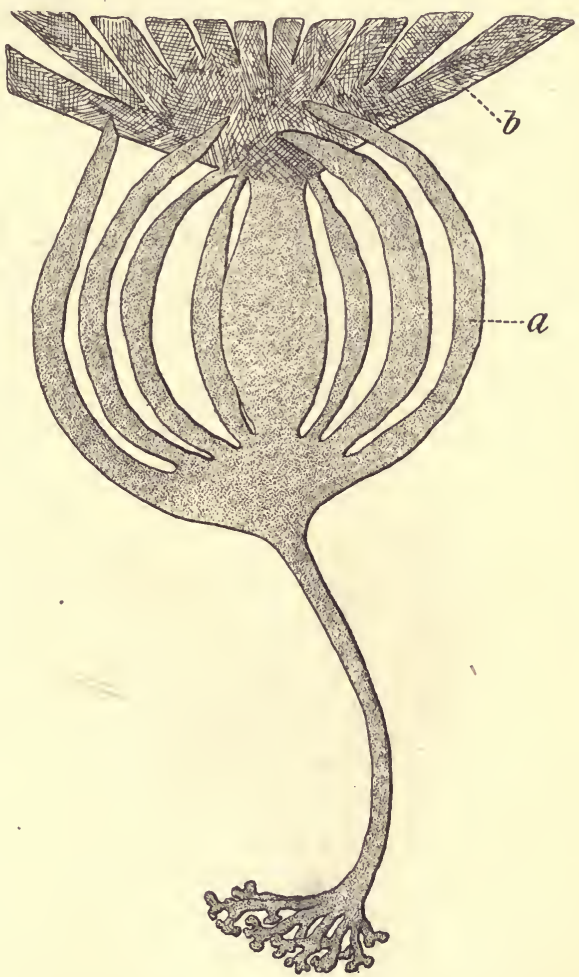

Fig. 159.-Laminaria di,itata (after Harvey; much reduced). The intercalary growing-point is situated at the junction of the old frond $(b)$ with the new frond (a); $a$ is gradually splitting into segments.

see p. 66) are developed on the shoot; they may be adhesive discs borne on the ends of branches of the shoot (e.g. Plocamium coccineum), or root-like out-growths as in Laminaria bulbosa, where at the base of the shoot, a large umbrella-shaped out-growth is formed, bearing numerous haptera on its upper and outer surface. 
The leaves vary in form. In some cases (e.g. Caulerpa, Fig. 162; Sargassum) they resemble the foliage-leaves of the higher

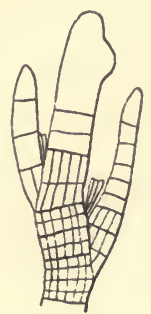

A.

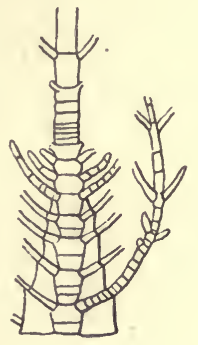

B.

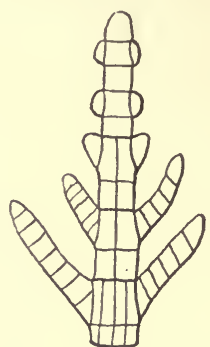

$C$.

F1G. 160.-Growing-points of Algæ. A apical growing-point, with apical cell, of Stypocaulon scoparium $(\times 30)$. B intercalary trichothallic growing-point (where the transverse lines are close together) of Desmarestia ligulata in longitudinal section $(\times 60)$. $C$ apical growing-point, with apical cell, of Chatopteris plumosa ( $\times 40$ ) (after Falkenberg).

plants; in others, (e.g. Cladostephus, Chara) they resemble the stem and its branches, but are distinguished by their limited

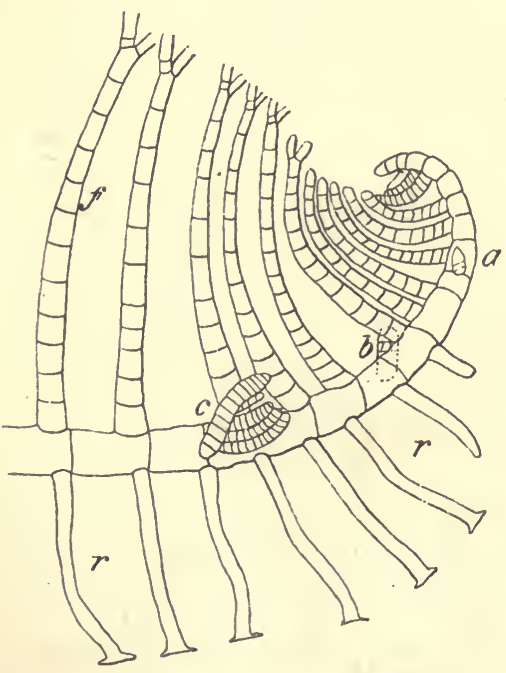

FIG. 161.-Polysiphonia (Herposiphonia) (after Naegeli). The dorsiventral horizontal stem bears the leaves $(f)$ on the dorsal surface; the root-hairs $(r)$ on the vertral surface; and the branches $(a b c)$ on the flanks. growth ; in others again (e.g. Polysiphonia and other Rhodophyceæ, Fig. 161), they are filamentous and hair-like.

The morphology of the reproductive organs is discussed in connexion with the processes of reproduction.

The Reproduction of the Algæ is effected in various ways. Vegetative multiplication takes place in the unicellular forms (e.g. Cyanophyceæ, Protococcoideæ, Desmidieæ, etc.) by cell-division, in some of the higher forms (e.g. Sphacelaria, Chara, Melobesia) by means of multicellular gemmæ (see p. 68). Non-motile cells, with a cellwall, which are probably gemmæ, are thrown off by 
Monospora (Rhodophyceæ), and by Vaucheria geminata, and sometimes by other species of Vaucheria (Chlorophyceæ). Reproduction by means of asexually-produced spores or gonidia occurs with but few exceptions (e.g. Conjugatæ, Fucaceæ, Characeæ). Sexual reproduction is general throughout the class, though it has not yet been observed in all forms; it appears to be definitively absent in the Cyanophyceæ, and in some of the lower Chlorophyceæ (e.g. some unicellular Protococcoideæ) and Phæophyceæ' (Syngeneticæ).

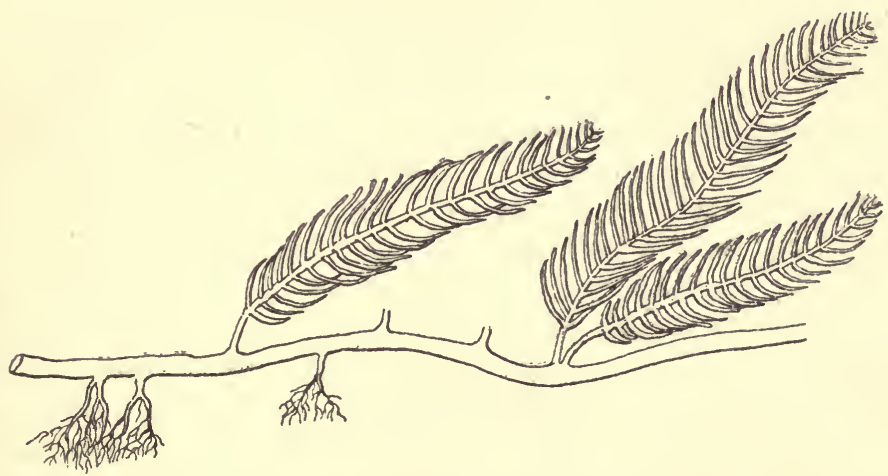

Fig. 162.-A portion of the body of Caulerpa plumaris showing dorsiventral arrangement of members. The horizontal stem bears leaves on its upper (dorsal) surface, and roots on its lower (ventral) surface.

There are various modes of sexual reproduction in the group. The following is an enumeration of them (see also p. 80) :-

I. Isogamy: the sexual cells are similar gametes; process, conjugation; product, a zygospore.

(a) Gametes ciliated (planogametes); set free; e.g. Ulothrix, Pandorina, Ectocarpus, Cutleria.

(b) Gametes not ciliated (aplanogametes); not set free in the Conjugatæ; set free in the Diatomaceæ.

II. Heterogamy :

(a) Oogamy: the female organ is an oogonium; the sexual cells are spermatozoids and oospheres, the former ciliated and free-swimming, the latter not ciliated but sometimes free-floating; process, fertilisation; product, an oospore; (e.g. Volvox, Vaucheria, Edogonium, Coleochæte, Characeæ, Fucaceæ).

(b) Carpogamy; the female organ is a procarp in which no female cell is differentiated; male cell free, not ciliated, a sperma-

v. s. B. 
tium; process, fertilisation; product, a fructification termed a cystocarp (Rhodophyceæ).

The evolution of sexuality can be well traced in the Algæ. Thas in Ulothrix (Confervoideæ) two kinds of zoogonidia are produced, microzoogonidia which are small, macrozoogonidia which are larger; the latter always germinate independently, but the microzoogonidia conjugate in pairs to form a zygospore, though, if they fail to conjugate, they are capable of independent germination; they are, in fact, imperfectly sexual gametes. In Ectocarpus (Phæosporeæ) also the sexuality of the gametes is imperfect. In most cases the microzoogonidia are incapable of independent germination, and are therefore completely sexual cells (planogametes).

The tvolution of sex can also be well traced in the Algæ by a comparison of the sexual cells of the higher and lower forms. In Ulothrix, for instance, the gametes are similar both in their form and in the part which they take in the sexual process. In Ectocarpus the gametes are externally similar, but they do not behave alike in the process of conjugation, for some come to rest, whilst others remain motile, as a preliminary to that process which consists in the fusion of a motile with a resting gamete; hence the former is considered to be male, the latter to be female. In Cutleria the gametes differ in size, and, though they are all motile at first, the larger gametes soon come to rest when conjugation follows; in this case difference of sex is indicated from the first by the larger size of the female gametes. In Fucus the differentiation is carried still further, in that the female gamete (now called an oosphere) is not ciliated nor motile, and is much larger than the motile male gamete (now called a spermatozoid); but both cells are extruded, from the organs in which they are formed, into the water. In the typical oogamous forms (e.g. Vaucheria, Coleochæte, Volvox, Chara) there is the further and final stage of sexual differentiation, that the oosphere is not extruded, but remains in the female organ (oogonium), whereas the spermatozoids are set free, and, still retaining the character of planogametes, swim by means of cilia, nltimately entering the oogonium and fertilising the oosphere.

Sexual difference may, however, exist without being accompanied by any external differentiation. For instance, the sexual cells of Acetabularia, Ulothrix, and Dasycladus, are in each case externally similar planogametes; but conjugation only takes place in Acetabularia and Ulothrix, between planogametes de- 
rived from distinct gametangia ; and in Dasycladus, only between planogametes derived from gametangia borne by distinct individuals. Hence it appears that the planogametes formed in any one gametangium of Acetabularia or of Ulothrix are all of the same sex; and, similarly, that the planogametes produced by any one individual of Dasycladus are all of the same sex; but, in the absence of any external differentiation, it is impossible to distinguish between the male and the female planogametes.

The sexual cells are aplanogametes, planogametes, oospheres, and spermatozoids (see p. 80); though they differ widely in various respects, they agree in being nucleated masses of protoplasm destitute of a proper cell-wall.

The aplanogametes are characterised by the absence of cilia and of any defined form; they are confined to the Conjugatæ and Diatomaceæ.

The planogametes are somewhat pear-shaped, the anterior more pointed end being destitute of the chromatophores which are present in the more rounded portion: They have two cilia which are inserted, in the isogamous Chlorophyceæ, at the pointed end of the cell ; in the isogamous Phæophyceæ, laterally at the junction of the anterior colourless portion with the posterior coloured portion of the cell. In conjugation, the planogametes first come into contact by their colourless anterior ends. Like the zoospores, the planogametes have commonly a red pigment-spot (see p. 102).

The oospheres are spherical cells, usually containing chromatophores either throughout their whole substance, or leaving a colourless area on one side, the rereptive spot, at which the spermatozoid enters in the process of fertilisation (e.g. Edogonium, Vaucheria, Sphæroplea; see p. 116).

The spermatozoids may be somewhat pear-shaped, resembling the zoogonidia of the plant, but smaller (e.g. Coleochæte, Edogonium); or they may be more elongated and club-shaped (e.g. Sphæroplea, Volvox); or still more elongated and spirally twisted (Characeæ). They usually bear two cilia at the pointed end; but in Vaucheria, Volvox, and the Fucaceæ, they are inserted laterally; in Eidogonium there is a circlet of cilia round the pointed colourless end. They are faintly coloured, in the Chlorophyceæ usually yellow; they sometimes have a red pigment-spot near the insertion of the cilia (e.g. Volvox, Fucacex).

The male cells of the Floridew and of the Dictyotaceæ are peculiar on account of the absence of cilia, and are distinguished 
by the special name spermatia. The spermatia of the Florideæ surround themselves with a proper wall at the time of fertilisation.

The sexual organs. In those Algæ in which the sexual cells are similar, and the sexual process is isogamous, the sexual organs are gametangia. In many cases they are unicellular and undifferentiated: thus, when the gametophyte is unicellular (e.g. Desmidieæ, Diatomaceæ) the cell itself constitutes the gametangium; and in some multicellular or cœnocytic forms (e.g. Zygnemeæ, Hydrodictyon, Confervoideæ) the gametangia are simply ordinary vegetative cells or cœnocytes. In some isogamous Algæ, however, the gametangia are differentiated as lateral appendages, and are multicellular, as in the Phæosporeæ; in Cutleria it is even possible to distinguish the male from the female gametangium.

When the gametangium is unicellular or cœnocytic, it usually gives rise to a number of gametes; but in the Conjugatæ a single gamete is formed. When the gametangium is multicellular, each cell usually gives rise to a single gamete; but in the male gametangium of Cutleria 2-8 gametes are developed in each cell.

The female organ, the oogonium, is in all cases unicellular or a cœnocyte; in Sphæroplea it is undifferentiated, retaining the form of a vegetative segment of the incompletely septate plant; in most cases it is more or less spherical in form, and in some species of Coleochrte it is prolonged at the apex into a delicate tube, the trichogyne. It opens, in most cases, by the absorption of the wall, at a point opposite the receptive spot of the oosphere when that is present; but in others (e.g. Volvox, Chara) it remains closed. In the former case the spermatozoid enters by the aperture; in the latter, it bores its way through the wall of the oogonium which becomes mucilaginous at its exposed surface. The oogonium of the Fucaceæ, Dictyotaceæ, and Tilopteridaceæ, ruptures and sets free the contained female cell or cells. Usually a single female cell (oosphere) is formed in an oogonium, by the rejuvenescence of its protoplasmic contents; but in various Fucaceæ, the protoplasm divides to form two, four, or eight oospheres, and in the cœnocytic oogonium of Sphæroplea there are several oospheres.

The female organ of the Rhodophyceæ, the procarp, is sometimes unicellular (e.g. Nemalieæ), but more commonly multicellular. It is in nearly all cases prolonged into a trichogyne, the basal portion being termed the carpogonium. The trichogyne remains closed. The protoplasm of the procarp does not undergo 
differentiation into a female cell comparable with the oosphere of the oogonium.

The male organ, the antheridium, is with few exceptions (e.g. Sphæroplæa) more or less differentiated in form, attaining its highest development in the Characeæ. It is usually nnicellular; but in Edogonium it consists of two cells, and of many in the Characew where its structure is highly complex. When the antheridium is unicellular, it usually gives rise to a number of male cells, but in Coleochæte and most Rhodophyceæ only to one. When it is multicellular, each fertile cell gives rise to a single spermatozoid.

Sexual organs are not known in the following forms: Cyanophyceæ, some Protococcoideæ, some Siphonaceæ, Syngeneticæ, some Phæosporeæ (e.g. Desmarestia; Laminariaceæ, except Chorda).

The asexual reproductive cells of the Algæ are formed either sexually or asexually: the former are either zygospores, or oospores; the latter are spores, those produced by the gametophyte (when this is the case) being distinguished as gonidia.

The zygospores and oospores occur exclusively in the Chlorophyceæ and Phæophyceæ: they are spherical nucleated cells with a cell-wall. The differentiation of the cell-wall varies with the nature of the spores and of the conditions to which they are likely to be exposed. In the Phæophyceæ the zygospore or the oospore germinates at once on its formation, and its wall remains thin, and consists only of a single layer. In the Chlorophyceæ, the sexually produced spore (except in Botrydium under favourable conditions) undergoes a period of quiescence before it germinates, and, except in marine forms (e.g. Acetabularia, Dasycladus), it is exposed during this period to the danger of desiccation. As a protection, its wall consists of two layers (see p. 69), a delicate endospore, and a hard cuticularised exospore, which often grows out into prominences, giving to the spore a stellate appearance.

The spores produced asexually by the sporophyte may be resting-spores with a thick wall, which may consist of two layers as described above (e.g. many Cyanophyceæ), or cells destitute of a cell-wall, either ciliated (e.g. zoospores of CEdogonium, Coleochæte, Sphæroplæa, Pandorina), or not ciliated (e.g. carpospores of the Rhodophyceæ).

The gonidia produced by the gametophyte are never " restingspores," but are destitute of a cell-wall, and are either ciliated (e.g. zoogonidia of Vaucheria, Edogonium, Coleochæte, Ulothrix, 
Ectocarpus), or not ciliated (e.g. tetragonidia of the Rhodophyсеæ).

The asexual repoductive organs are termed gonidangia when borne by the gametophyte, and sporangia when borne by the sporophyte. In the simple unicellular forms, the whole body may become a sporangium (e.g. Hæmatococcus): in some cœnobitic multicellular plants, there are no definite asexual reproductive organs, but any of the cells of the body may act as such (e.g. Ulothrix, Pandorina, Coleochæte, Ulva) without any special morphological differentiation; this is true likewise of the cœnocytic Algæ (Siphonoideæ, such as Botrydium, Vaucheria, Sphæroplea, Cladophora) where the whole or part of the body may act as a gonidangium. Specially differentiated gonidangia occur only in some Phæosporeæ, and in the Rhodophyceæ where they usually produce each four gonidia (tetragonidia) and are hence termed tetragonidangia: specially differentiated sporangia are developed in the sporophyte (cystocarp) of the Rhodophyceæ where they are termed carposporangia, and probably also in some Phæosporeæ: these organs are in all cases unicellular.

In the Cyanophyceæ the formation of spores is effected without any sporangium, for in these plants a cell of the body is converted into a spore by simple encystment.

As a rule a sporangium (or a gonidangium) gives rise to a number of spores (or gonidia); but only one gonidium is formed in the gonidangium of Vaucheria (see p. 115) and of Edogonium, and one spore in the carposporangium of the Rhodophyceæ.

The Life-History of the Algo. No alternation of generations can, of course, be traced in those Algæ, already enumerated, in which either asexual or sexual reproduction is unknown. In those in which both these modes of reproduction occur on distinct forms, there is usually an indication of alternation of generations, though it has not been traced in all cases. Thus, in most Chlorophyceæ, there is an alternation of this sort (e.g. Ulothrix, Pandorina, (Edogonium, Sphæroplea), that the zygospore or oospore represents the sporophyte, constituting in fact a unicellular sporanginm which produces two or four zoospores which, on germination, give rise to gametophytes. In Coleochæte the oospore undergoes celldivision, forming a small multicellular sporophyte each cell of which eventually gives rise to a zoospore.

In the Phæophyceæ, an alternation of generations appears to occur in the Cutleriaceæ, and. possibly in some other forms. The 
zygospore, on germination, gives rise to a plant, more or less resembling the gametophyte, which bears only asexual reproductive organs (zoosporangia) and is therefore the sporophyte.

In the Rhodophyceæ, there is an alternation of generations, the plant being the gametophyte (either actual or potential); the fructification (cystocarp) dereloped from the fertilised female organ (procarp) being the sporophyte. The spores of the sporophyte (carpospores) give rise on germination tơ gametophytes.

In discussing the alternation of generations of the Algæ, it must be borne in mind that the gametophyte can, in many cases, reproduce itself by means of gonidia, and that it may not always bear sexual organs: that it may be, in fact, a potential gametophyte. Instances of this occur in Coleochæte, the Rhodophyceæ, and others:

Other forms of polymorphism are of frequent occurrence, as int the Cyanophyceæ, Confervoideæ, Batrachospermum, Lemanea, Characeæ (see p. 14). Details of these are given in the special descriptions of the various families, in which also a more detailed account of the alternation of generations will be found.

Sub-Class I. Cranopiryde (also called Phycochromaceæ), or blue-green Algæ. The body consists of a single, more or less nearly spherical cell, as in most of the Chroococcaceæ (e.g. Glœocapsa, Fig. 163); or it is a multicellular layer one cell thick (e.g. Merismopedia); or it is filamentous; consisting of a row of cells (e.g: Oscillaria; Nostoc, Rivularia, Scytonema). When the body is filamentous, it sometimes presents a distinction of base and apex (e.g. Rivularia); and it is frequently branched, the branching being either spurious (e.g. Rivularia, Scytonemeæ) or true (i.e. formation of lateral growing-points, e.g. Sirosiphoneæ). In most cases growth and cell-division go on in all the cells of the body, but in the Scytonemaceæ only at the apex. The plant is usually free, but it grows attached in some species of Rivulariaceæ and Scytonemaceæ. A characteristic feature of the sub-class is the more or less bulky mucilaginous cell-wall which invests the cells and filaments. The filaments of the Oscillariaceæ exhibit a gliding, oscillating movement, but the mechanism of it is not fully understood.

Reproduction is mainly effected in a purely vegetative manner. In the unicellular forms (Fig. 163) each cell-division necessarily leads to the formation of new individuals. In the flattened forms (e.g. Merismopedia), when the body reaches a certain limit of size, 
it simply breaks up into a number of portions each of which becomes a now individual. In the filamentous forms, vegetative

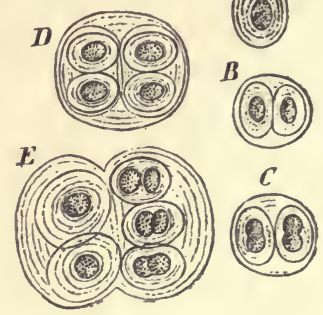

FIG. 163.-Glooocapsa $(\times 300)$ in various stages. $A$ becomes $B C D E$ by repeated division. (From Sachs.)

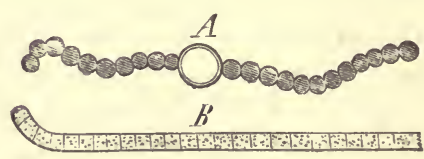

Fig. 161.- $A$ filament of Nostoc; the large unshaded cell is a heterocyst; $B$ portion of a filament of Oscillaria $(x 300)$.

propagation is effected by the breaking up of the filament into lengths, each such portion being termed a liormogonium; in most of them (except Oscillariaceæ) the limits of the hormogonia are indicated by large inert cells, heterocysts (Fig. 164 A), which differ both in size and colour from the living cells of the filament. The hormogonia are motile, though the mechanism of their morements is not understood; they eventually separate, and, escaping from
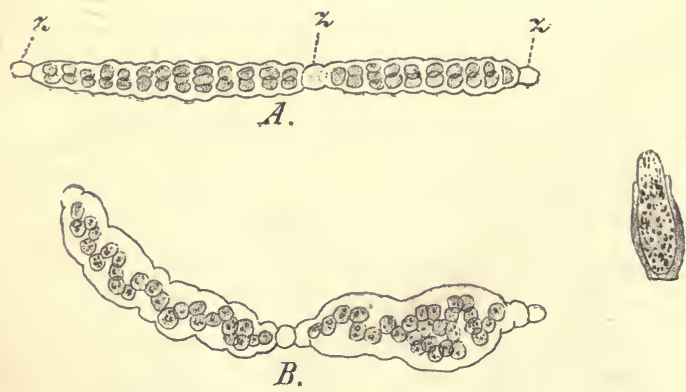

Fig. 165.-(After Thuret: $\times 330$ ), $A$ and $B$ development of a filament from a hormogonium of Nostoc vesicarium. A cells of hormogonium dividing at right angles to its long axis; $B$ rows of cells formed as in $A$ uniting at alternate ends, so as to constitute a Nostocfilament; $z$ heterocssts; $C$ germinating spores of Anabana licheniformis.

the common mucilaginous cell-wall of the filament, they develope by growth and cell-division into new filaments (Fig. $165 \mathrm{~A} \mathrm{~B}$ ).

In many cases special reproductive cells, spores, are produced. 
Each spore is formed from a single cell of the body, which surrounds itself with a thick firm exospore; the spore germinates under favourable conditions, the exospore being ruptured (Fig. $165 C$ ).

It is possible that zoospores are produced in some forms, but the evidence is at present inconclusive. No form of sexual reproduction has been observed in any member of this sub-class.

The cells of the Cyanophyceæ are nucleated, but the chlorophyll and the phycocyanin appear to be diffused throughout the cytoplasm, and not to be aggregated in special plastids.

The Cyanophycer are classified as follows :-

Order 1. Chroococcaceæ. Unicellular : spores formed.

Order 2. Nostocaceæ. Filamentous; filaments with heterocysts, without distinction of base and apex, wavy, unbranched; growth intercalary ; reproduction by hormogouia and spores (Fig. 165).

Order 3. Oscillariaceæ. Filamentous : filaments isolated, motile, without heterocysts, withont distinction of base and apex, straight, rigid, unbranched; growth intercalury; reproduction by hormogonia; no spores.

Order 4. Rivulariaceæ. Filamentous: filaments with heterocysts, and distinction of base and apex, spuriously branched; growth intercalary; reproduction by hormogonia and spores.

Order 5. Scytonemaceæ. Filamentous: filaments with heterocysts, with distinction of base and apex in some forms (Sirosiphoneæ) but not in others (Scytonemeæ), branched spuriously (Scytonemeæ) or truly (Sirosiphoneæ), gronth apical (both ends in Scytonemeæ); reproduction by hormogonia and spores.

It is doubtful to what extent these orders really represent distinct forms, for there is evidence that some Cyanophyceæ assums the different forms characteristic of these orders at various stages in their development, and under various external conditions, that is, that some at least of the Cyanophyceæ are polymorphic, and this renders their classitication uncertain.

The Cyanophyceæ resemble the Schizomycetes, among the Fungi, in many respects; as, for instance, in their general form and structure, in their vegetative multiplication, in their spore-formation, in the absence of sexual reproduction, in the formation of a bulky mucilaginous cell-wall, and in their polymorphism. On these grounds they are frequently placed, along with the Schizomycetes, in a distinct class Schizophyta. But this arrangement does not seem to secure any special advantage. It is more natural to regard the Cyanophyceæ and the Schizomycetes as parallel groups, the one belonging to the Algæ, the other to the Fungi.

Some of the Cyanophycer are endophytic, that is, they inhabit the 
tissues of higher plants ; thus, Nostoc is constantly found in the tissue of certain Hepaticæ (Blasia and Anthoceros), in the porous cells of the leaves of Sphagnum (Moss), and in the tissue of the stem of Gunnera (Dicotyledon).

The Cyanophyceæ are both marine and fresh-water: many grow on damp walls, rocks, etc.

Sub-Class II. ChLorophyces, or Green Algæ. In the simpler forms the plant (that is, the gametophyte in all species which are sexual) consists of a single cell (e.g. Protococcoideæ, some Desmidieæ); or it is cuenocytic, as in the Siphonoideæ, either unseptate (Siphonaceæ) or incompletely septate (Cladophoraceæ, Hydrodictyaceæ); it is, in fact, only in this sub-class that the cœnocytic structure occurs among the Algæ; or the body, is multicellular, with essentially similar cells and therefore cœnobitic (e.g. Spirogyra, Pandorina, Ulva), or exhibiting at least a distinction between vegetative and reproductive cells (e.g. Volvox, Chara). The only members of the sub-class in which there is any appreciable differentiation of the vegetative cells are the Characeæ.

The body presents all degrees of morphological differentiation; it may be a thallus, either spherical (e.g. Hæmatococcus, Volrox), or filamentous (e.g. Spirogyra, Ulothrix), or a flattened expansion (e.g. Ulva, Coleochæte); or a filament with rudimentary differentiation into root and shoot (e.g. (Edogonium); or it may present differentiation into stem, leaf, and root (e.g. Caulerpa, Fig. 162, Characeæ). It may be free or attached. Growth and cell-division conimonly go on in all the cells of the body, so that the growth is intercalary (e.g. Spirogyra, Edogonium, Ulva); it is but rarely that there is a definite growing-point, and then it is apical (Coleochæte, Characeæ, some Siphonoideæ); and in the cellular plants which have an apical growing-point, there is a single apical cell.

The sporophyte is very simple, both histologically and morphologically, in this sub-class. In most cases it is represented by the sexually'produced spore (e.g. Pandorina, CEdogonium, Sphæroplea) the contents of which undergo division, and, on germination, are set free as zoospores. In Coleochæte alone does the oospore undergo division with the formation of septa, so that the sporophyte is multicellular, but even in this case is quite rudimentary.

Vegetative multiplication by division occurs in some of the lower forms (e.g. Protococcoideæ) of this sub-class. Reproduction by zoospores and zoogoniaia is general (absent in Pleurococcaceæ, Conjugatæ, most Volvocoideæ, Characeæ); they are formed, not in 
specialised reproductive organs, but in any cell or part of the body. A sexual process has been observed in members of every division of this sub-class : it is either isogamous, consisting in the fusion of planogametes or aplanogametes (Conjugatæ), with the formation of a zygospore; or oogamous, consisting in the fertilisation of an oosphere, which is in no case extruded from the female organ, by a spermatozoid, with the formation of an oospore. The sexual organs are either gametangia, or antheridia and oogonia; they are unicellular in all the cellular forms (except the antheridium of Characeæ and that of some species of (Edogonium), and present various degrees of specialisation. A gametangium gives rise to many planogametes, but to not more than one aplanogamete; the oogonium produces but a single oosphere, except in the cœnocytic Sphæroplea; the unicellular (as also the conocytic) antheridium gives rise to numerous spermatozoids, except in Colenchæte and in some species of Cdogonium where it forms only one; in the multicellular antheridium of the Characeæ, numerous spermatozoids are developed singly in distinct mother-cells (see p. 115).

In those Chlorophyceæ in which both sexual and asexual sporeformation takes place, the life-history generally presents an alternation of generations.. There is, in addition to this, considerable polymorphism in many members of the sub-class, so that various forms which are considered to be independent members of the simpler families are now known to be merely phases in the lifehistory of more complex forms; for instance, various unicellular forms, such as Protococcus, Palmella, Glœocystis, etc., formerly classed among the Protococcaceæ, are now known to be stages in the life-history of other Protococcoideæ, Confervoideæ, Siphonoideæ, etc.

The Chlorophycer may be classified as follows :-

Series I. Protococcoideæ : plants unicellular, isolated or held together by mucilaginous cell-walls into colonies; non-motile; the body is a thallus, and has no apical growth; reproduction, vegetative by division, asexual by zoospores, rarely sexual and isogamous with conjugation of planogametes.

Series II. Volvocoideæ: plants unicellular or multicellular, and when multicellular not filamentous; not attached, motile by means of cilia; the body is a thallus, with limited growth; reproduction, vegetative by division, a sexual by zoospores, no zoogonidia; sexual, either isogamous with conjugation of planogametes, or oogamous.

Series III. Siphonoideæ : plants cœnocytic, unseptate or incompletely septate ; non-motile; the body may be a thallus or may be differentiated into stem, leaf, and root; with or without apical growth; reproduction, asexual by 
zoogonidia and zoospores; sexual, either isogamous (planogametes), or oogamous.

Series IV. Confervoideæ : plants generally multicellular, filamentous, branched or unbranched; growth frequently intercalary, rarely apical ; body attached or floating, a thallus, or sometimes with rudimentary differentiation into root and shoot; reproduction, asexual by zoogonidia and zoospores, in some cases; sexual, isogamous (either planogametes or aplanogametes), or oogamous.

Series V. Charoideæ: plants multicellular; body attached, differentiated into stem (with apical growth), leaf, and root; reproduction, vegetative by gemmæ, no zoogonidia or zoospores; sexual, oogamous, with multicellular antheridium of complex structure.

Series I. Pвотососcoidex. The forms included in this series are very various, and, inasmuch as their life-history is for the most part imperfectly known, it is uncertain to what extent they are independent, or are only phases in the life-history of each other or of higher Chlorophyceæ. It appears, however, that they may be fairly classified into two orders:-

Order 1. Pleurococcaceæ: cells isolated, or aggregated into colonies of more or less definite form; multiply only by cell-division; no other mode of reproduction.

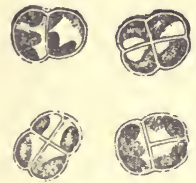

Fig. 166.-Pleurococcus vulgaris $(\times 540)$ : cells dividing.

To this order belong such isolated forms as Pleurococcus, Oocystis, and Eremosphæra ; and such aggregate forms as Palmophyllum, Palmodictyon, Scenedesmus. They generally grow in fresh water; but Pleurococcus grows on damp trees, stones, etc., and Palmophyllum is marine.

Order 2. Protococcaceæ : cells isolated, or aggregated into colonies of more or less definite form ; multiplication by cell-division is not general; reproduction, asexual by zoospores, or, less commonly, sexual isogamous (planogametes).

This order includes (1) isolated unicellular forms, either free, such as Chlorococcum, Halesphæra; or attacted at one end, such as Sciadium, Characium; or inhabiting the tissues of higher plants, such as Chlorochytrium, Phyllobium, Endosphæra; (2) cells aggreyated into mucilaginous masses cf indeterminate form, e.g. Chlorosphæra which lies in or on submerged freshwater-plants; (3) cells aggregated into mucilaginous masses of determinate form, the whole colony being generally attached at some definite point (e.g. Apiocystis, Tetraspora, Palmodactylon, Mischococcus, Hormotila, Oocardium), or free-floating (e.y. Dictyosphærium, Botryococcus).

In some of these forms there is what is termed a Palmella-stage, in which the cells multiply by division, surrounded by mucilage (e.g. Hormotila, Characium).

Isogamous reproduction by means of planogametes is known in Tetraspora, Mischococcus, Chlorochytrium, Endosphæra, Phyllobium. The zygospore, on germination, usually gives rise to one or two zoospores; but in the endophytic forms (Chlorochytrium, Phyllobium, Endosphæra) the still motile product of conjugation, the zygozoospore, penetrates into the tissues of its future host, 
and, surrounding itself with a cell-wall, directly constitutes itself a new individual.

Series II. Vouvocordex. The body, in this series, is free-swimming for at least a considerable portion of its life, and consists of one or more cells clothed with a somewhat mucilaginons cell-wall, through which the cilia (usually two from each cell) project into the water. According to the unicellular or multicellular structure of the body, two orders may be distinguished :-

Order 1. Chlamydomonadaceæ: body a single cell, resembling in many cases a zoospore in appearance, but differing essentially from it in possessing a cell-wall; some forms have a resting Palmella-stage, in which they multiply by division; sexual process, generally isogamous with fusion of planogametes, but sometimes in Chlamydomonas it is really oogamous, consisting in the fusion of a small (male) aplanogamete with a larger (female) aplanogamete; the reproductive cells (planogametes or aplanogametes) are formed by division; the zygospore represents the sporophyte, and generally gives rise, on germination, to two or four motile or non. motile individuals.

The principal genera are Chlamydomonas, Hæmatococcus (or Sphærella), Phacotus.

Order 2. Volvocaceæ: body multicellular, consisting of a definite or an indefinite number of cells, which may be all alike (cœnobium), or there may be a distinction between vegetative and reproductive cells; vegetative reproduction, by division of any or all of the cells of the body, or of certain special gonidial cells (Volrox), from each of which a new individnal is formed; sexual reproduction, isogamous by planogametes, or oogamous.

The order may be divided into

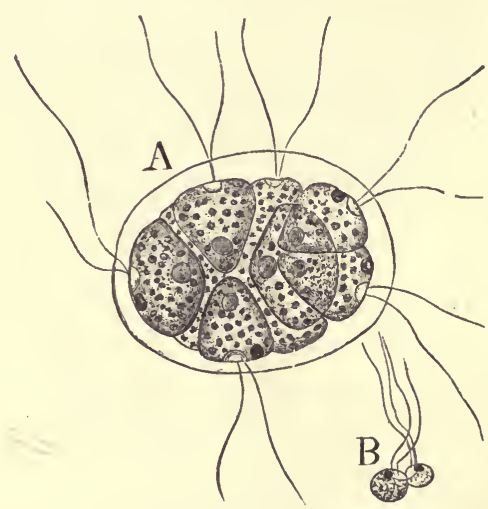

Frg. 167.-Pandorina Morum ( × 400), A vegetative stage. $B$ two planogametes in process of conjugation. two families in accordance with the nature of the sexual process:

Fam. 1. Pandorinea : sexual process isogamous; body a cœnobium consisting of a definite number (usually 16 in Gonium and Pandorina, and 8 in Stephanosphæra) of cells; any of the cells may divide to form a new individual, or to form planogametes; the zygospore (at least in Pandorina) representing the sporophyte, sets free one or two zoospores on germination.

The body of Pandorina is a solid sphere (Fig. 167); that of Gonium is a flat, square plate of cells ; that of Stephanosphæra consists of a zone of cells lying on the equator of the more or less nearly spherical mucilaginous common cell-wall.

Fam. 2. Eudorinea : sexual process oogamous; body, a hollow sphere, either a coenobium consisting of a definite number (generally 32) of cells (Eudorina); or consisting of a very large number of cells, some of which are specially 
differentiated as reproductive organs (Volvox). Eudorina is diœecious, the cells of the body of any one individual becoming either all oogonia or all antheridia; Volvox is sometimes monœcious, sometimes diœeious. The contents of the oospore undergo repeated bipartition until the requisite number of cells to form a new individual is attained. The vegetative development of new individuals from the body-cells of Eudorina, and from the special gonidial cells of

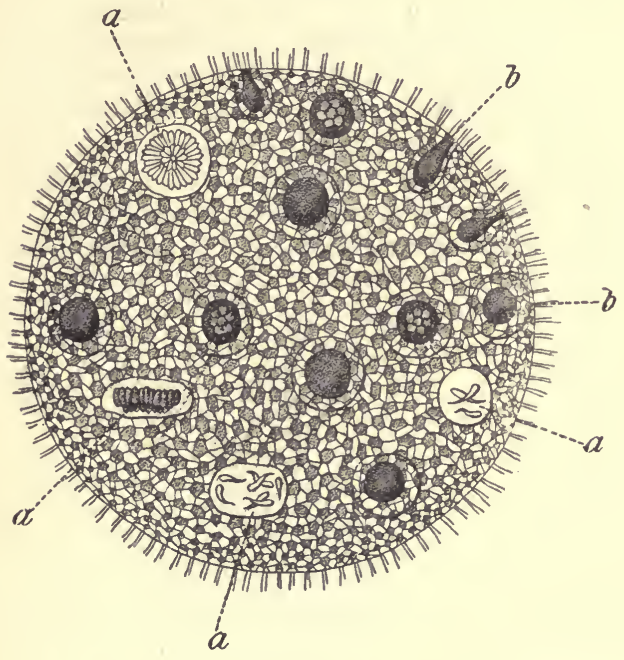

Frg. 168. - Volvox Globator (after Cohn; $\times$ about 100), monuscious, with antheridia $a$, and oogonia $b$.
Tolvox, takes place in precisely the same way as the development from the oospore. In Volvox. the small indiciduals formed vegetatively from the gonidial cells are set free into the cavity of the parent, where they remain until it dies, when they are set free. Thie spermatozoids of Volvox and Eudorina are clubshaped, yellow, with a red eye-spot (see p. 1(2), and bear two cilia, either at the pointed end (Eudorina), or inserted laterally (Volvox).

Series III. SiphonorDEA. The forms included in this series may be arranged in the three following orders :-Siphonaceæ, Cladophoraceæ, Hydrodictyaceæ.

Order 1. Siphonaceæ. The body is an unseptate cœnocyte, septa being only formed in connexion with the development of reproductive organs; it is usually attached, and presents a considerable variety of form ; it may be thalloid and then be tubular and much branched (usually in Vaucheria, Fig. 169, Phyllosiphon); or it may be differentiated into root and shoot, the shoot assuming various forms, such as a rounded cushion (Codium Bursa), or a simple vesicle (Botrydium, Fig. 171); or the shoot may be differentiated into stem and leaf (Acetabularia, Fig. 170, Bryopsis, Caulerpa. Fig. 162); it has sometimes continuous apical growth (e.g. Vaucheria); the wall is sometimes impregnated with chalk (e.g. Halimeda, Acetabularia).

Asexual reproduction is known to take place in only a few forms: it is effected by zoogonidia in Botrydium, where they are uniciliate; in Vaucheria, where they are multiciliate (see Fig. 75) ; in Derbesia, with a group of cilia at the anterior end ; in Halimeda, where they are biciliate; in Phyllosiphon, which is endophytic on Arisarum vulgare, it is effected by non-motile gonidia, as it is sometimes also in Vaucheria. In Vaucheria the gonidia are formed singly in simple gonidangia formed by septation of branches of the body; in Botrydium and Phyllosiphon they are formed in large numbers, in the former from the 
whole protoplasm of the body, in the latter from that of successive branches of

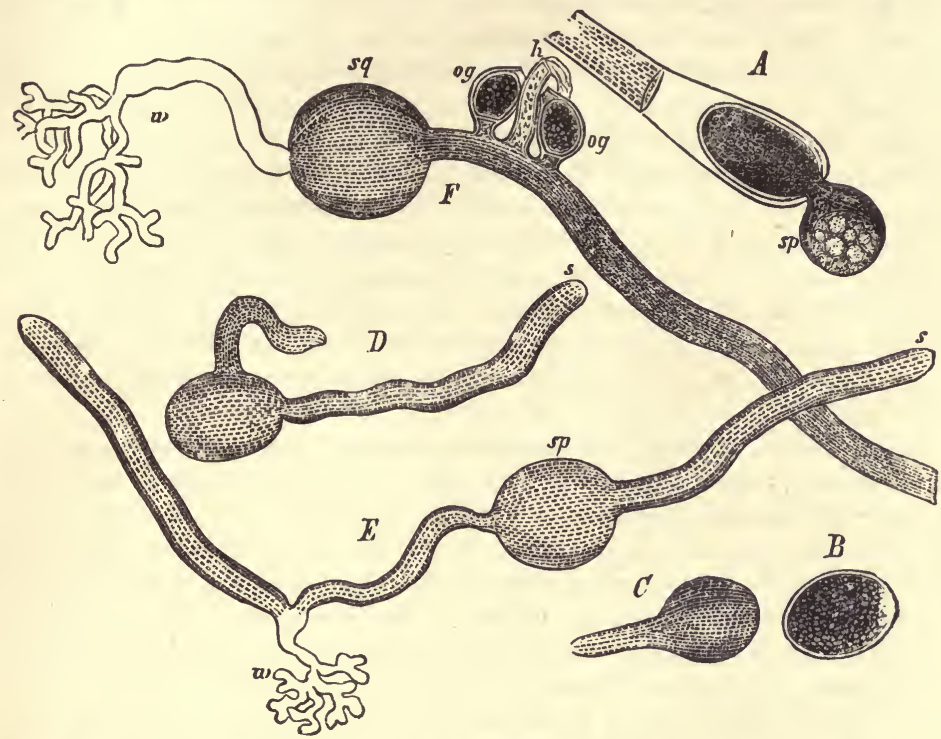

Fra. 189.-Vaucheria sessilis (× 30). A sp A newly-formed zoogonidium. B A resting zoogonidium. C, The commencement, $D$ and $E$ more advanced stages, of germination; $s p$ zoogonidium; $s$ apex of the green filament; $w$ a colourless adventitious root. F Fila. ment with sexual organs; og oogonium; $h$ antheridium after rupture. (After Sachs.)

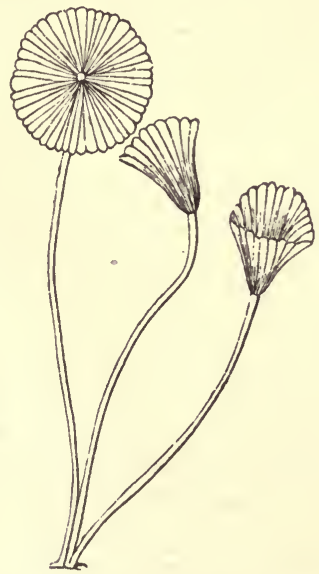

Fig. 170.-Acetabularia crenulata (after Kütz. ing; nat. size): the terminal circular disc consists of a whorl of coherent leaves; in these the gametangia are formed.

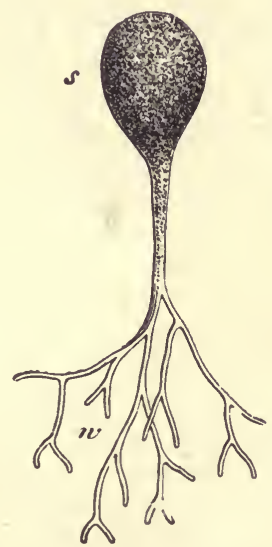

Frg. 171.-Botrydium granulatum $(\times 6): 8$ the green shoot; $w$ the colourless root. 
the tubular body; in Derbesia and Halimeda there are definite gonidangia, each producing a number of zoogonidia.

Sexual reproduction is generally isogamous by planogametes: Vaucheria is the only known oogamous form. Isogamy is kuown, certainly or probably, in Botrydium, Bryopsis (?), Codium (?), Dasycladus, Acetabularia. In Botrydium and Acetabuluria the gametangia are formed by the aggregation of the protoplasm (in the coherent leaves of the latter) into rounded masses which become surrounded by a wall, and are set free by the rupture of the parent organism; their contents undergo frequent division to produce the planogametes which are eventually set free; in Dasycladus and Codium the unilocular gametangia are rounded or oval, and are borne, in the former, terminally on the leaves, and in the latter, as lateral outgrowths on the thalloid shoot; in Bryopsis the small tubular leaves act as gametangia, being shut off by a septum from the branch bearing them.

In Botrydium. Acetabularia, and Dasycladus, the conjugating gametes are quite similar; but in Bryopsis and in Codium, the one (male) is small and brown or yellow, the other (female) is larger and green.

In Vaucheria, the sexual organs are unilocular antheridia and oogonia, and are developed as lateral branches which become shut off by a septum (Fig. 169); each antheridium gives rise to a number of biciliate spermatozoids; each oogonium gives rise to a single oosphere which is not extruded, and has a hyaline receptive spot directed towards the opening of the oogonium.

So far as the life-history of the Siphonaceæ is known, there is no indication of an alternation of generations; the plant is, in all cases, the gametophyte, and the product of the sexual process is a zygospore or an oospore which, on germination, developes directly into a new gametophyte.

The following are the families of the Siphonacer:-

Fam. 1. Vaucheriea: oogamous; body, simply tubular and branched; includes the single genus Vaucheria; marine and fresh-water.

Fam. 2. Derbesiere: probably isogamous; body simply tubular and branched; single genus Derbesia; marine.

Fam. 3. Codiere: isogamous, so far as known; body, tubular and much branched, the branches interwoven into a tissue, assuming various forms ; principal genera, Codium, Halimeda, Udotea ; marine.

Fam. 4. Dasycladea: isogamous; body tubular, short, differentiated into stem and leaf, the stem being an erect main axis ; leaves whorled, or bilaterally arranged (Bryopsis) ; principal genera, Dasycladus, Acetabularia, Bryopsis; marine.

Fam. 5. Caulerpea : reproduction not known; body, differentiated into root stem and leaf, dorsiventral; stem creeping, bearing roots below and leaves above; genera, Caulerpa, Chlorodictyon ; marine.

Fam. 6. Botrydiea : isogamous; body differentiated into root and shoot; shoot, vesicular, thalloid and unbranched; genera, Botrydium on mud, Codiolum marine.

Fam. 7. Phyllosiphonea : sexual reproduction not known; asexual reproduction by non-motile gonidia; body, tubular branched, or vesicular and unbranched, thalloid; endophytic; genera, Phyllosiphon in leaves of Arisarum vulgare, Phytophysa in shoots of Pilea. 
Order 2. Cladophoraceæ. The body is incompletely septate and the segments are coenocytic; it is filamentous, branched or unbranched, sometimes differentiated into root and thalloid shoot, attached or free-floating, the shoot with or without apical growth: reproduction, asexual by zoogonidia; sexual, isogamous, or oogamous.

The order comprises the families Sphæropleæ. Cladophoreæ, and Valonieæ.

Fum. 1. Spharoplea: the body consists of floating unbranched filaments, without distinction of base and apex, and with intercalary growth. Each segment contains numerous small chloroplastids as well as some larger chloroplastids with pyrenoids. Any segment of the body may become a sexual reproductive organ, eitber an oogon. ium or an antheridium, without any change of form; in the oogonium several oospheres are formed by free cell-formation (see p.121), and likewise in the antheridium, after repeated nuclear division, a great number of spermatozoids; the oospheres are not extruded, but are fertilised in the oogonium by srermatozoids which enter through an opening formed in the wall; the oospore, at first green, assumes a bright red colour, and on germination sets free $2-8$ zoospores, each of which gives rise to a new filament: thus the life-history indicates an alternation of generations, the oospore representing the sporophyte. Sphæroplea is the only genus, and it comprises but one species-S, annulina.

Fam. 2. Cladophorece: body filamentous, generally attached by a basal root-segment, branched (e.g. Cladophora, Pithophora) or unbranched (e.g. Urospora, Chætomorpha, Rhizoclonium), with usually intercalary growth (though it is apical in Cladophora and Pithophora); each segment contains a peripheral layer of chloroplastids (Fig. 172), continuous or interrupted, in which are scattered pyrenoids; reproduction, asexual by zoogonidia (except Rhizoclonium and Pithophora); an isogamous sexual process between planogametes has been observed in Urospora and Cladophora; reproductive cells formed in all or any of the segments of the body without special modification; the zygospore appears to develope directly into a new

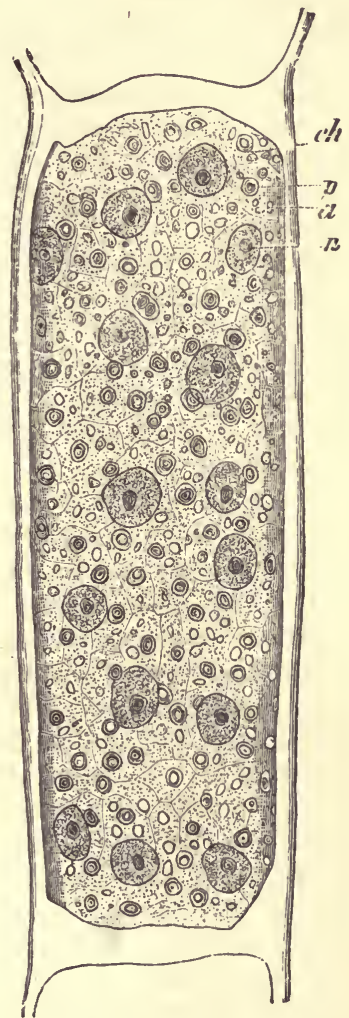

Fig. 172. - Cladophora glomerata (after Strasburger: $\times$ 510). A cœnocyte of the filament (chromic acid and carmine preparation): $n$ a nucleus; $c h$ a chloroplastid ; the polygonal chloroplastids form a continuous layer, the outlines of the individual plastids remaining visible; $p$ pyrenoids; $v$ starch. grains. plant (Cladophora), so that the sporophyte is not represented in the life-history. 
Vegetative propagation occurs in some forms: an entire segment (Rhizo: clonium), or a part of a segment (Pithophora), or several parts of a repeatedly septated segment (Urospora) become densely filled with protoplasmic contents and then break away from the body, and germinate either at once or after a period of rest; in Urospora this body, which appears in all cases to be of the nature of a gemma, sometimes gives rise to zoogonidia.

Cladophora and Chætomorpha occur in both salt and fresh water ; Pithophora exclusively in fresh water; Urospora exclusively in salt water; Rhizoclonium occurs both in fresh and salt water, and also in damp soil.

Fam. 3. Valoniece : body, essentially tubular and much branched, attached by a root, the thalloid shoot presenting various forms (vesicular or clavate, or a flattened expansion), with apical growth; the only form of reproduction known is asexual by zoogonidia (in Valonia, Siphonocladus, Anadyomene): principal genera, Valcnia, Dictyosphæria, Siphonocladus, Struvea, Anadyomene ; all marine.

Order 3. Hydrodictyaceæ: body thalloid, a non-motile unattached cœnobium, formed by the aggregation of originally distinct cells, of limited growth; a net (Hydrodictyon), or a flat plate (Pediastrum), or a solid sphere (Sorastrum), or a hollow sphere (Cœlastrum) : reproduction, asexual by zoogonidia (Hydrodictyon, Pediastrum) or non-motile gonidia (Cœlastrum, Sorastrum) ; sexual, isogamous by planogametes (known only in Hydrodictyon and Pediastrum).

It appears that Colastrum and Sorastrum are really cellular plants, each segment of the body being a cell with a single nucleus.

All four genera are confined to fresh water.

The following is a brief sketch of the life-history of Hydrodictyon. The asexual reproduction of this plant consists in the formation of a large number $(7,000-20,000)$ of zoogonidia in any one of the segments of the cœnobium; the zoogonidia do not escape from the segment (gonidangium), but swim actively within it for a time, when they come to rest, cohering, as they do so, to form a small net-like cœnobium, which is eventually set free by the disorganisation of the wall of the gonidangium, and then grows to the full size. The sexual reproduction consists in the formation in a segment (gametanginm) of the cœnobium, of a very large number $(30,000-100,000)$ of small planogametes; these are set free into the water, and conjugate to form zygospores. The zygospore, which has a thick wall and is angular in form, undergoes a period of quiescence; on germination its contents divide into two or more cells which are set free as zoospores, and, after a brief period of motility, come to rest. Each then surrounds itself with a thick cell-wall, and assumes a peculiar angular form, on account of which it has been termed the polyhedron-stage. The polyhedron grows and its contents divide into a number of zoospores; the outer coat of the polyhedron then ruptures, and the contents, surrounded by the thin inner coat, are extruded; the zoospores then arrange themselves into a small Hydrodictyon-plant. Thus the life-history of Hydrodictyon presents a definite alternation of generations; the plant is the gametophyte; the zygospore and the polyhedron together represent the sporophyte.

The life-history of Pediastrum is essentially the same as that of Hydrodictyon; but in Pediastrum the zoogonidia are set free from the gonidangium, sur- 
rounded by a delicate membrane within which they come to rest and cohere to form a Pediastrum.plant.

In Cœlastrum and Sorastrum the gonidia formed in the mother=cell either at once unite to form a new cœnobium, or they may be set free, and then each undergoes repeated division to form a new cœnobium. In view of the statement that these two genera are not oœnocytic, but cellular, and of the fact that in them the conobium may be formed by cell-division, it appears that their affinities are rather with the Protococcoideæ than with the Siphonoideæ.

Series IV. Confervordes. The forms included in this series may be arranged in the following orders :-

Sub-series A. Azoosporeæ: no zoogonidia or żoospores.

Order 1. Conjugatæ: sexual reproduction by aplanogametes.

Sub-series $B$. Zoosporeæ; asexual reprodüction by zoogonidia and zoospores.

Isogamous Orders :-

Order 2. Ulothricaceæ : body filamentous, unbranched.

Order 3. Chætophoraceæ: body filamentous, branched.

Order 4. Ülvaceæ: body a flat or tubular cellular expansion.

Oogamous Orders :- -

Order 5. (Edogoniaceæ: body flamentous, unbranched (except Bulbochæte).

Order 6. Coleochætaceæ: body filamentous, branched; oogonium with a trichogyne; sporophÿte multicellular.

An asexual formation of spores takes place in all the Confervoideæ, except the Conjugatæ. The sporophyte, in all cases in which it is fully known, gives rise to zoospores. The gametophyte multiplies itself by means of zoogonidia, and in some cases (Chætophoraceæ) by means of resting gonidia, The gonidangia are not differentiated, as any cell of the body may act as one. Several zoospores are usually developed in a single sporangial cell, but in some cases only one (e.g. zoogonidia of Widogonium and Coleochæte, zoospores of Coleochæte).

A sexual formation of spores takes place in all the Confervoideæ; in the isogamous forms the product of conjugation is a zygospore; in the oogamous forms it is an oospore. In the isogamous forms the sexual organs, or gametangia, are not differentiated; any or all of the cells of the body may act as gametangia ; the sexual cells are (except in the Conjugatæ) free-swimming similar planogametes; in the Conjugatæ the gametes are not set free into the water, and they are not ciliated. In some cases (e.g. Ulothrix, Chroolepus) the planogametes, if they fail to conjugate, are capable of independent germination, thus showing their imperfect sexual differentiation. The planogametes usually differ from the zoogonidia in being smaller. In the oogamous forms the sexual organs are antheridia and oogonia; they are more or less markedly differentiated. The sexual cells are oospheres and spermatozoids. The oospheres are formed singly in the oogonium. The spermatozoids are formed singly in the mother-cell; they resemble the zoogonidia of the respective plants, but are smaller and are not green.

The life-history of the Confervoideæ has been investigated with success in only a few forms (some Conjugatæ, Ulothrix, CEdogonium, Coleochæte). In the Conjugatæ, as there is no asexual produtcion of spores; there is no alternation of generations; in the others such an alternation can be traced. In these 
forms, the plant is the gametophyte, producing not only the sexual cells, bnt also zoogonidia. The sporophyte is the zygospore (Ulothrix), or the oospore (Edogonium), or a structure developed by cell-division from the oospore (Coleochæte). In Ulothrix and (Edogonium, the contents of the spore, whether zygospore or oospore, undergo division giving rise to two or more zoospores which are set free and, after a longer or shorter period of movement, come to rest and germinate, each developing into a gametopbyte. In Coleochrte, the contents of the oospore likewise undergo division, but the product is not several zoospores; it is a small multicellular body which constitutes the sporophyte, each cell of which eventually sets free its contents as a single zoospore which, on coming to rest, developes into a gametophyte.

It must be noted that in this series, as in others, the gametophyte does not always actually produce sexual organs; thus, in Coleochæte, there is generally a succession of such potential gametophytes produced by means of zoogonidia before an actual gametophyte makes its appearance.

There is evidence of considerable further polymorphism in the members of this group: some of them appear to have protococcoid or palmelloid forms; the flattened expanded forms have filamentous stages, etc.

The following is a brief account of the orders of the Confervoider :-

Order 1. Conjugatæ; the characteristics of this sub-order have been already stated; it need only be added that the plants are usually not attached. It includes the fannilies Desmidieæ, Zygnemeæ and Mesocarpeæ; all freshwater.

Family 1. Desmidiea. These are nnicellular organisms, either solitary or connected into filaments; they possess some power of locomotion. Each cell consists of a mass of protoplasm with a central nucleus, and contains two or more chloroplastids in whioh lie conspicuous pyrenoids. The cell-contents are arranged symmetrically in the two halves of the cell, and in many forms this bilateral symmetry is emphasised by a deep constriction in the median plane.

The Desmids multiply to a large extent by division; the cell is divided into two by the formation of a cell-wall

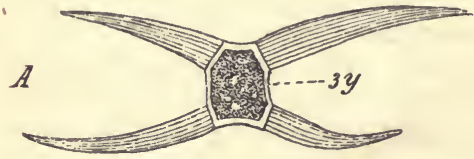

$B$.

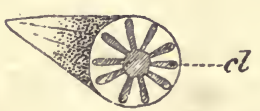

Frg. 173.-Closterium. $A$ in ennjugation; zy zygospore: $B$ in transverse section showing position of the chloroplastid $c l(\times 200)$. in the median plane, and then each half produces a new half corresponding to itself; hence the two halves of a cell are of different ages. The only other mode of reproduction is by means of zygospores formed by the conjugation of two individuals (Fig. 173). On germination the contents of the zygospore divide into two halves, each of which becomes an individual.

Among the commoner forms of the Desmidieæ are Closterium (Figs. 173 and 174), Staurastrum, Euastrum (Fig. 174 C.).

Family 2. Zygnemea. These plants, consisting of long, delicate, unbranched 
filaments composed of cylindrical cells, occur as floating green masses in ponds and springs. Each cell contains a peripheral layer of protoplasm in close contact with the cell-wall, enclosing a large central vacuole in which the nucleus is situated in a mass of protoplasm connected with the peripheral layer by several delicate protoplasmic filaments. The chloroplastids are the most conspicuous feature of the cell; in Spirogyra (Fig. 175) and Sirogonium, the chloroplastids, of which there may be from one to four, lie in the parietal protoplasm; they are spir-

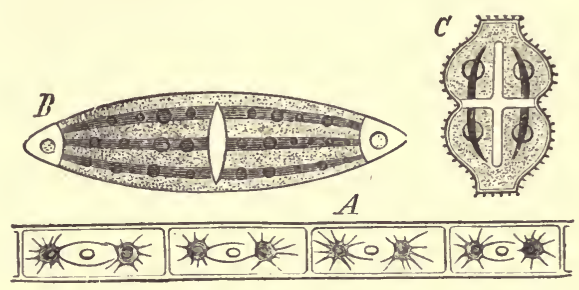

Fig. 174.-A Fragment of a filament of Zygnema ; in each cell are two star-shaped chloroplastids connected by a colourless mass of protoplasm in which lies the nucleus. $B$ Closterium. $C$ Euastrum, two Desmids with chloroplastids; in $\boldsymbol{B}$ there is a vacuole at each end in which a number of granules may be seen in motion.

ally twisted in Spirogyra, but are nearly straight in Sirogonium; like those of the Desmids, these chloroplastids contain several pyrenoids with associated starch-grains; in Zygnema (Fig. $174 \mathrm{~A}$ ) each cell contains two chloroplastids, suspended in the middle line, each containing a pyrenoid with starch-grains.

The filaments elongate by the growth and dirision of all the constituent cells, and readily break up into segments, consisting of one or more cells, which grow into new filaments.

The sexual organs (gametangia) are quite undifferentiated; any or all of the cells of a filament may act as sexual organs, the whole of its contents being converted into a single non-ciliate gamete. The sexual process (conjugation) consists in the fusion of the gametes derived from two cells belong ng generally to two filaments, but sometimes to the same filament. It is effected, in most cases, by the development of a lateral outgrowth from the middle of each

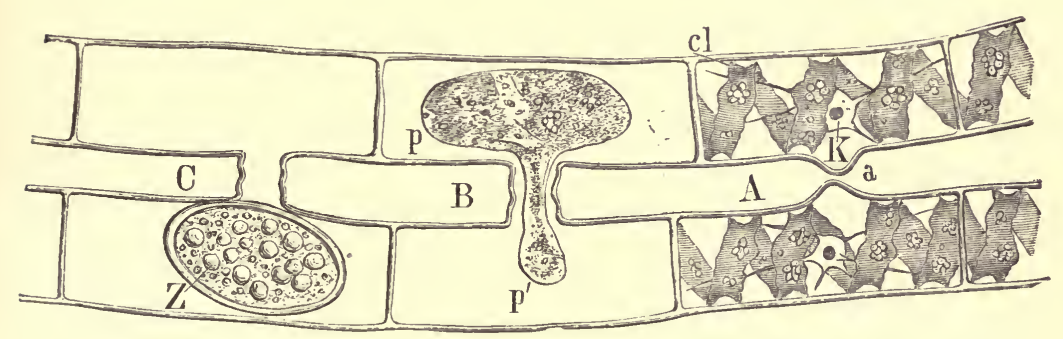

Fig. 175.-Conjugation in Spirogyra ( $\times 400)$. At $\boldsymbol{A}$ two cells of adjacent filaments are about to conjugate, and are putting out protuberances (a) towards each other; cl chlcroplastid; $k$ nucleus. At $B$ the gamete $p$ of the one cell is passing over and fusing with that of the other $(p)$. At $C$ the process of conjugation is completed, the zygospore $Z$ being the product.

gametangium; the two outgrowths meet (Fig. 175) and their walls become absorbed at the point of contact so that the cavities of the two gametangia are 
continuous. The protoplasmic contents of each cell contract away from the wall of each gametangium to form the gamete. Tue formation of the gamete takes place earlier in one gametangium than in the other, and the first-formed gamete travels across the convecting channel into the cavity of the other gametangium when it fuses with the other gamete; the resulting cell surrounds itself with a wall, and çonstitutes a zygospore. Since the first-formed gamete is the more active in the process of conjugation, it may be regarded as a male cell, the other as a female cell, so that there is a rudimentary differentiation of sex. Further, since the cells of any one filament all behave alike in the process of conjugation, it is possible to speak of male and female filaments or individuals. In Zygogonium, however, the gametes are similar, both as regards the time of their formation and their share in conjugation; in this form the gametes meet in the connecting channel and there fuse to form the zygospore.

Occasionally bodies resembling zygospores are formed in the cells of a filament without any conjugation; these are distinguished as azygospores, and are products of parthenogenesis (see p. 87).

After a period of rest, the zygospore germinates; the outer coat is ruptured, and the contents, covered by a thin cell-wall, protrude as a filament which is divided by a transverse septum into two cells; of these, the one becomes elongated and remains narrow in the cavity of the spore, undergoes no further division, and contains little or no chlorophyll, whereas the other becomes broader, contains one or more chloroplastids and, by repeated division, forms a filament. Thus there is at first a differentiation of the body into root and shoot, but this soon ceases to be apparent. It is most clearly marked in Spirogyra and Sirogonium (see Fig. 6). Principal genera : Zyguema, Spirogyra (incl. Sirogonium) Zygogonium.

Family 3. IIesocarpea. These plants resemble the Zygnemer in all the chief features of structure and reproduction, but can be distinguished by the following peculiarities. In the first place there is no contraction of the whole protoplasinic contents of the gametangium to constitute a gamete, but a portion only of the contents of the two (or sometimes three or four) cells fuse; secondly, conjugation always takes place so that the product of conjugation lies between, and not in, either of the gametangia ; thirdly, the product of conjugation is not at once a zygospore, but is a mass of protoplasm which becomes shut off fro the conjugating gametangia by the formation of a septum on each side; this mass of protoplasm then surrounds itself with a proper wall and proves itself to be a spore by germinating. There is no marked differentiation of the young plant into root and shoot. Azygospores are of frequent occurrence in this family (esp. Gonatonema). Genera: Mougeotia, Gonatonema.

Order 2. Ulothrichaceæ. The unbranched filament is attached by a narrow elongated, frequently colourless, root-cell; the growth in length of the filament is intercalary, that is, each cell elongates and divides by a trausverse wall into two,

The reprodnctive organs are quite undifferentiated; any cell of the filament may become an asexual organ, a gonidangium, or a sexual organ, a gametangium. In the former case the protoplasmic contents of the cell divide into two or four which are set free as zoogonidia; in the latter case the contents divide into eight or sixteen which are set free as planogametes. The zoogonidia are 
somewhat pear-shaped in form, the more pointed end being colourless and bearing four cilia and a pigment-spot; the planogametes resemble the zoogonidia but are proportionately smaller and have only two cilia. When the zoogonidia come to rest, they secrete a cell-wall, and become attached by the colourless end which forms the root cell of the developing filament. The planogametes conjugate to form zygospores, but if they fail to conjugate they may germinate independently, and they do so in the same manner as the zoogonidia only the resulting filament is smaller. The zygospore grows and attaches itself by its hyaline portion which derelopes into a root; after a period of quiescence its contents divide and are set free as $2-8$ zoospores resembling the zoogonidia. Fresh-water and marine. Principal genera: Ulothrix, Conferva, Hormidium, Microspora, Binuclearia.

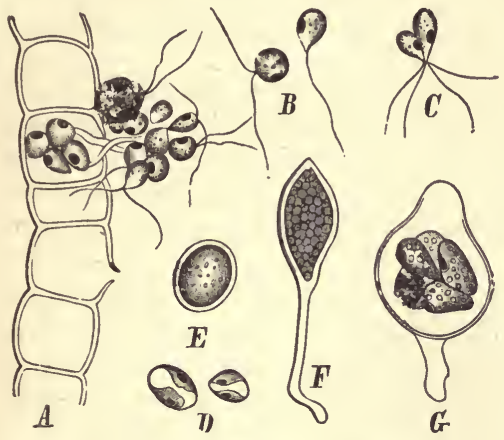

FIG. 176.-Ulothrix zonata: $\boldsymbol{A}$ part of a filament from a cell of which planogametes are escaping, the other cells having already emptied themselves; $B$ planogametes; $C$ the process of conjugation; $D$ young zygospores; $E$ mature zygospore; $F$ germinating zygospore with hyaline root; $G$ the contents of the embryonic shoot of the sporophyte dividing to form zoospores.

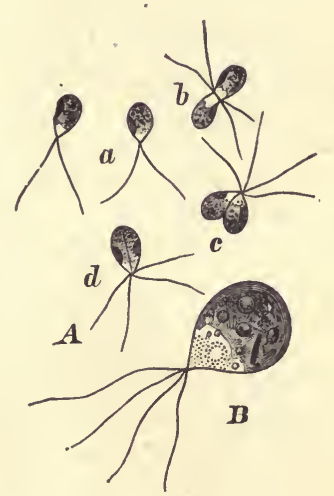

FIG. 177.- Ulothria zonata: A planngametes in different stages of conjugation $a-d ; B$ a zoogonidium. (After Dodel-Port.)

Order 3. Chætophoraceæ. The body is attached by a basal cell, and is erect or creeping; it is filumentous and much branched, and usually bears long hair-like outgrowths usually formed at the apex of the branches on the cessation of the merismatic activity of the apical growing-points; the further elongation of such branches is intercalary, being effected by the growth and division of one of the cells near its base.

Reproduction by zoogonidia is known in almost all the genera; the gonidangia are usually quite undifferentiated, though in some forms (e.g. Chroolepus) they differ in form from the ordinary vegetative cells; their development is limited in some cases, either to terminal cells (Microthamnion), or to the cells of the lateral branches (Draparnaldia) as distinguished from the main axis; the zoogonidia may be developed singly in the gonidangium (e.g. Chroolepus), in any case the number does not exceed four ; the zoogonidia have frequently four cilia.

Sexual isogamous reproduction is known in only a few genera (Stigeoclonium, 
Chroolepus, and some others) ; the gametangia are but little, if at all, differentiated from the vegetative cells of the body; in Chroolepus the gametes closely resemble the zoogonidia.

The germination of the zygospore is only known in Phæophila ; the contents escape as a non-motile cell which grows out basally into a root-like organ of attachment, and apically into the multicellular shoot-filament.

Principal genera: Chætophora, Stigeoclonium, Draparnaldia in fresh water; Chroolepus (Trentepohlia) grows on rocks and tree-trunks, and is peculiar on account of its orange or violet colour.

Order 4. Ulvaceæ. The membranous body consists of a single flat layer of cells (Monostroma), or of a single tubular layer of cells enclosing a cavity (Enteromorpha), or of two layers in close contact (Ulva); the body is attached, at least when young, by a root, and is sometimes branched (esp. Enteromorpha); the growth of the body is intercalary, all the cells being concerned in it.

Any cell of the body may become a gonidangium or a gametangium; the zoogonidia have four cilia, the planogametes two; conjugation of planogametes has been observed in the three above-mentioned genera; the zygospore, on germination, developes directly into a new plant, producing basally the root and distally a cellular filament which becomes the thalloid shoot. Inhabit both fresh and salt water.

Order 5. CEdogoniaceæ. Filaments unbranched (except Bulbochæte), attached by a root; growth intercalary. The mode of growth of the individual cells of Edogonium is peculiar; in the plane of division a ring of cellulose is formed round the cell-wall ; the cell-wall then ruptures, and the cellulose-rin ? is stretched so as to form a membrane across the rent; as this process takes place repeatedly near the upper end of the cell, the projecting edges of the repeatedly ruptured cell-wall form a series of caps; the transverse septa, dividing the elongated cells into two, are always formed toward the lower end of the cells.

Any cell of the body may be a gonidangium, setting free its protoplasmic contents as a single zoogonidium with a circlet of cilia round its more pointed colourless end. On coming to rest, the zoogonidium attaches itself by its colourless end, surrounds itself with a cell-wall, and grows into a filament; the colourless portion becomes the root-cell (see Fig. 74).

The sexual organs are differentiated. Some cells of a filament increase in size and become rounded in form, each constituting an oogonium. The protoplasm in each oogonium contracts away from the wall to constitute the single oosphere. Access to the oosphere is afforded either by the perforation of the oogonium-wall, or by the partial breaking-away of the cell immediately above the oogonium in the flament. The oosphere has a well-marked receptive spot. The antheridia are formed, either in the same or another filament as the species is monœcious or diœcious, by the repeated tranverse division of a cell of the filament; in some species the antheridium gives rise to a single spermatozoid, but in most it undergoes division into two cells each of which produces a spermatozoid. The spermatozoids resemble the zoogonidia, but are smaller and are yellow instead of green; they are set free, and finding their way to the oogonia, one enters an oogonium and fertilises the oosphere, penetrating into it at the receptive spot (Fig. 178). 
In some species, termed gynandrosporous, the filaments produce no antheridia, but only oogonia. Some of the cells of such a filament undergo transverse division to form short cells which somewhat resemble antheridia. The contents of each of these cells are set free as a single zoogonidium, termed an androspore, intermediate in size and colour between the ordinary zoogonidia and the spermatozoids, and resembling them in form. The androspore comes to rest, attaching itself to the wall of an oogonium (Fig 178), and germinates, forming a small filament, known as a dwarf-male, which consists of a rootcell and two or three cells above it; each of these upper cells is an antheridium, and its contents are set free as a single spermatozoid.

On germination, the contents of the oospore are set free as four zoospores, which resemble the zoogonidia, and germinates in the same manner. Freshwater: genera, Edogonium, Bulbochæte.

Order 6. Coleochætaceæ. Body filawentous, branclied, forming hemispuerical or disc-shaped cushions on snbmerged stones or parts of waterplants; the mode of growth is essentially apical, though in some forms (C. scutata) the apical ce.'I \& constitute a marginal series; most of the cells eventually develope the peculiar sheathing hairs which have suggested the name of the family. Fresh-water: Coleochæte, the sole genus.

The gonidaugia are undifferentiated ; any cell may set free its proto plasmic contents as a zoogonidium with two cilia.

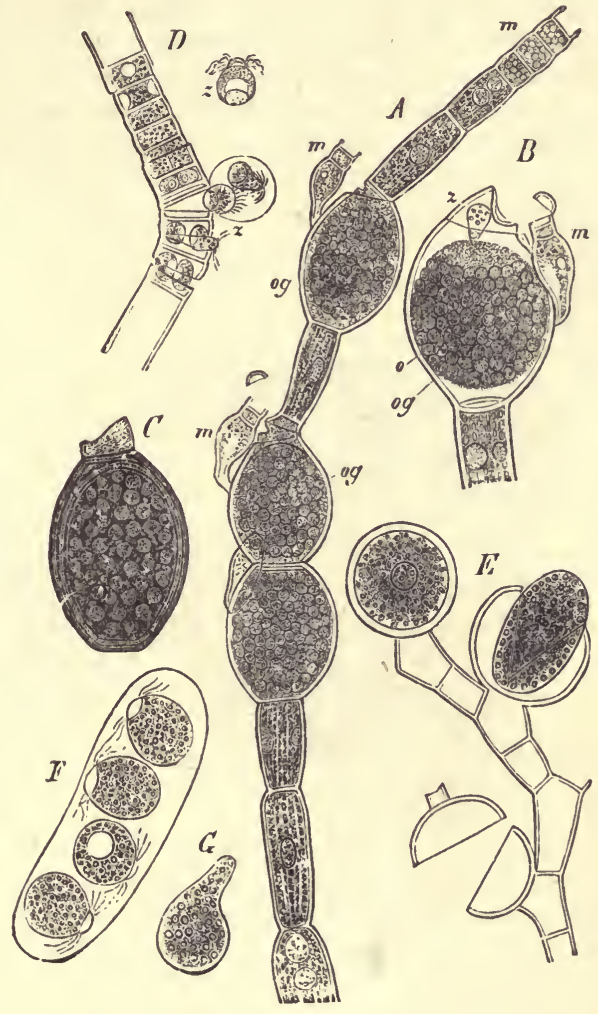

FıG. 178.-A Edogonium ciliatum (× 250). A Middle part of a sexual filament with three oogonia $(\mathrm{og})$ fertilised by the dwarf-male plants $(m)$, developed from zoogonidia formed in the cell $m$ at the upper part of the filament. $B$ Oogonium at the moment of ferilisation : $o$ the oosphere; og the oogonium; $z$ the spermatozoid in the act of forcing its way in; $m$ dwarf-male plant. $C$ Ripe oospore. $D$ Piece of the male flament of $E d$. gemelliparum, $z$ spermatozoids. E Branch of a Bulbochote, with one oogonium still containing an oospore, another in the act of allowing it to escape ; in the lower part an empty oogonium. F The four zoospores formed from an oospore. $G$ Zoospore come to rest. (After Pringsheim.) 
The sexual organs, oogonia and antheridia, are differentiated, especially in the more distinctly filamentous forms. In the filamentous forms (e.g. C. $\mu u l$ vinata, Fig. 179) the oogonia and antheridia are borne at the ends of the branches; the terminal cell of a branch enlarges to form an oogonium, becoming spherical, and growing out into a long filament, the trichogyne; the antheridia are developed as small flask-shaped cells from the terminal cells of a filament. In the discoid forms (e.g. C. scutata), the oogonia and antheridia are not terminal; the oogonium is simply an enlarged spherical cell and has no trichogyne; the antheridium is simply a small cell formed, in a group of four, by the division of one of the ve setative cells.

A single oosphere is formed in each oogonium, and a single spermatozoid in each antheridium. The spermatozoids, on being set free, find their way to the
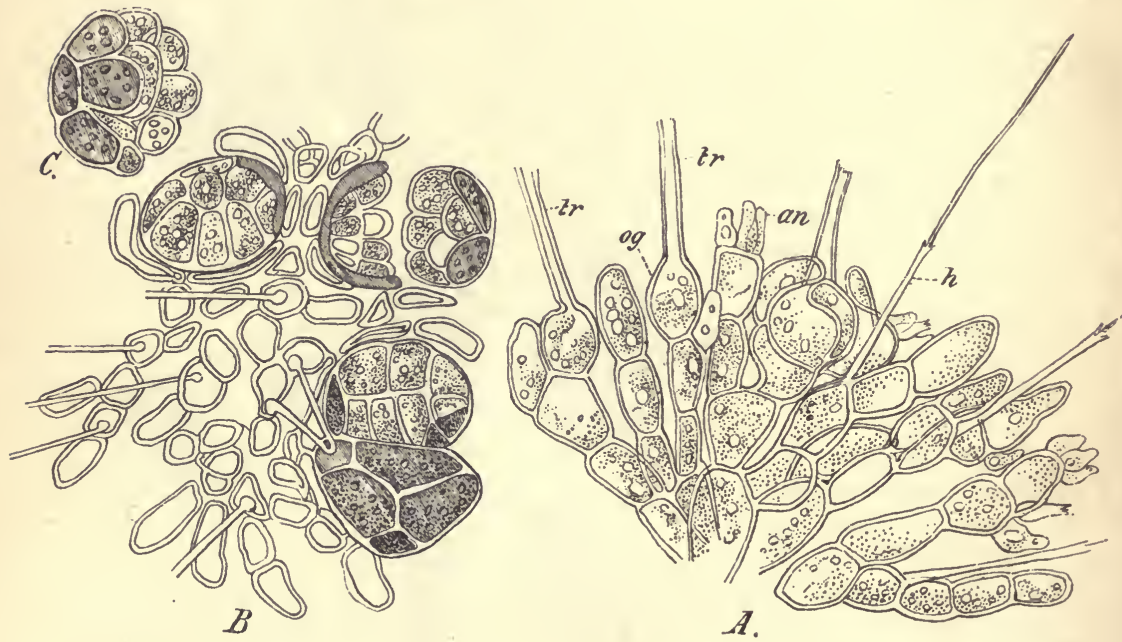

FIG. 179.-Coleochote pulvinata (×350: after Pringsheim). A Palt of an actnal gametophyte bearing oogonia og (with trichogynes $t_{r}$ ) and antheridia $a n ; h$ hairs. B portion of a plant in which a multicellular sporophyte has been developed in each fertilised oogonium. $C$ an isulated sporophyte the investment of which is ruptured prior to the setting free of zonspores.

oogonia, and, entering by an opening in the wall (in the trichogyne when it is present), reach the oospheres and fertilise them.

The effect of fertilisation is not only to cause the oosphere to become an oospore by clothing itself with a proper wall, but also to cause the neighbouring cells to grow round the oogonium and form a compact cellular investment for it. Surrounded by this investment, the oospore falls to the bottom of the water, as the plant dies down, and undergoes a period of quiescence. On germination it grows, splitting the investment, and divides to form a small multicellular body, the sporophyte, the existence of which shortly comes to an end by the escape of the whole of the protoplasmic contents of all the cells as 
zoospores, one from each cell, which resemble the zoogonidia, and germinate in a similar manner to form a (potential or actual) gametophyte.

Series V. Charoides. The forms included in this series constitute but a single order, the Characeæ.

Order I. Characeæ. The stem is distinctly segmented into nodes and internodes, the nodes being marked by the whorls of leaves which they bear, It consists of a longitudinal series of elongated oylindrical cells, each of which constitutes au internode, separated from each other by transverse plates of small ce'ls which are the nodes. In Chara there is, in addition, a cortex consisting of rows of cells, sometimes spirally twisted, produced by a growth of the peripheral cells of each node, both upwards and downwards, over the internodes above and below it.

All the cells contain small discoid ohloroplastids which lie imbedded in the protoplasm immediately beneath the cell-wall. The more internal portion of the protoplasmic layer shows the movement known as cyclosis; the central portion of the cell-cavity, when the cell is fully grown, is occupied by a large vacuole filled with cell-sap. Each cell contains a single nucleus when young; but the long internodal cells, when old, are found to contain many nuclei produced by the fragmentation of the original nucleus.

The growth in length of the stem is unlimited, and is effected by means of a hemispherical apical cell (Fig. 180). This cell unclergoes repeated division, a series of segments being cut off by transverse walls; after a segment has been cut off, the apical cell regains its normal size by growth, then another segment is cut off, followed by renewed growth,

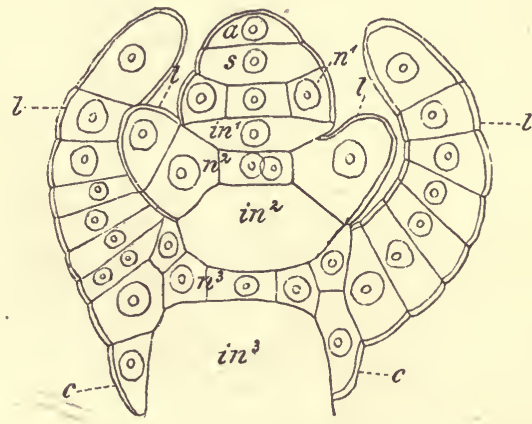

FIg. 130 nm of growing-point of stem of

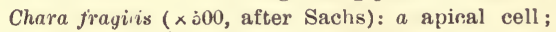
$s$ segment lately cut off; $n^{3} n^{2} n^{3}$ successive nodes; $i n^{1} i n^{2} i n^{3}$ successive internodes; $l$ leaves; $c$ cortical cells growing down over in from $n^{3}$.

and so on. Each segment is immediately divided into two cells by a trausrerse wall; of these two cells the upper, in all cases, becomes a node, dividing by vertical walls into the small cells, central and peripheral, of which the node consists; the lower, in all cases, becomes an internode; it does not divide, but simply grows in length. In Chara the young peripheral nodal cells keep pace ' with the growth of the internodal cells, forming the cortex over them.

The leaves and branches of the stem are all developed from the cells of the nodes; the leaves spring in a whorl, one from each of the peripheral cells of the node, and the branches are developed as buds in the axils of one or more of the leaves of each whorl.

The mode of growth and general morphology of the leaf is essentially the same as that of the main stem or one of its branches; it grows by means of an apical cell resembling that of the stem, and from the segments are formed 
nodes and internodes in regular succession; from the nodul cells of the leaf arise whorls of leaf-branches or lraflets. The ouly fundamental difference between the leaf and the stem of the Characen is that, whereas the apical growth of the latter is unlimited, that of the former is limited; the apical cell of the leaf at length ceases to divide, assuming a somewhat cylindrical form with a pointed tip.

The roots, with the exception of the first root of the embryo, are all adventi. tious, being developed from the lower nodal cells of the stem. They are simpler in structure than the stem or leaf, each consisting of a colourless filament of long, narrow cells; the growth is apical, thongh the apical cell is not specially differentiated as in the stem; the cells of the root are convected in a peculiar manner, the contiguous ends of the two cells having each somewhat the shape of the sole of a human foot; root-branches are developed from that portion of the cell, just above the articulation, which corresponds to the heel of the foot.

The sexual organs (Fig. 181) are in all cases borne on the leaves: the antheridium is developed from the terminal cell of a leaf or of a leaflet; the oogonium replaces a leaflet. The plaut may be either monoecious or diœecious.

The antheridium is a spherical body, of a green colour when young, but orange when mature, borne on a stalk. Its wall consists of eight cells, each of which is termed a sliceld, presenting marginal infoldings of the wall; the wall of the upper half of the antheridium consists of four triangular shiclds ; that of the lower half consists likewise of four triangular shields, each of which has its lower angle truncated to admit of the passage of the stalk-cell. On the inner surface of each ; shield, at its centre, is attached a cylindrical cell, the manubrium, which extends to near the centre of the antheridium. Each manubrium bears at its inner end a sımewhat spherical cell, the cupitulum. To each capitulum are attached usually six rounded cells, the secondary capitula. Connected with each secondary capitulum are two cells each of which bears a pair of long filaments, each filament consisting of about two hundred cells. The cells of the filaments are the mother-cells of the spermatozoids, each cell giving rise to a single spermatozoid.

The inale cell or spermatozoid cunsists of a club-shaped spirally-wound mass of protoplasm bearing two long cilia at its pointed anterior end (see p. 116). When the antheridium is mature the shields separate, the spermatozoids are set free from their mother-cells and escape into the water.

The oogonium is the enlarged terminal cell of the leaflet which it represents. Beneath the oogonium proper is a node, the central cell of which constitutes the stalk-cell of the oogonium, whilst the five peripheral cells of the node grow out into filaments which gradually become spirally twistel and enclose the oogonium; the tips of these filaments project at the free end of the oogonium, coustituting the crimn or coron', and are cut off from the rest of the filaments either by one transverse wall, so that the crown consists of five cells as in the Chareæ, or by two transverse walls, so that the crown consists of ten cells as in the Nitelleæ.

Each oogonium contains a single oosphere, a nucleated mass of protoplasm coutaining starch-granules, with a well-marked clear area, the receptive spot, at the apical end. Just previously to fertilisation one or more cells (wenduugs- 
zellen) are cut off from the basal portion of the oosphere by the formation of cell-walls; these cells are probably to be regarded as polar bodies.

At the time of fertilisation, the cells of the crown separate so as to form a channel leading to the apex of the oogonium. The wall of the oogonium is not

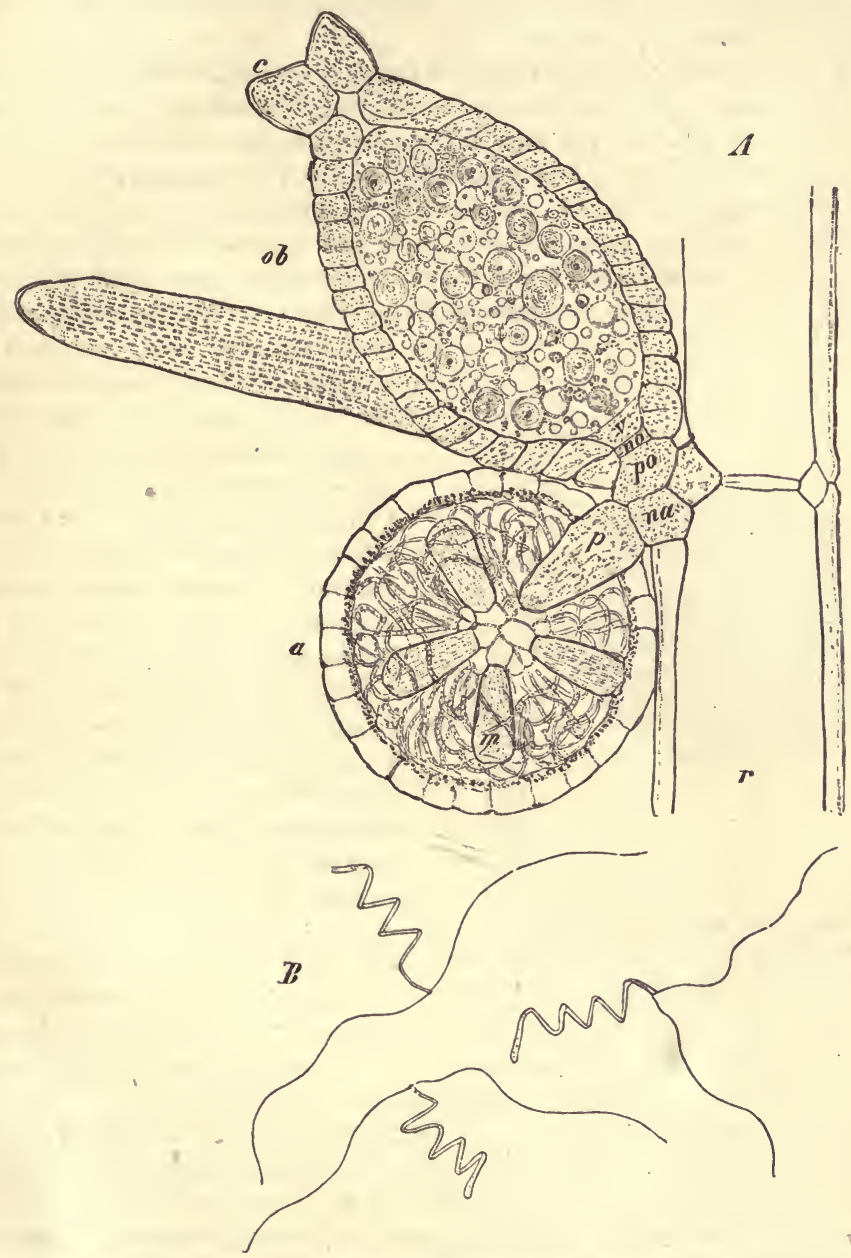

Fig. 181.-Chara fragilis, reproductive or qans (a fter Strasburger). A Median longitudinal section through a leaf (gametophyll) $r$, and the sexual organs which it bears; $a$ antheridium, borne on a nodal cell $n a$ by the stalk-cell $p ; m$ the manubria; $o b$ an oogonium, borne on a nodal cell no and an internodal stalk-cell po; $v$ wendungszelle; corona (all $\times 90)$. B spermatozoids $(\times 540)$.

ruptured, but it becomes mucilaginous. The spermatozoids enter the channel and reach the apex of the oogonium; one of them makes its way through the 
mucilaginous cell-wall, and, entering the oosphere at the receptive spot, fertilises it.

After fertilisation, the oosphere becomes an oospore, surrounding itself with a proper wall. The more internal walls of the investing filaments become thickened, and assume a dark brown colour. The whole organ falls off and undergoes a period of quiescence.

On germination, a planoconvex mass of clear protoplasm collects at the apical end of the oospore, the starch-granules being aggregated in the posterior part of the oospore; a transverse wall is then formed, separating these two parts from each other. The smaller cell then divides into two by a wall at right augles to the first, and from these two cells the embryo is developed. The hard investment of the oospore is ruptured at the apex, and the two cells grow out as filaments, the upper forming the shoot, the lower the root, of the embryo (Fig. 182). The root-cell may at once elongate into a colourless multicellular filamentous

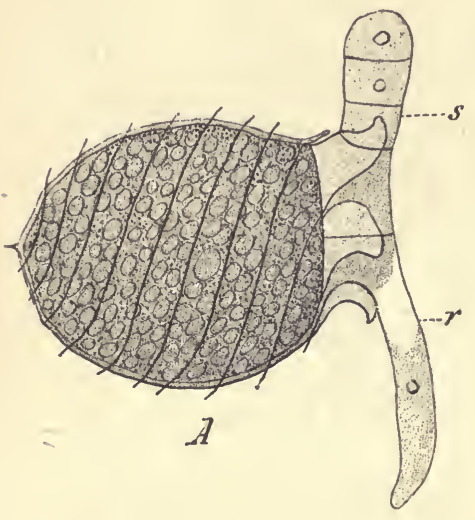

Fı. 182.-Meroblastic develnpment of the embryo from the oospore of Tolypella intricata ( $\times 90$ : after De Bary); 8 embryonic shoot; $r$ embryonic root.

brem bryo, except one cell which hecomes the apical cell of the stem of the adult plant, and, by its growth and division, gives rise to it (Fig. 183).

The embryogeny of the Characeæ is in the first place meroblastic (see p. 13), that is, the embryo is developed from a part only of the oospore. The larger posterior part of the oospore takes no share in the formation of the embryo, but serves to supply the embryo with the nutrient material necessary for the earlier stages of its development. Moreover it is heteroblastic, an embryonic form intervening between the oospore and the adult. The life-history presents no alternation of generations.

Parthenogenesis has been observed in Chara crinita; the oosphere of this plant germinates without fertilisation.

The Characeæ are extensively propagated in a vegetative manner. The roots sometimes develope into small spherical unicellular bulbils filled with starch ; 
in other cases the peripheral cells of subterranean nodes, instead of giving rise to leaves, grow out into small cellular appendages which become filled with starch, and are known as starch-stars. When the plant has died down in the winter, these bulbils and starch-stars persist, and, in the following spring give rise to new plants. Again, instead of normal branches, the plant may produce branches of peculiar structure, called embryonic branches because they resemble the embryo, which become separate and grow at once into new plants.

The Characeæ are classified as follows:-

Fam. 1. Nitellece : corona consisting of ten cells; includes the genera Nitella, Tolypella.

Fam. 2. Charea : corona consisting of five cells ; includes the genera Chara, Lamprothamnus, Lycnothamnus, Tolypellopsis.

The stem and leaves of the Nitelleæ bave no cortex ; those of most of the Chareæ have cortex. They all inbabit fresh or brackish water.

Sub-Class III. Phжорнасеж, or Brown Algæ. The body may consist of a single cell (e.g. Diatomacer, Syngeneticæ), but is generally multicellular; it is never conocytic. When multicellular, it presents various degrees of morphological differentiation, being usually differentiated into shoot and root, and in some cases (e.g. Cladostephus, Sargassum) into stem, root, and leaf.

Vegetative multiplication is common in the unicellular forms, in which it is effected by division; in a few forms (e.g. Choristocarpus, species of Sphacelaria) it is effected by means of gemmæ.

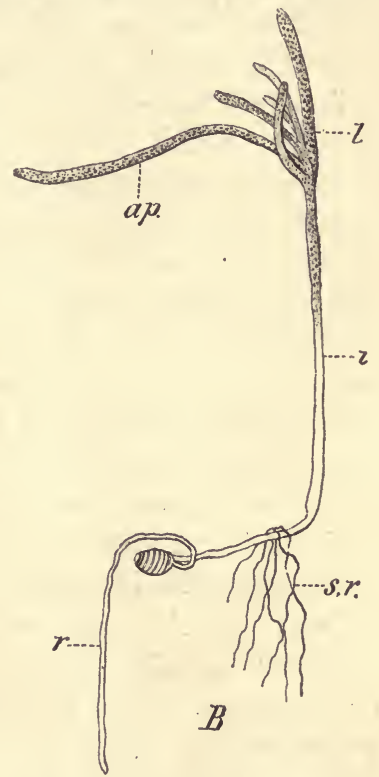

Fig. 183. - Chara fragilis (after Pringsheim : $\times$ 4). Heteroblastic embryogeny; $a p$ apical portion of shoot of the embryo; $r$ primary root of embryo, springing from the

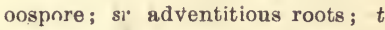
leaves, amongst which lies the growing-point of the adult shoot; $i$ intermediate cell.

The life-history of most of the members of this sub-class is but imperfectly known. In some cases it certainly does not present an alternation of generations, on account of the absence either of asexual reproduction (Fucaceæ) or of sexual reproduction (Syngeneticæ). In other cases, again, both sexual and asexual reproduction are known (e.g. some Ectocarpacea), but since the two kinds of reproductive organs are borne on the same individual, either simultaneously or at different times, no alternation of generations can be traced. In yet others, distinct sexual and asexual 
forms are known, but it is not clear whether the asexual forms are sporophytes or are merely potential gametophytes: in the Cutleriaceæ, however, it is highly probable that the asexual form is really a sporophyte, and this view may, for the present, be extended to the other more doubtful cases.

In all but the lowest forms there is a distinction between reproductive and vegetative cells, the former developing into more or less highly differentiated reproductive organs.

A sextal reproduction is effected by means of spores (or possibly gonidia), either zoospores (as in Syngeneticæ and Phæosporeæ) or non-motile spores (as in Tilopteridaceæ and Dictyotaceæ). The spores are developed either singly, or more commonly several together, in unicellular (and also necessarily unilocular) sporangia.

Sexual reproduction is either isogamous or oogamons: when isogamous, it may be effected by aplanogametes (Diatomaceæ), but more commonly by planogametes (Phæosporeæ) which usually resemble each other; but in some cases (e.g. species of Ectocarpus, Cutleriaceæ) they are of two kinds, differing in size and in the duration of their movement, the one which is smaller and more active being the male: when oogamous, it is effected by means of spermatozoids and oospheres, and is peculiar in that the oospheres, though not ciliated, are extruded from the female organ before fertilisation takes place. The gametophytes may be monœcious or diœcious. The sexual organs, in the isogamous forms, are gametangia, sometimes unicellular (Diatomaceæ) but more commonly multicellular (Phæosporeæ) ; in the latter case each cell of the gametangium gives rise either to a single planogamete or to several: they are in most cases all alike, thongh some (e.g. in species of Ectocarpus, Cutleriaceæ) consist of smaller and more numerous cells than the others and give rise to the smaller planogametes. In the oogamous forms, the oogonium is unicellular, giving rise to one or more (2-8) oospheres: the antheridium is multicellular in the Tilopteridaceæ and Dictyotaceæ, but unicellular in the Fucaceæ; in the former case each cell gives rise to a single spermatozoid, in the latter several spermatozoids are developed in the one cell.

Of the motile reproductive cells of this sub-class, the zoospores (or zoogonidia) and the planogametes, contrin chromatophores, and have two cilia inserted laterally; the spermatozoids, however, have no chromatophores, nor have the smaller planogametes in those cases in which the conjugating planogametes differ in size; the oosphere has no receptive spot. 
The Phæophyceæ may be classified as follows :-

Unicellular Forms :

Order 1. Syngeneticæ: no sexual reproduction.

Order 2. Diatomaceæ : sexual reproduction isogamous by aplanogametes.

Multicellular Forms :

Series (a) Phæosporeæ: sexual reproduction isogamous by planogametes ; asexual by zoospores (in some cases by zoogonidia).

Order 3. Ectocarpaceæ: including the families,

Ectocarpeæ (Ectocarpus, Pylaiella, Streblonema, etc).

Choristocarpeæ (Choristocarpus, Discosporangium).

Myriotricheæ (Myrotrichia).

Myrionemeæ (Myrionema, Microspongium, etc.).

Elachisteæ (Elachista, Giraudia, etc.).

Desmarestieæ (Desmarestia, Arthrocladia).

Spermatochneæ (Spermatochnus).

Sphacelarieæ (Sphacelaria, Stypocaulon, Chætopteris, Cladostephus, etc.).

Order 4. Eucœliaceæ; including the families,

Mesoglœeæ (Chordaria, Mesoglœa, Castagnea, etc.).

Sporochneæ (Sporochnus, Carpomitra).

Striarieæ (Striaria, Stictyosiphon, etc.).

Stilophoreæ (Stilophora).

Dictyosiphoneæ (Dictyosiphon, etc.).

Scytosiphoneæ (Scytosiphon, Colpomenia, Phyllitis, Asperococcus.)

Punctarieæ (Punctaria, etc.).

Order 5. Laminariaceæ (Laminaria, Alaria, Chorda, etc.).

Order 6. Cutleriaceæ (Cutleria, Zanardinia).

Series (b) Phæogamæ: sexual reproduction oogamous; asexual, wanting, or by non-motile spores: no gonidia.

Order 7. Tilopteridaceæ.

Order 8. Dictyotaceæ.

Order 9. Fucaceæ.

Order 1. Syngeneticæ. Body unicellular, the cells being held together by mucilage, forming a colony. Reproduction by division, and by asexually produced spores.

This order includes two genera, Hydrurus and Chromophyton; in the former the colony consists of many cells and is attached, in the latter it consists of eight cells and is unattached.

In Hydrurus, each cell is an ellipsoidal mass of protoplasm, enclosing a nucleus, one or two contractile vacuoles, and one or two chromatophores in the form of a plate or ribbon each containing a pyrenoid. The cells multiply by division. Asexual reproduction is effected by means of zoospores, formed by division of a cell into two or four, which are set free by the disorganisation of the investing mucilage and move by means of a single cilium; these come to rest, and each gives rise by division to a new colony. Also by means of rest. ing-spores formed one from each vegetative cell.

V. S. B. 
The structure of the cells of Chromophyton, and its modes of reproduction, are essentially the same as those of Hydrurus.

The Syngeneticæ somewhat resemble the palmelloid Protococcaceæ among the Chlorophyceæ, and may be regarded as the corresponding group in the Phæophyceæ. They grow only in fresh water; Hydrurus in cold, rapidly running streams.

Order 2. Diatomaceæ. Unicellular plants, either free, or connected into filaments or masses by mucilage; sometimes attached. Reproduction, vegetative by division; or by means of asexually produced spores; or sexual isogamous by the conjugation of aplanogametes. The cell-wall is impregnated with silica. Both fresh-water and marine.

The Diatomaceæ resemble the Desmidieæ in many respects; the two orders, are, in fact, corresponding forms in the Phæophyceæ and the Chlorophyceæ
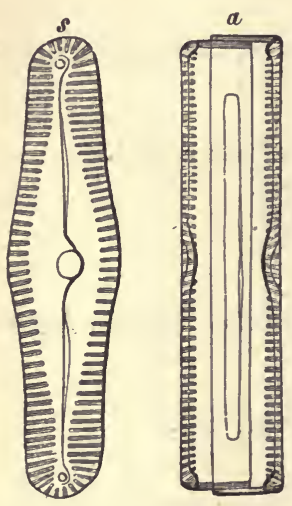

Frg. 184.-Pinnularia, a Diatom (mag. and diag.); a lateral view, showing the mode of connection of the two halves of the frustule; s surface view. respectively; but, besides their colour, the Diatoms differ from the Desmids in the presence of silica in their cell-wall.

The cell, or frustule, as it is called, is enclosed by a rigid wall. The wall, like that of the Desmids, consists of two halves, called valves, of different ages, which are not directly continuous, but are related to each other as the two parts of a pillbox, the one overlapping the other (Fig. 184). The cell-contents consist of a more or less vacuolated mass of protoplasm, which forms a layer in close contact with the inner surface of the cel]wall; in this there is a nucleus, sometimes parietal sometimes central, and chromatophores which may be very numerous and small, or few in number (sometimes only one) in the form of relatively large plates.

Vegetative multiplication by division takes place by the division of the protoplasm into two cells; each of these cells has one of the two valves' of the parent frustule on one side of it; it then secretes a new valve on its naked side, which is smaller than the older valve and fits inside its rim; thus two new individuals are formed.

It will be noted that this process of multiplication is accompanied by a decrease in size; and, were it repeated indefinitely, the cells would become very small. This process of diminution is interrupted by the formation of auxospures, either asexually or sexually. In the former case the protoplasmic contents of a cell escape from the separated valves, as an auxospore, which, after growing considerably, secretes two new valves forming a new and larger frustule. In the latter case, two naked cells which have thus escaped, conjugate to form an auxospore which becomes a new frustule. This process of conjugation differs, however, from that of the Desmidieæ, in that no resting zygospore is formed, but simply a new individual.

Series Pheosporex. The multicellular body is attached; it sometimes con- 
sists of a flattened dorsiventral branched filament, the branches of which are often coherent into a disc which adheres to the substratum by the ventral surface and bears vertical shoots on its dorsal surface (e.g. Ectocarpus, Myrionema, Pylaiella); the body is frequently more or less clearly differentiated into root and shoot, and in some cases (e.g. Cladostephus, Chrtopteris) the shoot is differentiated into stem and leaf; adventitious roots are very generally developed.

The body presents a considerable variety of structure. In the simplest forms (e.g. Ectocarpus, Pylaiella, Choristocarpus, etc.) it is filamentous and branched, the filament consisting of a single row of cells (monosiphonous); in others it is filamentous, consisting of several coherent longitudinal rows of cells (polysiphonous; e.g. Giraudia, species of Sphacelaria); or it is monosiphonous and partly or completely invested by a secondary parenchymatous tissue forming a sort of cortex (e.g. Desmarestieæ, Spermatochnus): or it is polysiphonous with a cortex (e.g. Sphacelaria scoparia, Chætopteris, Cladostephus); or, finally, it consists of parenchymatous tissue frequently differentiated into a smallcelled cortex and a medulla of large cells elongated parallel to the long axis of the plant (e.g. most Enceliaceæ, Laminariaceæ) ; the body frequently becomes hollow, a central cavity being formed (e.g. Asperococcus, Scytosiphon, Colpomenia, Striaria, Chorda). A body of monosiphonous or polysiphonous structure is articulated longitudinally into segments corresponding to the cells which constitute the filament or filaments; this is also generally the ease when such a body is corticated (e.g. Chætopteris, Arthrocladia).

Growth in length may be effected without a definite growing-point, all the cells being merismatic (e.g.generally in Ectocarpaceæ and Encœliaceæ), in which case growth is, as a rule, limited; or there may be a definite growing-point, which may be apical, with an apical cell (e.g. Sphacelarieæ, Dictyosiphon, Spérmatochnus) ; or the growing-point may be intercalary, either sub-apical (e.g. Chordaria) as also in Desmarestiaceæ (Fig. 160), Cutleriaceæ, and Sporochnaceæ where the growth is trichothallic (p. 223), or more or less basal, (e.g. Laminariaceæ). The division of the apical cell, or

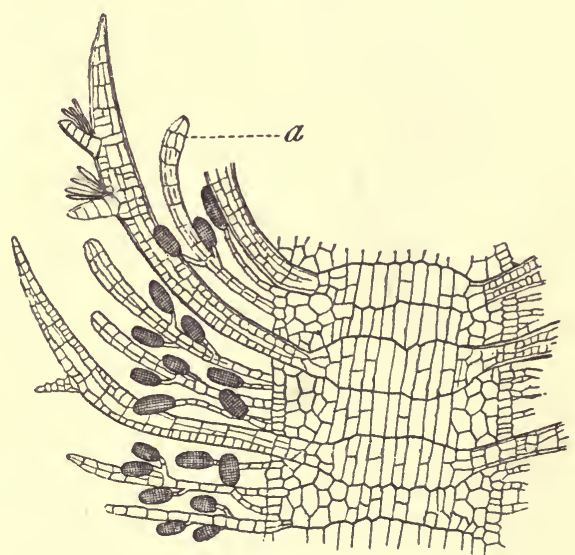

FIG. 185.-Longitudinal section through three internodes of a sexual plant of Cladostephus verticillatus: $a$ gametophyll; the larger appendages are foliageleaves. ( $\times 50$ : after Pringsheim.) of the initial cells, of the growing-point takes place only in one plane, the transverse. The segments thus formed undergo division either only transversely (monosiphonous forms), or longitudinally (polysiphonous), or in several planes. 
The sporangia (and gonidangia) are in all cases unicellular. In the simple filamentous forms they are somewhat enlarged and rounded cells, either interealary in position (e.g. Pylaiella), or terminal, occupying the place of a lateral branch, and generally sessile (e.g. Ectocarpus, Choristocarpus, Sphacelaria, etc.). In the more bulky thalloid forms, the sporangia may be merely developments of single superficial cells (e.g. Encœliaceæ, Laminariaceæ) scattered singly or in groups (sori) over the whole surface. In others again they are borne as lateral branches on hair-like outgrowths from the superficial cells (e.g. Chordariaceæ, Sporochnaceæ, Stilophoraceæ). In certain cases, where the shoot presents differentiation into stem and leaf (e.g. Chætopteris, Cladoste-
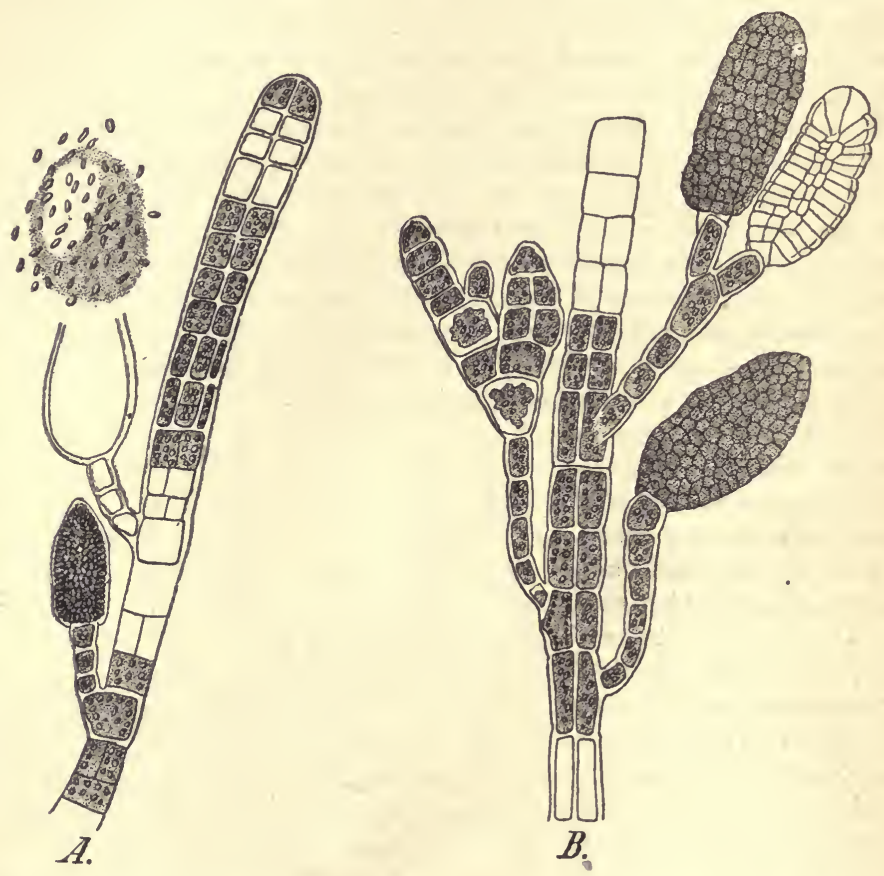

Frg. 186.-Fertile leaves of Cladostephus verticillatus: $A$ sporophyll; one of the unicellular sporangia has discharged its zoospores with a mass of mucilage; $B$ gametophyll, bearing the multicellular gametangia. ( $\times 280$ : after Pringsheim.)

phus), the sporangia are borne on specialised leaves, sporophylls (Fig. 186 ; see also p. 78).

The gametangia are in all cases multicellular, each cell constituting a loculus which gives rise to one or more planogametes. In their distribution and general morphology they resemble the sporangia. The gametangia of any one species are, as a rule, all exactly alike, but in some few cases they present two forms which differ in the size, and consequently in the number, of their constituent cells (e g. Ectocarpus fenestratus and $E$. secundus, Cutleriaceæ); the small- 
celled gametangia are considered to be the male, and the large-celled the female organs. The plants may be monceious or dicecious (Cutleria).

The zoospores and the planogametes are generally all very much alike: in Cutleria, however, and in those species of Ectocarpus which have two kinds of gametangia, the one kind of planogamete (female) is considerably larger than the other (male), and has a shorter period of motility; the smaller planogametes are developed in the small-celled gametangia. A sexual process has been observed in but few cases (Ectocarpus siliculosus, Scytosiphon lomentarius, Cutleria). In the two former the planogametes are externally similar, but they behave differently in the process of conjugation, some coming to rest earlier tban others, thus indicating that they are female. When the female planogamete is at rest, it is approached by a number of the still motile male planogametes (Fig. 187), one of which fuses with it. In Cutleria the larger planogamete soon comes to rest, and then one of the smaller planogametes fuses with it. In Ectocarpus siliculosus it has been observed that, if the planogametes fail to conjugate, they are capable of germinating independently; in Cutleria, also, the unfertilised female planogamete has been observed to germinate independently; these interesting cases of parthenogenesis indicate the incomplete development of sexuality in this group.

Inasmuch as the germination of the zygospore has only been observed in the case of Ectocarpus siliculosus and of the Cutleriacex, it is only with reference to these plants that any definite statement can be made as to the life-history obtaining in this group. In E. siliculosus the zygospore gives rise to a plant which resembles its parents, so that here there is no indication of an alternation of generations. In the Cutleriaceæ, on the other hand, the zygospore gives rise to an asexual form which is probably a true sporophyte; in the one genus, Zanar-

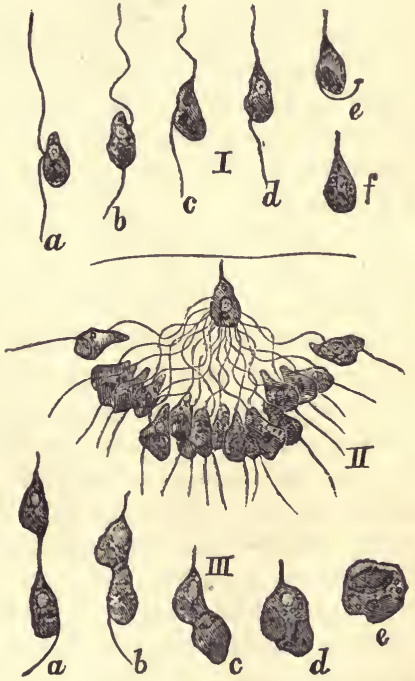

F1G. 187. - Sexual process in Ectocarpus siliculosus: I $a-f$. female planogamete coming to rest: II resting female planogamete suspended from the surface of the water, with numerous motile male planogametes: III conjugation of a male and a female planogamete. ( $\times 790$ : after Berthold.)

dinia, this asexual form closely resembles the sexual; in the other genus, Cutleria, the asexual form is very different from the sexual in appearance, and has long been regarded as a distinct genus under the name Aglaozonia. With regard to the other genera of the group, it is probable that in those forms (e.g. many Ectocarpaceæ) in which the same individual bears at one time sexual, and at another, asexual organs, there is no alternation of generations; and further, that in those forms (e.g. many Sphacelarieæ) in which the asexual and the sexual organs are never borne by the same individual, there is 
an alternation of generations, the asexual form being the sporophyte. It is also probable that in the case of those forms of which only individuals bearing either asexual (e.g. Desmarestia, Laminaria) or sexual (e.g. Scytosiphon, Phyllitis, Colpomenia) organs are known, the life-history may present an alternation of generations.

The Phæosporeæ are almost exclusively marine, the only fresh-water forms being the genus Pleurocladia (Ectocarpaceæ) and two species of the genus Lithoderma. The size of the plants included in this series varies widely, from microscopic Ectocarpaceæ to gigantic tree-like Laminariaceæ, such as Macrocystis, Nereocystis, etc., which may attain a length of several hundred feet. In some of the Laminarias, which have cylindrical stalk-like region in their thalloid shoot (see Fig. 159), secondary growth in thickness takes place by means of a merismatic layer. In these large forms, too, the conducting tissue is sometimes so far developed as to form sieve-tubes; though no woody tissue is developed, nor is it required in view of the fact that these plants live submerged.

Series Phжоgaмe. The orders comprised in this group are characterised by the oogamous sexual process, by the absence of gonidia, and by the nonmotile spores; the orders may be conveniently described separately, as they are well defined.

Order 8. Tilopteridaceæ. Body filamentous, differentiated into shoot and root; the shoot is, in its younger parts, monosiphonous; in its older parts polysiphonous, but without cortex; growth in length by means of intercalary growing-points; lateral members, some with unlimited growth (branches), some with limited growth; the root consists of a single row of cells, and its growth is intercalary, without any special growing-point; marine.

The asexual and sexual reproductive organs are borne on distinct individuals. The asexual organs are terminal, or less commonly intercalary, unicellular sporangia; the sexual organs are unicellular oogonia, and multicellular antheridia (resembling the gametangia of the Phæosporeæ), and are intercalary. The sporangium gives rise to a single non-motile spore, which, at the time it is set free, has a delicate cell-wall, and contains four nuclei. The oogonium (which somewhat resembles the sporangium in form) gives rise to a single oosphere, which, when it leaves the oogonium, has no cell-wall. Each cell of the antheridium gives rise to a single spermatozoid, oval in form, with two cilia. The sexual process and the germination of the oospore bave not been observed. The spore, on germination, undergoes repeated division, forming a solid multicellular body, from which a long root grows out; from the multicellular embryo spring the adult shoots.

The life-history of the Tilopteridaceæ probably presents an alternation of generations, the form bearing the asexual organs being the sporophyte: for instance, the forms known as Haplospora and Scaphospora are probably the asexual and sexual generations, respectively, of the same plant, a Tilopteris.

Order 9. Dictyotaceæ. Body flattened, ribbon or fan-shaped, sometimes dichotomously branched, consisting of several layers of parenchymatous cells, with a well-marked midrib in Dictyopteris, differentiated into root and shoot; growth of the shoot takes place in Dictyota by means of a single apical cell (see Fig. 140), in the other forms by a marginal series of merismatic cells. Both asexual and sexual organs are known. The asexual organs are unicellular 
sporangia, borne on distinct individuals; each sporangium sets free four spores (tetraspores), which are destitute of a cell-wall and of eilia. The sexual organs are unicellular oogonia and multicellular antheridia; the oogonia are generally in groups (sori), and each gives rise to a single oosphere, which is set free as a naked unciliated cell; the antheridia are always in groups (sori), and give rise to a large number of small, apparently non-motile, spermatozoids, which have no chromatophores. The process of fertilisation has not been

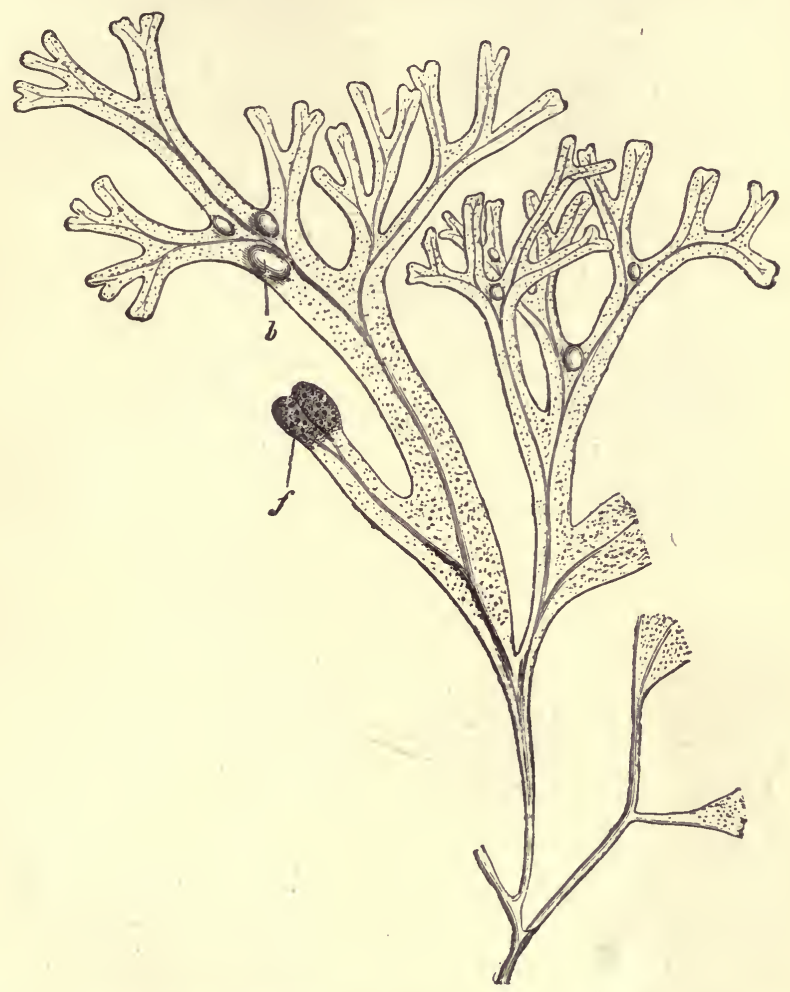

Fig. 188. - Fucus vesiculosus, about half nat. size : $b$ air-bladders; $f$ fertile branch.

observed. The male and female organs are either borne on the same plant (e.g. Padina), or on distinct plants (Dictyota, Taonia).

The tetraspores and the oospores germinate alike. The spore divides into two cells, one of which grows out into the filamentous primary root, the other grows out directly into the shoot in Dictyota and Zonaria; but in Taonia, Padina, and Dictyopteris, the development is heteroblastic, since the latter cell gives rise to a rounded multicellular embrso, from which the adult shoot grows out as a branch. In the embryonic shoot of Taonia and Dictyopteris there is a single apical cell, but eventually it gives place to a number of initial cells. 
It is extremely probable that the life-history of these plants presents a definite alternation of generations, the asexual form being the sporophyte. If this be so, the affinity to the Rhodophycer which is suggested by the similarity, of four spores developed in the sporangium of this group to the "tetraspores" of

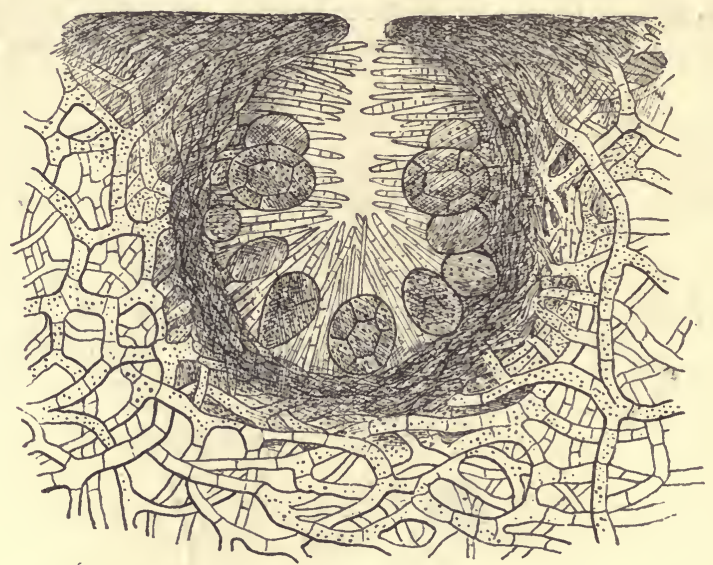

FiG. 189.--Section of a female conceptacle, with surrounding tissue, of Fucus vesiculosus, ( $\times 50$ : after Thuret.)
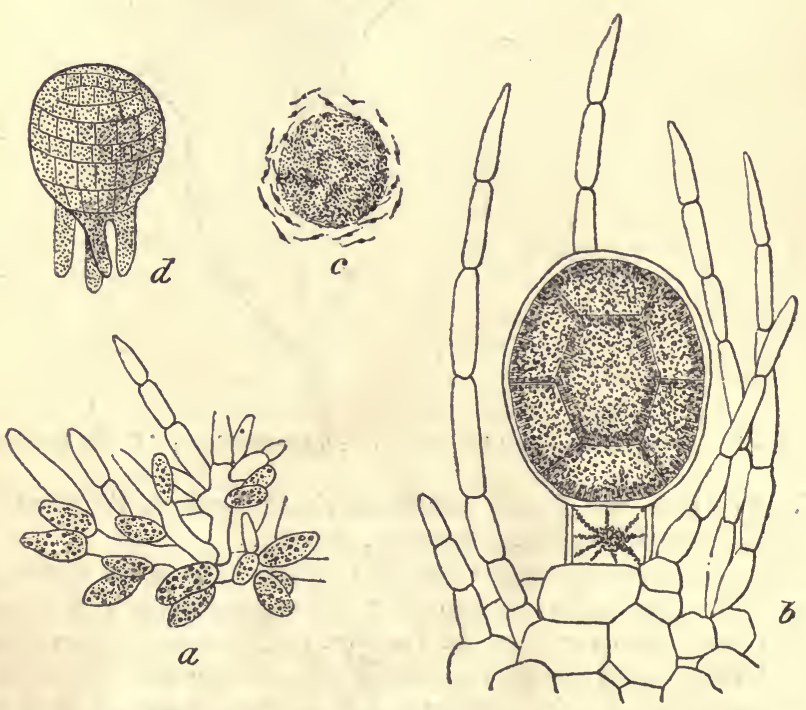

Fig. 190.-Fucus vesiculosus. a Paraphysis, from male conceptacle, bearing antheridia; $b$ an oogonium with paraphyses; $c$ process of fertilisation, the extruded oosphere surrounded by spermatozoids; $\alpha$ developing embrjo. ( $\times 160$ : after Thuret.) 

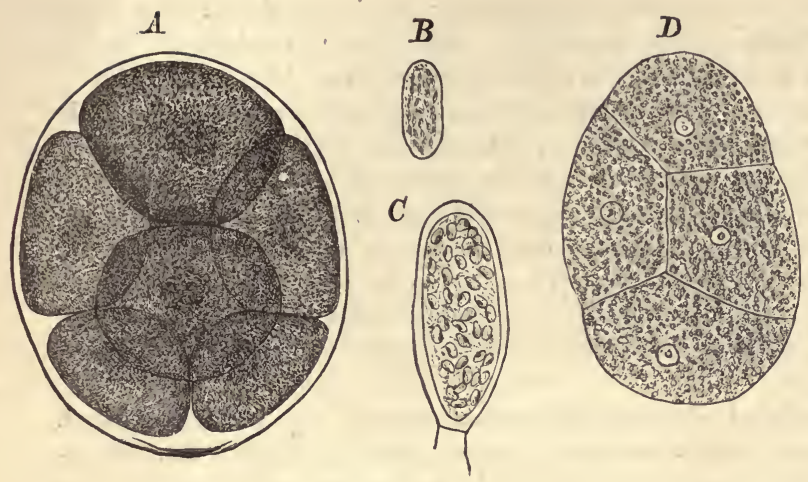

G

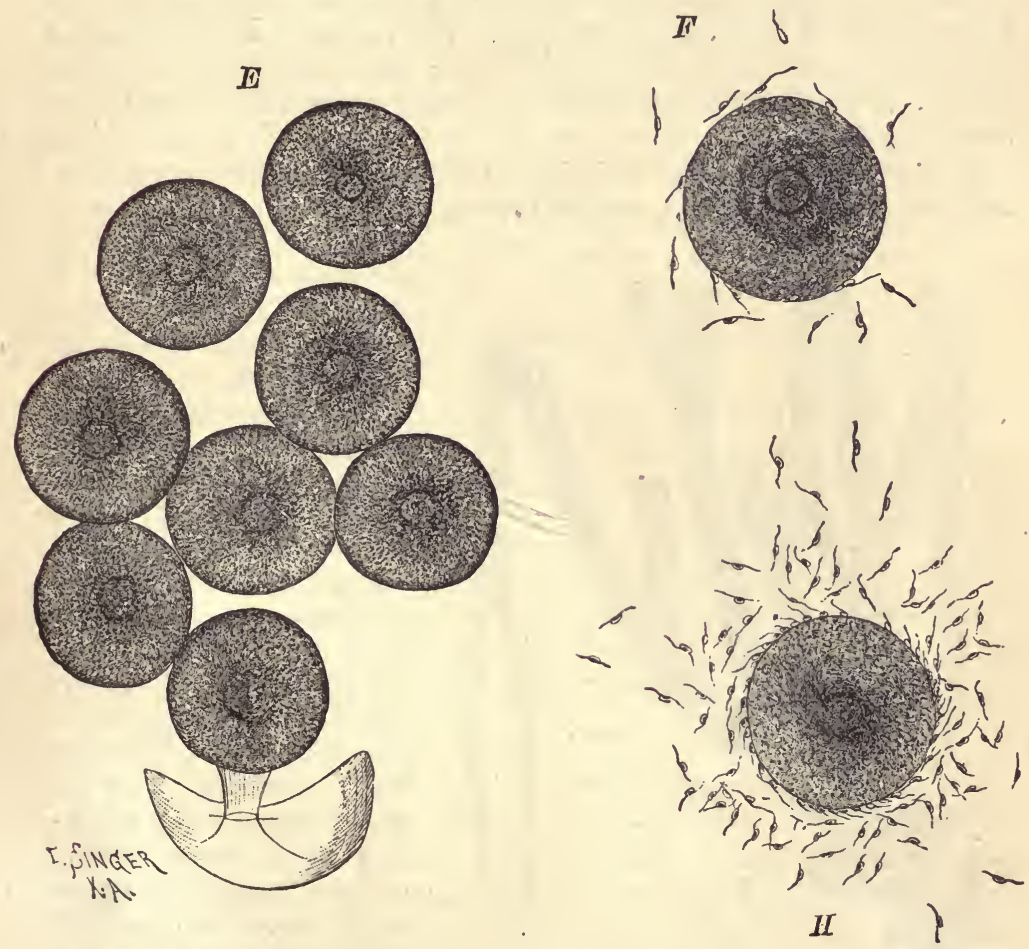

FrG. 191.-A Eight oospores extruded from the oogonium, surrounded by the inner layer of the cell-wall : $B$ contents of an antheridium set Iree, Eurrounded by a layer of the cellwall : $C$ antheridium : $D$ section of contents of an oogorium showing the divisions accompanying the development of the oospheres: $E$ oospheres set free in consequence of the rupture of the layer of cell-wall by which they were surrounded when first extruded: $F$ and $H$ oospheres, with spermatozoids: $G$ spermatozoids. $A-F$ Fucus platycarpus; $G H$, F. vesiculosus. ( $C$ and $G \times 540$; other figs. $\times 240$ : after Strasburger.) 
the Rhodophyceæ, becomes altogether illusory; for in the Dictyotaceæ these spores are developed on the sporophyte, whilst the "tetraspores" of the Rhodophyceæ are gonidia developed by the gametophyte. All marine.

Order 10. Fucaceæ. Body differentiated into root and shoot; shoot usually thalloid, either cylindrical or flattened; differentiated into stem and leaves in Sargassum; growth in length by a single apical cell; branching generally dichotomous. No asexual production of gonidia or of spores, and therefore no alternation of generations. Sexual organs, unicellular antheridia and oogonia ; spermatozoids, ciliated, formed several together in the antheridium; oospheres, set free but not ciliated; one (Pycnophycus, Himanthalia, Halidrys, Sargassum, Cystoseira), two (Pelvetia), four (Ascophyllum), or eight (Fucus) formed in each oogonium. Marine.

The body consists of what may be termed cortical and medullary tissue. The cortical tissue consists of closely-packed parenchymatous cells, the external layer of which, the limiting layer, is for a time merismatic, and plays an important part in the growth of the body. The medullary tissue consists of filamentous rows of cells the walls of which are mucilaginous and much swollen. The cortex is essentially the assimilatory tissue and the medulla the conducting tissue.

In some genera (e.g. Fucus vesiculosus, Ascophyllum; Halidrys, Cystoseira, Sargassum) there are large intercellular spaces, filled with air, which project on the surface, and are known as

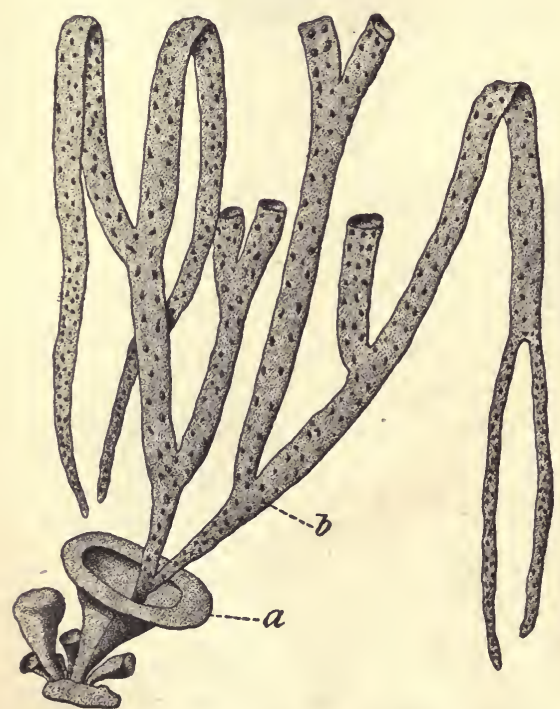

Fig. 192. - Himanthalia lorea (much reduced). a Vegetative part of body; $b$ branched gametophore. air-bladders; they serve as floats. In Halidrys and Sargassum the air-bladders are borne on special branches.

The sexual organs are in all cases borne in depressions of the surface known as conceptacles (Fig. 189.) The conceptacles are commonly confined to special portions of the thallus; either to the tips of the branches (e.g. Fucus, Cystoseira) or to special branches, the gametophores (e.g. Himanthalia, Ascophyllum, Sargassum). From the inner surface of the conceptacle there arise a number of hairs (paraphyses) among which the sexual organs are borne. The oogonia (Fig. 190) are nearly spherical, and are borne on a short stalk consisting of a single cell ; the antheridia (Fig. 190) are the lateral branches of some of the hairs. The plants may be monœecious (e.g. Fucus platycarpus, Halidrys, Pelvetia, Cystoseira, 
Sargassum), or diœcious (e.g. Himanthalia, Ascophyllum, Fucus vesiculosus and serratus) ; in the former case each conceptacle contains both antheridia and oogonia.

The oospore, which is the product of the fertilisation of an oosphere, germinates without any period of quiescence. It first becomes somewhat pear-shaped; it is then divided into two by a transverse wall; the more pointed of the two cells forms the primary root, whilst the other gives rise to the shoot (Fig $190 \mathrm{~d}$.)

Sub-Class IV. Rнодорнусеж or Red Algæ.' Multicellular plants; body, generally differentiated into shoot and root; shoot, sometimes differentiated into stem and leaf; flattened or filamentous; when filamentous, consisting of a single longitudinal row of cells (monosiphonous) or of several rows (polysiphonous) with or without a small-celled cortex; the filamentous forms grow by means of a single apical cell from which segments are cut off either by transverse walls, or by oblique walls alternately right and left; the flattened forms grow by means of a marginal series of initial cells; but in the Bangiaceæ there is no growing-point, all the cells being merismatic: branching, generally monopodial, but sometimes sympodial (e.g. Plocamium, Dasya): adventitious roots common.

Vegetative reproduction by gemmæ (o.g. Monospora, Melobesia) is rare.

Reproduction by means of asexually produced spores occurs throughout the sub-class; the sporophyte (cystocarp) always produces spores (carpospores); the gametophyte usually produces gonidia (usually tetragonidia) except in the Lemaneaceæ and most Helminthocladiaceæ; the gonidia are, as a rule, not borne on individuals which produce sexual organs (actual gametophytes), but on distinct individuals (potential gametophytes), though there are exceptions to this rule (e.g. Lomentaria kaliformis, Callithamnion corymbosum, Polysiphonia variegata, etc.).

The gonidia are produced in unilocular gonidangia, either singly, or two together, or sometimes as many as eight, but most commonly in fours; hence they are generally termed tetragonidia. The tetragonidia may be formed tetrahedrally in the gonidangium; or by transverse divisions, when they are said to be zonate; or by two divisions at right angles to each other, when they are said to be cruciate.

The arrangement of the gonidangia on the shoot is various. In simple monosiphonous forms (e.g. Callithamnion) the terminal cells of short lateral branches become gonidangia. In forms of 
more complex structure the gonidangia are developed internally, within the superficial layer of tissue. The gonidangia may be scattered over the surface of the shoot, or collected into special receptacles of various forms. In some cases (e.g. some Rhodomelaceæ, such as Dasya, Chondriopsis, Polysiphonia) the gonidangia are confined to certain specially modified branches (gonidiophores) which are termed stichidia. The tetragonidia are set free as spherical unciliated cells without a cell-wall.

The sexual organs are antheridia and procarps; they are usually borne by distinct individuals, but in some cases on the

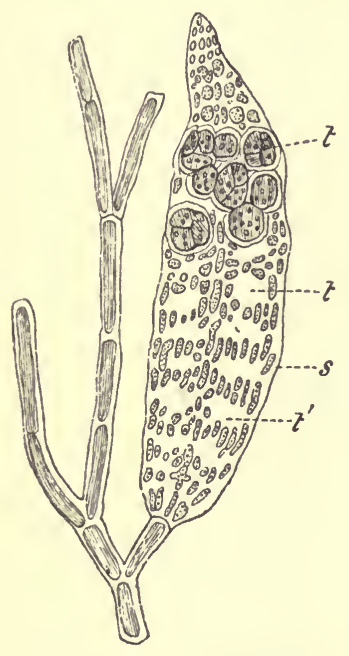

Frg. 193.-Portion of a branch of Dasya elegans, bearing a stichidium (s), with tetragonidangia $(t)$; $t^{\prime}$ empty tetragonidangium. ( $\times 25$ : after Kützing.) same (e.g. Grateloupia, Halymenia, Halarachnion, Nemastoma, Dudresnaya coccinea and purpurifera, Gloesiphonia capillaris, Helminthora divaricata).

The antheridia are small and unicellular; in the simple filamentous forms they occur singly or: in groups at the ends of the branches; in others of more complex structure, they are produced in special receptacles (e.g. Corallinaceæ); in the flattened parenchymatous forms they occur in groups on the surface; in those forms in which the shoot is differentiated into stem and leaf (e.g. some Rhodomelaceæ such as Polysiphonia fastigiata and nigrescens, Chondriopsis tenuissima) the antheridia are confined to the leaves, the whole or part of the leaf being specially modified for this purpose. The male cells (spermatia) are formed singly in the antheridia, and are set free as small, spherical or oval, unciliated cells destitute of a cell-wall; they acquire a cell-wall at the time of fertilisation; they contain no chromatophores, except in Bangiaceæ.

The procarp presents considerable variety of form and structure. It may be unicellular (e.g. Bangiaceæ, Chantransia, Batrachospermum, Lemanea, Nemalion), or multicellular, as is more commonly the case. The unicellular procarp consists simply of a carpogonium prolonged (except, perhaps, in Bangia) into a filament termed the trichogyne. Various descriptions are given of the structure of the multicellular procarp; however, it appears to 
consist essentially of a unicellular carpogonium (with a trichogyne) together with one or more specially differentiated auxiliary cells. In some cases (e.g. Dudresnaya coccinea, Squamariaceæ), the carpogonium and the auxiliary cells are not developed in the same procarp, but in distinct organs.

Whether the procarps be unicellular or multicellular, the carpogonia agree in that the trichogyne remains closed, and further, in that the protoplasm of the carpogonium does not undergo rejuvenescence to form a distinct female cell (oosphere) as is the case in the oogamous Algæ.

The carpogonium is (except in the Bangiaceæ) developed from the terminal cell of a lateral appendage; in some cases (e.g. Polysiphonia fastigiata and nigrescens) the lateral appendage is a leaf, the whole or part of which goes to form the procarp; in the Corallinaceæ the procarps are aggregated in receptacles.

The sexual process consists in the fusion of the protoplasmic contents of a spermatium with those of a trichogyne. The spermatium is brought by the water into contact with the projecting trichogyne to which it adheres, the spermatium being at this time covered with a cell-wall; the intervening cell-walls are absorbed at the point of contact, and the protoplasm of the spermatium enters the trichogyne.

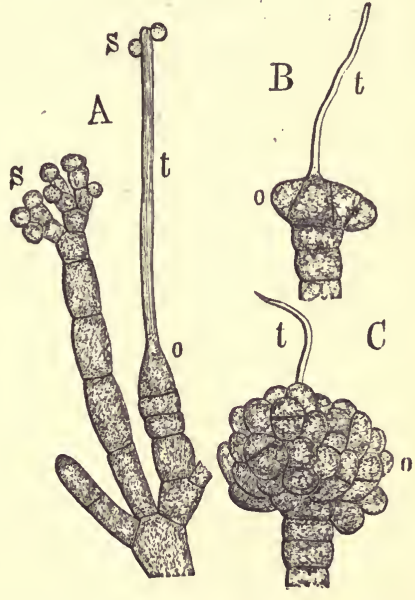

Fig. 194.-Sexual organs of Nemalion ( $\times 300) A$ ends of branches bearing a unicellular procarp $t-0$, and a group of antheridia $s$; the trichogyne $(t)$ of the procarp has two spermatia (s) adhering to it. $B$ early stage in the development of the cystocarp; the fertilised carpogonium is undergoing growth and division. C nearly mature cystocarp, consisting of a number of short filaments each terminating in a carposporangium. The development of the cystocarp is direct.

The product of fertilisation is a fructification termed a cystocarp, consisting of a number of carposporangia. The cystocarp is developed either directly or indirectly from the carpogonium: directly, when the procarp is unicellular; indirectly, when it is developed from both carpogonial and auxiliary cells: the trichogyne takes no part in the development of the cystocarp, being shat off by a septum. 
The simplest mode of direct formation of the cystocarp occurs in the Bangiaceæ; the cavity of the carpogonium becomes chambered, by the formation of cell-walls, into usually eight cells, each of which is a sporangium, giving rise to a carpospore: only a single spore is formed in the genus Erythrotrichia. In other cases of direct formation (e.g. Nemalion, Batrachospermum, Chantransia, Lemanea), the carpogonium gives rise to a number of filaments, termed ooblastema-filaments, which bear a cluster of sporangia (Fig. 194).

In the indirect formation of the cystocarp, the carpogonium fuses with one or more of the auxiliary cells. In the simplest case
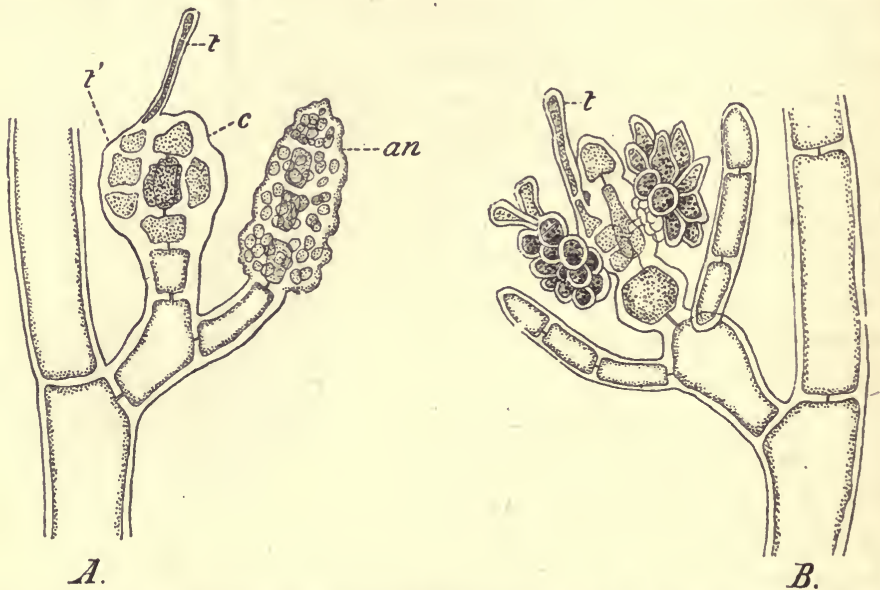

Frg. 195.-Sexual organs of Spermothamnion hermaphioditun. A Male and female organs; $c$ multicellular procarp; $t$ trichogyne; $t^{\prime}$ trichophore; an terminal cluster of antheridia. $B$ cystocarp developing from the fertilised procarp; a cluster of carposporangia is springing from each of the two opposite lateral auxiliary cells. The development of the cystocarp is indirect $(\times 300$ : after Naegeli).

(e.g. Gigartinaceæ, Rhodymeniaceæ, Sphærococceæ, Rhodomelaceæ), the carpogonium fuses directly with the auxiliary cell (or cells), and from the latter the sporangia, or filaments bearing sporangia, are formed. In other cases the carpogonium gives rise to one or more elongated, branched, ooblastema-filaments which fuse with one or more auxiliary cells, and the sporangia are produced. either from the ooblastema-filaments (e.g. Gelidiaceæ) or from the auxiliary cells (e.g. Squamariaceæ and other Cryptoneminæ).

In the Corallinaceæ, where the procarps are aggregated in receptacles, only a single cystocarp is formed from the whole group of procarps. Some of the procarps appear to be altogether abortive, and only those toward the centre of the group have tricho- 
gynes, whilst others seem to have only auxiliary cells: after fertilisation, the carpogonia of the central procarpia fuse with each other, and with the auxiliary cells of the other procarpia, forming a large cell from the periphery of which the carposporangia, constituting the cystocarp, are developed.

The cell-fusions alluded to above are frequently considered to be of the nature of a sexual process. For instance, in Dudresnay a coccinea, the procarp bearing the trichogyne is regarded as a trichophore, whilst the procarp which includes the auxiliary cell, but has no trichogyne, is regarded as the carpogonium proper: the ooblastema-filament which grows from the former and fuses with the latter, is, from this point of view, a trichnphoric tube which conveys the fertilising substance of the spermatium from the trichophore to the carpogonium. From the point of view of the foregoing paragraphs, the fusion of carpogonial with auxiliary cells is simply of nutritive importance. Though both views are tenable, the latter is strongly supported by the fact that in certain forms (e.g. some Gelidiaceæ such as. Wrangelia, Pterocladia) the ooblastema-filaments fuse with vegetative cells of the body.

In many cases the cystocarp consists merely of the cluster of sporangia (e.g. Bangia, Chantransia, Callithamnion, Dudresnaya); in other cases the cluster of sporangia is surrounded by a cellular investment, termed the pericarp, formed by the growth of adjacent sterile cells.

Each sporangium always gives rise to a single carpospore, which is set free as a somewhat spherical unciliated cell destitute of a cell-wall, and germinates without any quiescent period.

The germination of the tetragonidia and of the carpospores has only been followed in a few cases. Generally speaking the spore becomes elongated in form, and is attached by the more pointed end which is almost colourless; division by a transverse wall then takes place; the elongated attached cell developes into the root, the other into the shoot.

Batrachospermum and Lemanea are exceptions to the general rule that the germinating carpospore gives rise directly to the adult form, and afford good examples of heteroblastic embryogeny (see p. 14). In Batrachospermum, the carpospore gives rise to a small flattened embryo, from which there arise monosiphonous filaments; these filaments constitute what is termed the Chantransia-form which reproduces itself by means of gonidia ; from the Chantransiaform, the Batrachospermum-plant springs as a lateral branch, and, producing roots, becomes independent. In Lemanea the course of development is essentially the same, only that the Chantransia-form does not produce gonidia.

The life-history of the Rhodophyceæ is generally considered to 
present an alternation of generations; the plant is the gametophyte (either actual or potential) and the cystocarp is the sporophyte. In Batrachospermum and Lemanea the life-history is complicated by the polymorphism of the gametophyte.

The Rhodophyceæ are almost exclusively marine; the only fresh-water forms are Batrachospermum, Lemanea, and species of Chantransia, Bangia, and Hildenbrandtia.

The sub-class, sometimes also termed FloRIDEe, is subdivided into a number of orders, the limits of which are at present but imperfectly defined, of which the following are the principal :-

Series I. Nemalionine.

Order 1. Helminthocladiaceæ : principal genera, Batrachospermum, Chantransia, Helminthocladia, Nemalion, Scinaia, Helminthora.

"2. Lemaneaceæ: Lemanea.

" 3. Gelidiaceæ: principal genera, Caulacanthus, Pterocladia, Gelidium, Wrangelia, Naccaria.

Series II. Gigartinine.

Order 4. Gigartinaceæ: principal genera, Phyllophora, Gigartina, Chondrus, Iridæa, Gymnogongrus.

„5. Rhodophyllidaceæ: principal genera, Catenella, Rhodophyllis.

Series III. RhodYMenine.

Order 6. Sphærococcaceæ: principal genera, Gracilaria, Sphærococcus, Hypnea.

"7. Rhodymeniaceæ: principal genera, Rhodymenia, Lomentaria, Plocamium, Chylocladia, Champia.

„ 8. Delesseriaceæ: principal genera, Delesseria, Nitophyllum.

" 9. Bonnemaisoniaceæ: principal genera, Bonnemaisonia, Leptophyllis.

„10. Rhodomelaceæ: principal genera, Polysiphonia, Rhodomela, Rhytiphlœa, Chondriopsis, Dasya, Laurencia, Vidalia.

" 11. Ceramiaceæ: principal genera, Ceramium, Spermothamnion, Callithamnion, Griffithsia, Ptilota, Monospora.

Series IV. Criptonemine.

Order 12. Gloosiphoniaceæ: Gloosiphonia, etc.

„13. Grateloupiaceæ: principal genera, Grateloupia, Cryptonemia, Halymenia.

„14. Dumontiaceæ: principal genera, Dumontia, Dudresnaya.

" 15. Nemastomaceæ: principal genera, Schizymenia, Nemastoma, Furcellaria.

16. Rhizophyllidaceæ: Polyides, Rhizophyllis.

" 17. Squamariaceæ: principal genera, Peyssonnelia, Petrocelis, Hildenbrandtia.

Order 18. Corallinaceæ: principal genera, Corallina, Melobesia, Lithophyllum, Lithothamnion.

Series V. Porphyrine.

Order 19. Bangiaceæ: principal genera, Bangia, Porphyra, Erythrotrichia. 


\section{CLASS II.-FUNGI.}

This class, like the preceding, includes many very simple organisms, as well as others of tolerably high development. None of them contain chlorophyll; hence they cannot assimilate so simple a carbon-compound as carbon dioxide, but must take up their carbonaceous food in the form of rather complex compounds, and their structure and mode of life are correlated with this peculiarity. Some are parasitic, such as the Rusts and Smuts, and absorb these complex carbon-compounds from other living organisms, whether plants or animals. Others are saprophytes, absorbing these compounds from the remains of dead organisms, or from organic substance formed by living organisms: the numerous and often large Fungi which grow on humus or leaf-soil in forests, or on the bark of trees, are examples of the former case; the Yeasts and Moulds which make their appearance on juicy fruits, saccharine liquids, etc., are examples of the latter. Some Fungi are symbiotic; that is, they live in intimate relation (symbiosis) with plants which possess chlorophyll, and obtain from them the necessary carbonaceous food, but without destroying, or apparently injuring them. They commonly live with Algæ, forming Lichens (see p. 319); or in connexion with the roots of trees (esp. Cupuliferæ) and of Orchids, Leguminosæ, and other plants, or with prothallia (e.g. Lycopodium), forming what is known as Mycorhiza.

The vegetative body may be unicellular, or cœnocytic. In the former case it is small and rounded or rod-shaped in form. In the latter case the body is always a mycelium, consisting of more or less branched filaments, termed hyphoe. The mycelium may be unseptate, as in the Phycomycetes, in which case the body resembles in structure that of the Siphonaceæ among the Green Algæ (see p. 238). Or the mycelium may be septate, as in the higher Fungi, in which case it appears to be always incompletely septate; that is to say, the segments of the hyphæ which are marked out by the transverse septa, are not cells, each with a nucleus, but contain several nuclei, and are cœnocytes (as in the Cladophoraceæ among the Chlorophyceæ). The hyphæ grow in length at the apex in the manner of such Algæ as Vaucheria and Cladophora (see p. 222).

In some of the more complex forms, the hyphæ of the reprov. S. B. 
ductive organs form compact masses of tissue of a somewhat parenchymatous appearance, in which there is no differentiation of tissue-systems, but the superficial layers of hyphæ form a kind of tegumentary tissue, termed generally cortex. Considerable differences in the nature of the cell-wall may obtain in different parts of such organs, some walls being soft and mucilaginous, whilst others are relatively hard without, however, ever being lignified. In a few Mushrooms (e.g. Lactarius) some of the hyphæ form a system of laticiferous tissue, and in others glandular structures occur.

Except in the simplest forms, the body is generally more or less clearly differentiated into root and shoot. These members can be distinguished partly by their relative position, the root-hyphæ growing into the substratum, and the shoot-hyphæ into the air; and partly by the fact that the shoot-hyphæ bear the reproductive organs. Some parasitic forms have root-like organs, termed haustoria, which penetrate into the cells of the host; similar organs occur in some saprophytes, and in others (e.g. crustaceous Lichens) the roots (sometimes called rhizines) consist of bundles of hyphæ. There is in no case any differentiation of the shoot into stem and leaf.

The foregoing account does not apply to the body of the Myxomycetes, which consists of a multinucleate mass of protoplasm, termed a plasmodium, without any cell-wall. It is formed by the cohesion of a number of small, originally independent cells, like that of the Hydrodictyaceæ among the Algæ (see p. 242).

Vegetative propagation is common among the Fungi. The simplest form of it is simple cell-division (e.g. Schizomycetes), or that form of cell-division known as budding or sprouting (gemmation) (e.g. the Yeast-forms of various Fungi). It is effected in some cases (e.g. in some Zygomycetes, Ascomycetes, and Basidiomycetes) by unicellular gemmce of various sizes (termed chlamydogonidia when they are relatively large and thick-walled, and are adapted for a period of quiescence; oidium-cells, when they are small and thinwalled and capable of immediate germination) which are formed by the segmentation of a hypha by transverse septa into short cells which become somewhat rounded and separate from each other; on germination, each may give rise to a mycelium. In other cases (e.g. many Ascomycetes, such as the Sclerotinieæ, Pezizeæ, Claviceps, etc.; some Basidiomycetes, such as Coprinus stercorarius, 
species of Typhula and Agaricus), it is effected by bodies termed sclerotia; each sclerotium consists of a compact mass of hyphæ, filled with reserve materials, covered by a cortex of one or more layers of cells, which are thick-walled, and of a dark colour. They become detached from the mycelium on which they are formed, and are capable of retaining their vitality during a long dormant period ; on germination they give rise to shoots bearing reproductive organs.

A form of sclerotium is found also in the Myxomycetes. Here it consists of a plasmodium, or a part of a plasmodium, which has surrounded itself with a membrane, and remains for a longer or shorter time in a dormant condition. The individual amoboid cells may also surround themselves with a membrane and remain dormant, in the form of microcysts.

Reproduction is effected sexually or asexually. A sexual process takes place in the Zygomycetes; in the Peronosporaceæ; and apparently in some Ascomycetes, though this is a matter of controversy.

The modes of the sexual process are the following :-

I. Isogamy : sexual cells, similar aplanogametes which are not set free; process, conjugation; product, a zygospore; Zygomycetes.

II. Heterogamy :-

a. Oogamy: sexual cells, oospheres and undifferentiated male cells (spermatozoids in Monoblepharis?) ; process, fertilisation; product, an oospore; Peronosporaceæ, Ancylistaceæ.

b. Carpogamy: no differentiated female cell; female organ fertilised either by (1) the undifferentiated contents of the male organ (e.g. Eremascus, Pyronema); or (2) by differentiated male cells, spermatia (e.g. Collema) : product, a fructification termed an ascocarp : all the forms in which this mode occurs belong to the Ascomycetes.

There is no sexual process in the Schizomycetes, the Myxomycetes, in some of the Phycomycetes (Saprolegniaceæ), the great majority of the Ascomycetes, the Acidiomycetes, and the Basidiomycetes. In the Schizomycetes and Myxomycetes, the absence of a sexual process may be attributed to their rudimentary character; in the higher groups it is due to sexual degeneration. In the Saprolegniaceæ, female and, generally, male organs are deve- 
loped, but the male organs are functionless; still the female organs produce oospores, but they do so parthenogenetically. In the majority of the apparently sexual Ascomycetes, even when both kinds of sexual organs are present (e.g. Erysipheæ, Penicillium, Sordaria) it is a question if any sexual process takes place; in others, no male organ is present (e.g. Chætomium, Melanospora); in others again (e.g. Xylaria), the female organ is rudimentary, and in yet others (e.g. Claviceps, Cordiceps, Pleospora) it has entirely disappeared. Yet in all these cases an asocarp is produced, either parthenogenetically from the female organ, or vegetatively from the mycelium. In the Acidiomycetes, though there is apparently no female organ, yet a fructification termed an accidium, which seems to be homologous with the ascocarp of the Ascomycetes, is produced in most forms. In the Basidiomycetes, although they are the most highly organised Fungi, there are no sexual organs, and no fructification is produced which is homologous with the ascocarp of the Ascomycetes.

The sexual organs, with the exception of those of some Ascomycetes, are unicellular. They are either quite similar to each other, as in the Zygomycetes and some Ascomycetes (e.g. Eremascus), when they may be termed gametangia; or they may be more or less differentiated, as in the Oomycetes, and in some Ascomycetes (e.g. Erysipheæ, Collema, etc.), as male and female.

The male organ is a pollinodium in the Oomycetes and in some Ascomycetes (e.g. Pyronema, Erysipheæ, Ascobolus); it is generally unicellular but sometimes multicellular (e.g. Ascobolus). As it is developed in close proximity to the female organ, fertilisation is effected, in these forms, by absorption of the cell-walls at the point of contact of the two organs, or the development of a tube placing their cavities in communication.

In other Ascomycetes (e.g. Collema), what appears to be the male organ is a unicellular or multicellular filament, termed a sterigma, at the apex of which male cells (spermatia) are successively formed by abstriction. The sterigmata are developed in great numbers together within a special receptacle termed a spermogonium. In these forms the male and female organs are widely separated, and the male cells are conveyed by means of water to the female organ. Spermogonia also occur in the Acidiomycetes.

The female organ is either a unicellular closed oogonium (Oomycetes), or a unicellular or multicellular archicarp (Ascomycetes) 
The archicarp may consist (like the procarp of the Rhodophyceæ) of two parts; a receptive portion, the trichogyne, which is a more or less elongated multicellular filament, and a sporogenous portion, the ascogonium, from which, after fertilisation has taken place, the one or more sporangia (asci) of the ascocarp are developed.

Sexual cells are only clearly differentiated in the case of the female cells of the Oomycetes, and of the male cells of those Ascomycetes in which the sexual organs are not contiguous. The female cells of the Oomycetes are oospheres, spherical cells destitute of a proper wall. The male cells of the Ascomycetes in question are spermatia, small rounded or rod-shaped cells, with a cell-wall and without eilia. It must, however, be mentioned that considerable doubt exists as to the sexual nature of the spermatia; and, inasmuch as they have in many cases been found capable of germination, giving rise to a mycelium, there is evidence in favour of the view that they are merely asexual cells of the nature of gonidia (see p. 297).

In all other cases the protoplasmic contents of the sexual organs are not differentiated into cells of definite form; but the fusing masses of protoplasm of the Zygomycetes may be regarded as aplanogametes; and that portion of the protoplasmic contents of the pollinodium of the Peronosporaceæ which enters the oogonium and fertilises the oosphere, may be regarded as a male cell.

A formation of planngametes has been observed in a doubtful Chytridiaceous form Tetrachytrium triceps; and of spermatozoids with a single cilium in Monoblepharis spharica a form allied to the Peronosporaceæ; but these observations require confirmation.

An asexual formation of spores is of general occurrence. Where the life-history is such as to indicate an alternation of generations, these cells may be distinguished as gonidia and spores; it is, in fact, in the gametophyte that the greater variety and complexity of the asexual reproductive organs obtains.

In the Schizomycetes there are no special spore-bearing organs, but the protoplasm of the cells surrounds itself with a proper cellwall, and becomes a spore.

In the Myxomycetes sporangia are formed, attaining, in some forms, a high degree of complexity of structure.

In the gametophyte of the higher Fungi, the gonidia are formed, speaking generally, either in the interior of unilocular gonidangia (e.g. most Phycomycetes), or by abstriction, eithər singly or a 
number in succession, from certain special hyphæ (as in the Ascomycetes, Ecidiomycetes, and Basidiomycetes); in the latter case the gonidia may be generally designated stylogonidia.

These stylogonidia has received special names, such as uredospores, teleutospores, basidiospores, etc., with the object of indicating the group to which they belong, or peculiarities in their development. These terms (more correctly uredogonidia, teleutogonidia basidiogonidia) are explained in the descriptions of the various groups.

In either case, the gonidia are produced at the apex of an organ, a special branch of the mycelium, termed a gonidiophore. This may consist of a single hypha (e.g. Mncor, Peronospora, Penicillium, Puccinia), when it is said to be simple; or of a number of coherent hyphæ (e.g. the Mushroom, and the fructifications of other Basidiomycetes) when it is said to be compound.

The gonidiophores may be scattered over the mycelium, or they may be collected into receptacles termed pycnidia.

In the sporophyte of most Phycomycetes and all Ascomycetes, the spores are always found in the interior of a sporangium (termed, in the Ascomycetes, an ascus); in the Acidiomycetes they are formed by successive abstriction from basidial cells forming part of the æcidium. In some cases (e.g. certain Mucorinæ and Peronosporacex) the sporangia are borne on special hypha, which are termed simple sporophores; and the more complex ascocarps of the Ascomycetes may be regarded as compound sporophores.

The asexually-formed spores and gonidia are but rarely motile (e.g.ciliated zoospores and zoogonidia of Myxomycetes, Chytridiaceæ, and Oomycetes); in all other Fungi they are non-motile and have a cell-wall. There is considerable variety in their form, colour, etc. In some cases the spores or gonidia are compound; that is, they appear to consist of two or more cells (e.g. teleutogonidia of Puccinia Graminis and other Acidiomycetes; ascospores of some Ascomycetes such as Pleospora, Hysterium, Cordyceps, etc.); each cell, however, germinates independently and is therefore itself a spore or gonidium. These compound spores and gonidia are formed by the division of a primary mother-cell.

The Life-History of the Fungi is generally very much complicated by polymorphism. In most of the Schizomycetes, although there is no alternation of generations, there is remarkable polymorphism, especially in the higher forms which pass through several distinct phases in the course of their life. In the sexual forms an alter- 
nation of generations can generally be traced; thus, in the Phycomycetes, the plant is the gametophyte, and the sporophyte is either merely the oospore or zygospore, or it is the comparatively small mycelium (promycelium) developed on germination from the sexually-produced spore; similarly, assuming the sexuality of the group, in the simpler forms of the Ascomycetes, the plant is the gametophyte, and the ascocarp the sporophyte. In these simpler cases the only complication introduced into the life-history is that due to the fact that, as in many of the Algæ, the gametophyte reproduces itself by means of asexually-produced gonidia, and may not produce sexual organs; so that there may be a succession of potential gametophytes before the actual gametophyte presents itself.

In the life-history of some of the forms which have become asexual through sexual degeneration (e.g. many Ascomycetes, Acidiomycetes, Saprolegniaceæ), it is still possible to recognise the gametophyte. It is that form which gives rise to the structure which is identical or homologous with the product of fertilisation in the allied sexually complete forms. For instance, in the Saprolegniaceæ, that form which bears the organs in which the parthenogenetic oospores are formed, is the gametophyte; similarly, in the sexually degenerate Ascomycetes, the form which bears the ascocarp is the gametophyte; and again, in the Acidiomycetes, the form which produces the æcidium is the gametophyte.

In some Ascomycetes (e.g. Claviceps), and most Acidiomycetes the life-history is further complicated by the polymorphism of the gametophyte. Here the life-history of the gametophyte presents one and sometimes two (most Aicidiomycetes) entirely asexual gonidia-bearing forms.

In the life-history of the Basidiomycetes there is no form homologous with the sporophyte of any of the other groups of Fungi; the sporophyte is entirely unrepresented. The plant is therefore a gametophyte, and it is in some cases polymorphic. As it is altogether asexual, it corresponds to the asexual forms of the gametophyte in the life-history of those Ascomycetes and Acidiomycetes in which the gametophyte is polymorphic.

The foregoing account of the life-history of the higher Fungi is based upon the assumption that, in the Ascomycetes, the ascocarp is the product of a sexual process, or is the homologue of such a product. If, however, the view be taken that the Ascomycetes are altogether asexual, then the ascocarp may be regarded, not as the sporophyte, but as simply a special form of gonidiophore 
borne by the gametophyte, a conclusion which would equally apply to the æcidium of the Ecidiomycetes. In both these groups, as in the Basidiomycetes, the plant would still be the gametophyte, the sporophyte having entirely disappeared as a necessary consequence of the complete sexual degeneration of the gametophyte.

The Fungi may be classified as follows:-

Sub-Class I.-Schizomycetes: Body unicellular, or multicellular and filamentous; no special sporebearing organs; no sexual reproduction.

Sub-Class II.-Mrxomycetes: Body a plasmodium; spores formed in more or less well-developed sporangia; zoospores; no sexual reproduction.

Sub-Class III.-Phyсомycetes: Body generally either unicellular, or a cœnocytic unseptate mycelium; sexual reproduction general; zoospores (or zoogonidia) present in most orders.

Section A.-Zygomycetes: sexual process isogamous; product, a zygospore.

Section B.-Oomycetes; sexual process oogamous; product, an oospore.

Sub-Class IV.-Ascomycetes: Body usually an incompletely septate mycelium; sexual process carpogamous; the sporophyte is apparently represented by the ascocarp.

Sub-Class V.-Ainiomycetes: Body an incompletely septate mycelium; no sexual process; the sporophyte is apparently the æcidium.

Sub-Class VI.-Basidiomycetes :-Body an incompletely septate mycelium; no sexual process ; the sporophyte is unrepresented; compound gonidiophores are always formed.

Sub-Class I.-Schizomycetes. These organisms are either unicellular or multicellular; most of the unicellular forms are very minute. The cell consists of a mass of protoplasm, with a nucleus surrounded by a cell-wall which consists in some cases of cellulose, and in others of a proteid substance. In some cases the cells are coloured red, green, blue, etc.: a starchy substance, turning blue with iodine, is found in the cells of some forms (e.g. Bacillus Amylobacter).

The forms presented are extremely various. The individuals may be spherical, the Coccus-form (Fig. 196,a); or rod-shaped, the 
Bacterium-form (Fig. 196, $b$ ) ; or spirally-wound, the Spirillumand Spirochæte-forms (Fig. 196, d); or straight free filaments, the Bacillus-form; or straight filaments attached by one end, the Leptothrix-form; or the individuals may form cubical masses, as in Sarcina Ventriculi. Some forms (e.g. Bacterium, Spirochæte, and some Coccus-forms) are capable of locomotion; but it is uncertain how the movement is executed. These forms are provided with one (Coccus-form) or more (one or more at each end in Bacterium- and Spirochæte-forms) delicate filaments,

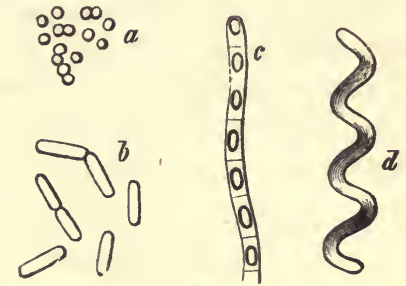

Fig. 196.-Different forms of Schizomycetes: $a$ Micrococcus ; $b$ Bacterium; c Bacillus with spores; $d$ Spirillum (diag. : $\times 600$ ).

which are regarded by some as vibratile protoplasmic cilia, by means of which movement is effected, whereas others consider them to be simply prolongations of the cell-wall.

A remarkable phase, common to the life-history of nearly all forms, more especially the unicellular, is the zoogloea-stage. It consists of great numbers of cells held together by bulky mucilage, to form either a membrane (e.g. the scum on putrifying liquids) or masses of the most various form. A striking zooglœa-stage is that known as Leuconostoc mesenterioides, which consists of wavy
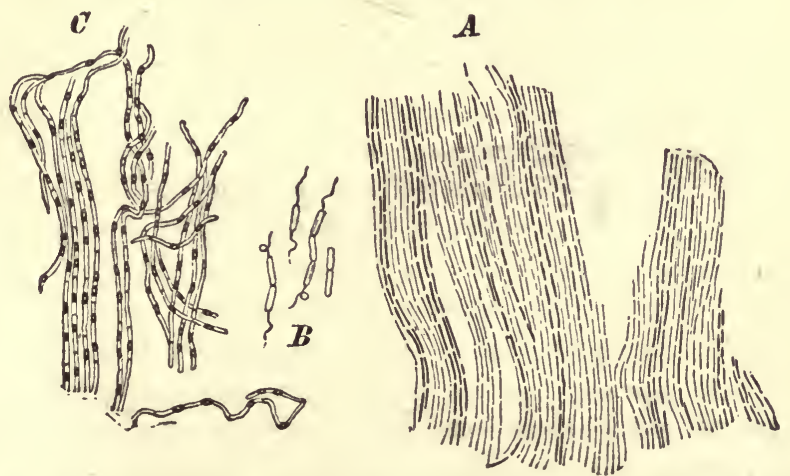

FIG. 197.-Bacillus subtilis. A zooglœa-stage; $B$ motile stage; $C$ zonglœa-stage, with spore-formation. (After Strasburger : $\times 800$.)

chains of cocci imbedded in a mass of mucilage, the whole resembling the structure of Nostoc in the Cyanophyceæ (p. 2:31). 
Although a special name has been given to each of the multifarious forms assumed by the Schizomycetes, it must not be assumed that each form to which a name has been given constitutes a distinct species. On the contrary, the Schizomycetes are highly polymorphic, and the various simpler forms are, for the most part, merely phases in the life-history of the more complex forms. The Schizomycetes may be classified, in accordance with these facts, as follows :-

1. Coccacea: exist in the free coccus-form, or in the zooglœa-stage. Leuconostoc is the only form which has been fully investigated.

2. Bacteriacea : exist in the coccus-form, the bacterium-form and the bacillus-form; any of which may pass through a zooglœa-stage.

Genera: Bacterium (c.g. Bacterium Termo); Clostridium (e.g. Clostridium butyricum, causing butyric fermentation); Bacillus (e.g. Bacillus subtilis) developed in infusions of haj.

3. Leptothrichiea: unbranched, attached, filamentous forms; giving rise to coccus, bacterium, and spiral forms, which may pass through a zoogloestage. Genera : Leptothrix, Beggiatoa, Crenothrix.

4. Cladothrichiea : resemble the preceding, but the attached filaments are (spuriously) branched. Genus, Cladothrix.

The Schizomycetes multiply mainly by cell-division (whence their name), and they do so with great rapidity under favourable conditions; the nucleus undergoes mitotic division in connexion with this process. In many forms reproduction is also effected by means of spores (e.g. Leuconostoc mesenterioides, Bacillus subtilis and Anthracis, Clostridium butyricum). Each spore is formed from a cell, the protoplasmic contents contracting from the cell-wall and surrounding themselves with a thick proper wall; the spore is set free by the decay of the old cell-wall. Spore-formation generally takes place in the zoogløa-stage, and is promoted by conditions which are unfavourable to growth and multiplication by division. The vitality of the spores is remarkable, being retained under conditions, such as extremes of temperature, desiccation, etc., which would prove fatal to the organisms themselves.

The most conspicuous feature in the physiology of the Schizomycetes is their capacity for decomposing organic compounds, inducing various fermentative processes, such as the lactic and the butyric fermentation of various kinds of sugars, etc., (but never the alcoholic fermentation), and the putrefactive fermentation of complex nitrogenous organic substances, such as proteids, etc. Some are parasitic in the bodies of animals, such as Sarcina Ventriculi, Leptothrix buccalis which causes decay of the teeth, and the various 
forms of Bacterium which cause Phthisis, Cholera, Anthrax, and other diseases.

The particular form presented, and the degree of the physiological activity manifested, at any given time, is determined by the external conditions, such as the nature of the obtainable food, the temperature, the presence or absence of oxygen, etc.; important variations in any of these conditions may induce change from one form of the organism to another and may modify its physiological activity.

There is a general resemblance in organisation and reproduction between the Schizomycetes and the Cyanophyceæ, as well as a remarkable correspondence between individual forms belonging to the two groups. On this ground they are sometimes placed together in a distinct group, the Schizophyta. It is, however, preferable to place them respectively in the classes Fungi and Algæ as corresponding sub-classes.

Sub-Class II. Myхомусетеs. These organisms are characteristically saprophytic, living on decaying organic substances, such as spent tan, decaying leaves, tree-stumps, etc.

Their life-history is, in most cases (Endosporeæ), as follows:- On the germination of the spores, the contents of each spore escape as a zoogonidium, a naked mass of protoplasm, enclosing a nucleus and a contractile vacuole, provided with a single cilium; this constitutes the mastigopod stage, and in this stage the cells multiply by division. After a period of active swimming, the zoogonidium draws in its cilium, and now creeps about by means of temporary protrusions of its protoplasm termed pseudopodia; this is the amcebuid or myxopod stage, and in this stage also multiplication by division takes place. The amœbæ then collect together, cohering into a plasmodium; the protoplasm of the amœbæ in some cases fuses completely so that the plasmodium presents no cellular structure, whereas in others (pseudoplasmodium) the outlines of the coherent amœbæ persist; but, in any case, there is no fusion of the nuclei of the constituent amœbæ, so that the plasmodium is multinucleate and conocytic.

The plasmodium creeps about, like a gigantic amœba, by means of pseudopodia, until spore-formation begins. At this time the plasmodium comes to rest; and it either forms a single sporangium, or divides into several portions each of which forms a sporangium. The mass of protoplasm then assumes the form of the future sporangium; the external portion of it hardens to form the wall, 
while the internal portion, after rapid mitotic nuclear division, separates into cells each of which secretes a proper wall and becomes a spore. In most forms a portion of the internal protoplasm goes to form a number of filaments, generally tubular, either free or connected into a net-work, which constitute the capillitiun. The wall dries, and eventually ruptures, and the spores are scattered by the expansion and hygroscopic movements of the elastic capillitium. In many cases the sporangium has a stalk,

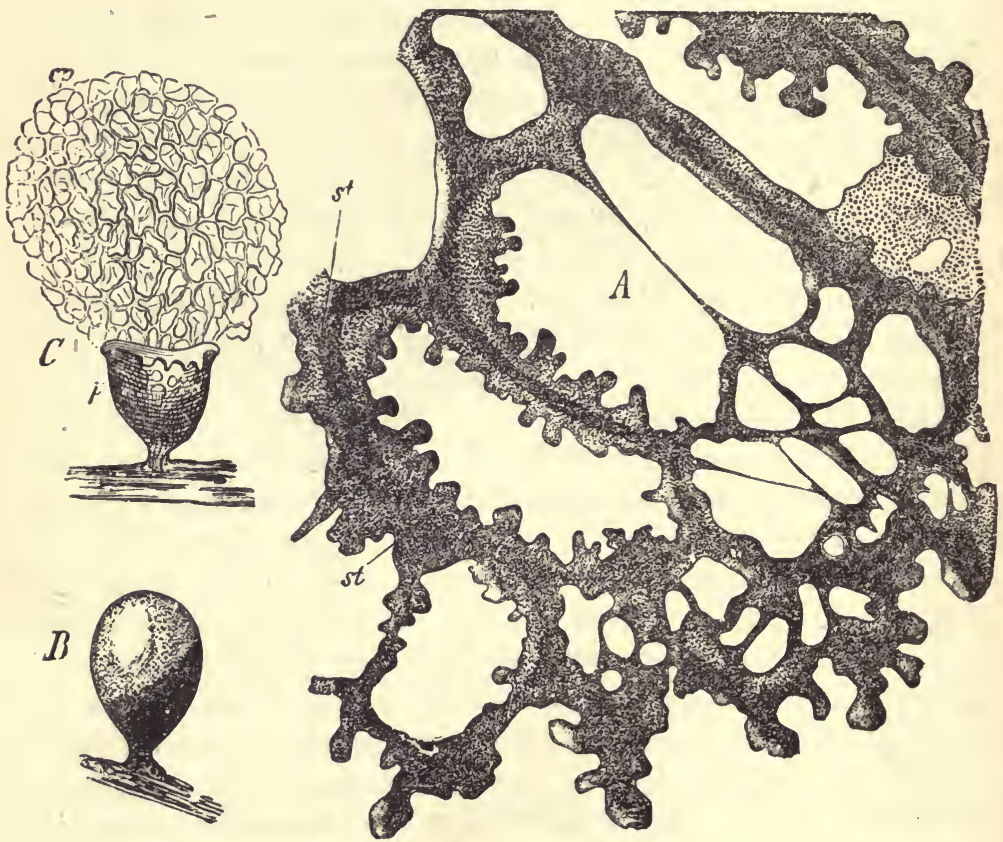

Fı. 198.-A Part of a plasmodium of Didymium leucopus ( $\times 300$ ). B A closed sporangium of Arcyria incarnata. C The same after the rupture of its wall $(p)$ and expansion of the capillitium $c p(\times 20)$. (After Sachs.)

(sporophore) which is sometimes continned into the cavity of the sporanginm as a columella.

In the Exosporeæ the spores are not formed in the interior of a sporangium, but by abstriction from the ends of filaments developed from the surface of the sporophore.

In some forms (e.g. Fuligo varians) a compound sporangium is formed, termed Athalium, by the combination of a number of plasmodia. 
The sporangium-wall and capillitium give the reactions of cuticularised cell-wall.

The life-history, as sketched above, varies somewhat in different forms. In some (e.g. Dictyosteliaceæ, Guttulineæ) the mastigopod stage is wanting, the spores giving rise directly to amœbæ. Again, the mastigopods or the amœbæ may surround themselves with a membrane and go through a resting-stage as microcysts; or the whole or part of a plasmodium may do the same as a sclerotium.

Closely connected with the Myxomycetes proper is the group of the MonaDINEx. In their structure and life-history they generally resemble the Myxomycetes; but a plasmodium-stage occurs in but few forms, and then it is minute and of simple structure; they are further characterised by the formation of zoocysts, which give rise to ciliated or amœboid zoogonidia. The Monadineæ are parasitic.

The Sub-Class may be sub-divided as follows :-

Division I. Monadineæ: aquatic, often parasitic; usually produce zoocysts; plasmodium small or wanting.

A. Azoosporece: zoospores amøboid; Vampyrellex, etc.

B. Zoosporea : zoospores ciliated; Plasmodiophoreæ, etc.

Division II. Eumycetozoa: subaerial, not parasitic: no zoocysts; body, a plasmodium with well developed fructification.

1. Sorophorea : zoospores simply amoeboid; the cells of the plasmodium (pseudoplasmodium) distinct: spores not developed in sporangia, but free on the surface in groups (sori) : Guttulineæ, Dictyosteliaceæ.

2. Endosporea : zoospores at first ciliated, becoming subsequently amœboid; body, a true plasmodium; spores developed in a sporangium with a capillitium; to this group belong most of the Myxomycetes (e.g. Didymium, Arcyria, Stemonitis, Fuligo, Badhamia, etc.).

3. Exosporea : zoospores at first amœboid, becoming subsequently ciliated, and finally amoboid again : body, a true plasmodium : spores developed on the surface of basidioid sporophores; Ceratium.

\section{Sub-Class III. Phycomycetes. Section A. Zygomycetes.}

This section includes the following orders:-

Order 1. Chytridiaceæ: simple unicellular or mycelioid forms ; asexual reproduction by zoospores (and zoogonidia).

Order 2. Mucorinæ: body, a well-developed unseptate mycelium; no motile spores or gonidia.

Order 3. Entomophthoraceæ: body, an incompletely septate mycelium; no motile spores or gonidia.

Order 1. Chytridiaceæ. Body, a single rounded cell, or a simple mycelium; sexual reproduction known in some forms; asexual reproduction by zoospores (in sexual forms by both zoogonidia and zoospores); mostly parasitic, generally 
nn Algæ, or on aquatic Fungi, but sometimes on Phanerogams, and on aquatic animals.

In accordance with the form and structure of the lbody, the Chytridiaceæ may be sub-divided into two groups; the Myxochytridineæ (including such genera as Sphærita, Olpidium, Ulpidiopsis, Synchytrium, etc.) where the body is a single spherical or oval cell, destitute, for a time at least, of a cell-wall; and the Mycochytridineæ where the body has a cell-wall from the first, and is usually more or less mycelioid, and is commonly branched.

The asexual organs of reproduction are in all cases unicellular, and present two distinct forms; a thin-walled sporangium (gonidangium in the sexual forms) which at once gives rise to zoospores; a thick-walled sporangium (sometimes termed a resting-spore), formed by a process of encystment in the asexual forms, by a sexual process in the sexual forms where it represents the sporophyte, which only gives rise to zoospores after a longer or shorter period of quiescence.

The simpler forms (Myxochytridineæ) are holocarpic; that is, the whole cell becomes a sporangium, being invested by a cell-wall. The other forms are eucarpic, that is, a part only of the body goes to form the sporangium; some of them (Sporochytrie:e) are monocarpic, that is, each produces but one sporangium; whilst others are polycarpic (Hypochytrieæ), that is, each forms several sporangia. In any case the formation of reproductive organs closes the life of the individual.

The zoospores (and zoogonidia) vary somewhat in form, but are generally spherical or ovoid, with either one or two cilia. They are generally formed directly from the contents of the sporangium (or gonidangium), but in Synchytrium the contents undergo division, and escape from the sporangium, surrounded by a delicate membrane, as a group of cells (sorus) each of which gives rise to a number of zoospores. When the sporangium is, as is frequently the case, formed within the cells of a host-plant, it puts out a tubular outgrowth which reaches the surface, and thus the zoospores are set free, and, in their turn, make their way into the tissues of a host.

A sexual process, of the nature of conjugation, has been observed in some forms, both of the Myxochytridinæ and of the Mycochytridineæ, but the differentiation of the sexual organs as male and female is only rudimentary. In the former case (e.g. Olpidiopsis) two unicellular individuals of unequal size fuse together, the contents of the smaller (probably the male) passing over into the larger cell. In Polyphagus, one of the simpler Mycochytridineæ, one individual extrudes its protoplasmic contents as a naked sphere to which another individual applies one of its hyphæ through which its contents are conveyed into the sphere. The product of conjugation is a zygospore, which, like the thick-walled sporangia, gives rise to a number of zoospores on germinating after a period of quiescence.

An indication of an alternation of generations may be traced in the lifehistory of the sexual members of the order. The plant is the gametophyte, reproducing itself by zoogonidia formed in thin-walled gonidangia; the zygospore is the sporophyte, giving rise to zoospores, each of which, on germination, gives rise to a gametophyte.

This order is one of great systematic interest, inasmuch as it shows affinity 
to so many other different forms. It is allied, on the one hand, by the siraple Myxochytridineæ to the Monadineæ, and thus also to the rest of the Myxomycetes. On the other hand it is allied to the simple Oomycetous Phycomycetes, the Ancylistaceæ, a group which is sometimes actually included in the Chytridiaceæ; and, again, through such forms as the Cladochytrieæ, to the Ustilagineæ.

Order 2. Mucorinæ. Body an unseptate mycelium, septa being only developed in connection with the formation of reproductive organs; reproduc. tion by gonidia and spores, and by zygospores formed by conjugation; mostly saprophytic, but some are parasitic on other Fungi.

The mycelium ramifies in the substratum (Fig. 199). The asexual reproductive organs are developed as simple gonidiophores which grow erect into the air. In the Mucoraceæ the simple gonidiophores are unbranched, and each bears
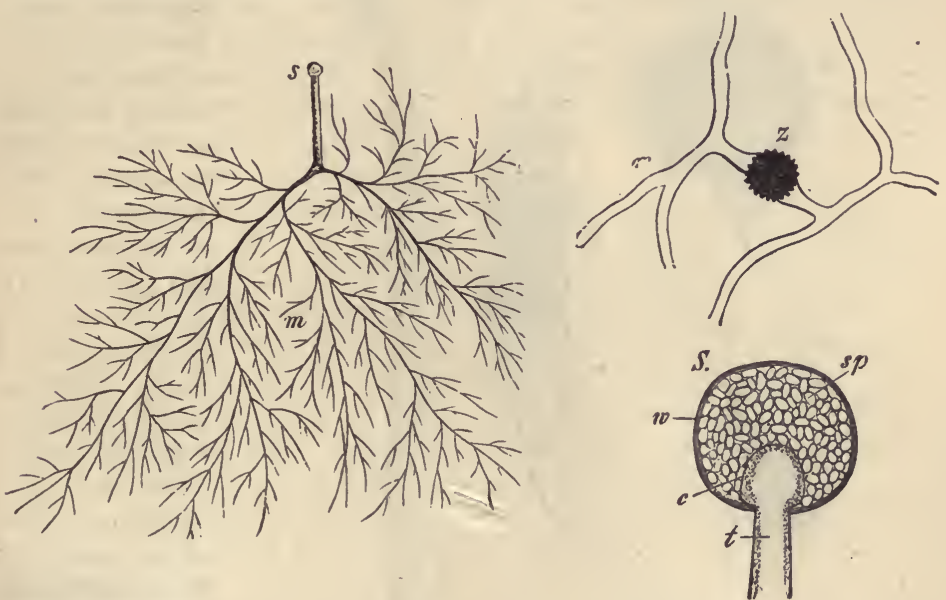

Fıg. 199.-Mucor Mucedo : $m$ a mycelium bearing a simple gonidiophore with a terminal gonidangium $s$; $S$ a gonidangium much magnified; $t$ the end of the gonidiophore dilated into the columella $c$; $w$ the wall of the gonidangium; $s p$ the gonidia; $z$ zygospore formed by the fusion of the contents of two gametangia.

at its apex a single gonidangium; the gonidiophore projects into the cavity of the gonidangium as a columena (Fig. 199). In the Chrtocladieæ and the Piptocephalideæ the gonidiophore is branched and more or less septate; it produces a number of gonidia by abstriction from the tips of its branches. On germination, the gonidium gives rise to a mycelium similar to that from which it was derived.

The gametophores are short swollen hyphæ; by the formation of a septum near the tip of the gametophore, a terminal cell is produced, which is the sexual organ or gametangium; the protoplasmic contents of the gametangium constitute the gamete. Two gametophores from adjacent vegetative hyphæ come into contact at their tips; the walls of the two gametangia are absorbed at the point of contact; the protoplasmic contents (gametes) of the gametangia 
fuse to form the cell which surrounds itself with a coat of two layers and becomes a zygospore (Fig. 200). Azygospores are frequently produced, exclusively in some cases (Mucor neglectus and tenuis).

In some forms the effect of conjugation extends to the adjacent hyphæ; thrs,

in Phycomyces, branched hyphæ are developed,
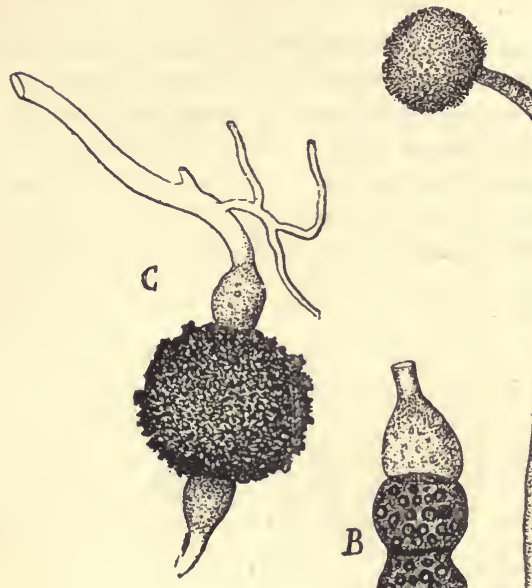

D

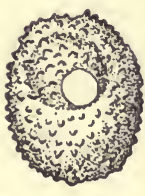

A
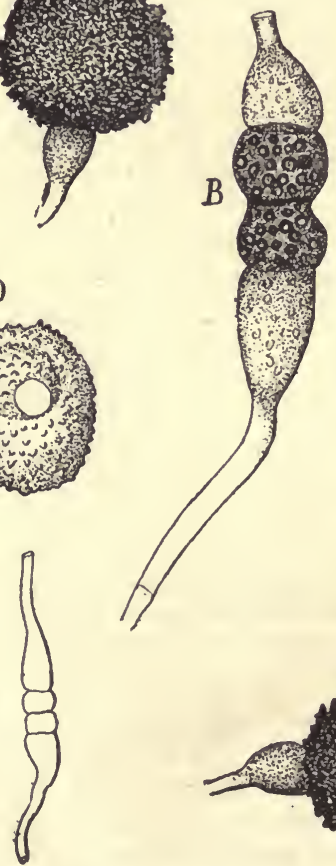

E

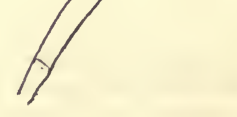

Fig. 2C0.-Mucov Mucedo. A Diagram of sexual process; two gametophores in coritact; at the end of each gametophore a cell, the gametangiom, has been cut off by a septum; $\boldsymbol{B}$ commencing development of the zygospore from the fused gametangia ; $C$ ripe zygospore, still connected with the gametophores; $D$ free zygospore, showing one point of attachment; $E$ germinating zygospore, bearing a small promycelium, the sporophyte, with a single sporangium (after Brefeld). after conjugation, from the gametophores, and form an incomplete covering to the zygospore ; and in Mortierella the adjacent vegetative lhyphr are stimulated to growth and form a dense hyphal investment to the zygospore.

In many cases the zygospore, on germination, gives rise to a small branched or unbranched mycelium, which bears a single simple sporophore resembling the gonidiophore of the plant to which it belongs. The spores derived from this sporophore give rise, on germination, to the large mycelium bearing gonidiophores and gametophores. In other cases, however, the zygospore gives rise to a mycelium bearing sexual or- 
gans. In the genus Mortierella (so far as is known), the zygospore does not actually germinate itself, but a number of sporangia spring from the hyphal investment surrounding it.

The mycelium, when under unfavourable conditions, gives rise to unicellular gemmæ, either chlamydogonidia or oidium-cells : the latter multi,ly by gemmation in a yeast-like manner (e.g. Mucor racemosus) and, like Yeast, have the power of causing alcoholic fermentation; this takes place especially when the hyphæ are immersed in liquid. The hyphæ become segmented into a row of cells by the formation of transverse septa, and the cells then separate and become free. The chlamydogonidia are thick-walled and large; the oidium-cells are smaller and thin-walled (see p. 274).

The typical life-history presents an obvious alternation of generations. The plant is the gametophyte, inasmuch as it either actually produces sexual organs (when it is an actual gametophyte), or, though capable of producing sexual organs it does not do so, owing to external conditions (when it is a potential gamstophyte); the gametophyte reproduces its like by means of the gonidia. The promycelium, derived from the zygospore, is the sporophyte, inasmuch as it is incapable of producing sexual organs. In some cases, however, the zygospore gives rise to the mycelium bearing sexual organs.

The Mucorinæ may be sub-divided as follows :-

Sub-Order $A$. Sporangiophoræ : gonidia developed inside a gonidangium.

Fam. 1. Mucoracea: the gonidangium has a columella; the zygospore is naked or invested only by a few loose hyphæ; principal genera, Mucor, Phycomyces, Sporodinia, Thamnidium, Pilobolus.

Fam. 2. Mortierellea: the gonidangium has no columella; the zygospore is invested by a compact mass of hyphæ: Mortierella.

Sub-Order $B$. Conidiophoræ : gonidia formed by abstriction from sterigmata.

Fam. 1. Chatocladiea : gonidia developed singly on the sterigma; the gametophores are straight: Cbætocladium.

Fam. 2. Cephalidea : several gonidia developed from each sterigma; the gametophores are curved: Piptocephalis, Syncephalis.

The Mortierelleæ, Chætocladieæ, and Cephalideæ, are for the most part parasitic on various Mucoraceæ.

Order 3. Entomophthoraceæ. Body an incompletely septate mycelium; reproduction by means of non-motile gonidia, and by zygospores formed by conjugation; mostly parasitic on insects.

The mycelium ramifies in the body of the insect, and in most cases produces simple gonidiophores which, after the death of the insect, project from its body, each forming a single gonidium by abstriction at its apex; the gonidium is thrown off to a considerable distance, so that the body of the insect becomes surrounded by a halo of gonidia. This may commonly be seen in the case of flies in the autumn, which are frequently attacked by a member of this order (Entomophthora Musca) and remain sticking to window-panes. The gonidium, on germination, puts out a hypha which penetrates into the body of another insect; this hypha may either grow directly into a mycelium in the body of the insect (e.g. Entomophthora radicans, ovispora, curvispora), or it may produce by abstriction a number of gonidia which may multiply by budding in a yeastlike manner within the body of the insect, and it is these which produce my- 
celia. The mycelium becomes completely exhausted in forming the gonidia, so that when this process is completed, both the fungus and the insect are dry and shrivelled.

In some cases few or no gonidia are formed, but zygospores or azygospores. The zygospores are produced by the protusion of transverse protuberances between two segments of adjacent hyphæ; the walls of these protuberances are absorbed at the point of contact, the contents fuse, and the product surrounds itself with a proper wall, and constitutes a zygospore (Entomophthora ovispora, and curvispora). In other species spores quite similar to the zygospores, termed azygospores, are formed, but without conjugation; the azygospores are formed parthenogenetically. On germination (as observed in Entomophthora Grylli), the zygospore gives rise to a hypha, the promycelium, which forms a gonidium at its apex.

The life-history of the sexual forms shows a clear alternation of generations. The plant is the gametophyte which, as is so commonly the case among the Thallophytes, reproduces itself asexually by means of gonidia, and gives rise to zygospores as well. The promycelinm is the sporophyte, as it never can develope sexual organs and produce zygospores. By analogy, in those forms which are not known to produce zygospores, the plant is a gametophyte, and the sporophyte is absent.

Section B. Oomycetes.

This section of the Phycomycetes includes the following orders:

Order 1. Ancylistaceæ: body generally unbranched; oogonia intercalary; contents of oogonium not differentiated into oosphere and periplasm; pollinodium functional.

Order 2. Peronosporaceæ: body branched; oogonia terminal or intercalary; contents of oogonium differentiated into oosphere and periplasm; pollinodium functional.

Order 3. Saprolegniaceæ: body branched; oogonia generally terminal, rarely intercalary ; contents of oogonium not differentiated into oosphere ard periplasm; pollinodium absent, or, if present, functionless.

Order 1. Ancylistaceæ. This order consists of a few forms which are parasitic on freshwater Algæ. The body is simply a tube, lying in the cell of the host. It becomes branched only in some forms (Lagenidium), and then only in connexion with the development of reproductive organs. It eventually becomes septate transversely, and each segment becomes a reproductive organ, either sexual or asexual, so that these organisms are holocarpic and monocarpic.

The asexual organs are gonidangia, which, in most cases, give rise to zoogonidia; but in Ancylistes this is not the case, where the gonidangium germinates as if it were a gonidium, sending out a hypha which makes its way into a host. 
The sexual organs are fairly differentiated oogonia and pollinodia, and it is on this account that this order is removed from the Chytridiaceæ, with which it is closely allied, and is included in the Oomycetes. In fertilisation, the whole contents of the pollinodium enter the oogonium and fuse with the whole contents of the oogonium to form an oospore. The plants are either monœcious (Myzocytium, Lagenidium), or diøcious (Ancylistes). The germination of the oospore is known only in Ancylistes, where it developes into a hypha which bores into a host.

Order 2.-Peronosporaceæ. The forms comprised 'in this order are mostly parasitic, chiefly on Phanerogams, but some species of Pythium inhabit the dead bodies of plants and animals.

The asexual reproduction of the gametophyte is effected, in most forms, by gonidangia developed at the ends of the branches of the simple gonidiophores

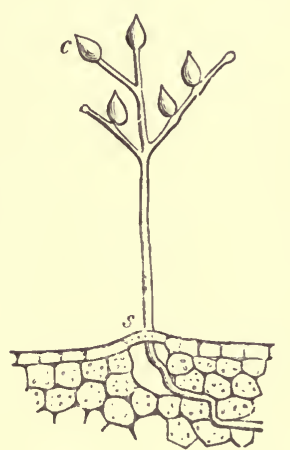

FIG. 201.- Part of a section of a Potato. leaf infested by Phytophthora infestans: $s$ the gonidiophore passing out into the air through a stoma ; $c$ the gonidangia.
(Fig. 201; Fig. 203 A): no such organs have, however, been observed as yet in Pythium vexans or P. Artotrogus. In some forms (Planoblastæ) the gonidangium gives rise to zoogonidia either before or after it has fallen off the gonidiophore (Fig. $203 B, C)$; whilst in other forms

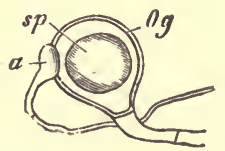

FIG. 202.-Phytophthora omnivora. An oogonium $(O g)$, containing an oospore (sp); $a$ a pollinodinm which has fertilised the oosphere. $(\times 400$.

(Siphoblastæ) it falls off and germinates as if it were itself a gonidium, growing out into a hypha, and so into a mycelium.

The oogonium is spherical, and remains closed (Fig. 202). The protoplasmic contents undergo differentiation into a single oosphere which is surrounded by the remainder of the protoplasm, the periplasm. The oosphere is multinucleate in some forms, though it has been described as ultimately uninucleate in Pythium.

The pollinodium is developed terminally, either on a hypha springing from beneath the oogonium, or on an adjacent hypha, and is club-shaped. Its protoplasmic contents undergo differentiation into a male cell (aplanogamete) and into periplasm.

At the time of fertilisation, the pollinodium is closely applied to the oogonium and sends out a delicate tube which penetrates through the wall of the oogonium and reaches the oosphere. The tube then opens, and the male cell passes out of the pollinodium into the oosphere and fertilises it. The oosphere then surrounds itself with a proper wall and becomes the oospore. In some 
genera (Peronospora, Cystopus) an external coat, the episporium or perinium, is formed round the oospore from the periplasm.

The germination of the oospore takes place in different ways in different species. In Phytophthora omnivora and Pythium proliferum it gives rise to a small mycelium (promycelium) which produces a few spores, from which sexual plants are developed. In other species (e.g. Cystopus candidus) the contents of the oospore are set free as a number of zoospores. In yet other species (e.g.

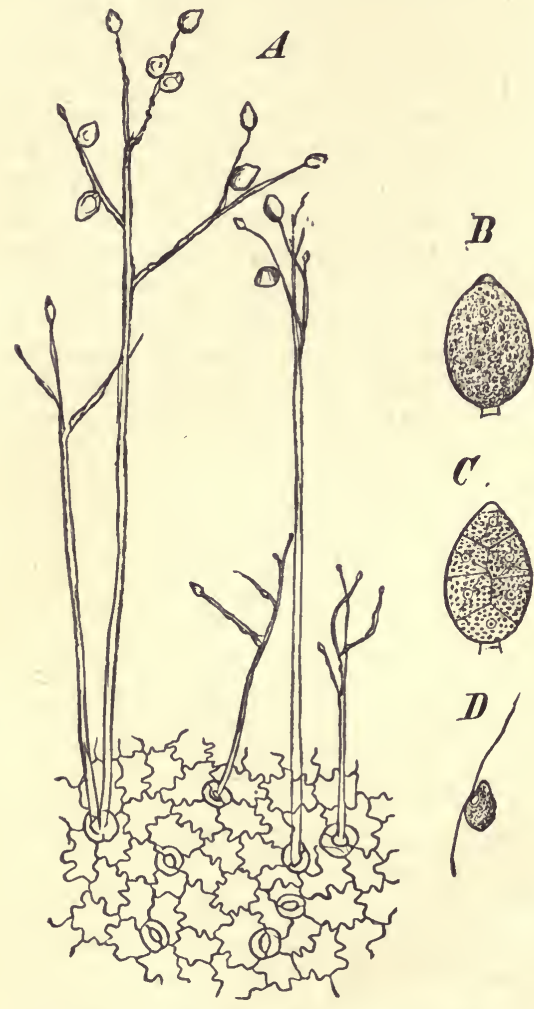

Fig. 203.-A Surface-view of the epidermis of a Potato-leaf with the gonidiophores of Phytophthora infestans projecting out of the stomata $(\times 90)$. B A ripe gonidangium. $C$ Another nndergoing division. D A zoogonidium. ( $\times 540$ : after Strasburger.)

Pythium de-Baryanum, Pythium Artotrogus, Peronospora Valerianella), the oospore gives rise to a sexual plant.

The life-history of most of the Peronosporacer presents an alternation of generations. In all cases the plant is the gametophyte. In those species in which the oospore gives rise to a promycelium, the promycelium is the sporophyte; in those in which the oospore gives rise to zoospores, the oospore itself represents the sporophyte; and, finally, in those in which the oospore at once gives rise to a sexual plant, the sporophyte is altogether unrepresented.

The Peronosporaceæ may be subdivided as follows :-

Planoblasta:-the gonidangia gives rise to zoogonidia on germination : Cystopus, Pythium, Phytophthora, etc.

Siphoblasta:- the gonidangia germinate as if they were gonidia, giving rise to a hypha: Peronospora, Bremia.

There is a doubtful genus, named MonoblepHaris, probably allied to the Peronosporaceæ, which is remarkable in that the male organ is an antheridium, since it gives rise to a number of uniciliate spermatozoids, and in that the oogonium opens at the apex to permit the entrance of the spermatozoid to the single oosphere. The antheridium is a cell just behind the oogonium, which is terminal. The oosphere is formed from the entire protoplasmic contents of the oogonium. The mycelium also bears gonidangia, which give rise to 
zoogonidia. The germination of the oospore has not been observed. These observations require confirmation; if they are accurate, Monoblepharis is the only Fungus which has spermatozoids, and an oogonium which opens.

In the genus Peronospora, which is represented by many species ( $P$. parasitica on Capsella, $P$. calotheca on Rubiaceæ, etc.), only one gonidangium is borne by each branch of the gonidiophore which protrudes through a stoma. In Phytophthora the sporangia are displaced laterally by branches which arise from the hyphæ bearing the sporangia, at their points of origin. To this genus belongs $P$. infestans, which produces the potato-disease. The tissues of the host undergo decomposition in the infected parts and turn black: the mycelium of the Fungus extends from the circumference of these spots, and throws up gonidiophores through the stomata (Fig. 203). The gonidangia of the parasite are carried by the wind to healthy plants and infect them: the zoogonidia also penetrate through the soil to the tubers, and the mycelium which is developed from them extends into the young Potato-plant which grows from the tuber. No sexual reproductive organs have been observed in this Fungus as yet. Phytophthora omnivora infects and destroys the seedlings of the Beech and other plants. In Cystopus (C. candidus on Capsella and other Crucifers, C. cubicus on Compositæ) gonidiophores bearing numerous sporangia are formed in great numbers close together under the epidermis, and cause its rupture.

Order 3.-Saprolegniaceæ. The Saprolegniaceæ all live in water, and are mostly saprophytic, though some are parasitic; one species causes the Salmon-disease.

Asexual reproduction of the gametophyte is effected entirely by zoogonidia, but in Aplanes Braunii they are not set free but germinate within the gonidangium; they are formed in terminal but not otherwise especially differentiated gonidangia (Fig. 204). On coming to rest they germinate to form a mycelium. They are, in some forms, surrounded by a thin cell-wall at their first formation.

The oogonia and pollinodia (when present) rosemble those of the Peronosporaceæ. The number of oospheres in the oogonium varies

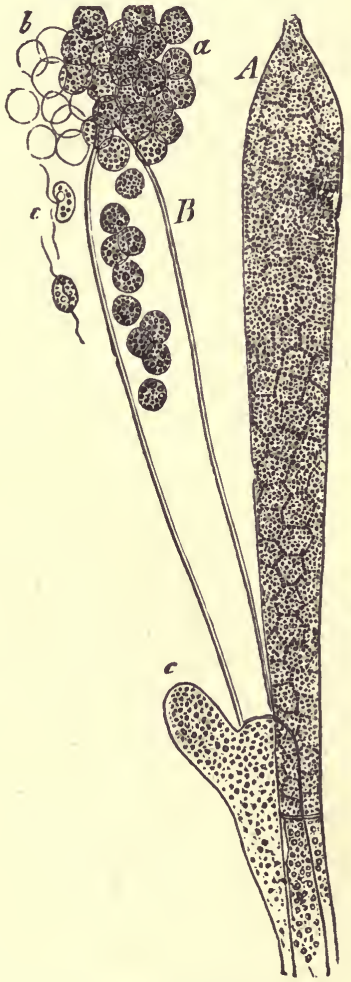

Frg. 204.-Gonidangium of an Achlya. A Closed. $B$ The zoogonidia are escaping; $c$ a lateral branch; $a$ zoogonidia just escaped; $b$ empty membranes: e swarming zoogonidia. ( $\times 550$ : after Sachs.)

widely in different individuals; sometimes there is only one (Leptolegnia, Aphanomyces); but as a rule there are many, as many as 30-40; in either case there are developed from the whole of the protoplasm of the oogonium. 
The male and female sexual organs are commonly borne on the same hypha, but in some cases (e.g. Saprolegnia dioica and anisospora) this is not the case; however, it is not clear that these species are actually diœcious. In some species (Saprolegnia Thureti, torulosa, monilifera, and Achlya stellata) no male organs are developed as a rule; in others (Saprolegnia mixta, Achlya spinosa) they are as often absent as present; in others they are frequently absent (Aphanomyces stellatus, Saprolegnia hypogynx, Aplanes Braunii); in others, finally, they are always present (Achlya racemosa and polyandra, Saprolegnia monoica).

When pollinodia are present, they are closely applied to the oogonium; sometimes several are applied to one oogonium. In some forms (e.g. Saprolegnia asterophora) the pollinodium undergoes no change, or it sends out a short tube which enters the oogonium but does not touch the oospheres. In most others the pollinodium sends out one or more tubes which enter the oogonium and come into close contact with the oospheres. But in all cases the tubes remain closed, and no act of fertilisation has been observed. The oospheres, however, all become oospores; but since there is apparently no fertiligation, this change is produced parthenogenetically.

The germination of the oospores presents the same variations as in the Peronosporaceæ. The life-history of the Saprolegniaceæ is therefore essentially the same as that of the Peronosporaceæ.

The principal genera are Saprolegnia, Achlya, Aphanomyces, Dictyucbus, Aplanes, Apodya.

Sub-Class IV.-ASCOMYCETES. This sub.class includes a vast number of forms, both saprophytes and parasites. Some of them (e.g. Penicillium glaucum, Eurotium Aspergillus) are familiar as the blue or green moulds appearing on jam, old boots, etc.; others (Erysipheæ) as mildew on roses, etc: Cordyceps infests the larvæ of insects.

On the assumption of the sexmality of the Ascomycetes (see p. 279), the life-history of typical members of this group presents a well-marked alternation of generations; the plant is the gametophyte; the ascocarp is the sporophyte; an alternation which is the same as that of the Rhodophyceæ among the Algæ. The similarity is further emphasised by the fact that, as in the Rhodophyceæ, the gametophyte may be potential. In some cases the life-history is complicated by the polymorphism of the gametophyte, which includes in its life-history one or more entirely asexual gonidia-bearing forms. These various life-histories are briefly illustrated by the following examples.

1. The gametophyte produces no gonidia (e.g. Eremascus albus, Gymnoascus, most Ascomycetous Lichen-fungi, Ascobolus furfuraceus, Pyronema). In these the life-history is perfectly simple, 
consisting in an alternation between the plant bearing sexual organs (gametophyte) and the ascocarp (sporophyte). On germination the spores (ascospores) produced in the ascocarp give rise to the sexual plant.

2. The gametophyte produces gonidia but not on a special form (e.g. Erysipheæ, Eurotium, Penicillium). In these the gametophyte reproduces itself by means of gonidia ; in the Erysipher and Eurotium the gametophyte generally produces sexual organs eventually, that is, it generally becomes an actual gametophyte; in Penicillium the formation of sexual organs takes place only exceptionally under special conditions, so that many successive generations of potential gametophytes may be produced by means of gonidia before an actual gametophyte makes its appearance. This may occur also in the Erysiphex.

3. The gametophyte produces gonidia and is polymorphic. This life-history can be clearly traced in Claviceps purpurea, the Ergot of Rye. The mycelium is developed in the ovary of the Ryeflower, and forms a continuous layer of hyphæ, a compound gonidiophore, at the surface, from which immense numbers of gonidia are formed by abstriction, imbedded in a mucilaginous substance known as Honey-dew. This substance is eaten by insects, and thus the gonidia are carried to other flowers and there reproduce the fungus. This is the Sphacelia-form. When the rye is ripening, the mycelium forms a dense sclerotium (see p. 275), fusiform, about an inch long, of a dark purple colour at the surface. This is the Ergot, and it remains dormant until the following spring. On germination the sclerotium gives rise to several filaments termed stromata, about an inch long, each composed of a strand of hyphæ, which bear a swollen knob at their apices (Fig. 212). All over the surface of the knob are a number of depressions, in each of which there is an ascocarp (perithecium) containing a number of asci, and in each ascus there are eight filiform ascospores. The ascospores are carried by the wind to the Rye-flowers and there give rise to the Sphacelia-form. A somewhat similar life-history is that of Peziza Sclerotiorum, though the alternation of the two forms of the gametophyte is not so regular: the asexual form of the gametophyte (which corresponds to the Sphacelia-form of Claviceps) bears simple gonidiophores and is known as Botrytis cinerea.

In some cases only gonidia-bearing forms are known (e.g. 
Aspergillus clavatus, Botrytis Bassii, species of Isaria, Cladosporium Herbarum, etc.).

The Reproductive Organs of the Gametophyte are asexual and sexual.

The asexual organs are gonidiophores, either simple or compound (see Figs. 205, 211), branched or unbranched; the gonidia are formed by abstriction from short tubular outgrowths of the unbranched, or of the terminal cells of branches of the branched, gonidiophore, termed sterigmata. In many cases the gonidiophores are collected into special receptacles termed pycnidia.

The sexual organs are modified hyphæ. They may be unseptate (e.g. Eremascus, Eurotium Aspergillus, Pyronema), or septate (e.g. Ascobolus, Collema); they may be

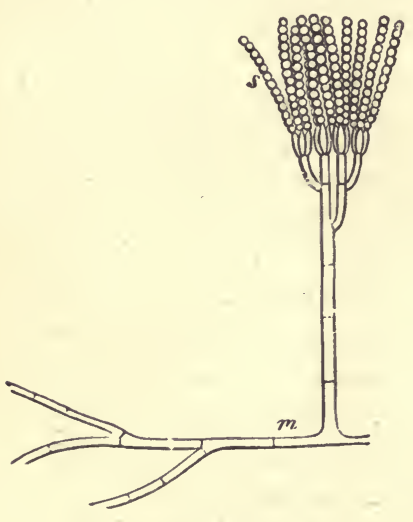

Fı. 205. - Gonidiophore of Penicillium glaucum: 8 a row of gonidia on a sterigma; $m$ hypha of the mycelium. $(\times 150$. quite similar (e.g. Eremascus) or more or less differentiated; they may come into close contact (e.g. Eremascus, Eurotium, Pyronema), or they are developed at a distance from each other (e.g. Collema, Polystigma).

When, as in Eremascus, the sexual organs are undifferentiated, no special names are given to them; but when they are differen. tiated the female organ is termed an archicarp, and the male organ a pollinodium when developed close to the female organ, or a sterigma when developed at a distance from it.

In some forms (e.g. Collema, Pyronema) the archicarp consists of two parts; a receptive portion, filamentous in form, the trichogyne; a fertile portion, the ascogonium (compare Rhodophyceæ, p. 268). In the simpler forms, the trichogyne is absent (e.g. Eurotium, Erysipheæ, Ascobolus), the archicarp consisting solely of the ascogonium. The form of the ascogonium is either filamentous, sometimes spirally coiled (e.g. Collema, Fig. 208, Eurotium, Fig. 211); or, it is dilated, and spherical or oval (e.g. Pyronema, Fig. 207, Erysipheæ).

The pollinodium may be filamentous (e.g. Eurotium), or dilated and club-shaped (e.g. Pyronema, Erysipheæ). 
The sterigmata are borne in receptacles termed spermogonia. The spermogonium consists of a wall formed of coherent hyphæ from which a number of free hyphæ, the sterigmata, grow into the interior and produce, by repeated abstriction at their apices, a number of small rod-shaped cells, the spermatia, with a cellwall, which seem, in some cases, to be the male cells (see p. 277). These cells reach the surface through the small opening of the spermogonium.

Whilst it is true that, in very many cases, the spermatia germinate like gonidia, this does not absolutely prove that they may not be imperfect or degenerate sexual cells; the independent germination of undoubted male cells is not uncommon in the Algæ (p. 226).

A process of fertilisation has not been observed in all forms in which sexual organs are present; but it has been observed in the

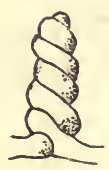

A

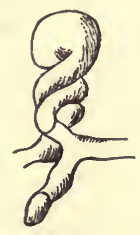

B.

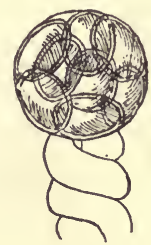

$C$.

Fig. 206.-Sexual reprodnction of Eremascus albus. A Sexual organs in contact. $B$ Fusion of the organs at the apex, with developing ascocarp. CMature ascocarp, consisting of a single ascus containing eight ascospores. ( $\times 1000$ : after Eidam.)

following cases which are representative of the various modes in which it may take place.

In Eremascus (Fig. 206) the apices of the undifferentiated sexual organs come into contact, and, the cell-walls being absorbed at the point of contact, the protoplasmic contents fuse.

In Pyronema the trichogyne comes into close contact with an adjacent pollinodium; the cell-walls become absorbed at the point where the apex of the trichogyne presses against the pollinodium, and the contents of the two organs fuse (Fig. 207).

In Collema (Fig. 208) it appears that the spermatia are brought, by means of water, into contact with the projecting trichogyne; one of them adheres to the trichogyne; the cell-walls are absorbed at the point of contact, and the protoplasm of the spermatium enters the trichogyne.

It is probable that, in consequence of sexual degeneration, the 
sexual organs are functionless in the majority of those Ascomycetes in which both kinds of them are present. In some forms sexual degeneration has proceeded so far that no male organ is developed (e.g. Chætomium, Melanospora); in others there is not only no male organ, but the female organ is either rudimentary, being represented only by a structure known as Woronin's hyphæ (e.g. Xylaria), or cannot be detected at all (e.g. Claviceps, Pleospora).

The Reproductive Organs of the Sporophyte.-The sporophyte is

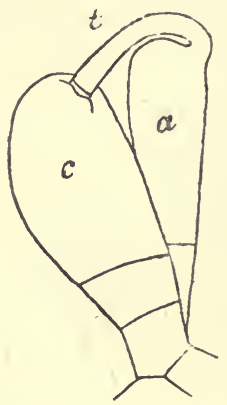

Fig. 207. - Sexual reproduction in Pyronema confluens : $c$ archicarp with trichogyne $(t)$ which bas fused with the pollinodium $a$. ( $\times 300$ : after Kihlman.)

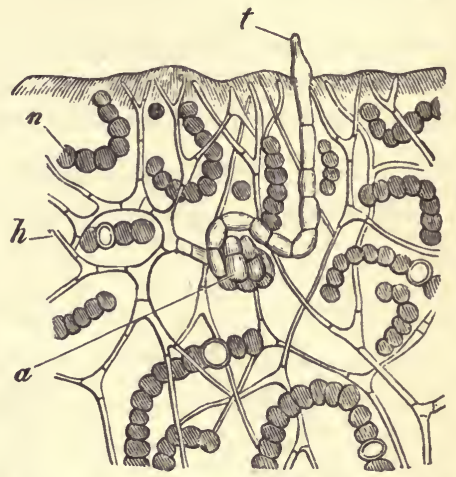

FrG. 208.- Section of the homoiomerous thallus of Collema (a Lichen): $a$ the ascogonium; $t$ the trichogyne; $h$ the hypha; $n$ the algal filaments(Nostoc). ( $\times 350$ : after $8 t a b])$.

a fructification termed the ascocarp, which (assuming its sexual origin, p. 279) corresponds to the cystocarp of the Rhodophyceæ. In those Ascomycetes in which there is an archicarp, the ascocarp is developed directly or indirectly from that organ, either as the result of fertilisation, or parthenogenetically, in those forms respectively in which a sexual process does or does not take place. When no archicarp is present, or when it exists in only a rudimentary form (Woronin's hypha), the ascocarp is developed directly from the mycelium.

The simplest form of ascocarp is found in Eremascus (Fig. 206). After the sexual process has taken place, a large spherical cell is formed at the point of junction of the two sexual organs. This cell is an ascus, and produces within it eight ascospores. Here the whole ascocarp consists of a single naked ascus.

The ascocarp of Podosphæra (one of the Erysipheæ) is but little more complex than that of Eremascus. Here likewise the archicarp gives rise directly to a single ascus; but an investment is 
formed round the developing ascus by the growth round it of hyphæ from the adjacent mycelium, which cohere to form a layer of parenchymatous tissue.

In the majority of forms the development of the ascocarp is indirect. The archicarp gives rise to a greater or smaller number of filaments, branched or unbranched, the ascogenous hyphce (which closely correspond to the ooblastema-filaments of the Rhodophyceæ, see p. 270), from which the asci are formed as branches, and which together form a compound sporophore. The asci are developed close together, forming a hymeniul layer or group, and may or may not be enclosed, either completely or partially, by an investment formed from the surrounding mycelium. In the latter case, vegetative hyphæ grow in among the ascogenous hyphæ and terminate in a number of sterile filaments, the paraphyses, which are situate in the hymenial layer between the asci.

The following forms of ascocarp may be distinguished amongst those which have a cellular investment:- the cleistothecium; the investment remains closed until it decays and ruptures to permit of the escape of the ascospores (see Figs. 209, 211): the perithecium; a narrow aperture is developed opposite to the hymenial layer (see

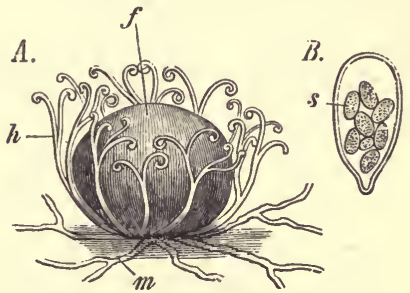

Fig. 209.-A Ascocarp of Uncinula bicornis (Erysipheæ), slightly magnified : $m$ mycelium; $f$ cleistothecium; $h$ investing filaments. $B$ An ascus from the cleistothecium, containing eight asco. spores (more highly magnified).

Fig. 212): the apothecium; the investment is somewhat saucershaped, so that the hymenial layer is fully exposed (see Fig. 213).

The ascus is in all cases unicellular. It may be either spherical (e.g. Eremascus, Eurotium), or oval, or club-shaped (e.g. Peziza) in form. In some cases the ascospores are ejected with considerable force; in others they are set free on the mucilaginous degeneration of the wall of the ascus.

The ascopores are formed by free cell-formation (see Fig. 80, p. 122) from a portion only of the protoplasmic contents of the ascus, preceded by nuclear division. The unused portion of the protoplasm is termed the epiplasm, and is rich in a carbohydrate called glycogen. In nearly all cases eight ascospores are formed; in some cases each of the eight spore-rudiments undergoes division to form a compound spore (e.g. Hysterium, Pleospora, etc.), the cells of which may either separate or remain coherent. The form of the asco- 
spore is spherical, or oval, or rarely filamentous (e.g. Claviceps, Fig. 212). The wall generally consists of exosporium and endosporium : the protoplasm generally contains oil-drops.

The germinating ascospore usually gives rise directly to the gametophytic mycelium; but in some forms (e.g. Polystigma) it gives rise to a promycelium bearing small gonidia, termed sporidia, and it is from the sporidium that the gametophytic myceliuın is developed.

\section{The Ascomycetes may be classified as follows:-}

Order I.-Gymnoasceæ : asci without any investment, or with only a rudimentary investment, either solitary, or forming a hymenial layer.

The typical members of this group are Eremascus (Fig. 206), Gymnoascus, and Exoascus parasitic on various trees.

It is now customary to place in this order the family of the SACCHARomycetes, or Yeast-Fungi, which is familiar on account of the alcoholic fermentation of saccharine solutions which some of its members excite (e.g. Saccharomyces Cerevisice used in brewing, and S. ellipsoideus, which causes the fermentation of the grape-juice in the manufacture of wine). The plant is usually a single small spherical or oval nucleate cell, and multiplies rapidly by budding (Fig. 210).

When budding is proceeding very rapidly, the suc-

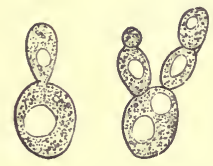

Fig. 210.-Growing cells of Yeast (Saccharomyces Cerevisice); the clear spaces in the cells are vacuoles. $(\times 300$. cell. The spores retain their vitality under conditions, such as desiccation, absence of food, extremes of temperature, etc., which would prove fatal to the Yeast-plants. The spores germinate, on attaining appropriate conditions of moisture and temperature, and give rise to Yeast-cells by budding.

Inasmuch as the formation of the spores in a Yeast-cell takes place in the same manner as the formation of spores in an ascus, the Yeast-cell may be regarded as an ascus. It is on this account that the Saccharomycetes are included in the Ascomycetes, and in the Gymnoascex on account of their naked asci. They are, however, reduced and sexually degenerate forms.

It must be borne in mind that cells very similar to those of the true Saccharomycetes, multiplying in the same manner, and often capable of exciting the alcoholic fermentation of sugar, may be formed by gemmation from the gonidia of various kinds of higher Fungi (e.g. Musor racemosus, Penicillium glaucum, some Entomophthoraceæ, Ustilagineæ, and Basidiomycetes) under special conditions. These Yeast-like cells, however, grow into mycelia under appropriate treatment. However, it is still a question whether all the forms of Saccharomycetes may not be merely secondary gonidial forms or gemmæ of mycelial Fungi. 
Order II.-Pyrenomycetes : asci forming a hymenial layer, with an investment; the ascocarp is either a cleistothecium or a perithecium; a stroma is present in some families.

The ascocarp is a cleistothecium in the sub-order Perisporiaceæ, including the families Erysipheæ (the Mildews) and Perisporieæ (e.g. Eurotium and Penicillium); in these families there is no stroma.

In this order the Tuberaceæ, Truffles, may be included (e.g. Tuber astivum,
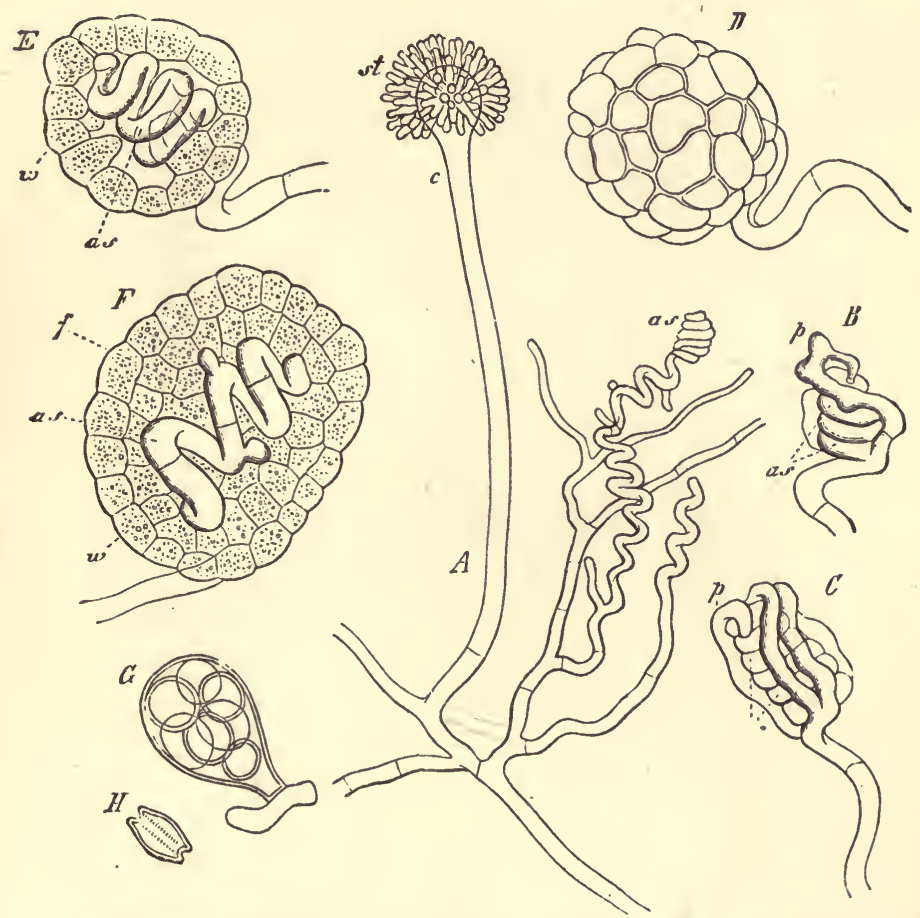

Fra. 211.-Eurotium repens. A A portion of the mycelium with a simple gonidiophore (c) bearing gonidia; the gonidia have already fallen off from the sterigmata $(s t)$; as, a young ascogonium. B Ascogonium (as) with a pollinodium $(p)$. C Another, with hyphæ growing up round it. $D$ A cleistothecium seen on the exterior. $E F$ Sections of unripe cleistothecia; $w$ the investment; $f$ ascogenous hyphæ arising from the ascogonium, which subseqently bear the asci. $G$ An ascus. $H$ A ripe ascospore. (Magnified: after Sachs.)

brumale, etc., Elaphomyces granulatus) ; the only reproductive organs which they are known to possess are the large cleistothecia which have a complex structure.

The ascocarp is a perithecium in the sub-orders Hypocreaceæ (e.g. Polystigma, Melanospora, Nectria, Epichloë, Claviceps, Cordyceps), Sphæriaceæ (e.g. Chætomium, Sordaria, Xylaria, Hypoxylon, Pleospora, Sphærella), and Dothideaceæ: a stroma, which varies much in form, is frequently present. 
Among the simple forms with free perithecia may be mentioned the genera Chætomium; Sordaria; Trichosphæria; Sphærella, many species of which appear on dead leaves as black spots; Calosphæria, which forms its long slender perithecia in groups on the wood and bark of cherry-trees (C. Princeps); Pleospora; Massaria ; etc.

In the compound forms, those, that is, which have a stroma, the stroma forms warty incrustations or patches of irregular outline, which have a punctated appearance owing to the numerous openings of the perithecia: Diatrype

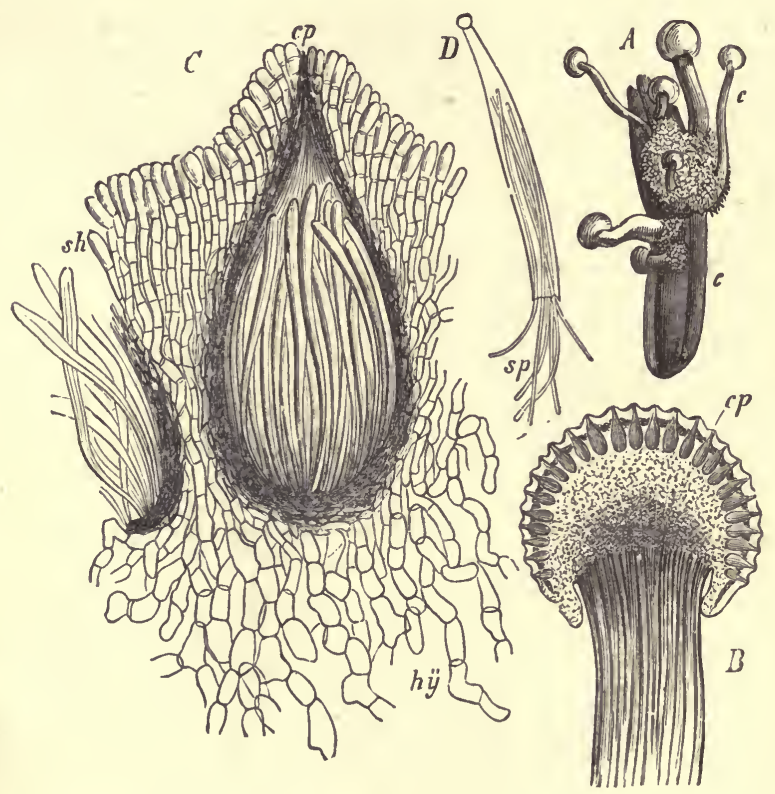

FIG. 212.-Claviceps purpurea. A A sclerotium (c) bearing stromata (x 2). B Section of a stroma; $c \rho$ the perithecia. C A perithecium more highly magnified. $D$ An ascus ruptured; the elongated spcres (sp) are escaping. (After Sachs.)

disciformis, which forms black warts as large as peas, belongs to this group, it is very common on dead boughs; also Nectria cinnabarina, which has a bright red stroma, and occurs on many kinds of dead wood; Nectria ditissima causes a disease on the branches of Beech-trees. In other cases the stroma developes into an upright club-shaped or branched tufted body, like the stromata of Xylaria, for instance, which occur very frequently on the trunks of trees; of Cordyceps, which grow from the bodies of insects; of Claviceps, which spring from the Ergot-sclerotium (see p. 295). In most forms, the stroma bears a crop of gonidia before it developes the perithecia.

Order III.-Discomycetes : the ascocarp is an apothecium of various form ; a stroma sometimes present.

The order may be divided, according to the form of the apothecium, into the 
two sub-orders Pezizaceæ and Helvellaceæ. In the former the apothecium is cup-shaped, the hymenium covering the concave surface, and is closed in the early stages of its development; in the latter the apothecium is borne on the convex, smooth or reticulate surface of an erect stroma.

The sub-order Pezizaceæ includes several families, the Phacidieæ, Pezizeæ, Bulgariex, etc. As representative may be mentioned Rhytisma Acerinum, the mycelium of which infests the leaves of the Maple, but the development of the apothecium does not take place until after the leaves have fallen; and other similar forms which inhabit the leaves of the Silver Fir, Spruce, and otber trees: Ascobolus, which grows on dung: the various species of Peziza, with brightly coloured apothecia, growing on rotting wood, etc. : Bulgaria, with a gelatinous apothecium, growing on dead branches of the Oak.

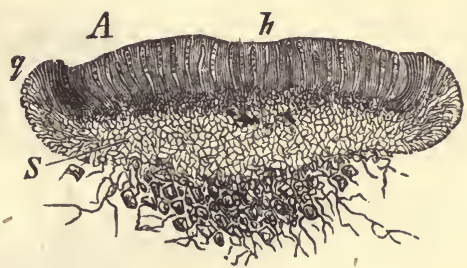

FIG. 213. - Longitudinal section of the apothecium of Peziza convexula: $h$ the $\mathrm{hy}$ menium. (After Sachs.)

The sub-order Helvellaceæ includes the genera Morchella (the Morell, esculent), Gyromitra, Helvella, etc.

Sub-Class V.-Acidomycetes. This sub-class includes a considerable number of parasitic plants known as Rusts and Smuts. They are characterised by their remarkably complex life-history, due to the polymorphism of what represents the gametophyte, which presents two or more gonidia-bearing forms : and by the fact that neither gonidia nor spores are developed in the interior of a sporangium or gonidangium, but are formed by abstriction. A sporophyte is indicated in one order of the sub-class, but not in the other, and this constitutes the essential difference between them; it is indicated by the fructification which is termed an Ecidium. Whilst, as a matter of fact, it is not certainly known that the plants in question have sexual organs, and that the æcidium is the product of a sexual process, there are some grounds for regarding the æcidium in this sub-class as the homologue of the ascocarp in the Ascomycetes, and for the view that, in both subclasses, the æcidium and the ascocarp respectively represent the sporophyte (p. 279).

The sub-class is divisible into two orders :-

Order 1. Uredineæ : have an æcidium-form, as a rule.

Order 2. Ustilagineæ: never have an æcidium-form.

Order I.-Uredineæ. This order comprises those parasites which are generally known as Rusts, on account of the rusty appearance which they give 
to their host-plants at a certain stage of their life-history, when they bear at the surface a great number of orange-coloured gonidia.

The life-history of these plants presents, in many cases, a clear alternation of generations, together with polymorphism of the gametophyte which has an asexual form; moreover the different forms of the gametophyte are sometimes heterocious, that is, they inhabit different hosts.

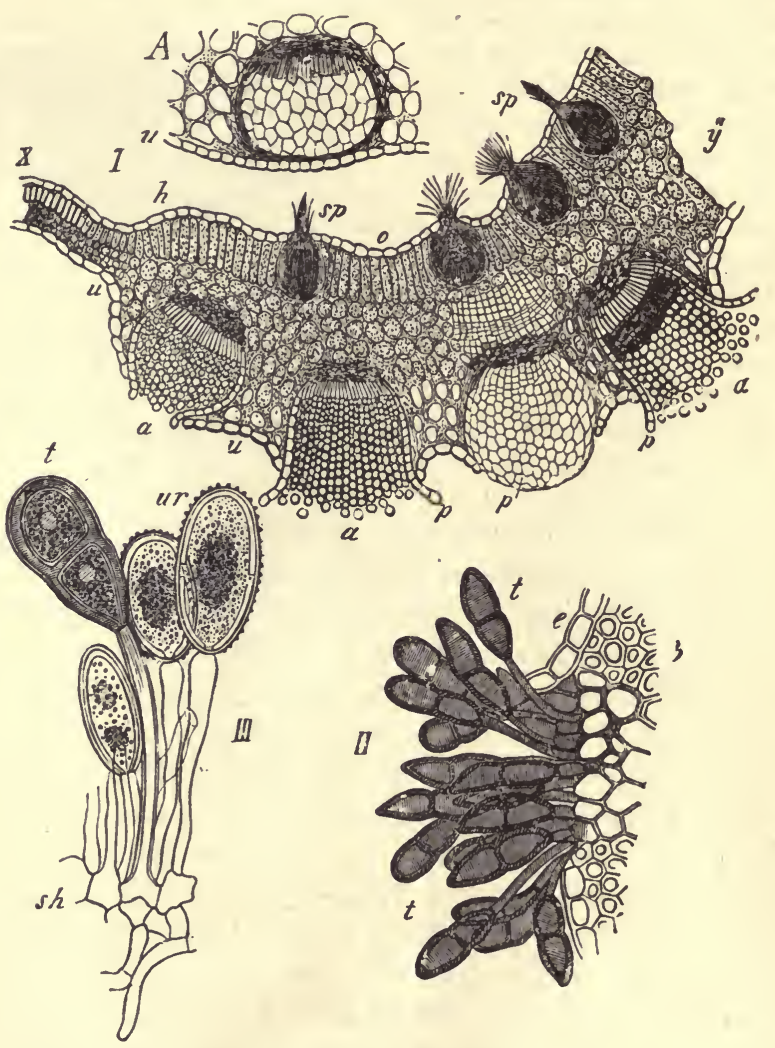

FrG. 214.-Puccinia Graminis. I Transverse section of a leaf of Barberry, with æcidia (a); $p$ the wall of the æcidium; $u$ lower, $o$ upper surface of the leaf, which has become thickened at $u, y$, in consequence of the presence of the parasite; on the upper surface are spernogonia (sp). A A young æcidium which has not yet opened. II Sorus of teleutogonidia $(t)$ on the leaf of Triticum repens; $e$ its epidermis. III Part of a sorus of uredogonidia on the same plant; $u r$ the uredogonidia; $t$ a teleutogonidium. (After Sachs.),

Puccinia Graminis affords an example of the most complex life-history with heterocism. It inhabits Wheat, Rye, and other Grasses, and develops its mycelium in the tissues of the young plants. During the summer it produces groups of simple gonidiophores, at the apex of each of which a single oval 
gonidium, termed a uredogonidium, of an orange colour, is formed by abstriction (Fig. 214, III); in consequence of the great development of cells at these points the epidermis of the host is ruptured, and the groups of uredogonidia are visible on the surface as rusty spots. These uredogonidia are scattered by the wind, and infect other Grass-plants; on reaching a leaf, the uredogonidium germinates at once, forming a hypha, which enters through a stoma into the interior of the leaf, where it developes into a mycelium bearing uredogonidia. This stage in the life-history is termed the Uredo-form.

Later in the season, when the tissues of the hosts are becoming hard and dry, the Uredo-form no longer produces uredogonidia, but dark-coloured often compound gonidia, known as teleutogonidia (Fig. 214,II), developed in the same way as the uredogonidia. The teleutogonidia remain quiescent during the winter. When they germinate in the following spring, one or both of the cells gives rise to a small, free, nonparasitic mycelinm (promycelium), from each of the cells of which a delicate gonidiophore is produced, which developes a small gonidium (termed a sporidium). by abstriction at its apex (Fig. 215).

The sporidia are scattered by the wind, and if they fall on the leaves of the Barberry they germinate, giving rise to a hypha which pierces the epidermis of the leaf, and then forms a dense mycelium in the intercellular spaces of the mesophyll. At certain points the tissue of the leaf is hypertrophied, forming cushions, which project on the under surface. Towards the upper surface of the cushion there are formed on the mycelium small receptacles, the spermogonia (Fig. $214 s p$ ), each of which con-

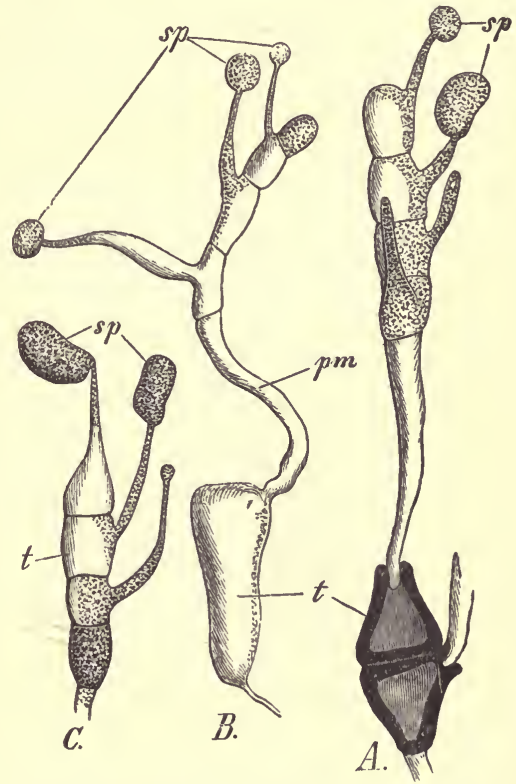

FrG. 215.-Germination of teleutogonidia of various Uredineæ: $A$ of Puccinia Graminis ( $\times$ 400 ; $B$ of Melampsora ( $\times 300)$; $C$ of Coleosporium ( $\times 230) ; t$ teleutogonidium; $p m$ promycelium; sp sporidia.

tains a number of unicellular hyphæ, radiating from the wall towards the centre, which are termed sterigmata; each of these produces at its apex by abstriction a small cell, the spermatium, which escapes from the spermogonium; spermogonia are formed, though less frequently, on the under surface. Large spherical structures are formed on the under surface of the cushion (Fig. 214); these are the acidia. This form of the fungus is known as Acidium Berberidis. Each æcidium consists of a hymenial layer of simple unicellular sporophores at its base, from the apices of which a number of spores (acidiospores) are formed by successive abstriction; the æcidium has a definite wall which ruptures at the 
surface to set free the spores. The spores are conveyed by the wind to Grassplants, on the leaves of which they germinate, putting out hyphæ which penetrate into the interior through the stomata, giving rise to the mycelium which bears the uredogonidia, and subsequently the teleutogonidia.

On the assumption (see p. 279) that the æcidium, like the ascocarp of the Ascomycetes, represents the sporophyte in the life-history of these plants, all the other forms of the plant are stages in the life-history of the gametophyte, namely the Uredo-form, the promycelium, the Elidium-form. Of these, the two former are altogether asexual; the form bearing the æcidium, by analogy with the sexual Ascomycetes, represents the actual gametophyte; but although the sterigmata in the spermogonia may, by analogy with some of the Ascomycetes, be regarded as male organs, and the spermatia as male cells, no female organ, corresponding to the archicarp, has yet been discovered.

The following species have essentially the same life-history as that deseribed

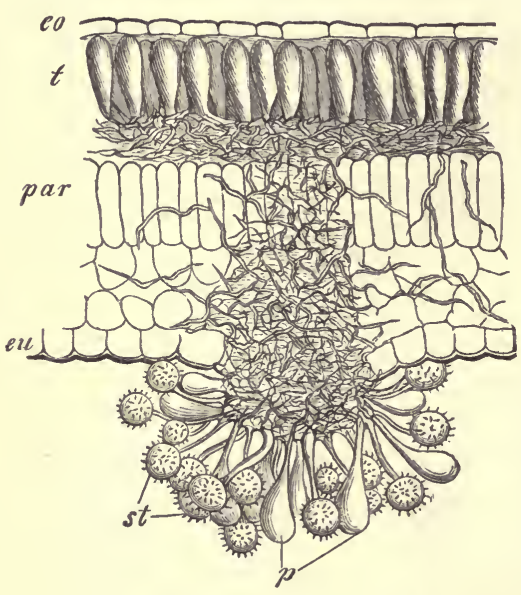

FIG. 216.-Transverse section of a Willow-leaf infested by Melampsora salicina : par mesophyll of leaf; eo upper, eu lower epidermis. On the under side a sorus of uredogonidia (st) with paraphyses $(p)$ has broken through the epidermis; beneath the upper epidermis is a sorus of young teleutogonidia $(t) .(\times 260$. above, though the host-plants are different in all eases; the species of Heteruromyces, such as Uromyces Por, U. Dactylidis, U. Junci, U. Pisi, etc.; the species of Heteropuccinia, to which group Puccinia Graminis belongs, such as $P$. coronata, $P$. sessilis, P. Rubigo-vera, P. Caricis, etc.; the species of Eucoleosporium, such as Coleosporium Senecionis ; the species of Euchrysomyxa, such as Chrysomyxa Rhododendri, C. Ledi.

The following are the more important variations on the lifehistory given above :-

a. The Uredo-forn is absent. In the Endophylleæ the æcidiospore gives rise, on germination, to a promycelium, which produces sporidia (as described above); the sporidium gives rise to a mycelium bearing reidia.

b. The Uredo-form only produces teleutogonidia, otherwise the life-history is the same as that of Puccinia Graminis (e.g. Gymnosporangium).

c. The Aecidium-form is absent; the Uredo-form produces only teleutogonidia : here the only forms are the Uredo-form bearing teleutogonidia, and the promycelinm bearing sporidia, which give rise to the Uredo-form on germination (e.g. species of Puccinia [Leptopuccinia] such as P. Malvacearum, P. Arenaria, P. Circea).

d. There are no distinct Uredo-forms and AEcidium-forms : the same mycelium gives rise first to æcidia and then to teleutogonidia (e.g. species of Uromy- 
copsis, such as Uromyces Behenis, U. Scrophularia; species of Pucciniopsis, such as Puccinia Berberidis, P. Liliacearum, P. Tragopogi; species of Phragmidiopsis, such as Xenodochus carbonarius). In some of the foregoing cases the mycelium may bear a few uredogonidia; in Phragmidium uredogonidia are always formed.

It is not, however, always the case that when there are distinct Uredo- and Ecidium-forms, these are heterœeious; they frequently inhabit the same hostplant, that is, they are autrcious (e.g. species of Auteu-uromyces, such as Uromyces Fabc, U. Orobi, U. Trifolii, etc.; species of Auteupuccinia, such as Puccinia Galii, P. Asparagi, P. Caltha, etc.) When there are not distinct Uredo- and Fidium-forms the fungus can only be autœcious.

The reproductive organs and cells, as described above, present certain variations by which the different genera are distinguished. Thus; in Endophyllum, the group (sorus) of teleutogonidia is invested by a definite wall; in Gymnosporangium and Cronartium, the teleutogon i d i ophores form a projecting c o $1 \mathrm{u} \mathrm{m} \mathrm{n}$ which, in Gymnosporangium, is gelatinous. In Coleosporium the promycel ium is unic e 11 u lar (Fig. 215 C), whereas in all other forms it is multicellular; in this

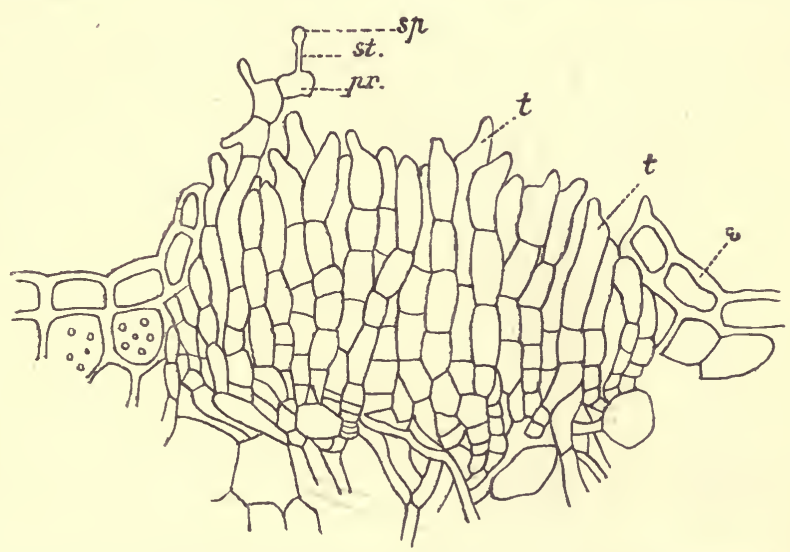

Frg. 217.-Chrysomyxa Rhododendri in a leaf of Rhododendron hirsuturn : vertical section of a sorus of teleutogonidia ; $e$ epidermis of under surface of the leaf; $t$ terminal teleutogonidia beginning to germinate; to the left a teleutogonidium has germinated, giving rise to a promycelium $(p r)$ with sporidium ( $s p$ ) borne on a sterigma st. ( $\times 140$ : after de Bary.)

genus also several uredogonidia are formed successively from the same gonidiophore. The primitive teleutogonidium undergoes no division, so that only one is found on each gonidiophore, as in Uromyces; or it divides transversely once to form two gonidia, as in Puccinia; or several times, to form a row of gonidia, as in Phragmidium; or obliquely, to form a group of three gonidia, as in Triphragmium. The groups (sori) of uredogonidia are sometimes invested by a wall, as in Cronartium. In Phragmidium the wall of the æcidium differs from that of the other forms in that it does not consist of a definite layer of cells, but is represented by a number of club-shaped unicellular hairs.

In most cases the teleutogonidium is a resting-gonidium; but in some forms, such as Leptouromyces (e.g. Uromyces pallidus, U. Ficariæ, U. Croci, etc.), Leptopuccinia (e.g. Puccinia Malvacearum, P. Buxi, P. Circae, etc.) Chryso. 
myxa, the teleutogonidia germinate, producing sporidium-bearing promycelia, as soon as they are ripe and before they have fallen off (Fig. 217).

In addition to the fructifications already described, there is a form, known as Ceoma, about which there is some uncertainty as to whether it represents a sorus of uredogonidia or an rcidium; in some cases it appears certainly to be the latter.

Besides the genera enumerated above, the life-history of which has been more or less investigated, there are a number of Uredo- and Ecidium-forms, as well as most Cæoma-forms, the connexion of which has not yet been ascertained. These are, for the present, simply designated Uredo, Ecidium, Cæoma, constituting temporary form-genera.

The list on p. 309 illustrates the life-history and heterœcism of the principal genera.

Order 2.-Ustilagineæ. This order comprises those parasites which are known as Smuts. The life-history of most of the members of this order, is

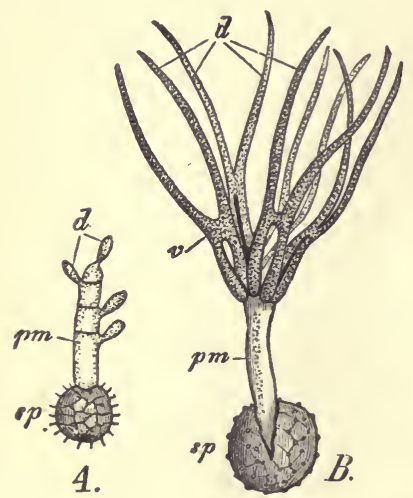

FIG. 218.-Germinating resting-gonidia : $A$ of Ustilago receptaculorum; $B$ of Tilletia Caries $(\times 460): s p$ the gonidium; $\mathrm{pm}$ the promycelium; $d$ the spondia: in $B$ the sporidia have coalesced in pairs at $v$. briefly as follows. The plant produces numerous thick-walled, often black (Smut) resting-gonidia, the development of which is usually intercalary (resembling that of chlamydogonidia) on more or less specialised mycelial branches (gonidiophores). On germination, the resting.gonidium forms a number of reproductive cells, sporidia, of various form; the sporidia are usually developed on a small promycelium, which may be either multicellular (Fig. $218 \mathrm{~A}$ ), or unicellular (Fig. 218 B); but in one genus, Protomyces, they are developed inside the restinggonidium, which acts as a gonidangium, the only instance of the kind in the Ecidiomycetes. In most forms these sporidia then coalesce in pairs; but in any case they germinate, either producing at once the mycelium which will bear the resting-gonidia (e.g. Protomyces), or a second promycelium bearing secondary sporidia, from which the mycelium bearing resting-gonidia is developed (e.g. Tilletia Caries).

In some species (e.g. Entyloma Ranunculi, Tuburcinia Trientalis) the mycelium, before it produces the resting-gonidia, developes another kind of gonidia ; these are small, thin-walled, somewhat spindle-shaped cells, developed by abstriction from the ends of unbranched simple gonidiophores.

The sporidia, when cultivated in nutrient solutions, may be made to multiply actively by gemmation, producing a number of yeast-like cells.

With regard to the life-history of the order, it may be pointed out, in the first place, that the resting-gonidia correspond to the teleutogonidia of the Uredinex; secondly, that the sporidia in the two orders correspond; and lastly, that the 

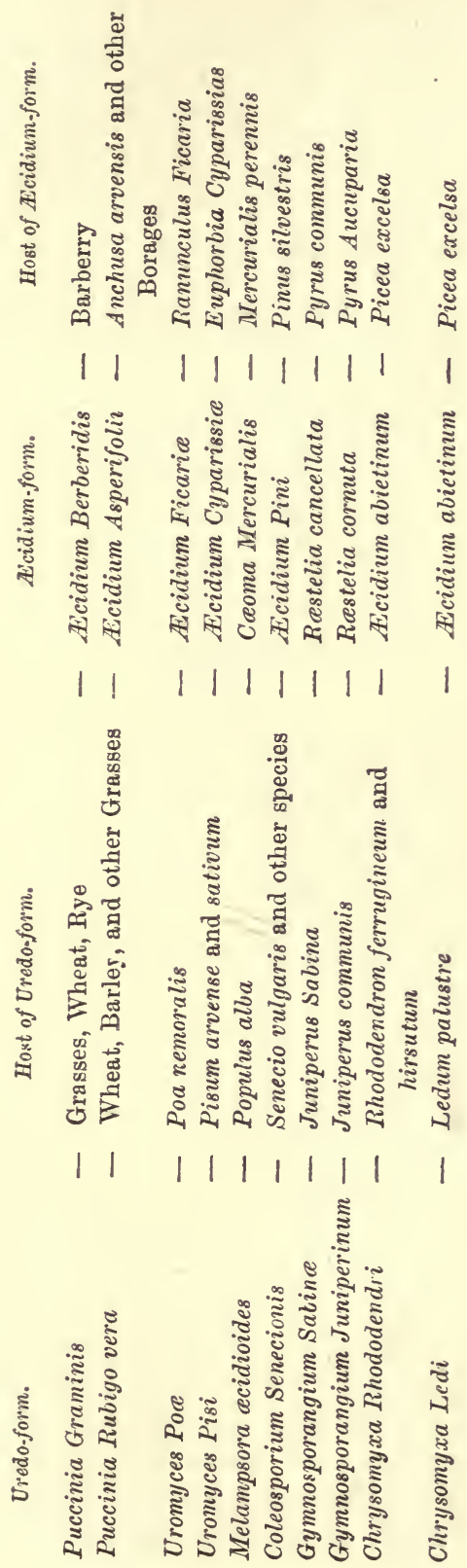
thin-walled gonidia of the Ustilagineæ (when present) correspond to the uredogonidia of the Uredineæ. The gametophyte of the Ustilagineæ thus presents very much the same polymorphism as that of the Uredinew; but there is nothing in the former order to correspond to the æcidium of the latter.

The affinities of the Ustilagineæ are of great interest. On the one hand they are clearly allied, as shown in their life-history, to the Uredineæ, and (as is explained on p. 314) with the Basidiomycetes. On the other hand they are allied to the Chytridiaceæ, and less closely, to the Entomophthoraceæ. They differ from the Chytridiaceæ, however, in that their mycelium is septate, and in that the gonidia are produced by abstriction, and are not motile. Protomyces, however, closely resembles some forms included in the Chytridiace (Physoderma), in that it produces its sporidia in the interior of the restinggonidium, and in that the sporidia, like the gonidia of Physoderma, are nonmotile; but Protomyces has a septate mycelium, whilst Physoderma has not.

The most important and the most common species are Ustilago Carbo, which especially attacks Oats, but other Cereals and Grasses as well: U. Maidis, which produces large tumours in the Maize, filled with resting-gonidia: Urocystis occulta, which fructifies in the leaves and haulms of the Rye: Tilletia Caries, the Smut of Wheat; this is dangerous because the grains filled with resting-gonidia remain closed, and are therefore harvested with the sound ones. Many other species and genera infest wild plants.

Sub-Class VI.-BASIDIOMYCETES. This sub-class includes a large number of plants, both saprophytes and parasites, the fructifications of which are well-known as Mushrooms, Toadstools, and Puff-Balls; they are the most highly organised of the Fungi.

The body is a branched septate mycelium, growing in the substratum, and bearing the reproductive organs which come to the surface.

The reproductive organs are gonidiophores of two kinds, compound and simple. Of these the compound gonidiophore is universal, and is characteristic of the sub-class; it constitutes the fructification commonly known as a Mushroom, a Toadstool, etc. The structure of the compound gonidiophore may be illustrated by reference to the cornmon mushroom (Agaricus campestris). It consists of a stalk, termed the stipe, bearing at its apex a large circular, somewhat umbrella-shaped expansion, the pileus. On the underside of the pileus are a number of radiating plates of tissue, the lamellae (Fig. 219), corered with the gonidia-bearing layer of cells, the hymenial layer or hymenium. The lamellæ collectively constitute the liymenophore. Towards the upper end of the stipe is a ring of tissue, the annulus, the torn remains of a 
membrane (the velum) which extended from the stipe to the margin of the pileus, enclosing the hymenial cavity (Fig. 222).

The stipe consists of a number of closely-packed branching hyphæ, which, at its apex, spreads out to form the tissue of the pileus. In the pileus, the hyphæ branch repeatedly, the hyphæ towards the lower surface forming the lamellæ. Each lamella (Fig. 219 B) consists of a mass of hyphæ, constituting the trama; as the hyphæ approach the surface of the lamella, the cells become shorter. The last cells, before reaching the hymenial layer, are very short, and constitute a definite layer, known as the subhymenial layer (Fig. $219 B C s h)$. The terminal cells of the byphæ constitute the hymenial layer (Fig. $219 \quad B \quad h y$ ). This consists of somewhat elongated club-shaped cells, some of which bear gonidia, and are termed basidia, whilst the others are sterile, and are termed paraphyses (Fig. 219 C $q$ ). Each basidium de-

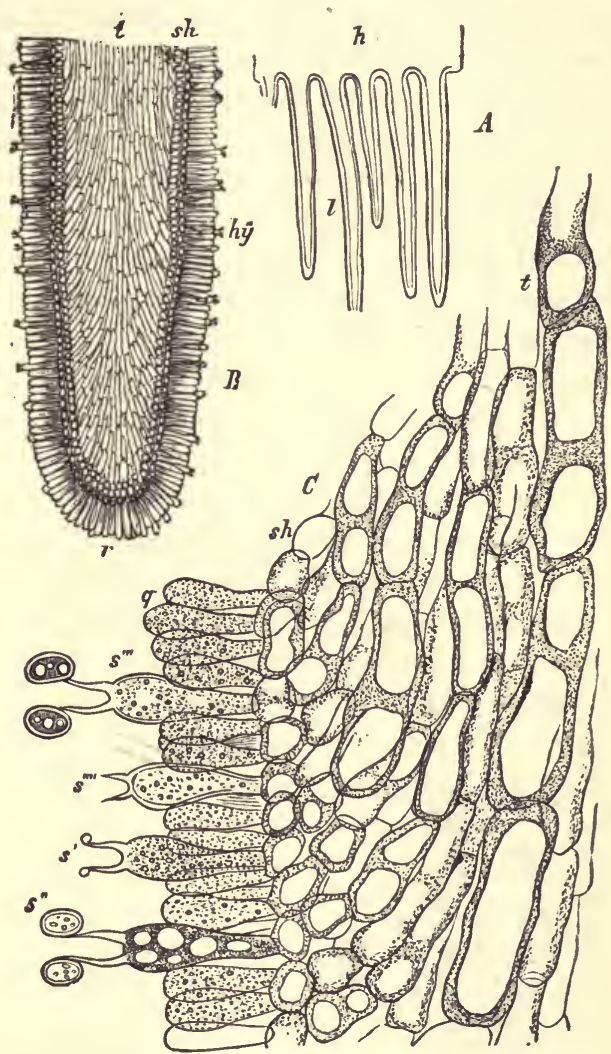

Fig. 219.-Agaricus campestris. A Tangential section of the pileus, showing the: lamellæ $(l)$ of the bymenophore. $\boldsymbol{B}$ A similar section of a lamella more highly magnified; $h y$ the hymenium; $t$ the central tissue called the trama. $C$ A portion of the same section more highly magnified $(\times 550): q$ young basidia and paraphyses; $s^{\prime}$ the first formation of gonidia on a basidium; $s^{\prime \prime}$ more advanced stages; at $s^{\prime \prime \prime \prime}$ the gonidia have fallen off. (After Sachs.) velopes at its apex four delicate outgrowths, the sterigmata, and at the apex of each sterigma a single small gonidium $\left(C s^{\prime} s^{\prime \prime}\right)$ is 
formed. These gonidia are termed basidiogonidia, with reference to their mode of origin.

The form of the compound gonidiophore, as also the relation of its different parts, varies widely in the orders and families of the sub-class. As the more minute peculiarities are described in the account of these groups, only the important diversities are now mentioned. In the familiar Auricularieæ, Tremellineæ, Dacryomycetes, Clavarieæ, Thelephoreæ, Hydneæ, most Polyporeæ, and some Agaricinæ, the hymenium is exposed from its first development, and the gonidiophore is consequently said to be gymnocarpous. In Polyporus volvatus, species of Boletus, and in some Agaricinæ (e.g. sub-genera Armillaria, Psalliota, of the genus Agaricus, etc.) the hymenium is covered for some time by a membrane, termed a velum partiale, as described above (see Fig. 222); the gonidiophore is then termed hemi-angiocarpous. Finally, the whole gonidiophore may be surrounded by a membrane, which is dehiscent or indehiscent, and is then said to be angiocarpous. This is due to the fact that the gonidiophore is developed from the internal portion of the primitive mass of hyphal tissue, the external portion constituting the enveloping membrane. This arrangment obtains in various genera of Agaricinæ, such as Agaricus (subgenera Amanita, Fig. 222, Lepiota) and Coprinus, and generally in the order Gasteromycetes. This membrane is termed, in the case the Agaricinæ, a velum universale; in that of the Gasteromycetes, a peridium. When it is dehiscent, and the

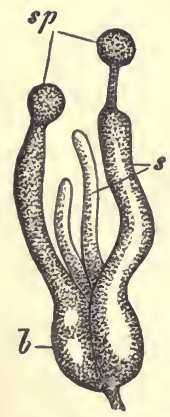

F1G. 220.-Multicellular basidium of Tremella : 8 sterigma; $8 p$ basidiogonidia. ( $\times 350$. gonidiophore is stipitate, a portion of it remains surrounding the base of the stipe as a volva.

In species belonging to all the families of Hymenomycetes, except Clavarieæ and Hydneæ, and also in some other forms (e.g. Nidularia pisiformis), certain large projecting sterile cells, termed cystidia (Fig. 223), are formed in the hymenium, the function of which is not fully understood.

In the higher Basidiomycetes (Autobasidiomycetes) the basidia are unicellular, but in the lower forms (Protobasidiomycetes) they are multicellular, either with transverse septa (Pilacreæ, Auricularieæ), or with longitudinal septa (Tremellineæ, Fig, 220). 
The number of gonidia borne by a unicellular basidium is usually four; but it may be one (species of Hymenogaster), or two (Calocera, Dacryomyces, species of Octaviana and Hymenogaster), or 4-8 (Phalloideæ). In the case of the multicellular basidium, each cell bears one basidiogonidium.

Simple gonidiophores have been discovered in several forms (Pilacre Petersii, Auricularia sambucina and mesenterica, Exidia, Ulocolla, Craterocolla, Sebacina, Tremella mesenterica and lutescens, Tomentella, Exobasidium, Heterobasidium [Polyporus] annosum [Trametes radiciperda], Dacryomyces). In these forms the basidiogonidium gives rise, on germination, to a mycelium, sometimes small and unbranched, which is either itself the simple gonidiophure, or bears simple gonidiophores, on which gonidia are formed by abstriction. The same mycelium may subsequently bear the compound gonidiophores; or the gonidia-bearing form may reproduce itself through successive generations until at length, under appropriate conditions, the form bearing the compound gonidiophores occurs. In the genus Craterocolla, the simple gonidiophores are collected into sori developed in special receptacles.

The gonidia of Tremella, cultivated in nutrient solution, multiply rapidly by budding, producing yeast-like cells, which have not, however, the power of exciting alcoholic fermentation.

The formation of unicellular gemmæ (see p. 274), is of common occurrence in the Basidiomycetes; either in the form of chlamydogonidia (e.g. Nyctalis, Oligoporus, Fistulina), or, more commonly (e.g. Ulocolla, Dacryomyces deliquescens, species of Coprinus, Clavarieæ, Lenzites, Pholiota, Collybia, Nyctalis, Phlebia, Polyporus, Cyathus, etc.) in the form of oidinm-cells. The chlamydogonidia are especially developed in the basidial fructifications of the plants in which they occur: the oidium-cells are generally developed from the vegetative mycelium, either the whole of it or individual hyphæ, forming sometimes a more or less definite fructification (Dacryomyces deliquescens). In some Agaricinæ (e.g. Coprinus, Clavarieæ, Stropharia stercoraria, Psathyrella, etc.) the oidium-cells appear to be incapable of germinating.

Sclerotia (see p. 275) are known in some cases. The mycelium (e.g. Typhula variabilis, and complanata, Coprinus stercorarius, Tulostoma) produces sclerotia as an antecedent to the formation of the compound gonidiophores; the sclerotia become quite free from the mycelium, and may be kept for months without losing their vitality. On germination each sclerotium gives rise to one 
or more compound gonidiophores. The most remarkable sclerotia are those of Agaricus melleus, a Fungus which is very destructive to timber. The mycelium gives rise to dark-coloured compact strands of hyphæ, of the pseudo-parenchymatous structure characteristic of sclerotia; but they are peculiar in possessing contiuned apical growth, and by this means they soon become long filaments, known as Rhizomorpha. It is in this way that the Fungus spreads from tree to tree: the Rhizomorpha-filaments grow underground from the roots of an infected tree to those of a healthy tree (usually a Conifer); it penetrates into them and spreads in the tissues external to the wood in the form of a white fan-shaped mycelium. The compound gonidiophores (Agaricus melleus) are borne either on the subterranean Rhizomorphafilaments, or on the parasitic mycelium ; in either case the gonidiophores come to the surface.

The homologies of the reproductive organs of the Basidiomycetes are not difficult to trace. The development of the basidiogonidia on the basidia, more especially in the Protobasidiomycetes, recalls the germination of the teleutogonidia and resting-gonidia of the Uredineæ and Ustilagineæ respectively; of those Uredineæ in particular (Leptouromyces, Leptopuccinia) in which the teleutogonidia germinate without having fallen off the plant bearing them (compare Fig. 217 with Fig. 220), the sterigmata being all that remains of the promycelium. A mushroom is, then, a compound gonidiophore producing basidia (or teleutogonidia) which germinate, without falling off, and give rise to basidiogonidia (or sporidia). The gonidia developed on the simple gonidiophores (when present) of the Basidiomycetes may be compared with the similar gonidia of the Ustilagineæ, and with the uredogonidia of the Uredineæ. These homologies may be comprehensively indicated in a tabular form :-

Gametophyte.

Uredineæ. uredogonidium teleutogonidium sporidium Ustilagineæ gonidium resting-gonidium sporidium Basidiomycetes gonidium basidium

basidiogonidium
Sporophyte.

æcidium with

[spores.

It will be seen that in neither the Ustilagineæ nor the Basidiomycetes is there any organ to correspond with the recidium of the Uredineæ.

The foregoing table also indicates the nature of the life-history of the Basidiomycetes. As in the Ustilagineæ, so in the Basidio- 
mycetes, the sporophyte is entirely unrepresented in consequence of the complete disappearance not only of the sexual organs of the gametophyte, but of any representative of the product of a sexual process. The various forms occurring in the life-history of any Basidiomycete belong to the gametophyte; these forms are, however, less distinct from each other than are the corresponding forms of the Acidiomycetes, so that the life-history is here more concise.

The Basidiomycetes are classified as follows:-

Series I. Pвотоваsidiomycetes : basidia multicellular, four-celled, each cell bearing a gonidium; simple gonidiophores generally present.

Fam. 1. Pilacrea. The septa in the basidia are transverse; the compound gonidiophore is differentiated into stipe and pileus, and is angiocarpous, the hymenium, which is on the upper surface of the pileus, being covered by a membrane (velum) which eventually decays; each cell of the basidium produces a single gonidium.

The family includes the genus Pilacre, with the two species $P$. faginea (on Beech), and P. Petersii (on Hornbeam).

Fam. 2. Auriculariea. The septa in the basidia are transverse; the compound gonidiophore, not differentiated into stipe and pileus, is gymnocarpous; the hymenium is irregularly folded and is gelatinous when wet; each cell of the basidium bears a single gonidium on a sterigma.

The family includes the genus Auricularia, growing on the stems of trees.

Fam. 3. Tremellinea. The septa in the basidia are longitudinal; the compound gonidiophore, not differentiated into stipe and pileus, is gymnocarpous; the hymenium is irregularly folded and generally gelatinous; each cell of the basidium bears a gonidium on a terminal sterigma (Fig. 220).

The family includes the genera Exidia, Tremella, Craterocolla, Sebacina, and Gyrocephalus, growing on decaying wood, tree-trunks, etc.

Series II. A тtobasidiomycetes. Basidia unicellular; simple gonidiophores in some forms.

Order 1. Hymenomycetes. Compound gonidiophore gymnocarpous, or hemi-angiocarpous, or rarely angiocarpous ; in any case the hymenium is exposed before the maturity of the basidiogonidia ; each basidium bears 2-6 (usually 4) apical sterigmata each of which bears a gonidium.

Fam. 1. Dacryomycetes. Basidia elongated, with two sterigmata ; compound -gonidiophores sometimes gelatinous, gymnocarpous, presenting in some forms (e.g. Dacryomitra) rudimentary differentiation into stipe and pileus, sometimes branched (e.g. Calocera).

The family includes the genera Dacryomyces, Guepinia (with a cup-like gonidiophore resembling the apothecium of Peziza), Dacryomitra, and Calocera the gonidiophore of which resembles that of the Clavarieæ.

Fam. 2. Clavariece. The compound gonidiophore is fleshy and gymnocarpous, either uubranched (e.g. Pistillaria), or branched, cylindrical (e.g. Clavaria, Fig. 221 ), or flattened and expanded (e.g. Sparassis), not differentiated into stipe and pileus; the hymenium covers the whole surface of the gonidiophore, or is 
limited to the upper part (e.g. Typhula); the basidium has sometimes only two sterigmata (e.g. Pistillaria, Typhula).

Fam. 3. Thelephorea. In the lowest forms there is no compound gonidiophore but merely a hymenial layer (e.g. Exobasidium); in others the gonidiophore is gymnocarpous, forming an incrustation on the substratum, and bearing the hymenium on its upper surface (.$g$. Coniophora, Hypochnus, Corticium); in the high forms (e.g. Thelephora, Stereum, Cyphella, Craterellus), the gonidiophore, af various form, branched or unbranched, bears the hymenial layer on its under surface; the hymenophore is smooth, with projections or pits.

Fam. 4. Hydnea. In the lower forms the compound gonidiophore forms an incrustation on the substratum, with the hymenium on the upper surface $(e . g$. Odontia, Grandinia); in the higher forms (e.g. Sistotrema, species of Hydnum) ; the hymenium is borne on the under surface of the gonidiophore, which is, in

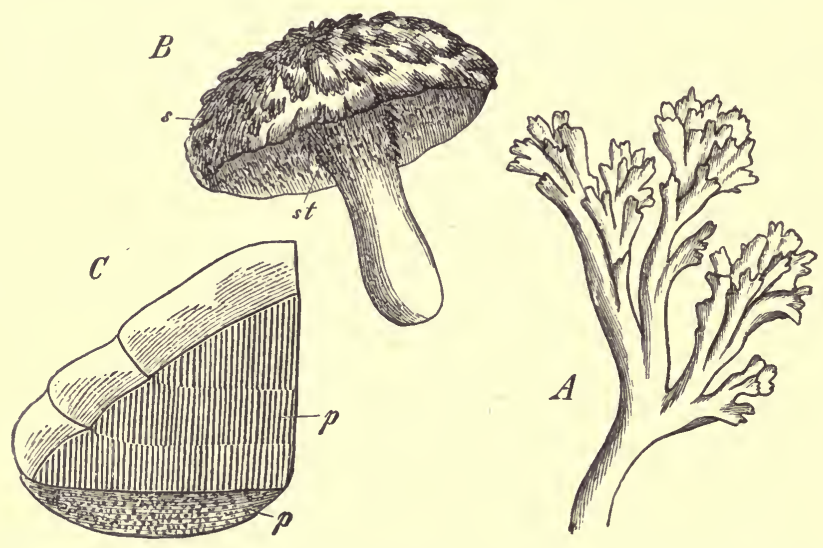

Fig. 221.-A Part of compound gonidiophore of Clavaria flava (nat. size). B Compound gonidiophore of Hydnum imbricatum : st the spiny projections of the hymenophore; $s$

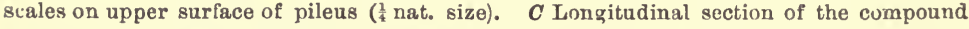
gonidiophore of a Polyporus: $p$ tubes of the hymenophore, lined by the hymenium, appearing on the under surface as pores.

some cases, differentiated into stipe and pileus; in all cases the hymenophore bears a number of spinous projections over which the hymenium extends (Fig. $221 \mathrm{~B}$ ), and is gymnocarpous.

Fam. 5. Polyporece. The compound gonidiophore may be a flattened expansion with the hymenium on the upper surface (e.g. Porothelium); or semicircular, and attached laterally, with the hymenium on the under surface (e.g. Merulius, Dædalea, species of Polyporus, Fig. $221 \mathrm{C}$ ); or differentiated into stipe and pileus with the hymenium on the under surface (e.g. Boletus); the hymenophore is indented with pits or tubes, which are lined by the hymenium. The gonidiophore is generally gymnocarpous, but there is a velum partiale in some forms (e.g. Boletus versipellis, viscidus, floccopus, Polyporus volvatus). The Dry Rot of timber is caused by members of this family.

Fam. 6. Agaricince. The compound gonidiophore is a pileus, with or without 
a stipe; it bears on its under surface (rarely on its upper surface) a lamellate $\mathrm{I}$ hymenophore (see Fig. 219) ; the gonidiophore may be gymnocarpous ; or hemiangiocarpous having a velum partiale (e.g. Cortinarius where the velum is like a spider's web; the sub-genus Psalliota of the genus Agaricus, including A. campestris, the common Mushroom, etc.) ; or angiocarpous, having a velum universale (e.g. the sub-genera Volvaria, Lepiota, and Amanita of the genus Agaricus; Nyctalis, Coprinus, etc.); in some species of Amanita there is both a velum universale and a velum partiale.

The great genus Agaricus is subdivided into a number of sub.genera belonging to various groups distinguished by the colour of their basidiogonidia. Amongst the other genera Coprinus has a gonidiophore which very soon undergoes disintegration, forming a black shiny fluid; Lactarius contains milky juice (latex). In Cantharellus the lamellæ are prolonged down the stipe. Of edible species the following may be named: Cantharellus cibarius, Lactarius déliciosus, Agaricus campestris, the Mushroom, A. procerus distinguished by a movable ring, and A. casareus: the poisonous species are Lnctarius torminosus and Agaricus (Amanita) muscarius.

Whilst the compound gonidiophore is generally fleshy, in some genera it is of a hard or leathery consistency; these live commonly on old wood; such are Panus, with a small pileus mounted on an eccentric stipe ; Lenzites, where the pileus is lateral and sessile; Marasmius, the elegant

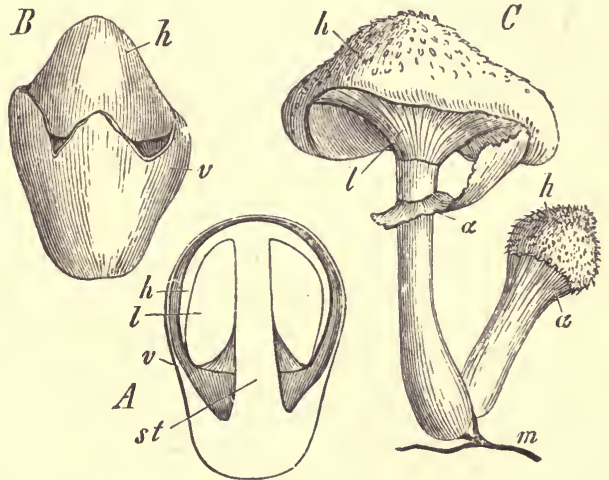

FIG. 222. $-A$ Section of young compound gonidiophore of Agaricus (Amanita) vaginatus : $v$ the velum universale; st the stipe; $h$ the pileus; $l$ the lamella: $B$ the same somewhat older; the velum $v$ is ruptured. C Agavicus melleus: $m$ the mycelium (Rhizomorpha); in the smaller specimen to the right the hymenophore is still covered by the velum partiale $a$; in the larger specimen the velum is almost completely ruptured, and remains attached to the stipe as the ring, a. ( $\frac{1}{2}$ nat. size.)

pilei of which are often seen on the leaves of Conifers which have fallen off.

Order 2. Gasteromycetes. Angiocarpous; the hymenium is either not exposed at all, or only after the basidiogonidia are mature, by the dehiscence or rupture of the peridium. The number of gonidia borne by a basidium varies from 1-8; the sterigmata are apical, except in the genus Tulostoma, where they are lateral. The hymenophore is here a more or less distinct organ, and is termed the gleba.

Fam. 1. Hymenogastrece. The compound gonidiophore is subterranean. It consists of a thick indehiscent peridium, filled with a spongy persistent gleba, the chambers of which are lined by the hymenium (Fig. 224 $A$ ).

Principal genera: Hymenogaster, Octaviana, Rbizopogon, Melanogaster, Hysterangium, Hydnangium. 
Fam. 2. Sclerodermece. The structure of the compound gonidiophore is essentially the same as that of the preceding family, but it is not subter-

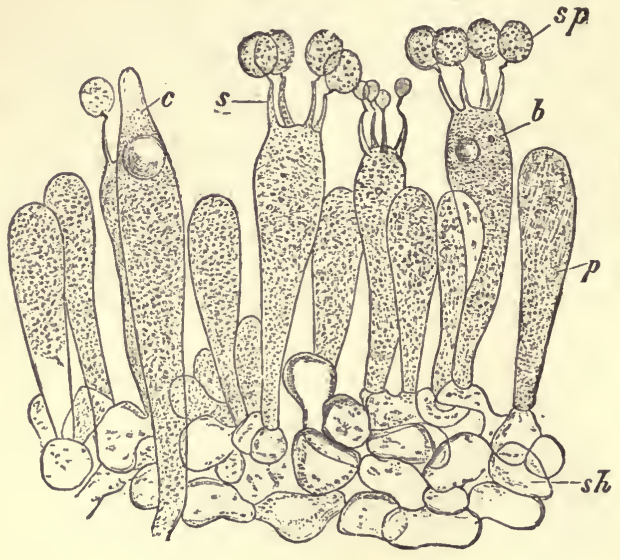

Fig. 223.-Part of the hymenium of Russula rubra: sh subhymenial layer; $b$ basidium; $s$ sterigma; $s p$ basidiogonidia; $p$ paraphyses; c a cystidium. ( $\times 540$ : after Strasburger.) ranean.

Principal genera: Scleroderma, Polysaceum.

Fam. 3. Nidulariea. The peridium is dehiscent at the apex. The tramal tissue of the gleba undergoes mucilaginous degeneration and dis. appears, leaving the hymenium-bearing cham. bers as closed indehis. cent vesicles (peridiola), either lying free (Nidularia) in the vase-shaped peridium, or loosely attached to its inner surface by strands (funiculi) of hyphæ (Cyathus, Crucibulum, Fig. 224 $C D$ ).

Fam. 4. Lycoperdea. The peridium is generally dehiscent, differentiated into two or more layers, constituting two distinct membranes-the exoperidium and the endoperidium. The tissue of the gleba constitutes, at the maturity of the spores, a powdery mass, including, in most genera (except Calostoma, Sphærobolus) hyphal filaments forming a capillitum (Fig. $224 \mathrm{~B}$ ).

The mode of dehiscence presents variations in the different genera. Thus in Bovista and Lycoperdon. (PuffBalls) the exoperidium becomes dry and breaks up into fragments, whilst the endoperidium dehisces forming a small apical aperture through which the basidiogonidia escape.

In Geaster (Star Puff-Ball) the exoperidium splits at the apex into several pointed segments which bend con-

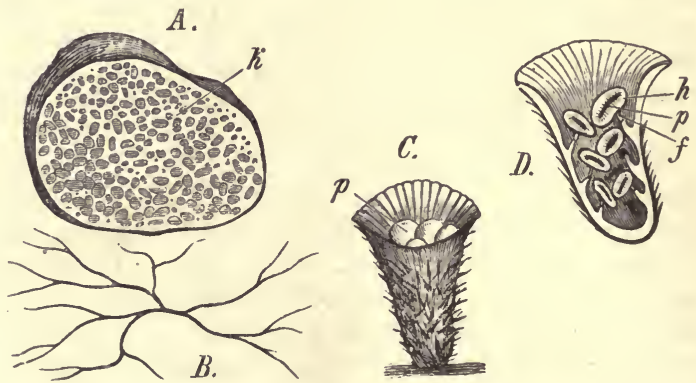

Fig. 224.-A Compound gonidiophore of Rhizopogon in section (nat. size): $k$ the hymenial chambers. $B$ Capillitial flament of Lycoperdon (much mag.). $C$ and $D$ Compound gonidiophore of Cyathus striatus" (nat. size): $C$ entire, showing the isolated hymenial chambers (peridiola) : $D$ in longitudinal section ; $p$ peridiolum; $h$ bymenium; $f$ funiculus, attaching the peridiolum to the peridium. 
vexly outwards, bearing the endoperidium centrally, either with or without a stalk, on the convex surface; the endoperidium, which encloses the gleba, dehisces with a small apical aperture.

In Tulostoma and Battarea the tissue within the peridium undergoes differentiation into a gleba and a stipe. When the spores are mature, the stipe elongates, rupturing the exoperidium, and carries up the gleba, enclosed in the endoperidium, at its apex with a portion of the exoperidium; the rest of the exoperidium remains as a volva round the base of the stipe. In Tulostoma the endoperidium dehisces at the apex forming a small aperture; in Battarea the endoperidium covering the under surface of the discoid gleba decays.

Fam. 5. Phalloidea. The peridium is dehiscent, and the gleba becomes mucilaginous.

In the genus Ithyphallus (e.g. Phallus impudicus) the peridium consists of three layers, of which the innermost and outermost are thin and firm, whilst the intermediate layer is bulky and mucilaginous. The internal tissue is differentiated into a gleba and a stipe. When the basidiogonidia are mature, the stipe elongates suddenly, ruptures the peridium at the apex, aud carries up the gleba, which is now mucilaginous. The elongated stipe is hollow and perforated at the apex; the upper portion of the stipe bears a thick membrane attached at the apex, with a reticulated surface, the remains of the gleba. The ruptured peridium remains as a volva round the base of the stipe.

In the genus Clathrus the peridium is differentiated, as in Ithyphallus, into three layers, the mucilaginous intermediate layer being traversed by anastomosing plates of tissue, which connect the

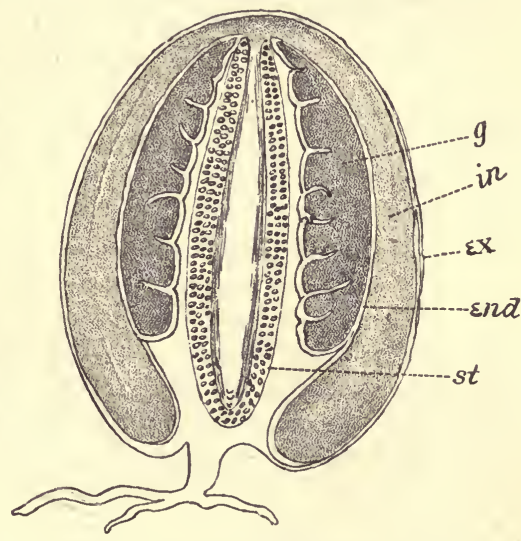

FIG. 225.- Section of compound gonidiophore of Phallus impudicus : st stipe; end endoperidium; $e x$ exoperidium; in intermediate mucilaginous layer; $g$ gleba. (Reduced: after Sachs.)

internal and external layers. From the internal layer of the peridium a capillitium is formed (something like that of some of the Myxomyeetes, but much stouter, see Fig. 198), which surrounds the central gleba. The gleba is connected with the base of the peridium by a mass of cartilaginous tissue. Before expansion the whole gonidiophore has a somewhat spherical form. When the spores are mature, the eapillitium expands, rupturing the peridium at the apex, and lifts the gleba in its interior out of the peridium, which remains round the base as a volva. The gleba undergoes mucilaginous degeneration.

Subsidiary Group. Lichenes. A Lichen consists of a Fungus and an Alga, or more than one, living in intimate connexion, and both contributing to their mutual welfare-that is, symbiotically (see p. 273).

The Lichen-Fungus has always a mycelioid body, and is the constituent of 
the Lichen which bears the reproductive organs. From the nature of these organs the Lichen-Fungi have been found to belong chiefly to the discomycetous and pyrenomycetous Ascomycetes, but a few are basidiomycetous, belonging to the orders Hymenomscetrs and Gasteromycetes. The Lichens may be

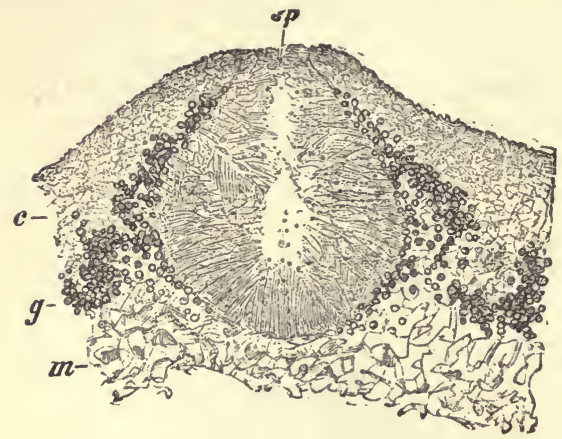

FIG. 226.-Section of a spermogonium of Anaptychia ciliaris : $s p$ the aperture at the surface; $c$ cortex, and $m$ medullary portion, of the thallus; $g$ layer of algal cells. (After Strasburger.)

1. Hymenolichenes (Hymenomycetous Rhipidonema, Laudatea. classified as follows, according to the nature of the Fungus.

I. Ascolichenes (Ascomycetous Lichens).

1. Discolichenes (Discomy. cetous Lichens), e.g. Parmelia, Collema, Usnea, Peltigera, Sticta, Cladonia, etc., Lecidea, Graphis.

2. Pyrenolichenes (PsrenomycetousLichens), e.g. Pertusaria, Ephebe, Lichina, Verrucaris, Endocarpon, etc.

II. Basidiolichenes (Basidiomycetous Lichens).

Lichens), Cora, Dictyonema,

2. Gasterolichenes (Gasteromycetous Lichens), Emericella.

The reproductive organs of the Ascolichenes are sterigmata, producing spermatia, contained in spermogonia (Fig. 226); archicarps (in the order Collemaceæ), differentiated into a coiled ascogonium and a multicellular projecting trichogyne; and ascocarps, which are either apothecia (discomyce-

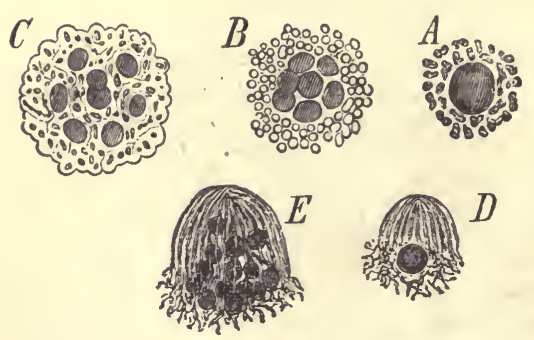

Frg. 227. $-A-D$ Soredia of Usnea barbata. A A simple soredium, consisting of an algal cell covered with a web of hyphæ. B A soredium, in which the algal cell has multiplied by division. C A gronp of simple soredia, resulting from the penetration of the hyphæ between the algal cells. D E Germinating soredia : the hyphr are forming a growing. point, and the algal cells are multiplying. (After sachs.) tous) or perithecia (pyrenomycetous) ; the archicarp, apparently after fertilisation (see p. 298), gives rise to filaments which form the hymenial layer (consisting of asci and paraplysses) of the apothecium, and ontgrowths from the adjacent vegetative hyphæ form the wall (excipulum) of the apothecium.

In the fructification of the Basidiolichenes there is a hymenial layer consisting of paraphyses and basidia, the latter bearing apical sterigmata, on each of which a basidiogonidium is produced by terminal abstriction.

Lichens are also reproduced 
by gemmæ, termed soredia, which consist of one or more algal cells invested by hyphæ; they are budded off from the surface of the thallus, and grow into new plants (Fig. 227).

The Lichen-Algæ belong either to the Cyanophyceæ or to the Chlorophyceæ. In the following list the principal algal forms with their corresponding Lichens are enumerated.

\section{A. Cyanophyceæ.}

Scytonemaceæ (Scytonema, Sirosiphon) . Ephebe, Spilonema, Polychidium, Rhipidonema, Dictyonema, Heppia, Porocyphus.

Rivulariacer . . . . . . Lichina, Racoblenna.

Nostocaceæ . . . . . . . Collema, Lempholemma, Leptogium, Peltigera, Pannaria.

Chroococcaceæ. . . . . . . Omphalaria, Euchylium, Phylliscium, Cora.

\section{B. Chlorophyceæ.}

Protococcaceæ (Pleurococcus, Cystococcus, etc.)

Sticta, Physcia, Evernia, Cladonia, Usuea, Parmelia, Anaptychia, Endocarpon, etc.

Confervoideæ (Trentepohlia) . . . . . Graphideæ, Verrucarieæ.

Coleochætaceæ . . . . . . Opegrapha.

The algal cells or filaments may be distributed throughout the thallus, when it is said to be homoiomerous (Fig. 208); this is usually the case in gelatinous Lichens (such as the Collemaceæ), in which the Alga belongs to the Cyanophyceæ, but also in some non-gelatinous forms in which the Alga belongs to the Chlorophyceæ (such as Cœnogonium, Racodium, and others, in which the Alga is Trentepohlia): or they may be arranged in a definite layer near the surface of the thallus, when it is said to be heteromerous (Fig. 229), as in the case of nearly all these Lichens of which the Algæ belong to the Chlorophycer, and some in which the Algæ belong to the Cyanophyceæ (e.g. Peltigera, Pannaria). In some heteromerous forms (e.g. Thelidium), the Algæ are quite on the surface. Occasionally (e.g. Endocarpon) algal cells are present in the hymenium.

It may be generally stated that the form of the thallus is determined in the homoio-

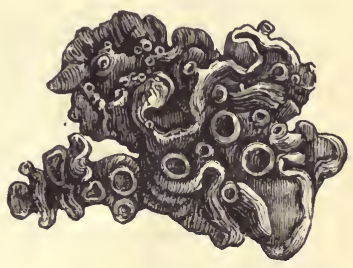

Fig. 228. - A gelatinous Lichen, Collema pulposum, slightly magnified. It is homolomerous, and the Alga is Nostoc. (After Sachs.) merous Lichens by the Alga, in the heteromerous Lichens by the Fungus. In the latter case three main forms are distinguished :-

(a) fruticose Lichens, in which the thallus grows erect, branching in a shrublike manner. Of this form are the various species of Usnea (Fig. $230 \mathrm{~A}$ ), and allied genera with a cylindrical thallus, which grow on trees: Roccella tinctoria grows on rocks in regions bordering on the Mediterranean; from it and 
other allied Lichens litmus is prepared : Ramalina and Evernia, with a ribbonshaped flattened thallus, occur on trees and wooden fences: Cetraria islandica. is the Iceland Moss, which forms a mucilaginous fluid when boiled with water : Anaptychia ciliaris, which resembles the foliaceous Lichens, with a flattened thallus, is common on the trunks of trees: Cladonia has a scaly decumbent thallus, from which erect branches spring bearing the apothecia; Cladonia fimbriata is common; Cladonia rangiferina, the Reindeer Moss, occurs on moors: Sphærophorus has the same external appearance, but it is pyrenocarpous.

(b) foliaceous Lichens, in which the thallus is flattened and adheres to the substratum: the green (rarely bluish-green) algal cells form a single layer beneath the upper surface (Fig. 229). The margin of the thallus is usually lobed.

Purmelia parietina occurs, with its bright yellow thallus bearing apothecia,

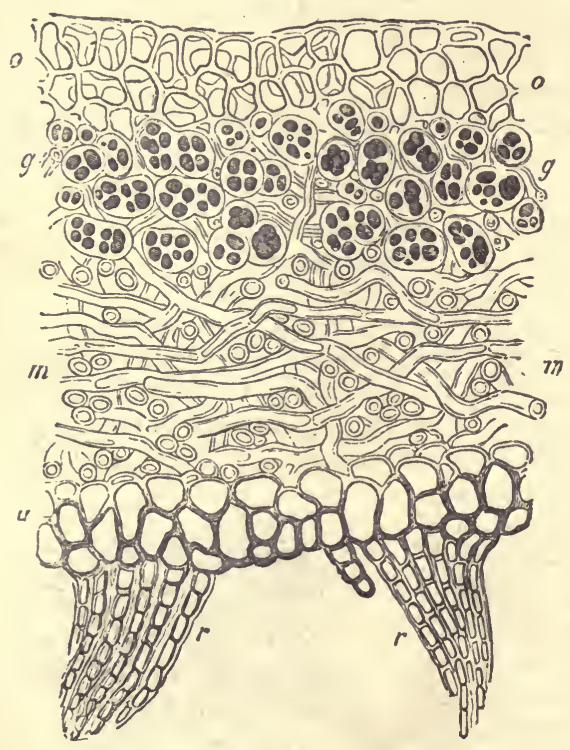

Fig. 229.-Transverse section of the heteromerous thallus of Sticta fuliginosa $(\times 500)$. o Cortex of the upper surface; $u$ under surface; $m$ network of hyphæ forming the medullary layer; $g$ algal cells; $r$ root-like ontgrowths (rhizines) of the under surface. (After Sachs.)

which Lecanora subfusca occurs on the trunks of trees: the Lecideaceæ, which occur mainly on earth and rocks, Lecidea geographica, forming bright yellow incrustations of considerable extent on silicious rocks : the Graphideæ, of which Graphis scripta is common on the trunks of Beeches and other trees: the small Calicieæ, which are common on wooden fences: the Bæomyceæ, of which 


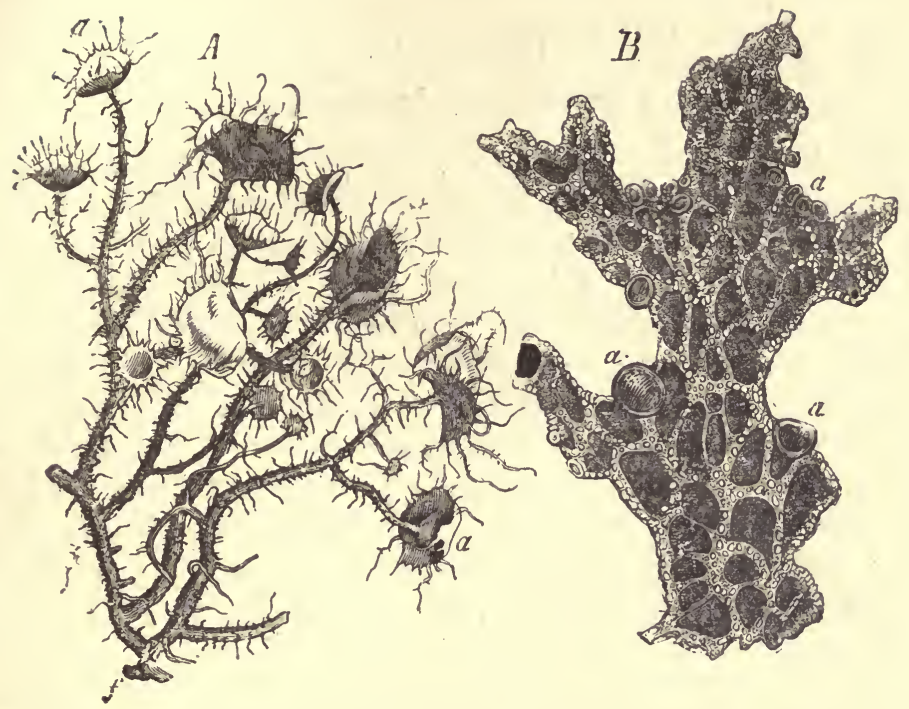

Frg. 230.-A A fruticose Lichen, Usnea barbata, with apothecia, a. B A foliaceous Lichen, Stictx pulmonacea, with apothecia, $a$ (nat. size). (After Sachs.)

Boomyces rufus is common on sandy soil: the Verrucarieæ, the Pertusarieæ, etc.

Many species of crustaceous Lichens inhabit the highest peaks of the Alps, and other lofty mountains, on which there is no other vegetation, and they contribute materially to the weathering of the rocks and to the formation of a vegetable soil. When they grow on the trunks of trees, they occur more especially upon those which have a smooth surface; the formation of a rough bark seems to interfere with their growth. Lichens may become completely dried up without losing their vitality.

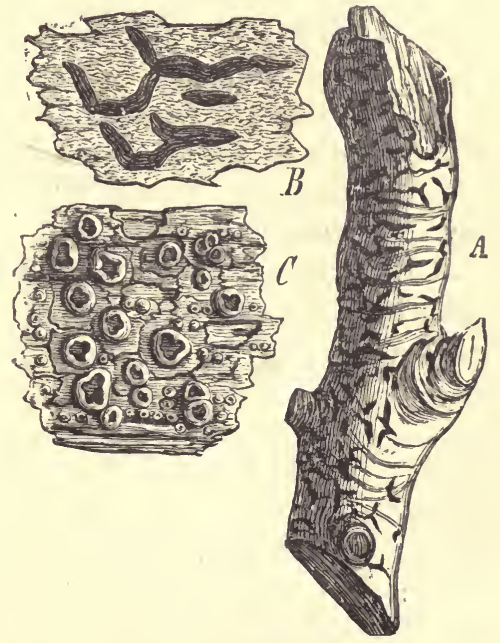

Frg. 231.-Crustaceous Lichens. $A$ and $B$ Graphis elegans: $B$ slightly magnified. C Pertusaria Wulfeni, slightly magnified. (After Sachs.) 


\section{GROUP II.}

\section{BRYOPHYTA (Muscineæ).}

The plants forming this group, that is the Liverworts (Hepaticæ) and the Mosses (Musci), are characterised by the following distinctive features. Their life-history presents a regular and wellmarked alternation of generations: the gametophyte is the more conspicuous form, constituting "the plant," and does not possess the power of reproducing itself asexually by gonidia, which is so common among the Thallophyta: the sporophyte is a sporogonium, presenting indications of differentiation into root and shoot, but not of the shoot into stem and leaves; it never becomes an independent individual, but remains attached to the gametophyte, from which it derives much of its nutriment. In some of the Mosses there is an indication, in both the sporophyte and the gametophyte, of a differentiation of vascular tissue.

The Gametophyte is heteroblastic (see p. 14) in its development. The germinating spore does not at once give rise to what is known as the "Moss-plant," but prodnces an embryonic body, the protonema, which consists generally of a branched filament, but occasionally of a flat layer, of cells which contain numerous chloroplastids. The protonema is generally inconspicuous and short-lived in the Hepaticæ, whilst in the Musci it is more amply developed and may, either wholly or in part, persist from year to year.

The "Moss-plant" is the adult sexual form. It does not possess any true roots, but is attached to the soil either by unicellular root-hairs (Hepaticæ), or by multicellular protonematoid filaments termed rhizoids (Musci). The body of the "Moss-plant" is essentially a shoot, which is highly developed and specialised in connexion with the functions which it performs - the development of the sexual reproductive organs and, in the case of the shoots bearing female reproductive organs, the nourishment of the attached sporophyte developed in consequence of fertilisation. The adult shoot arises as a lateral (rarely terminal) bud on the protonema: the protonema may give rise to a single shoot (Hepaticæ) or to several (generally in Musci). In the latter cases, the adult shoots may become distinct "plants" by the complete or partial dying away of the protonema. The symmetry of the shoot is, almost uniformly, dorsiventral in the Hepaticæ and radial in the Musci. It is either thalloid, as in most Hepaticæ; or it is 
differentiated into stem and leaf, as in the higher Hepaticæ (foliose Jungermanniaceæ) and in the Musci.

The sexual organs are borne on the adult shoot, and are antheridia and archegonia. They are rarely borne singly or scattered, but more commonly in groups (sori) surrounded by some kind of protective investment to which the general term involucre may be applied. In some cases the portion of the shoot which immediately bears the sexual organs is more or less specialised as a receptacle, and in others special reproductive branches, gametophores, are differentiated, and may be either antheridiophores or archegoniophores. In the lower Hepaticæ the sexual organs are generally borne on the upper (dorsal) surface of the shoot, whilst

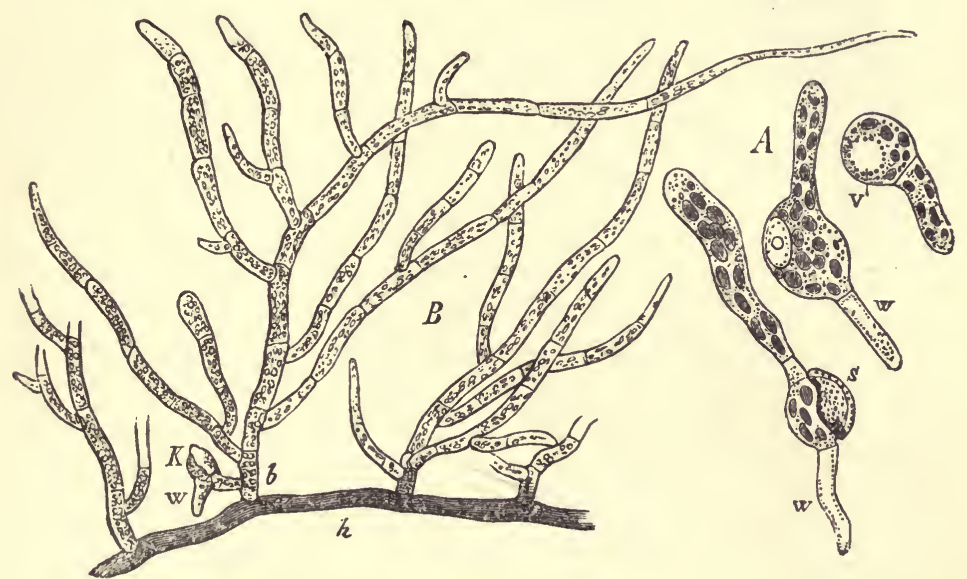

Frg. 232.-Funaria hygrometica (Moss). A Germinating spores: $v$ rhizoid; 8 exospore. $B$ Part of a protonema, about three weeks after the germination of the spore: $h$ a procumbent primary shoot with brown wall and oblique septa, out of which arise the ascending branches with limited growth: $K$ rudiment of a leaf-bearing axis with rhizoid (w). $(A \times 550: B$ about 90.$)$

in the higher Hepaticæ (Jungermanniaceæ acrogynæ) and in the Mosses they are borne at the apex.

The distribution of the sexual organs is various: the male and female organs may be borne on distinct shoots, when they are direcious; or on different branches of the same shoot, when they are monoecious but diclinous; or together in the same sorus, when they are monoclinous. In Mosses it appears to be the rule, in diœcious forms, that a protonema always bears both male and female shoots. 


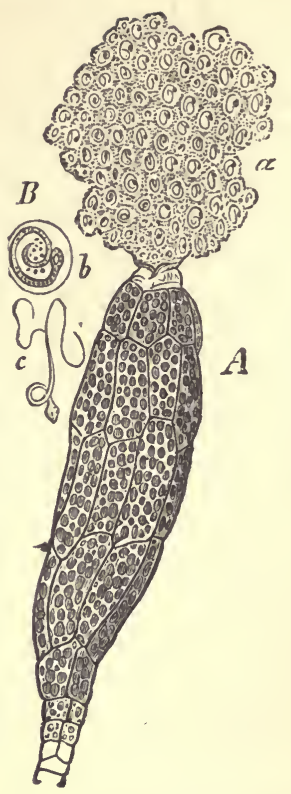

Fig. 233.-Funaria hygromet. rica (Moss). A An antheridium bursting : $a$ the spermatozoids ( $\times$ 350), $B$ Spermatozoicis $(\times 800) ; b$ in the mother-cell; c free spermatozoid of Poly. trichum.

The sexual organs are always multicellular. The antheridium (Figs. 233, 234 ) is a capsule of various shape, having a longer or shorter stalk; its wall consists of a single layer of cells which contain chloroplastids when young; internally it consists of very numerous small cells, each of which eventually gives rise to a single spermatozoid.

The spermatozoid is a cell, consisting of a naked filament of protoplasm, spirally twisted, thickened at the posterior end where lies the nucleus, tapering at the anterior end where it terminates in two long cilia by means of which it swims (see p. 116); the spermatozoids are set free by the rupture of the antheridial wall, which usually takes place at the apex of the antheridium.

The archegonium is flask-shaped and shortly stalked (Figs. 235, 236) ; it consists of a slightly dilated basal portion, the venter, and of a long slender neck. The axis of the archegonium, when young, is occupied by a central row of cells ; the basal cell of this row, lying in

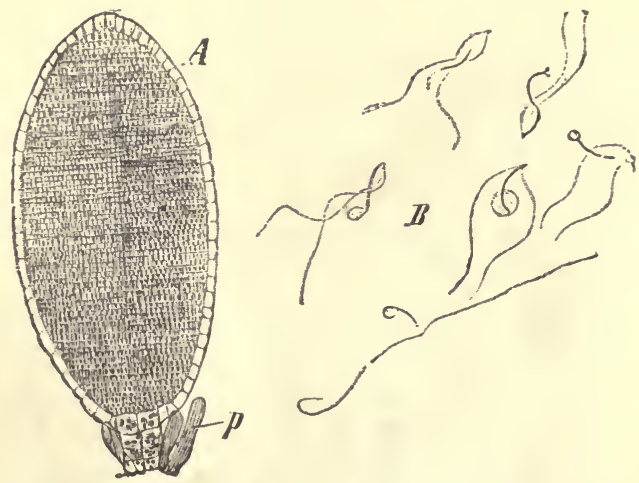

Fig. 234.-A Antheridium of Marchantia polymorpha (Liverwort) in optical longitudinal section: $p$ paraphsses $(\times 90)$. $B$ Spermatozoids $(\times 600)$ : (after Strasburger). the venter, is the central cell of the archegonium ; it grows considerably, and eventually divides into two unequal parts, an upper and smaller, the ventral canal-cell, and a lower and larger. which is the female reproductive cell or oosphere: the upper cells of the 
central row constitute the neck-canal-cells. At maturity the terminal cells, lid-cells, of the neck separate; the neck-canal-cells and the ventral canal-cell become mucilaginous and disorganised, so that the oosphere is placed in communication with the exterior by the canal of the neck. Fertilisation takes place when the plants are more or less covered with water from rain or dew. Then the antheridia dehisce, the spermatozoids are set free, and, since the male and female organs are at no great distance, they, swimming by means of their cilia, come into the neighbourhood of the archegonia; they are attracted to enter the necks of archegonia by the escaping mucilage formed by the disorganisation of the canalcells, which contains an organic acid which has been shown to be especially attractive to spermatozoids. One of the entering spermatozoids travels down the canal to the oosphere, which it penetrates, the nucleus of the
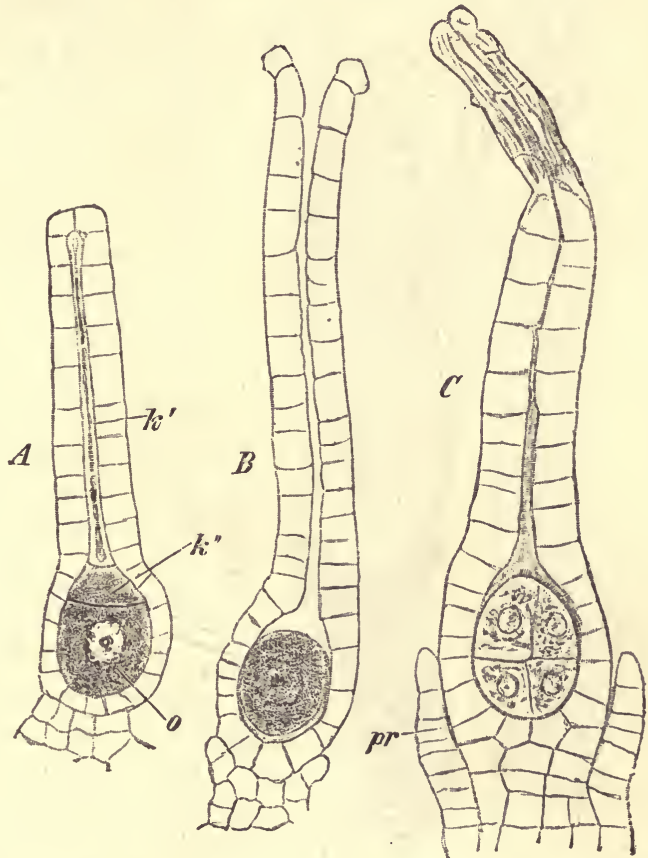

FrG. 235,-Marchantia polymorpha. A Young; B mature, but unfertilised, archegonium. $C$ Fertilised archegonium, with dividing oospore. $k^{\prime}$ Neck-canal-cells; $k^{\prime \prime}$ ventral canal-cell; o oosphere; $p r$ perigynium. ( $\times 540$ : after Strasburger.) ${ }^{b}$

spermatozoid fusing with that of the oosphere. Fertilisation is now complete; the fertilised oosphere surrounds itself with a cellwall and becomes the oospore, which begins to divide and to develope into the sporophyte.

The effect of fertilisation is not confined to the oosphere. The adjacent tissue of the shoot is stimulated to growth, and in some 
forms (Sphagnaceæ, Andreæaceæ) it grows out into a long leafless stalk, the pseudopodium, which carries up the fertilised archegonium on its apex. The venter of the archegonium also grows, forming, either by itself or together with the adjacent tissue of the shoot (as commonly in the Hepaticæ), an investment, termed the calyptra, which surrounds the developing embryo within and,

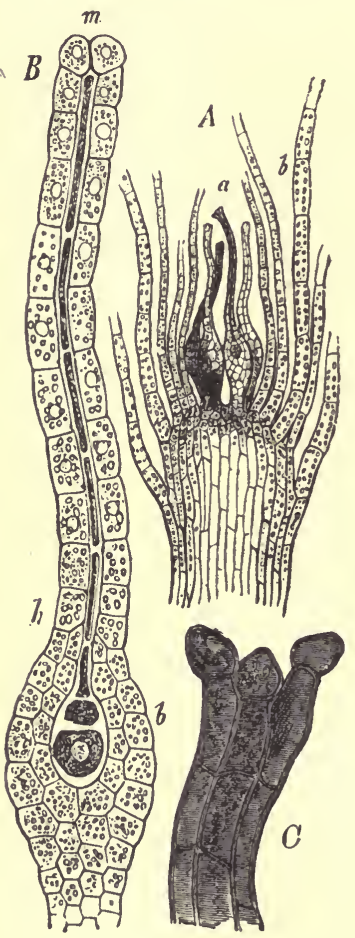

FIG. 236.-Funaria hygrometrica. A Longitudinal section of the summit of a weak female plant $(\times 100): a$ archegonia ; $b$ leaves. $B$ An archegonium $(\times 550)$ : $b$ ventral portion with the oosphere; $h$ neck; $m$ mouth still closed; the cells of the axile row are beginning to be converted into mucilage. $C$ The part near the mouth of the neck of a fertilised archegonium with dark red cell-walls. (After Sachs.) for a longer or shorter time, keeps pace with its growth.

The gametophyte, though it cannot produce gonidia, has a remarkable power, especially in the Musci, of reproducing itself vegetatively. This is effected frequently by the gemma, formed from various parts of the body: the leaves, for instance, in the foliose Hepaticæ; or in distinct receptacles termed cupules, as in the Marchantieæ and some Musci. The gemmæ are either unicellular or multicellular, and, in the latter case, may be either spherical or flattened in form. In the branched forms vegetative propagation is effected by the dying away of the main shoot or of the larger branches, the smaller branches becoming isolated and constituting independent plants. In the Musci almost any part is capable, under favourable conditions, of growing out into protonemal filaments on which new adult shoots are developed.

With regard to the histology of the adult shoot, it need only be pointed out that rudimentary vascular tissue, absent in the Hepaticæ, is to be found in the stems and the midribs of the leaves of many Musci; and, further, that the epidermis is not clearly differentiated as a tissue-system, and is 
destitute of stomata. It is true that in some Hepaticæ (e.g. Anthoceros, Marchantia, etc., Fig. 241) there are structures in the superficial layer which are erroneously called stomata; these are merely pores, and differ altogether in structure and development from the true stomata which are to be found on the sporophyte of Anthoceros and of most Musci, as well as on the sporophyte of the higher plants.

The SPorophyte, the asexual spore - producing form, is developed from the oospore within the venter of the archegonium (Fig. $237)$; its development is direct and holoblastic. The oospore divides first into two cells by a transverse wall, the basal wall, at right angles or obliquely to the long axis of the archegonium; the upper cell, the one next the neck, is termed the epibasal cell, the lower the hypobasal cell. This is followed in some Hepaticæ (Marchantiaceæ, Anthocerotacex) by the formation of two walls, at right angles to the basal wall and to each other, which are known as the quadrant and octant walls, since they respectively segment the oospore into quadrants and octants of a sphere. In other Hepaticæ, and generally in the Musci, the segmentation into oc-

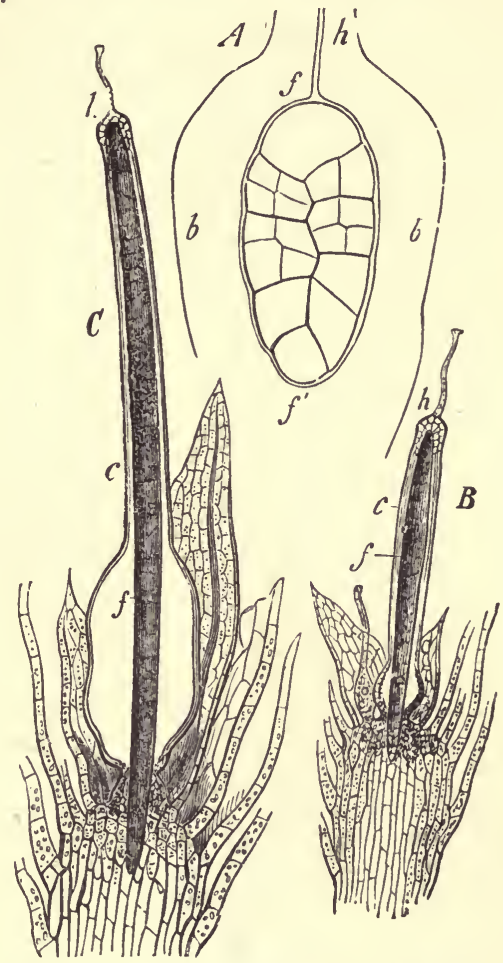

FIG. 237.-Funaria hygrometrica. A Development of the sporogonium $(f f)$ in the ventral portion $(b b)$ of the archegonium (longitudinal section $\times 500)$. $B C$ Different further stages of development of the sporogonium $(f)$ and of the calyptra (c); $h$ neck of the archegonium. (x about 40.)

tants is confined to the epibasal cell, the hypobasal cell either remaining undivided, or dividing irregularly. With the exception of some of the lower Hepaticæ (Riccieæ), where epibasal and hypobasal cells alike contribute to the formation of the capsule in which the spores are developed, the epibasal cells alone give rise 
to the capsule. The hypobasal cell gives rise to the foot, which is well-dereloped in the lower forms of both Hepaticæ and Musci, but is rudimentary in the higher. The foot, as stated on page 14, is essentially an embryonic organ; but it persists, acting, when sufficiently developed, as the organ of absorption and attachment, throughout the life of the Moss-sporophyte, because the sporophyte, since it does not become free and independent, does not altogether develope beyond the embryonic stage. In most forms the epibasal half of the oospore also gives rise to a longer or shorter stalk, the seta, by the elongation of which the capsule is raised up out of the calyptra. In those Hepaticæ which have a seta, its elongation, and the consequent rupture of the calyptra, takes place suddenly when the capsule is already mature and the spores fully
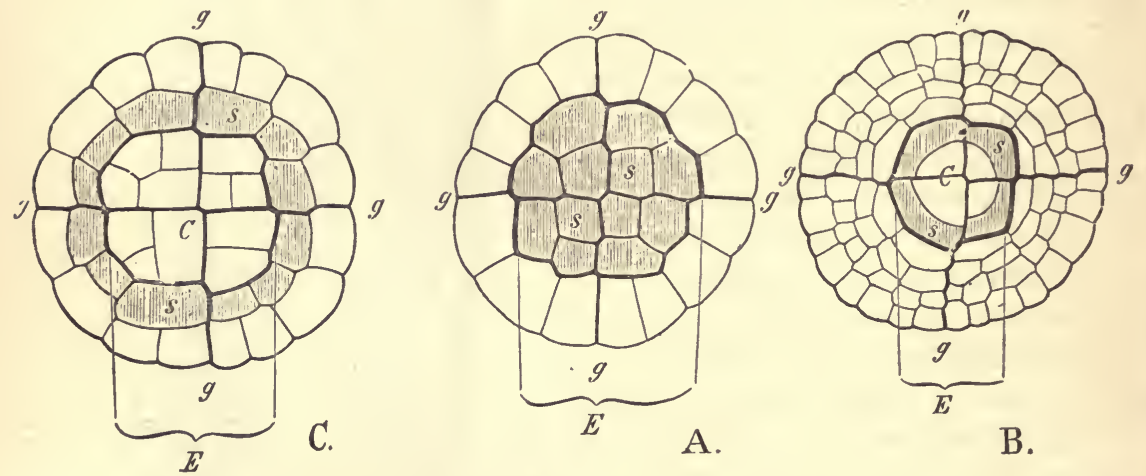

B.

F1G. 238.-Comparative morphology of the sporogonium in the Bryouhyta : diagrammatic transverse sections of the young capsule. A Sphærocarpus (typical Liverwort); $B$ Ceratodon (typical Moss); $C$ Anthoceros (aberrant Liverwort). $\boldsymbol{E}$ Endothecium: $\boldsymbol{g}-\boldsymbol{g}$ primary divisions (quadrant and octant walls); $s$ (shaded) archesporium; $C$ columella. ( $A$ and $C$ after Leitgeb; $B$ after Kienitz-Gerloff.)

developed; in the Musci its elongation is gradual, whilst the capsule is still rudinentary, and the rupture of the calyptra takes place relatively early. In the Hepaticæ and some Musci (Sphagnaceæ, Archidium, Phascum, Ephemerum) the whole of the ruptured calyptra remains as a sheath, the vaginula, round the base of the seta: but in the higher Musci (Andreæaceæ, most Bryineæ) the calyptra is ruptured transversely into an upper and a lower half; the latter constitutes the vaginula, whereas the former is carried up as a cap on the top of the capsule. In some forms, where the true hypobasal foot is rudimentary (some Jungermanniaceæ and Bryineæ) and is functionless, the base of the seta 
becomes dilated to form a false foot (epibasal) which performs the functions of attachment and absorption.

The tissue of the developing capsule becomes differentiated into an external layer (or layers) of cells, termed the amphithecium, which, in nearly all cases (except Anthocerotaceæ and Sphagnaceæ) forms only the wall of the capsule; and an internal solid mass of cells, the endothecium. The spores are developed from a mass or a layer of cells termed the archesporium. In the Hepaticæ the archesporium includes the whole of the endothecium (except in Anthocerotaceæ, Fig. $238 \mathrm{C}$ ), and the archesporial cells are either all sporogenous (Riccieæ) or, as is more frequently the case, some of them are sterile and generally become spirally thickened and elongated in form when they are termed elaters. In the Moss Archidium there is no defined archesporium, the sporogenous cells being scattered throughout the endothecium. In the Anthocerotaceæ and in the Musci (except Archidium) the archesporium is a layer of cells : it is generally the external layer of the endothecium, but in most of the Anthocerotaceæ and in the Sphagnaceæ it is the innermost layer of the amphithecium. In these forms where the archesporium is a layer of cells, the internal sterile tissue of the endothecium constitutes what is termed the columella. The archesporial cells are either themselves the mother-cells of the spores, or they undergo division to form these cells. Each mother-cell gives rise to four spores; the nucleus divides into two, and each of these divides again; the protoplasm aggregates round the four nuclei, constituting four cells which surround themselves with a proper wall and which are the spores. They do not usually all lie in one plane, but are placed tetrahedrally. The mature spore is a cell, consisting of a mass of protoplasm, with a nucleus, and containing chloroplastids, starch-grains and oil-drops; the wall consists of two layers of the usual structure (see p. 69). During the formation of the spores the mother-cells become isolated from each other, floating freely in a mucilaginous liquid in the interior of the capsule.

The escape of the spores from the capsule is effected in various ways. In some cascs the wall of the capsule simply decays (e.g. Riccieæ, Phascum), or it splits into valves (e g. Jungermanniaceæ), or the upper part is thrown off as a lid or operculum (e.g. some Marchantieæ, Sphagnaceæ, most Bryineæ).

On being set free, the spores germinate, when the conditions are favourable, giving rise to the protonema. The brittle exo- 
sporium being ruptured, the contents, covered by the endosporium, then generally grow out in the form of a filament, which is the beginning of the protonema. In some rare cases (e.g. Pellia, Andreæa) cell-divisions take place within the spore before the exosporium is ruptured, so that the protonema is from the first a mass or a layer of cells.

The body developed from the oospore, which constitutes the asexual generation or sporophyte of the Bryophyta, is termed the sporogonium. With regard to its general morphology it may be considered (except in Riccieæ) to present differentiation into root and shoot; the foot, however rudimentary, developed from the hypobasal half of the oospore, represents the root; the capsule and the seta (when present), developed from the epibasal half of the oospore, represent the shoot. The shoot is in no case differentiated into stem and leaf. In the Riccieæ the products of the hypobasal and epibasal cells are quite similar, so that the whole thalloid sporogonium consists only of a capsule. Hence, whilst it is the rule in the Bryophyta that sporogenous cells are only developed in the shoot-portion of the sporophyte, that is, are derived only from the epibasal cell, in the Riccieæ the derivatives of the hypobasal cells are also sporogenous.

The sporogonium is not an independent sporophyte, but remains attached to the gametophyte, obtaining from it either the whole or a portion of its food. It must, however, be clearly understood that there is no continuity of tissue between the two germinations; the sporophyte is simply inserted into the tissue of the gametophyte. In the Hepaticæ the sporophyte is short-lived (except in Anthoceros), and is entirely dependent upon the gametophyte for its nutrition. In Anthoceros, and in most of the Musci, the capsule possesses more or less well-developed assimilatory tissue, and its epidermis is provided with stomata, so that the sporophyte is capable of using the carbon dioxide of the air as its carbonaceous food, and is dependent upon the gametophyte only for its supply of water and salts. In many of these forms the seta has a central strand of rudimentary vascular tissue through which the water and salts, absorbed from the gametophyte, can travel to the region of the capsule where assimilation and transpiration are carried on. The Bryophyta (Muscineæ) are divided into two classes, the distinctive characters of which are as follows :-

Class III.-Hepatice (Liverworts).

Gametophytic Characters. Protonema, generally short-lived, inconspicuous, a flattened expansion. 
Adult shoot, generally dorsiventral; thalloid in many forms; has unicellular root-hairs; no trace of vascular tissue; leares (when present) destitute of a midrib.

Sporophytic Characters. The sporogonium remains within the calyptra until the spores are ripe; the ruptured calyptra remains as a vaginula, no portion of it being raised as a cap on the sporogonium; the elongation of the seta (when present) is sudden; the growth of the sporogonium is not effected by a two-sided apical cell.

The archesporium (except in the Anthocerotaceæ) is a mass of cells co-extensive with the endothecium; in all cases (except Riccieæ) some of the archesporial cells are sterile, being frequently developed into elaters; a columella is present only in the Anthocerotaceæ.

There is no trace of vascular tissue in the sporophyte, nor are there any stomata in its epidermis (except Anthocerotaceæ).

Class IV.-Muscr (Mosses).

Gametophytic Characters. Protonema frequently persistent, well-developed, generally filamentous. Adult shoot, radial or isobilateral; always differentiated into stem and leaf; no roothairs, but branched multicellular rhizoids; stem frequently with a central strand of rudimentary vascular tissue; leaves generally with a midrib.

Sporophytic Characters. The sporogonium escapes from the calyptra at an early stage ; a portion of the calyptra (with certain exceptions) is carried up as a cap on the sporogonium; the elongation of the seta is gradual; the growth of the sporogonium is (except Sphagnaceæ) effected by a two-sided apical cell.

The archesporium is not co-extensive with the endothecium, but is a layer of cells (except Archidium); the archesporial cells are all sporogenous, none being sterile or forming elaters; there is a well-developed columella in the capsule.

The seta frequently has a central strand of rudimentary vascular tissue; the epidermis of the capsule is generally provided with stomata.

\section{Class III.-Hepatic (Liverworts).}

A. The Gam вторнүте. The spore gives rise, on germination, to a small protonema which is sometimes filamentous, but more generally a flattened cellular expansion.

The Adult Shoot springs from the protonema. Its symmetry is dorsiventral, except in Haplomitrium and some species of Riella 
in which it is radial. It is generally thalloid, but is differentiated into stem and leaves in some forms (e.g. foliose Jungermanniaceæ). Its growth is effected by an apical growing-point in which there is either a group of initial cells (Marchantiaceæ, Anthocerotaceæ), or a single apical cell (Jungermanniaceæ). The branching is commonly dichotomons, taking place in the plane of expansion; but the development of branches from the ventral surface is constant in several genera.

The dorsiventral shoot bears numerous unicellular root-hairs (absent in Haplomitrium) on its ventral (lower) surface; when thalloid it also bears multicellular scales (ventral scales) on the same surface; when foliose, it bears on this surface a row of small rudimentary leaves, termed amphigastria, the fully developed foliage-leaves being borne in tiwo lateral rows, one on each flank of the shoot.

In the great majority of Hepaticæ, the sexual organs are borne on the dorsal (upper) surface, either scattered or in groups; and sometimes upon a specially modified portion of the shoot, termed the receptacle, either sessile or stalked; in the latter case the shoot (e.g. higher Marchantieæ) may be more or less clearly differentiated into a vegetative and a reproductive part (gametophore). It is only in some of the Jungermanniaceæ (Jungermanniaceæ acrogynæ) that the sexual organs are developed at the apex of the branches of the shoot, a feature in which they approach the Musci.

The protonema bears but a single adult shoot; and this, owing to the transitory nature of the protonema, soon becomes an independent plant. The plant is generally monœcious, but sometimes dioecious.

B. The Sporophyte is developed from the fertilised oosphere (oospore) in the archegonium (see p. 329). It is a sporogonium, which may consist merely of a capsule (Riccieæ); or it may be differentiated into a capsule and a foot (e.g. Anthoceros); or into a capsule, a longer or shorter seta, and a foot (e.g. Marchantiaceæ); or into a capsule, a seta, and a rudimentary (hypobasal) foot (some Jungermanniaceæ), a false foot (epibasal) being in some cases developed from the lower part of the seta. It never grows by means of a two-sided apical cell as it does in the Mosses.

The internal differentiation of the capsule presents the following varieties:-It is in all cases differentiated into amphithecium and endothecium ; in all, except most Anthocerotaceæ, the archesporium is co-extensive with the endothecium; in the Antho- 
cerotaceæ, the whole or part of the endothecium constitutes a columellix, a feature in which the Anthocerotaceæ resemble the Mnsci.

In the Riccieæ (except Oxymitra) the whole archesporium is sporogenous, whereas in all other forms some of the archesporial cells are sterile, and in many they are developed into elaters, elongated cells with spirally thickened walls, generally becoming free from each other.

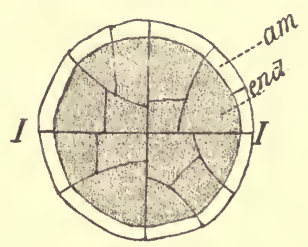

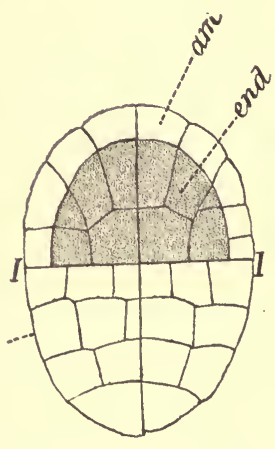

$B$

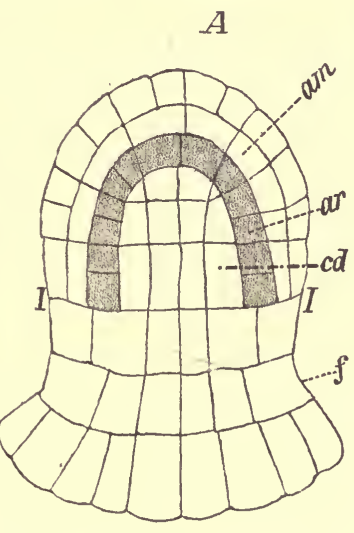

$C$

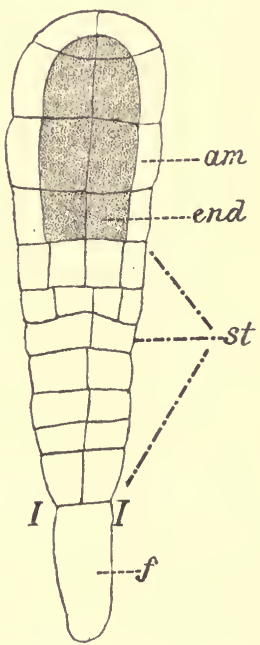

$D$

FIG. 239.-Comparative morphology of the sporogonium in the Hepaticæ: diagrammatic longitudinal sections. A Riccia; $B$ Marchantia; $C$ Anthoceros; $D$ Ralula. $I-I$ basal wall; $f$ foot; st seta; am amphithecium; end endothecium; ar archesporium (shaded); col columella. (After Gobel.)

The sporogonium remains enclosed in the calyptra until the spores are mature when, if a seta be present, it suddenly elongates and ruptures the calyptra, which persists as a vaginula at its base. The capsule opens either by the decay of its wall, or more generally by the splitting of the wall from the apex downwards into valves; in some Marchantieæ a lid, the operculum, is formed and the capsule is opened by the throwing off of the lid. 
The Hepaticæ are classified as follows:-

Order I. Marchantiaceæ. Order II. Jungermanniaceæ. Order III. Anthocerotaceæ.

Order I. Marchantiaceæ.

A. The Gametophyte. The spore gives rise on germination to a short unbranched filamentous protonema which developes at its apex into a flattened cellular expansion, from the margin of which the adult shoot (commonly known as the plant) springs as a lateral branch.

The Morphology of the Adult Shoot. The adult shoot is undifferentiated into stem and leaf. Its symmetry is dorsiventral; on the lower (ventral) surface it bears numerous root-hairs, and also scales which are arranged in one or two rows, or irregularly (Ricciocarpus natans, Clevea, Sauteria, Corsinia), but are absent in Riccia crystallina; on the upper (dorsal) surface the reproductive organs are borne. In the Riccieæ the shoot presents a dorsal furrow, and in the Marchantieæ a midrib.

Growth is effected by an apical growing-point, situated in a depression, possessing a transverse row of initial cells from which segments are cut off dorsally and ventrally; the initial cells also undergo longitudinal division, and thus increase in number.

The normal mode of branching is that which takes place in the plane of expansion; it is dichotomous, and is effected in the manner described on p. 184.

Less commonly, branches are formed as outgrowths from the ventral aspect of the growing-point, as in certain Marchantieæ (e.g. Targionia, Fimbriaria, Plagiochasma, Clevea, Preissia). This depends upon the fact that, in these forms, the growth of the fertile normal branches is arrested by the formation of reproductive organs: hence the further development of the shoot can only be effected by ventral branching. Adventitious ventral branches are common in the Riccieæ.

The sexual organs are in all cases developed on the dorsal surface, each antheridium or archegonium arising from a single superficial cell. In the simpler forms they are arranged in a continuous median row, developed in acropetal succession (e.g. sexual organs of Riccia, antheridia of Boschia, Clevea hyalina, sometimes Sauteria alpina), or in a series of groups (e.g. Ricciocarpus notans, Oxymitra, Corsinia, archegonia of Boschia, antheridia of most of the lower Marchantieæ); in the higher forms they are borne on a special structure termed a receptacle.

The receptacle. The primitive form of the female receptacle is to be found in Corsinia (var. involucrata). Here each group of archegonia is sunk in a pit on the dorsal surface; from the bottom of the pit there grows up among the archegonia a protuberance, which produces a membranous umbrella-like covering (perichatium) for them; this protuberance represents the receptacle. In some of the lower Marchantieæ (e.g. Plagiochasma, Clevea) the receptacle is developed in much the same way, but the archegonia are borne upon it; the receptacle becomes raised on a short stalk and, by the unequal growth of its surface, the archegonia (usually three to four in number) become displaced to the under side. In these cases the receptacle is simply an excrescence of the dorsal surface.

In the higher Marchantieæ the adult shoot is frequently differentiated into a 
vegetative and a reproductive portion, the gametophore: the gametophore is a branch (or a branch-system) bearing a terminal receptacle, in which either the male (antheridiophore) or the female (archegoniophore) organs are developed.

In the simpler forms (e.g. Sauteria, Fimbriaria, Duvalia, Grimaldia, Reboulia) the archegoniophore is simple, that is unbranched; the stalk presents a single furrow which represents the ventral surface of the shoot. In Lunularia the stalk is simple, but the receptacle itself is branched, presenting four groups of archegonia, each group corresponding to one of the coherent branches of which the receptacle consists; hence the archegoniophore is compound. In Marchantia, Preissia, and Dumortiera, the stalk has two ventral furrows, showing that it consists of the two coherent branches of the first dichotomy. The receptacle itself is repeatedly branched: thus in Preissia there are four groups of archegonia, corresponding to four branches; in Marchantia and Dumortiera there are eight. The receptacle is more or less distinctly lobed,
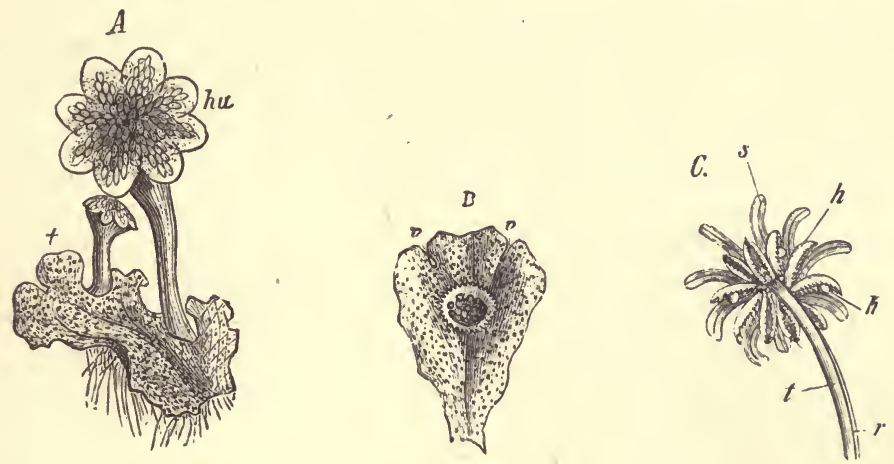

Frg. 210.-A Portion of a plant of Marchantia polymorpha ( $t$ ), with antheridiophores. $B$ Portion of a plant with a cupule containing gemmæ; $v v$ apices of the two branches. (After Sachs.) C An archegoniophore with a doubly furrowed $(r)$ stalk $t$, bearing a terminal branched receptacle of which $s$ is one of the rays; $h$ perichætium; $k$ sporogonia.

thus showing its compound nature; each group of arcbegonia is situated between the bases of two adjacent lobes. The complete elongation of the stalk does not take place until the archegonia are fully developed, or even until one of them has been fertilised.

It is only in a few of the higher Marchantiex that there is a highly developed antheridiophore. In the lowest forms the antheridia are developed in dorsal groups, the formation of which does not arrest the further apical growth of the branch; in Grimaldia and Reboulia, the formation of the groups of antheridia causes temporary arrest of apical growth; in Lunularia and Duvalia the formation of a group of antheridia permanently arrests the apical growth of the branch, the group being therefore terminal. In Fegatella, Preissia, Marchantia, and Dumortiera, a definite terminal receptacle is formed; it is discoid in form, and (except Fegatella) it is elevated on a special antheridiophore; it is compound, having several growing-points, each of which gives 
rise to antheridia in acropetal succession, and then ceases to grow; the stalk has two ventral furrows, showing that it consists of two coherent branches.

In all cases the antheridia, and in many the archegonia, become overgrown by the surrounding tissue, so that they lie in depressions formed in essentially the same manner as the air-chambers described below; a narrow canal leads down to each antheridium; but the necks of the archegonia are long enough to reach to the surface. The growth of this tissue is especially active around the archegonia, so that a membranous investment is formed enclosing either a single archegonium, when the archegonia are developed singly, or a group of archegonia, when they are developed several together, which is termed the involucre. This consists essentially of two parts; a basal portion, consisting of an extension of the air-chamber-layer of the shoot, and of a more delicate marginal portion (perichætium), formed by the outgrowth of the superficial cells of the basal portion, variously lobed and laciniate. In some cases (e.g. Corsinia) the development of the perichrtium only takes place after fertilisation.

In the Marchantieæ, the receptacles are surrounded at their first formation by involucral scales of various form, leafy or hair-like, which are excrescences of the adjacent tissue. When the receptacle subsequently becomes raised on a stalk, the involucral scales generally remain as a sheath round the base of the stalk; but some may be carried up with the stalk in its growth, as is especially the case in Lunularia.

In Marchantia, Preissia, and Fimbriaria, the venter of each archegonium becomes surrounded by a sac-like membrane, developed from the stalk-cell of the archegonium, which is termed the perigynium (Fig. 235). The development of the perigynium begins when the archegonium is nearly mature.

The distribution of the sexual organs is various : the plants may be monœcious (some species of Riccia, also Corsinia, Plagiochasma, Sauteria, Peltolepis, Grimaldia, Reboulia, most species of Fimbriaria, Duvallia, Targionia, Cyathodium), or diøcious (some species of Riccia, Ricciocarpus natans, Oxymitra, Boschia, Clevea, Fegatella, Lunularia, Preissia generally, Marchantia, Dumortiera). In the monœcious species of Riccia (except $R$. fluitans, where they alternate regularly in a single row), the antheridia and archegonia are intermingled; but in all other monœcious forms they are developed either in separate sori, or on distinct branches (diclinous); in Preissia both antheridia and archegonia have been found to occur exceptionally on the same (androgynous) receptacle (monoclinous). The antheridia are borne, in Sauteria, Targionia, and Cyathodium, on the ventral branches exclusively; it is probable that this is also the case in the apparently diceious forms of Fimbriaria.

The Structure of the Adult Shoot. The dorsal portion of the shoot consists, in all the Marchantiaceæ, of parenchymatous tissue, made up of cells containing chloroplastids, which includes a number of air-chambers, giving it an areolated appearance, whence it is termed the air-chamber-layer. The chambers are formed by the unequal growth of the cells near the growing-point, in consequence of which the surface presents alternating elevations and depressions. In most species of Riccia the air-chambers are narrow canals, elongated perpendicularly to the surface; in $R$. crystallina they are much widened, and open to the surface by the whole extent; in R. fluitans (Ricciella canaliculata) the 
wide air-chambers become roofed over by the growth of the superficial cells of the intervening dissepiments, and in the aquatic form became completed closed, but in the terrestrial form they communicate with the exterior by meaus of a simple pore surrounded by four guard-cells. In R. glauca and its allies, the air-chambers become completely elosed in, but the superticial layer eventually breaks down. Ricciocarpus natans, Oxymitra, Corsinia, and many Marchantieæ (e.g. Sauteria, Clevea, Targionia) have a similar structure to that of the terrestrial form of $R$. fluitans, but the pore is surrounded by a larger number of guard-cells, in several rows, but all lying in the same'plane; in Sauteria, Clevea, and Peltolepis, the guard-cells have their radial walls peculiarly thickened, giving a star-like appearance to the pore. In Preissia and Marchantia the structure and development of the pores is different; here the primary airchambers become completely closed in; at the central meeting-point the growth of the superficial cells continues, but vertically instead of horizontally, leading to the formation of vertical rows of cells which subsequently separate, leaving
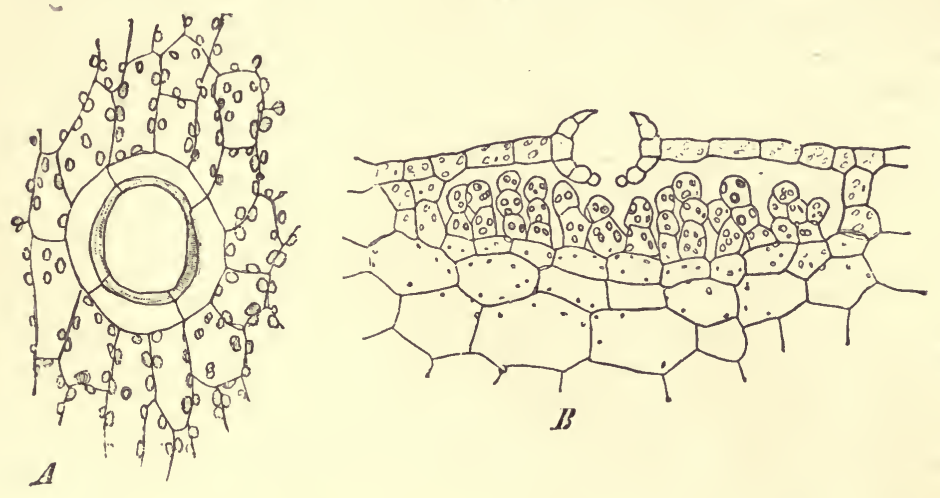

Fı. 211.-Marchantia polymorpha. A A pore seen in surface view. B Section of a portion of the dorsal region of the thallus, showing the air-chamber containing assimllatory tissue, and the compound pore. ( $\times 240$ : after Strasburger.)

a canal between them. This structure is distinguished as a compound pore. Compound pores of this sort are found in the receptacles of other Marchantieæ, the vegetative parts of which have simple pores.

In many forms, the cells containing chloroplastids (assimilatory tissue) are simply those which form the walls of the air-chambers ; in Corsinia and Sauteria these cells project somewhat into the cavity of the air-chamber, whilst in others (e.g. Boschia, Marchantia, Preissia, Lunularia, Fegatella, Targionia) the cells forming the floor of the air-chamber, or the sides, or even the roof, grow out into branched or unbranched filaments which fill most the air-cuvity, thus largely increasing the assimilatory tissue.

Beneath the air-chamber-layer is a compact tissue, consisting of several layers of cells elongated in the direction of the long axis of the branch, which is without intercellular spaces, and contains but few chloroplastids. In the 
Marchantieæ the walls of these cells are generally thickened and pitted; some of the cells contain mucilage, and in Fegatella the mucilage-cells form continuous rows; other cells contain a dark-coloured oil-drop, though such cells also occur in the air-chamber-layer; in Preissia brown-coloured sclerotic fibrous cells occur, arranged in longitudinal strands.

The ventral surface is formed by a layer of cells which, in the simpler forms, is not specially differentiated, but in some the cells of this layer are remarkable for their small size ; in Marchantia and Preissia there are several layers of these small cells, forming a sort of ventral cortex.

The ventral scales consist of a single layer of cells, the walls of which generally assume a violet colour; each scale is developed from a single superficial cell, or, as generally in the Riccieæ, from a transverse row of cells. In Marchantia polymorpha, in addition to the scales which arise from the midrib, there are others which spring from the surface of the lamina.

Unicellular root-hairs are produced in all Marchantiaceæ; the commonest form has thin walls; in the Marchantieæ a second form occurs, in which peglike thickenings of the wall project into the cavity of the cell : the simple roothairs are developed mainly on the midrib, the thickened hairs mainly on the lamina.

Gemme are produced in Lunularia and Marchantia in special receptac'es, termed cupules, borne on the dorsal surface of the shoot; in Lunularia the cupule is crescent-shaped, in Marchantia it is circular (Fig. $240 \mathrm{~B}$ ). The cupule is formed by an outgrowth of the air-chamber layer, and in Marchantia its margin is prolonged into laciniæ. The gemmæ spring from single cells of the floor of the cupule, which elongate upwards and divide transversely into a stalk-cell and a terminal cell, which, by repeated growth and division, forms a flattened plate of tissue, several layers of cells thick at the middle, thinning out to a single layer at the margin, with a growing point in a depression on each lateral margin. The symmetry of the gemmæ is isobilateral; but when they fall on to the soil and begin to grow, the undermost surface becomes the ventral, and the uppermost the dorsal. Some of the superficial cells have no chloroplastids; those of the surface next the soil grow out into root-hairs.

B. The Sporophyte. The degree of morphological and histological differentiation of the sporophyte presents wide divergences in the different groups. The oospore undergoes division by a wall, generally inclined at an acute angle to the long axis of the archegonium, the basial wall, into two halves, the epibasal and the hypobasal; each of these is then divided into bwo by a wall at right angles to the basal wall, and each of these again by a wall at right angles to the two preceding walls; thus the embryo comes to consist of eight cells (octants).

In the Riccieæ, the whole embryo simply forms a spherical capsule: in the Marchantieæ, the capsule is developed entirely from the epibasal cells, whilst the hypobasal cells give rise to a bulbous foot, which attaches the embryo to the parent. and to a short stalk which bears the capsule, and is formed at a relatively late stage by intercalary growth. In the Corsinieæ the embryo is differentiated into capsule and foot, but it is uncertain whether or not the limit between these two organs is marked, as it is in the Marchantieæ, by the basal wall (see Fig. 239). 
The differentiation of the tissue of the capsule into amphithecium and endothecium is well-marked, except in the Riccieæ. The archesporium is coextensive with the endothecium.

In the Riccieæ the whole of the archesporial cells are sporogenous (except perhaps Oxymitra); in Corsinia, some of the archesporial cells are sterile, but these undergo no special differentiation; in Boschia and in the Marchantiex the sterile cells assume an elongated form, and their walls undergo spiral or annular thickening: these specially modified sterile cells are the elaters, and, being very hygroscopic, they assist in the scattering of the spores. Each sporogenous cell gives rise to four spores.

The wall of the capsule, which consists generally of a single layer of cells, is but slightly developed in the Riccieæ, and becomes entirely disorganised during the development of the spores. In Corsinia the wall is not highly developed, but it persists till the spores are ripe, when it ruptures irregularly ; in Boschia it is more highly developed, the cells presenting half-ring thickenings on their lateral and internal walls. In the Marchantiex the cells of the walls are generally thickened; the thickenings may be fibrous, in which case the capsule opens by the splitting of the wall longitudinally into a number of teeth, though in Targionia the splitting is irregular; or the thickenings (sometimes absent) are confined to the walls at right ungles to the surface, in which case the capsule opens by the separation of its upper third as a lid or operculum, as in the Operculatæ.

The spores are generally tetrahedral, with two coats, the outer of which (exosporium) is tuberculate or reticulate on the surface. On germination the exosporium of the tetrahedral spore ruptures at the point of junction of the three projecting angles. The spores of Lunularia and Marchantia are small and spherical; the exosporium is feebly developed, and presents a granular thickening. In consequence of the thinness of the exosporium, the whole spore is enabled to enlarge cousiderably on gerinination, and it does not rupture at any special point. In Fegatella, cell-divisions take place in the spores before they are scattered.

The venter of the archegonium keeps pace with the growth of the developing embryo, forming the calyptra, and encloses it until the spores are ripe. In the Riccieæ the spores are set free by the gradual disorganisation of the calyptra and of the tissue of the thallus in which the calyptra is imbedded; in the other Marchantiaceæ the capsule is forced out of the calyptra by the elongation of the short stalk.

The Marchantiaceæ are classified as follows :-

Fam. 1. Ricciea. The gametophyte is characterised by the simple structure of the adult shoot; the air-chamber has a simple pore in only a few forms [Riccia (Ricciella) canaliculata, Ricciocarpus, Oxymitra]; the assimilatory tissue is confined to the walls of the air-chamber. The sexual organs are not borne on a receptacle, but are developed in a row, or in groups, in the dorsal furrow, and become overgrown by the tissue of the thallus. The sporophyte is characterised by the absence of differentiation of a foot or seta, consisting, as it does, simply of a capsule; all the archesporial cells give rise to spores (except the few sterile cells in Oxymitra), and the wall of the capsule becomes disorganised during the ripening of the spores. 
The genera are: Riccia, of which there are many species arranged in the two sections Euriccia and Ricciella; Ricciocarpus, represented only by the species $R$. natans; Oxymitra (Tesselina).

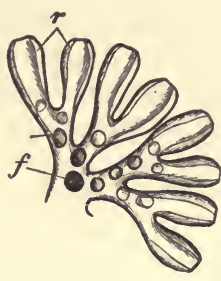

FIG. 242.-Dorsal surface of portion of thallus of Riccia glauca (nat. size): $r$ the dorsal furrows of the lobes; $f$ sporogonia develop. ing in the receptacles.

Fam. 2. Corsiniea. The gametophyte resembles, on the whole, that of the lower Marchantier in it * general structure; it has a midrib which projects on the under surface; it is characterised by the arrangement of the archegonia, which are borne in dorsal groups, not on a receptacle (indicated in Corsinia), but in pits, the surface of which produces a dense growth of hairs. The sporophyte is differentiated into foot and capsule; the wall of the capsule persists until the spores are ripe; some of the archesporial cells are sterile and, in Boschia, become elaters.

The family includes the two genera Corsinia and Boschia (Funicularia): each genus has but a single species; Corsinia marchantioides is European; B. Wedtellii is found in Brazil.

Fam. 3. Marchantiec. The gametophyte has a well-developed air-chamber layer on the dorsal surface; the air-chambers have each a well-marked pore, which is either-simple or compound ; in the higher forms the air-chambers are filled with filaments of assimilating cells: on the ventral surface are two rows of scales and two kinds of root-hairs. The archegonia are borne in groups on a receptacle which is either dorsal, as in the lower forms, or termiual on a gametophore, as in the higher. The sporophyte is differentiated into foot, seta, and capsule; some of the archesporial cells are sterile, and become elaters.

The following sections of Marchantieæ may be distinguished :-

a. Astropora : characterised by the thickening of the radial walls of the cells surrounding the simple pores of the air-chambers, in which there is no development of filamentous assimilatory tissue. There is no antheridial receptacle in Sauteria and Clevea, where the antheridia are borne in a row on the surface of a veutral antheridiophore, but it is well-developed and dorsal in Peltolepis; there is a terminal archegoniophore in Sauteria, aith usually a single ventral furrow, and in Peltolepis, with two ventral furrows; but in Clevea there is no archegoniophore, but a dorsal stalked unfurrowed receptacle.

Genera: Sauteria, Peltolepis, Clevea.

b. Operculata: characterised by the mode of dehiscence of the capsule, the upper third of the wall being thrown off as an operculum: the family includes the genera Plagiochasma (Aytonia), Reboulia, Duvalia (Neesiella), Grimaldia, Fimbriaria (Hypenantron). The pores are simple, and the air-chambers usually do not contain filamentous assimilatory tissue. The archegonial receptacle is dorsal and stalked in Plagiochasma and Grimaldia; in the other genera it is borne on an archegoniophore with a single ventral furrow. The antheridial receptacles are sessile; in Duvalia they are terminal.

c. Targionia, iucluding Targionia and Cyathodium. The archegonia are developed in a sessile group at the apex of a branch; if one of the archegonia is fertilised, the further growth of the branch is arrested, but if not, growth is resumed, and the group of archegonia becomes dorsal; the antheridia are borne 
in terminal groups on short ventral branches. A single sporogonium is dedeveloped in each group of archegonia, and becomes enclosed in a perichætium; it dehisces by teeth, but in Cyathodium a small operculum is also formed. The pores of the air-chamber layer are simple; a formation of filamentous assimilatory tissue in the air-chambers occurs in Targionia.

d. Composite, including Fegatella (Conocephalus), Lunularia, Dumortiera. Preissia (Chomiocarpon), and Marchantia; characterised generally by the compound (branched) nature of the gametophore: however, the archegoniophore is unbranched in Fegatella, and in Fegatella and Lunularia there is no antheridio. phore, the male receptacles being sessile on the dorsal surface of the thallus. The air-chambers contain filamentous assimilatory tissue; the pores are compound in Preissia and Marchantia; the air-chamber layer is degenerate in Dumortiera.

Order II. Jungermanniaceæ.

A. The Gametophyte. On germination the spore gives rise to a protonema which may be a solid ellipsoidal mass of cells (as in Pellia) with a root-hair at one end ; or a flattened plate of cells (Radula, Frullania); or a filament, sometimes branched (Lophocolea, Chiloscyphus); however, the differences in form of the protonema are not of great morphological importance since, in many cases, flattened and filamentous forms have been found to be produced from spores of the same plant.

The protonema gives rise to the adult shoot by the formation, either from a marginal cell, if it is flat, or from the terminal cell, if it is filamentous, of a growing-point with a single apical cell.

The Morphology of the Adult Shoot. The adult shoot may be differentiated into stem and leaf, as in the foliose forms; or undifferentiated, as in the thalloid forms. Its symmetry is generally dorsiventral; the only radially symmetrical, erect-growing forms being Haplomitrium and some species of Riella (e.g. R. helicophylla and Parisii).

The morphology of Riella demands special notice. It is a foliose form, and is peculiar in that the stem bears, on one side, a membranous wing which is more or less well-developed in the different species. Riella Notarisii and Reuteri are prostrate dorsiventral forms, and in them the wing is on the dorsal surface of the stem: R. helicophylla and Parisii are radial and erect; in the latter both the stem and the wing are vertical; in the former the wing is spirally wound round the erect axis.

Most of the thalloid forms (except Pellia, Aneura, Sphærocarpus) have a distinct midrib. The shoot bears numerous unicellular root-hairs, as also club-shaped glandular hairs which secrete mucilage, on its ventral (under) surface.

In the dorsiventral foliose forms, the stem bears a row of leares on each flank, and generally a row of amphigastria on its ventral surface; amphigastria, are, however, absent or rudimentary in some forms (e.g. Fossombronia, Androcryphia, Petalophyllum, Radula, Lejeunia calcarea, Jungermannia bicuspidata, Scapania, species of Riella, etc.), but are represented (except Radula and Lejeunia calcarea) by papillæ bearing glandular hairs. In Blasia there are two rows of amphigastria as well as ventral scales. The ventral surface of the shoot also generally bears root-hairs, springing from the superficial cells of the stem, but 
occasionally from the amphigastria (e.g. Lejeunia, Frullania, Mastigobryum, Lepidozia, Lophocolea, etc.): they are absent in Trichocolea; and in Radula they are developed on the convex surface of the lower lobes of the lateral leaves.

In the radial foliose forms, the leaves are borne in three rows in Haplomitrium, and in two rows in the radial species of Riella (helicophyll $x$ and Parisii); here there is no distinction of amphigastria. Root-hairs are absent in Haplomitrium, their functions being discharged by root-like branches: in the above species of Riella the root-hairs are borne on the swollen basal end of the stem.

Papillæ bearing glandular hairs, secreting mucilage to moisten the growingpoint, are very generally developed; they are transitory, and are therefore only to be found near the growing-point. In the dorsiventral forms they are developed mainly on the rentral surface, either as appendages of the amphigas.

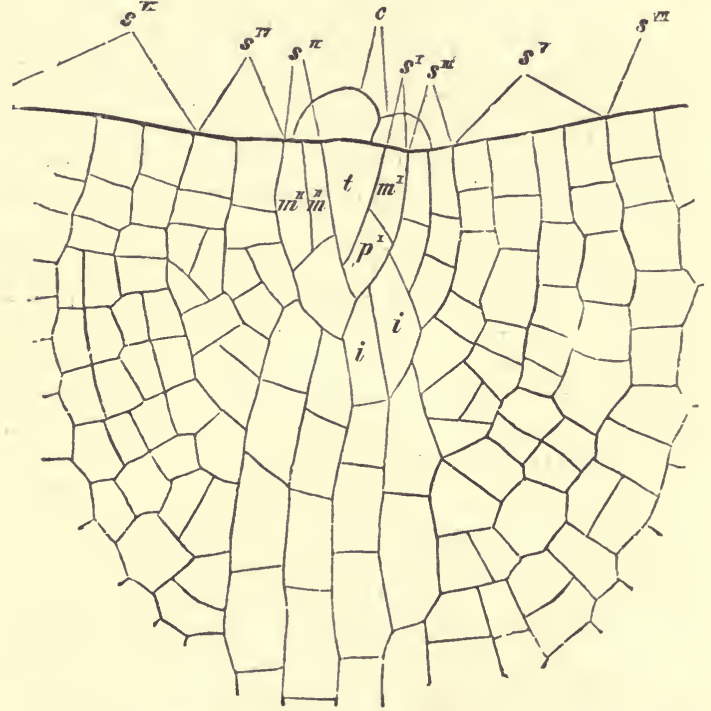

Fig. 243.-Growing-point of thallus of Metzgeria furcata. $t$ Apical cell ; $s^{\prime}$ etc., successive segments; $m^{\prime} m^{\prime \prime}$ marginal cells ; $p^{\prime}$ superficial cell; $i$ i cells of the midrib; c clavate hairs. ( $\times 510$ : after Strasburger.) tria or (as mentioned above) as representing them in those forms in which the amphigastria are wanting or rudimentary. In the foliose forms similar papillæ are also developed as appendages of the young lateral leaves; notably in the radially sym. metrical genus Haplomitrium.

The growth of the shoot is effreted by an apical growingpoint which possesses (except perhaps in Blasia and Pellia, in which there appears to be a group of initial cells) a single apical cell. The apical cell of the thalloid forms is most commonly two-sided (Fig. 243); the base is directed outwards, the apex inwards, and from the two sides segments are cut off alternately right and left. The apical cell of the foliose forms, with the exception of Fossombronia and Riella which have a two-sided apical cell, is a three-sided pyramid; its base is directed outwards, its apex inwards, one side is ventral and the other two are dorso-lateral; this latter statement does not, of course, apply to Haplomitrium. In Blasia and Pellia cell-division in the growingpoint appears to take place much as in the Marchantiaceæ. 
The normal mode of branching in the dorsiventral forms is that which takes place at the growing-point in the plane of expansion. In the thalloid forms, as also in the foliose Fossombronia and Blasia, it may be described as dichotomous (see p. 184) although the apical cell does not undergo division so as to form the apical cells of two branches; the apical cell of the parent shoot persists, and that of the branch is developed from an adjacent segment, either before or after further division. When the two shoots develope with equal vigour, the resulting branch-system resembles a dichotomy; but when the parent shoot grows the more vigorously throughout, the branches are lateral upon it and the branch-system is a monopodium (see p. 34). In the foliose forms the mode of normal branching is generally monopodial. The apical cell of a lateral branch is developed from the lower (ventral) half of a dorsolateral segment cut off from the apical cell; either from the whole of the seg. ment, or from the posterior (basiseopic) portion of it.

In the radial Haplomitrium, the branching is monopodial and the branches are borne on all sides of the stem, either in the leafy region or on the subterranean parts. They are not developed from the apical growing-point, and are probably all adventitious.

A development of branches on the ventral surface is not uncommon either in the thalloid (e.q. Metzgeria, Symphogyna, Umbraculum on the midrib) or in the foliose forms (e.g. Mastigobryum, Lepidozia, Calypogeia, Jungermannia [Cephalozia] bicuspidata, Lophncolea bidentata). Since the origin of these branches can in some cases be distinctly traced (e.g. Mastigobryum, Symphogyna) to the apical growing point, and since they are generally developed in acropetal succession and in definite positions (in the axils of the amphigastria of the foliose forms), they are regarded as normal and not as adventitious. The branch-rudiment does not, however, always immediately develope, but may be quiescent for a longer or shorter time. Their origin is frequently endogenous. These ventral branches are generally more or less moditied sexual branches (gametophores); but in Mastigobryum sterile branches occur which are long and delicate, with rudimentary leaves, and are known as fagella. Similar flagella occur in other foliose genera, such as Lepidozia and Calypogeia ; they are not, however, ventral branches, but modified lateral branches.

Adventitious branches are often formed on the older parts of the shoot; in Metzgeria, from marginal cells of the lamina; in Pellia and Sphærocarpus, from single cells of all parts of the dorsal, and sometimes also of the ventral surface; in Jungermannia bicuspidata and Blasia, fro'n cells of the ventral surface of the stem: in Lophocnlea bidentata, from the marginal cells of the leaves. Their origin is generally exogenous, but sometimes endogencus.

In many cases (e.g. Blasia, Sphærocarpus, Lophocolea bidentuta, Jungermannia bicuspidata) the adventitious branches become separated from the parent plant, and develope into new individuals, thus subserving vegetative propagation.

Closely connected with the adventitious branching is the formation of gemme. In Aueura, certain cells of the margin and of the dorsal surface of the shoot each become divided into two, and the two cells thus formed are set free as a bicellular gemma, with probably a proper wall of its own, by the rupture of the enclosing wall. In Blasia, the gemmæ, which are solid multicellular nearly 
spherical bodies, are developed in special receptacles (cupules) situated on the dorsal surface of the apex of the shoots; their mode of origin resembles that of the gemmæ of Marchantia. In most foliose forms the gemmæ are developed from marginal cells of the leaves (e.g. Jungermannia ventricosa, Scapania nemorosa), or from cells near the growing.point of the stem (e.g. Jungermannia bicuspidata). In these forms the gemmæ are usually uni- or bi-cellular, but in Radula complanata (where they are formed on the leaf-margin) they are flat multicellular plates of tissue.

The leaves are developed, generally speaking, one from each segment formed at the growing-point. In the typical Acrogynæ each dorso-lateral segment gives rise to a lateral leaf, and each ventral segment to a ventral leaf (amphigastrium); though, as already mentioned, the amphigastria are wanting in many species. A characteristic feature of the leaves of this group is that they are

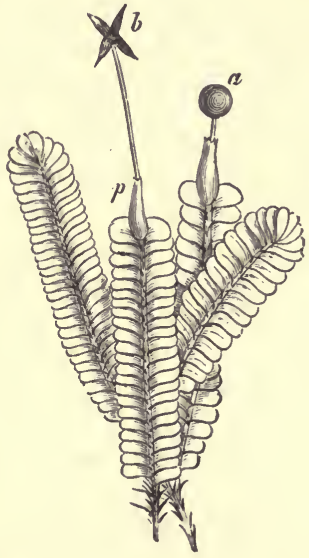

FIG. 244.-Branches of one of the acrogynous Jungermannieæ, Plagiochila asplenioides, seen from above: the leaves are succubous; at the apex, two of the shoots bear sporogonia, the one (b) having dehisced, the other $(a)$ being still closed; $p$ the involucre.

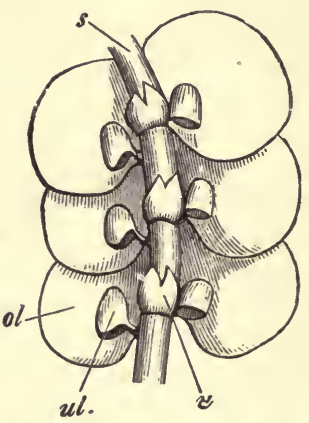

FIg. 245.-Part of a shoot of Frullania dilatata seen from below ( $\times 20)$ : $u l$ auriculate lower leaf-lobes ; ol upper leaf-lobe; the leaves are incubous; $u$ amphigastrium.

distinctly bilobed, at least when young ; this is due to the fact that the mothercell of the leaf is divided into two which give rise to the two lobes. The leaves are sessile, and their insertion is at first transverse to the long axis of the stem, so that one lobe is superior or dorsal, the other inferior or ventral; but by subsequent displacement it becomes oblique. Since the leaves are situated close together, they thus come to overlap each other, and this overlapping presents two forms : either the posterior edges of the leaves overlap the anterior edges of those next bebind them (Fig. 244), when the leaves are said to be succubous; or the anterior edges of the leaves overlap the posterior edges of those next in front of them (Fig. 245), when the leaves are said to be incubous. The growth of the leaf is generally apical at first, and subsequently basal. 
In some of the foliose Anacrogynæ (Fossombronia, Androcryphia, Petalophyllum) the development of the leaves is essentially similar to that of the lateral leaves of the Acrogynæ; but in none of the Anacrogynæ is the leaf bilobed. In Haplomitrium each segment gives rise to a leaf which is developed in the same manner as those of the Mosses: in Riella each segment gives rise to two leaves: in Blasia there are two rows of lateral leaves and two rows of amphigastria.

In some epiphytic forms (e.g. Frullania) the lower lobe is somewhat cupshaped (Fig. 245), and is termed an auricula; it constitutes a receptacle for water. In some, also, (e.g. Frullania, Lejeunia, Scapania), the upper lobes of the leaves of male fertile shoots are moditied to constitute protective organs for the antheridia.

The leaf-formation of Blasia is quite peculiar, especially in this respect, that the first development of the lateral leaves takes place in the same plane as that of the stem, with a subsequent slight obliquity, so that the leaves are incubous. Each lateral leaf bears at its base, on the under surface, two (sometimes only one) appendages which are termed auriculæ but are not morphologically similar to the auriculæ mentioned above as occurring in Frullania. The auricula of Blasia consists of a cellular wall enclosing a cavity, with a narrow apical aperture, from the centre of the floor of which there springs a glandular huir secreting mucilage. Into this cavity filaments of Nostoc (see p. 234) make their way, so that it becomes filled with a mass of this Alga. The hair then grows out into a number of branches, resembling root.hairs, which ramify in the mass. This symbiosis (see p. 273) appears to be advantageous both to the Nostoc and to the Blasia. An auricula which does not become infested with Nostoc remains relatively small. The amphigastria of Blasia are stalked and peltate; they bear a glandular hair which is situated at first on the margin of the amphigastrium at the apex, becoming gradually displaced until its insertion is at the centre of the free surface.

The sexual orguns are generally borne on the main axis and its normal branches, but in many cases (e.g. Metzgeria, Mastigobryum, Calypogeia, Lepidozia, Saccogyna, Lophocolea, many species of Jungermannia) they are confined to more or less specialised ventral branches (gametophores). The place of development of the archegonia affords the basis for the classification of the Jungermanniaceæ into the two main groups, Acrogynæ and Anacrogynæ. In the former, which includes all the foliose forms (except Blasia, Fossombronia, Androcryphia, Petalophyllum, Haplomitrium, Riella), the archegonia are produced from the apical cell and its youngest segments at the growing-point; hence when the formation of the archegonia takes place on a shoot its further elongation is arrested. In the latter group, which includes all the thalloid forms and the exceptional foliose forms just mentioned, the archegonia are produced laterally, on the dorsal surface in the dorsiventral forms, on all sides in the radial forms (species of Riella, Haplomitrium); hence the growth in length of the shoot is not necessarily arrested.

The archegonia of the Acrogynæ ars borne either singly (Lejeuuia, Phragmicoma), or in groups of two (Frullania) or more (e.g. Radula, Alicularia, Lophocolea). Each archegonium is developed from, a single cell; when the archegonium is single it is developed from the apical cell; when there are 
several archegonia, the development of them begins in the youngest segmentcells of the growing-point. The archegonia are surrounded by the leaves of the apex; and in most cases the leaves of the last whorl are coherent, forming an involucre, surrounding the single archegonium or the group of archegonia. In the Jungermannieæ Geocalyceæ (e.g. Calypogeia, Saccogyna) the involucre arises as an annular outgrowth, forming a large cavity enclosing the archegonia; after fertilisation, it attains a relatively large size, and forces itself partially into the soil (hence the name Geocalyx), which may even root itself.

The a chegonia of the thalloid Anacrogynæ are borne in median dorsal groups : in the dorsiventral foliose Anacrogynæ (Blasia, Fossombronia, Androcryphia, Petalophyllum), they are borne singly or in groups on the dorsal surface of the stem, and in the dorsiventral Rielleæ singly on the flanks of the stem: in the radial Anacrogynæ (Riella helicophylla, Haplomitrium) they are borne singly, scattered over the whole length of the stem as in the former, or confined to the apical region as in the latter. They are in all cases provided with some sort of protective organ. Among the thalloid Anacrogynæ the group of archegonia is surrounded, in Metzgeria, Aneura, and Psendoneura, by an involucre consisting of the short modified gametophore (ventral in Metzgeria); in Pellia, Symphogyna, and Sphærocarpus a group (or each archegonium as generally in Sphærocarpus) is surrounded by an involucre developed as an outgrowth of the tissue of the fertile branch; in Blyttia, Mörkia, Umbraculum (hence termed Diplomitrieæ) there is a double involucre, generally resembling the preceding, but the inner involucre (periggnium ?), attains its full development only after the fertilisation of an archegonium of the group; finally, in Monoclea, the archegonium becomes overgrown by, and hence sunk in, the tissue of the shoot. Among the foliose Anacrogynæ, the archegonia are generally protected by perichætial leaves, and further by an involucre or perigynium (absent in Haplomitrium) which generally invests a single archegonium, and in some cases (Blasia, Fossombronia, Androcryphia) is only developed after fertilisation. In Blasia the growth of tissue subsequently to fertilisation is so active that the fertilised archegonium becomes completely sunk in the tissue of the shoot.

The autheridia are borne, in all Jungermanniaceæ (except Haplomitrium) on the dorsal surface of the shoot; in Haplomitrium they are borne in three rows on the sides of the apical region.

In Riella helicophylla the antheridia are borne sunk in the tissue of the free edge of the membranous wing. As the symmetry of the plant is radial, it presents no distinction of dorsal and ventral surfaces; still the position of the antheridia in $R$. helicophylla is dorsal by analogy, since in the dorsiventral $R$. Reuteri, the wing, which likewise bears the antheridia, is an outgrowth of the dorsal surface of the stem; antheridia have been observed as yet only in these two species of Riella.

The antheridia are shortly stalked and are in all cases provided with a protection. In Metzgeria the group of antheridia is invested by an involucre which consists of the short modified ventral gametophore: in the other thalloid Anacrogynæ, as also in Androcryphia, Blasia, Petalophyllum, and Riella, each antheridium is invested by an involucre which grows up around it, so 
that it appears to be sunk in the tissue of the shoot. In Fossombronia, Haplomitrium, and the Acrogynæ, the antheridia are protected by the leaves : in the Acrogynæ the antheridia are borne, singly or several together, in the axils of leaves; and in some forms (e.g. Scapania, Lejeunia, Frullania) the upper lobe of the protecting leaf is modified in form.

The distribution of the sexual organs varies even in the species of some of the genera. Among the Anacrogynæ, Metzgeria, Pseudoneura, Mörkia, Umbraculum, Petalophyllum, Sphærocarpus, Haplomitrium, Blyttia (generally), and Hiella helicophylla, are diœcious; whereas Pellia, Aneurá (some species), Fossombronia, Symphogyna, Androcryphia, and Riella Reuteri, are generally monœcious. In the monœcious forms the antheridia and archegonia are generally borne on distinct branches (diclinous), but sometimes on the same branch (monoclinous), as in Androcryphia and occasionally in Blyttia. When a dorsiventral shoot bears only antheridia or archegonia, they are developed in the median line; but when it bears both organs, the archegonia are median and the antheridia lateral.

The Acrogynæ are generally monœcious and diclinous.

The structure of the adult shoot of the Jungermanniacex is very simple. - In thalloid forms which have no midrib, the shoot consists of parenchymatous cells forming a single layer at the margin and several layers (e.g. Pellia, Aneura, Sphærocarpus), in the middle line of the shoot; in those which have a midrib (e.g. Metzgeria, Symphogyna, Blyttia, etc.), the midrib consists of several layers of cells, whereas the lamina consists of only a single layer. In Symphogyna and Blyttia the midrib is traversed by a strand of elnngated prosenchymatous cells having thickened and more or less pitted walls. In Blasia the stem has an axial strand of elongated cells with delicately pitted walls.

In the Acrogynæ, the stem generally consists of an axial strand of relatively thin-walled cells, surrounded by a cortex of narrow thick-walled cells; but in those forms which give rise to endogenous ventral branches (e.g. Calypogeia) the cortical cells of the ventral surface of the stem are not thick-walled. The leaves are sinply single layers of similar cells, and have no midrib.

The root-hairs are, in all cases, destitute of the peculiar thickenings so characteristic of the Marchantiaceæ.

B. The Sporophyte. The course of the development of the sporophyte is, in its main features, essentially the same throughout the Jungermanniaceæ.

The oospore is divided by a transverse (basal) wall into two halves, epibasal and hypobasal. The epibasal cell gives rise to the capsule and its stalk (setaj. It divides transversely, and the longitudinal divisions follow in both cells so that the epibasal half of the embryo consists of two tiers of each consisting of four cells. Further growth in length is effected by the cutting off, by transverse walls, of segments from the cells forming the apical tier; but this apical growth is arrested, sooner or later, by the formation of walls parallel to the free surface (periclinal) in the apical cells, and also frequently in some of those below them, which indicate the differentiation of the capsule-wall (amphithecium) from the internal mass of cells (endothecium) which give rise to the spores and elaters. The cells below the capsule may, however, continue to grow and divide transversely, and by means of this intercalary growth the full length of the seta is attained. 
Though the mode of growth of the epibasal half of the embryo is most commonly that described above, it not infrequently happens that the growth of the two longitudinal halves is unequal, owing to the fact that the first longitudinal wall is not perpendicular to the basal wall, but is oblique. Consequently the apex is occupied by the two cells of the longer half, and in those cases in which the apical growth is long-continued the result is that the capsule may be developed entirely from one longitudinal half of the embryo. This mode of development has been observed in Blasia, Pellia, Fossombronia, Haplomitrium, and Symphogyna; in Fossombronia and Symphogyna an embryo of this kind appears to grow in length, for a time at least, by means of a two-sided apical cell.

In many of the Jungermanniaceæ (e.g. Pellia, Lepidozia, Jungermannia, Calypogeia, Frullania) the lower end of the seta developes into a bulbous mass of cells forming a false foot, the upper margin of which grows up so as to form a sheath round the lower part of the seta in some cases.

The development of the hypobasal portion of the embryo is comparatively insignificant; in most cases it is merely a small appendage to the lower end of the seta. The hypobasal cell enlarges somewhat, without undergoing any division (e.g. Radula, Madotheca, Lepidozia, often in Pellia and Symphogyna); or it undergoes transverse division to form a filament of two or three cells, the lowest of which becomes elongated and grows down among the cells at the base of the archegónium (e.g. Metzgeria, Aneura, Jungermannia bicuspidata); or it divides by a longitudinal wall into two cells which gr.w out into papillæ (Frullania dilatata), or, by further division its produces four papillæ (Calypogeia Trichomanis); or, finally, it divides irregularly to form a small group of cells (Blasia). In some forms, however (e.g. Fossombronia, Petalophyllum, probably also Sphærocarpus, Riella helicophylla, Notarisii, and Reuteri), the hypobasal cell appears to give rise to a true foot, bulbous in form, comparable to that of the Marchantieæ (see p. 340).

In the further differentiation of the capsule, the cells of the amphithecium undergo periclinal division so that the wall eventually consists of two or more (up to six) layers of cells ; though in Haplomitrium, Sphærocarpus, and Riella, the wall consists throughout of a single layer of cells. In the wall-cells anuular thickenings are developed, which are usually transverse; but in Haplomitrium there is a single annular thickening situated longitudinally; the cells are unthickened in Sphærocarpus and Riella. The planes of dehiscence of the capsule, except in those forms which dehisce irregularly (Riella, Sphærocarpus), are marked out by four longitudinal rows of small-celled tissue which correspond in position with the walls between the four apical cells of the growing embryo.

The archesporium, which is co-extensive with the endothecium, presents various degrees and forms of differentiation. In Riella and Sphærocarpus it comes to consist of a number of cubical cells, some of which become the mother-cells of the spores, whereas the others persist as unaltered sterile cells. In all the other Jungermanniaceæ some of the cells of the endothecium are sterile, but they develope into elaters, becoming elongated in form and spirally thickened, having sometimes two spirals (Haplomitrium, Plagiochila, Scapania, Jungermannia, Lophocolea, Lepidozia, Radula, Fossombronia, Symphogyna, Blasia, etc.), or only one (in the Jubuleæ, e.g. Lejeunia, Frullania, and in 
Aneura, Metzgeria). The relative arrangement of the sterile and fertile cells, dependent upon the growth of the capsule along different diameters, varies somewhat. In the lower forms, the elongated archesphorial cells are arranged more or less longitudinally, either quite straight (e.g. Frullavia, Lejeunia, Symphogyna, Umbraculum), or radiating from the apex of the capsule (Metzgeria, Aneura), or radiating from the base of the capsule (Pellia, Radula): whereas in the higher forms (Lepidozia, Calypogeia, Jungermanuia), these cells are placed horizontally round a central longitudinal axis, except at the apex where they radiate. In most cases the sterile and fertile archesporial cells are mingled together, but in some cases certain parts of the archesporium give rise especially to spores and others to elaters. Thus, in Pellia, the cells towards the base and those in the longitudinal axis of the capsule form only elaters, whereas in Jungermannia the formation of elaters is confined to the cells near to the wall.

Whilst the development of the embryo is taking place, growth is also proceeding in the archegonium and the adjacent tissue, giving rise eventually to the calyptra. Several of the archegonia of a group may be fertilised, but generally only one gives rise to a fully developed sporogonium, and itself takes part in the formation of the calyptra. The calyptra is sometimes developed from the venter of the archegonium alone (e.g. generally in the Acrogynæ, and in Metzgeria, Fossombronia); in the Anacrogynæ the adjacent tissue of the shoot frequently takes part in its formation, as is shown by the fact that the unfertilised archegonia of the original group are found on the sides, or even on the top of the calyptra (e.g. Aneura, Symphogyna). The wall of the calyptra consists of one or more layers of cells, and keeps pace with the growth of the embryo which it encloses until the spores are mature. The cells of the seta then rapidly elongate, causing the rupture of the calyptra, and the capsule is exposed. The capsule then dehisces, generally into four valves, sometimes irregularly, and the spores are set free.

The Jungermanniaceæ may be classified as follows :-

Series I. Anacrogrne: growth in length not necessarily arrested by the development of archegonia.

Section A. Anelatereæ : the sterile cells in the capsule do not develope into elaters.

Fam. 1. Riellea: including the two genera Riella (foliose) and Sphærocarpus (thalloid); further characterised by the absence of annular thickenings in the cells of the wall of the capsule, by the irregular dehiscence of the capsule, and (probably) by the development of a true (hypobasal) foot.

Section B. Elatereæ: the sterile cells in the capsule develope into elaters. a. Thalloid Forms.

Fam. 2. Metzgeriea: genera, Aneura and Pseudoneura (Riccardia), Metzgeria.

"3. Diplomitrié: Blyttia and Mörkia (Pallavicinia), Umbraculum (Hymenophyton), Pellia, Symphogyna.

$\beta$. Foliose Forms.

Fam. 4. Codoniea: Fossombronia, Androcryphia (Noteroclada), Petalophyllum, Blasia.

"5. Haplomitriea: Haplomitrium, Calobryum. 
Series II. Aclogrne: growth in length arrested by the development of archegonia; all foliose.

Fam. 6. Gymnomitriea: Gymnomitrium, Sarcoscyphus (Marsupella), Alicularia (Nardia), etc.

„7. Jungermanniea: Plagiochila, Jungermannia, Lophoco'ea, Scapania, etc.

„ 8. Geocalycea: Saccogyna, Calypogeia, etc.

"9. Trichomanoidea : Lepidozia, Mastigobryum, etc.

", 10. Ptilidea: Trichocolea, Ptilidium, Seudtnera, etc.

"11. Pla'yphyllea: Radula, Madotheca.

,, 12. Jubulea : Phragmicoma, Lejeunia, Frullania, etc.

Order III. Anthocerotaceæ.

A. The Ganeторнхте. The protonema developed from the germinating spore is a flattened plate of cells; in Anthoceros the formation of the flattened plate is sometimes preceded by the outgrowth of the contents of the spore, covered by the endosporium, into a filament at the apex of which the plate of cells is developed; in Dendroceros the first cell-divisions connected with the formation of the protenema frequently take place wilhin the spores before they

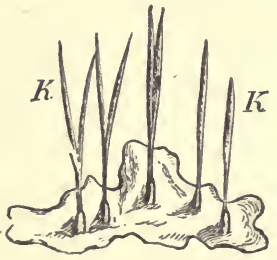

Frg. 246.-Anthoceros lavis (nat. size). $K$ The capsules, some as yet nnopened. are shed from the sporogonium. The adult shoot is developed as a lateral out-growth from the flattened protonema.

The Morphology of the adult shoot. The adult shoot is thalloid, and its symmetry is dorsiventral. It is semi-circular, or nearly circular, in outline in Anthoceros and Notothylas; but in Dendroceros it is elongated and branched, in which genus it has a strongly developed midrib which projects especially on the ventral (under) surface. There are no ventral scales on the under surface, but numerous nnicellular root-hairs.

The growth of the shoot is effected, in Anthoceros and Notothylas, by a series of marginal growing-points ; in Dendroceros, by a growing-point at the apex of the main shoot and of each of its branches. In the growing-point there is a row of initial cells, each of which acts as an apical cell; their form is wedgeshaped in Anthoceros, dorsal and ventral segments being alternately cut off by the formation of oblique walls; in Dendroceros their form is nearly hemispheral, the base being internal, and segments are cut off by the successive formation of transverse wills at right angles to the long axis of the shoot.

Branching, or at least the formation of new growing-points, takes place in the manner described for the Marchantiaceæ (p. 184).

The sexual organs are developed from the dorsal segments formed in the growing-point, and are situated in the middle line behind each growing-point in Anthoceros and Notothylas, on the midrib in Dendroceros. The antheridia, which have a long stalk in Dendroceros, are dereloped endogenously, and remain enclosed in the tissue until maturity; they are developed either singly (some species of Anthoceros, Dendroceros) or in groups. The archegonia are sunk in the tissue, the apex of the neck reaching to the dorsal surface of the shoot. The shoots are monœcious; the sexual organs are sometimes intermingled in the same group (frequently in Anthoceros). 
In exceptional cases the antheridia of Anthoceros may be developed at the surface, i.e. exogenously.

The structure of the adult shoot. The adult shoot, in Anthoceros and Notothylas, consists of several layers of cells in the middle line, thinning out to a single layer of cells at the margins. The tissue in the middle line consists of longitudinally elongated cells, the walls of which, + specially in the older parts of the shoot, frequently present reticulate or even spiral thickening. In $D$ endroceros there is a prominent midrib, on each side of which is attached a laminar portion, consisting of a single layer of cells; in some species there are no intercelular spaces, but in others there are air-chambers in the midrib, which give to its surface the areolated nppearance so well-marked in the Marchantiaceæ (see p. 338).

A characteristic structural feature is the presence of apertures of the nature of pores in the superficial layer of those parts of the shoot which consist of several layers of cells. They occur generally only on the under (ventral) sur. face of the shoot, but in some species of Dendroceros (D. javanicus, crispatus, Breutelii) they are present on the dorsal surface also. The pore is bounded by two guard-cells, formed by the division of one of the superficial cells. It leads into a cavity which is, from the first, filled with mucilage. Into this cavity the Alga Nostoc obtains access through the pore, and there grows and multiplies. The growth of the Nostoc in the cavity is accompanied by active growth of the cells of the surrounding tissue, so that the whole mass projects from the surface of the shoot, and the guard-cells grow and divide, so that the cavity becomes completely closed. At the same time, filamentous septate outgrowths arise from the cells of the wall of the cavity, which ramify throughout the mucilaginous mass (comp. Blasia, p. 347).

The chloroplastids of the Anthocerotaceæ are peculiar, on account of their relatively large size, and of the fact that they occur singly in the cells and con. tain a pyrenoid (see p. 100).

B. The Sporophyтe. The early stages in the development of the sporophyte of the Anthocerotacex appear to be much the same as in the case of other Liverworts (Fig. 239 C). The oospore divides transversely into an epibasal and a hypobasal half : and each of these divides by two perpendicular walls so that the embryo consists at this stage of eight cells. The cells of the epibasal half divide transversely several times, and then further apical growth in length is arrested by the formation of periclinal walls, marking the differentiation of amphithecium and endothecium, first in the four apical cells, and subsequently in those below them. By the repeated formation of periclinal walls, the amphithecium comes to consist of several layers of cells. The hypobasal cells undergo but few divisions, giving rise to a bulbous foot, the superficial cells of which grow out into papillæ and penetrate between the cells of the adjacent tissue of the gametophyte.

The details of the differentiation of the epibasal portion of the embryo vary considerably. In Anthoceros and Dendroceros (Figs. 238, 239) the archesporium is developed from the innermost layer of cells of the amphithecium, a peculiarity, the only other instance of which, in the Muscineæ, is to be found in the Sphagnacex (p. 331) : the endothecium gives rise to an axial strand of sterile tissue, termed the columella, which is completely invested (except at the base,

V. S. B. 
where it is continuous with the tissue of the foot) by the archesporium. In Notothylas, the archesporium is commonly co-extensive with the endothecium; but in some forms the archesporium is developed from only the external layer of the endothecium, the rest of the endothecium constituting a columella (as in the Bryineæ among the Musci).

In all three genera some of the cells derived from the archesporium are sterile. In Dendroceros these cells develope into elaters with spiral thickenings, each elater consisting of a row of several cells with an apparently continuous spiral band. In some species of Anthoceros (e.g.vicentianus, giganteus, etc., constituting the subgenus Anthocerites) there are elaters quite similar to those of Dendroceros: in other species (e.g. tuberculatus, glandulosus) the elaters have the same form, but they have no spiral band; in others (lavis, punctatus) the sterile cells do not form distinct elaters, but a network of sbort cells, with spiral thickening, in the meshes of which lie the mother-cells of the spores. In Notothylas the sterile cells do not develope into elaters; they are so arranged as to form chambers, in which lie the mother-cells of the spores.

The sporogonium of Anthoceros and Dendroceros has no seta; when the apical growth has ceased, the capsule continues to elongate by basal growth, and hence does not ever become fully mature throughout. In Notothylas the sporogonium has a short seta, and elongates by intercalary growth, the growing-point being situated at the junction of the capsule with the seta; but the intercalary growth is of limited duration, so that the whole capsule becomes mature throughout, and frequently becomes disconnected from the seta. The pod-shaped capsule of Anthoceros and of Dendroceros splits from the apex into two valves (Fig. 246). Stomata occur in the epidermis of the capsule in most species of Anthoceros, but they appear to be wanting in the other genera.

Since the archegonia are sunk in the tissue of the shoot, the calyptra, which invests the developing embryo, is developed mainly from the surrounding tissue, and only to a small extent from the wall of the archegonium.

\section{CLASS IV. MUSCI (Mosses).}

A. The Gametophyte. The protonema is more conspicuons in the Musci than in the Hepaticæ: it sometimes persists until the sporogonia are developed and the spores are ripe (e.g. Ephemerum), and in many cases the subterranean portion persists from year to year. It is generally filamentous and much brariched; but in some forms it is a flattened expansion (e.g. Sphagnum, Andreæa), or cylindrical branched and shrubby (Andreæa), or it bears lateral flattened expansions which are assimilatory organs (e.g. Andreæa, Tetraphis, etc.). The filamentous protonema consists of a subaerial and of a subterranean portion, which differ in that the cells of the former contain chloroplastids, their walls are colonrless, and the septa are transverse; whereas those of the latter do not 
contain chloroplastids, and their walls are brown and their septa oblique. The protonema presents, in fact, a certain differentiation into shoot and root, the term rhizoids being applied to the root-like filaments. This differentiation is, however, of little morphological value, since the differences between the shoot- and root-filaments depend entirely on external conditions: thus, if the rhizoids be exposed to light they assume the characters of the subaërial filaments. In Andreæa the differentiation is altogether wanting. The flattened protonema of Sphagnum bears rhizoids on its margins and under surface.

The growth in length of the protonemal filaments is apical: the terminal cell behaves as an apical cell from which segments are successively cut off by transverse or oblique walls.

The Adult Shoot arises as a lateral bud on the subaërial portion of the protonema. In some cases (Bryineæ) the subterranean portion gives rise to lateral buds : these are small, spherical or lenticular, multicellular bodies of a brown colour, filled with reserve materials, and are termed bulbils; when they are brought to the surface they give rise to adult shoots, either directly or with the intervention of protonema.

The adult shoot is in all cases differentiated into stem and leares, and may be branched or unbranched. Its symmetry is commonly radial or isobilateral, less commonly dorsiventral. In the former case it is attached to the soil by rhizoids springing from its basal portion; in the latter, by rhizoids developed on its under surface. In Sphagnum, rhizoids occur only on young shoots.

The growth of the adult shoot (and its branches) is affected by means of an apical growing-point with a single apical cell which is generally a three-sided pyramid: in Fissidens, however, though the subterranean shoots, and in some species the subaërial lateral shoots, have a three-sided apical cell, yet, under the influence of light, the apical cell eventually becomes two-sided.

Each segment cut off from the apical cell gives rise to a leaf: hence the arrangement of the leaves, and the symmetry of the shoot, is generally determined by the form of the apical cell. Thus in Fissidens, the leaves are arranged in two rows and the symmetry of the shoot is isobilateral: in other cases (e.g. Fontinalis) the leaves are in three rows, and the symmetry of the shoot is radial. But to this rule there are exceptions. Thus, in the sterile shoots of Schistostega, although the apical cell is three- 
sided, the leaves are arranged, in consequence of subsequent displacement, in two rows, and the symmetry of the shoot is isobilateral. Again, in Sphagnum, Polytrichum, Andreæa, etc., the leaves are not arranged in three rows with a divergence of $\frac{1}{3}$, but spirally with dirergences of $\frac{2}{5}, \frac{3}{8}$, etc., because the walls of the segments cut off successively from any one side of the three-sided apical cell are not parallel to each other, but are inclined at an angle. The symmetry of the shoot is, however, radial.

Branching is confined to perennial shoots, and is lateral, never. dichotomous. When the growth of the main shoot is arrested by the formation of sexual organs at the apex (acrocarpous), one (or more) of the lateral branches (termed innovations) close behind the apex assumes the characters of the main shoot and carries on the growth: the resulting branch-system is cymose, either sympodial or dichasial according to the number (one or more) of the innovations at each branching. When the growth of the main stem is not thus arrested, the sexual organs being borne on lateral branches (pleurocarpous), the branch-system is monopodial and racemose.

The branches (except the innovations) frequently differ in various ways from the primary shoot. Thus, in Sphagnum and other pleurocarpous Mosses, the leaves of the branches differ in size and shape from those of the primary shoot: in other forms (e.g. Thuidium) the lateral branches have limited growth.

The development of the branches, though never axillary, is intimately connected with the arrangement of the leaves, since the apical cell of a branch is developed from the same segment as the corresponding leaf. Each branch is developed beneath the corresponding leaf, either in the median line (e.g. Fontinalis), or on one side of it (e.g. Sphagnum). However, a branch is not. developed in connexion with each leaf.

In most cases the adult shoot does not present any differentiation into a vegetative and a reproductive portion (gametophore), but such a differentation is to be found in certain forms. Thus, in Splachnum, the male organs are borne upon a leafless prolongation of the shoot: again in Schistostega the fertile and the sterile shoots differ from each other in form; the sterile shoot is leafless at the base, but from the middle npwards it bears two rows of leaves inserted longitudinally, so that the shoot resembles a small fernleaf; the fertile shoot bears at its upper part a tuft of leares in five rows, inserted obliquely or transversely, whilst the lower part 
is either leafless or bears a few leaves like those of the sterile shoot.

In Sphagnum and Andreæa, the apex of the female shoot grows out, after fertilisation of the archegonium, into a long leafless shoot termed a pseudopodium, which bears the sporogonium (here destitute of a seta) at its apex. In Aulacomnium and Tetraphis there is a somewhat similar terminal shoot, likewise termed a pseudopodium, which bears at its apex a cluster of gemmæ.

The Leaves present considerable variety in size and form (heterophylly, see p. 57) : they may be divided, in the first instance, into foliage-leaves and involucral leaves.

The foliage-leaves are simple and sessile; they are usually inserted transversely on the stem, and are closely packed. They are generally larger towards the upper than towards the lower part of the shoot. In most pleurocarpous Mosses the leaves of the lateral branches differ more or less from those of the main stem. In some forms (e.g. Bryum roseum, Clinacium, etc.), where the branches take the form of creeping runners or stolons, the leaves of these branches are reduced to scales (cataphyllary leaves).

The involucral leaves are arranged in one or more whorls, forming an involucre round the sexual organs. Those surrounding a group of male organs are commonly larger than the foliageleaves, and in some cases (e.g. Polytrichaceæ) are coloured red or yellow. Those surrounding a group of female organs differ but little from the foliage-leaves : the more internal leaves are smaller than the external: the innermost leaves, distinguished as perichoetial leaves, are quite rudimentary when the archegonia are mature, but after fertilisation has taken place they grow up round the base of the seta of the sporogonium.

The S'exual Organs are borne in groups (rarely singly) at the apex either of the main shoots (acrocarpous), or of lateral branches (pleurocarpous), surrounded by involucral leaves, each group with its involucre constituting a receptacle. Generally speaking the growth of the shoot or branch ceases with the development of the sexual organs, the apical cell itself giving rise to an antheridium or an archegonium; but in some male receptacles (e.g. Polytrichaceæ and some other Bryineæ, also Sphagnum) the apical cell persists as such; consequently the elongation of the shoot or branch is not necessarily arrested by the development of the antheridia, and appears to grow through the receptacle.

Among the sexual organs there are usually present multicellular 
hairs, termed paraphyses: they are often filamentous, but in some cases (e.g. male receptacle of Funaria) the terminal cells are large and rounded; they are hyaline, or coloured red or yellow, sometimes brownish, and the cells frequently contain chloroplastids. They are more numerous and more highly developed in the male than in the female receptacles; they are rarely absent in plants which grow in dry situations, but frequently in those forms which grow in water or in damp places. Their function seems to be that of secreting water to prevent the drying-up of the sexual organs.

The antheridia are generally club-shaped (spherical in Sphagnum), and are shortly stalked (see Fig. 233); the base of the stalk is dilated in some cases (e.g. Andrexa). The antheridia generally open at the apex to allow the spermatozoids to escape. The archegonia are stalked; the neck is long, and the venter is but slightly dilated (Fig. 235).

The distribution of the sexual organs is various. The plant may be monœcious (i.e. may bear both kinds of sexual organs), or it may be diœcious: amongst the monœcious forms may be distinguished those which are monoclinous, that is, which have both male and female organs in the same receptacle (e.g. Bryum lacustre, cuspidatum, etc.), the archegonia being in the middle; and those which are diclinous, that is, which bear the male and female organs in distinct receptacles: sometimes (e.g. Bryum pendulum, arciicum, etc.) the plants are heteroclinous or polygamous, that is, some receptacles are hermaphrodite, whilst others are unisexual. In the diceious species the male plant is usually the smaller, and is short-lived. In some species the plants are sometimes monœcious (either monoclinous or diclinous) and sometimes dicecious.

The Structure of the Adult Shoot. The stem presents more or less well-marked histological differentiation. The outer portion generally consists of one or more layers of elongated prosenchymatous cells, with thickened walls which are yellow or brown, forming the cortex which passes by gradual transition into thinwalled parenchymatous ground-tissue; in the subterranean shoots of the Polytrichaceæ, however, the cortex is parenchymatous and thin-walled, whilst the central tissue is thick-walled.

In many species a central strand, lying in the longitudinal axis of the stem, can be distinguished, the structure of which presents two principal varieties; it may be simple, consisting of a group of thin-walled tracheides, destitute of protoplasmic cell-contents (e.g. species of Mninm, Meesia longiseta, Archidium alternifolium); or it 
is compound, consisting of a group of thick-walled tracheides, or of several groups of thin-walled tracheides with intervening parenchymatous or prosenchymatous cells, surrounded by several layers of thin-walled elongated cells with oblique ends, containing abundant protoplasm and starch-grains (e.g. Polytrichaceæ). This central strand is, in fact, a rudimentary vascular stele : the tracheides, though unlignified, represent the wood or xylem: in the simple. form, the phloem is unrepresented; in the compound form it is represented by the elongated cells which surround the xylem.

The degree of development of the xylem of the central strand is dependent upon external conditions. It is well developed in those forms (e.g. Polytrichum, Bryum, Phascum, Funaria, Fissidens, Meesia, Splachnum) which grow under such conditions that, whilst transpiration is active, an adequate supply of water can be absorbed. It is, on the contrary, rudimentary or absent in those forms which (a) live under conditions in which they are liable to be dried up (e.g. Hypnum, Barbula, Orthotrichum, etc.); or (b) which grow in very wet situations, or actually in water (e.g. Sphagnum, Fontinalis, etc.).

The structure of the leaves shows considerable variety. Most commonly the leaf-blade consists of a single layer of cells, containing chloroplastids, with or without a midrib. In the midrib of those forms which have a central strand in their stems, there are one or more rudimentary vascular bundles of a structure corresponding to those in the stem. These bundles enter the stem as leaf-traces, and either end blindly, or join the central strand of the stem. The rest of the midrib is made up chiefly of thick-walled prosenchymatous cells.

The most remarkable deviations from the usual structure of the lamina are those offered by the Sphagnacex and the Polytrichaceæ. In the Sphagnaceæ the constituent cells are of two kinds : large empty cells with perforated walls (see infra, p. 364), and small cells containing chloroplastids. In the Polytrichaceæ, the assimilatory tissue is borne on the surface of the broad midrib in the form of numerous longitudinal plates, one cell thick. Something similar occurs in Aloina (Aloidella) and some other forms, where the upper half of the inner surface of the leaf is covered with hairs, the cells of which contain many chloroplastids.

The rhizoids which spring from the shoot are essentially similar to those of the protonema: in the Polytrichacex they become wound together into strands. 
The gametophyte of the Musci possesses a remarkable capacity for vegetative propagation. Thus the perennial protonema of many species serves year by year to produce new adult shoots which, not unfrequently, become distinct plants. In the pleurocarpous forms (e.g. Sphagnum, Hypnum) the main axes gradually die away from behind, the lateral branches becoming isolated, and constituting the main axes of new plants. In probably the majority of the Musci almost any portion of the body, a piece of stem or a leaf, will, under proper conditions, grow out into protonemal filaments, which give rise to adult shoots in the usual manner. In certain species, belonging to the Bryineæ (Aulacomnium palustre, A. androgynum, Tetraphis pellucilla), multicellular gemmæ are produced at the apex of the stem, either free or enclosed in a cupule (Tetraphis). In Aulacomnium palustre the gemmæ appear to be modified leares; in $A$. androgynum and in Tetraphis the gemmæ are smaller, and consist of but few cells; in Tetraphis they are borne on long stalks. On being placed under favourable conditions, the cells of the gemma grow out into protonema.

$B$. The Sporophyte. The oospore divides into two by a wall (basal wall) transverse to the long axis of the archegonium: from the epibasal half is developed the capsule (theca) and its long or short stalk (seta), whilst the hypobasal half gives rise to a more or less well-developed foot: the whole being termed the sporogonium.

The segmentation of the oospore into octants (see p. 329) is confined to the epibasal cell, and even this can only be traced in Sphagnum, which in this respect resembles the Liverworts. In the other Mosses, the epibasal cell undergoes one or more transverse divisions, after which two oblique walls, cutting each other at an acute angle, are formed in the terminal cell; the cell marked out by these two oblique walls is a two-sided apical cell by the growth and segmentation of which the further development of the embryo is effected.

At an early stage in the differentiation of the capsule (see Fig. $238 \mathrm{~B}$ ) the amphithecium, consisting of one or more layers of cells, can be distinguished from the endothecium. The amphithecium constitutes eventually the wall of the capsule; the internal tissues being formed for the most part from the endothecium.

The archesporium becomes differentiated in various positions within the young capsule. It is differentiated, in the Sphagnacer, from the innermost layer of the amphithecium; in the Andreæaceæ and Bryineæ, from the external layer of the endothecium: in 
Archidium there is no archesporial layer, but the sporogenous cells are scattered throughout the endothecium. The cells which bound the archesporium on each side constitute the spore-sac. The endothecial tissue which lies internally to the archesporium constitutes the columella. In the Sphagnaceæ and Andreæaceæ the archesporium is a hollow hemisphere covering the top of the columella like a cap ; in the Bryineæ the archesporium is a, hollow cylinder surrounding the columella which extends to the apex of the capsule. In Archidium and in the Bryineæ a large intercellular space is developed in the amphithecium, between its outer and its two inner layers ; in most Polytrichaceæ a similar intercellular space is developed in the endothecium internally to the spore-sac, between it and the central portion of the columella.

At maturity the internal cells of the capsule becomedry and disorganised, so that it simply contains the spores which now lie loose in its cavity. It dehisces by the throwing off of its apical portion as a lid or operculum in Sphagnaceæ and the higher Bryineæ (Stego(arpæ); or by longitudinal fissures, as in Andreæaceæ; or it ruptures irregularly or simply decays, as in Archidium and the lower Bryineæ (Cleistocarpæ). In the higher Bryineæ the mouth of the dehisced capsule bears a fringe, the peristome, the development and structure of which will be described subsequently (p. 368).

The basal portion of the capsule, where it joins the seta, is termed the neck. In the Polytrichaceæ the neck is considerably dilated, as also in various species of Splachnum (e.g. S. sphoericum, vasculosum, etc.) whilst in Splachnum luteum and rubrum it grows out into an umbrella-shaped structure. When the neck is thus markedly developed it is termed the apophysis.

The histological differentiation of the sporogonium is wellmarked. There is a well-defined epidermis, in which, on the capsule, stomata of various forms are generally present (absent in Andreæaceæ, Archidium, and some Bryineæ); either scattered all over, as in the Sphagnaceæ; or confined to a particular region of the capsule, generally the neck or the apophysis, in the Bryineæ. The operculum and the peristome (Bryineæ) show considerable complexity of structure. The structure of the seta in the higher Bryineæ, where alone it is elongated, very much resembles that of the stem: in many forms, even in such in the stem of which no central strand is present, there is a central strand in the seta, marked off from the ground-tissue by one or two layers of sheathcells. In the Bryineæ also, the structure of the neck (or apo- 
physis) is generally characterised by the presence of loose assimilatory tissue, rich in chloroplastids, the intercellular spaces of which communicate with the outer air by means of the stomata.

The hypobasal cell undergoes relatively few divisions. In the Sphagnaceæ, Andreæaceæ, and Archidium, it gives rise to a bulbous foot. In the Bryineæ (e.g. Orthotrichum, Barbula, Atrichum where the hypobasal cell undergoes a single division by a transverse wall) the true foot is rudimentary, but it is functionally replaced (e.g. Phascum, Ephemerum, Polytrichnm) by the dilated lower end of the seta which constitutes a false foot.

After fertilisation, the venter of the archegonium developes into the calyptra which, for a time, keeps pace with the growth of the contained embryo, but is eventually ruptured by the gradual elongation of the seta. In Sphagnaceæ, in Archidium, and in Phascum and Ephemerum among the lower Bryineæ, the whole of the ruptured calyptra remains as a sheath, the vaginula, round the base of the short seta; in the Andreæaceæ and in the higher Bryineæ the lower portion remains as the vaginula, whilst the upper portion is raised up like a cap (still called calyptra) on the top of the elongating sporogonium. The floor of the receptacle (i.e. the apex of the sexual shoot) is also stimulated to growth, forming in most cases a conical projection on which are borne the paraphyses and the unfertilised archegonia, whilst in Sphagnaceæ and Andreæaceæ it elongates into the long pseudopodium (see p. 328) The perichætial leaves also grow up round the lower part of the seta or of the pseudopodium.

The sporogonium, possessing, as it usually does, assimilatory tissue and stomata, can assimilate the carbon dioxide of the air, and can transpire actively. The supply of water necessary to meet the loss by transpiration is obtained, together with salts in solution, from the gametophyte, being absorbed by the true (hypobasal) or the false (epibasal) foot, and it travels to the capsule through the rudimentary xylem-tissue of the central strand present in the seta of the higher forms. It is a point of considerable physiological interest that the absorption of water in the first instance by the gametophyte is apparently effected for the most part by the leaves rather than by the rhizoids.

The remarkable capacity for vegetative propagation manifested by the gametophyte is shared by the sporophyte. It has been ascertained that if portions of the capsule or of the seta, whilst the cells are still liring, be kept under favourable conditions, the 
superficial cells will grow out into protonemal filaments. In this way the gametophyte may be derived from the sporophyte by budding, without the intervention of spores; when this occurs it is a case of apospory (see p. 87).

The Mosses are classitied as follows:-
Order I. Sphagnaceæ.
Order III. Archidiaceæ.
" II. Andreæaceæ.
"IV. Bryineæ.

Order I. Sphagnaceæ (Bog-Mosses).

A. The Gametophyte. The spore gives rise on germination to a filamentous protonema; when germination takes place in water, the protonema remains tilamentous and branches, but when it takes place on a solid substratum the prutonema assumes the form of a branched cellular expansion attached to the substratum by root-like protonemal filaments. In either case adult shoots are developed as branches upon the protonema.

The Morphology of the ddult Shoot. 'Tue shoot is radially symmetrical, and is differentiated into stem and leaves. It consists of a main axis bearing numerous lateral branches.

Growth is effected, in both the main axis and the lateral branches, by means of a growing-point in which there is a three-siced apical cell.

The Sexual Organs are borne on specially modified lateral branches (gametophores), the antheridia and archegonia being borne on distinct branches, and in some species on distinct shoots.

A branch which bears antheridia (antheridiophore) is elongated and is covered with small, closely packed, imbricate leaves, by the side of each of which an antheridium is developed. The antheridium, which is raised upon a long stalk, is spherical; it opens by the splitting of the wall into valves from the apex downwards.

A branch which bears archegonia (archegoniophore) is short; it bears at its apex a group of (1-5) archegonia, surrounded by rather large involucral leaves with rudimentary perichætial leaves.

'i'he Structure of the Adult Shoot. The main axis has no central strand; it consists of a mass of elongated thin-walled parenchymatous cells, which gradually passes over into an external zone of prosenchymatous cells, the walls of which are thick and brown; externally to this is a cortex, consisting of 1-5 layers of cells which are usually empty, and have large holes in their walls (except the Sphagna cuspidata); in some cases (Sphagna cymbifolia) the cortical cells have spiral thickenings.

The cortex of the lateral branches generally consists of one or two layers of cells. In all, except the Sphagna cymbifolia, the external walls of the cortical cells are not perforated, though the lateral and transverse walls are perforated; except in the case of certain large retort-shaped cells, situated near the insertion of the leaves, which have an external opening at the upper end.

The leaves vary in form according to their position; thus stem-leares, branchleaves, small scaly leaves, and involucral leaves may be distinguished. They are sessile, and have a broad insertion; in most cases the leaf is connected with the prosenchymatous tissue of the stem, the leaf-tissue extending through the 
cortex. The stem-leaves have, at the base, a pair of lateral appendages, the auriculæ.

The leaf consists of a single layer of cells, and has no midrib. It is made up of two kinds of cells : larye empty cells of various forms with perforated walls frequently with spiral or some similar form of thickening: small cells, arranged between the preceeding, containing protoplasm and chloroplastids. The relative arrangement of these two kinds of cells afford a means of classification. Nostoc and other Algæ are frequently found in the large empty cells.

The Sphagnaceæ have no special organs for vegetative propagation; but they multiply vegetatively by the dying away of the main stems so that the lateral branches became separate and constitute distinct plants: consequently these plants are found in considerable masses. They inhabit damp, boggy spots, and retain a considerable quantity of water in the open cells of the branches aud

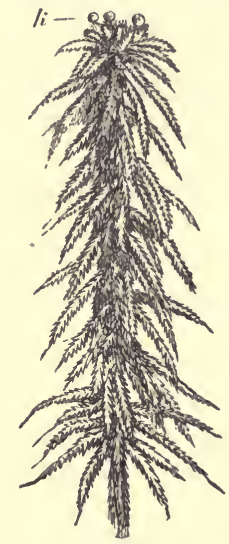

Frg. 247.-Part of shoot of Sphagnum acutifolium (nat. size). $1 /$ Capsules.

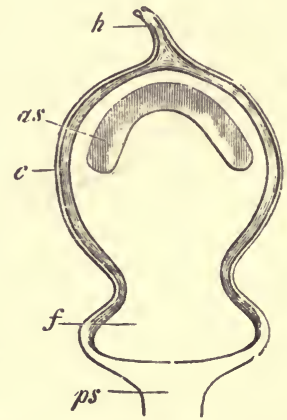

FrG. 248,-Longitudinal section (diagrammatic: $\times 19$ ) of the sporogonium of Sphagnum : ps pseudopodium; $f$ foot; $c$ calyptra with neck of archegonium $h$; as archesporium.

leaves. Masses of Sphagnum thus saturated with water form peat-mosses or peat-bogs, the water being raised to the surface by means of the capillary system formed by the open cells.

B. The Sporophyte. The oospore, as in other Mosses, is divided by the transverse basal wall into an epibasal and a hypobasal half. The epibasal half gives rise to the capsule: it grows at first apically, segments being formed by transverse walls, each segment being divided into four cells (quadrants) by walls at right angles to $\mathrm{e}$ ach other: after six or eight segments have been formed, apical growth ceases, the further growth being intercalary. The cells of each segment become differentiate $d$ each into an external and an internal cell; the external ' cells constitute the amphithecium, the internal cells the endothecium. The amphithecium comes to consist of several layers by periclinal divisions, the first formed and most internal layer constituting, in its upper half, the archesporium; the endothecium constitutes the columella. Thus the archesporium is a hollow hemisphere which covers the columella as a cap. There is no intercellular cavity formed in the capsule. 
The hypobasal half of the oospore undergoes but few divisions, forming a bulbous foot, the superficial cells of which grow out into short papillæ.

The fully developed sporogonium consists of a capsule attached to the foot by a very short seta; the wall of the capsule consists of a single layer of cells, ancl has numerous stomata. The capsule opens by the throwing off of the apical portion of the wall as an operculum. There is no peristome.

When the calyptra is ruptured, it remains as a vaginula round the base of the capsule. No part of it is carried upon the top of the capsule.

The growth of the archegoniophore is stimulated by fertilisation. It grows (Fig. 249, ps) out at its apex into a long, leafless stalk, the pseudopodium, expanded at the top into a cushion of cells in which the foot of the sporogonium is embedded; the perichætial leaves grow and surround the base of the stalk.

The order consists of the single genus Sphagnum, of which there are many species.

\section{Order II. Andreæaceæ.}

A. The Gamerophyte. The germination of the spore and the various forms of protonema are in many respects peculiar. Cell-divisions take place within the spore before the rupture of the outer coat (exosporium), a plate of four cells, sometimes a mass of a larger number of cells, being formed. By the expansion of these cells the exosporium is burst; one or more of the peripheral cells then grow out into branched filaments which grow apically, segments being formed by successive transverse walls; longitudinal walls are also formed, so that the fila.
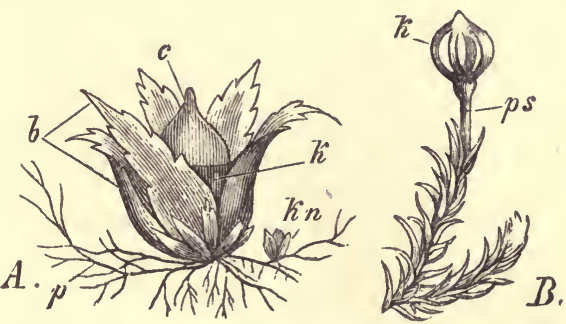

Frg. 249.-A Plant of Ephemerum serratum, one of the Bryineæ $(\times 20): p$ protonema ; $k n$ bud; $b$ leaves; $k$ sporogonium; c calyptra. B Andiecea petrophila $(\times \theta)$ : ps pseudopodium; $k$ capsule which has dehisced.

ments consist of two or more longitudinal rows of cells, and may develope into flattened lobed plates of tissue. In some cases cell-divisions take place in three dimensions, so that the protonema becomes cylindrical, consisting of four rows of cells, and produces filamentous branches; these cylindrical shoots become erect, and present a shrubby appearance. Erect, flat, leaf-like plates of tissue may be formed as lateral outgrowths on the protonema, resembling similar structures in other Mosses [e.g. Tetraphis (Georgia) pellucida; Tetrodontium Brownianum]. All these forms of protonema, except the leaf-like structures, give rise to adult shoots as lateral buds.

The Murphology of the Adult Shoot. The adult shoot consists of a short main stem, closely covered with leaves, and is more or less branched. In an old shoot the branch-system is a sympodium: the lateral branches are produced laterally at the growing-point, and when, owing to the formation of reproductive organs at the apex, the growth of a main stem is arrested, they become nearly erect and continue the growth of the shoot. Growth is apical, and is 
effected by means of a three-sided apical cell. The leaves are sessile, the lower leaves are small and deciduous.

The Sexual Organs are borne in terminal groups on the shoots; the male and female organs are always borne on distinct branches, generally on the same plant (monœcious), or on distinct plants (diœcious): since, in both cases, the apical cell of the shoot gives rise to a sexual organ, the growth of the shoot is arrested by the development of the reprodnctive organs. The group of sexual organs is surrounded by involucral leaves, and amongst them are developed filamentous paraphyses. The antheridia have short stalks: the archegonia have short stalks and very long necks.

The Structure of the Adult Shoot is simple; there is no central strand ; the peripheral cells are narrower than the internal cells, and their walls are of a yellowish colour.

The leaves consist of a single layer of cells all containing chloroplastids : in some species there is a midrib consisting of several layers of cells.

B. The Sporophyte. A two-sided lenticular apical cell is formed, in the epibasal cell, by two oblique intersecting walls, from the two sides of which about twelve segments are alternately cut off. In the upper segments cut off from the apical cell the amphithecium and the endothecium are differentiated; the two lower segments (on each side) form the short seta of the sporogonium. The hypobasal cell undergoes a few divisions to form the foot.

The archesporium is differentiated from the external layer of the endothecium, the rest of the endothecium forming the columella. The archesporium has the form of a hollow cone, covering the top of the columella; no intercellular spaces are formed.

When the calyptra is ruptured, the upper portion is borne on the top of the capsule as a cap; the lower, the vaginula, invests the short seta. The capsule dehisces by four longitudinal fissures, extending to neither the base nor the apex $($ Fig. 249 B) : there is no operculum, or peristome, nor has the wall of the capsule any stomata.

The shoot is stimulated to growth, after fertilisation, producing a short leafless pseudopodium, which carries up with it the unfertilised archegonia of the group: the perichætial leaves also develope, and invest the base of the pseudopodium.

The Andreæaceæ are small cæspitose Mosses (Fig. 250 b) growing on rocks in mountainous districts. The order consists of the single genus Andreæa.

Order III. Archidiaceæ.

A. The Gametophyte. The protonema is filamentous, and the subterranean portions of it are perennial : it gives rise to numerous adult shoots.

The Morphology of the Adult Shoot. The adult shoot consists of a very short stem with"scattered leaves. It bears lateral branches, both sterile and fertile: the former are long and decumbent, and give rise in the succeeding year to erect fertile shoots. The male and female organs are either borne, together with paraphyses, terminally on distinct branches of the same plant; or the antheridia are borne singly in the axils of the perichætial leaves of the female receptacle.

The Structure of the Adult Shoot. There is a central strand of conducting tissue, surrounded by parenchymatous cells; externally is a layer of narrow 
thick-walled cells. The leaves have a prominent midrib; the lamina consists of a single layer of cells.

B. The Sporophyte. The first stages of the development resembles those of Andreæa. The epibasal half of the embryo grows for a short time by means of a two-sided apical cell. It undergoes differentiation, by the formation of periclinal walls, into amphithecium and endothecium; in the upper two-thirds, of the capsule the innermost layer of the amphithecium becomes separated from the outer layers, a large intercellular space being formed between them. There is no archesporial layer or columella, but isolated internal cells of the endothecium are spore-mother-cells, each giving rise to four spores. The lower part of the epibasal half forms the very short seta or neck. The hypobasal half gives rise to a bulbous foot. There are no stomata on the capsule.

The ruptured calyptra surrounds the base of the sporogonium as a vaginula; no portion of it is raised up on the top of the capsule. The capsule ruptures irregularly.

The order includes the genus Archidium with the single species A. phascoides (alternifolius.)

Order IV. Bryineæ.

A. The Gametophyte. The protonema is filamentous, though in some cases (e.g. Tetraphis pellucida and other Georgiaceæ) it develops flattened cellular appendages which are assimilatory organs (see Andreæaceæ, p. 365). The sub-aërial portion of the protonema is generally short lived, though in some cases it persists (e.g. Ephemerum) at least until the sporogonium has been developed and the spores are ripe: the subterranean portion frequently persists from year to year. The subaerial portion gives rise to the gametophores as lateral buds; in some forms the subterranean portion produces lateral buds in the form of bulbils (p. 355) which, when they are brought to the surface, give rise to gametophores either directly or indirectly with the intervention of protonema. It is commonly the case that, when protonema is kept dry, some of the cells grow larger and their walls thicker, whilst the other cells perish; the persistent cells, when moistened, develope into filaments.

The Adult Shoot does not present, with regard either to its morphology or its histology, any especially characteristic features; it varies in size from a mere bud in such forms as Phascum and Ephemerum, where it is annual, to a shoot several inches long in such forms as Fontinalis and Polytrichum where it is perennial. In the latter case there is generally a central strand, and frequently leaf-traces, in the stem. It may be either acrocarpous or pleurocarpous, a feature which is important in the classification of the group. The leaves have commonly a midrib : those of Leucobryum resemble those of Sphagnum in that they consist of two kinds of cells, an internal layer of small living cells with chloroplastids, and external layers of dead cells with perforated walls ; the peculiar structure of the leaves of Polytrichum has been already described (p. 359).

B. The Sporophyтe presents features, both as to its morphology and histology, which are characteristic of the group. It is differentiated into a true hypobasal foot, a seta, and a capsule. The true foot is rudimentary. The seta is relatively short in the lower forms: a false (epibasal) foot is frequently developed from the lower portion of the seta. The neck of the capsule has nearly always stomata in its epidermis, and is developed into a distinct. 
apophysis in some forms (e.g. Splachnum, Po'ytrichum). Part of the external layer of the endothecium becomes the archesporium, which forms a hollow cylinder round the columella, but does not extend over the top of it: an airchamber is developed in the amphithecium round the spore-sac, and is generally traversed by strands of cells (containing chloroplastids) stretching from the wall of the capsule to the spore-sac. In the lower forms the capsule is either indehiscent, its wall becoming eventually disorganised, or it ruptures irregnlarly; in the higher forms, the apical portion of the wall is thrown off as an operculum, and a peristome is generally developed round the aperture thus formed. In all cases a portion of the calyptra is carried up as a cap on the top of the developing sporogonium.

The Bryineæ are classified as follows :

\section{Tribe I. Cleistocarpæ.}

Tribe II. Stegocarpæ.

Tribe I. Cueistocarpes. The adult shoots are generally minute, unbranched, annual, and always acrocarpous; there is generally a central strand in the stem, and a mid-rib in the leaf.

With regard to the sporogonium, the seta is generally short, sometimes expanded at the base into a false (epibasal) foot (e.y. Phascum, Ephemerum), without any central strand in some forms.

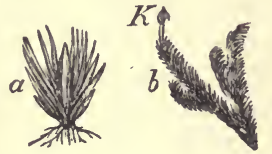

Frg. 250.-a Ephemerum seratum ( $\times 3): b$ shoot of Andreaa nivalis, with $(K)$ capsule (nat. size). The capsule does not open by means of an operculum, nor has it any peristome (a rudimentary operculum can be detected in Astomum, Mildeella, and a few other forms, as also a rudimentary peristome in Mildeella); it either ruptures irregularly, or the wall simply decars.

The following are the principal families and genera of the Cleistocarpæ:

Fam. 1. Ephemeracere : Ephemerum (Fig. 249 d), Nanomitrium.

, 2. Physcomitrellacea: Physcomitrella.

" 3. Phascacea : Phascum, Acaulon, Mildeella, Astomum.

" 4. Bruchiacea: Pleuridium, Bruchia.

, 5. Voitiacece : Voitia, by far the largest forms in the tribe.

Tribe II.-Stegocarpe. The characteristics of this tribe are to be found in the sporogonium, which is distinguished by the formation of an operculum and, generally, of a peristome.

The operculum is developed from the apical portion of the capsule, either from the epidermis alone (e.y. Georgiaceæ), or from it and one or more of the subjacent amphithecial layers. The cell-walls become cuticularised and assume $\mathrm{n}$ yellow or brown colour. The outline of the operculum is circular; its form cap-like, more or less flattened in some cases, more or less conical in others, sometimes apiculate.

The limit between the developing operculum and the rest of the capsu!e (urn) is generally marked by a slightly prominent zone, consisting of one or more rows of rather large epidermal cells, with cuticularised outer walls, termed the ring or annulus : its position is just above the level of the top of the spore-sac and of the air-chamber.

The peristome is developed within the operculum, from the innermost layer 
or layers of the amphithecial cells, the entire walls, or only portions of the longitudinal and transverse walls, of larger or smaller plates of these cells, become thickened, cuticularised, and coloured yellow or brown. The unthickened cell-walls, or the unthickened portions of them, break away as the capsule becomes ripe, leaving only the thickened portions forming, as it were, a skeleton attached to the urn just below the level of the annulus. The following are the principal varieties of peristome-formation. In the Georgia. ceæ (e.g. Tetraphis) the peristome is developed from the two layers of cells beneath the epidermis which forms the operculum: the walls of these cells all become thickened; when the operculum falls off this plate of tissue splits from the centre into four equal segments which are the teeth of the peristome. In most Mosses the peristome is formed from a single layer of cells, and consists of two rows of teeth, an inner and an outer. This double peristome is dependent upon the distribution of

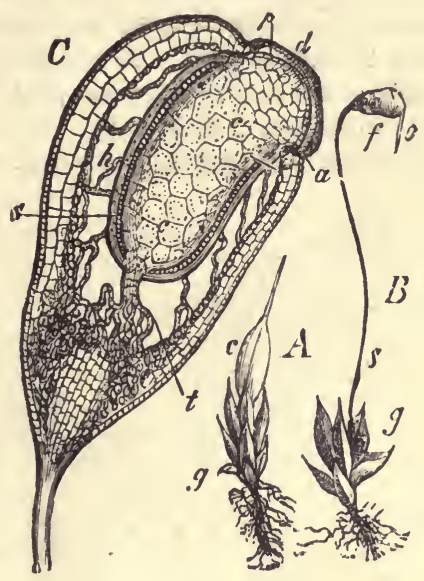

Frg.251.-Funaria hygrometrica. A An adult shoot $(g)$, bearing a calyptra (c). B A plant ( $g$ ) bearing a nearly ripe sporogonium; $s$ its seta; $f$ the capsule; $c$ the calyptra. C Median longitudinal section of the capsule: $d$ operculum; $a$ annulus; $p$ peristome ; $c c^{\prime}$ columella; $h$ air-cavity; $s$ the archesporium. the cuticularisation of the walls: both the internal and the external walls of the peristomial cell-layer become cuticularised, but the lateral and part of the transverse walls joining them remain unaltered and eventually break away, leaving the thickened internal and external walls as separate strips, which may be further divided longitudinally into teeth. The teeth of the outer peristome are generally larger than those of the inner which are sometimes dis-

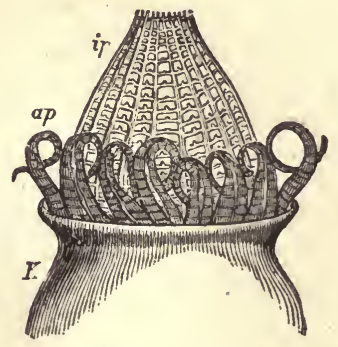

FiG. 252.-Mouth of the theca of Fontinalis antipyretica. ap Outer peristome; ip inner peristome. ( $x$ 50.) tinguished as cilia; their number is a power of two (4-8-16-32-64.) There is considerable variety in the structure and form of the peristome; this affords a means of classification. The genus Polytrichum, for instance, is characterised by the fact that the teeth of the peristome consist of strands of thickwalled fibres, the tips of which are not free, as is usually the case, but are connected by a membrane stretched over the aperture of the urn, termed the epiphragm.

A peristome is not present in several genera (e.g. Gymnostomum, Hymenostomum, Schistostega, etc.); nor in some species (e.g.

V. S. B. 
species of Pottia and Encalypta, Seligeria Doniana, Orthotrichum gymnostomum, etc.) belonging to genera in which a peristome is usually present.

As the capsule matures, the cells (except the spores) lose their cell-contents ; and those whose walls have not become thickened and cuticularised, dry up and shrink, the shrinkage being necessarily accompanied by the tearing of the thin walls in various parts. The persistent cuticularised walls are highly hygroscopic, and it is in consequence of the tensions set up by the unequal stretching and contraction of these walls, due to variations in their moisture, that the splitting off of the operculum is effected.
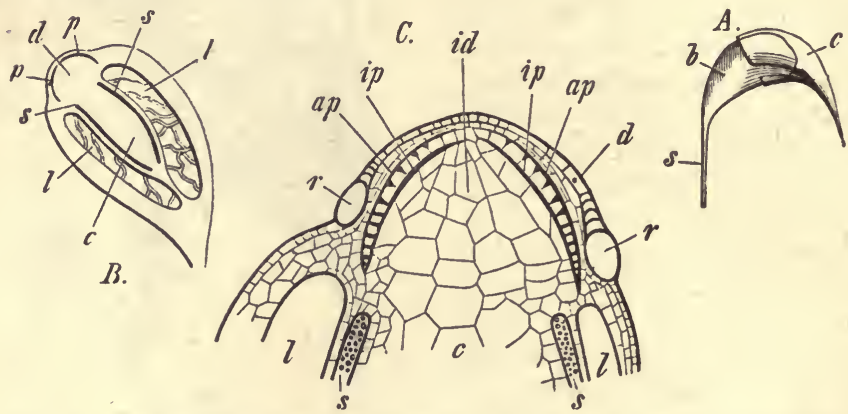

FrG. 253.-Sporogoninm of Funaria hygrometrica. A, s seta; $b$ capsule; $c$ calyptra $(\times 5)$. $B$ Section of a half-developed capsule $(\times 10): c$ columella ; 8 archesporium; $l$ air-cavity ; $d$ sub-opercular tissue; $p$ peristome. $C$ Apical portion of the same capsule $(\times 40)$; $d$ operculum; $i d$-sub-opercular tissue; ap outer peristome; ip inner peristome; $r$ ring; $l$ airepace; c columella; s spore-sac.

The Stegocarpæ are classified as follows:-

Sub-tribe ACROCARPE : archegonia terminal on the main shoots; but the sporogonia are sometimes apparently lateral in consequence of the growth of lateral branches (innovations) which force the apex of the main shoot to the side. The following are the principal families and genera :-

Fam. 1. Weisincea : Hymenostomum, Gymnostomum, Weisia.

"2. Dicranacea: Dicranum, Dicranella.

"3. Leucobryacea : Leucobryum.

" 4. Fissidentacee : Fissidens.

" 5. Seligeriacea : Seligeria-small mosses growing only on rocks.

6. Pottiacea : Pottia, Tortula, Barbula, Trichostomum, Ceratodon.

"7. Grimmiacea : Grimmia, Racomitrium, Hedwigium.

" 8. Orthotrichacea : Orthotrichum, Zygodon.

"9. Encalyptacea : Encalypta.

"10. Georgiacea : Georgia (Tetraphis), Tetrodontium.

, 11. Schistostegacea: Schistostega.

" 12. Splachnacea: Dissodon, Tayloria, Splachnum.

, 13. Funariacea : Physcomitrinm, Funaria.

14. Mniacea : Mnium, Meesia, Aulacomnium.

, 15. Bryacea : Bryum, Webera.

16. Polytrichacea : Atrichum, Polytrichum, Pogonatum.

"17. Buxbaumiacea: Buxbaumia. 
Sub-Tribe PLEUROCARPE : Archegonia (and subsequently the sporogonia) borne terminally on short lateral branches. The following are the principal families and genera :-

Fam. 18. Fontinalacea : Fontinalis.

"19. Neckeracea : Neckera, Leptodon, Leucodon.

"20. Hookeriacea : Daltonia, Hookeria.

, 21. Fabroniacece : Fabronia, Anacamptodon, Myrinia.

" 22. Thuidiacea: Leskea, Thuidium.

"23. Hypnacea : Climacium, Brachythecium, Hypnum, Hylocomium, Eurhynchium.

The following are among the more familiar species of acrocarpous Mosses :-

Dicranum scoparium, with sickle-shaped leaves, is common in woods. "Leucobryum glaucum has leaves consisting of several layers of cells, which resemble those of Sphagnum in their structure; it occurs in Pine-woods and on moors. Ceratodon purpureus, with a red seta and a short stem, is very common in various localities. Barbula muralis grows in patches on walls and rocks; the midrib of the leaves is prolonged into a bair, so that the patches of Moss look greyish. Tetraphis pellucida has bright green leaves; it grows on decayed tree-trunks, and bears gemmæ of peculiar form. Grimmia pulvinata occurs on walls and stones in round greyish-green patches; the capsules have very short setæ. Orthotrichum affine and other species have also shortlystalked capsules, and are common on trees. Funaria lygrometrica (Figs. 251-3) has an oblique, pearshaped capsule; the long setæ have the peculiarity of contracting into a spiral on being wetted and dried; it is common on walls and paths. Polytrichum formosum (Fig. 254) and other species are the largest of our indigenous acrocarpous Mosses; they have large dark green leaves and long hairy calyptræ, and are common in woods and on heaths.

The following are among the more familiar species of pleurocarpous Mosses:-

Fontinalis antipyretica floats in water. Neckera crispa, with flat outspreading leaves, grows on rocks. Thuidium abietinum and other species grow on banks and in woods; they have regular, pinnately branched stems, and very small, closely-set leaves. Leucodon sciuroides is common on tree-trunks. Brachythecium rutabulum is common in woods. Eurhynchium prcelongum, with long creeping stems,

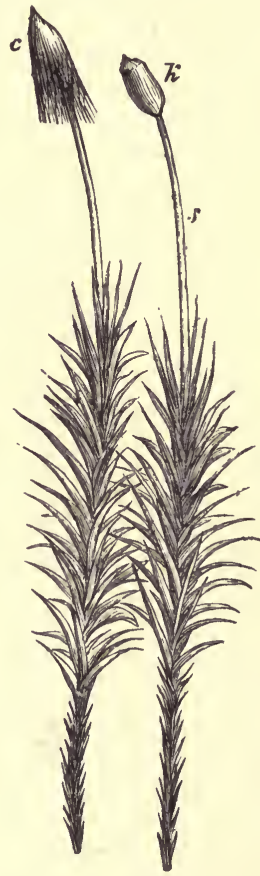

Fig. 254. -Two plants of Polytrichum formosum bearing sporogonia (nat. size). $k$ The capsule; $s$ the seta; c calyptra. occurs in woods and damp gardens. Hypnum cupressiforme is very common on tree-trunks, and $H$. cuspidatum and giganteum in bogs and ditches. Hylo. comium triquetrum is very commonly used for garlands; this and H. splendens, with remarkably regular ramification, are both common in woods. 


\section{GROUP III. \\ PTERIDOPHYTA (Vascular Cryptogams).}

The distinguishing characteristics of the plants forming this group are the following :-The life-histor'y presents a well-marked alternation of generations, as in the Bryophyta; but here it is the sporophyte which is the more conspicious form, constituting "the plant." The sporophyte becomes quite distinct from the gametophyte at an early period: it is differentiated (with but few exceptions) into root, stem, and leaf; and in all cases it contains well-developed vascular tissue. The gametophyte, generally termed the prothallium, is a relatively small thalloid body, usually short-lived, containing no trace of vascular tissue.

The group includes the three classes, Filicinæ, Equisetinæ, Lycopodinæ.

The SpoRophyte is developed from the oospore: its embryogeny is direct and holoblastic. The oospore undergoes division, in all cases, into an epibasal and a hypobasal half, by a basal wall which is either more or less nearly parallel to the long axis of the archegonium (Leptosporangiate Filicinæ) or more or less nearly transverse to it: the epibasal half usually faces the neck of the archegonium, but in the Lycopodinæ the hypobasal half occupies this position. In the Filicinæ and Equisetinæ, the formation of the basal wall is followed by the formation of another wall at right angles to it (quadrant-wall) so that the embryo now consists of four cells which are quadrants of a sphere, and this is followed by the formation of a third wall (octant-wall), at right angles to both the preceding, so that the embryo now consists of eight cells which are octants of a sphere. In the Lycopodinæ the segmentation leading to the formation of quadrants and octants is confined to the epibasal half, the hypobasal half remaining undivided or undergoing a few irregular divisions. From the epibasal half, the primary stem and one or two primary leaves (cotyledons) are developed in all cases. The hypobasal half gives rise, in the Filicinæ and Equisetinæ, to the primary root and to the foot, with but few exceptions (e.g. Salvinia in which there is no primary root) : in the Lycopodinæ the hypobasal half gives rise to a suspensor, an organ homologous with the foot of the Bryophyta.

The foot (as also the suspensor: see p. 14) is an embryonic 
organ, no trace of which persists in the adult. It is the organ of attachment of the embryo-sporophyte to the gametophyte; and it is also the absorbent organ by which the embryo, until it is able to absorb and assimilate food for itself, obtains its nourishment from the prothallium (compare Bryophyta, p. 330).

The development of a suspensor in the Lycopodinæ is an adaptation correlated with the fact that the nourishment of the embryo in that group depends upon its coming into direct contact with the tissue of the massive gametophyte, the cells of which are filled with nutritive substances.

A primary root, that is, a root developed from the hypobasal half of the oospore, and so situated at its origin that its growing-point is in a straight line with that of the stem (see p. 15), only occurs in the Filicinæ and Equisetinæ; but even here it does not persist as a tap-root in the adult: in these plants numerous adventitious roots are developed. In the Lycopodinæ, where there is no primary root, all the roots are adventitious.

Some adult forms are altogether without roots: as Salvinia, and some species of Trichomanes, among Filicinæ; Psilotum and Tmesipteris, among Lycopodinæ. The functions of the root are discharged, in Salvinia by modified leaves, in the others by modified branches. In the absence of information as to the embryogeny of these rootless plants, except Salvinia, it is not possible to state definitely that they are, like Salvinia, rootless from the first: for it is conceivable that they may have a short-lived primary root which entirely disappears as the embryo developes.

The branching of the root is generally lateral in the Filicinæ and Equisetinæ; it is dichotomous in the Lycopodinæ and in Isoetes. In the former case, the lateral rootlets are developed, in the Filicinæ, from cells (rhizogenic) of the endodermis which are opposite to the xylem-bundles of the stele; in the Equisetinæ, from the cells forming the inner layer of the two-layered endodermis.

The stem is generally short and unbranched in the Filicinæ; generally elongated and much branched in the Equisetinæ and Lycopodinæ.

The leaves are differentiated into foliage-leares and sporophylls in the Equisetinæ and generally in the Lycopodinæ, but not in the Filicinæ as a rule: the foliage-leaves are relatively large in proportion to the stem in the Filicinæ, relatively small in the Lycopodinæ, reduced to cataphylls in the Equisetinæ. 
The growth in length of root, stem, and leaf, is effected by an apical growing-point: the growing-point has generally a single apical cell in the Filicinæ and Equisetinæ (except root and stem of Marattiaceæ and Isoetes); in the Lycopodinæ (as also in the foregoing exceptional Filiciuæ) there is generally a group of initial cells.

The anatomy of the stem presents considerable variety. The primary stem is in all cases monostelic (p. 152): it may continue to be monostelic (e.g. Lycopodiaceæ, Isoetes, Osmundaceæ, etc.), but more commonly it becomes polystelic (most Filicinæ), or schizostelic (Equisetinæ, Ophioglossaceæ). The vascular tissue of the wood consists of lignified spiral (protoxylem) and scalariform tracheides, or less commonly vessels; the bast contains no companion-cells. The bundles are generally closed (except Botrychium, Helminthostachys, Isoetes); cauline (except Isoetes, Osmunda, Equisetinæ, where they are common). The relative arrangement of wood and bast in the stele is generally concentric (see p. 175) in the Filicinæ and Selaginellaceæ, and radial in the Lycopodiaceæ: or the bundles may be conjoint and collateral as in Ophioglossaceæ, Isoetaceæ, Osmundaceæ, Equisetinæ. The pericycle is sometimes absent (e.g. Ophioglossum; some Leptosporangiate Filicinæ, in which it is replaced by a layer of the endodermis).

The anatomy of the root calls for no special remark, except that in the Equisetinæ there is no pericycle, but a two-layered endodermis.

The reproductive organs are sporangia, generally borne on the leaves (sporophylls) but sometimes directly on the stem (e.g. Selaginella). Each sporophyll may bear many sporançia on its inferior (dorsal) surface, as generally in the Filicinæ and Equisetinæ; or a single sporangium on its upper surface (e.g. Lycopodinm, Isoetes), or in its axil (Selaginella).

When the sporophyll bears many sporangia, they are usually arranged in groups; each group is termed a sorus, and the more or less well-developed cushion of tissue from which the sporangia spring is termed the placenta. The sorus may be naked; or it may have a membranous covering, the indusium (e.g. many Filicinæ).

In the Filicinæ the sporophylls are not confined to any special portion of the shoot, so as to constitute a flower: but in some cases (e.g. Osmunda, Ophioglossaceæ, Marsileaceæ) they differ in form and structure from the foliage-leaves. In the Equisetinæ the sporophylls are highly specialised, and are grouped-into cones 
(flowers) at the ends of the fertile branches: similar cone-like flowers, with less specialised sporophylls, occur in various Lycopodinæ.

The sporangia are unilocular, though in Isoetes they are incompletely chambered by trabeculæ: they are developed singly or in groups (sori); in the latter case they are usually distinct, but in some cases they are coherent (Marattiaceæ, except Angiopteris ; Psilotaceæ) forming a synangium (see p. 72): the synangium should not, however, be regarded as the result of the cohesion of originally distinct sporangia, but as a group of sporangia which have not separated. The sporangium is developed either from a single superficial cell (leptosporangiate); or from a group of superficial cells (eusporangiate), and sometimes from deeper cells as well : the mother-cells of the spores are derived from an archesporium which is either a single hypodermal cell or a group of hypodermal cells.

The spores produced in the sporangia; are single cells, with generally two coats, endospore and exospore. Many of the Pteridophyta produce spores which are all quite alike, whence they are said to be homosporous; whereas others produce spores of two kinds, small spores (microspores) and large spores (macrospores), and are said te be heterosporous.

The sporangia of the heterosporous forms are distinguished as microsporangia and macrosporangia according to the kind of spores which they develope : and when the sporophylls bear either only microsporangia or only macrosporangia they are distinguished as microsporophylls and macrosporophylls. The number of macrospores produced in the macrosporangium is generally small, though they are numerous in Isoetes : thus there are four in Selaginella, only one in the Hydropterideæ.

The spores are generally set free by the dehiscence of the sporangia: but in Salvinia the whole sporangium falls off and the spores germinate within it.

B. The Gametophyte. The spore, on germination, gives rise to a prothallium which is the gametophyte. It is very small and inconspicuous, as compared with the sporophyte; its body is, generally speaking, thalloid; there is no vascular tissue in its structure, and in many cases it does not become free from the spore. It usually lives through but one short period of growth.

In any one of the homosporous forms, the prothallia developed from the spores are all essentially alike; generally speaking, any 
one prothallium bears both male and female reproductive organs. The morphology of the prothallium varies widely in these forms: it may be a branched cellular filament (some Hymenophyllaceæ), or a flattened expansion (Equisetinæ, most Ferns), containing chlorophyll abundantly; or it is tuberous (Ophioglossaceæ, Lycopodiaceæ), either wholly or in part destitute of chlorophyll. It becomes entirely free from the spore.

"In the heterosporous forms the gametophyte is represented by two individuals - a male and a female prothallium; the former is the product of the germination of a microspore, the latter of the germination of a macrospore. As compared with those of the homosporous forms, the prothallia of the heterosporous forms are relatively small; moreover they do not become independent of the spores from which they are developed. The male prothallium is reduced to little more than a single male organ; the female prothallium is a small, usually green, cellular body projecting more (e.g. Salvinia) or less (e.g. Selaginella) through the ruptured outer coat of the macrospore.

Generally speaking, the symmetry of the prothallium is dorsiventral; in the free-growing forms, the under surface generally bears numerous unicellular root-hairs. In some cases the prothallium shows more or less well-marked differentiation into a vegetative portion and a gametophore which may bear either both kinds of sexual organs, or, more commonly, one kind only; when the gametophore bears only male organs it is distinguished as an antheridiophore; when only female organs, as an archeyoniophore. The distribution of the sexual organs on the prothallinm varies; they are frequently confined to one surface, but are occasionally scattered over the whole surface. The number of the sexual organs on a prothallium is in some cases only one, in others it is considerable.

The sexual organs are antheridia (male) and archegonia (female). The structure of the antheridium is simple; it consists of a wall, a single layer of cells, enclosing the mother-cells of the spermatozoids. The antheridia are developed from single superficial cells of the prothallium; when the prothallium is thin, the antheridia project on the surface; when the prothallium is tuberous, the antheridia become sunk in the tissue.

The archegonium consists of a venter and a neck. As the venter is, in all cases, sunk in the tissue of the prothallium, it has no proper wall of its own, and is, in fact, simply a cavity in the 
tissue; the short neck consists of a single layer of cells in four rows. The mature archegonium contains, in the venter, the female cell (oosphere).

The archegonium is dereloped from a single superficial cell of the prothallium. This cell divides transversely into two, an upper and a lower; the former, by growth and division, forms the neck of the archegonium; the lower cell projects into the developing neck, and the projecting portion becomes cut off, constituting the neck-canal-cell which sometimes divides again into two (Marattiaceæ, Lycopodium); the remainder, now termed the central cell of the archegonium, divides transversely into two unequal parts, the upper and smaller being the ventral canal-cell, the lower and larger being the oosphere: As the archegonium becomes mature, the canal.cells become mucilaginous, the neck opens by the separation of the cells at the apex, and the archegonium is ready for fertilisation.

The male cell, or spermatozoid, is a naked motile cell; it is a spirally coiled filament, pointed at the anterior end which bears the cilia, becoming thicker towards the opposite end; the cilia are numerous in Filicinæ (incl. Isoetes) and Equisetinæ; two in Lycopodinæ.

Each spermatozoid is developed singly in a mother-cell in the antheridium; it consists of kinoplasm with a nucleus (see p. 116). 'The whole of the contents of the mother-cell are not, however, devoted to the spermatozoid: a portion remains unused, and is discharged together with the spermatozoid, to which it adheres for a time as a protoplasmic vesicle containing, amongst other constituents, a portion of the nuclear substance of the mother-cell (see Fig. 266).

The female cell, or oosphere, is a naked spherical cell lying in the venter of the archegonium. Its development is described above.

Fertilisation is effected by the entrance of spermatozoids into the open neck of the mature archegonium, and the subsequent fusion of one of them with the oosphere. When, as is usually the case, numerous prothallia are developed near together on the ground, and become wetted by rain or dew, the ripe antheridia burst and set free the spermatozoids which, swimming actively in the water, are attracted to the mature archegonia by means of an acid excretion which is discharged from the neck of the archegonium when it opens. The effect of fertilisation on the oosphere is that it at once surrounds itself with a cell-wall becoming the oospore, and then begins to develope into the young sporophyte. 
In a few cases (e.g. species of Trichomanes and Lycopodium) the gametophyte (prothallium) multiplies vegetatively by means of gemmæ, which are short spindle-shaped rows of cells in the one case, and globular multicellular bodies in the other.

The Life-History of the Pteridophyta presents in all cases, a perfectly clear alternation of generations, the sporophyte and the gametophyte being completely distinct. The oospore developes into "the plant," be it Fern, Equisetum, or Lycopod, which bears the sporangia and spores, and is the sporophyte. The spores, when shed, germinate to form the gametophytes (prothallia) bearing the sexual organs.

In some cases among the Ferns, the transition from the one generation to the other may be affected without the intervention of a spore of any kind. Thus (e.g. Pteris cretica, Aspidium falcatum, Todea africana), the sporophyte is developed from the gametophyte without the intervention of an oospore; there are either no archegonia on the prothallium (Pteris cretica), or if present they are sterile; the sporophyte is developed as a bud upon the prothallium (apogamy, see p. 87). Again, in other species (Polystichum angulare var. pulcherrimum, Athyrium Filix-fomina var. clarissima), the gametophyte is developed from the sporophyte without the intervention of the asexually-produced spores (apospory, see p. 87): in the latter plant sporangia are developed, but instead of producing spores they grow out into prothallia; in the former plant there is no trace of any sporangia, and the prothallia are formed as outgrowths on the tips of the leafpinnæ.

The Pteridophyta are classified as follows :-

Class V. FILICINA. The sporophyte is characterised by having relatively large and few leaves; the sporophylls are generally similar to the foliage-leaves and are not aggregated into flowers; the sporangia are numerous on the sporophyll (except Isoetes) and are arranged in sori; the archesporium is a single cell (except Isoetes); the embryo has a primary root (except Isoetes, Salvinia, 'and possibly some species of Trichomanes) but no suspensor.

The characters of the gametophyte vary widely. The spermatozoids are multiciliate.

Sub-Class HoMosporex. The sporophyte produces spores of one kind only; the prothallia are, as a rule, monœcious, and become free from the spore. 
Section Eusporangiatæ. Each sporangium is developed from a group of superficial cells.

\section{Order 1. Ophioglossacece. Order 2. Marattiacece.}

Section Leptosporangiatæ. Each sporangium is developed from a single superficial cell. (Filices in limited sense).

Order 1. Osmundaceo.

"2. Schizoeaceos.

"3. Gleicheniaceo.
Order 4. Polypodiacece.

"5. Cyatheacece.

", 6. Hymenophyllacece.

Sub-Class Heterosporee. The sporophyte produces microspores and macrospores; the former give rise to male, the latter to female, prothallia; the prothallia do not become free from the spore.

Section Eusporangiatæ. Each sporangium is developed from a group of superficial cells.

\section{Order 1. Isoetacene.}

Section Leptosporangiatæ. Each sporangium is developed from a single superficial cell, (Rhizocarpæ or Hydropterideæ).

\section{Order 1. Salviniacece. Order 2. Marsileacece.}

Class VI. EQUISETIN Æ. The sporophyte is characterised by the well-developed branched stem, with small whorled leaves forming a sheath at each node; the small peltate sporophylls are aggregated into a cone-like flower at the apex of each fertile shoot, and bear a few sporangia on the inner (inferior) surface; the archesporium is a single cell; the embryo has a primary root and no suspensor. All the existing forms are homosporous and eusporangiate.

The gametophyte is a free, green, membranous prothallium, generally diœcious; the spermatozoids are multiciliate.

\section{Order 1. Equisetacece.}

Class VII. LYCOPODIN A. The sporophyte is characterised by the well-developed branched stem with numerous small scattered leaves; the sporangia are borne singly either on the upper surface of a sporophyll, or on the stem; the sporophylls resemble the foliage-leaves, but are sometimes aggregated into cone-like flowers; 
the archesporium is multicellular; the embryo has a suspensor, but no primary root. All the existing forms are eusporangiate.

The characters of the gametophyte vary widely. The spermatozoids are biciliate.

Sub-Class Homospores: the sporophyte produces spores of one kind only; the prothallia are free, more or less tuberous, monœecious.

Order 1. Lycopodiacece. Order 2. Psilotacece.

Sub-Class Heterosporea: the sporophyte produces microspores and macrospores; the former gives rise to male, the latter to female, prothallia; the prothallium does not become free from the spore.

\section{Order 1. Selaginellacece.}

The relations of these various groups may be simply expressed as follows :-

Filicine. Equisetine. Lycopodine.

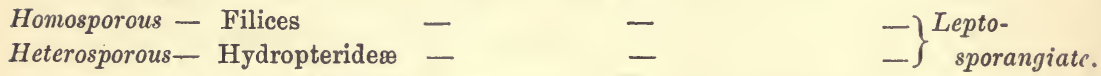

$$
\begin{aligned}
& \begin{array}{l}
\text { Homosporous - } \left.\left\{\begin{array}{l}
\text { Ophioglossaceæ } \\
\text { Marattiaceæ }
\end{array}\right\}-\text { Equisetaceæ }-\left\{\begin{array}{l}
\text { Lycopodiaceæ } \\
\text { Psilotaceæ }
\end{array}\right\}\right\}- \text { Eusporangiate. } \\
\text { Heterosporous - Isoetaceæ }- \text { (none existing)- Selaginellaceæ }
\end{array}
\end{aligned}
$$




\section{CLASS V.-FILICIN A.}

The mutual relations of the orders forming this class are clearly expressed in the following table:-

\author{
Homosporece. Ophioglossace
Marattiaceæ.
}

Leptosporangiatce. Osmundaceæ. Schizæaceæ. Gleicheniaceæ. Polypodiaceæ. Cyatheaceæ. Hymenophyllaceæ.

Heterosporece. Isoetaceæ.
Salviniaceæ. Marsileaceæ.

\section{A. Homosporous Eusporangiate.}

Order 1. Ophioglossaceæ. This order includes the three genera Ophioglossum, Botrychium, and Helminthostachys.

Sporophyte. The stem is a subterranean rhizome (except in epiphytic Ophioglossums), which does not branch at all in Ophioglossum, and but little in Botrychium and Helminthostachys; it is usually short and erect, but in Helminthostachys it is elongated, dorsiventral, and creeping. The rather thick and fleshy roots are unbranched in Ophioglossum, but they give rise to adventitious buds; they are branched in Botrychium and Helminthostachys, and produce no buds. The leaves are developed close together at the apex of the rhizome, and are not circinate, or only slightly so, in vernation; their growth is so slow that a leaf does not appear above ground until the fifth year after its first development; generally, only a single leaf appears above ground each year, when more are developed some of them are sterile. The sporophylls are remarkable for their peculiar branching (see p. 51); they are petiolate, and the petiole branches into two, the one bearing a sterile and the other a fertile lamina (Fig. 255), the fertile branch being situated on the ventral surface of the sterile; the sterile lamina is leafy, whilst the fertile lamina consists of little more than the sporangia. In Ophioglossum the sterile lamina is entire, and the fertile lamina is spicate with two lateral rows of sporangia; in Botrychium the sterile lamina is pinnate, and the fertile lamina is bi-pinnate with marginal sporangia; in Helminthostachys the sterile lamina is digitate pedate, and the fertile lamina is spicate with the sporangia in pedicellate clusters. The sporangia are embedded in the tissue of the sporophyll in Ophioglossum, but are free in Botrychium and Helminthostachys: they are not arranged in sori ; they are globose, have no annulus, but dehisce into two equal valves by a transverse (Ophio glossum, Botrychium) or vertical (Helminthostachys) slit; the wall of the sporangium consists of several layers of cells; the spores are numerous and tetrahedral; the archesporium is the hypodermal terminal cell of the axial row of cells in the young sporangium, and is not tetrabedral.

The sporophyte is characterised histologically by the absence of sclerenchyma, 
and by the schizostelic structure of the stem with collateral vascular bundles; the stem is also gamodesmic in Botrychium and Helminthostachys, which thus resemble Equisetum silvaticum (see Fig. 116), whilst Ophioglossum resembles Equisetum litorale. There is a single three-sided apical cell in the growingpoint of both stem and root. Ophioglossum is peculiar in that there is no

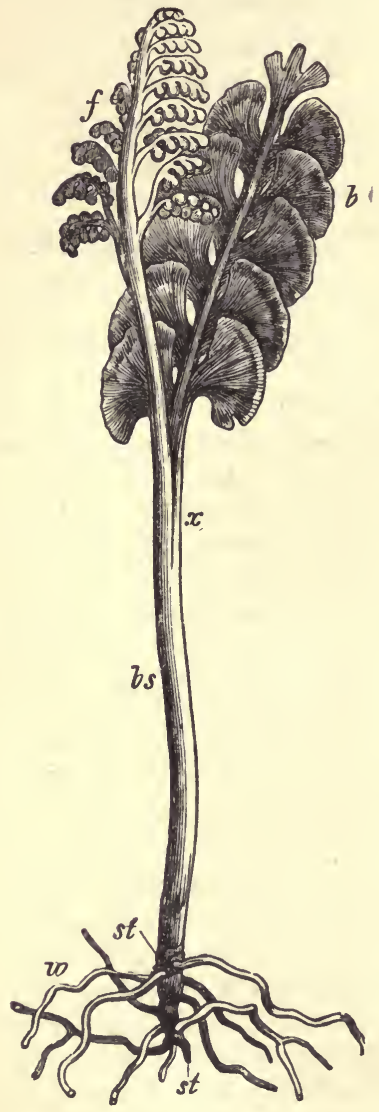

F1G. 255. - Botrychium Lunaria (nat. size): $w$ roots; st stem; bs leaf-stalk; $x$ point where the leaf branches; the sterile lamina (b) separating from the fertile branch (f). pericycle in the stele of either stem or root; and in that, in some species (O. vulgatum, lusitanicum, etc.) the stele of the root has two xylem-bundles, but ouly one bast-bundle. The collateral bundles of the stem of $\mathrm{Bo}$. trychium and Helminthostachys have rudi. mentary cambium, which gives rise to a few secondary xylem-tracheids; these two genera have also a formation of superficial cork on the stem, and sometimes on the root. Nothing is known as to the embryogeny of the sporophyte.

GaMeTophyte. The germination of the spores has not been observed, but the mature protballium has been described in the case of Ophioglossum pedunculosum and Botrychium Lunaria. In both cases it is tuberous, subterranean, destitute of chlorophyll, monœcious; the antheridia are sunk in the tissue, and the short necks of the archegonia project but little. It appears that the prothallium is saprophytic, though possibly it may possess chlorophyll in the early stages of its development. It is altogether undifferentiated in Botrychium, being a somewhat ovoid body not more than half a line long, with long seattered root-hairs, bearing the antheridia chiefly on its upper surface, the archegonia chiefly on the lower. In Ophioglossum pedunculosum it appears to be differentiated into a vegetative and a repro. ductive portion; it consists, at first, of a small round tuber from which springs a cylindrical shoot which grows upward to the surface of the soil. When the shoot reaches the surface it ceases to elongate and becomes lobed, assuming a green colour; it bears antheridia and archegonia, and is therefore a gametophore, as distinguished from the original tuber which bears no sexual organs.

Ophioglossum vulgatum (the Adder's tongue) is the British species of this genus; 0 . lusitanicum has, however, been found in Guernsey. The epiphytic species are $O$. pendulum and 0 . palmatum, both tropical forms; the latter has 
palmately-lobed sterile fronds. Botrychium is represented in the British Flora by $B$. Lunaria (the Moon-wort) which occurs in hilly districts. Helminthostachys includes the single species $H$. zeylanica which occurs in the Eastern tropics.

Order 2. Marattiaceæ. This order includes the genera Marattia, Angiopteris, Kaulfussia, and Danæa, none of which are European, but are mainly tropical.

Sporophyte. In its general morphology the sporophyte agrees with that of the Ophioglossaceæ; but the leaves are more numerous, much larger, compound, and circinate in vernation, and each bears a pair of stipules. Branching of the stem occurs only in Danæa ; in Kaulfussia the stem is a subterranean, creeping, dorsiventral rhizome. The roots are somewhat fleshy, and are much branched. The apical growing-point of both root and stem consists of a group of a few (four or more) initial cells. The sporophylls are not differentiated into a sterile and a fertile portion, but have the appearance of foliage-leaves. The numerous sporangia are borne in sori on the ribs of the under surface of the sporophyll ; in Angiopteris the sporangia of a sorus are free, whilst in all the other genera they are coherent, forming a synangium (see p. 72 and p. 375). The sporangia are not embedded in the placenta; they are generally sessile, but the synangium is sometimes (Marattia, sect. Eupodium) shortly stalked; they have no annulus; they dehisce generally by a longitudinal' slit on the inver side, but in Danæa by a single apical pore; the wall of the mature sporangium consists of several layers of cells. The archesporium is the terminal hypodermal cell of the axile row of cells of the young sporangium. The spores are numerous, and are either tetrahedral or radial.

The stem is polystelic; the arrangement of the phloem-and xylem-bundles of stem and leaf is completely concentric; there is no well-marked endodermis, except in Danæa; there is no sclerenchyma in Angiopteris, and in the other genera (except Danæa) it is not so well developed as in the leptosporangiate Ferns; the tissues are penetrated by lysigenous gum-passages.

The embryology of the sporophyte is known in Angiopteris and Marattia. The oospore divides by a basal wall which is transverse to the long axis of the archegonium; octants are then formed, as in the leptosporangiate Ferns; from the epibasal octants (furthest from the neck of the archegonium) arise the primary leaf (cotyledon) and stem; from the hypobasal octants (next the neck of the archegonium) arise the foot and the primary root; the cotyledon grows straight upwards and penetrates the tissue of the prothallium overlying it.

Gametophyte. On germination the spore gives rise to a dorsiventral green prothallium, which begins as either a plate or a mass of cells, and only rarely (under abnormal conditions) as a filament; it grows by an apical cell, and produces root-hairs posteriorly. A projecting cushion of tissue, representing a gametophore, is developed on the under surface in the median line; it produces first antheridia and then archegonia, so that, in a fully-developed prothallium, the antheridia are on the posterior and the archegonia on the anterior portion of the gametophore; some antheridia are, however, also developed on the upper surface of the prothallium; the antheridia are completely, the archegonia almost completely, sunk in the tissue. The neck-canal-cell generally divides transversely into two. 


\section{B. Heterosporous Eusporangiate.}

Order 3. Isoetaceæ. This order includes the single genus Isoetes which comprises about fifty species belonging to all parts of the globe. Some of these are terrestrial (I. Duriai and Hystrix), whilst others are either altogether aquatic (e.g. I. lacustris, echinospora, etc.), or amphibious (e.g. I. velata, setacea, boryana). The British species are I. lacustris, eclinospora, and Hystrix.

Isoetes has, of recent years, been generally included among the Lycopodinæ; but it betrays a relationship to the Filicinæ in so many features, such as its general habit, its embryogeny, the absence of any cone-like fructification, the form of its spermatozoids, that it appears to be more natural to place the plaut in that group.

Sporophyte. The stem is small, unbranched, short and tuberous, with either two or three longitudinal furrows which give it a lobed appearance. It is closely corered with numerous, relatively long (1-12 in.), sessile leaves. From the furrows of the stem there spring numerous, dichotomously branched, somewhat fleshy roots.

The growth in length of the stem, which is very slow, is effected by an apical growing-point consisting of several initial cells. 'The growing-point of the root consists of small-celled meristem, and presents a similar differentiation to that of the root of Dicotyledons (see pp. 145 and 154).

The leaves are either fertile or sterile; the fertile leaves each bear a single sporangium, and are termed macrosporophylls or microsporophylls in accordance with the nature of the sporangium which they severally bear. The order of development of the leaves in each year is that first of all macrosporophylls are produced, then microsporophylls, and finally a few sterile leaves in some species. Hence, when the development is completed, the macrosporophylls are external in the rosette, the sterile leaves (when present) internal, and the microsporophylls intermediate. The sterile leaves persist during the winter, and form a protection in the next spring to the young leaves developed internally to them at the growing-point.

The fertile leaves, whether macro- or micro-sporophylls, consist of a broad, sheathing base, with membranous margins, which bears a narrow subulate lamina, flattened somewhat on the upper (ventral) surface. Close above the insertion, on the upper or inner surface of the leaf-base, is a pit, the fovea, in which the single sporangium is situated. In some species the margin of the fovea is prolonged into a membrane, the velum, which either partially (e.g. I. lacustris), or completely (terrestial species), covers the sporangium. This structure appears to be lomologous with the indusium present in some of the leptosporangiate Ferns (see p. 391). Above the fovea, in the middle line, is another smaller pit, the foveola, occupied by the somewhat swollen base of a projecting flattened membranous structure, the ligule, which is developed from a single superficial cell of the young foveola, and is relatively much larger in the quite young leaf than in the adult.

The sterile leaves are less highly developed than the fertile; they are smaller, especially as regards the leaf-base. In the terrestrial species they are reduced to scaly cataphyllary leaves of a brown colour. The leaf grows for but 
a very short time by means of an apical growing point. Its further growth is intercalary by means of a zone of merismatic cells situated just above the ligule. In the sporophylls the tissue below the ligule also remains merismatic for a time, thus providing the necessary space for the sporangium.

The sporangium is developed from a group of cells in the forea. The archesporium consists of a layer of hypodermal cells in the young sporangium. In a microsporangium all the archesporial cells grow and divide so as to form rows radiating from the free surface to the attachment of the sporangium. Some of these rows of cells soon cease to grow, and are not sporogenous, but remain as plates of tissue, termed trabecula, which imperfectly chamber the cavity of the microsporangium. Of the remaining cells, the majority constitute the mother-cells of the microspores invested, towards the wall of the sporangium, by sterile cells forming the tapetum. In a macrosporangium, the fertile archesporial cells undergo but a single division, whilst the trabeculæ are formed as in the microsp or angium. The large mothercells of the macrospores are isolated, and each is invested by a tapetal layer. Each spore-mothercell gives rise, finally, to four spores. With

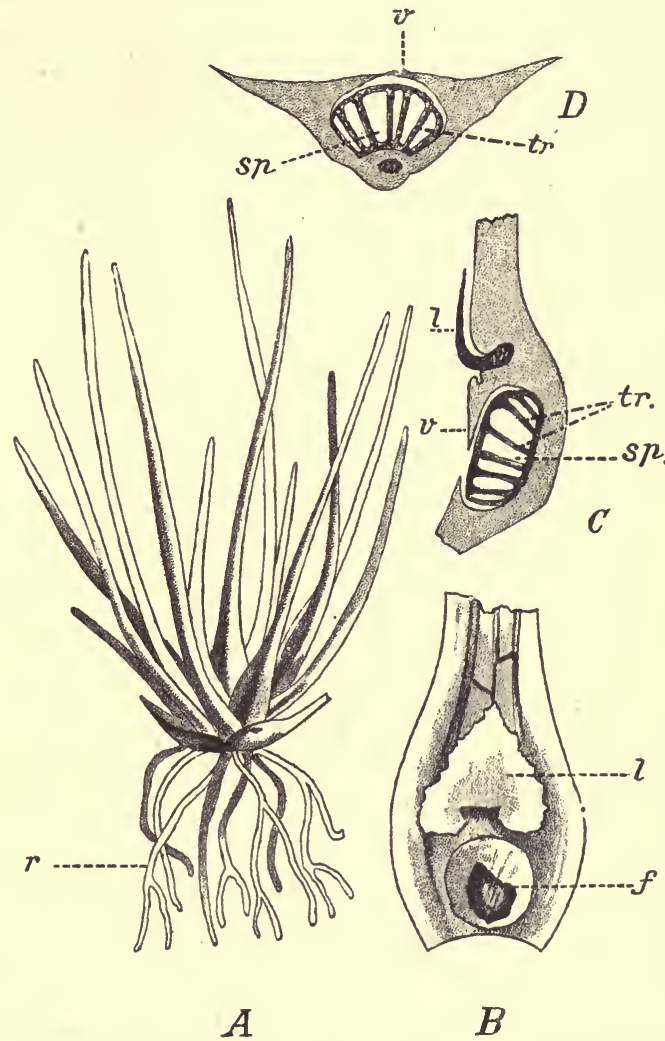

Fro. 256.-Isoetes lacustris (after Luerssen). A Plant, half nat. size: $r$ dichotomously branched roots. $B$ Inner (ventral) surface of base of a sporophyll: $l$ ligule; $f$ fovea. $C$ Longitudinal section of base of a sporophyll: sp the sporangium in the fovea; $t r$ the trabeculæ; $v$ the velum; $l$ the ligule. $D$ Transverse section of the base of a sporophyll: letters as in $C$. regard to the morphology of the sporangium it may be pointed out that the segmentation of the archesporium by the formation of the trabeculæ, which is characteristic of Isoetes, is probably to be taken as indicating a tendency towards the develope-

V. S. B. 
ment of several distinct sporangia in the place of one, a tendency which is more clearly marked in the Marattiaceæ.

With regard to the histology of Isoetes, the monostelic stem has a solid central mass of vascular tissue formed by the collateral bundles coming from the leaves. The wood consists of very short reticulated and spiral tracheids with scattered parenchymatous cells, and is surrounded by a layer of transparent tissue, consisting of shortly prismatic cells with broad and delicate pits, which represents the bast. From the lower surface of the vascular mass, opposite the furrows of the stem, are given off the bundles which go to the roots.

The stem undergoes slow growth in thickness, effected by a merismatic layer situated externally to the layer of prismatic cells, and only interrupted by the passage of bundles from the axial vascular cylinder of the stem to the leaves and roots. The merismatic layer gives rise to tissue both internally and externally. The internal tissue consists of vascular tissue, and is formed in relatively small quantity; the external tissue is bulky, and consists of pareuchymatous cortical cells. This cortical tissue is not produced uniformly all round, but on two or three sides, according to the species. It is to this that the lobed and furrowed appearance of the stem is due.

The leaves are characterised by the presence of four longitudinal rows of large intercellularair-spaces, extending from one end to the other in the mesophyll, and by the presence of a single median vascular bundle. In the aquatic species there are no stomata in the epidermis; the intercellular spaces are situated deeply within the tissue, and there are no hypodermal strands of sclerenchymatous tissue. In the amphibious and terrestrial species there are stomata, the intercellular spaces are superficial (immediately beneath the epidermis in terrestrial species), and there are longitudinal hypodermal strands (4-6) of sclerenchyma. tous tissue which give rigidity to the leaf.

The root has an essentially diarch stele, which becomes, however, monarch as in Ophioglossum vulgatum. It is surrounded by a well-marked bundlesheath. The cortical tissue is clearly marked, by intercellular spaces, into an inner and an outer region.

Tue development of the embryo-sporophyte begins with the formation of the basal wall, which is obliquely transverse to the loug axis of the archegonium, and divides the oospore into an epibasal and a hypobasal half. Both these cells undergo division into two, by the formation of a wall, the transverse wall, at right angles to the basal wall, so that the embryo now consists of four quadrant-cells; and this appears to be generally followed by the formation of a vertical wall, the median wall, at right angles to the two preceding, so that the embryo comes to consist of eight octant-cells. Owing to the difficulty of distinguishing the growing-point of the young stem, there is still some uncertainty as to the exact relation of the members of the embryo to these octants, but it appears to be probably somewhat as follows: The first leaf (cotyledon) arises from the two upper epibasal octants; the growing-point of the stem, together with the first root, arises from the two lower epibasal octants; the four hypobasal octants give rise to the large foot. If this be so, then the first root, springing as it does from the epibasal half of the embryo, must be regarded, not as a true primary root, but as an adventitious root, a view which is supported by the fact that the origin of the growing-point of the root, though not abso- 
lutely exogenous, is superficial. In this respect Isoetes would differ from the other Filicinæ.

The first indication of the development of the members is the segmentation of each octant after the manner of a tetrahedral apical cell, so that for a short period, stem, root, and leaf may be said to grow by means of an apical cell. By the formation of periclinal walls, these cells are soon converted into a merismatic tissue.

The growth of the cotyledon and of the first root is rapid; that of the stem slow : the cotyledon and the first root soon make their way out of the macrospore, when the former becomes green and the latter curves into the soil: the growing-point of the stem is deeply seated between the bases of the cotyledon and of the rot. A second leaf is early developed from the growing-point of the stem and is opposite to the cotyledon : these two first leaves are smaller than those produced later, and have only two longitudinal rows of air-chambers instead of four. The second root is developed endogenously from a group of cells at the base of the second leaf : it is clearly adventitious.

GАMEторнтте. As Isoetes is heterosporous, the gametophyte is represented by distinct male and female individuals, which remain connected with the spores producing them.

The male individual is developed from a microspore. The microspore-which has the form of the quadrant of a sphere and is consequently of the bilateral or radial type-undergoes, on germination, division by a transverse wall, formed near one of its somewhat pointed ends, into two cells, a large and a small : the Iatter is the vegetative cell, and undergoes no further change; the former is the mother-cell of the maleorgan or antheridium. The prothallium here is thus very much reduced, consisting of a single antheridium and of a single purely vegetative cell. The antheridium, developed by the growth and division of the mother-cell, consists of four peripheral cells furming the wall, and of four central cells, each of which gives rise to a single spirally coiled multiciliate spermatozoid.

The female individual is developed from a macrospore. The macrospores are much larger than the microspores, and are nearly globular in form, though they belong to the tetrahedral type, as can be seen by the three ridges on the spore where it was in contact with the other three developed from the same mother-cell. On germination, the nucleus of the macrospore undergoes repeated division; this is followed by free cell-formation in the apical region (the pointed end where the three ridges meet) of the macrospore, the result being the formation of a small-celled tissue; subsequently cell-formation extends into the basal portion of the spore, a tissue being formed there consisting of relatively large cells with coarsely granular contents. Thus the macrospore becomes completely filled with a mass of cellular tissue which constitutes the female prothallium : the upper small-celled tissue is the essentially reproductive portion, whilst the lower large-celled tissue simply serves as a depository of nutritive substances.

The female organ, the archegonium, is developed from one of the superficial cells of the small-celled prothallial tissue, after the manner described on page 377. It appears that two or three archegonia are usually formed : but if none of these primary archegonia are fertilised, a small number of additional archegonia may be subsequently developed. 
The archegonia are exposed, for the purpose of fertilisation, by the splitting of the coats of the macrospore along the three ridges already described: the prothallium does not, however, project from the spore, nor does it become green. After fertilisation, the oospore developes into the embryo as described above : the foot of the embryo grows down into the large cells of the basal portion of the prothallium, absorbs the nutritive substances which were stored up in them, and thus supplies the embryo with food until such time as its leaves and roots are sufficiently developed to enable it to nourish itself in the usual way.

\section{HOMOSPOROUS LEPTOSPORANGIAT环 (Filices).}

The orders constituting this group have so much in common that they may be advantageously considered all together.

Sporophyte. The body is differentiated into stem, leaf, and root (generally): the leares are large in proportion to the stem, and are relatively few in number.

The stem has either radial or dorsiventral symmetry. In the former case it is commonly short and straight; it grows into the air erect, or at any degree between the vertical and the horizontal; its surface is generally completely covered by the insertions of the spirally arranged leaves, and by adventitious roots: it becomes, however, elongated, to a considerable height sometimes, in the Tree-Ferns.

In the latter case, the stem grows as a rhizome either on or in the soil, or on the surface of some tree upon which the plant lives as an epiphyte: the leaves are borne on its dorsal surface, either in two rows (e.g. species of Aneimia and Polypodium), or in a single row (e.g. Lygodium palmatum, Polypodium Heracleum and $P$. quercifolium): from the lower (ventral) surface, spring the adventitious roots.

The growth in length of the stem, is effected by a growing-point with a single apical cell (with the occasional exception of Osmunda): the apical cell is, as a rule, a three-sided pyramid with its spherical base at the surface: but in Pteris aquilina it is usually a two-sided lenticular cell, with its longer axis in the dorso-ventral plane.

The radial stems branch but little, least of all when the stem is elongated, as in the Tree-Ferns; and such branching as there is appears to be mainly adventitious, the buds springing from the bases of the leaves. In the dorsiventral stems there is normal lateral branching, which takes place in the transverse plane: the 
branches are borne on the flanks of the stem, and are frequently (e.g. some Hymenophyllaceæ) axillary in their origin.

The leaves are for the most part foliage-leaves, though scaly leaves are found on the subterranean rhizomes of Onoclea Struthiopteris and Osmunda regalis, and in some cases the sporophylls are more or less differentiated from the sterile leaves.

The foliage-leaves are relatively large, sometimes entire (e.g. Scolopendrium), but generally more or less deeply and repeatedly
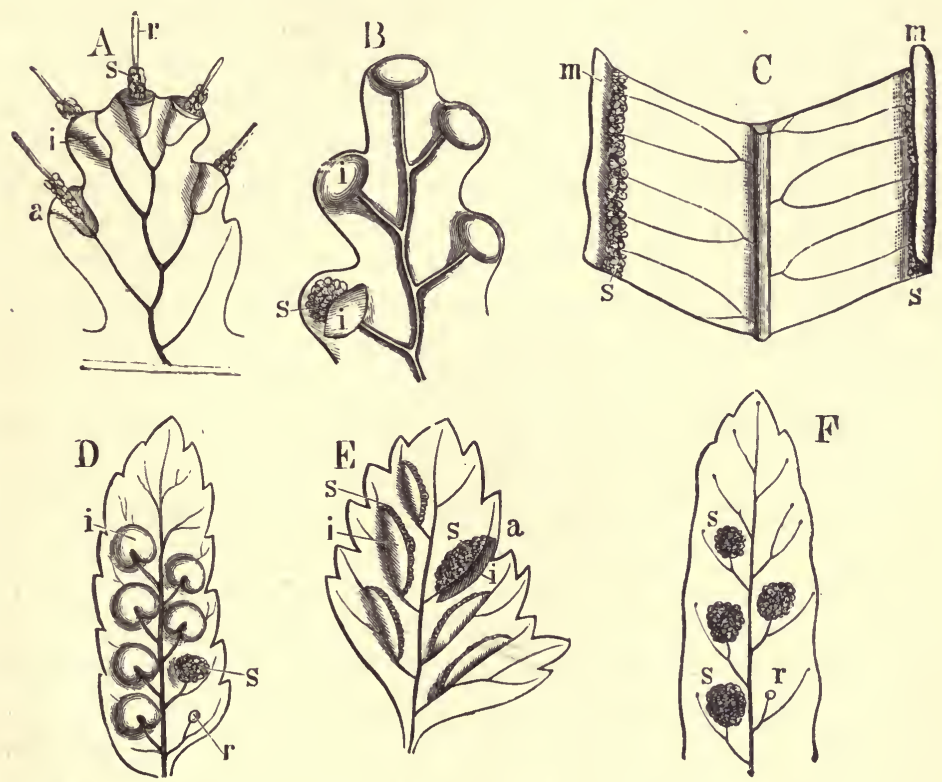

Fig. 257.-Sori (s) of the most important groups of Leptosporangiate Ferns, all seen from below. A Pinna of Trichomanes sinuosum, one of the Hymenophyllaceæ: $r$ projecting placenta; $s$ sporangia; $i$ indusium; at $a$ half of the indusium is removed. B Pinna of Davallia (Leucostegia)-at $s$ the one-valved indusium (i) is turned back. $C$ Part of a leaf of Pteris serrulata $: s$ the sporangia; $m$ the inverted margin. $D$ Lacinia of Nephrodium-at $s$ the indusinm is removed, and at $r$ the sporangia also. $E$ Lacinia of an Asplenium-at $a$ the indusium is turned back. F Pinna of Polypodium vulgare with naked sori-at $r$ the sporangia are removed. (All are $\times 3$ to 6 .)

pinnately lobed or branched; sometimes dichotomously branched (e.g. Platycerium, species of Schizæa).

The leaves in all cases have apical growth; the growing-point has, in most of the orders, a two-sided apical cell, whilst in the Osmundaceæ the apical cell is tetrahedral. In Lygodium, where the leaf is a climbing organ, the apical growth is long continued. 
The leaf arises from a single superficial cell of the growingpoint of the stem. When young it is strongly hyponastic (see p. 60), so that, as it elongates and branches, both the main axis of the leaf (phyllopodium) and the lateral branches become inrolled upon themselves like a crosier: in other words, the vernation is circinate: as it grows older the growth becomes epinastic, and thus the leaf becomes expanded.

In the great majority of these Ferns the sporophylls are simply foliage-leaves bearing sporangia on the dorsal surface, but in certain cases they are more or less specialised. Thus, in Onoclea Struthiopteris, the sporophylls are smaller than the foliage-leaves, and have narrower pinnæ: in the Hard Fern, Blechnum boreale, the sporophylls are longer and have narrower pinnæ than the foliage-leaves: in Osmunda regalis the pinnæ of the upper branches of the sporophyll are reduced to little more than the midrib, the pinnules being represented by clusters of sporangia: in Aneimia (e.g. A. Phyllitidis) generally the lowest pair of pinnæ of the sporophyll alone bear sporangia; these pinnæ consist merely of the nervature bearing numerous sporangia, and are erect on much elongated secondary petioles : in Platycerium alcicorne there is a curious instance of heterophylly: the foliage-leaves are broad, and closely appressed to the substratum, whereas the sporophylls are erect, nairow, and branched.

The sporangia are but rarely borne on the superior (ventral) surface of the sporophyll (e.g. Olfersia cervina); more commonly on the margin (e.g. Hymenophyllaceæ, Dicksonia, Davallia); but as a rule, on the dorsal surface, either near to the margin (e.g. Pteris, Adiantum), or distant from it (e.g. Asplenium, Aspidium, etc). They are usually developed in connexion with the nervature of the sporophyll, but sometimes also from the intervening tissue of the lamina (Acrosticheæ, such as Polybotrya, Chrysodium) : in the former case they occur in groups, termed sori, which are commonly isolated, but occasionally (e.g. Pteris) a continuous marginal sorus is formed.

The sorus generally consists of a large number of sporangia: in the Gleicheniaceæ, however, the number is small (2-8); and in some cases (e.g. Lygodium) there is only a single sporangium. The sporangia of the sorus are borne on a projection of tissue, the placenta or receptacle, which presents various forms : it may be a slight rounded elevation (e.g. Aspidium); or more elongated and conical (e.g. Cyathea, Hymenophyllum); or very long and 
filiform, bearing sporangia only at its base (e.g. species of Trichomanes); or a ridge (e.g. Pteris, Blechnum).

The sorus is quite bare in many, forms (Gleicheniaceæ; Osmundaceæ; Alsophila among Cyatheaceæ; Schizæaceæ, except Lygodium; Polypodieæ); in others it is more or less covered by a protective membrane, the indusium, which is an outgrowth of the tissue of the leaf, generally of the epidermis alone. When it springs from the placenta below the sorus (indusium inferum), it is somewhat cup-shaped: in the extreme case of Diacalpe (Polypodiaceæ) the indusium forms a completely closed globular investment to the sorus; it is urceolate and entire in Trichomanes (Fig. 257 A), Lygodium, Cyathea, Davallia : it is bilabiate in Hymenophyllum; two-valved in Cibotium, Dicksonia; or it consists of

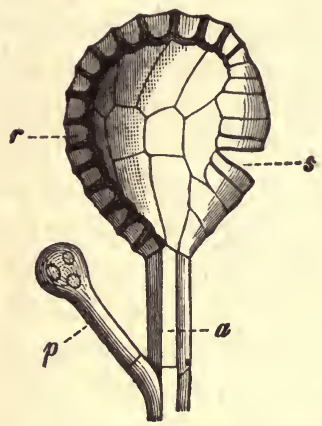

Frg. 258.-A dehisced sporangium of Aspidium Filix-mas $(\times 90)$ : a the stalk, with a glandular hair $p$; $r$ the annulus; 8 the stomium.

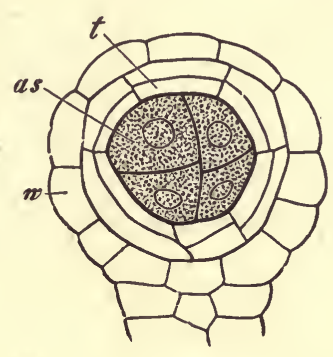

A.

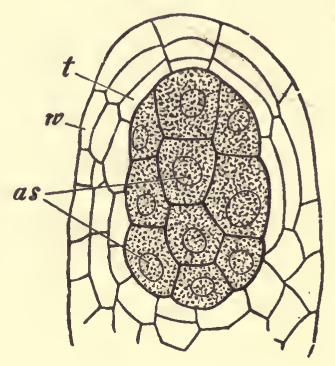

B.

FrG. 259.-Sections of young sporangia; $A$ of a Fern (Mohria), $B$ of Equisetum $(x 150)$ : w wall ; $t$ tapetum; as archesporium.

a single lateral valve, as in Hemitelia and Cystopteris : in Woodsia the calyciform indusium is laciniate, the laciniæ frequently ending in long hairs. When it springs from the apex of the placenta, above the sorus (indusium superum), the indusium has the general appearance of a peltate scale, either orbicular in outline (Aspidium) or reniform (Nephrodium, Fig. $257 \mathrm{D}$ ). When it is developed on one side of the sorus (indusium laterale), the indusium is a long narrow scale, attached along its length, and overlying the sorus (e.g. Asplenium [Fig. $257 \mathrm{E}$ ], Blechnum, Scolopendrium). In some cases, where the sori are near the margin, they are protected by a false indusium, which is merely the incurved margin of the leaf (e.g. Cheilanthes, Adiantum, some species of Pteris). In Pteris 
aquilina, and some other species (section Ornithopteris), in' addition to the false indusium, there is also a membrane along the inner side of the sorus, which is a kind of lateral indusium, adapted to protect a continuous marginal sorus.

In some cases hairs of various form, termed paraphyses, also spring from the placenta among the sporangia; not uncommonly; when the sorus is naked, these hairs are scaly, often peltate, and
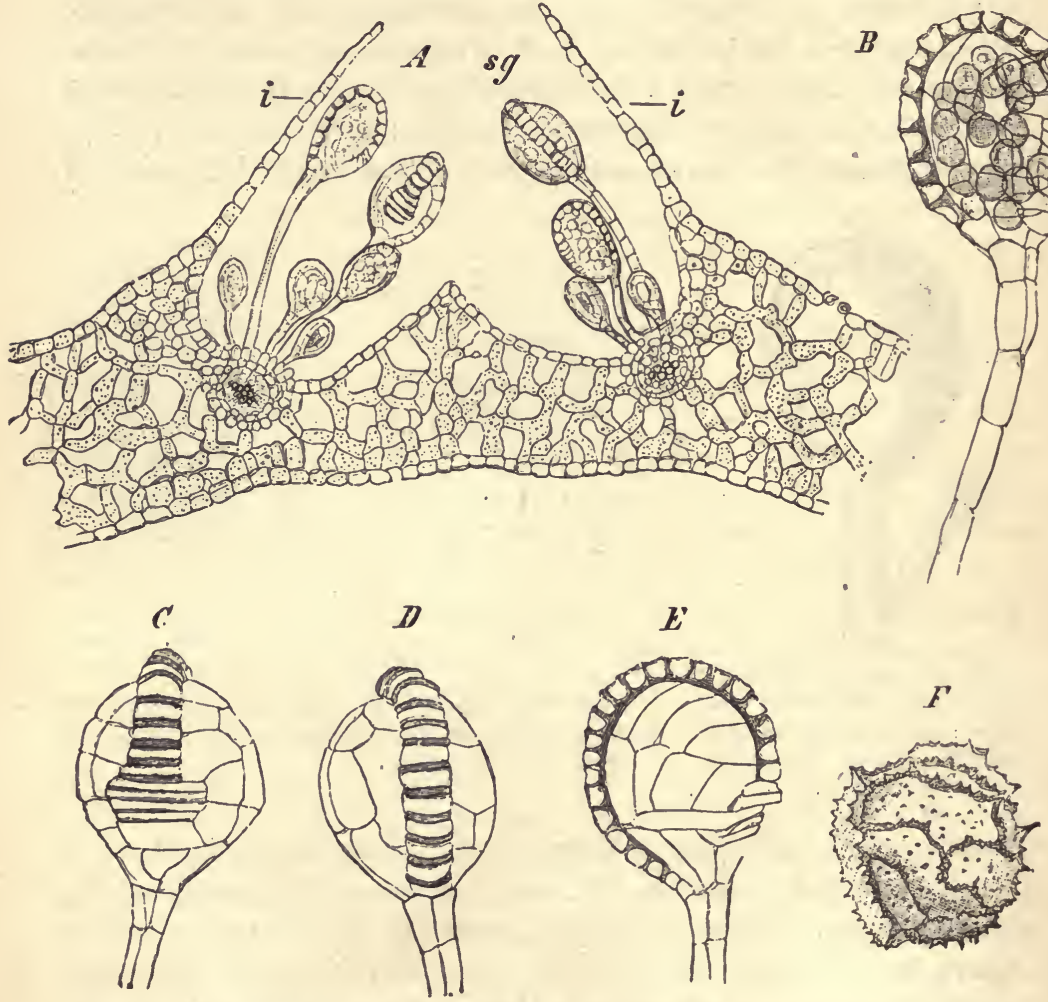

F1G. 260.-Scolopendrium vulgare (Hart's-tongue Ferr). A Transverse section of a so1 us; $i$ indusium; $8 g$ sporangia. $B-E$ Sporangia; $B$ and $E$ seen sideways; $C$ in front; $D$ frum the back; $F$ a spore. $(A \times 50 ; B-E \times 145 ; F \times 540$ : after Strasburger.)

serve to protect the sporangia (e.g. Notochlæna, Platycerium, Peltolepis, Hymenolepis, etc.). In some forms (e.g. Aspidium Filixmas) the stalks of the sporangia bear glandular hairs; sometimes even the sporangia themselves (e.g. Polypodium crassifolium).

With the possible exception of the Osmundaceæ, each sporangium 
is dereloped from a single superficial cell. The cell grows so as to project more or less: it is then divided into two cells-an onter, the mother-cell of the sporangium; an inner, the stalk-cell-by a wall which may be horizontal (most Polypodiaceæ) or oblique (as in Hymenophyllaceæ, Schizæaceæ). As the mother-cell of the sporangium grows, it undergoes division by the successive formation of three oblique walls, intersecting one another below at an angle of about $60^{\circ}$, and reaching above to the wall of the mothercell; at this stage the sporangium consists of three latero-basal external cells surrounding the pointed lower end of a tetrahedral cell, the spherical base of which occupies the summit of the sporangium. A wall is now formed in the tetrahedral cell, parallel to its spherical free surface, and intersecting the three oblique walls; so that the sporangium now consists of four peripheral cells, forming the wall, and a central cell. From the central cell are cut off, by successive walls parallel to its sides, four cells which give rise to the tapetum by subsequent growth and radial, and sometimes tangential, division; the remaining internal tetrahedral cell constitutes the unicellular archesporium from which the spores are derived.

As the young sporangium grows, it gradually assumes its definitive form (oval-lenticular, as in Polypodiaceæ, Cyatheaceæ; discoid, as in Hymenophyllaceæ; ovoid, as in most Schizæaceæ; globose, as in Ceratopteris and Mohria). The four primary peripheral cells undergo repeated radial division, and form the wall of the sporangium, which ultimately consists of a single layer of cells with cuticularised walls : a portion of the wall is in all cases developed to form the ring or annulus, by means of which the dehiscence of the sporangium is effected, the walls of which are specially thickened and cuticularised, coloured yellow or brown, and are elastic. The form and position of the annulus varies in the different groups: in the Polypodiaceæ (Fig. 260), where the sporangium is attached to' the stalk by the margin, the incomplete annulus is a projecting row of cells with their longer axes transverse, extending round the margin in the plane of the stalk, with which it is connected on one side, but not quite reaching it on the other; in the Cyatheaceæ, in which the form and attachment of the sporangium is similar, the annulus is slightly inclined to the plane of the stalk, and it is quite complete; in the Hymenophyllaceæ and Gleicheniaceæ,.where the discoid sporangium is attached by its under surface, the annulus forms a complete ridge round the margin, more or less nearly at right angles to the plane of attach- 
ment; in the Schizæaceæ the annulus is a dome-shaped group of cells at the apex of the oroid sporangium.

As the development proceeds, the formation of the spores takes place in the interior of the sporangium. The archesporial cell undergoes repeated division, with the result that usually sixteen cells are formed, which are the mother-cells of the spores. At this stage the tapetal cells undergo disintegration, so that the mass of spore-mother-cells floats freely in the liquid thus produced. Each mother-cell then undergoes division to form four spores; the planes of division may be either such that the developing spores all lie in one plane, when the mature spores are bilateral (e.g. many Polypodiaceæ, as Aspidium, Asplenium, Nephrolepis, Blechnum, Polypodium, etc.; Gleicheniaceæ; Schizæa);

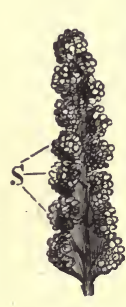

A

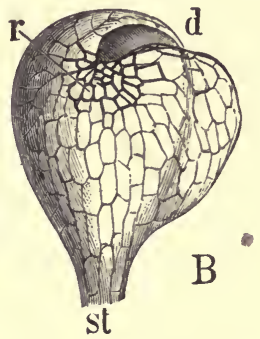

Fig. 261.-Osmunda regalis. A Fertile pinna with naked marginal sori (8). Some mesophyll is, however, developed at the base (nat. size), $\boldsymbol{B} \mathbf{A}$ single sporangium $(\times 200)$ : st the short stalk; $r$ the annulus ; $d$ the longitudinal slit. or such that the spores are arranged in a pyramidal manner, when the mature spores are tetrahedral (Hymenophyllaceæ; Cyatheaceæ; most Schizæaceæ; some Polypodiaceæ, as generally in the Pterideæ; Osmundaceæ: see $\mathrm{p}$. 126).

The sporangium of the Osmundaceæ differs in various respects from that of the other Leptosporangiate Ferns; its origin from a single superficial cell cannot be so easily traced, as the mother-cell does not project, and the succession of cell-divisions is not regular; the archesporial cell is frequently not tetrahedral in form, and the resulting sporemother-cells are more numerous than in the other Ferns (as many as 128); the sporangium is somewhat pear-shaped, with a rudimentary annulns consisting of groups of cells situated laterally towards the upper surface (Fig. 261).

The sporangium may be sessile (Gleicheniaceæ, most Schizæaceæ, Hymenophyllaceæ); or shortly stalked (Lygodium, Cyatheaceæ, Osmundaceæ) ; or it may have a usually rather long slender stalk consisting of two or three longitudinal rows of cells (Polypodiaceæ); this is dependent upon whether the originally-formed stalk-cell developes further or not.

The spores are set free by the dehiscence of the sporangium; 
this takes place at a certain part which, though different in the various forms of sporangia, is always closely connected with the annulus and is termed the stomium (see Fig. 258); dehiscence begins by a split between (not through) the cells of the stomium. In the Polypodiace the plane of dehiscence is at right angles to the long axis of the sporangium, and the stomium is situated on the margin between the end of the annulus and the stalk; in the Cyatheaceæ, where the stomium is included in the annulus, the plane of dehiscence is as in the Polypodiaceæ; in the Hymenophyllaceæ and Gleicheniaceæ the stomium is included in the annulus, and the plane of dehiscence is vertical; in the Schizæaceæ the stomium is on the more concave surface, and the dehiscence is lateral longitudinal; in the Osmundaceæ the stomium extends from above the annulus, over the summit of the sporangium, and it is in this vertical plane that dehiscence takes place.

A striking feature in the general morphology of these plants is the presence on the stem and the bases of the leaf-stalks, especially when young, of numerous scaly hairs (ramenta or paleoe), which consist usually of a single layer of cells, with more or less thickened brown walls; they are of various shape, and frequently have marginal glandular hairs secreting tannin or mucilage, the latter generally in the neighbourhood of a growing-point of stem or leaf. Less commonly, glandular hairs are developed on the leaves, as in species of Gymnogramme (Gold and Silver Ferns), in which the under surface of the leaves is covered with a yellowish dust, consisting of minute needles of resinous and waxy substances, secreted by the hairs. Root-hairs occur on subterranean stems and leaf-stalks.

A primary root is developed, probably in all forms, but in no case does it persist in the adult. In the full-grown plant all the roots are adventitious; they spring in great numbers from the stem or the leaf-stalks. The roots are small and branched; the branching is lateral, and the growing-points of the young roots are developed each from a single cell of the bundle-sheath (endodermis), termed a rhizogenic cell, situated opposite to a xylem-bundle of the central cylinder. In most cases the growingpoint of the root has a single pyramidal apical cell (see Fig. 115) with three flat sides and a spherical base directed outwards. But in the Osmundaceæ the structure of the growing-point is not constant; there may be a single apical cell of varying form, or a group of initial cells. 
Adventitious buds, subserving vegetative propagation, are commonly produced; they arise most frequently on the subterranean portions of leaf-stalks (as in Pteris aquilina, Aspidium Filix-mas), and sometimes, as in Onoclea Struthiopteris, the bud grows into a subterranean stolon which eventually throws up at its apex a whorl of green leaves, thus constituting a new plant; but also frequently from the lamina, as in Asplenium (Diplazium) celtidifolium, A. bulbiferum, and other species. The bud originates from a single epidermal cell.

General Histology.-The structure of stem, petiole, and root, is characterised throughout by the presence of hypodermal layers, and, generally, of scattered strands of sclerenchymatous tissue, consisting of more or less elongated ground-tissue cells with more or less thickened brown-coloured walls; and by the predominance of scalariform vascular tissue in the xylem which consists, with but few exceptions, of tracheides.

The stem is, at its first development, monostelic, with a single axile stele: in some forms this structure obtains (with or without pith) throughout the whole stem (e.g. Hymenophyllaceæ, Lygodium, Schizæa, stolons of Nephrolepis): in the Osmundaceæ the stem is monostelic throughout, the stele eventually consisting of a ring of bundles enclosing a pith: in the other families the stem becomes polystelic.

In the monostelic stem the bundles are sometimes conjoint and collateral (e.g. Trichomanes among Hymenophyllaceæ, Osmundaceæ) : in all other cases the arrangement of the bundles in the stele is concentric, or, more strictly speaking, bicollateral, since the phloem does not quite completely surround the xylem-bundles. The concentric steles are cauline and diarch, with usually an endodermis and a pericycle': in some cases, however, where the stele is small (e.g. some species of Polypodium) there is no pericycle, its place being taken by a layer of cells formed by the division of the primitive endodermis ( $p .165)$ into two layers.

In the polystelic stem the course of the steles is such that they form a meshwork, each mesh corresponding to the insertion of a leaf : the bundles of the leaf join those forming the corresponding mesh in the stem. The form of the mesh is determined by the number and insertion of the leaves: when the leaves are numerous and closely arranged, the meshes are relatively short and broad; when the leaves are few and scattered, the meshes are long and narrow. In dorsiventral stems, a regular meshwork is only 
present towards the surface where the leaves are borne; i.e. towards the dorsal surface (see p. 388).

In a monostelic stem, such as that of Osmunda, though the
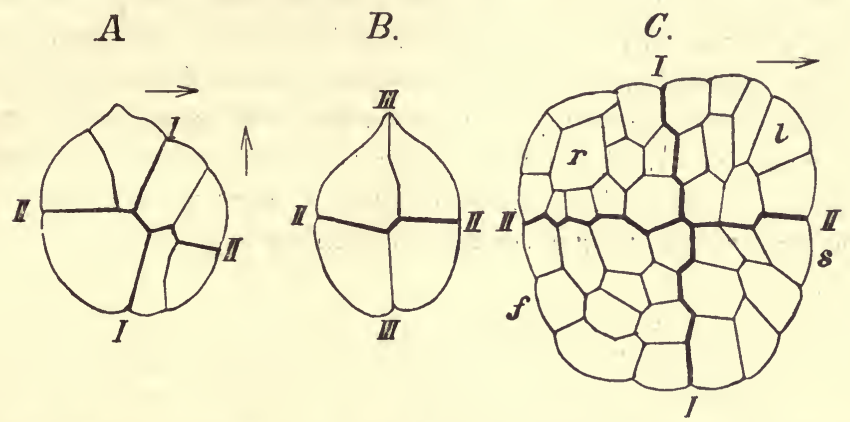

Frg. 262.-Embryogeny of the sporophyte of Pteris serrulata ( $\times 235$ : after Kienitz-Gerloff). $\boldsymbol{A}$ In longitudinal section : $\boldsymbol{B}$ transverse section, at right angles to the preceding : $C$ older embryo in longitudinal section. The vertical arrows indicate the long axis of the archegonium, pointing to the neck ; the horizontal arrows indicate the longitudinal axis of the prothallium, pointing to its organic apex. I-I Basal wall; II-II transverse wall; III-III median wall : $r$ apical cell of root; $l$ apical cell of cotyledon; $s$ apical cell of stem; $f$ foot.

bundles are numerous, no such meshwork is formed. The bundles are here common. A single bundle enters the stem from each leaf, runs straight through several internodes, and then curves to join with the bundle of an older leaf, seven leaves intervening between the two.

Embryogeny of the Sporophyte. The sporophyte is developed from the fertilised female cell, the oospore: the development has only been studied in species of Polypodiaceæ, and has been found to be as follows. The oospore is first of all divided into two cells by the formation of a wall, the basal, wall, which nearly coincides with the long axis of the archegonium: a second wall is then formed, the transverse wall, at right angles to the preceding, with the result that the spherical embryo now consists of four cells or quadrants : then a third wall, the median wall, is formed in a plane

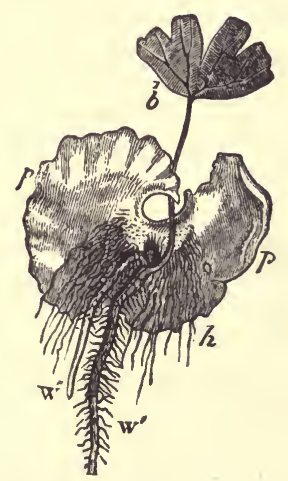

FrG. 263.-Adiantum CapillusVeneris. The prothallium $(p p)$ seen from below with young Fern attached to it by its foot ; $b$ its first leaf or cotyledon; $w^{\prime}$ its primary, $w^{\prime \prime}$ secondary, roots; $h$ root-huirs of the prothallium (x about 3). (After Sachs). 
at right angles to both the preceding walls, the embryo now consisting of eight equal cells or octants. Of these octants, four belong to one half of the embryo, which is termed the epibasal half; and four to the other half, the hypobasal half: from these octants the primary organs of the sporophyte are developed. Beginning with the four epibasal octants, the two apical octants (i.e. nearest to the neck of the archegonium) give rise to the growing-point of the first leaf or cotyledon: of the two deeper (towards the venter of archegonium) octants, the one constitutes the growing-point of the stem, whilst the other gives rise to nothing beyond possibly some

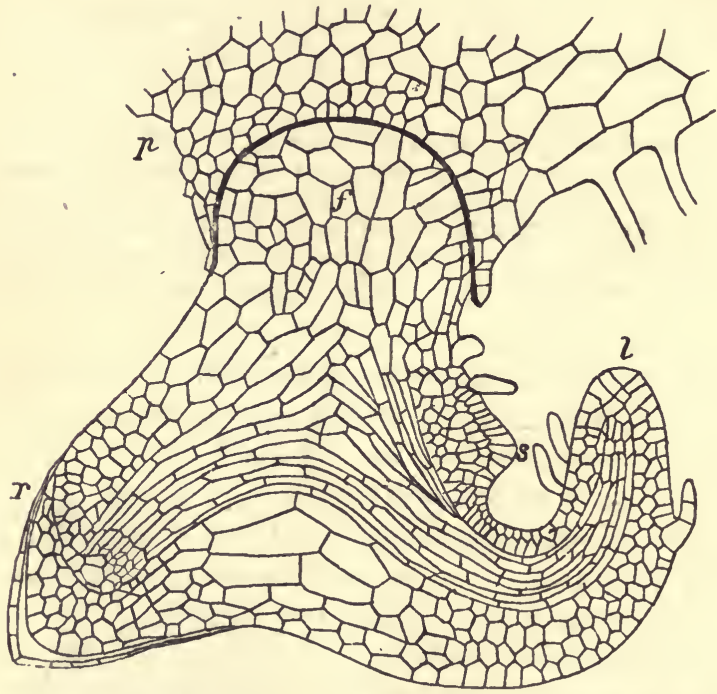

Fsg. 264.-Section of young plant of Pteris aquilina still attached to the prothallium by its foot: $p$ prothallium; $f$ foot; $r$ primary root; 8 growing:point of primary stem; $l$ primary leaf or cotyledon. (Magnified: after Hofmeister.) hair's. Of the four hypobasal octants, one of the two apical octants gives rise to the growingpoint of the primary root, which is diametrically opposite to the growing point of the stem; whilst the other gives rise to no special member : the two deeper h y pobasal octants give rise to the embryonic absorptive organ, the foot. The gradual development of these members is dependent upon growth and corresponding cell-division, and at an early stage histological differentiation into cortical and stelar tissues is apparent in them. For a time the tissue of the venter of the archegonium keeps pace by growth with the increasing size of the embryo : but eventually the primary root and the cotyledon become free, and ultimately also the stem (Fig. 264). In the meantime the embryo is nourished by means of the foot which has become a mass 
of tissue filling the venter of the archegonium : it absorbs from the adjacent cells the organic substances formed in the prothallium by means of the chloroplastids which most of the cells contain. The primary root and the cotyledon'are both small and short-lived: the former is succeeded by the numerous adventitious roots, the latter by the true foliage-leaves. The foot is a merely embryonic organ: it disappears when the young sporophyte has become firmly attached to the substratum, and is capable of independently absorbing and assimilating food.

Gametophyte. The gametophyte is a prothallium, always containing chloroplastids, generally a dorsiventral, flattened, cellular expansion, or sometimes filamentous, which is developed from a spore, but which becomes completely free from the spore; there is frequently a more or less marked differentiation of a sexual receptacle, which may attain the dignity of a gametophore, but is, however, exclusively female. In the dorsiventral prothallium the reproductive organs, as also the root-hairs, are confined to the inferior (ventral) surface.

The prothallium is typically monocious : the male organs, or antheridia, are developed first, and are consequently situated towards the posterior or basal end of the prothallium; the laterformed archegonia lie towards the anterior or apical end. It sometimes happens, however, that, owing to imperfect nutrition, the growth of the prothallium does not proceed beyond the stage necessary for the formation of the antheridia, so that exclusively male prothallia may be sometimes found; less commonly, wellnourished prothallia fail to produce antheridia, and consequently exclusively female prothallia are found. The practical result of this successive formation of the antheridia and archegonia is that but few of them can possibly mature at the same time on one and the same prothallium; the prothallium is in effect dichogamous, and, consequently, cross-fertilisation is almost certainly ensured.

The development of the prothallium commences with the rupture of the outer coat (exospore) of the germinating spore, which takes place either along three lines meeting at an angle, when the spore is tetrahedral, or by a longitudinal slit when the spore is bilateral, the contents covered by the inner coat (endospore) being exposed. Most commonly this cell grows out into a filament, cell-divisions taking place in the transverse plane only, so that the prothallium consists of a longitudinal row of cells. At length a longitudinal wall is formed in the terminal cell of the filament; cell-division 
then proceeds in two plaries, giving rise to a flattened plate of cells, further growth being effected by means of a two-sided apical cell. After a time the activity of the apical cell ceases, a periclinal wall being formed in it; whatever further growth takes place is effected by

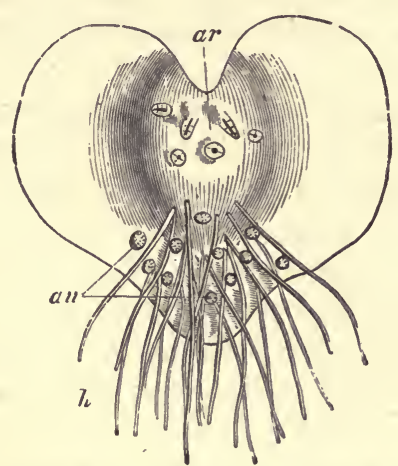

Frg. 265.-Diagram of the protballium of a Leptosporangiate Fern : under side ( $\times 10)$. ar Archegonia; an antheridia; $h$ root-hairs.

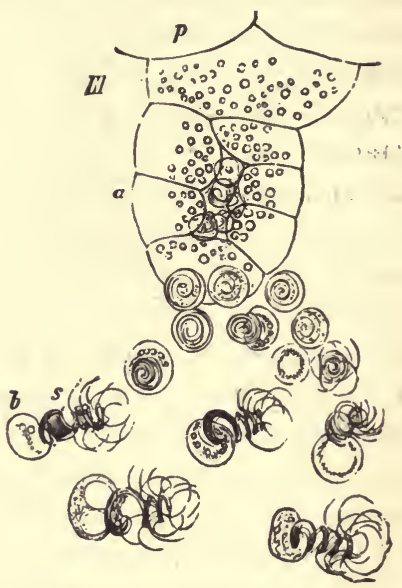

Frg. 266. - Antheridium of Adiantum Capillus-Veneris $(\times$ 550).$\quad p$ Prothallium; $a$ antheridium; $s$ spermatozoid; $b$ the vesicle containing starch-grains.

the marginal cells. At this stage the prothallium becomes somewhat heart-shaped, the anterior depression indicating the position of the organic apex. The cells lying anteriorly in the middle line now begin to divide in a plane parallel to the sur.ace, with the result that the prothallium becomes thickened in this region, and

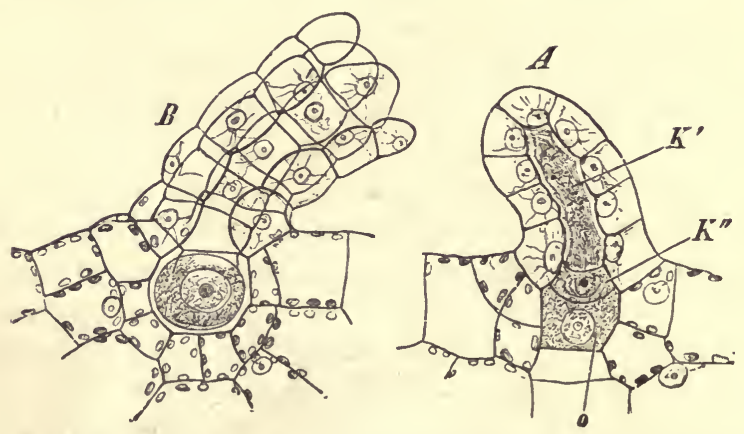

Fre. 267.-Polypodium vulgare. A Young archegonium, not jet open : $K^{\prime}$ neck-canal-cell; $K^{\prime \prime}$ ventral canal-cell : o young oosphere. $B$ Matare archegonium open. ( $\times 240$ : after Strasburger.) eventually a "cushion" of tissue, several layers of cells in thickness, is produced, which projects on the lower (ventral) surface, and bears the archegonia. 
The foregoing account refers especially to the Polypodiaceæ and to the Cyatheaceæ: it also applies generally to the Schizæaceæ, though here the activity of the apical cell is of shorter duration. In the Gleicheniaceæ occasionally, in the Osmundaceæ always, there is no filamentous stage in the development of the prothallium, but it at once developes into a plate or mass of cells. Moreover, in the Osmundaceæ there is an indication of a differentiation of the prothallium into shoot and root, since the first septum formed in the germinating spore is transverse, dividing a posterior cell, which contains relatively few chloroplastids and sometimes none, from an anterior cell in which they are numerous: the posterior cell grows into a simple hair which may be regarded as representing a root (see p. 61), whilst the anterior cell divides to form the shoot of the prothallium. In the Hymenophyllaceæ the prothallium is comparatively rndimentary and presents remarkable peculiarities. In $\mathrm{H}_{y}$ menophyllum, the filamentous stage is either wanting or is of very short duration: the prothallium is irregular in form and is dichotomously branched, a rare occurrence sometimes also presented by old prothallia of Osmunda: it bears groups of archegonia on its under surface but close to the margin, and it may consist throughout of a single layer of cells, or of two or three layers where the archegonia are borne. These peculiarities find their parallel in certain aberrant forms among the Polypodiaceæ (Vittaria, Monogramme). In Trichomanes, the prothallium is characteristically filamentous, consisting of a single much-branched row of cells, and somewhat resembles the protonema of Mosses. In some species (Trichomanes incisum and sinuosum), some of the lateral branches develope into flattened cell-plates, on the margin of which archegonia are borne: in others (e.g. T. pyxidiferum) there are no such flattened expansions, but the cells of some of the branches divide so as to form a small solid cell-mass which bears archegonia.

The gametophore. In none of these Ferns is there any special organ developed to bear the antheridia, so that the gametophore is always an archegoniophore.

There are to be observed in the Ferns (as is also the case in the Hepaticæ) all stages between a mere receptacle and a fully developed archegoniophore. The simplest case is, perhaps, that of Hymenophyllum, where each marginal group of archegonia may be regarded as a receptacle, though the cushion is but slightly developed; in the majority (most Polypodiaceæ, Cyatheaceæ,

v. S. B. 
Gleicheniaceæ generally) there is a well-developed cushion, sitnated anteriorly in the middle line, whilst in the Schizæaceæ it is on one side; in the Osmundaceæ the receptacle is in the form of a midrib, projecting on the nnder surface, bearing a longitudinal series of archegonia on each flank. In other cases there is a definite archegoniophore, that is, the receptacle is borne on a stalk which is a ventral branch of the prothallium. Thus, in Gymnogramme leptophylla (Polypodiaceæ), the cushion on the ventral surface of the prothallium elongates into the soil and there becomes tuberous, and it is on the upper surface of this tuberous archegoniophore that the archegonia are produced. Again, in Aneimia (Schizæaceæ), if the first-formed archegonia fail to be fertilised, the cushion has been observed to grow out into an archegoniophore. Finally, the flattened or massive cellular. appendages of the filamentous prothallium of Trichomanes incisum and sinuosum may be also regarded as archegoniophores.

The antheridia are generally borne on the posterior portion of the prothallium, scattered without any definite order. It occasionally happens that they occur in the female receptacle, or even on an archegoniophore; thus, in some Hymenophyllums, antheridia have been found in the groups of archegonia, and they are frequently developed on the cushion in Polypodiaceæ and Schizæaceæ; they are also developed on the flat archegoniophores of Trichomanes sinuosum, and on the archegoniophore of Aneimia.

The sexual organs. The antheridium is developed from a single superficial cell. The free surface of this cell grows out into a blunt protuberance, which is cut off by a transverse wall. The projecting cell thus formed generally undergoes division by the formation of a transverse wall near its base, so that it comes to consist of two cells, the lower of which is the stalk-cell, the upper, the antheridial cell. The latter grows, becoming more or less spherical, and undergoes repeated cell-divisions which result in the formation of a wall, consisting of a single layer of cells, surrounding a large central cell from which, by further division, the mother-cells of the spermatozoids are formed. When mature, absorption of water causes the rupture of the antheridium; the mother-cells of the spermatozoids are now set free, and the spermatozoids soon escape from the mother-cells as coiled ciliated filaments, each having usually attached to it posteriorly a vesicle of granular protoplasm, the remains of the contents of the mothercell (see Fig. 266). 
The archegonium. The general description given above (p. 377) of the development and structure of the archegonium, and of the process of fertilisation, will suffice for this group of the Pteridophyta. It should, however, be mentioned that only a single neckcanal-cell is developed.

The root-hairs retain in all cases their typical unicellular structure. They arise as tubular outgrowths from single cells, having, at first, colourless walls, which eventually become thickened, and assume a brown colour; the cavity of the hair is cut off by a septum from that of the cell from which it springs; their form is most commonly elongated and cylindrical, but sometimes (e.g. Hymenophyllaceæ) they are short and slightly branched. The development of the root-hairs begins at the earliest stage in the formation of the prothallium. Generally speaking, the roothairs are developed laterally, and as the prothallium assumes the flattened expanded form, the derelopment extends inwards from the margin, over the inferior surface, and forwards as far as the posterior part of the cushion; but in Osmunda, they are chiefly developed along the middle line of the midrib, between the two lateral rows of archegonia, and in Hymenophyllum they are developed in isolated groups near the edge.

The life of the gametophyte is, as a rule, short, being limited by the fertilisation of an archegonium. If, however, fertilisation does not take place, the prothallium continues to grow for several months, or even years in the case of Osmunda.

The gametophyte, in many instances, produces its like; either by means of adventitious branches, which become isolated and then derelope into prothallia; or, by means of gemmæ, which are thrown off and form prothallia. Propagation by means of adventitious branches has been occasionally observed in various Polypodiaceæ and Cyatheaceæ, more especially in prothallia which have remained exclusively male; in Gleicheniaceæ, Osmundaceæ, and Schizæaceæ (Aneimia, Mohria), the formation of these branches is the rule; it is common in Hymenophyllam. In Aneimia and Mohria alone, the adventitious branches spring from the the cushion; in the other cases the branches are generally developed each from a single marginal cell of the prothallium. It has been ascertained in certain cases (e.g. Cyathea, some Polypodiaceæ, Aneimia) that the prothallia developed by means of these adrentitious branches are exclusively male. The development of these branches may, it appears, be induced by injury to the prothallium. 
Propagation by means of gemmæ is common in the Hymenophyllaceæ, but it has also been observed in certain Polypodiaceæ (Vittaria, Monogramme). In Hymenophyllum, the gemmæ are small flat plates of eells; in species of Trichomanes, Vittaria, and Monogramme, they are short spindle-shaped filaments, consisting of a single row of (6-9) cells, borne on a unicellular stalk or sterigma; in Trichomanes, the gemma is attached at its centre to the stalk, so that its long axis is at right angles to the stalk; in Vittaria and Monogramme, the gemma is attached to the stalk by one end. The sterigmata are developed either singly or several together, from a single cell of the prothallium; and the gemmæ may be borne singly or several together on one sterigma.

It will have been observed that the gametophyte of the homosporous leptosporangiate Ferns presents, in its development, its root-hairs, its propagation by adventitious shoots and gemmæ, remarkable and suggestive resemblances to the gametophyte of the Hepaticæ. In the general morphology, too, of the gametophyte, there are striking correspondences between the two groups: thus, in both groups (with certain exceptions in both) the first stage in the life of the gametophyte is a filamentous protonema, which is, however, relatively small and short-lived, except in the Fern Trichomanes where the gametophyte does not develope beyond the protonematous stage. The protonema in both groups gives rise to a single flattened, expanded shoot, the adult sexual shoot of the Hepaticæ, the prothallium of the Ferns; this bears the sexual organs either directly on a receptacle, or indirectly on a special branch (gametophore). The Fern Trichomanes presents, on the whole, more similarity to the Mosses than to the Liverworts in its more highly developed protonematous stage bearing numerous gametophores, which may be compared to the numerous adult sexual shoots developed on the Moss-protonema, though in Trichomanes there is no such development of vegetative organs as there is in the Moss-shoots.

Order 1. Hymenophyllaceæ; this order contains the simplest forms. The leaf-blade almost always consists of a single layer of cells; the sorus is always marginal (Fig. $257 \mathrm{~A}$ ) and indusiate, the sporangium sessile or shortly-stalked, and the annulus entire and horizontal.

Almost all the species are tropical. Trichomanes radicans and Hymenophyllum Tunbridgense and unilaterale (or Wilsoni) alone occur in Britain. Some species of Trichomanes have no true roots.

Order 2. Polypodiaceæ. The annulus of the stalked sporangium is incomplete and vertical (Fig. 258 r), that is to say, it is not continuous at the base: 
indusium present or absent. Almost all our native Ferns belong to this order, which is exceptionally rich in genera.

The following families may be distinguished, characterised by the position of the sorus.

(a) Davalliece. Sorus marginal, or nearly so ; inferior indusium cup-shaped in Eudavallia, or one-valved as in Leucostegia, etc. (Fig. 257 B). Includes the large genus Davallia: no European species.

(b) Pteridea. Sori coalescent along the margin of the leaf (Fig. $257 \mathrm{C}$ ), with a spurious indusium. Pteris (Pteridium) aquilina, the Bracken, has a stem which grows at sıme depth below the surface of the soil, and throws up every year a single large, much-st gmented leaf (frond) : it has also a true lateral indusium. Adiantum, the Maiden-hair Fern, belongs to this group, as also Cheilanthes.

(c) Aspleniec. The sorus, which is situated on the under surface of the leaf, is elongated or linear, and the lateral indusium springs from the vein to which it is attached (Fig. $257 \mathrm{E}$ ). Asplenium Ruta muraria, the Wall-Rue, is not uncommon on walls and rosks; A. Trichomanes is also abundant, with simple pinnate leaves and a shining black rachis. Athyrium Filix fomina, the Lady Fern, is common in damp woods. Scolopendrium vulgare, the Hart's-tongue, with entire leaves, is common in damp hedgerows and woods. Blechnum (Lomaria), the Hard Fern, as also Ceterach, may be included here, though the indusium may be rudimentary or absent.

(d) Aspidiec. Sorus on the lower surface of the leaf, orbicular in form and covered by a peltate or reniform superior (Fig. $257 \mathrm{D}$ ) or inferior indusium. Nephrodium (Lastrau) Filix mas, the male Fern, and other species resembling it, with a thick tufted crown of leaves, are not rare in woods. Aspidium is the Shield Fern : A. (Polystichum) Lonchitis is the Holly Fern: Woodsia, Onoclea, and Cystopteris (Bladder Fern), with an inferior indusium, also belong to this group.

(e) Polypodiea. The sorus, which is on the under surface of the leaf, is naked (Fig. $257 \mathrm{~F}$ ). In the section Polypodium the leaves are articulated to the stem, so that when they die and fall off they leave a roundish scar: the leaves are usually borne in two rows on the dorsal surface of the rhizome. Polypodium vulgare, with simple pinnate leaves, is common on tree-trunks, rocks, etc. In the section Phegopteris the leaves are not articulated to the stem, so that when they die, fragments of the leaf-stalks remain attached to it. Allosorus (Cryptogramme) crispu: is the Parsley Fern.

(f) Acrostichece. The whole underside of the leaf is covered with naked Eporangia. To this family belong a number of tropical Ferns of the two genera Platycerium and Acrostichum with its numerous sub-genera, Polybotrya, Olfersia, Elaphoglossum, etc.

Order 3. Cyatheaceæ. Distinguished from the Polypodiaceæ only by the presence of a complete annulus.

The Tree-Ferns belong to this family. Cibotium and Dicksonia have marginal sori with two-valved inferior indusia: Cyathea, Hemitelia, and Alsophila have their sori on the under surface of the leaf: Alsophila alone has no indusium; in Cyathea it is cup-shaped, and in Hemitelia one-valved.

Order 4. Gleicheniaceæ, including the genus Gleichenia, with a horizontal annulus; no indusium : all tropical. 
Order 5. Schizæaceæ, including the genera Schizæa, Aneimia, Mobria and Lygodium, with a projecting apical annulus to the almost sessile sporangium, occur only in the tropics. Lygodium is the most remarkable genus; its pinnate leaves grow to a great length, and twine round supports by means of their midribs : it alone has an indusium, and the sorus is usually unisporangiate.

Order 6. Osmundaceæ. The shortly-stalked sporangia have a rudimentary annulus consisting of a group of cells (Fig. $261 \mathrm{Br}$ ) just below the apex; they burst open by a longitudinal slit on the side opposite to this.

Osmunda regalis, the Fern-Royal, is a not very common but well-known Fern. Only the upper pinnæ of the leaves are fertile, and develope little or no mesophyll; the sori are marginal, and consist of a great number of sporangia; they have no indusium (Fig. $261 \mathrm{As}$ ). The only other genus is Todea, belonging mainly to Australasia.

\section{HETEROSPOROUS LEPTOSPORANGIAT E.}

(Hydropterideæ or Rhizocarpæ.)

This group includes the four genera, Salvinia, Azolla, Marsilea, Pilularia; of these the two former constitute the order Salviniaceæ, the two latter the order Marsileaceæ. They are all more or less aquatic in habit, Salvinia and Azolla being free-floating fugacious plants, whilst Marsilea and Pilularia are perennials growing in bogs and marshes.

SPOROPHYTE.-The stem is a horizontal dorsiventral rhizome. It generally bears foliage-leaves in alternating longitudinal rows (four rows in Salvinia; two rows in the other genera) on the dorsal (superior) surface; and roots in one (Marsileaceæ) or two (Azolla) longitudinal rows on the ventral (inferior) surface. In Salvinia, however, there are no roots, but the stem bears in place of them two rows of submerged leaves on its ventral surface. The lateral branches, sometimes very numerous, are borne on the flanks.

In the Salviniacen the apical growing-point of the stem has a two-sided apical cell, situated in the vertical plane, from which lateral segments are cut off alternately right and left: each segment is divided by a horizontal wall into a dorsal and a ventral half, and each of these is again divided by a transverse wall so that each segment gives rise to four cells: thus the growing-point consists fundamentally of eight longitudinal rows of cells, four belonging to the dorsal, and four to the ventral region, of which the two uppermost may be designated the dorsal rows, the two next the dorso-lateral rows, the two next the ventro-lateral rows, 
and the two lowest the ventral rows. In Salvinia the foliage-leaves are alternately developed from the dorsal and the dorso-lateral cells; hence they lie in four alternating longitudinal rows; the submerged leaves are developed from the ventro-lateral cells in two rows. In Azolla the leaves are developed only from the dorsolateral cells, and the roots from the ventral cells. In both genera the lateral branches are developed from the ventro-lateral cells.

In the Marsileaceæ the apical cell is tetrahedral: of the three sides from which segments are cut off, two are dorso-lateral and one is ventral : the leaves are developed from the upper portions, the branches from the lower portions, of the dorso-lateral segments : the roots are developed from the ventral segments.

The foliage-leaf presents a considerable variety of form. In Salvinia it is broad and flat, sessile and entire, with a well-marked midrib : in Azolla the leaf is small and two-lobed, the lower lobe being submerged whilst the upper floats on the surface of the water: in Marsilea the leaf has a long erect petiole bearing a paripinnate bijugate compound lamina of four leaflets: in Pilularia the leaf is cylindrical and erect.

The growth in length of the leaf is effected, in Salvinia, Marsilea, and Pilularia, by an apical growing-point having a wedge-shaped apical cell: the growth in breadth of the lamina is effected, in the two former, by marginal growth. In Azolla the development of the leaf is effected altogether by marginal growth.

Circinate vernation obtains in the Marsileaceæ, but not in the Salviniacer: in Salvinia the vernation is conduplicate, and in Azolla the lamina is expanded from the first.

In Salvinia the leaves are borne in a whorl of three at a node, two being a pair of opposite foliage-leaves, and the third a submerged leaf: in the other genera the phyllotaxis is alternate.

The submerged leaf of Salvinia consists of a number of long filamentous branches, springing from a short petiole, and densely covered with multicellular hairs.

The sporangia are of two kinds, microsporangia and macrosporangia: they are borne in sori enclosed in structures termed sporocarps. The morphology of the sporocarp is, however, altogether different in the two orders, and the same term ought not to be applied to both: it would be well to restrict the term "sporocarp" to the more complex fructifications of the Marsileaceæ.

In the Salviniaceæ the so-called sporocarp is simply a sorus of 
sporangia, either microsporangia or macrosporangia, but not both, surrounded by an inferior indusium (Fig. 268). In Salvinia the sori are borne at the apices of the basal branches of a submerged leaf, and may be comparatively numerous (4-20) on one leaf: in Azolla the sori are borne at the apices of the segments of the lower (ventral) submerged lobe of a leaf, and that leaf is always the first (basal) leaf of a fertile branch which is sometimes less vigorously developed than the
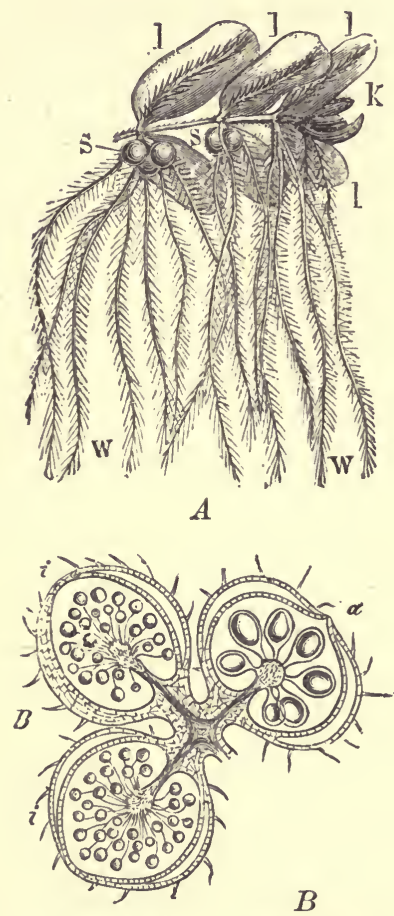

FrG. 263.-A Apical portion of the stem of Salvinia natans, seen obliquely from below (nat. size): $l \imath$ aerial leaves; $w w$ aquatic leaves, with sori, $8 \mathrm{~s}$; $k$ terminal bud of the stem. $B$ Longitudinal section through three fertile teeth of an aquatic leaf ( $x 10)$, forming two sori with microsporangia, $(a)$ one with macrosporangia ; $i$ indusium. (After Sachs.) purely vegetative branches; each leaf usually bears only two sori, but in $A$. nilotica there are four. In Salvinia the sori are all of the same size, whereas in Azolla the sori containing microsporangia are considerably larger than those containing macrosporangia. In both genera the tip of the fertile leafsegment expands into a cellular cushion, the placenta, from the superficial cells of which the sporangia are developed : the indusium is developed as an annular outgrowth from the base of the placenta, becoming cup-shaped, and eventually closing over the sorus: it consists of two layers of cells which, in Salvinia, are separated by large air-chambers and are connected by longitudinal cellular trabeculæ. In both genera the microsporangia of a sorus are numerous (about 40 in Azolla, more in Salvinia): the macrosporangial sorus consists, in Salrinia, of many (up to 25) macrosporangia, whereas in Azolla there is but one. Both kinds of sporangia are borne by the same plant.

In the Marsileaceæ the sporocarp consists of a leaf-branch enclosing a number of sori, and each sorus includes both micro- and macrosporangia. In Marsilea 
the fertile leaf-branches spring from the ventral surface of the petioles of the foliage-leaves (compare Ophioglossaceæ), and each bears a sporocarp at the end of a longer or shorter stalk: the petiole bears a single fertile leaf-branch near its base in some species, or two or more adnate branches springing from the same point; or it bears (e.g. M. polycarpa) a series of 10-20 branches, one above the other, each bearing a single sporocarp. In Pilularia the fertile leaf-branches appear to be also developed from the ventral surface of the foliage-leaves : each leaf has at its base a single almost sessile sporocarp.

The sporocarp of Marsilea (Fig. 269) is dorsiventral, somewhat pod-shaped, with its dorsal margin directed upwards; the stalk is continued along the dorsal margin as a midrib : the sporocarp may, in fact, be regarded as being developed from the laminar portion of the leaf-branch. The sporocarp of Pilularia is globular, though it is slightly pointed at the apex: it may be likewise regarded as being a leafbranch, four (usually) leaflets or segments being concerned in its construction. In both genera, especially in Marsilea, the wall of the sporocarp is composed of several layers of cells with thick hard walls: vascular bundles, springing from the stalk, are distributed in the wall.

The number of sori in the sporocarp of Marsilea varies from five to twenty-three in the different species: they are developed in tubular cavities, extending from the ventral margin of the sporocarp for some distance towards the dorsal margin, which are disposed in two longitudinal rows, one row on each side of the middle line: when young, these cavities are open at the ventral margin, but the

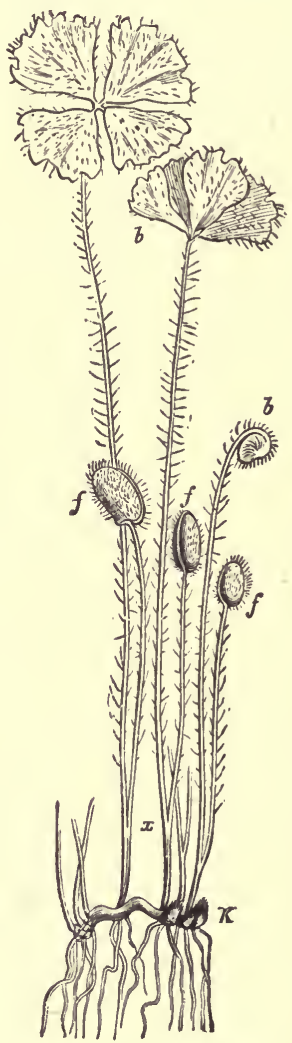

FIG. 269.-Stem of Marsilea Salvatrix with leaves (reduced one-half). $K$ Terminal bud; $b \quad b$ leaves; $f f$ sporocarps born on petioles. apertures become closed as the sporocarp matures: the external wall of each cavity developes into a projecting ridge of tissue, the placenta, which bears the sorus, consisting of a single median row 
of macrosporangia and a double row of microsporangia on each flank. The cavities are surrounded by parenchymatous tissue.

The globular sporocarp of Pilularia contains four (sometimes two or three) cavities, extending longitudinally from the base to the apex, enclosed by parenchymatous tissue. The placenta is a ridge of tissue on the external wall of the cavity, bearing the sorus which consists, in its upper part, of microsporangia, and in its lower of one or more macrosporangia. The cavities at first communicate with the outer air at the apex of the sporocarp, but eventually become completely closed.

In their development, the sporangia of the Heterosporous Leptosporangiatæ resemble those of the Homosporous Leptosporangiatæ (see p. 392) in all essential points : but no annulus is developed. In each sporangium sixteen spore-mother-cells are developed from the single tetrahedral archesporial cell, and each of these mother-cells undergoes division to form four spores: but whereas in the microsporangia all these sixty-four spore-rudiments develope into microspores, in the macrosporangium only one developes into a macrospore, the others being abortive.

The development of the spores in this group, is remarkable on account of the important part played by the multinucleate protoplasmic mass (epiplasm), derived from the disorganisation of the tapetal cells, in which the free spore-mother-cells are embedded at the time when the development of the spores is commencing. Taking first the Salviniaceæ: the microsporangium of Salvinia contains, when mature, a number of microspores embedded in a spongy mass of a substance, which gives some of the reactions of corky cell-walls and is derived from the protoplasm of the tapetal cells : in Azolla the microspores are likewise embedded in this substance, but in more than one group or massula (2-8) according to the species. Each massula is surrounded by a membrane, bearing in some species a number of anchor-like hairs, the glochidia (absent in $A$. pinnata and A. nilotica): membrane and glochidia are developed whilst the massula still consists of living protoplasm. In Salvinia the macrospore also is invested by a layer of this spongy substance, constituting the epispore or perinium. This is also the case in Azolla, but here the perinium is remarkably developed. Over the rounded dorsal surface of the radial macrospore, the perinium is a thick membrane, firm at the surface, spongy within, with warty projections bearing filaments of the same substance: on the three flattened surfaces of the ventral 
aspect of the macrospore the perinium forms three (A. filiculoides and caroliniana) or by segmentation nine ( $A$. pinnata and nilotica) large spongy masses which constitute the so-called floats of the spore: at the pointed apex of the spore, between these masses, the perinium usually terminates in a tuft of delicate filaments.

In the Marsileaceæ the spores become invested by a perinium, secreted by the epiplasm, consisting of an inner layer made up of prisms placed with their long axes perpendicular to the surface of the spore, and of an outer layer which is homogeneous in the case of the microspore; but in the case of the macrospore it is stratified, swells up enormously on being wetted, and gives the cellulose-reaction.

In all cases the spore has its own proper coats, the exospore and the endospore, of the usual constitution. It contains a mass of granular protoplasm, with a nucleus, and encloses numerous starch-grains, oil-drops, and proteid granules.

The dissemination of the spores is effected by somewhat peculiar means. In Salvinia the spores remain enclosed in the sporangia, but the sporangia break off from their stalks and float on the surface of the water. In Azolla the indusium, as also the wall of the free microsporangia, slowly decays, and the massulæ of microspores escape; but the macrospore remains covered in its upper end by the wall of the sporangium and by the indusium: in those species in which glochidia are present, the massulæ become hooked on to the projecting filaments of the macrospores. In the Marsileaceæ the hard sporocarp must first of all be opened; this is effected by the mucilaginous walls of the internal tissue of the mature sporocarp, which, when the sporocarp is moistened, absorb water and swell up considerably. In Pilularia the tension thus produced causes the wall of the sporocarp to split into 2-4 valves at the apex, and through this opening the mucilage escapes carrying with it the spores. In Marsilea there is a well defined strand of swelling tissue extending along the dorsal and ventral margins of the sporocarp and forming a continuous ring with which is connected the tissue enclosing the chambers containing the sori: when water gains entrance to the mature sporocarp, this tissue swells and, first of all, causes the rupture of the wall of the sporocarp along the ventral suture; the ring continues to swell and drags out with it the chambers and the contained sori till they lie freely in the water; it is estimated that the ring swells up to about 200 times its original size; the delicate tissue sur- 
rounding the sori soon becomes disorganised, as also the walls of the sporangia.

The root is altogether absent in Salvinia; in the other genera the primary root is of but short duration, and the root-system consists of nnmerous adventitious fibrous rootlets which have an apical growing-point with a tetrahedral apical cell. In Azolla the root-cap is but imperfectly developed, and in $A$ caroliniana it is completely thrown off after a time.

General Histology. In the Salviniacer the stem is monostelic; there is an axial, closed, concentric, vascular cylinder, without any pericycle but with a two-layered endodermis of which the outer layer has the characteristic markings in the radial cell-walls.

In the Marsileaceæ the stem is polystelic and gamostelic; there are five steles which are distinct at the growing-point but fuse further back forming a hollow cylinder enclosing some groundtissue which looks like, but is not, a pith.

On the whole the histology of these plants generally resembles that of the allied homosporous Ferns, though in consequence of their more or less aquatic habit the intercellular spaces of these plants are more conspicuous, especially in Salvinia and in the root of Pilularia where they form large air-chambers.

Azolla presents a case of symbiosis which resembles that of Anthoceros (p. 353). On the upper surface of the dorsal lobe of each leaf, near the base, a pit is formed which has a narrow aperture and is occupied by Nostoc-filaments (Anabæna) amongst which branch hairs which are developed from the epidermal cells lining the pit: these filaments also occur in the macrosporangiate indusium, having entered before the indusium becomes closed.

The Embryogeny of the Sporoplyte. The early divisions of the oospore are essentially the same as in the allied homosporous Ferns. The individual peculiarities of subsequent development are briefly as follows. In Salvinia the whole of the hypobasal half goes to form the foot, no primary root being developed; of the four epibasal octants, one gives rise to the growing-point of the stem, and two to that of the first leaf or cotyledon, and from the basal region of these octants a transverse layer of cells is cut off which eventually elongates forming a cylindrical hypocotyl, sometimes termed the caulicle; the cotyledon is termed the scutiform leaf on account of its form and mode of attachment; the young stem first produces one or two isolated foliage-leaves, and then the regular development of the whorls of two foliage-leaves and one water-leaf 
(see p. 407) begins. In the other three genera, two of the epibasal octants give rise to the first cotyledon, one to the growingpoint of the stem, and the fourth to a second cotyledon, so that here there are two cotyledons: the hypobasal octants give rise to foot and root in the usual manner.

The Gametophyte. As these plants are heterosporous, the gametophyte is represented by distinct male and female individuals : these remain connected with the spores producing them.

The male individual is developed from a microspore: it consists of a rudimentary prothallium bearing generally a single male organ (antheridium), though in Salvinia there are apparently two antheridia.

In Salvinia the germination of the microspores takes place within the microsporangium; the inner coat (endospore) of the spore grows out as a longer or shorter tube through the ruptured outer coat (exospore), and erentually makes its way through the wall of the sporangium so that its free end is in the water outside : a transverse wall is formed within it which cuts off the apical portion of the tube as the fertile portion of the prothallium.

In Azolla the microspores germinate within the massula. The exospore of the tetrahedral spore ruptures along the three edges, and the endospore protrudes as a papilla at the apex. A transverse wall is formed across the base of the papilla, which now becomes the mother-cell of the single antheridium. The spermatozoids probably escape from the massula on the deliquescence of its substance. In the Marsileaceæ the male prothallium is formed altogether within the microspore: the spore divides into two cells, a smaller basal cell which represents the vegetative portion of the prothallium, and a larger one which is the mother-cell of the antheridium. In all cases the prothallium has no chlorophyll.

The male organ, or antheridium, is developed from the antheridial mother-cell mentioned above. It generally undergoes divisions so as to form a central cell surrounded by a single layer of cells forming the wall of the antheridium. But Salvinia is peculiar in that the central cell of each antheridium is not completely surrounded by a parietal layer of cells, but comes to the surface of the antheridium. The central cell then undergoes further divisions to form the mother-cells of the spermatozoids of which there are eight in the Salviniaceæ (four in each antheridium of Salvinia) and thirtytwo in the Marsileaceæ.

The male cells, or spermatozoids, resemble those of the homo- 
sporous leptosporangiate Ferns in all essential features of their form and development, as also in their extrusion from the antheridium. In the Marsileaccæ, the male prothallium is enclosed within the microspore until the antheridium is mature, when the spore-walls are ruptured by the swelling. of the cells of the contained prothallium, and the spermatozoids are set free.

The female individual is a small multicellular prothallium of a green colour, and is developed from a macrospore to which it remains attached. The development of the prothallium begins inside the macrospore at its pointed apical end, where there is an aggregation of protoplasm in which the nucleas lies. The nucleus divides, and this is followed by the formation of a cellwall between the two nuclei, cutting off the apical portion of the spore, as a small cell, from the basal larger portion; this first wall is termed the diaphragm, and it marks off that portion of the macrospore which gives rise to the prothallium from that portion which takes no part in the process. The small cell then undergoes repeated division to form the prothallium which consists, in the Salviniaceæ, of several layers of cells (at least in the middle region), and in the Marsileaceæ of two layers only. As the prothallium developes, the coats of the macrospore split into three valves at the apex, so that now the prothallium is in direct relation with the exterior. Whilst in the Marsileacer the prothallium projects but little from the spore, in the Salviniaceæ (especially Salvinia), where it is larger, the greater part of it is outside. In Azolla its outline is that of a rounded triangle, projecting between the lobes of the epispore, and throwing off the cap formed by the wall of the sporangium and the indusium; in Salvinia it is more acutely triangular, two of the corners (anterior) growing out into long wing-like appendages, and breaking through the wall of the sporanginm.

There is no clear differentiation of an archegoniophore, such as occurs in some of the homosporous Leptosporangiatæ (see p. 401), though there is an indication of this in Salvinia where the prothallium projects somewhat in the median line, especially anteriorly, where the archegonia are borne.

No cell-formation takes place in the larger basal portion of the macrospore below the diaphragm, though nuclear division has been observed in Azolla. This eventually becomes filled with starch and other nutritive substances for the nutrition of the embryo. 
The female organ, or archegonium, differs in no essential feature of structure or development from that of the homosporous leptosporangiate Ferns. In the Marsileaceæ, only a single archegonium is developed; it arises from a cell in the middle of the upper surface of the prothallium; in Azolla, if the archegonium does not become fertilised, a few more archegonia may be subsequently developed; in Salvinia, at least three archegonia are always formed, the first anteriorly in the middle line, the second and third one on each side of the first. If none of these become fertilised, the prothallium resumes its growth both in breadth and length, and a second row of archegonia is formed in front of the first. Similarly a third and a fourth row, with an increased number of archegonia in each (seven or more), may be successively produced. In Pilularia also the prothallium grows to a considerable size if the archegonium is not fertilised, though no more archegonia are formed.

The female cell, or oosphere, de-

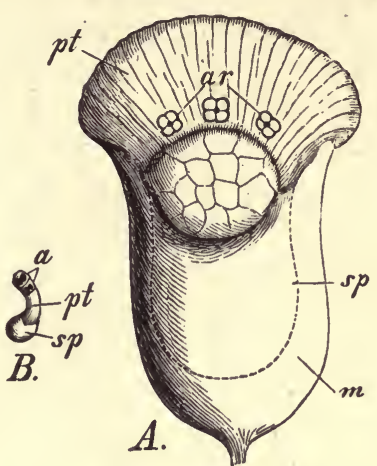

Fig. 270.-Gametophyte of Salvinia $(\times 60)$. A Microsporangium $m$ with a germinated macrospore $s p$ (dotted outline); pt female prothallium projecting from the apex of the spore; ar archegonia. B A microspore isolated from a micro. sporangium: $s p$ spore; $p t$ male prothallium; $a$ antheridia. veloped in each archegonium, does not require any special description.

Order 7. Salviniaceæ: microsporangia and macrosporangia in distinct sori, each sorus being covered by an indusium; the spores are surrounded by spongy mucilage, forming an episporium or perinium round the individual macrospores, and holding all the microspores together within the sporangium (Salvinia) or in several groups or massulæ (Azolla); the female prothallium is relatively large and bears several archegonia.

No species of Azolla is European: Salvinia natans occurs in Southern Europe.

Order 8. Marsileaceæ : microsporangia and macrosporangia in the same sorus, a number of sori being enclosed in the specially modified sporophyllsegment, the whole forming a sporocarp. Each spore is invested by a mucilaginous prismatic perinium. The female prothallium is relatively small, and bears but a single archegonium.

Pilularia globulifera is the one British species belonging to this order. The European species of Marsilea are M. pubescens, which occurs in the Mediterranean region, and $M$. quadrifoliata, in Central Ẹrope. 


\section{CLASS VI. EQUISETINA.}

This class includes, among existing plants, only the homosporous order, Equisetaceæ; but there are many extinct fossil forms, some of which are undoubtedly heterosporous.

Order 1. Equisetaceæ. This order includes the single genus Equisetum (Horsetail). Of the tweuty species of this genus, about half are British ( $E$.

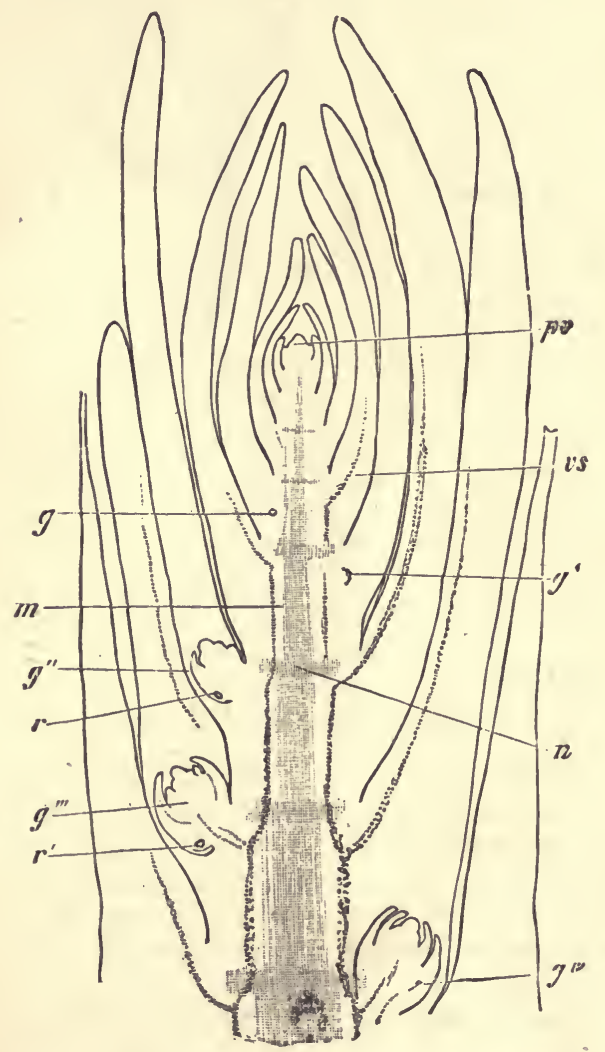

FıG. 271. Median longitudinal section of the apical portion of a vegetative shoot of Equisetum arvense; $p v$ apical growing-point; $g$ bud-rudiment; $g^{\prime}-g^{\prime \prime \prime}$ stages in the development of lateral buds; $r r^{\prime}$ developing adventitious roots on the buds; $m$ central ground-tissue (not pith); vs developing (common) vascular bundle; $n$ nodal diaphragms. ( $\times 26$ : after Strasburger.) arvense, maximum, silva. ticum, palustre, limosum, hyemale, trachyodon, $v a$ riegatum, pratense, litor. ale).

The Sporophyte. The stem consists of a horizontal, subterranean, muchbranched rhizome; some of the branches come to the surface, and are the sub-aerial shoots. The rhizome and its branches are very distinctly segmented into nodes and internodes. At each node is borne a whorl of scaleleaves forming a continuous sheath. The branches, as also the adventitious roots, spring from the nodes, a bud being developed in the axil of each leaf, and an adventitious root from the base of each bud; but in the sub-aerial shoots the rudimentary roots do not grow out, whilst in the subterranean shoots relatively few of the buds grow into branches. In certain species (E. arvense, silvaticum, maximum, $p a-$ lustre, etc.) some of the subterranean branches become tuberous.

The sub-aerial shoots generally live for one season only, and are herbaceous in texture, but in some species they persist (e.g. E. hiemale, trachyodon, variegatum). They are 
generally green in colour, and their surface is more or less strongly ribbed. Some of these shoots are sterile, whilst others are fertile, bearing the sporangia. In most species the sterile and fertile shoots are alike (Equiseta homophyadica), but in the four species $E$. arvense, maximum, silvaticum, pratense (Equiseta heterophyadica) they are more or less widely different. Thus in E. arvense and maximum, the fertile shoots are developed early in the spring, and are unbranched, whereas the copiously branched sterile shoots are not developed till the summer; moreover the fertile shoots are not green. In E. pratense the differences between the fertile and sterile shoots is less marked, the former bearing a few whorls of simple branches. In E. silvaticum the fertile shoot has no branches at first, but after the shedding of the spores the terminal cone dies off, the shoot throws out branches, and thus comes to be a sterile shoot. In some species the sub-acrial shoots are generally unbranched (e.g. E. hiemale, trachyodon, variegatum).

The leaves are either cataphylls or sporophylls. The cataphylls, representing the foliage-leaves, are borne in whorls at the nodes, having a common attachment, so that they form a leaf-sheath at each node. They are small and brown in colour.

The sporophylls, like the cataphylls, are developed in whorls, but owing to the fact that the internodes between the whorls do not elongate, the sporophylls are aggregated into a conelike flower situated terminally on the shoot (Fig. 272), or less commonly (e.g. E. palustre) on some of the lateral branches. The leafsheath below the cone,

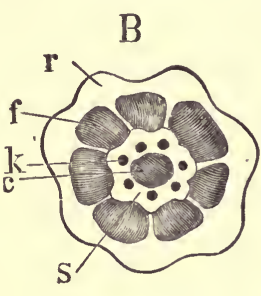

A
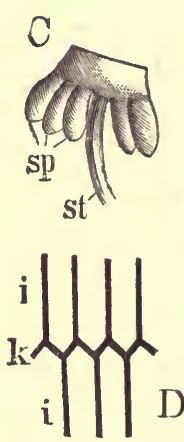

D

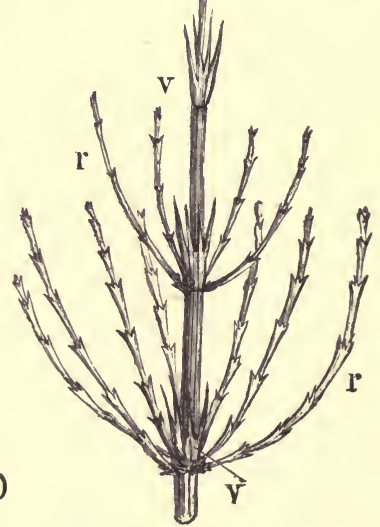

Fra. 272.-A Upper portion of a fertile branch of Equisetum palustre. Leaf-sheaths, below which the branches $(r)$ spring; w the uppermost sterile sheath (ring) ; $a$ the flower; $b$ the peltate sporophylls. $B$ Transverse section of the stem $(\times 6)$ : $c$ central cavity; $s$ the vascular bundles arranged in a circle, each having a carinal cavity, $k ; f$ the vallecular cavities; $r$ the ridges. $C$ Sporophyll with sporangia $(\times 10)$ : st the stalk; $s p$ the sporangia. $D$ Diagram of the course taken by the vascular bundles where two internodes meet; $i$ ithe internodes; $k$ the node. marking off the reproductive from the vegetative region of the shoot, is peculiar, being generally very much reduced, and is termed the ring (see p. 79).

Each sporophyll has a small hexagonal lamina which is inserted on the axis of the cone by a short stalk attached to the centre of the inner surface of the 
lamina. Thus the sporophyll is peltate. It bears on its inuer (dorsal) surface, a small number (5-10) of sporangia arranged round the leaf-stalk.

The sporangia are somewhat elongated in form, and are sessile. The wall of the sporangium consists of a single layer of cells with spiral thickening. Dehiscence takes place longitudinally on the side facing the leaf-stalk. The archesporium is usually a single (not tetrahedral) cell from which are derived the mother-cells of the spores, each of which give rise to four spores.

The spores, which are all of one kind, are developed tetrahedrally, but are nearly spherical when ripe. Each spore has two coats, extine and intine, and originally a perinium is present. The perinium, as it developes, becomes irregularly thickened in such a way that, when the thin portions are destroyed, the thickened portions remain as four filaments, the elaters, all attached at one point only to the spore. These elaters are very hygroscopic. When the air is dry they expand, and staud out stiffy from the spore; when moistened, they suddenly roll up spirally round the spore. The spores become entangled by their elaters, so that when set free from the sporangium a number of the spores fall to the ground, and germinate near together.

The roots are all adventitious, though a short-lived primary root is developed. They are developed at the nodes of the rhizome.

General Histology. A striking feature in the anatomy of the stem is the presence of large, mainly lysigenous, air-cavities : thus, in some snecies, the rhizome has a large central cavity in each internode (E. silvaticum [Fig. $273 C, a$ ], arvense, maximum); a similar cavity is present in the internodes of the aerial shoots of nearly all the species (Fig. $273 \mathrm{~A}, a$ ) ; the central cavities of successive internodes are shut off from each other by diaphragms at the nodes (Fig. $271 n$ ) : a series of similar cavities occurs always in the cortex, alternating with the vascular bundles internally and with the surface-ribs externally, hence termed vallecular carities (Fig. 273 b); finally, in connexion with each vascular bundle, there is a large cavity, the carinal cavity (Fig. 273 c), extending, like the others, from one node to another.

The growing-point of the stein, and of its branches, is apical, and has a tetrahedral apical cell (Figs. 112, 113). The stem is, except at first, schizostelic (see p. 152); the schizosteles may be either distinct (rhizomes and aerial shoots of E. limosum and litorale [Fig. $273 \mathrm{~B}$ ] ; rhizomes of $E$. hiemale, trachyodon, and ramosissimum); or they may fuse (gamodesmic, see p. 170), so that the endodermis becomes continuous, forming either only a well-marked external layer (rhizomes and aerial shoots of $E$. arvense, maximum, pratense, scirpoides, palustre [Fig. $27 \dot{A}$ ] ; aerial shoots of $E$. silvaticum), or well-marked external and internal layers (rbizome of E. silvaticum [Fig. 274 $C$ ] ; rhizome and aerial shoot of $E$. variegatum; aerial shoots of $E$. hiemale, trachyodon, ramosissimum).

Each schizostele contains a single bundle which is collateral, closed and common, with very rudimentary xylem consisting of the few annular vessels of the protoxylem and of two small groups of scalariform tracheids.

In the aerial shoots (except specialised fertile shoots of $E$. arvense, etc.) there is a considerable development of assimilatory tissue in the cortex, strands of this tissue corresponding in position with the furrows on the surface in which the stomata are developed; whilst opposite the ridges on the surface there are cortical strands of sclerenchyma. The development of assimilatory tissue in 
the shoots and branches is correlated with the absence of foliage-leaves, the functions of foliage-leaves having therefore to be discharged by the shoots and branches. The epidermal cell-walls are impregnated with silica.

The root grows in length by means of a tetrahedral apical cell; in its mode of growth, development of root-cap, etc., it essentially resembles that of the Ferns. Its structure is rather peculiar:-the vascular cylinder consists (usually) of three wood-bundles and three bast-bundles, and is invested by two layers of sheathing-cells, the outer of which has the characteristic marks of an endodermis, whilst the inner appears to be a pericycle and gives rise to the growing-points of the lateral roots; however, the inner layer is, as a matter of fact, not a pericycle, but the innermost layer of the cortex, the endodermis
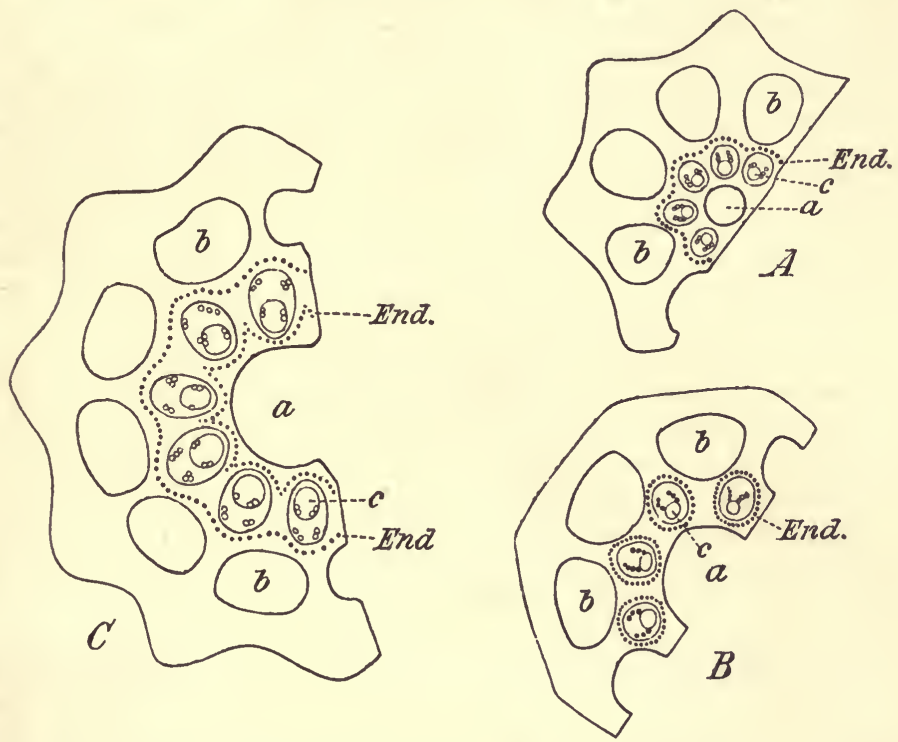

FIG. 273.-Portions of transverse sections of stems of species of Equisetum, illustrating schizostely (after Pfitzer: $\times 36$ ). B Typical schizostelic rhizome of $E$. litorale; $C$ schizostelic gamodesmic rhizome of $E$. silvaticum; $A$ aerial stem of $E$. palustre, in which the structure is the same as in $C$, but the markings of the internal endodermal layer are not developed, so that the stem appears to be monostelic; $a$ central cavity; $b$ valleculur cavities in the cortex; c carinal cavities in the schizosteles; End. endodermis.

being the last layer but one of the cortex. Hence it appears that here, as in the Ferns, the lateral roots spring from the innermost layer of the cortex. There is no pericycle in the root of Equisetum.

Embryogeny of the Sporophyte. The oospore is divided by a transverse basal wall, and then becomes segmented into octants, as in the Filicinæ. Of the four epibasal octants, one gives rise to the growing point of the primary stem; two to the first cotyledon; and the fourth to the second cotyledon: the two cotyledons cohere to form a leaf-sheath round the young primary stem. Of the four 
hypobasal octants, one gives rise to the growing-point of the primary root, and two to the foot.

The primary stem grows erect, and its leaf-sheaths are three-toothed, the three leaves corresponding to the three segments cut off from the apical cell of the stem; it branches at its base; stouter shoots with an increasing number of teeth in the leaf-sheaths are successively produced, and eventually a branch is produced which becomes the perennial subterranean rhizome.

The GaMEToph YTE is a green, dorsiventral, lobed prothallium which becomes quite free from the spore. The prothallia are generally diceious, the female prothallia being larger than the male; but the distinction of sex is not absolute, for the female prothallia may eventually bear male organs, and the male prothallia female organs; it appears to depend largely on conditions of nutrition.

The germinating spore divides into two cells: one of these contains no chloroplastids, and grows out into a hair which represents a root (see p. 61), the other contains chloroplastids, and grows and divides to form the first lobe of the prothallium, which branches as its development proceeds, some of the branches of the female prothallia growing erect. On its under surface the prothallium bears numerous root-hairs.

At first the prothallium consists throughout of a single larer of cells; in the female prothallium, however, one of the lobes becomes thick and fleshy, consisting of several layers of cells formed by repeated horizontal cell-division, and this constitutes the archegoniopliore.

The male organ, or antheridium, is developed from a single cell of the margin of the male prothallium : this cell undergoes repeated division, with the result that a wall, consisting of a single layer of cells, is formed surrounding a central cell from which, by subsequent divisions, the numerous mother-cells of the male cells are developed : the antheridium eventually dehisces by the separation of the cells forming the roof, in consequence of the swelling-up of the contents of the antheridium. The male prothallium bears several antheridia, one being developed terminally on each lobe, and others in succession on the lateral margins.

The male cell, or spermatozoid, is larger than that of any other Pteridophyta ; it has only two or three coils, and bears a tuft of short cilia at its anterior pointed end.

The female organ, or archegonium, resembles, in all essential features of its structure and development, that of the typical Filicinæ: a distinctive peculiarity is afforded by the long recurved terminal colls of the neck, and by the relatively small neck-canal-cell. Each prothallium bears a number of these organs: they are developed each from an anterior marginal cell, and, as the prothallium continues to grow, the organs come to lie on its upper surface.

The female cell is an oosphere, and calls for no special remark. 


\section{CLASS VII.-LYCOPODIN Æ.}

\section{SUB-CLASS HOMOSPOREÆ.}

Order 1. Lycopodiaceæ. This order contains the two genera Lycopodium and Phylloglossum: the former is a large genus, six species being British ( $L$. Selago, inundatum, annotinum, clavatum, alpinum, complanatum) and commonly termed Club-mosses: the genus Phylloglossum has a single species (P. Drummondii) found in Australia and New Zealand.

The Sporophyte. The stem. In Lycopodium the stem is slender and much branched, erect (e.g. L. Selago), or growing horizontally on the surface of the ground (e.g. L. clavatum [Fig. 274] annotinum), or beneath the surface as a rhizome (e.g. L. alpinum, complanatum) : the branching is in some cases dichotomous, in others monopodial : it may take place in all directions or in one plane only (L. complanatum).

In Phylloglossum the stem (protocorm) is a tuber, bearing an apical tuft of leaves: the only branch formed developes into next year's tuber.

The leaves. In some species of Lycopodium all the leaves are alike (e.g. L. Se(ago); but in most species, as also in Phyllo-

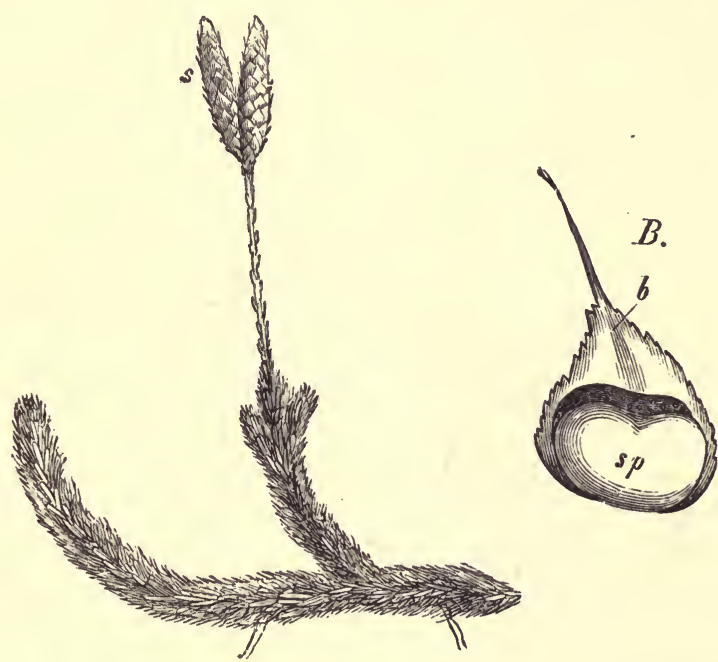

Fig. 274.-Portion of Lycopodium clavatum, somewhat smaller than nat. size: 8, the cone-like flower. $B$ a single sporophyll $(b)$ from the cone, bearing a sporangium $s p$, which has dehisced $(\times 10)$. glossum, the foliage-leaves and the sporophylls are more or less widely different.

The foliage-leaves are small and very numerous in Lscopodium; their arraugement is various, whorled, or spiral, or in decussate opposite pairs ( $L$, complanatum, etc.) : in the last case there is beterophylly, as the decussate leaves on the flattened sterile shoots vary in size, those on the lateral margins of the shoots being larger than those on the flattened surfaces. The leaves are sessile, simple, and have a rudimentary midrib.

In Phylloglossum the foliage-leaves are few (3-7); they are sessile, simple, somewhat awl-shaped, and about half an inch long.

The sporophylls present considerable variety. In L. Selago and its allies they are quite like the foliage-leaves; in most species of Lycopodium (e.g. L. inundatum, 
clavatum, Phlegmaria, etc.) the clearly differentiated sporophylls are aggregated into terminal cone-like flowers, and in some cases the branch bearing the cone grows out into a long peduncle ( $L$. clavatum, complanatum, etc.).

In Phylloglossum the small sporophylls are aggregated into a cone borne terminally on a peduncle which grows from the apex of the tuber: the lower sporophylls only are fertile.

The sporangia are, in both genera, borne singly on the upper surface of the sporophylls near their base. The archesporium consists of a single row ( $L$. Selago, Phylloglossum) or of a few rows (I. clavatum) of cells which, by their division, give rise to the mother-cells of the spores. The sporangia are unilocular, somewbat reniform in shape, and (in Lycopodium) seated on a short broad stalk : they dehisce by a longitudinal slit.

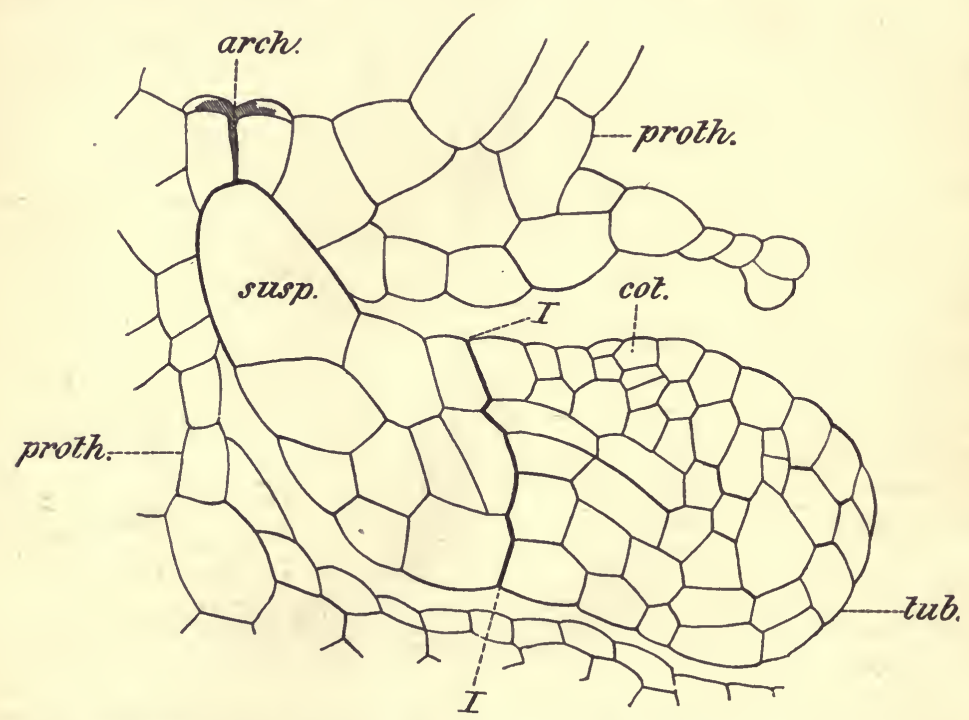

FIG. 275.-Embryogeny of Lycorodium cernuum ( $\times 300:$ after Treub). The embryo is just emerging from the prothallium proth.; arch. the neck of the archegonium; $I-I$ basal wall; susp. suspensor; cot. cotyledon; tub. tuberous protocorm.

The spores are all of one kind, and are tetrahedral in form : they have the ordinary structure.

The roots are all adventitious. In the erect species of Lycopodium they spring as a tuft from the basal end of the stem : in the procumbent species they are born singly on the under surface of the stem. The roots branch dichotomonsly in alternate planes. In Phylloglossum the short unbranched roots (1-3) spring from the tuber just below the insertion of the leaves : they are of exogenous origin.

General Histology. The growing-point of stem and root alike consists, in Lycopodium, of small-celled meristem, no apical cell being present. Both 
stem and root have an axial vaseular eylinder consisting of alternating bundles of wood and of bast arranged radially : thus the stem is monostelic, and its structure only differs from that of the stouter roots in respect of the larger number of bundles present: in smaller roots there is only one wood- and one bast-bundle. In the stem the bundles frequently anastomose, more especially in the erectgrowing species, so that transverse sections taken at different levels present diverse pictures. The wood-bundles consist of scalariform tracheids, with the exception of the protoxylem. Neither stem nor root grows in thickness. In both stem and root there is an endodermis, the cells of which have the characteristic marking when young but eventually become thick-walled and corky: the endodermis does not, however, appear to be the innermost layer of the cortex ; between it and the vascular bundles is what appears to be a pericycle, consisting of two or three or more layers of cells, but this apparent pericycle is really the innermost re. gion of the cortex. The adrentitious roots are developed from the pseudo-pericycle of the stem. The leaves of Ly. copodinm are of very simple structure; they usual'y have stomata on both surfaces.

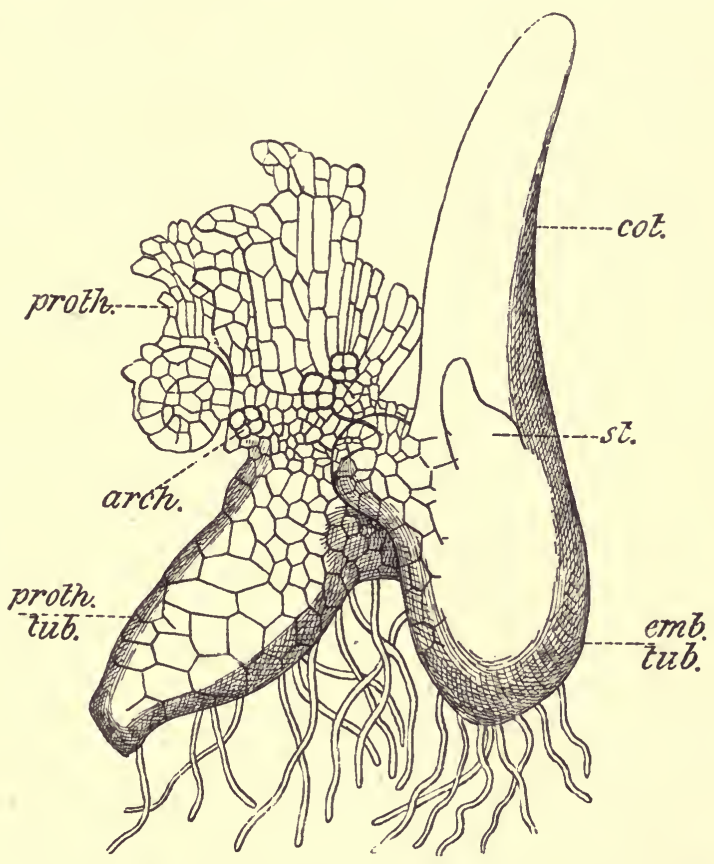

FrG. 276.-Embryogeny of Lycopodium inundatum ( $\times 42$ : after Goebel): proth. prothallium; proth. tub. tuberous portion of the prothallium; arch. archegonium; emb.tub. tuberous protocorm of the embryo; cot. cotyledon; st. second leaf, at the base of which is the growing-point of the stem.

In Phylloglossum, likewise, the growing-point of both stem and root has no apical cell. The tuber consists wholly of parenchymatous tissue. In each leaf and root there is a single bundle: these bundles anastomose at the point of origin of these members : when there is a sporangiferous shoot it contains an axial strand of vascular tissue connected at the base with those of the roots and leaves. The bundles are rudimentary and ill-defined.

Embryogeny of the Sporophyte. The early stages have only been observed in 
L. Phlegmaria, where the oospore is divided by a transverse basal wall, the cell next to the neck of the archegonium being the hypobasal cell, and the lower cell the epibasal. The hypobasal cell developes into a short, cylindrical, usually nnicellular, suspensor. The somewhat hemispherical epibasal cell becomes seg. mented into four octants by two walls at right angles to each other and to the basal wall, and then the octants are divided transversely, by a wall at right angles to the two preceding, into two tiers or stages of four cells each. Of these two tiers the lower forms a short hypocotyl (as in Salvinia, see p. 412) which is commonly (but erroneously) called the foot, though it is morphologically quite different from the foot of the Filicin: and Equisetinæ, the true homologue of the foot in those groups being the suspensor in this. The upper tier of cells gives rise to the first leaf or cotyledon, and to the primary stem. The first root eventually springs adventitiously from cells belonging to the upper tier, below the cotyledon : its origin is exogenous.

In the other species which have been studied (L. cernuum and inundatum), whilst the early stages are probably much the same as in L. Phlegmaria, some important differences become apparent later. The primary stem is not imme. diately developed, as in L. Phlegmaria, but in its place a tuberous protocorm (closely resembling that of Phylloglossum) is vroduced, carrying the cotyledon and other subsequently developed leaves, on its summit, and bearing adventitious roots of exogenous origin at its base: the proper primary stem is eventually developed at the summit of the protocorm.

Nothing is known of the embryogeny of Phylloglossum.

Vegetative Propagation. In the creeping forms, as the main stems die off the younger branches become independent and constitute new individuals. In some species there are gemmæ, as in L. Selago, where they are borne on the stem, and are modified leafy branches; and as in $L$. cernuum, where they are small tubercles, closely resembling the tuberous embryonic protocorm, and are borne on the roots.

The Gametophyte. In so far as the gametophyte has been investigated, it is a monœcious prothallium, either containing chlorophyll ( $L$. inundatum and cernuum), or destitute of chlorophyll (L. annotinum and Phlegmaria) and saprophytic. The gametophyte of Phylloglossum is unknown.

The contents of the germinating spore (in $L$. inundatum) undergo division into two cells: of these the one, the hypobasal cell, representing the rootportion of the gametophyte, contains no chlorophyll, and merely grows somewhat without undergoing division: the other, epibasal, contains chlorophyll and, supturing the exospore, grows and divides to form the shoot of the gametophyte, the further development of which is effected for a time by an apical cell, and subsequently by marginal growth.

The morphology of the prothallium offers considerable variety. In L. inundatum and cernuum the prothallium is tuberous (see Fig. 276); its base is embedded in the soil, and bears root-hairs; its apex projects above the surface and bears a tuft of green leafy lobes: the sexual organs are developed in a zone from a layer of tissue which long remains merismatic and which is situated just below the apical tuft of lobes; occasionally some antheridia are developed on the lobes. In L. annotinum the prothallium is also tuberous : it is somewhat ovoid in form, bearing root-hairs on its lower surface, and reproductive organs 
on the discoid central region of the upper surface. Whilst in the foregoing cases the prothallium is very small and simple, in L. Phlegmaria aud some other'species (L. carinatum and Hippuris) it is considerably larger and more complex. It consists here of a cylindrical, monopodially-branched body, with apical growing-points similar in structure to those of the sporophyte. The superficial layer of cells, representing an epidermis, gives rise to a number of root-hairs. The sexual organs are developed on special branches, gametophores, though antheridia sometimes occur on the vegetative branches; the gametophores are shorter and thicker than the vegetative branches, sometimes even tuberous, and bear the sexual organs on the upper surface surrounded by stout multicellular hairs, paraphyses.

The male organs, antheridia, are sunk in the tissue of the prothallium : they resemble those of the Eusporangiate Filicinæ. Their development precedes that of the female organs.

The male cells, spermatozoids, are oval in shape, and have two cilia: a vesicle is extruded from the mother-cell together with the spermatozoid, as in the Filicinæ.

The female organs, archegonia, have short necks which project but little above the surface of the prothallium. They have the structure usual among Pteridophyta : in L.Phlegmaria there are generally several neck-canal-cells.

The female cell, oosphere, requires no special description.

In consequence of its position and of its mode of development, the embryo is forced downwards into the tissue of the fleshy prothallium, being anchored, as it were, at one end by the suspensor. As it grows it destroys the cells of the prothallium with which it comes into contact, and absorbs the nutritive sub. stances stored in these cells by means of the so-called foot, the superficial cells of which grow out into short papillæ. In its further growth the embryo becomes more and more curved until it regains the surface of the prothallium and pro: jects. In L. Phlegmaria the embryo remains for some time enclosed in a sac, the calyptra, formed by active growth of the prothallial tissue.

The life of the prothallium is short and closes, in most cases, with the development of an embryo from the oospore, but in L. Phlegmaria it seems to persist from one season to another. In the latter species the prothallia are multiplied vegetatively by the isolation of branches, as also by small multicellular bulbils,

A remarkable biological feature is the constant association of a Fungus (probably a Pythium) with the prothallia, as also with the embryo, of L. cernuum and inundatum.

Order 2. Psilotaceæ. This order consists of the two genera Psilotum and Tmesipteris; of these the former is widely distributed in the tropics; the latter is contined to Australia, New Zealand, and Polynesia, and lives epiphytically, aud perhaps parasitically, on the trunks of Tree-Ferns.

The Sporophyte. The most striking feature in the morphology of these plants is the total absence of roots, the functious of these organs being performed by specially adapted stem-brauches bearing minute scale-leaves, and covered with root-hairs.

The stem. In Psilotum the subterranean shoots have unlimited apical growth: they are much branched, apparently dichotomously, but it seems probable that the brauching is really lateral. Tue subaerial shoots generally arise as lateral 
branches on the subturranean shoots: they have limited apical growth; they are branched, the mode of branching being probably the same as that of the subterranean shoots; and they bear small scattered leaves.

T'he stem of Tmesipteris appears to agree in all essential morphological points with that of Psilotum; but with this conspicuous difference, that it is much less branched.

The leaves. In both genera the leaves of the subaerial shoots are of two kinds. In Psilotum the vegetative leaves are minute scales, whereas in Tmesipteris they are relatively well-developed as foliage-leaves : they are simple and sessile. The sporophylls, on the contrary, are petiolate and bilobed in both genera, a single sporangium being borne on the upper surface of each sporophyll just at the junction of the bases of the two lobes.

The sporangia are synangia (p. 375); that is, they are not unilocular, but multilocular capsules: in Psilotum the synangium is generally trilocular (sometimes 2-4 locular), in Tmesipteris bilocular. Each loculus opens by a longitudinal slit. The origin of the archesporium has not been fully traced : but it appears probable that it consists primarily of a layer of cells, some of which become the mother-cells of the spores, whilst the rest are sterile and form the tissue of the walls separating the loculi.

The spores are developed in tetrads from the mother-cells; bilaterally, as in Tmesipteris ; or either bilaterally or tetrahedrally, as in Psilotum. They have the typical structure.

General Histology. The shoots of both genera are monostelic. The arrangement of the bundles is radial, much as in Lycopodium; but the number of the bundles is generally smaller, especially in the subterranean shoots where there may be only two protoxylem-bundles. There is no secondary growth in thickness. The growth in length of the shoots is effected by an apical growingpoint which, when the shoot is quite young, consists of small-celled meristem; but in which a three-sided pyramidal apical cell can in certain cases (subterranean sboots of Psilotum) be detected at a later stage.

The leaves have a midrib with a single bundle, which is, however, very rudimentary in Psilotum triquetrum.

Veg tative propagation takes place in Psilotinm by means of gemmæ, developed on the rhizomes, consisting of a single layer of cells, ovoid and Hattened in form.

The Gametophyte. No observations have as yet been made on the gametophyte of either genus, and consequently the embryogeny of the sporophyte is also unknown.

\section{SUB-CLASS HETEROSPOREE.}

Order 3. Selaginellaceæ. This order consists of the single genus Selaginella, of which the numerous species are very widely distributed, but only one, S. spinosa (selaginoides), is British.

The Sponophyte. The primary stem is slender and elongated, erect, or more communly procumbent; its symmetry is bilateral, isobilateral when erect, dorsiventral when procumbent; the branches spring from the flanks of the primary stem, and, as this is subsequently repeated, the resulting branch-system lies in one plane; the mode of branching is lateral, though it appears to be 
dichotomous. In some ferv species, however, the branches have radial symmetry (e.g. S. spinosa).

At the points at which the normal branching takes place, leafless branches, termed rhizophores, are in some species developed in a plane at right angles to that of the normal branching; thus in S. Kraussiana they arise singly on the upper surface of the stem at the points of normal brauching, whilst in $S$. Martensii two are developed at each such point, one on the upper and one on the lower surface. The direction of growth of the rhizophore is such that the apex eventually penetrates into the soil, when roots arise from it and it ceases to grow.

These organs have been regarded as roots, and are sometimes so designated still. But in view of the important morphological facts that the rhizophore is of exogenous origin like the leafy branches; that it has no root-cap, whilst the true roots of Selaginella have one; and finally, that sometimes a rbizophore will develope leaves and even cones, the probability is that they are modified branches comparable with the root-like branches of the Psilotaceæ.

The leaves can be readily distinguished as either foliage-leaves or sporophylls. A characteristic feature in their morphology is the development of a small ligule on the upper surface of each leaf near its base.

The foliage-leaves are simple, small, sessile, and rather numerous. Those borne on the radial branches are all alike, and are arranged spirally; the bilateral branches show remarkable heterophylly, there being leaves of two sizes in decussate pairs, each pair consisting of one large and one small leaf; when the branch bearing these two kinds of leaves is dorsiventral, the four rows of leaves show displacement with the result that the two rows of small leaves are borne on the upper surface of the branch, and the two rows of larger leaves are borne infero laterally (Fig. 277).

The sporophylls are generally collected into more or less distinct cone-like flowers; they do not differ materially from the foliage-leaves, and, like them, may be all of one size or of two sizes.

The sporangia are shortly stalked and unilocular; they arise singly from a group of superficial cells of the stem just above the insertion of each sporophyll; the wall, when mature, consists of two layers of

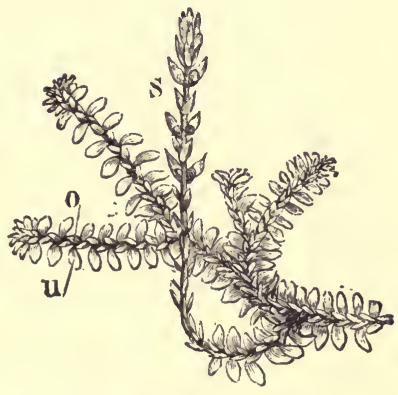

Frg. 277.-Selaginella helvetica (nat. size): $s$ the upright fertile shoot, with sporangia in the axils of the leaves. On the procumbent sterile shoots, the leaves on the unier side $(u)$ are larger than those on the upper side (o). cells; the archesporium probably consists of a single row of cells, and is entirely sporogenous.

There are two kinds of sporangia, macrosporangia and microsporangia, distinguished by the kind of spores which they produce, and by their size. The macrosporangia each give rise to generally four (sometimes 2 or 8 ) relatively large macrospores ; the microsporangia each give rise to a conside: able number of microspores. 
The relative distribution of the two kinds of sporangia presents some varia tion. As a rule both kinds of sporangia are present in the same cone, so that it may be described as consisting of microsporophylls and macrosporophylls; in this case there may be several macrosporophylls at the lower part of the cone, or only a single one.

The spores are developed in fours from the mother-cells resulting from the growth and multiplication of the archesporial cells. They are developed tetrahedrally: but in the macrosporangium usually ouly one of the mothercells undergoes division to form spores. The structure of the spores is normal.

The roots are all adventitious and endogenous. In some species (e.g. S. cuspidata and Wildenovii) they spring directly from the lower surface of the stem at the points where branching

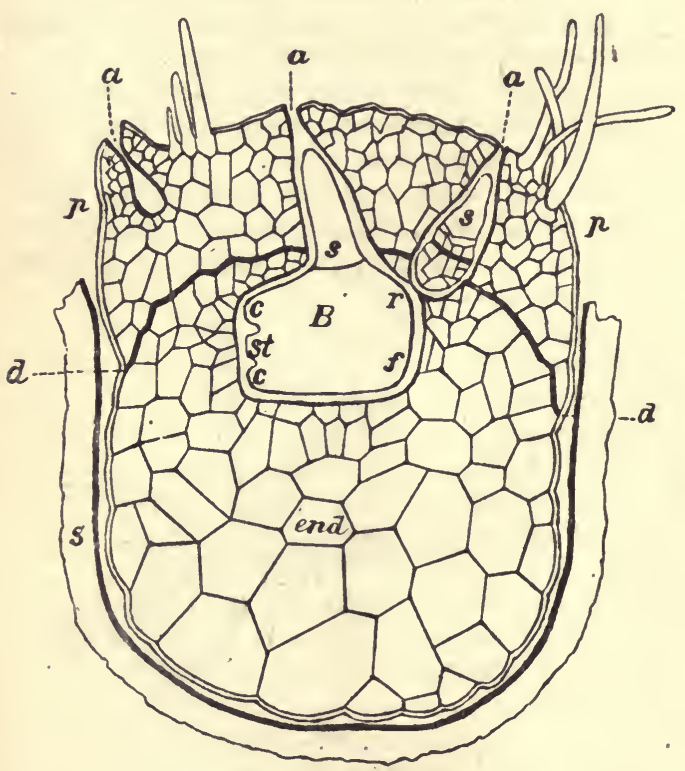

Frg. 278.-Prothallium and embryo of Selaginella Martensii ( $\times 165$ : after Pfeffer): $s$ coat of macrospore; $p$ prothallium; $a$ archegonium; $d$ - $d$ diaphragm; end so-called endosperm : $B$ an embryo (there is a smaller one to the right): $s$ suspensor; c $c$ developing cotyledons; st stem; $r$ origin of the root; $f$ socalled foot: takes place. In other (e.g. S.Martensii and liruussiana) cases they spring from near the apex of the rhizophores after the rhizophores have reached and entered the soil. The roots branch monopodially.

General Histology. The stem is, in some species (S. spiuulosa and denticulata) monostelic, but in most species it is polystelic (two or three). The epidermal and the fundamental tissue of the stem is prosenchymatous, without intercellular spaces. In correlation with this each stele is suspended, by delicate trabecular cells developed from the endodermis, in an air-chamber: each vascular bundle going to a leaf is in a similar chamber which communicates in the lamina with the external air through the stomata. Each stele is surrounded, towards the air-chamber, by a pericycle cunsisting of one or sometimes two layers of cells. The stele is diarch, or polyarch, circular or oval in transversa section, the wood-bundles joining in the centre. 
Rhizophore and root are both monostelic, and without air-chambers: the stele is monarch.

The bundles are all closed; there is no secondary growth in thickness.

The leaves are very simple in structure: they have a midrib with a single vascular bundle: the epidermal cells contain chloroplastids which, like those in the otber cells, are large and are present in small numbers (sometimes only one) in the cells. The stomata are usually confined to the under surface, on the sides of the midrib.

The growth in length of the stem is effected by an apical growing.point which has, in some species (e.g. S. Martensii) a two-sided or three-sided apical cell, whilst in others (e.g. S. Lyalli, Pervillei, etc.) it consists of small-celled stratified meristem. The structure of the growing-point of the rhizophore agrees with
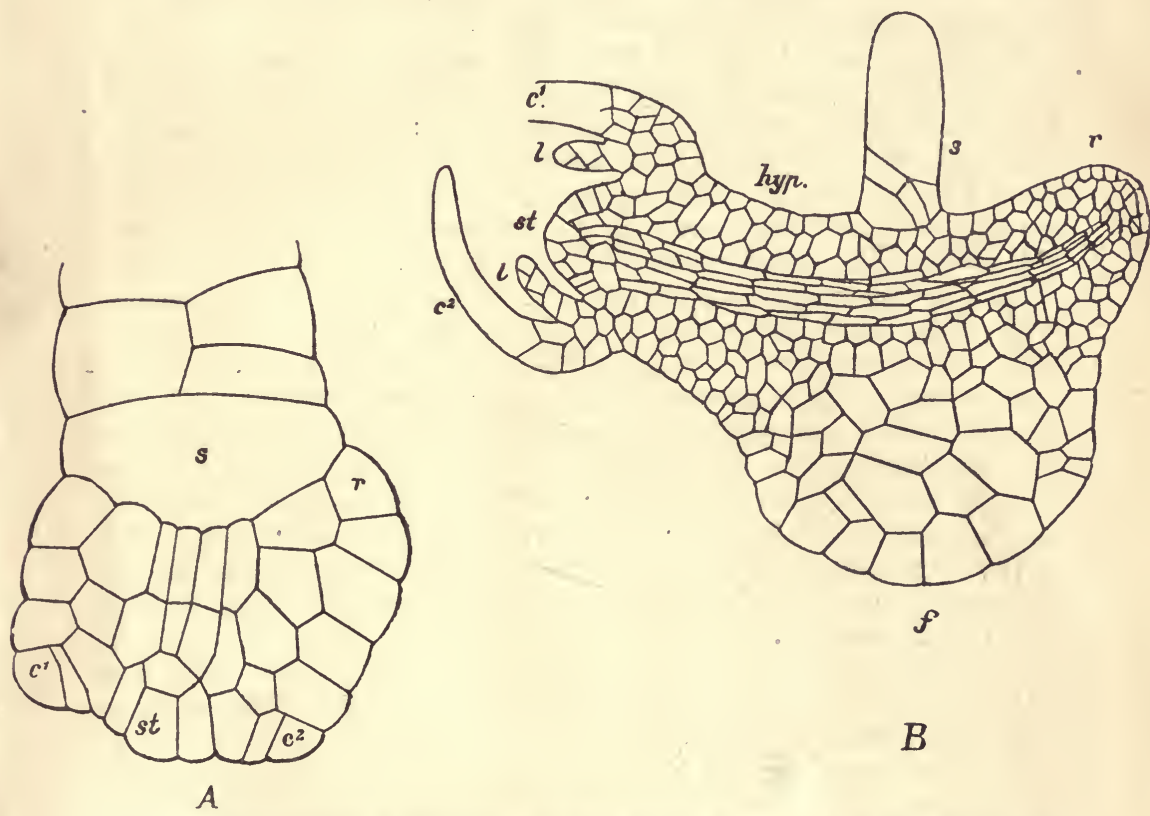

Fra. 279.-Embryogeny of Selaginella Martensii (after Pfeffer). Two isolated embryos at different stages. $A$ Younger embryo $(\times 510) B$ older $(\times 165): 8$ suspensor; $c^{l} c^{2}$ cotyledons; st stem; $l$ young foliage-leaves; hyp hypocotyl; $r$ root ; $f$ so.called foot.

that of the stem in the various species : but the apical cell, when present, is a four-sided pyramid at first, becoming eventually two-sided. The growingpoint of the root has a tetrahedral apical cell.

Embryogeny of the Sporophyte. The embryogeny of Selaginella closely resembles that of Lycopodium. The oospore undergoes division, a transverse basal wall being formed: the upper or hypobasal cell developes into a unicellular or few-celled suspensor which is homologous with the foot in the Bryophyta: the lower or epibasal cell appears to undergo division into four 
octants, which eventually form two tiers of cells : from the basal tier of cells the hypocotyl is developed; from the apical tier the growing-point of the stem and those of the two cotyledons. The hypocotyl elongates, and curves so as to escape from the prothallium and the spore; the convexity of the curve becomes somewhat protuberant and is usually (but erroneously) termed the "foot," though it doubtless acts as an organ of absorption; morphologically it cannot be a foot since it is epibasal in origin; it would more appropriately be termed a feeder (p. 14). The first root eventually springs, endogencusly and adventitiously, from the posterior portion of the convex surface of the hypocotyl; it is not a true primary root because it is epibasal in origin.

\section{The Gametophyte.}

Selaginella being heterosporous, the gametophyte-generation is represented by distinct male and female individuals, which are rudimentary prothallia bearing the male and female organs respectively.

The male prothallium is developed inside the microspore: the germination of the spore begins with the formation of a wall across the pointed apical end of the spore, cutting off a small cell, the vegetative cell : the rest of the spore goes to form the single antheridium which consists of a layer of parietal cells enclosing the mother-cells of the spermatozoids. When the development of the spermatozoids is completed, the coats of the microspore burst, as also the wall of the antheridium, and the spermatozoids are set free.

The male cells or spermatozoids consist of a somewhat club-shaped slightly twisted body, bearing two cilia at its pointed anterior end.

The female prothallium is developed inside the macrospore (Fig. 278): germination begins with the formation of a wall, termed the diaphragm, across the apical end of the macrospore : in the smaller upper cell thus cut off cell-division proceeds, resulting in the formation of the meniscus-shaped prothallium consisting of compact small-celled tissue : the larger portion of the spore, below the diaphragm, is rich in reserve materials: : here cell-formation goes on but slowly, a large-celled loose tissue (sometimes called endosperm) being produced which serves to nourish the embryo which is forced down into it by the elongation of the suspensor.

The walls of the spore eventually split along the angles, thus forming an apical aperture by means of which the upper surface of the prothallium, which now becomes green, is exposed.

The female organ or archegonium is developed from a single superficial cell at the centre of the upper surface of the prothallium (here several cells thick) ; it does not call for any special description : if the first archegonium fails to become fertilised, others may be subsequently formed.

The female cell or oosphere is contained in the venter of the archegonium. 



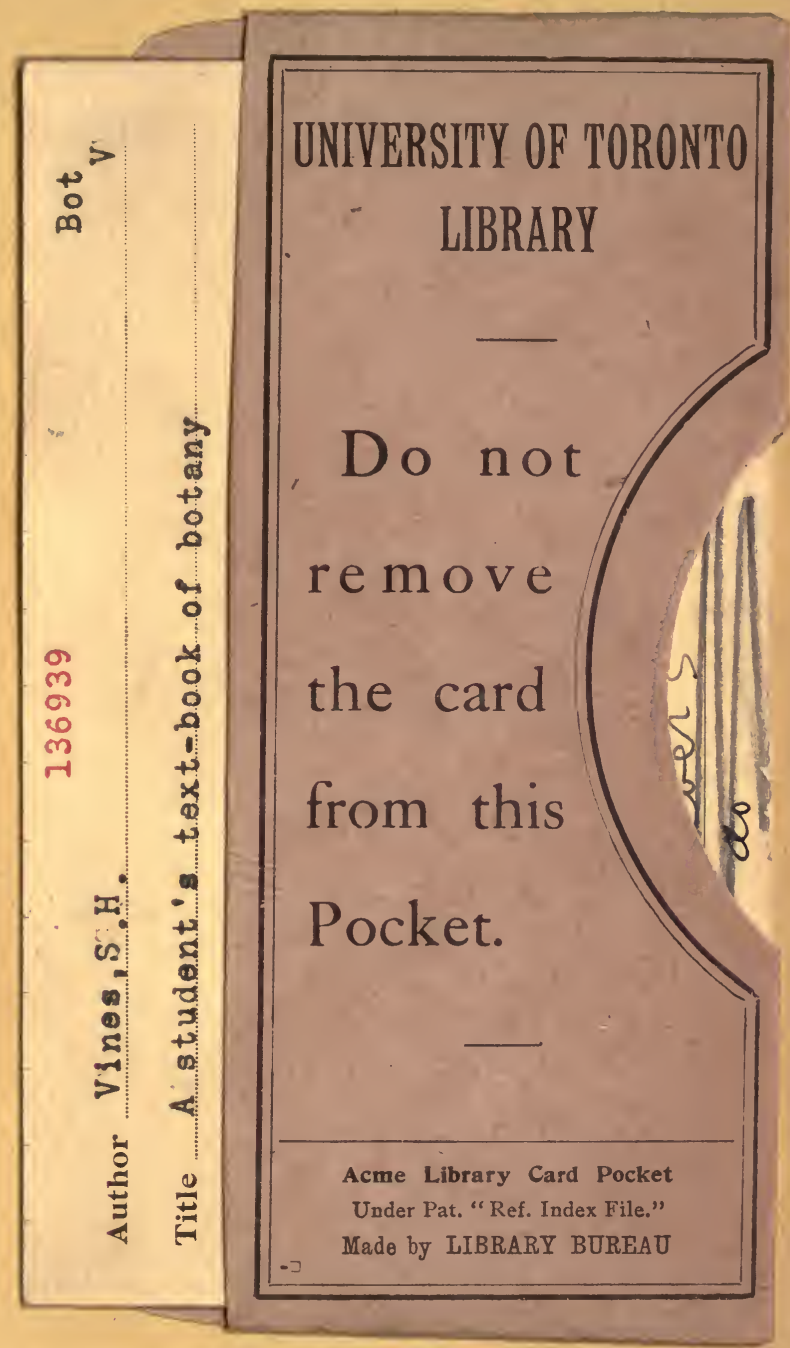


